\title{
CONTRIBUIÇÃO AO ESTUDO METALOGENÉTICO DO DEPÓSITO DE OURO DE SALAMANGONE, DISTRITO AURIFFERO DE LOURENÇO, AMAPÁ
}

Sonia Aparecida Abissi Nogueira

Orientador: Prof. Dr. Jorge Silva Bettencourt

TESE DE DOUTORAMENTO

Programa de Pós-Graduação em Recursos Minerais e Hidrogeologia

SÃo PAULO

2002 


\section{UNIVERSIDADE DE SÃO PAULO \\ INSTITUTO DE GEOCIÊNCIAS}

\section{CONTRIBUIÇÃO AO ESTUDO METALOGENÉTICO DO DEPÓSITO DE OURO DE SALAMANGONE, DISTRITO AURÍFERO DE LOURENÇO, AMAPÁ}

Sonia Aparecida Abissi Nogueira

Orientador: Prof. Dr. Jorge Silva Bettencourt

TESE DE DOUTORAMENTO

Programa de Pós-Graduação em Recursos Minerais e Hidrogeologia

SÃO PAULO

2002 
a meus filhos, Melanie e Matias,

com todo carinho 


\section{AGRADECIMENTOS}

Agradecer significa, antes de tudo, reconhecer que não estamos sozinhos perante as dificuldades e desafios de nossa vida. A muitas pessoas gostaria de estar agradecendo, neste momento, pela importância e contribuição que deram para que este trabalho fosse concluido.

Ao professor e amigo Jorge Silva Bettencourt pela compreensão, paciência e valiosa orientação e, principalmente, pelo exemplo de pessoa e profissional.

À amiga e excelente orientadora, Rosa Maria Bello, por sua determinação e disposição tanto em ensinar, assim como em aprender, sobre o universo de tão pequeninas inclusões fluidas.

Aos professor e amigo João Moreschi pelas inúmeras conversas sobre depósitos, jazidas, ouro, e tantas coisas em comum.

Ao professor Valdecir Janasi por sua grande contribuição e paciência na orientação dos estudos de petroquímica.

Ao colega de turma e professor Colombo Celso Tassinari pela valiosa ajuda na análise e interpretação dos dados de geocronologia.

Ao amigo e colega Candeias por sua ajuda inestimável nos intrincados, para mim, problemas de análise estrutural e na colaboração, tão esmerada e dedicada, na confecção da tese. Em especial, pela sua presença amiga e paciente neste período de tantas dificuldades.

À Mineração Novo Astro e toda sua equipe de geólogos que, à época dos levantamentos de campo, deram todo o apoio financeiro e troca de conhecimentos, sobre a Mina de Salamangone.

À Diretoria do Instituto Geológico, em especial a seus diretores Cláudio José Ferreira e Ricardo Vedovello pelo apoio institucional e liberação para que pudesse concluir meus estudos.

À FAPESP pelo apoio financeiro mediante projeto de auxílio a pesquisa, coordenado pelo professor Jorge Silva Bettencourt, que permitiu a realização das análises necessárias para o desenvolvimento dos estudos.

A todos os colegas e amigos do Instituto Geológico, em especial, ao Tarcísio, Hélio Shimada, José Maria, Francisco Negri, pelo grande apoio e tantas horas de lazer e despreocupação. Ao Paulo Padilha pela paciência em me ajudar com os mapas.

A tantos colegas e amigos da pós-graduação que estiveram comigo durante todos esses anos que, nomeá-los seria deixar alguém esquecido. Por isso, a todos, quero agradecer muito a amizade, o coleguismo, as discussões e tantas coisas importantes que aconteceram. 
Aos amigos e valiosos colaboradores deste Instituto de Geociências, que com seu trabalho nos laboratórios, biblioteca, xerox, gráfica e administração, foram de fundamental importância no andamento dos meus trabalhos.

À amiga de peso, Panzer, por sua ajuda e grande espirituosidade, perante tudo que a vida nos oferece.

À Nice e Nena, duas grandes amigas, sem as quais não poderia, nestes últimos anos, ter avançado na vida.

Aos meus filhos, Melanie e Matias, pelo amor, carinho e paciência que têm me dedicado. 


\section{SUMÁRIO}

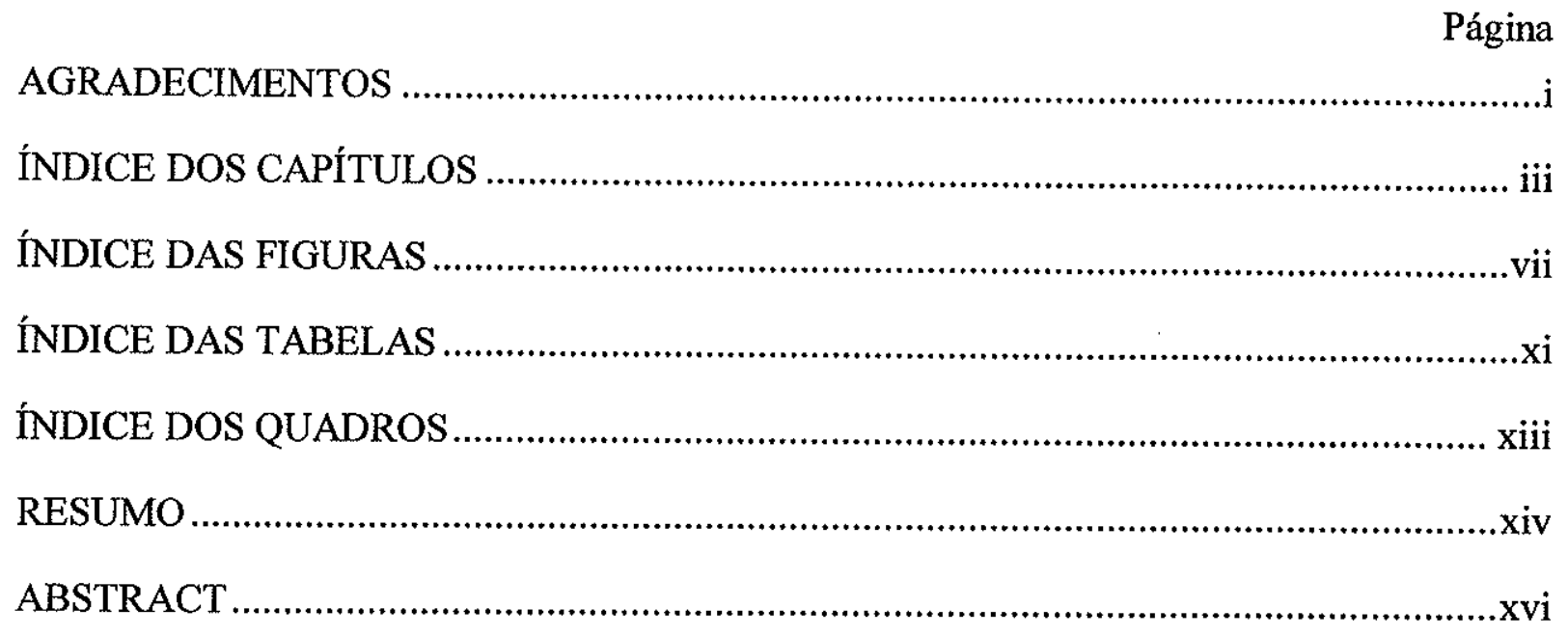

\section{ÍNDICE DOS CAPÍTULOS}

CAPÍTULO 1: Introdução .01

1.1. Fundamentos .01

1.2. O Estágio Atual do Conhecimento de Depósitos Filonares de Ouro................................02

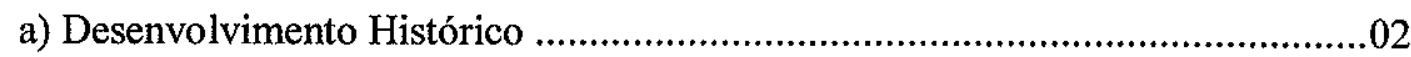

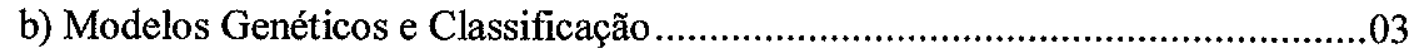

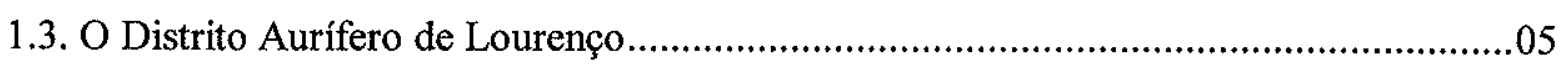

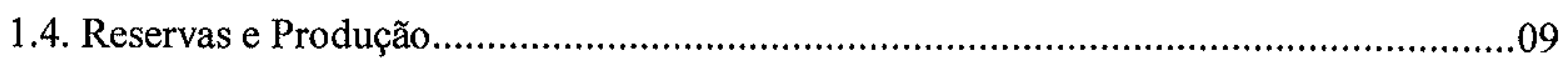

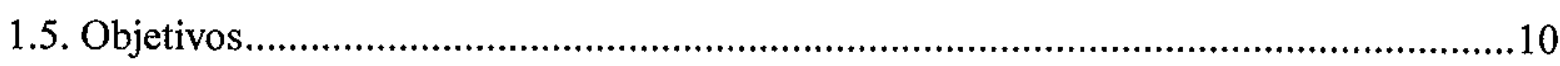

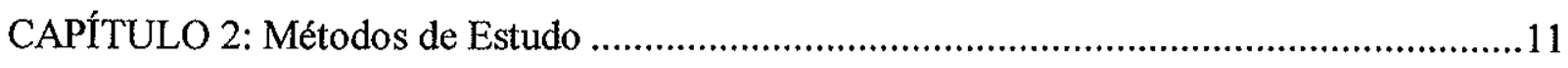

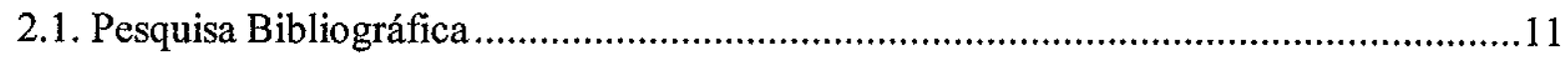

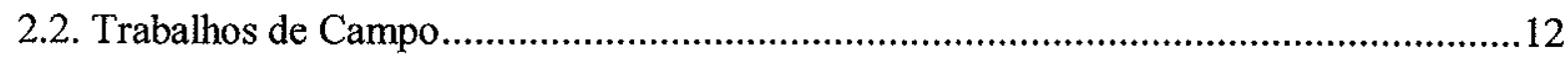

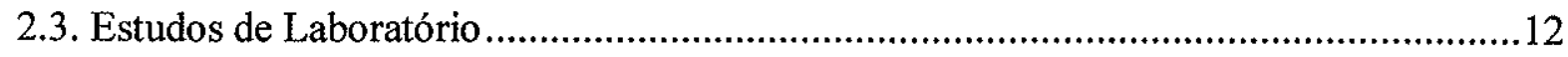

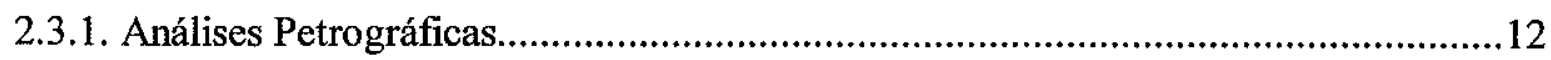

2.3.2. Análises Químicas em Rocha Total................................................................ 14

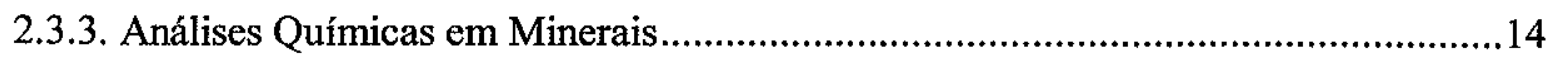

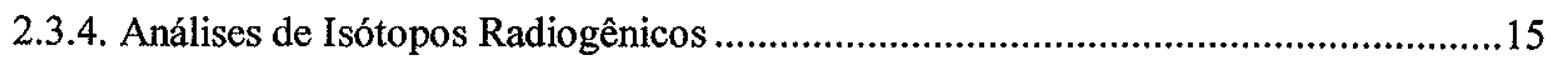

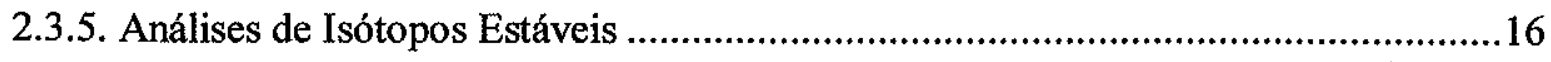

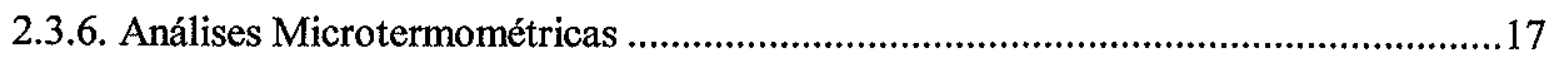




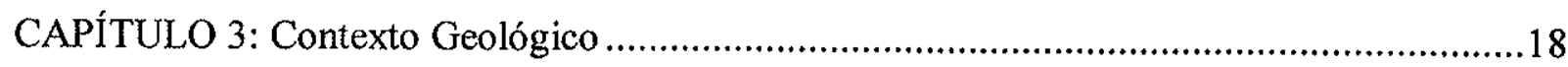

3.1. Histórico do Conhecimento Geológico Regional ......................................................18

3.2. Geologia do Distrito Aurífero de Lourenço..............................................................21

3.2.1 Súmula da Geologia do Distrito Aurífero de Lourenço, segundo Terraconsult (1986)

3.2.2. Geologia do Distrito Aurífero de Lourenço via análise integrada de dados geofísicos, geológicos e de sensoreamento remoto ..................................27

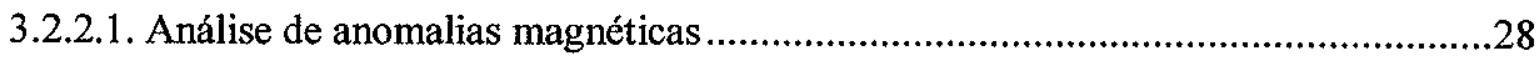

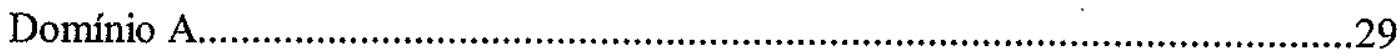

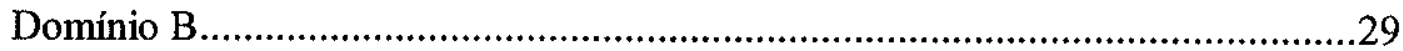

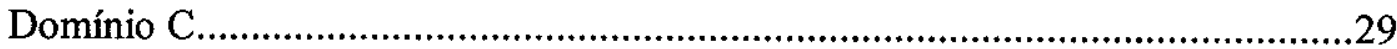

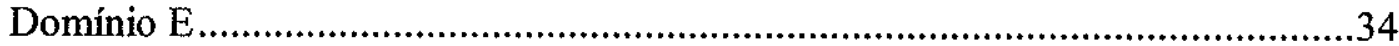

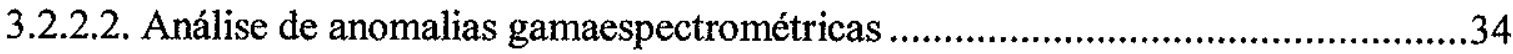

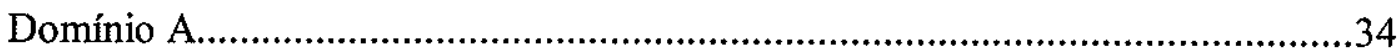

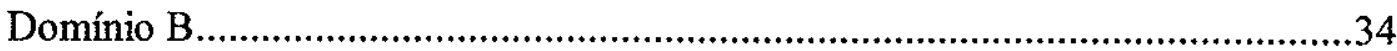

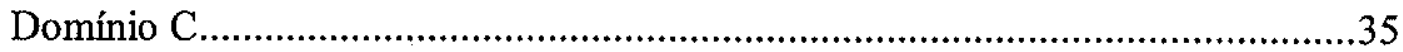

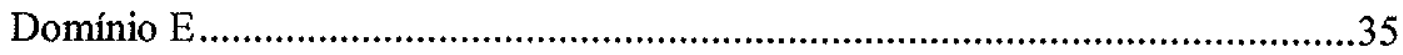

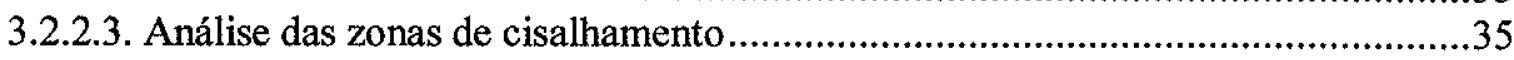

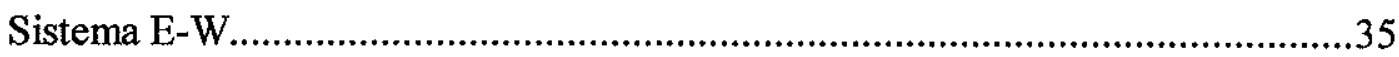

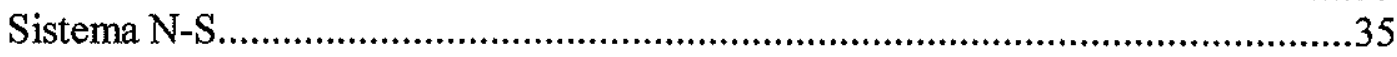

Sistema de lineamentos regionais conjugados $\mathrm{N} 60^{\circ} \mathrm{W}$ e $\mathrm{N} 60^{\circ} \mathrm{E}$..........................36

Sistemas lineares $\mathrm{N} 40^{\circ}-45^{\circ} \mathrm{W}, \mathrm{N} 10^{\circ}-30^{\circ} \mathrm{W}, \mathrm{N} 10^{\circ}-30^{\circ} \mathrm{E}$ e $\mathrm{N} 70^{\circ}-75^{\circ} \mathrm{W}$................36

CAPÍTULO 4: Geologia da Área da Mina de Salamangone ...............................................37

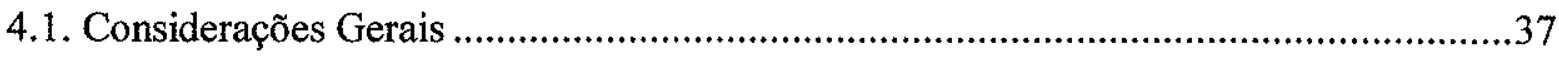

4.2. As Rochas Encaixantes da Mineralização ..............................................................42

4.2.1. A associação tonalítica-granodiorítica.........................................................42

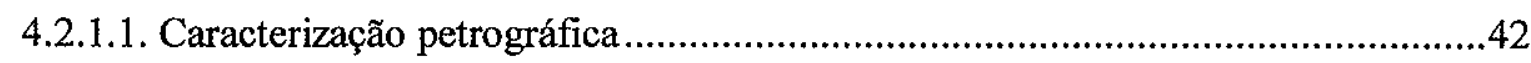

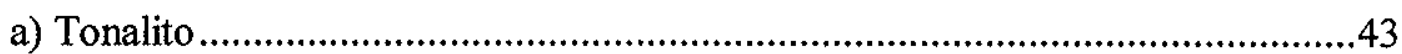

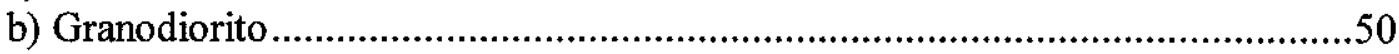

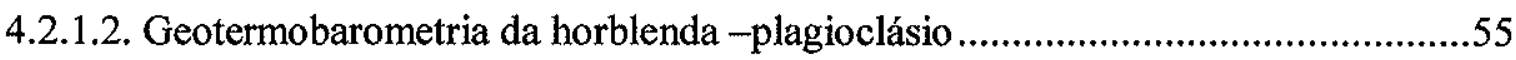

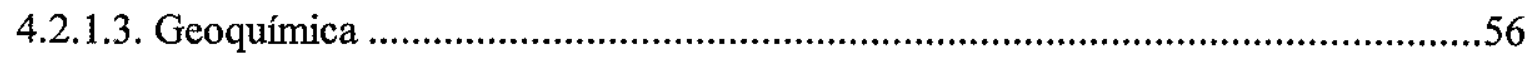

Afinidades geoquímicas.............................................................................5. 57

Comportamento dos elementos maiores e traços ...............................................57

Elementos Terras Raras e padrão dos elementos expandidos............................62

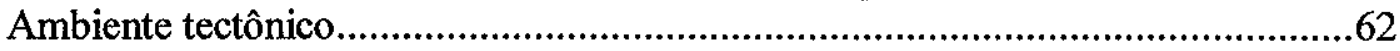

Comparação com granitóides de outras regiões................................................65

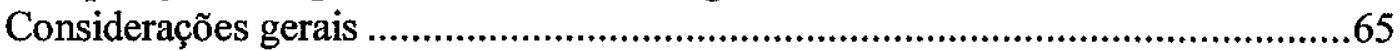

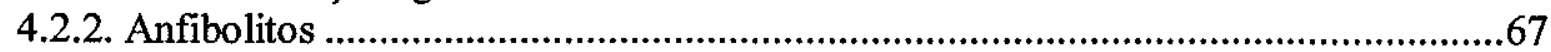

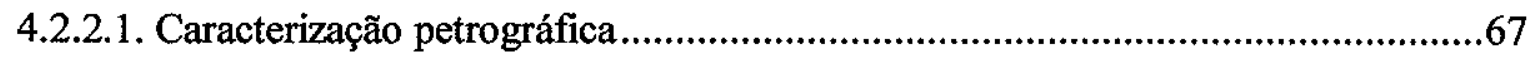




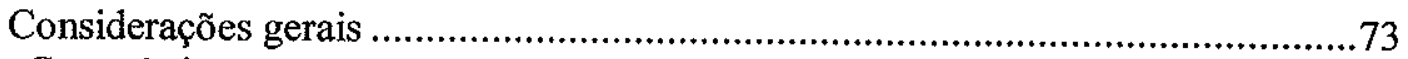

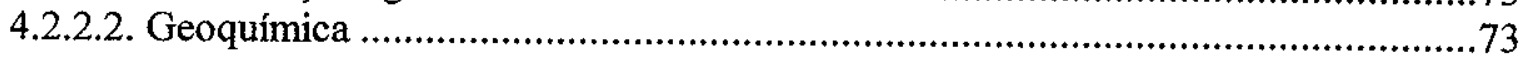

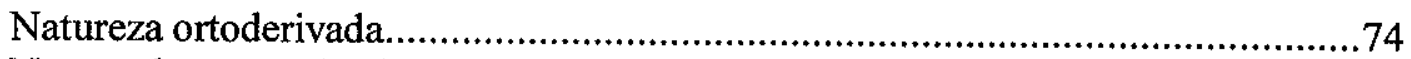

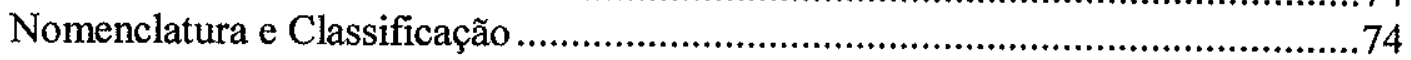

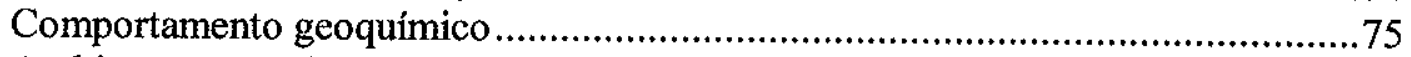

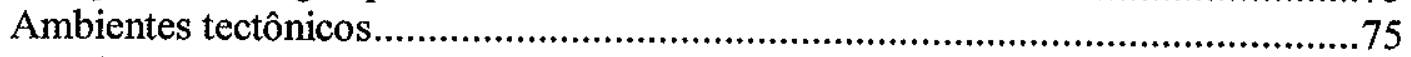

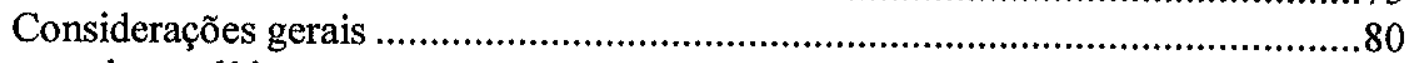

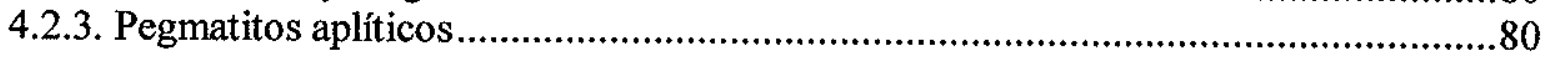

CAPÍTULO 5: Geocronologia e Geoquímica Isotópica das Rochas Encaixantes da Mineralização ............................................................................. 82

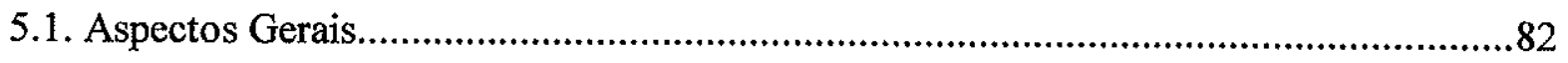

5.2- Dados Geocronológicos da Mina de Salamagone e sua Interpretação .........................84

5.3. Análise Comparativa com Outras Áreas da Província Maroni-Itacaíunas ....................87

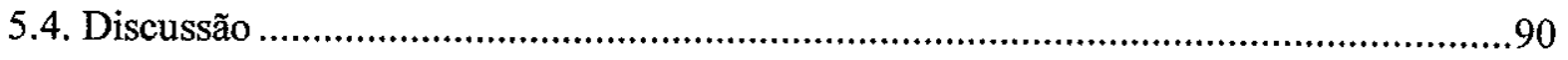

CAPÍTULO 6: O Sistema Filoneano do Depósito de Salamangone ......................................91

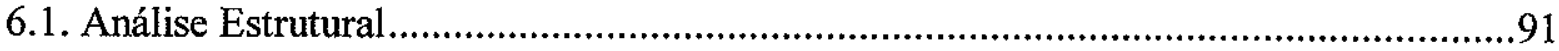

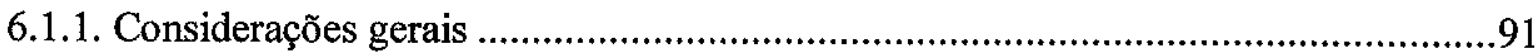

6.1.2. Foliação milonítica $(\mathrm{X})$ e cisalhamento dúctil-rúptil ou rúptil $(\mathrm{Cz})$.......................92

6.1.3. Juntas e falhas pós intrusão de pegmatitos ........................................................93

6.1.4. Indicadores cinemáticos : estrias e lineação mineral.............................................98

6.2. Feições Geométricas e Estruturais do Sistema Filoniano...........................................98

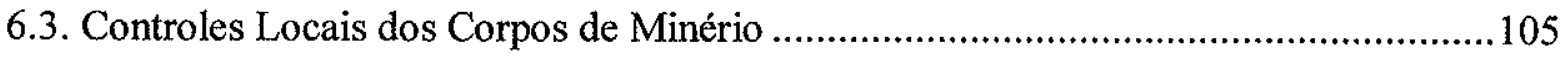

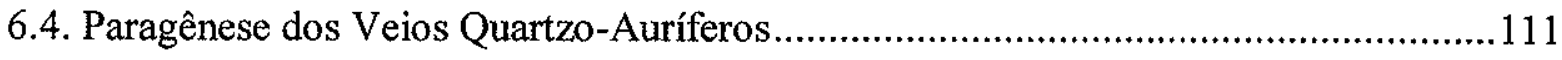

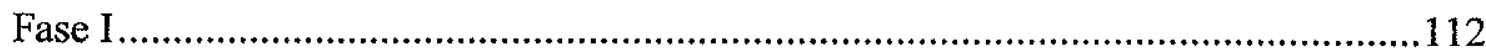

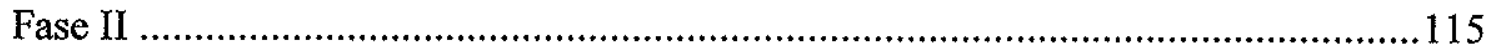

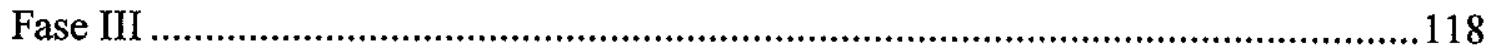

Composição química dos sulfetos e geotermometria da arsenopirita........................118

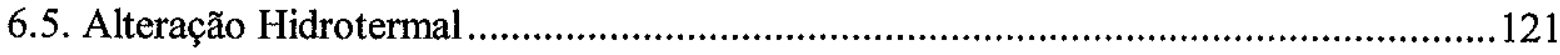

6.6. Mudanças Químicas que acompanham a Alteração Hidrotermal ..............................125

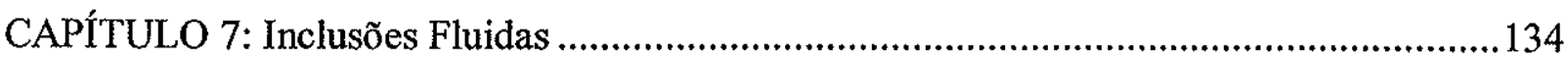

7.1. Ocorrência e Natureza das Inclusões Fluidas ..................................................134

7.2- Microtermometria Das Inclusões Fluidas.........................................................136

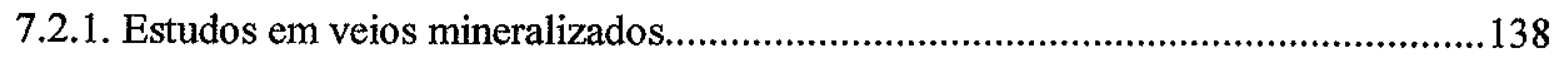


7.2.1.1. Veios mineralizados não orientados .138

a) Sistema salino com eutéticos muito baixos..............................................138

b)-Sistema salino com eutéticos entre $-53^{\circ} \mathrm{C} \mathrm{e}-41^{\circ} \mathrm{C}$......................................139

7.2.1.2. Veios de quartzo mineralizados orientados....................................................144

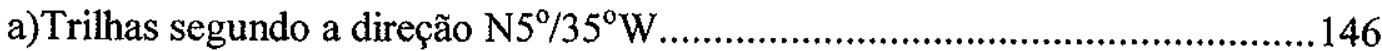

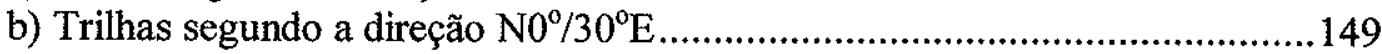

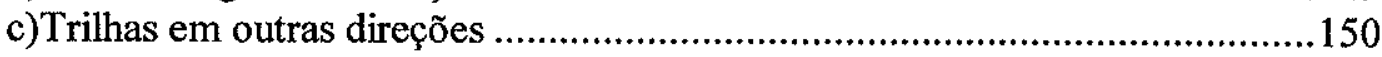

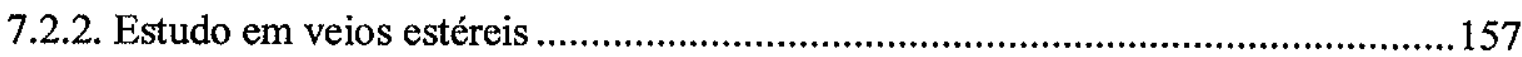

a)-Sistema salino com eutéticos entre $-49^{\circ} \mathrm{Ce}-42^{\circ} \mathrm{C}$.....................................157

b)-Sistema salino com eutéticos entre $-65^{\circ} \mathrm{C}$ e $-58^{\circ} \mathrm{C}$....................................... 157

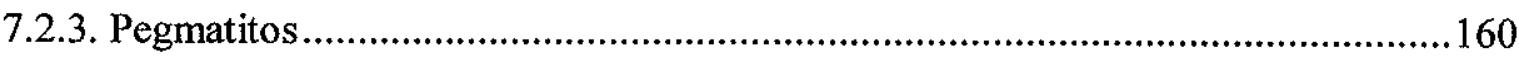

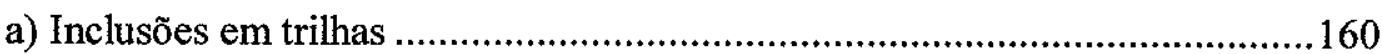

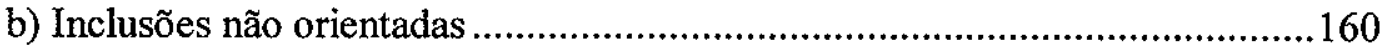

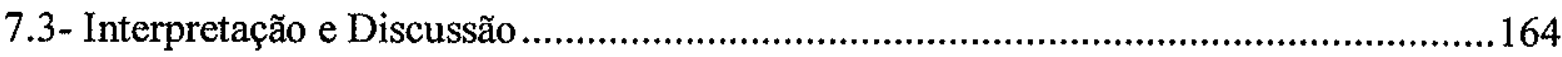

Controle estrutural de trilhas e inclusões fluidas..................................................165

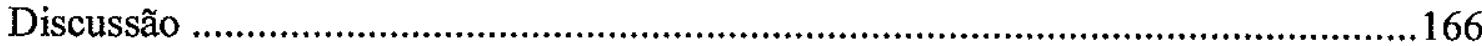

CAPÍTULO 8: Isótopos Estáveis: Estudos Preliminares....................................................168

8.1. Introdução

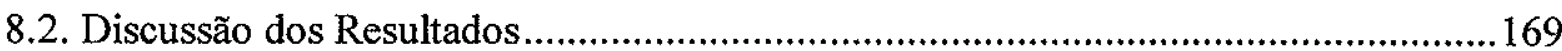

CAPÍTULO 9: As condições de formação do depósito de Salamangone: modelo genético preliminar.................................................................................173

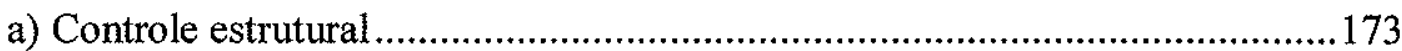

b) A idade da mineralização ....................................................................173

c) Processos de transporte e deposição do ouro ....................................................174

d) A evolução do sistema hidrotermal aurífero...................................................176

e) Modelo genético preliminar ...........................................................................179

CAPÍTULO 10 - Considerações Finais ..............................................................................183

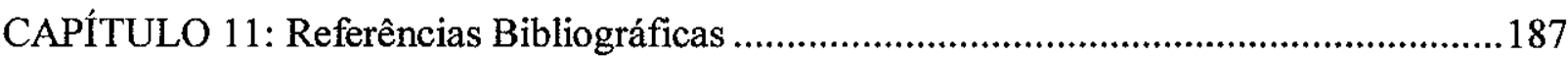

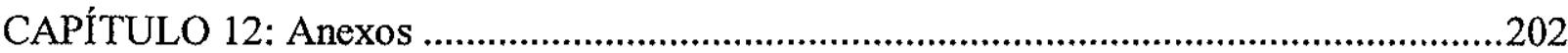




\section{ÍNDICE DAS FIGURAS}

Figura 1.1 - Localização do Distrito Aurífero de Lourenço .07

Figura 1.2 - a) Vista aérea da Mina de Salamangone. b) Vista geral da cava, observando-se os antigos taludes da mina a céu aberto. c) Detalhe da entrada da mina subterrânea

Figura 2.1 - Localização dos furos de sondagem e pontos de afloramentos.

Figura 3.1 - Localização do Distrito Aurífero de Lourenço no Amapá na Província Maroni-Itacaíunas

Figura 3.2. Esboço geológico do Estado do Amapá.........................................................20

Figura 3.3 - Esboço da região abrangida pelo Escudo das Guianas .......................................21

Figura 3.4 - Esboço geológico do Distrito Aurífero de Lourenço, AP.....................................25

Figura 3.5 - Localização das áreas de levantamento aerogeofísico..........................................28

Figura 3.6 - Mapa de contorno de campo magnético. Região de Lourenço ..............................30

Figura 3.7 - Mapa de sombras. Região do Lourenço …………..........................................31

Figura 3.8 - Mapa de interpretação de dados de levantamentos magnetométricos e gamaespectométricos.............................................................32

Figura 3.9 - Mapa de interpretação de dados de levantamentos aeromagnéticos ......................33

Figura 4.1 - Mapa geológico (simplificado) das galerias do nível $358 \mathrm{~m}$...............................38

Figura 4.2 - Mapa geológico das galerias do nível $345 \mathrm{~m}$.....................................................39

Figura 4.3 - Geologia do nível $54 \mathrm{~m}$ da Mina de Salamangone...............................................40

Figura 4.4 - Relações de contato entre as rochas encaixantes da mineralização quartzo-aurífera .....

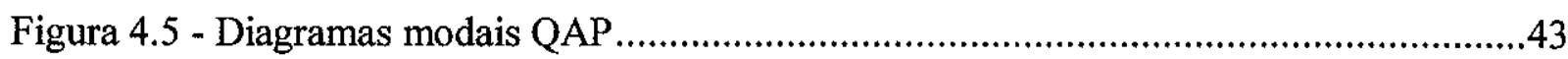

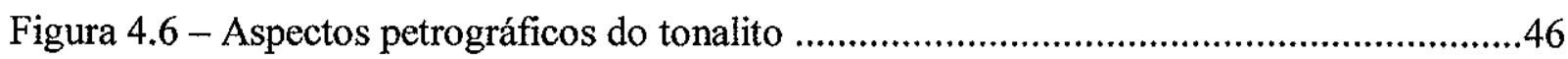

Figura 4.7 - a) Diagrama de classificação de plagioclásios; b) Diagrama de variação catiônica para biotita; c e d) Diagramas de classificação e composição de anfibólios.

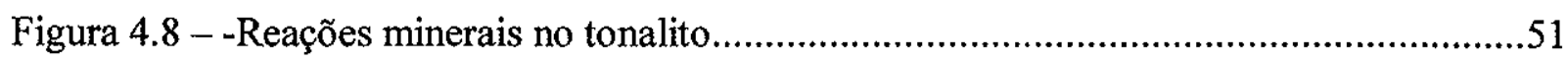

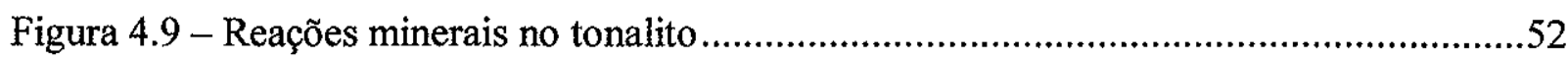

Figura 4.10 - a) Rocha tonalítica alterada pela ação dos fluidos mineralizantes......................53

Figura 4.11 - Aspectos petrográficos do granodiorito ………………….......................54

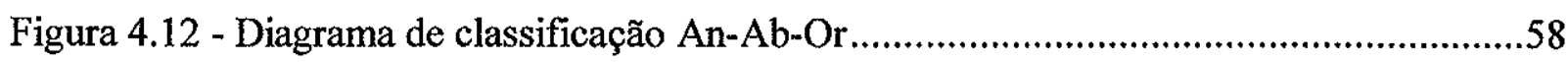

Figura 4.13 - a e b) Diagramas normativos Q-Ab-Or e K-Na-Ca.............................................58

Figura 4.14 - a) Diagrama ( La/Yb)N vs. $Y b N$; b) Diagrama $\mathrm{Sr} / \mathrm{Y}$ vs. $\mathrm{Y}$ e c)

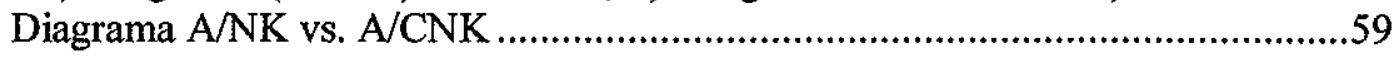

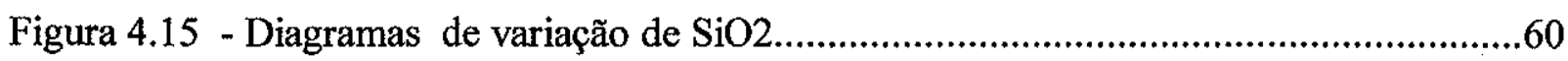


Figura 4.16 - Diagramas de variação entre elementos maiores (\%) e elementos traços (ppm)

Figura 4.17 - Diagramas a) padrão de distribuição dos ETR e b) padrões de elementos expandidos

Figura 4.18 - Diagramas de discriminação tectônica.

Figura 4.19 - Diagramas de comparação entre os granitóides da Mina de

Salamangone e tonalitos da área Cayenne-Régina, na Guiana Francesa .66

Figura 4.20 - Aspectos petrográficos do anfibolito .69

Figura 4.21 - Aspectos petrográficos do anfibolito .70

Figura 4.22 - a e b) Diagramas de classificação e composição de anfibólios 72

Figura 4.23 - Diagramas para caracterização da origem dos protolitos das rochas anfibolíticas. .76

Figura 4.24. Diagramas de classificação química dos anfibolitos .77

Figura 4.25- Diagramas de: a) sílica vs. álcalis e b) AFM. .77

Figura 4.26 - Padrão de distribuição dos ETR .78

Figura 4.27 - Padrão de distribuição dos elementos incompatíveis .78

Figura 4.28. Diagrama $\mathrm{K} 2 \mathrm{O}$ vs. TiO2 vs. $\mathrm{P} 2 \mathrm{O} 5$ .79

Figura 4.29 - Diagramas triangulares discriminantes de ambientes tectônicos .79

Figura 4.30 - Aspectos do pegmatito

Figura 5.1 - Diagrama isocrônico U/Pb. .85

Figura 5.2. Diagrama de evolução isotópica $\varepsilon(\mathrm{Nd})$ versus tempo geológico $\mathrm{T}(\mathrm{Ga})$ .85

Figura 5.3. Diagramas isocrônicos $\mathrm{Rb} / \mathrm{Sr}$ .88

Figura 6.1 - a) Superfícies de cisalhamento rúptil $(\mathrm{Cz})$, b) Destaque da superficie de cisalhamento, c) Detalhe da zona de cisalhamento .94

Figura 6.2 - a) Vista do talude da Lapa, b) Detalhe da fotografia anterior, notando-se o padrão anastomosado da zona de cisalhamento, c) Travessa de acesso ao nível $274 \mathrm{~m}$.

Figura 6.3 - Estereogramas de contorno de pólos das normais .97

Figura 6.4 - Projeção superficial, na cava, dos veios de quartzo auríferos 100

Figura 6.5 - Seção transversal (integrada) ao sistema filoneano .101

Figura 6.6 - Planta integrada exibindo as projeções dos veios Principal, Capa e Lapa nos níveis inferiores

Figura 6.7 - Domínios dos corpos de minério Capa, Principal e Lapa .103

Figura 6.8 - Desenho esquemático da frente de lavra do Filão Capa, no nível $264 \mathrm{~m}$, cabeceira sul, da Mina de Salamangone

Figura 6.9 - Desenho esquemático da frente de lavra do Filão Principal, no nível $290 \mathrm{~m}$. 
Figura 6.10 - Desenho esquemático da frente de lavra do Filão da Lapa, no nível $264 \mathrm{~m}$

Figura 6.11 - Feições de deformação nos veios de quartzo de Salamangone

Figura 6.12 - Projeção ortogonal em planta dos corpos mineralizados nos níveis $334 \mathrm{~m}$ e $224 \mathrm{~m}$

Figura 6.13 - Seqüência paragenética esquemática do sistema de veios de quartzo

Figura 6.14 - Feições de deformação do quartzo.

Figura 6.15. Fase I da mineralização no depósito de Salamangone.

Figura 6.16 - Fase II da mineralização no depósito de Salamangone

Figura 6.17 - Aspectos da forma de ocorrência do ouro na Fase II de mineralização

Figura 6.18 - Campos de estabilidade das fases minerais do sistema Fe-As-S

Figura 6.19 - Aspectos relativos à alteração hidrotermal do tonalito no depósito de Salamangone.

Figura 6.20 - Zoneamento lateral da alteração hidrotermal em torno dos veios de quartzo

Figura 6.21 - Representação gráfica, através do diagrama "isocon" do balanço de massa entre as amostras do tonalito R-01 e R-27

Figura 6.22 - Representação gráfica, através do diagrama "isocon" do balanço de massa entre as amostras do tonalito R-01 e R-11

Figura 6.23 - Representação gráfica, através do diagrama "isocon" do balanço de massa entre as amostras do tonalito SHN-11 e SHN-29

Figura 6.24 - Representação gráfica, através do diagrama "isocon" do balanço de massa entre as amostras do tonalito SHN-11 e SHN-17.

Figura 6.25 - Seção $\mathrm{S} 30^{\circ} \mathrm{W}$ (nível $345 \mathrm{~m}$ ) ilustrando as concentrações e o halo de dispersão de Au e As.

Figura 6.26 - Seção S30 $\mathrm{W}$ (nível $345 \mathrm{~m}$ ) ilustrando as concentrações e o halo de dispersão de Au e As.

Figura 6.27 - Perfis mostrando a variação da composição dos óxidos das amostras de tonalito

Figura 7.1 - Aspectos da forma de ocorrência das inclusões fluidas em quartzo do depósito de Salamangone

Figura 7.2 - Histogramas de freqüências das temperaturas de mudança de fase das inclusões em quartzo de veios mineralizados (amostras não orientadas)....

Figura 7.3 - Histogramas de freqüências das temperaturas de mudança de fase das inclusões em quartzo de veios mineralizados (amostras não orientadas)

Figura 7.4 - Inclusões fluidas em quartzo de veios mineralizados 
Figura 7.5 - Amostra R-22, orientada segundo a direção $\mathrm{N} 40^{\circ} \mathrm{W}$ do veio de quartzo Principal.

Figura 7.6 - Rosácea representando a orientação dos principais planos de fraturas portadoras de inclusões fluidas.

Figura 7.7 - Rosácea representando a orientação dos principais planos de fraturas portadoras de inclusões fluidas.

Figura 7.8 - Histogramas de freqüências das temperaturas de mudança de fase das inclusões em quartzo de veios mineralizados (amostras orientadas)

Figura 7.9 - Histogramas de freqüências das temperaturas de mudança de fase das inclusões em quartzo de veios mineralizados (amostra orientada)

Figura 7.10 - Diagrama Tfg vs Te para inclusões dispostas em trilhas $\mathrm{N} 5 / 35^{\circ} \mathrm{W}$.

Figura 7.11 - Diagrama Tfg vs Te para inclusões dispostas em trilhas N0/30 ${ }^{\circ} \mathrm{E}$

Figura 7.12 - Diagrama ThL-V(L) para inclusões dispostas em trilhas $\mathrm{N} 5 / 35^{\circ} \mathrm{W}$.

Figura 7.13 - Diagrama ThL-V(L) para inclusões dispostas em trilhas $\mathrm{N} 0 / 30^{\circ} \mathrm{E}$

Figura 7.14 - Histogramas de freqüuencias das temperaturas de mudança de fase das inclusões em quartzo de veios mineralizados (amostra orientada)

Figura 7.15 - Histogramas de freqüências das temperaturas de mudança de fase das inclusões em quartzo de veios mineralizados (veio estéril)

Figura 7.16 - Inclusões fluidas em veio de quartzo estéril e pegmatito

Figura 7.17 - Histogramas de freqüências das temperaturas de mudança de fase das inclusões em quartzo de veios mineralizados (pegmatito)

Figura 8.1 - Valores de $\delta{ }^{18} \mathrm{O}$ dos veios de quartzo-auríferos de Salamangone e de depósitos da Austrália.

Figura 9.1 - A) Diagrama isocrônico $\mathrm{Pb} / \mathrm{Pb}$ de cristais de arsenopirita, da fase I da mineralização. $\mathrm{B}$ e C) Dados de composição isotópica de $\mathrm{Pb}$ de arsenopirita, em curvas de evolução do modelo de plumbotectônica,

Figura 9.2 - A) Diagrama esquemático dos ambientes tectônicos de depósitos minerais epigenéticos, enriquecidos em ouro 


\section{ÍNDICE DAS TABELAS}

Tabela 2.1 - Elementos analisados, métodos e limites de detecção (\% em peso para os elementos maiores; ppm para elementos menores, traços e terras raras, e ppb para $\mathrm{Au}, \mathrm{Pt}$ e $\mathrm{Pd}$ )

Tabelas 4.1a - Análise modal do tonalito

Tabelas $4.1 \mathrm{~b}$ - Análise modal do granodiorito

Tabela 4.2a - Composições químicas e proporções catiônicas $(\mathrm{O}=32)$ para plagioclásios, de rocha tonalítica pouco afetados pela mineralização

Tabela 4.3 - Composições químicas e proporções catiônicas $(\mathrm{O}=22)$ para biotita de amostras de tonalito pouco afetado pela mineralização

Tabela 4.4 Composições químicas e proporções catiônicas $(\mathrm{O}=23)$ para anfibólios, de amostras de tonalito pouco afetado pela mineralização

Tabela 4.5 - Temperaturas obtidas do geotermômetro hornblenda-plagioclásio $\mathrm{T}(\mathrm{Hbl}-\mathrm{Pl})$, em amostras de tonalito pouco afetado pela mineralização

Tabela 4.6a - Análises químicas de elementos maiores (\%) e traços (ppm) em rocha total de tonalito

Tabela 4.6b - Análises químicas de elementos terras raras - ETR (ppm) em rocha total de tonalito

Tabela 4.6c - Análises químicas de elementos maiores (\%) e traços (ppm) em rocha total de granodiorito

Tabela 4.6d - Análises químicas de elementos terras raras - ETR (ppm) em rocha total de granodiorito

Tabela 4.7 - Análises químicas de tonalito da região de Cayenne-Reginá (c), na Guiana Francesa

Tabela 4.7 - Norma CIPW do tonalito (a) e granodiorito (b) da Mina de Salamangone e de tonalito da área de Cayenne-Reginá (c), na Guiana Francesa

Tabela 4.9 - Análises modais dos anfibolitos, amostrados nas travessas de acesso aos Níveis 54 e $229 \mathrm{~m}$ da mina e nos furos de sondagem $\mathrm{SH}-77$ e FI-121

Tabela 4.10 - Composições químicas e proporções catiônicas $(\mathrm{O}=23)$ para anfibólios de amostras de anfibolito

Tabela 4.11 - Composições químicas e proporções catiônicas $(\mathrm{O}=32)$ para plagioclásios de amostras de anfibolito

Tabela 4.12 - Composições químicas e proporções catiônicas $(\mathrm{O}=22)$ para biotita de amostras de anfibolito

Tabela 4.13 - Análises químicas das rochas anfibolíticas amostradas na galeria do nível $345 \mathrm{~m}$ 
Tabela 5.1 - Composição isotópica U/Pb em zircão de tonalito 228

Tabela 5.2 - Composição isotópica $\mathrm{Sm} / \mathrm{Nd}$ de tonalito e granodiorito. 229

Tabela 5.3 - Composição isotópica $\mathrm{Rb} / \mathrm{Sr}$ do tonalito, granodiorito, aplito e tonalito hidrotermalizado

Tabela 5.4 - Composição isotópica K-Ar em biotita do tonalito

Tabela 6.1 - Resumo das atitudes médias das famílias de descontinuidades das zonas de cisalhamento na cava a céu aberto e níveis inferiores de lavra subterrânea.

Tabela 6.2 - Resumo dos parâmetros estruturais das zonas de cisalhamento e dos corpos de minério, no nível $274 \mathrm{~m}$.

Tabela 6.3 - Dimensões dos corpos de minério Principal, Capa e Lapa, que constituem o sistema filoneano do depósito de Salamangone, a partir do nível $345 \mathrm{~m}$

Tabela $6.4 \mathrm{a}$ - Análises químicas de arsenopirita, da fase I da mineralização, dos filões Capa, Lapa e Principal

Tabela $6.4 \mathrm{~b}$ - Análises químicas de arsenopirita, da fase II da mineralização, dos filões Capa, Lapa e Principal

Tabela 6.4c - Análises químicas da pirrotita, lollingita e calcopirita da fase I da mineralização, dos filões Capa, Lapa e Principal

Tabela $6.4 \mathrm{~d}$ - Análises químicas de pirita, da fase II da mineralização, dos filões Capa, Lapa e Principal.

Tabela 6.4e - Análises químicas de ouro das fases I e II da mineralização, dos filões Capa, Lapa e Principal

Tabela 6.5a - Análises químicas de elementos maiores (\%) e traços (ppm), $\mathrm{Au}, \mathrm{Pt}$ e $\mathrm{Pd}(\mathrm{ppb})$, em rocha total de tonalito da travessa de acesso ao nível $54 \mathrm{~m}$

Tabela $6.5 \mathrm{~b}$ - Análises químicas de elementos maiores (\%) e traços (ppm), $\mathrm{Au}, \mathrm{Pt}$ e Pd (ppb), em rocha total, de amostras de tonalito do furo de sondagem SH-140, localizado na capa dos corpos de minério

Tabela 7.1 - Dados microtermométricos em veios de quartzo mineralizado e estéril e dos pegmatitos.

Tabela 8.1 - Composição isotópica do conjunto dos minerais amostrados e resultados termométricos

Tabela 9.1 - Dados isotópicos $\mathrm{Pb} / \mathrm{Pb}$ de cristais de arsenopirita da fase $\mathrm{I}$ de mineralização 


\section{ÍNDICE DOS QUADROS}

Quadro 1.1 - Reservas do minério primário, lavrado até à época do fechamento da mina.

Quadro 1.2 - Evolução da produção de minérios secundário e primário (*Dados relativos à produção até julho de 1995)

Quadro 3.1 - Unidades litológicas identificadas na região centro-leste do Amapá e tentativa de correlação estratigráfica (Terraconsult 1986)

Quadro 9.1 - Sumário dos atributos essenciais do Depósito de Salamangone 180 


\section{RESUMO}

O Distrito Aurífero de Lourenço, localizado na região centro-norte do Estado do Amapá, insere-se na Província Geocronológica Maroni-Itacaíunas, de idade Paleoproterozóica, onde ocorrem rochas supracrustais que foram afetadas por metamorfismo de alto grau e parcialmente migmatizadas, bem como complexos cálcio-alcalinos.

$O$ depósito de Salamangone hospeda-se em granitóides de composição tonalítica a granodiorítica, de caráter cálcio-alcalino, metaluminosos a levemente peraluminosos. Exibem concentrações relativamente elevadas de LILE e TR leves e baixas taxas de $\mathrm{Nb}$, Ta, Ti e $\mathrm{Zr}$, indicando que teriam sido gerados em ambiente de arco vulcânico.

Análises U-Pb (zircão) em tonalito forneceram idade de cristalização de $2,16 \mathrm{Ga}$, enquanto dados de $\mathrm{Sm} / \mathrm{Nd}$ indicam idades modelo $\left(\mathrm{T}_{\mathrm{DM}}\right.$ ) da ordem de 2,34Ga (granodiorito) e $2,24 \mathrm{Ga}$ (tonalito), com valores positivos de $\varepsilon_{\mathrm{Nd}}\left(\mathrm{T}_{\mathrm{DM}}\right),+2,88$ (granodiorito) e $+3,02$ (tonalito), permitindo interpretar que os protólitos desses granitóides foram diferenciados diretamente do manto, com pequena residência crustal, e estariam relacionados a arco juvenil Paleoproterozóico. A isócrona de referência $\mathrm{Rb} / \mathrm{Sr}$ (rocha total) dos granitóides apontou uma razão inicial em torno de 0,702 , indicando uma fonte mantélica (juvenil) para o magma gerador dessas rochas, corroborando os dados de geoquímica.

A mineralização aurífera consiste em um sistema de veios de quartzo epigenéticos, enriquecidos em Au e As, controlado por uma zona de cisalhamento dúctil-rúptil. O sistema filoniano compreende três corpos principais, designados de Capa, Principal e Lapa, considerados como sendo veios de cisalhamento ou veios em falhas, tipificados por uma estrutura laminada ou em ribbon, a indicar episódios repetidos de fraturamentos e deposição mineral. A paragênese dos veios comporta 2 fases principais de mineralização: a Fase $\mathrm{I}$, de maior deposição de quartzo, associada a processos de interação rocha-fluido, que provocou a sulfetação intensa na rocha tonalítica encaixante, e, predominantemente, em ribbons dentro dos veios, originando arsenopirita, lollingita, pirrotita e calcopirita, ressalvando-se que o ouro ocorre, principalmente, nos limites da arsenopirita e lollingita. Esta fase de mineralização se formou num intervalo de temperaturas, entre $400^{\circ}$ e $565^{\circ} \mathrm{C}$, estas calculadas por meio do geotermômetro arsenopirita. Datação $\mathrm{Pb} / \mathrm{Pb}$ em cristais de arsenopirita desta Fase I forneceram uma isócrona $\mathrm{Pb}-\mathrm{Pb}$ de referência de $2002 \pm 61 \mathrm{Ma}$ e a composição isotópica sugere um reservatório crustal mais profundo para o $\mathrm{Pb}$, entre as curvas, de evolução da crosta superior e de ambiente orogênico; a Fase II de mineralização constitui o episódio principal de deposição do ouro. Este ocorre sob a forma livre e associado à arsenopirita, pirita e galena e 
resultou de processos de remobilização, a partir de soluções aquosas de alta salinidade, atuantes ao longo da zona de cisalhamento. Os processos de alteração hidrotermal envolveram, principalmente, silicificação, sulfetação, saussuritização e cloritização da rocha tonalítica encaixante, desenvolvendo uma zona distal com pouca influência da mineralização, e uma zona proximal onde o balanço químico indica ganhos acentuados em $\mathrm{As}$ e $\mathrm{Au}$, com pequena participação de $\mathrm{MgO}$ e $\mathrm{CaO}$ e perdas de $\mathrm{Al}_{2} \mathrm{O}_{3}, \mathrm{~K}_{2} \mathrm{O}$ e $\mathrm{Na}_{2} \mathrm{O}$.

Inclusões fluidas primárias, contendo soluções responsáveis pela Fase I de mineralização, não foram preservadas, tendo sido destruídas por vários episódios superpostos de deformação, responsáveis pela grande quantidade de planos de inclusões fluidas secundárias, observados nas amostras de quartzo. Uma solução aquosa complexa, contendo $\mathrm{Ca} \pm \mathrm{As}(?)$, extremamente salina, aprisionada em inclusões fluidas, contidas em um conjunto de trilhas com direção entre $\mathrm{N}^{\circ}-35^{\circ} \mathrm{W}$, pode ter sido responsável pela remobilização e precipitação do ouro primário, durante a Fase II de mineralização. A recorrência de episódios de deformação com aporte e circulação de novos fluidos dentro da zona de cisalhamento, que hospeda o depósito de Salamangone, é demonstrada pela presença flagrante de soluções, essencialmente aquosas e com salinidades variadas, que indicam um amplo processo de mistura, envolvendo um fluido extremamente salino que evolui para termos com composições de salinas cada vez mais baixas. A origem dessas soluções pode, provavelmente, ser atribuída a uma mistura de salmouras profundas de natureza metamórfica, com fluidos hidatogênicos.

Os dados isotópicos, disponíveis para a área de Lourenço e regiões vizinhas, na Guiana Francesa e Guiana, sugerem um modelo de evolução crustal geodinâmico, baseado no desenvolvimento de um arco magmático cálcio-alcalino, entre 2250 e 2000Ma. Este fato pode ser interpretado admitindo-se a subducção de uma litosfera oceânica, pré-colisão, entre massas continentais representadas, à época, pela Província Central Amazônica (Bloco Carajás-Iricoumé) e pelo Craton do Oeste Africano.

Os períodos mais importantes de formação de depósitos de ouro orogênicos do Paleoproterozóico correlacionam-se, muito bem, com os episódios de crescimento da crosta continental juvenil, notando-se que os eventos de concentração de ouro se posicionam entre 2,1 e 1,8 Ga, incluindo a geração de importantes depósitos nos cratons do Oeste Africano e Amazônico e no Orógeno Trans-Hudsoniano (Goldfarb et al. 2001). Deste modo, Salamangone constituiria um depósito aurífero orogênico mesozonal, originado durante processos de deformações compressional a transpressional, em orógenos de acresção, associados à margem convergente Paleoproterozóica. 


\section{ABSTRACT}

The Lourenço Au-District is located in the central portion of the State of Amapá, within the Maroni-Itacaiunas Province, 2.2-1.95 Ga (Teixeira et al. 1989), of the Amazonian Craton. The Lourenço region is included within a Paleoproterozoic suite of high-grade partially migmatized metamorphic supracrustal rocks and calc-alkaline complexes.

The Salamangone gold deposit lies within a calc-alkaline, metaluminous to slightly peraluminous tonalite to granodiorite pluton. It is characterized by high contents of incompatible trace elements and LREE, showing a geochemical signature of volcanic-arc granites.

Zircons extracted from the tonalite were analyzed by the U-Pb method, and analytical points are plotted on a concordia diagram. The discordia calculated for 14 data points has an upper intersection at $2.16 \pm 0.13 G a$, the inferred crystallization age of the tonalite, and a lower intercept $0.48 \pm 0.13 \mathrm{Ga}$, respectively. The $\varepsilon_{N d}$ values were corrected using $2.16 \mathrm{Ga}$ age determined for the tonalite. The $\varepsilon_{N d(2.16 G a)}$ values vary from +2.88 to +3.02 , which suggest that the magmatic source region was mainly a depleted mantle with little or no contamination from Archean crust. The low initial ${ }^{87} \mathrm{Sr}{ }^{86} \mathrm{Sr}$ ratios obtained for both contemporaneous granodiorite and tonalite vary from 0.702 to 0.703 , in agreement with the Sm-Nd isotope data.

The deposit, clearly related to the epigenetic style of mineralisation, mainly encompass tree ore bodies, named: Filão Principal, Filão Capa and Filão Lapa. A ductilebrittle shear zone striking $N 50^{\circ}-60^{\circ} \mathrm{W}$ and dipping $55^{\circ}$ to $70^{\circ} \mathrm{NE}$ controls all of these veins.

The primary mineralisation consists of ribbon banded quartz veins enriched in Au and $A s$, exhibiting relatively low enrichment of $\mathrm{Ag}, \mathrm{Pb}, \mathrm{Cu}, \mathrm{Bi}$. On the basis of the internal structure and texture, the veins can be classified as laminated. The alteration processes so far recognized are represented by silicification, sulphidation, saussuritization and chloritization of the host tonalite, producing a proximal alteration zone marked by enrichment in As and Au and a poorly mineralized distal zone.

The textural and chronological relationships between the most common sulfide minerals, associated with the gold mineralisation, indicate a distinct paragenetic sequence, Stage I: arsenopyrite, pyrrotite, löllingite and chalcopyrite. Gold, located at grain boundaries between arsenopyrite and löllingite, is related to sulphidation hydrothermal processes. Temperatures yielded by the arsenopyrite thermometer are about 400 to $565^{\circ} \mathrm{C}$. For directly date the ore minerals, age determinations were made on samples of arsenopyrite by stepwise 
leaching technique using $\mathrm{Pb}-\mathrm{Pb}$ systematic. The analytical points define an isochron, which yield an age of $2002 \pm 61 \mathrm{Ma}$, consistent with the mineralisation stage I. The radiogenic Pb$\mathrm{Pb}$ isotopic composition suggests a deep orogenic crustal source for the Pb. Stage II: arsenopyrite, pyrite and minor galena. It was the predominant period of gold deposition, which is related to remobilization processes.

The primary stage I mineralization fluid inclusions are not at all preserved and recognized in the studied quartz samples, because they were destroyed by superposed episodes of deformation. However, abundant secondary aqueous healed fluid inclusions planes were observed. More complex $N 5^{\circ}-35^{\circ} \mathrm{W}$ trending $\mathrm{Ca} \pm \mathrm{As}$ (?) high salinity aqueous fluids, active during later stages of deformation within shear zone, are probably responsible for remobilization of gold from deeper levels, during stage II mineralization.

The wide range of salinities recorded in the aqueous fluid inclusions might be referred to the mixture of high-salinity aqueous fluids with low-salinity fluids. These fluids were probably derived from a mixture of deep metamorphic brines with shallow meteoric waters of deep circulation.

The isotopic data available for the Lourenço Au-District and neighboring regions in French Guiana and Guiana, strongly suggest a geodynamic crustal evolution model, based on the development of a calc-alkaline magmatic arc in the time interval $(2.25-2.0 \mathrm{Ga})$. This can be explained by subduction of oceanic lithosphere in the beginning of the collision between two continental masses composed at that time by the Central Amazonian Province-CarajásIricoumé Block and the West African craton.

The important periods of Archean and Paleoproterozoic orogenic gold-deposit formation correlate well with episodes of growth of juvenile continental crust, where the goldforming events concentrated between 2.1 and $1.8 \mathrm{Ga}$, including deposition of the important ores, mainly, in the West Africa craton, Amazonian craton and Trans-Hudson orogen. In this way, the Salamangone gold deposit represents an orogenic mesozonal gold deposit, which was formed during compressional to transpressional deformation processes at Paleoproterozoic convergent plate margins in accretionary orogens. 


\section{CAPÍTULO 1}

\section{Introdução}

\subsection{FUNDAMENTOS}

Os depósitos de ouro filonares associados às rochas granitóides localizam-se em diversos ambientes tectônicos. Nos terrenos granito-greesntone são representados por um grupo coerente de depósitos epigenéticos, formados ao longo de profundidades variáveis da crosta, durante eventos sincrônicos e de ampla distribuição, associados às fases tardias da evolução tectonotermal de áreas cratônicas (Groves et al. 1998). Esses depósitos constituem um grupo importante embora, representem, coletivamente, apenas uma pequena porcentagem das reservas mundiais (Cassidy et al. 1998). Apresentam um número de características comuns, tais como: forte controle estrutural, principalmente por estruturas de caráter rúptil em contraste com aquelas observadas em depósitos associados com greenstones; acentuado enriquecimento em $\mathrm{Au}$, com valores variáveis de $\mathrm{Ag}, \mathrm{As}, \mathrm{W}, \mathrm{Bi}$ e $\mathrm{Te}$, e concentrações relativamente baixas de metais base $(\mathrm{Cu}, \mathrm{Pb}, \mathrm{Zn})$; deposição da mineralização aurífera a partir de fluidos predominantemente constituídos por $\mathrm{H}_{2} \mathrm{O}-\mathrm{CO}_{2}-\mathrm{S} \pm \mathrm{CH}_{4}$, com salinidade baixa a moderada e depósitos usualmente com baixa tonelagem e teores muito irregulares.

$\mathrm{O}$ depósito de ouro de Salamangone representa um dentre os vários depósitos e prospectos de ouro, que ocorrem no Distrito Aurífero de Lourenço, localizado na região centro-norte do Estado do Amapá, que faz parte de um conjunto de rochas supra-crustais afetado por metamorfismo de alto grau, parcialmente migmatizado e de complexos cálcioalcalinos, de idade Paleoproterozóica. O sistema filoniano quartzoso hospeda-se em rochas granitóides de composição tonalítica e granodiorítica.

A Mineração Novo Astro SA. - MNA, detentora dos direitos de lavra da jazida de Salamangone, encerrou as atividades da mina em 1995, após ter produzido cerca de 16 toneladas de ouro, associado à rocha sã, saprolito e latossolos, desde 1984.

Os levantamentos e estudos realizados no depósito de Salamangone devem ser vistos como experiências pioneiras no Distrito Aurífero de Lourenço, sujeitas a complementações futuras. Trabalhos adicionais de levantamento geológico subterrâneo detalhado e de análise estrutural seriam fundamentais para o melhor entendimento do sistema filoniano e da zona de cisalhamento, do comportamento tridimensional dos corpos de minério e das relações entre as rochas encaixantes da mineralização. Além disso, detalhamento da alteração hidrotermal e 
maior número de análises isotópicas, seriam importantes para uma definição mais segura do modelo genético do depósito.

A região onde se insere o depósito de Salamangone foi objeto dos estudos previstos no projeto de auxílio à pesquisa, concedido pela FAPESP (Processo № 96/03942-0), intitulado "Estudo das rochas granitóides e mineralizações associadas da Província Estanífera do Sul do Pará e do Distrito Aurífero de Lourenço, Amapá", com coordenação geral do Prof. Dr. Jorge Silva Bettencourt. O projeto foi concluído em 1999 e permitiu a realização dos diferentes tipos de análises, necessárias para o desenvolvimento da tese em questão.

\subsection{O ESTÁGIO ATUAL DO CONHECIMENTO DE DEPÓSITOS FILONARES DE OURO}

Os depósitos filonares de ouro acham-se incluídos no grupo dos depósitos hidrotermais, originados de fluidos aquosos quentes, que percorrem um determinado caminho em níveis crustais superiores e depositam uma massa de minerais a partir da solução original, mais ou menos modificada, concentrando um número limitado de espécies minerais, em especial, sulfetos, (Skinner 1979).

\section{a) Desenvolvimento Histórico}

$\mathrm{Na}$ década de 80, a compreensão dos depósitos de ouro em geral e, em especial, dos depósitos de ouro filonares associados a "greenstone belts" de idade arqueana, apresentou sua fase de maior avanço, debate e controvérsia, quando vários temas foram alvo de interesse e estudos, tais como: origem dos fluídos mineralizantes e dos metais associados, os processos de deposição, o controle estrufural e ambiente tectônico desses depósitos.

Durante esse período os dois pontos de maior discussão foram: a) a origem singenética ou epigenética dos depósitos de ouro "stratabound' e, em segundo plano, os depósitos estratiformes, e b) a origem dos fluidos mineralizantes e seus componentes, do qual o ouro é precipitado. Esses debates acham-se refletidos em várias publicações coletivas e individuais, citando-se entre muitas: Boyle (1979), Foster (1984), Colvine et al. (1984), MacDonald (1986), bem como numa grande quantidade de trabalhos individuais.

Nos anos recentes, estudos integrados envolvendo ambientes tectônicos, controles estruturais, natureza e composição dos fluidos mineralizantes e controles deposicionais, principalmente de mineralizações auríferas do Arqueano, têm conduzido a uma convergência 
de idéias, de tal forma que uma origem epigenética tem sido aceita para a maioria desses depósitos. Grande parte dos modelos propostos destacam a canalização de fluidos de composição aquo-carbônica $\left(\mathrm{H}_{2} \mathrm{O}-\mathrm{CO}_{2}\right)$, com baixa salinidade, ao longo de falhas ou zonas de cisalhamento, onde as reações rocha-fluído ocasionariam a precipitação do Au sob condições adequadas de P-T. Esses estudos são encontrados em várias publicações, citando-se entre elas: Perring et al. (1987), Goode et al. (1988), Hodgson (1989), Keays \& Skinner (1989), Colvine (1989), Ho et al. (1990a e b), Groves et al. (1989), Groves (1993a), Foster (1989), Foster \& Pipper (1993), Ladeira (1991a), Kerrich (1993), Phillips \& Powell (1993), Solomon \& Groves (1994), Ridley et al. (1996), Robert \& Poulsen (1997); Groves et al. (1998), Poulsen et al. (2000).

Por outro lado, um grande número de proposições sobre a origem dos fluidos mineralizantes aparecem durante a década de 80, incluindo: a) a crosta superior, especialmente as sucessões tipo greenstone (Groves et al. 1984, Groves \& Phillips 1987), b) a crosta inferior, com ou sem influência de componentes derivados do manto (Colvine et al. 1984, Fyon et al. 1989), c) magmas félsicos (Burrows et al. 1986, Hattori 1987, Callan \& Spooner 1989) e d) magmas lamprofíricos (Rock et al. 1988). Esses trabalhos envolvem principalmente métodos que contemplam estudos de microtermometria em inclusões fluidas e de isótopos estáveis de $\mathrm{O}, \mathrm{H}$ e C.

Recentemente, estudos de isótopos radiogênicos $(\mathrm{Rb} / \mathrm{Sr}$ e $\mathrm{Pb} / \mathrm{Pb})$ têm contribuído fundamentalmente, ao estabelecimento da origem da fonte dos fluidos e de seus componentes mineralizantes, aliados às técnicas de termodinâmica e geoquímica tradicionais, além dos estudos de inclusões fluidas e isótopos estáveis. No entanto, apesar de todas estas técnicas de trabalho, permanecem divergências sobre o assunto. Exemplo disso, são os trabalhos de: Nesbitt (1988) e Nesbitt \& Muehlenbachs (1989) que propõem uma derivação por convecção de água meteórica, para os fluidos auríferos dos depósitos da Cordilheira oeste do Canadá; Spooner (1991) que reafirma um modelo magmático para a origem dos sistemas de veios de quartzo auríferos do Arqueano e Groves et al. (1993a e b) que, baseado em dados de isotópos radiogênicos ( $\mathrm{Pb}$ em sulfetos e $\mathrm{Sr}$ em scheelitas) e de equilíbrio termodinâmico sugerem, para esses fluidos, uma origem seja de magmas granitóides gerados na crosta inferior, ou de equilibrio entre fluidos oriundos de regiões ainda mais profundas (por exemplo: zonas de subducção) e protolitos dessas mesmas rochas. Nas duas situações haveria um possível envolvimento de água meteórica ou do mar, nos níveis crustais mais superiores. 


\section{b) Modelos Genéticos e Classificação}

Quanto aos tipos de modelos genéticos propostos para os referidos depósitos, Kerrich (1993) traçou sua linha evolutiva, iniciando as considerações de forma muito interessante, citando os diferentes tipos genéticos, com os quais têm sido nominados: arqueanos, mesotermais, gold-only (somente de ouro), etc.

O termo depósito de ouro arqueano deve-se à sua relativa abundância em greenstone belts do Arqueano Superior, ressalvando-se que, hoje, são também reconhecidos em cinturões metamórficos de idades Proterozóica e Cenozóica. O termo depósito de ouro mesotermal é especificamente usado com relação ao ambiente de geração (terrenos metamórficos de facies xisto verde transicionando para anfibolito), e não como referência ao processo formador. Recentemente esses depósitos foram encontrados, também, associados a terrenos de grau metamórfico muito baixo ou muito alto, apresentando várias características em comum com aqueles de facies xisto verde-anfibolito. O termo gold-only deriva do fato desses depósitos apresentarem não só um enriquecimento muito maior de ouro com relação aos metais base, como também uma proporção $\mathrm{Au}: \mathrm{Ag}$, geralmente $>1$.

Diversos processos formadores têm sido propostos para explicar a origem dos depósitos de ouro filonares, sendo Boyle (1979) o primeiro a estudá-los sob o ponto de vista geológico e geoquímico, principalmente no Canadá, propondo um modelo de difusão lateral. Outros modelos propostos envolvem processos de exalações singenéticas, seguindo a tendência de modelos singenéticos de depósitos de metais base, do tipo sulfetado maciço, muito em voga na década de setenta. Citam-se também, modelos baseados na premissa de que alguns tipos litológicos específicos, são intrinsecamente ricos em ouro.

Um grande avanço na compreensão destes depósitos foi dado por Fyfe \& Henley (1973), quando consideraram que as zonas de cisalhamento, serviriam de condutos para os fluidos metamórficos gerados em profundidade. O próximo passo no desenvolvimento de um modelo integrado foi o reconhecimento feito por Fyfe \& Kerrich ( 1985), de que os mesmos ocorreriam em um ambiente geodinâmico especifico, qual seja o de margens continentais convergentes.

Este conceito foi retrabalhado e ampliado por Wyman \& Kerrich (1988), Barley et al. (1989), Hodgson \& Hamilton (1989), Kerrich \& Wyman (1990), Barley \& Groves (1992), Kerrich \& Cassidy (1994), que apresentaram um modelo, pelo qual as províncias metalogenéticas com depósitos filonares auríferos de todas as idades (Arqueanas, Proterozóicas e Fanerozóicas) estão caracteristicamente associadas com estruturas regionais 
em ambientes orogênicos ou de margem convergente. A abundância de mineralização aurífera filonar relativa ao Arqueano Superior seria correlacionada a um período de aquecimento global intenso, com rápido crescimento e estabilização da crosta continental por acresção de arcos insulares e terrenos do tipo greenstones. A abundância no Mesozóico - Holoceno refletiria subducção em torno das margens da Bacia do Pacífico, durante o atual ciclo tectônico. A despeito da menor quantidade, muitos depósitos do tipo orogênico são encontrados também, no Proterozóico e Fanerozóico.

Estudos realizados por Groves et al. (1991) e Groves (1993a e b) forneceram um modelo integrado, nomeado crustal continuum, segundo o qual esses depósitos formar-se-iam ao longo de profundidades variáveis da crosta, sob diferentes regimes estruturais e condições P-T, estendendo-se desde ambientes de facies de metamorfismo muito baixo até facies granulito.

O reconhecimento desse continuum englobando os depósitos filonares de ouro e, sua relação com processos de deformação em ambientes compressivos e transpressivos, ao longo de margens de placas convergentes associadas a orógenos acrescionais e colisionais, levaram Groves et al. (1998) a denominá-los de depósitos de ouro orogênicos. Considerando sua profundidade de formação, os autores subdividiram os depósitos orogênicos em: epizonal $\left(<6 \mathrm{~km}\right.$ e temperaturas entre $150^{\circ}$ e $\left.300^{\circ} \mathrm{C}\right)$, mesozonais $\left(6-12 \mathrm{~km}\right.$ e temperaturas entre $300^{\circ} \mathrm{e}$ $475^{\circ} \mathrm{C}$ ) e hipozonais $\left(>12 \mathrm{~km}\right.$ e temperaturas $\left.>475^{\circ} \mathrm{C}\right)$, mantendo a terminologia proposta por Gebre-Marian et al. (1995). Em Goldfarb et al. (2001), temos a continuidade do uso da classificação de depósitos de ouro orogênicos, com a apresentação de sua distribuição ao longo do tempo geológico.

Para se chegar a este nível de entendimento, no que diz respeito tanto à origem dos fluidos mineralizantes e de seus componentes, como dos prováveis modelos genéticos, os métodos de estudo evoluíram, desde o estabelecimento dos controles estruturais e relações espaciais das mineralizações, passando por dados de inclusões fluidas, isótopos estáveis e equilíbrio termodinâmico, até os estudos mais recentes de isótopos radiogênicos.

No Brasil depósitos filonares auríferos são encontrados, principalmente, associados a: - terrenos de natureza granito-greenstone, de baixo grau metamórfico e de idade ArqueanaProterozóico Inferior, nas províncias auríferas do Quadrilátero Ferrífero, Itapicuru e Crixás, conforme exemplificado nos trabalhos de Leonardo et al. (1991), Ladeira (1991b), Kishida et al. (1991), Lacerda (1991), entre outros; 
- granitóides do Arqueano da província de Carajás e do Paleoproterozóico das províncias de Tapajós e Juruena-Teles Pires, apresentados nos estudos de Huhn (1996), Santos \& Leonardo (1995), Coutinho et al. (1997), Botelho \& Moura (1998), entre outros.

\subsection{O DISTRITO AURÍFERO DE LOURENÇO}

A região de Lourenço é um exemplo clássico de área garimpo no Brasil. Os dados apresentados a seguir foram extraídos de Lestra \& Stoll Nardi (1984), Terraconsult (1986) e Ferran (1988).

O ouro foi descoberto pela primeira vez, na região, no final do século passado por exploradores oriundos da Guiana Francesa. No ano de 1883, relata-se que um pioneiro da região chamado Lorenz, encontrou ouro em aluvião na área que hoje se conhece por Lourenço.

Durante a última década do século passado instalou-se em Lourenço a Societé Française de L'Amerique Equatoriale, que passou depois a pertencer à The Carsewene Developments, Anglo-French Gold Mining Company, com o objetivo de desenvolver as mineralizações auríferas primárias da área. Essa companhia construiu uma pequena fundição de ouro próximo a Calçoene, e uma estrada de ferro de $110 \mathrm{~km}$ ligando esta cidade com os primeiros agrupamentos na hoje conhecida Vila de Lourenço.

As atividades desta companhia concentraram-se na mineração dos depósitos primários, tipo veio, principalmente no Monte de Salamangone. Por volta de 1900 essa importante, porém efêmera atividade, foi interrompida, quando o contestado voltou definitivamente ao território brasileiro. No início do século XX a área estava praticamente abandonada, terminando assim, o primeiro ciclo do ouro no Amapá, que produziu cerca de 3 toneladas de metal.

A primeira metade do século $\mathrm{XX}$, década de 30 , assistiu a surtos esporádicos de garimpagem, como os do rio Cassiporé, pouco a norte de Lourenço. Foi no final da década de 40 que Joel Ferreira de Jesus, garimpeiro, implantou uma lavra racional, com desmonte hidráulico no veio do Mutum, perto de Lourenço. Os primeiros requerimentos de pesquisa são de 1970 e no início de 1983, a Companhia Mineração e Participação - CMP, adquiriu os direitos minerários de Joel Ferreira de Jesus, transferidos posteriormente para a Mineração Novo Astro S.A. - MNA. Iniciaram-se então, as pesquisas no Morro de Salamangone e em outras ocorrências vizinhas: Lataia, Mutum e Labourie. Em 1984 foi instalada uma planta experimental para lavrar a face norte do Morro de Salamangone, produzindo, neste ano, cerca 
de $100 \mathrm{Kg}$ de ouro de material secundário, de natureza eluvial e coluvial. O aproveitamento deste tipo de minério, em lavra a céu aberto, prolongou-se até 1990. O início da lavra de minério primário, através de trabalhos subterrâneos, ocorreu a partir de 1988, com paralisação em junho de 1995, quando foram encerradas as atividades mineiras pela MNA.

No período de 1985-1986 cerca de 2000 a 3000 garimpeiros trabalharam na região de Lourenço, concentrando suas atividades em explotação do material aluvionar aurífero, principalmente nos vales dos rios Regina, Limão, Português e Baixo Lataia. Uma mineração que merece ser mencionada, é a de concessão do grupo brasileiro-japonês Yokio Yoshidone, distante cerca de $1,6 \mathrm{~km}$, na direção sudeste de Lourenço, também com lavra paralisada.

A área de estudo se localiza no Morro Salamangone, situado na Serra Lombarda, na parte centro-norte do Estado do Amapá, a sudoeste da localidade de Lourenço, distante $80 \mathrm{~km}$ no rumo oeste do Município de Calçoene, Figuras 1.1 e 1.2. O acesso, a partir de Macapá, pode ser feito por via aérea, em aviões mono e bimotores até à pista de pouso localizada na própria mina, ou por via terrestre, através da rodovia BR-150 que liga Macapá ao Distrito de Loureço.

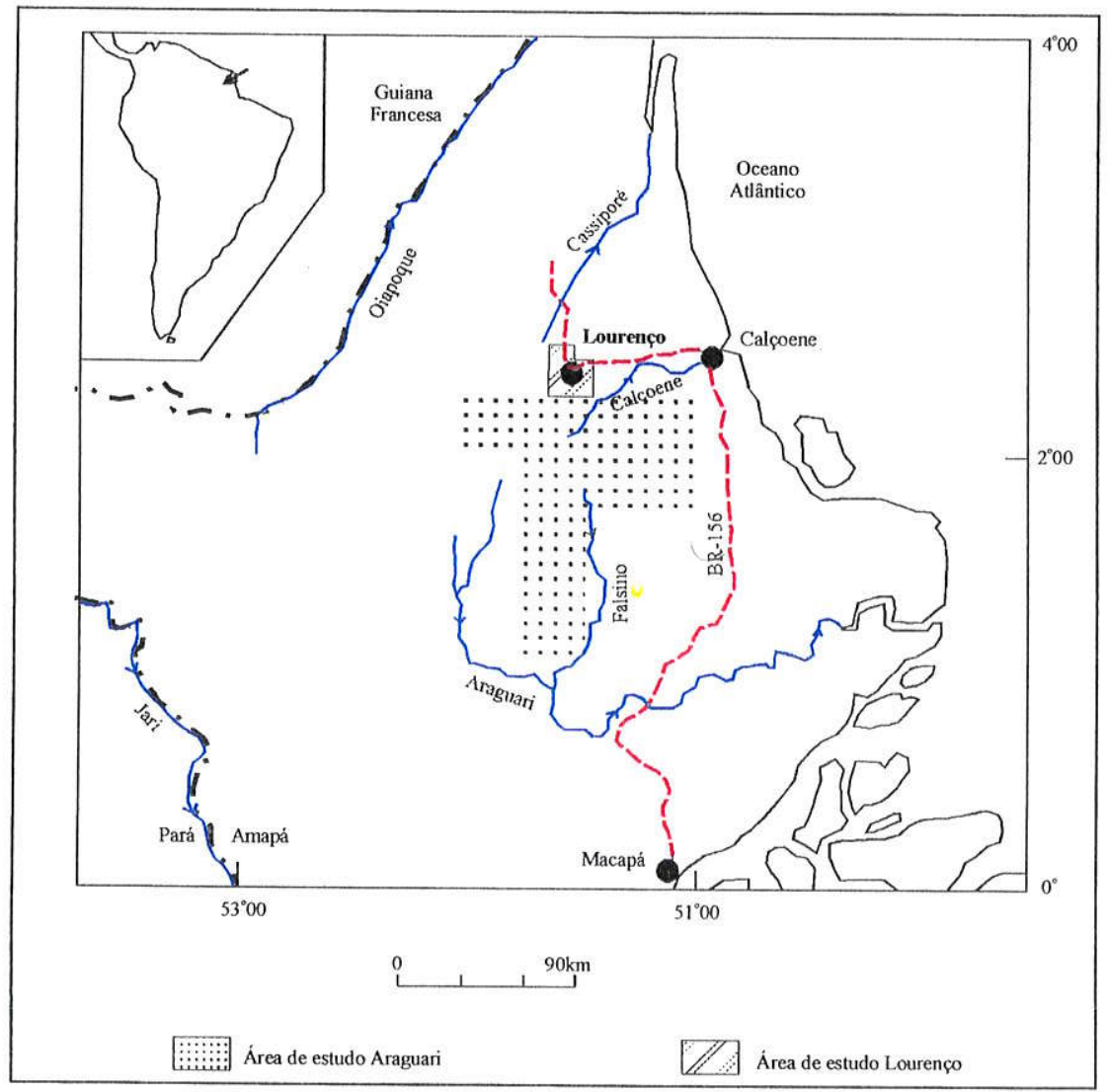

Figura 1.1 - Localização do Distrito Aurífero de Lourenço e da região do projeto Araguari (onde foram desenvolvidos estudos prospectivos para ouro pela empresa Terraconsult em 1986). 

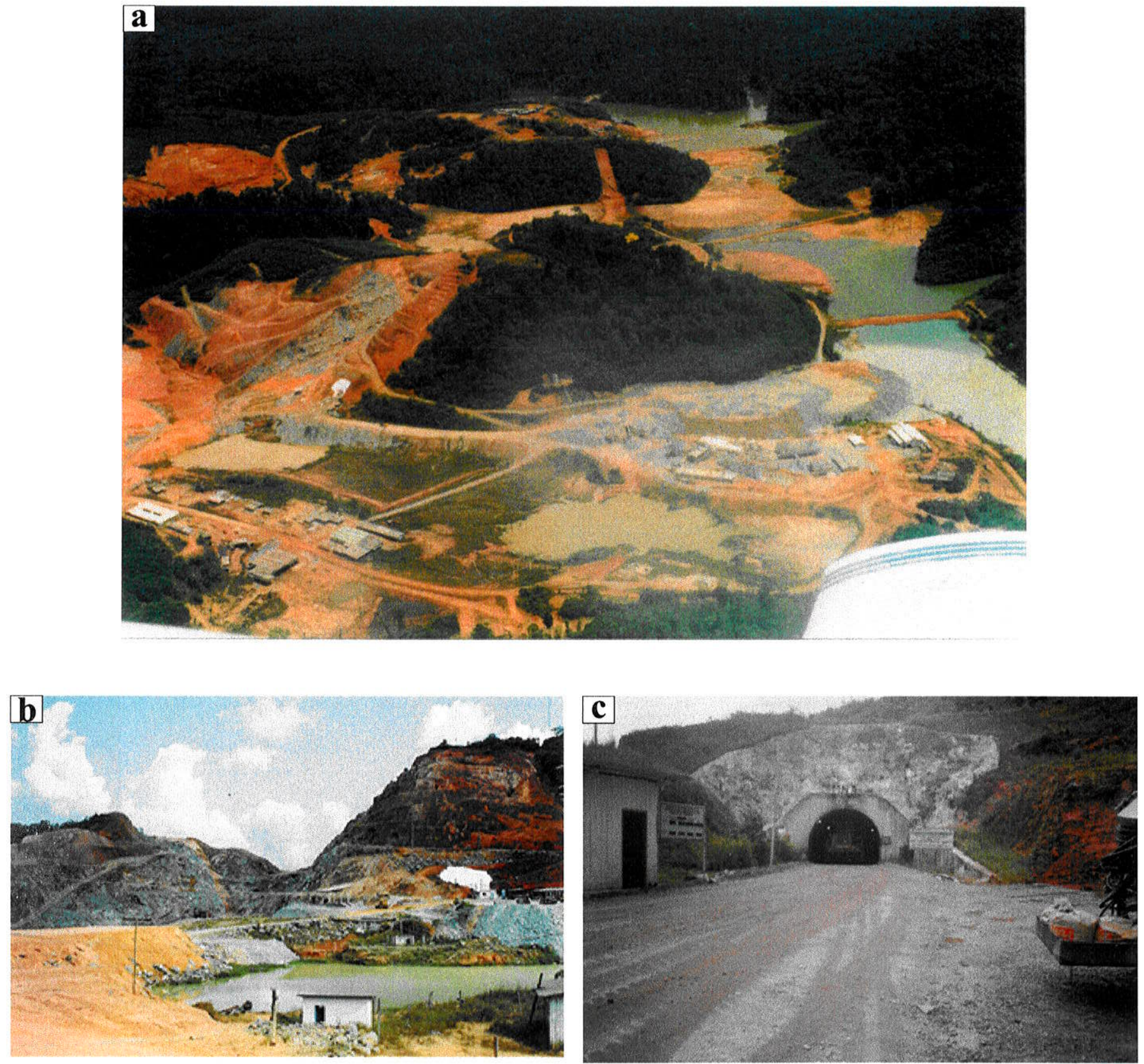

Figura 1.2 - a) Vista aérea da Mina de Salamangone. A antiga cava a céu aberto e a entrada da mina subterrânea estão à esquerda, b) Vista geral da cava, observando-se os antigos taludes da mina a céu aberto. A entrada para os níveis subterrâneos está à direita, c) Detalhe da entrada da mina subterrânea. (Fotografias obtidas entre 1991 e 1992). 


\subsection{RESERVAS E PRODUÇÃO}

Os dados de reserva apresentados no Quadro 1.1, foram fornecidos pela empresa e são da época da paralisação das atividades de lavra, em julho de 1995. Referem-se às reservas do minério primário. A área da reserva geológica medida é aproximadamente igual à área da reserva lavrada.

\begin{tabular}{l|c|c|c|c|c|c}
$\begin{array}{c}\text { Corpo de } \\
\text { minério }\end{array}$ & Espessura (m) & $\begin{array}{c}\text { Minério } \\
\text { s/diluição (t) }\end{array}$ & $\begin{array}{c}\text { Teor Au } \\
\text { s/diluị̧ão (g/t) }\end{array}$ & $\begin{array}{c}\text { Minério } \\
\text { c/diluição (t) }\end{array}$ & $\begin{array}{c}\text { Teor Au } \\
\text { c/diluição (g/t) }\end{array}$ & $\begin{array}{c}\text { Au } \\
\text { contido (kg) }\end{array}$ \\
\hline Principal & 2,37 & 331.665 & 23,17 & 507.447 & 15,14 & 7.684 \\
Capa & 1,35 & 112.361 & 28,22 & 147.193 & 21,54 & 3.171 \\
Lapa & 1,60 & 111.213 & 18,23 & 169.483 & 12,40 & 2.028. \\
Total & & 555.239 & 23,20 & 824.123 & 15,75 & 12.883
\end{tabular}

Quadro 1.1 - Reservas do minério primário, lavrado até à época do fechamento da mina.

No Quadro 1.2 abaixo, é apresentada a evolução da produção dos minérios, secundário e primário, lavrados durante a vida da mina.

\begin{tabular}{l|l|c|c|c} 
Ano & \multicolumn{1}{|c|}{ Tipo de minério } & Volume mainerado & $\begin{array}{c}\text { Ouro 999,9 (g) no } \\
\text { período }\end{array}$ & $\begin{array}{c}\text { Ouro 999,9 (g) } \\
\text { acumulado }\end{array}$ \\
\hline $\mathbf{1 9 8 4}$ & Secundário $\left(\mathrm{m}^{3}\right)$ & 95.291 & 106.761 & 106.761 \\
$\mathbf{1 9 8 5}$ & Secundário $\left(\mathrm{m}^{3}\right)$ & 167.182 & 428.792 & 535.553 \\
$\mathbf{1 9 8 6}$ & Secundário $\left(\mathrm{m}^{3}\right)$ & 178.226 & 788.517 & 1.324 .070 \\
$\mathbf{1 9 8 7}$ & Secundário $\left(\mathrm{m}^{3}\right)$ & 437.299 & 1.328 .780 & 2.652 .850 \\
& Secundário $\left(\mathrm{m}^{3}\right)$ & 744.016 & & \\
$\mathbf{1 9 8 8}$ & Primário $(\mathrm{t})$ & 25.180 & 2.060 .382 & 4.713 .232 \\
& Secundário $\left(\mathrm{m}^{3}\right)$ & 383.836 & & \\
$\mathbf{1 9 8 9}$ & Primário $(\mathrm{t})$ & 130.596 & 1.710 .793 & 6.424 .025 \\
& Secundário $\left(\mathrm{m}^{3}\right)$ & 202.826 & & \\
$\mathbf{1 9 9 0}$ & Primário $(\mathrm{t})$ & 162.301 & 1.505 .312 & 1.929 .337 \\
$\mathbf{1 9 9 1}$ & Primário $(\mathrm{t})$ & 162.393 & 2.098 .565 & 10.027 .902 \\
$\mathbf{1 9 9 2}$ & Primário $(\mathrm{t})$ & 170.525 & 3.062 .745 & 13.090 .647 \\
$\mathbf{1 9 9 3}$ & Primário $(\mathrm{t})$ & 177.136 & 3.082 .177 & 16.172 .824 \\
$\mathbf{1 9 9 4}$ & Primário $(\mathrm{t})$ & 189.545 & 2.484 .438 & 18.657 .262 \\
$\mathbf{1 9 9 5 *}$ & Primário $(\mathrm{t})$ & 105.000 & 1.300 .000 & 19.957 .292
\end{tabular}

Quadro 1.2 - Evolução da produção de minérios secundário e primário (*Dados relativos à produção até julho de 1995). 
As reservas lavráveis de minério secundário em saprolito foram estimadas em cerca de $500 \mathrm{t}$ a um teor de $6 \mathrm{~g} / \mathrm{t}$, passível de beneficiamento, por gravimetria, e equivalente a $3 \mathrm{t}$ de ouro. A relação estéril-minério era de 2:1. No elúvio-colúvio foi estimada uma reserva de cerca de $870 \mathrm{~kg}$ de ouro passível de beneficiamento, também, por processos gravimétricos.

\subsection{OBJETIVOS}

O objetivo deste trabalho está ligado à necessidade de se avançar no conhecimento dos processos petrogenéticos e metalogenéticos de depósitos filonares quartzo-auríferos, controlados por zonas de cisalhamento, que atravessam rochas granitódes de natureza tonalítica-granodiorítica, do Paleoproterozóico. A apresentação dos dados, sua análise e interpretação constituem um esforço pioneiro na caracterização e compreensão dos depósitos de ouro, na região do Distrito Aurif́fero cie Lourenço, no Amapá, devendo representar uma contribuição para subsídio, principalmente, a trabalhos futuros.

Os estudos visaram:

a) caracterizar os tipos de rochas encaixantes da mineralização;

a) definir a distribuição e o comportamento dos sistemas dos veios quartzosos auríferos associados as zonas de cisalhamento;

b) identificar os padrões de alterações, ocasionados pelos fluidos mineralizantes nas rochas encaixantes;

c) identificar modificações de volume e massa, bem como modificações químicas que acompanham a alteração e mineralização, com vistas à avaliação da mobilidade de elementos metálicos e do potencial mineral do sistema filoniano;

d) caracterizar a paragênese do minério;

e) obter parâmetros que auxiliem na caracterização da composição dos fluidos mineralizantes e nas condições físico-químicas atuantes durante a formação do depósito mineral;

f) obter parâmetros sobre a idade das rochas encaixantes e do evento mineralizador;

g) estabelecer a síntese evolutiva das soluções mineralizantes e as condições de deposição e fontes do ouro;

h) avaliar a relevância dos dados geológicos, geoquímicos, isotópicos, microtermométricos, etc., na elaboração de um modelo genético conceitual do depósito, que possa contribuir à pesquisa e prospecção de ouro em ambientes geológicos semelhantes. 


\section{CAPÍTULO 2}

\section{Métodos de Estudo}

De acordo com o exposto anteriormente, o uso de técnicas mais recentes, além das tradicionalmente utilizadas, é fundamental à compreensão da petrogênese e metalogênese dos depósitos de ouro filonares. São apresentados abaixo, os métodos de trabalho utilizados para o desenvolvimento da tese.

\subsection{PESQUISA BIBLIOGRÁFICA}

A situação atual de conhecimento dos depósitos acima referidos, assim como da evolução das técnicas de estudos para sua compreensão foram amplamente pesquisadas, conforme apresentado no ítem 1.1. Esse trabalho de revisão bibliográfica, foi fundamental para situar o objeto da tese dentro deste contexto e fornecer parâmetros orientativos à escolha dos métodos de estudo mais adequados às finalidades pretendidas.

Igualmente, procedeu-se a um levantamento das pesquisas geológicas efetuadas na região em questão, envolvendo estudos sobre geologia, geocronologia, metalogenia, entre outros, consubstanciados nas seguintes publicações: Choubert (1974); Cordani et al. (1979); Dall'Agnol et al. (1987); De Vletter et al. (1998); De Vletter \& Kroonenberg (1987); DNPM (1974 e 1988); DNPM-CPRM (1979a e b,1985a, b e c); Faraco et al. (1994); Ferran (1988); Gibbs \& Barron (1983 e 1993); Gruau et al. (1985); Hurley et al. (1968); Issler et al. (1974); Issler \& Lima (1987); Jorge João et al.(1982a e b); Lafrance et al. (1999); Ledru et al. (1997); Lestra \& Stoll Nardi. (1984); Lima (1974); Lima et al (1991); Macambira et al. (1990); Milési et al. (1995); McReath \& Faraco (1997); Montalvão \& Tassinari (1984); Priem et al. (1971); Priem (1998); Santos et al. (1984); Sato \& Tassinari (1997); Scarpelli (1966); Schobbenhaous (1984); Silva (1984); Sousa Júnior et al. (1988); Tassinari (1996); Tassinari \& Macambira (1999); Teixeira et al. (1984, 1985 e 1989); Vanderhaeghe et al. (1998): Veiga et al. (1985) e Voicu et al. (2001).

Todo este acervo de informações foi inventariado, examinado e sistematizado, visando com isso, o estabelecimento de uma base para o desenvolvimento de trabalhos posteriores.

Como parte da pesquisa bibliográfica efetuou-se, também, a compilação dos dados obtidos durante as fases de desenvolvimento dos trabalhos realizados na mina, que integram 
relatórios técnicos da Terraconsult (1986), Geodinâmica (1991 e 1992), Costa (1991), Bettencourt (1987, 1988, 1989, e 1990) e Bettencourt \& Ferreira (1993), além de informações da equipe de geólogos da Mineração Novo Astro S.A.

\subsection{TRABALHOS DE CAMPO}

Foram executadas duas etapas de campo, entre 1991 e 1995. Numa primeira etapa, procedeu-se ao levantamento, junto com a equipe de geólogos da mina, dos trabalhos desenvolvidos na Mina Salamangone, através da compilação e análise dos dados do mapeamento geológico e estrutural efetuados nas galerias e travessas que cortam o corpo do minério e rochas encaixantes e sobre a campanha de sondagem. Essas informações foram de grande importância à compreensão dos controles estruturais e do tipo de sistema filoneano que ocorre no depósito.

Numa segunda etapa, desenvolvemos um estudo mais detalhado das frentes de lavra e dos furos de sondagem com coleta sistemática de amostras das rochas encaixantes e do minério. Foram amostradas frentes de lavra nas galerias de desenvolvimento nos níveis 54 , 264, 274 e $290 \mathrm{~m}$ e nas travessas de acesso aos níveis 54 e $229 \mathrm{~m}$, bem como 24 furos de sondagem, com finalidades de análises petrográficas, químicas, isotópicas e microtermométricas, localizados na Figura 2.1.

\subsection{ESTUDOS DE LABORATÓRIO}

Para se atingir os objetivos pretendidos, foram utilizadas diversas técnicas de análises, apresentadas a seguir.

\subsubsection{Análises Petrográficas}

Os estudos petrográficos foram realizados com o objetivo de caracterizar e descrever os tipos litológicos encaixantes da mineralização aurífera e a zona quartzosa mineralizada. São fundamentais ao estabelecimento das relações entre os constituintes mineralógicos e as texturas, assim como da paragênese do minério e da zona de alteração. Além disso, auxiliaram no direcionamento da seleção de amostras para análises químicas (rocha total e mineral), isotópicas (isótopos radiogênicos e estáveis) e microtermométricas (inclusões fluidas). 


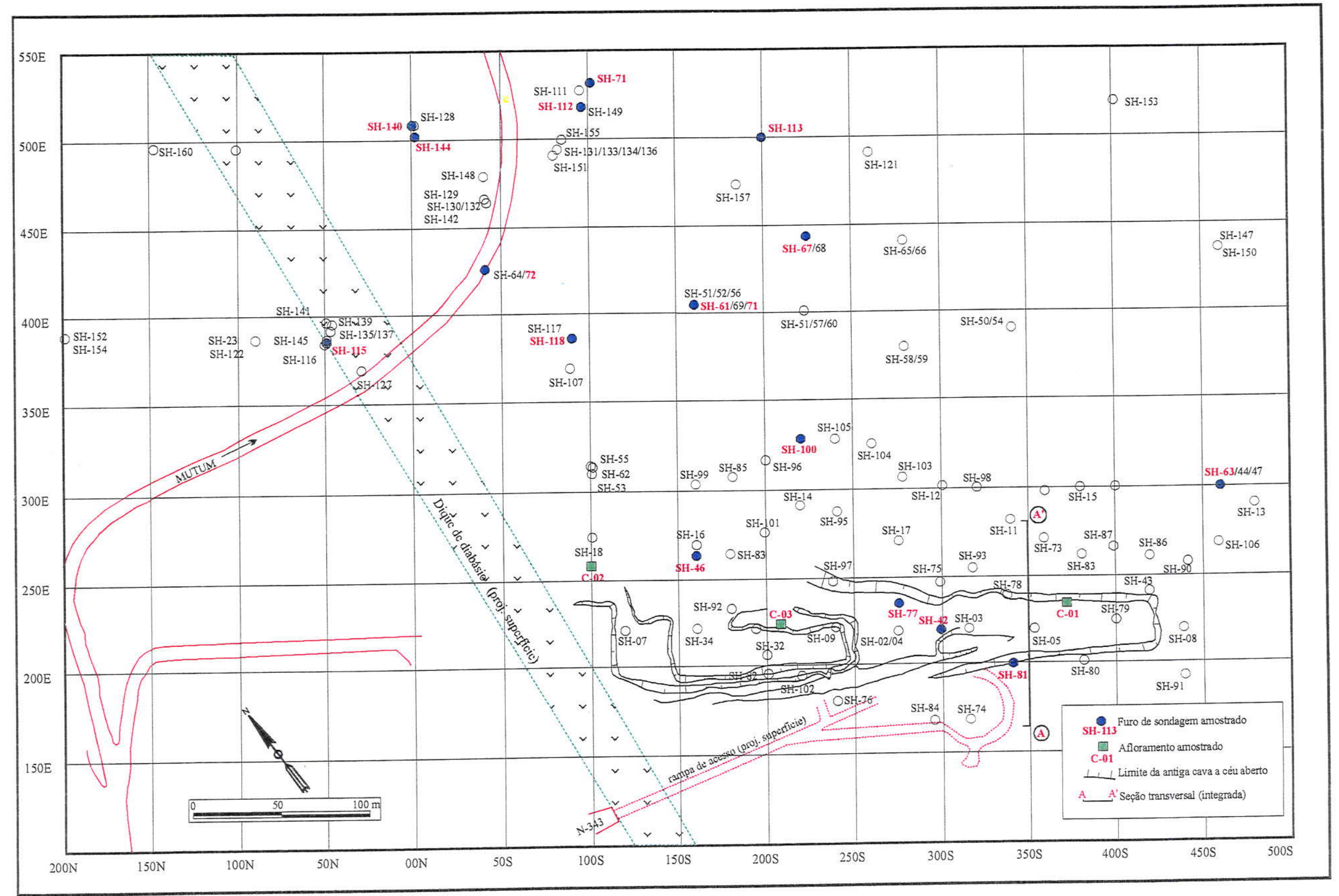

Figura 2.1 - Localização dos furos de sondagem e pontos de afloramentos amostrados, na área da Mina de Salamangone. 
Para tanto, foram utilizadas técnicas de: a) microscopia óptica visando o reconhecimento dos minerais transparentes e opacos e suas texturas características, contagem modal, alterações de minerais e as relações paragenéticas afeitas à mineralização e b) microscopia eletrônica de varredura (MEV), para melhor caracterização das fases minerais do minério. Os aspectos mais relevantes, nos dois casos, foram documentados através de fotografias.

As análises de microscopia ótica (seções delgadas e polidas), foram realizadas utilizando-se os fotomicroscópios petrográfico Zeiss Axioplan do Departamento de Geologia Sedimentar e Ambiental - DGSA do IGUSP e Jenapol do Instituto Geológico, da Secretaria do Meio Ambiente do Estado de São Paulo. As análises de microscopia eletrônica, foram efetuadas no Laboratório de Caracterização Tecnológica (LCT), do Departamento de Engenharia de Minas da Escola Politécnica da USP e no laboratório de Microscopia Eletrônica do DGSA/IGUSP.

\subsubsection{Análises Químicas em Rocha Total}

A análise química em rocha integrada à petrografia foi utilizada para auxiliar na caracterização dos tipos de rochas presentes na área, bem como seus protolitos; na quantificação dos graus e estilos de alteração; na constatação da mobilidade dos elementos durante os processos de alteração hidrotermal e na interpretação sobre $o$ ambiente geoctectônico de formação dessas rochas.

As análises químicas em rocha total, envolvendo os elementos maiores, traços e terras raras, de amostras representativas de tonalito, granodiorito e anfibolito pouco afetados pela mineralização e de tonalitos localizados dentro do halo de alteração provocado pelo evento mineralizador, foram executadas no ACTLABS- Activation Laboratories Ltd. Ancaster, Ontário, Canadá. A Tabela 2.1 sintetiza os dados referentes aos ensaios analíticos.

Para o tratamento dos dados geoquímicos foi utilizado o programa Minpet for Windows, versão 2.02 (Richard 1995), além de da planilha EXCEL for Windows 97, para cálculos das demais fórmulas.

\subsubsection{Análises Químicas em Minerais}

A interpretação dos dados analíticos químicos de hornblenda, biotita e feldspato das rochas encaixantes da mineralização e dos sulfetos associados ao ouro, combinada àquelas 
dos dados petrográficos e químicos das rochas contribuíram para: a caracterização mais precisa das fases minerais estudadas, a caracterização das variações do quimismo e mobilidade dos elementos nessas rochas e zonas mineralizadas e estabelecimento do equilíbrio termodinâmico e condições de formação das fases minerais, através da utilização de geobarômetros e geotermômetros.

\begin{tabular}{c|c|l} 
Elementos & \multicolumn{1}{|c}{ Métodos } & \multicolumn{1}{|c}{ Precisão Relativa } \\
\hline Oxidos maiores & ICP & $0.01 \%$ \\
Elementos traços & ICP/MS & Conforme obs. última linha \\
ETR & ICP/MS & La, Ce, Nd, Sm, Gd, Tb, Dy, Ho, \\
& & $\begin{array}{l}\mathrm{Er}, \mathrm{Yb}=0.01 \mathrm{ppm} \\
\mathrm{Pr}, \mathrm{Eu}, \mathrm{Tm}=0.005 \mathrm{ppm}\end{array}$ \\
& & $\mathrm{Lu}=0.002 \mathrm{ppm}$ \\
$\mathrm{Au}, \mathrm{Pt}, \mathrm{Pd}$ & $\mathrm{Au}=1 \mathrm{ppb}, \mathrm{Pd}, \mathrm{Pt}=0.1 \mathrm{ppb}$ \\
\hline
\end{tabular}

Obs. Limites de deteç̧ão (ppm): $\mathrm{V}=1 ; \mathrm{Cr}=1 ; \mathrm{Co}=0,1 ; \mathrm{Ni}=1 ; \mathrm{Cu}=5 ; \mathrm{Zn}=2 ; \mathrm{Ga}=1, \mathrm{Ge}=1 ; \mathrm{As}=1 ; \mathrm{Rb}=0.01$; $\mathrm{Sr}=0.01 ; \mathrm{Y}=0.1 ; \mathrm{Zr}=0.01 ; \mathrm{Nb}=0.01 ; \mathrm{Mo}=0.01 ; \mathrm{Ag}=0.5 ; \mathrm{In}=0.1 ; \mathrm{Sn}=0.2 ; \mathrm{Sb}=0.01 ; \mathrm{Cs}=0.01 ; \mathrm{Ba}=0.01 ; \mathrm{Hf}=0.05$; $\mathrm{Ta}=0.005 ; \mathrm{W}=0.01 ; \mathrm{Tl}=0.01 ; \mathrm{Pb}=1 ; \mathrm{Bi}=0.05 ; \mathrm{Th}=0.005 ; \mathrm{U}=0.005 ; \mathrm{Sc}=0.1 ; \mathrm{Be}=1$

Tabela 2.1 - Elementos analisados, métodos e limites de detecção (\% em peso para os elementos maiores; ppm para elementos menores, traços e terras raras, e ppb para $\mathrm{Au}, \mathrm{Pt}$ e $\mathrm{Pd}$ ).

As análises foram realizadas no Laboratório de Microssonda Eletrônica do IGUSP, utilizando-se microssonda eletrônica JEOL, modelo JXA-8600S, provida de cinco espectrômetros de dispersão de comprimento de onda (WDS), cada qual com dois cristais analisadores, com automação de fabricação NORAN, e sistema Voyager 3.61.

As determinações quantitativas dos elementos foram executadas, fixando-se as voltagens de aceleração a $15 \mathrm{kV}$ e a de corrente do feixe eletrônico em $20 \mathrm{nA}$. O diâmetro do feixe eletrônico foi estabelecido em $\leq 5 \mu \mathrm{m}$ para micas e anfibólio, $10 \mu \mathrm{m}$ para plagioclásio e $30 \mu \mathrm{m}$ para os minerais sulfetados e ouro.

\subsubsection{Análises de Isótopos Radiogênicos}

Os estudos de isótopos radiogênicos envolveram análises das rochas encaixantes da mineralização, pelos métodos $\mathrm{Rb} / \mathrm{Sr}$, e $\mathrm{Sm} / \mathrm{Nd}$ (rocha total) e $\mathrm{U} / \mathrm{Pb}$ (zircão), com a finalidade de: estabelecer as idades de cristalização e de metamorfismo das mesmas; caracterizar as idades de seus protolitos, assim como a natureza das suas áreas fontes, mediante a determinação das idades TDM e dos parâmetros $\varepsilon \mathrm{Nd}, \mathrm{fSm} / \mathrm{Nd}$, Ri.

Foram realizadas datações $\mathrm{Rb} / \mathrm{Sr}$ (rocha total) e $\mathrm{K} / \mathrm{Ar}$ em biotita de tonalito, situado dentro da zona afetada pela alteração hidrotermal provocada pela interação rocha-fluido, bem 
como de $\mathrm{Pb} / \mathrm{Pb}$ em sulfetos. Essas datações contribuíram para a caracterização da idade do evento mineralizador.

As datações foram executadas no Centro de Pesquisas Geocronológicas CPGeo/IGUSP, com exceção das datações $\mathrm{U} / \mathrm{Pb}$ em zircão e $\mathrm{Pb} / \mathrm{Pb}$ em rocha total, realizadas no "Laboratories of the Institute of Precambrian Geology and Geochronology, Russian Academy of Sciences (IPGG-RAS)", St. Petersburg, Russia. As medidas das razões isotópicas $\mathrm{Pb} / \mathrm{Pb}$ foram executadas em um espectrômetro de massa IPGG-RAS Finnigan MAT 2618, e as análises de zircão e o tratamento de abrasão seguiram o método de Krogh $(1973,1982)$.

Os conteúdos de $\mathrm{Rb}$ e $\mathrm{Sr}$ foram determinados por fluorescência de raio- $\mathrm{X}$, e os valores de $\mathrm{Sm}$ e $\mathrm{Nd}$ por diluição isotópica, seguindo os princípios analíticos contidos em Sato et al. (1995). Os conteúdos de $\mathrm{Pb} / \mathrm{Pb}$ em sulfetos foram obtidos pelas técnicas de dissolução total e lixiviação de concentrados de arsenopirita, obedecendo a rotina do laboratório do CPGeo. As leituras espectrométricas foram feitas em um espectrômetro de massa do tipo VG-354. O conteúdo de $\mathrm{K}$ foi determinado por um espectrômetro de chama, e os valores de Ar por um espectrômetro de massa de fonte gasosa, Reynolds MS-1, de acordo com os procedimentos analíticos descritos por Amaral et al. (1966).

Os resultados isotópicos finais de $\mathrm{Rb} / \mathrm{Sr}, \mathrm{U}-\mathrm{Pb}$ e $\mathrm{Pb} / \mathrm{Pb}$ foram tratados usando-se o programa Isoplot de Ludwing (1999), sendo que as isócronas com valores de MSWD elevados, tiveram o cálculo de suas idades baseadas no Modelo 3. As idades foram calculadas com a constante $\lambda_{\mathrm{Rb}}=1.42 \times 10^{-1}$ anos $^{-1}$, proposta por Steiger and Jäger (1977), enquanto que para as idades modelo $\mathrm{Sm} / \mathrm{Nd}\left(\mathrm{T}_{\mathrm{DM}}\right)$ foi usado o modelo do manto empobrecido de De Paolo (1988).

\subsubsection{Análises de Isótopos Estáveis}

As soluções hidrotermais são constituídas, basicamente, por $\mathrm{H}_{2} \mathrm{O}$ contendo quantidades subordinadas de outros voláteis, tais como: $\mathrm{CO}_{2}, \mathrm{SO}_{2}, \mathrm{Cl}, \mathrm{F}$, etc., além de outros sais e metais dissolvidos, (Skinner 1997). Na determinação da origem dos fluidos de depósitos minerais hidrotermais, utiliza-se a sistemática dos isótopos estáveis nos principais elementos constituintes das soluções: $\mathrm{O}, \mathrm{H}, \mathrm{S}$ e C.

A realização de análises de isótopos de oxigênio (em quartzo do tonalito e dos veios mineralizado e estéril) e de hidrogênio (em biotita de tonalito pouco alterado e de ribbons), objetiva identificar a origem e características dos fluidos envolvidos no evento mineralizador, bem como determinar as temperaturas de cristalização de pares geotermométricos. Por sua 
vez, as análises de $\mathrm{S}$ em sulfetos associados à mineralização, foram utilizadas para a determinação da fonte do $\mathrm{S}$.

As determinações das razões isotópicas de oxigênio e enxofre foram realizadas no Geochron Laboratories Krueger Enterprises, Cambridge/Massachusetts, USA. Foram utilizados os padrões: SMOW para as razões ${ }^{18} \mathrm{O} /{ }^{16} \mathrm{O}$ e D/H, e trolita de Canion Diablo, para a razão ${ }^{34} \mathrm{~S} /{ }^{32} \mathrm{~S}$.

\subsubsection{Análises Microtermométricas}

As medidas microtermométricas de inclusões fluidas em quartzo dos veios mineralizados, visaram determinar a composição dos fluidos responsáveis pela mineralização e as condições físico-químicas atuantes durante a formação do depósito mineral.

Desta forma, para auxiliar na compreensão dos processos de alteração hidrotermal, transporte e deposição do ouro, assim como na definição de um modelo genético para o depósito de Salamangone, foi utilizada, entre outras ferramentas, o estudo de inclusões fluidas em grãos de quartzo dos veios mineralizados e estéreis, e de pegmatitos. Seu enfoque corresponde à caracterização dos parâmetros físico-químicos, tais como: densidade, salinidade, composição e temperaturas mínimas de aprisionamento dos sistemas.

Esses parâmetros combinados aos dados de paragênese e do equilíbrio termodinâmico das fases sulfetadas presentes no minério e, aqueles obtidos nas análises de isótopos estáveis em quartzo e sulfetos, serão fundamentais no estabelecimento de uma síntese evolutiva das soluções mineralizantes e das condições de deposição e fontes do ouro.

As medidas microtermométricas foram obtidas mediante a utilização de platina de resfriamento e aquecimento Chaixmeca, tipo MTM 85, que permite atingir um intervalo de temperatura de -180 a $+660^{\circ} \mathrm{C}$. Este equipamento está acoplado a um sistema de leitura e registro dos dados Newport e a um miroscópio binocular Leitz Welzlar. Para os cálculos das propriedades dos fluidos, a partir dos dados microtermométricos obtidos nas inclusões fluidas, utilizou-se do programa FLINCOR, Brow 1989.

Todas as determinações microtermométricas foram realizadas no Laboratório de Inclusões Fluidas do Departamento de Mineralogia e Geotectônica do IGUSP, sob a supervisão da Dra Rosa Maria da Silveira Bello. 


\section{CAPÍTULO 3}

\section{Contexto Geológico} Loureço, abordada no texto, revelou uma situação deficiente, com poucos projetos e estudos

O levantamento de trabalhos sobre a geologia do Estado do Amapá e da região de sistemáticos, que foram analisados e consubstanciados no texto abaixo apresentado.

\subsection{HISTÓRICO DO CONHECIMENTO GEOLÓGICO REGIONAL}

A área de estudo localiza-se na parte central do Estado do Amapá, no âmbito do Craton Amazônico (Almeida 1978), dentro do Cinturão Móvel Maroni-Itacaiúnas, estabelecido originalmente por Teixeira et al. (1989), e revisto por Tassinari (1996), Figura 3.1. Para Gibbs \& Barron (1983 e 1993), essa região insere-se no Escudo das Guianas.

Os estudos geológicos sistemáticos efetuados no Estado do Amapá são escassos, ressalvando-se o Projeto RADAM (DNPM 1974), o primeiro a apresentar um esboço consistente da geologia regional, na escala ao milionésimo, ressentindo-se, entretanto, da escassez de dados de campo. O DNPM-CPRM (1979a e b) apresentou estudos realizados em regiões próximas, geologicamente similares, e cartografadas à escala 1:100.000 e o DNPMCPRM (1985a, b e c), com o Projeto Mapas Metalogenéticos e de Previsão de Recursos Minerais, estudou as Folhas NA 22-V-D (Lourenço), NA 22-Y-D (Macapá) e NA 22-Y-B (Rio Araguari).

Posteriormente, Lima et al. (1991) tomando como ponto de partida os trabalhos desenvolvidos pelo DNPM (1974), no Projeto RADAM, mais os trabalhos obtidos através de projetos específicos, realizados em sua maioria pelo convênio DNPM/CPRM, acima citados, além de outros, propôs uma sistematização da geologia do Amapá, mostrada na Figura 3.2.

De acordo com esta sistematização, as rochas aflorantes na região de Lourenço fariam parte da Suíte Metamórfica Lourenço, em substituição à Sequência Cassiporé de Veiga et al. (1985), constituída por um conjunto de rochas supra-crustais afetadas por metamorfismo de alto grau, parcialmente migmatizadas, com direção NW-SE. Esta Suíte junto com o Grupo Vila Nova (Lima et al. 1974), definido principalmente na porção sul do Estado do Amapá, e o Grupo Paramacá (Série Paramacá de Choubert 1974), na região limítrofe entre Amapá e Guiana Francesa, representariam seqüências supracrustais do Paleoproterozóico. 


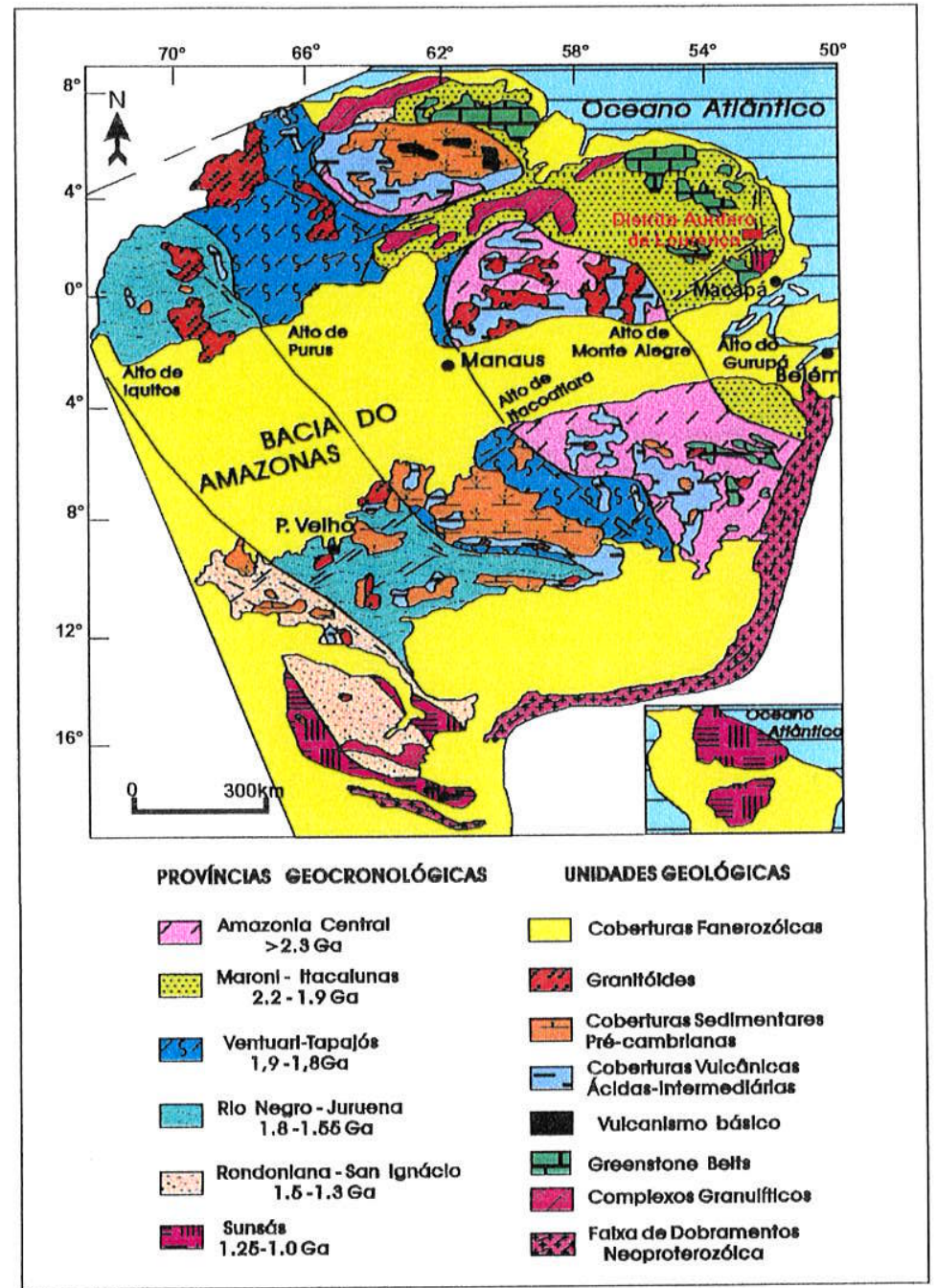

Figura 3.1 - Localização do Distrito Aurífero de Lourenço no Amapá na Província MaroniItacaíunas, de acordo com o Mapa de Províncias Geocronológicas do Craton Amazônico, Tassinari (1996).

Terraconsult (1986) descreveu esse conjunto como sendo constituído por anfibolitos, biotita-xistos, cherts e tonalitos, formando as elevações da chamada Serra Lombarda, do divisor Cassiporé-Calçoene, e que segundo um trend NW-SE, prossegue para a Guiana Francesa, na região do Camopi. Sugere para o conjunto o nome de Grupo Serra Lombarda.

Em sua sistematização, Lima et al. (1991), definiram um cinturão de cisalhamento dúctil-rúptil, cognominado Caroni- Quatro Pancadas, envolvendo a região dos rios Flechal e Tartarugal Grande, passando pela região de Lourenço e indo até à localidade de Caroni no limite com a Guiana Francesa. A direção da faixa é NW-SE, e abarca a zona de exposição da Suíte Metamórfica Lourenço. A esta zona de cisalhamento estariam associados os principais bens minerais, em especial o ouro, Figura 3.3. 


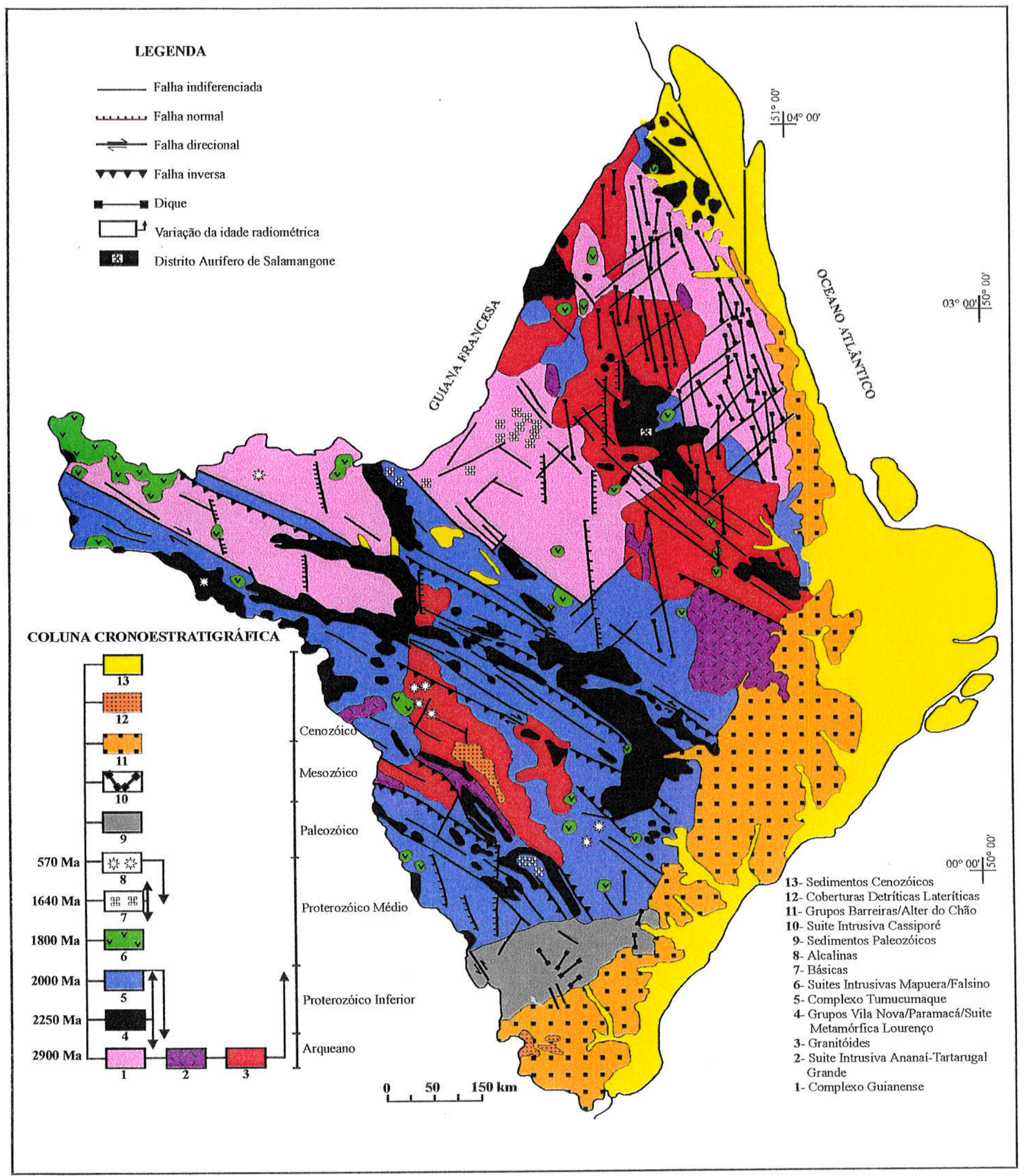

Figura 3.2. Esboço geológico do Estado do Amapá (Fonte: Lima et al. 1991, modificado de Lima et al. 1974, Veiga et al. 1989 e Rodrigues et al. 1990). 
Toda a região é cortada por diques de diabásio (Diabásio Cassiporé), de orientação norte-sul, de idade Permo-Triássica, associados a fraturas de distensão contemporâneas à abertura do oceano Atlântico, Figura 3.2 (Lima et al. 1991).

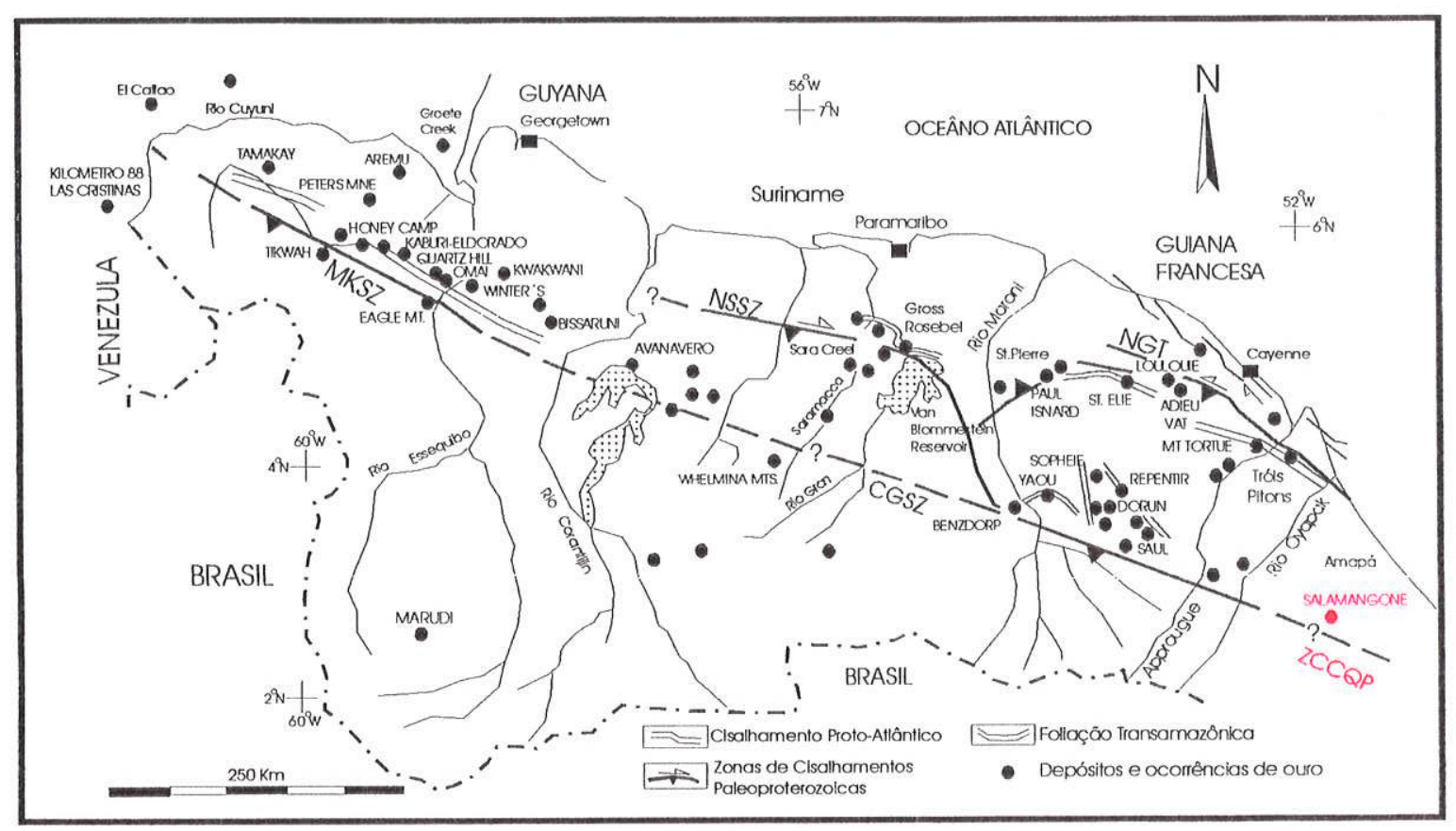

Figura 3.3 - Esboço da região abrangida pelo Escudo das Guianas mostrando a relação espacial entre as grandes estruturas tectônicas e os depósitos e ocorrências de ouro (modificado de Voicu et al. 2001). Simbologia: NGT - Norte Guiana Trough; CGSZ Central Guiana Shear Zone; NSSZ - Northern Suriname Shear Zone; MKSZ - MakapaKuribrong Shear Zone; CZCQP - Zona de Cisalhamento Caroni-Quatro Pancadas (Lima et al. 1991).

\subsection{GEOLOGIA DO DISTRITO AURÍFERO DE LOURENÇO}

Com base nos trabalhos desenvolvidos na região, complementados com os nossos dados adicionais gerados em estudos realizados no Morro de Salamangone, onde se localiza o depósito filonar quartzo-aurífero lavrado pela Mineração Novo Astro S.A., apresenta-se, a seguir, um quadro mais detalhado da geologia do Distrito Aurífero de Lourenço. 


\subsubsection{Súmula da Geologia do Distrito Aurífero de Lourenço, segundo Terraconsult} (1986)

A Mineração Novo Astro S.A., detentora dos direitos de lavra do depósito aurífero de Salamangone, contratou, em 1986, os serviços da Companhia Terraconsult, para executar investigações geológicas detalhadas (mapeamento geológico, amostragem sistemática em sedimentos de corrente e solo, geofísica e sondagem) concentradas, principalmente, numa área de cerca de $200 \mathrm{~km}^{2}$ em torno da localidade de Lourenço (Àrea de Lourenço). Adicionalmente, interpretações fototogeológicas e aerogeofísicas foram realizadas sobre uma área de cerca de $10.000 \mathrm{~km}^{2}$ situada entre o rio Araguari, ao sul, e a localidade Lourenço, a norte (Área Araguari), Figura 1.1.

Com base nesses levantamentos e estudos, a Terraconsult (1986) estabeleceu um quadro geológico regional, Quadro 3.1, pelo qual delineou-se 6 unidades geológicas principais, com a identificação de algumas sub-unidades, e tentou-se correlacionar com as informações geológicas disponíveis à época (DNPM 1974 e Schobbenhaous 1984), para a região norte-nordeste do Brasil.

A identificação das unidades geológicas, baseada em interpretações fotogeológicas apoiadas por evidências de campo, assim como as relações espaciais e de tempo entre elas, foram consideradas satisfatórias pela Terraconsult (1986). Entretanto, ressaltam que algumas unidades e as subunidades subordinadas, especialmente aquelas de caráter intrusivo, podem apresentar relações espaço-temporais diferentes. A resposta definitiva a este respeito, só poderia ser alcançada por determinações geocronológicas que, no caso, estariam fora do escopo do projeto de pesquisa mineral desenvolvido na região, àquela época.

Com relação específica à região do Distrito Aurífero de Lourenço, apresenta-se a seguir um esboço de sua geologia, baseado nos trabalhos de prospecção mineral desenvolvidos pela Terraconsult (1986). As condições de afloramentos das unidades geológicas são extremamente ruins, pois quase toda a região acha-se coberta por latossolos e saprolitos profundos, que apresentam em média espessuras de cerca de 40 a $50 \mathrm{~m}$, o que prejudicou os trabalhos de mapeamento. Além dos poucos afloramentos de rocha sã existentes e de alguns matacões, foram utilizadas informações obtidas nos pontos da amostragem de sedimentos de corrente e de solo. Assim sendo, merece destacar o esforço dos autores para esboçar um quadro geológico na região, frente a tantas dificuldades, e produto resultante, deve se visto como uma iniciativa pioneira, numa área de pouco, ou quase nenhum conhecimento geológico. 
$\mathrm{Na}$ área de Lourenço não foram observadas todas as unidades geológicas delineadas para a área de Araguari, região maior de estudo, Figura 1.1, e discriminadas no Quadro 3.1. Um esboço de sua geologia é apresentada na Figura 3.4, onde foram assinalados, também, os pontos amostrados de afloramentos de rocha e os locais de realização das amostragens de solo e de sedimentos de corrente. As unidades geológicas identificadas foram descritas de forma muito simplificada, em Terraconsult (1986), e são apresentadas a seguir.

a) rochas granitóides gnáissicas, gnaisses e migmatitos, que predominam em cerca de $40 \%$ da área, principalmente nos setores norte e sudoeste, em terrenos baixos, de relevo suave, com um padrão de drenagem relativamente denso, cujas condições geológicas, segundo Terraconsult (1986), seriam similares àquelas descritas para o Complexo Guianense (Issler et al. 1974 e Choubert 1974). Essas rochas foram correlacionáveis à sub-unidade A1, do Quadro 3.1 .

b) tonalitos, gnaisses tonalitícos e, subordinadamente, granodioritos, dominam a parte central da área, alinhando-se segundo direção sudeste-noroeste e desenvolvem uma zona com relevo alto de montanhas subarredondadas. Esta zona corresponde a uma porção da cadeia da Serra Lombarda, recebendo por isso o nome de Facies da Serra Lombarda, sub-unidade B-1 (Quadro 3.1), correlacionada com o Grupo Vila Nova (Issler et al. 1974

c) rochas anfibolíticas ocorrem segundo lentes associadas aos tonalitos. Afloram segundo manchas e configuram um cinturão arqueado, que se estende desde a região nordeste da localidade de Lourenço, abrangendo as áreas da Mineração Yoshidome e o setor sul do Igarapé Labourie. Na região de Lourenço esses corpos anfibolíticos foram incluídos, pela Terraconsult (1986), a exemplo dos tonalitos , na sub-unidade B1 (Quadro 3.1), dentro da Facies Serra Lombarda, correlacionada com o Grupo Vila Nova (Issler et al. 1974).

d) rochas metassedimentares, tais como xistos, filitos e quartzitos, que representam afloramentos de pequena extensão, geralmente na forma de lentes associadas a corpos de anfibolitos, também incluídas na sub-unidade B1 (Quadro 3.1) e, igualmente, correlacionáveis ao Grupo Vila Nova. 


\begin{tabular}{|c|c|c|c|c|c|c|c|}
\hline \multicolumn{2}{|c|}{$\begin{array}{l}\text { UNIDADE } \\
\text { PRINCIPAL }\end{array}$} & $\begin{array}{l}\text { SUB- } \\
\text { UNIDADE }\end{array}$ & $\begin{array}{l}\text { PRINCIPAIS TIPOS DE } \\
\text { ROCHA }\end{array}$ & \begin{tabular}{|c|} 
TIPOS DE ROCHA \\
OBSERVADOS NA \\
REGIÄO DE LOURENÇO
\end{tabular} & $\begin{array}{l}\text { ASPECTOS } \\
\text { FOTOMORFOLÓGICOS }\end{array}$ & \multicolumn{2}{|c|}{$\begin{array}{l}\text { TENTATIVA DE } \\
\text { CORRELAÇÄO } \\
\text { ESTRATIGRÁFICA }\end{array}$} \\
\hline \multicolumn{3}{|c|}{$\mathbf{F}$} & \multicolumn{3}{|c|}{ Sedimentos inconsolidados e produtos de alteração intempérica. } & \multirow{2}{*}{\multicolumn{2}{|c|}{\begin{tabular}{|c|} 
Quaternário \\
Episódio Cassiporé (Lima et al. \\
1974) \\
Permo-Triássico \\
\end{tabular}}} \\
\hline \multicolumn{3}{|c|}{$\mathbf{E}$} & $\begin{array}{l}\text { Rochas intrusivas de compo- } \\
\text { sição basáltica. }\end{array}$ & Diabásio, gabro. & $\begin{array}{l}\text { Lineamentos com orientação preferencial NS, } \\
\text { estruturas tipo diques e resistência à erosão. }\end{array}$ & & \\
\hline \multirow{4}{*}{$\begin{array}{c}\text { Ciclo } \\
\text { Intrusivo } 2\end{array}$} & \multirow{4}{*}{$\mathbf{D}$} & D-4 & $\begin{array}{l}\text { Rochas intrusivas de compo- } \\
\text { sição granítica. }\end{array}$ & Granito. & Relevo tipo inselberg, com montanhas elevadas. & \multirow{4}{*}{$\begin{array}{l}\text { Evento Mapuera? } \\
\text { (Lima et al. 1974) }\end{array}$} & \multirow{6}{*}{$\begin{array}{l}\text { Evento } \\
\text { Transa- } \\
\text { mazônico } \\
\text { (Protero- } \\
\text { zóico) }\end{array}$} \\
\hline & & D-3 & $\begin{array}{l}\text { Rochas intrusivas de compo- } \\
\text { sição principalmente granítica } \\
\text { (alcalina?). }\end{array}$ & Rochas granitóides. & Relevo baixo, localmente com drenagem anelar. & & \\
\hline & & D-2 & \begin{tabular}{|l|}
$\begin{array}{l}\text { Rochas intrusivas de compo- } \\
\text { sição principalmente granítica. }\end{array}$ \\
\end{tabular} & (Não observado). & Semelhante à D-1, com drenagem menos densa. & & \\
\hline & & D-1 & $\begin{array}{l}\text { Rochas intrusivas de compo- } \\
\text { sição principalmente granítica. }\end{array}$ & $\begin{array}{l}\text { Granito, monzogranito (to- } \\
\text { nalito). }\end{array}$ & $\begin{array}{l}\text { Relevo baixo, de montanhas subcirculares e } \\
\text { drenagem dendrítica densa. }\end{array}$ & & \\
\hline \multirow[b]{2}{*}{$\begin{array}{c}\text { Ciclo } \\
\text { Intrusivo } 1\end{array}$} & \multirow[b]{2}{*}{$\mathbf{C}$} & $\mathbf{C - 2}$ & $\begin{array}{l}\text { Rochas intrusivas de compo- } \\
\text { sição, granítica a granodiorítica. }\end{array}$ & (Não observado). & $\begin{array}{l}\text { Relevo semelhante à } \mathrm{C}-1 \text {, com drenagem } \\
\text { dendrítica de densidade média. }\end{array}$ & \multirow[b]{2}{*}{$\begin{array}{l}\text { Evento Falsino } \\
\text { (Lima et al.1974) }\end{array}$} & \\
\hline & & C-1 & $\begin{array}{l}\text { Rochas intrusivas de compo- } \\
\text { sição, granítica a granodiorítica. }\end{array}$ & (Não observado). & $\begin{array}{l}\text { Relevo baixo, de terrenos ondulados com } \\
\text { montanhas tipicamente alongadas e lobadas, de } \\
\text { baixa resistência à erosão. Drenagem dendritica } \\
\text { espaçada. }\end{array}$ & & \\
\hline \multirow{4}{*}{$\begin{array}{l}\text { Emba- } \\
\text { samento } 2\end{array}$} & \multirow{4}{*}{$\mathbf{B}$} & B-2 (3) & Xistos e rochas intrusivas. & (Não observado). & Terreno com ondulação suave e drenagem densa & \multirow{3}{*}{$\begin{array}{c}\text { Facies Serra do } \\
\text { Navio (Scarpelli } \\
1966)\end{array}$} & \multirow{4}{*}{$\begin{array}{c}\text { Grupo } \\
\text { Vila Nova } \\
\text { (Lima et } \\
\text { al. 1974) } \\
\text { Protero- } \\
\text { zóico }\end{array}$} \\
\hline & & B-2 (2) & Xistos e rochas intrusivas. & (Não observado). & $\begin{array}{l}\text { Terreno com ondulação suave e drenagem com } \\
\text { densidade média. }\end{array}$ & & \\
\hline & & B-2 (1) & $\begin{array}{l}\text { Metassedimentos, metavulcâ- } \\
\text { nicas e meta-anfibolito. }\end{array}$ & (Não observado). & $\begin{array}{l}\text { Terreno elevado e drenagem com alta intensidade } \\
\text { de entalhe. }\end{array}$ & & \\
\hline & & B-1 & $\begin{array}{l}\text { Tonalito, granodiorito, me- } \\
\text { tassedimentos e metavulcânicas. }\end{array}$ & $\begin{array}{l}\text { Tonalito, tonalito-gnaissico, } \\
\text { granodiorito, anfibolito, fili- } \\
\text { to e fels. }\end{array}$ & Relevo elevado, com montanhas subcirculares. & $\begin{array}{l}\text { Facies Serra } \\
\text { Lombarda } \\
\text { (Terraconsult } \\
1986 \text { ) } \\
\end{array}$ & \\
\hline \multirow{2}{*}{$\begin{array}{l}\text { Emba- } \\
\text { samento } 1\end{array}$} & \multirow[b]{2}{*}{$\mathbf{A}$} & $\mathbf{A}-\mathbf{2}$ & $\begin{array}{l}\text { Série complexa de: gnaisses, } \\
\text { migmatitos, granulito } \quad \mathrm{e}\end{array}$ & (Não observado). & $\begin{array}{l}\text { Relevo baixo, de terreno suave e drenagem } \\
\text { dendrítica densa. }\end{array}$ & \multirow{2}{*}{\multicolumn{2}{|c|}{$\begin{array}{c}\text { Complexo Guianense } \\
\text { (Choubert 1974, Issler et al. } \\
\text { 1974) } \\
\text { Arqueano-Proterozóico }\end{array}$}} \\
\hline & & A-1 & granitóides indiferenciados. & $\begin{array}{l}\text { Granito, tonalito, granito- } \\
\text { gnaissico. }\end{array}$ & $\begin{array}{l}\text { Relevo baixo, de terreno suave e drenagem } \\
\text { dendrítica com densidade média. }\end{array}$ & & \\
\hline
\end{tabular}

Quadro 3.1 - Unidades litológicas identificadas na região centro-leste do Amapá e tentativa de correlação estratigráfica (Terraconsult 1986). 


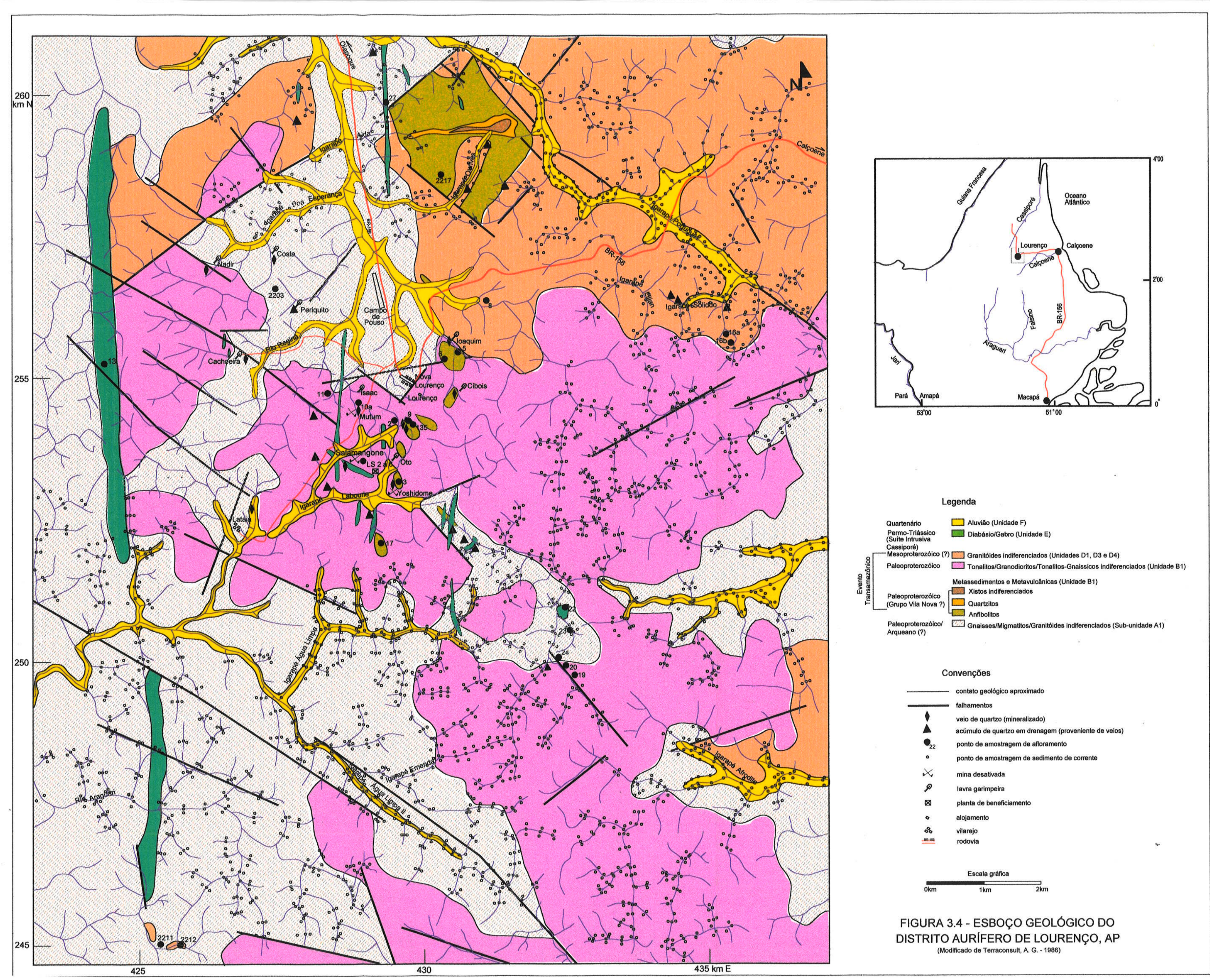


e) rochas de composição predominantemente granítica, ocasionalmente tendendo a monzonítica, que mostram uma relação espacial intrusiva, e portanto mais novas que as demais unidades litológicas anteriormente citadas, incluídas no ciclo intrusivo 2 e correlacionáveis ao evento Mapuera, Lima et al. 1974, (Quadro 3.1).

f) os veios de quartzo estão freqüentemente associados a sistemas de lineamentos regionais que cortam as unidades geológicas, acima descritas. A maioria orienta-se segundo a direção $\mathrm{NW}$, com mergulhos acentuados para NE ou SW, apresentando espessuras entre poucos centímetros até 5 metros, com média abaixo de 1 metro, e extensão lateral que dificilmente excede a 50 metros. Estas observações foram bastante prejudicadas, devido à falta de afloramentos contínuos. As localidades onde foram identificados afloramentos com maior expressão de veios de quartzo, situam-se nas proximidades das antigas minerações de Mutum e de Lataia (atualmente inundada), no Morro de Salamangone, na Mina de Yoshidome e na área de garimpo Nadir.

g) Veios pegmatíticos que desenvolvem-se em estruturas de baixo ângulo de mergulho, com direções diversas e espessuras de cerca de 0,3 a 1 metro atravessando todas as unidades geológicas da região de Lourenço e, nitidamente, posteriores aos veios de quartzo.

h) Diques básicos que atravessam toda a região estudada, com direção predominante nortesul, facilmente identificáveis pela sua orientação e resistência à erosão. Numerosos diques, de pequena extensão e com larguras de poucos metros até 50 metros, podem ser observados na região central, enquanto que um dique maior, de cerca de $17 \mathrm{~km}$ de extensão e $250 \mathrm{~m}$ de largura, desenvolve-se paralelamente ao limite oeste da área investigada, constituindo três manchas alongadas. Esses diques básicos, incluídos na unidade $\mathrm{E}$, foram correlacionados ao Evento Cassiporé (Lima et al. 1974), de idade Permo-Triássica, de acordo com o Quadro 3.1.

i) Material aluvionar recente não consolidado encontrado na maioria dos vales dos principais sistemas de drenagem, tais como do rio Regina, Araguari e Igarapés Português, Labourie, Lataia, etc. Esses sedimentos fazem parte da unidade F, correlacionada ao Quaternário, no Quadro 3.1.

No esboço geológico da região, Terraconsult (1986) indica, tão somente, direções estruturais regionais, restituídas por fotogeologia. No Distrito de Lourenço, segundo os 
autores, destaca-se a estrutura da Serra Lombarda que alinha-se, preferencialmente, numa direção sub-paralela à orientação NW-SE. Os lineamentos principais acompanham essa direção e parecem representar as estruturas primárias da região, sendo atravessados por lineamentos secundários com orientação NE-SW. Ao lado desses lineamentos maiores, um sistema de lineamentos de orientação E-W, seciona a estrutura da Serra Lombarda. Essas informações constam do esboço geológico, Figura 3.4.

\subsubsection{Geologia do Distrito Aurífero de Lourenço via análise integrada de dados geofísicos, geológicos e de sensoreamento remoto}

Em face das dificuldades encontradas para a elaboração de um mapa geológicoestrutural do distrito, com vistas a servir de base à pesquisa de descoberta de novos depósitos auríferos, a Companhia de Mineração do Amapá - CMA, executou via PROSPEC S.A., em 1991, o Projeto Aerogeofísico Lourenço, que consistiu do levantamento aerogamaespectrométrico e aeromagnético do Distrito Aurífero de Lourenço, Figura 3.5, cujas características técnicas foram as seguintes:

- Empresa executora-Prospec S.A.

- Data de levantamento - novembro de 1991.

- Plataforma de aquisição - helicóptero esquilo HB-350B.

- Altura média de vôo - 30 metros.

- Direção das linhas de medida $-\mathrm{N} 37^{\circ} \mathrm{E}$ na área Lourenço e $\mathrm{N} 45^{\circ} \mathrm{E}$ na área Tajauí.

- Espaçamento entre linhas de medida - 200 ou 100m (detalhe) na área de Lourenço, $250 \mathrm{~m}$ na área de Tajauí.

- Intervalo médio de amostragem - 6 amostras por segundo para a magnetometria, 1 amostra por segundo para a gamaespectrometria.

- Volume de cristal - 1024 polegadas cúbicas.

- Gamaespectrômetro - Geometrics GP-800.

- Magnetômetro - vapor de cesio Scintrex com resolução de 0,01 nT, com sensor montado em bird. 


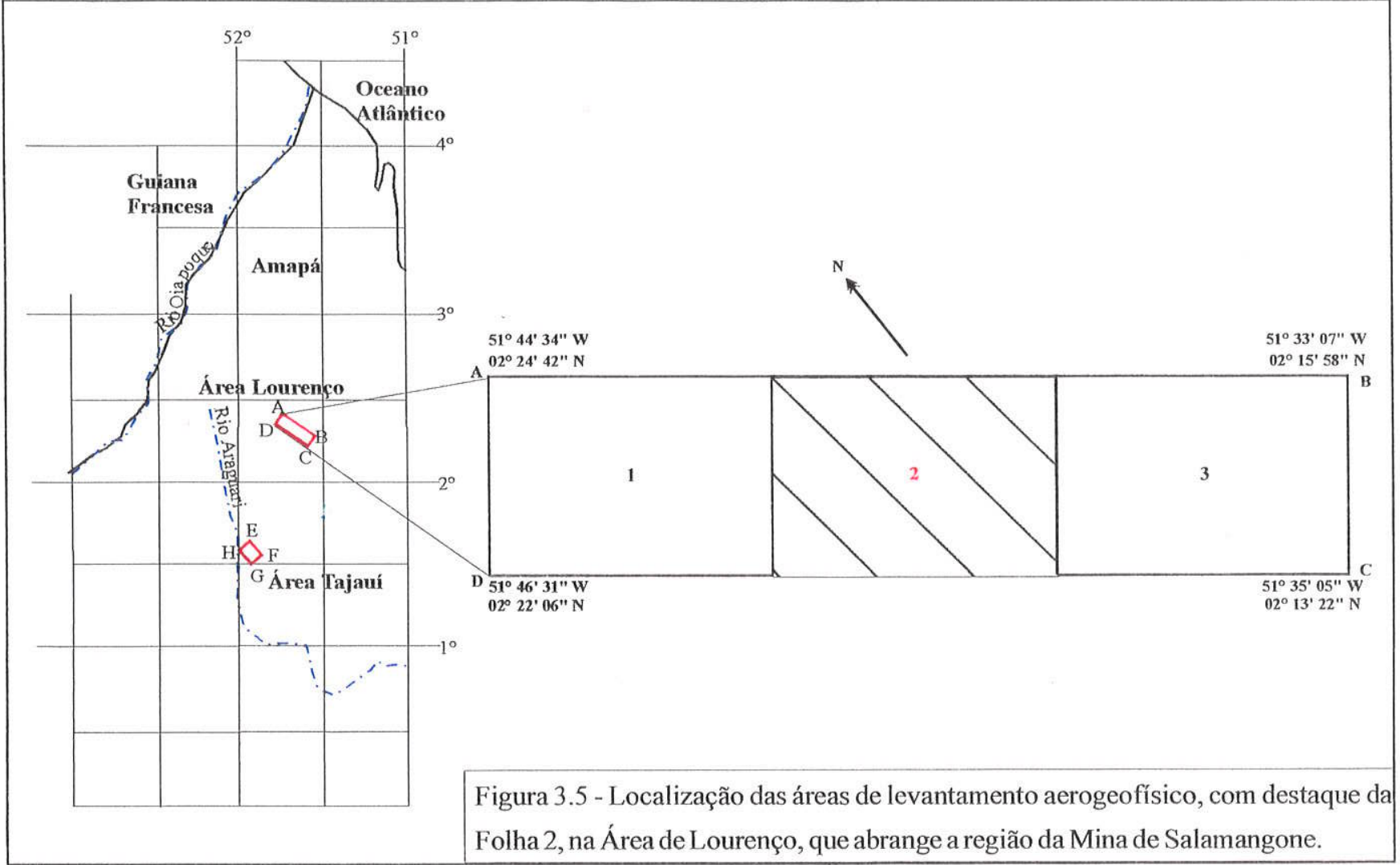

Os resultados aerogeofísicos obtidos foram reinterpretados por Bettencourt \& Ferreira (1993), visando a integração dos dados geofísicos e geológicos, dirigidos não só ao reconhecimento de novos alvos auríferos, como também ao planejamento de trabalhos de geofísica terrestre subsequentes. Deixa-se claro que não é objetivo deste estudo, discutir em detalhe, os materiais e métodos de estudo, mais especificamente as técnicas de processamento utilizadas no levantamento aerogeofísico. A interpretação e resultados obtidos foram modificados para este estudo e apresentados a seguir.

\subsubsection{Análise de anomalias magnéticas}

O processamento dos dados do campo magnético anômalo, Figuras 3.6 e 3.7, sua interpretação e integração possibilitaram a confecção dos mapas de domínios magnéticos e padrões de lineamentos correlatos, Figuras 3.8 e 3.9, do Distrito Aurífero de Lourenço. Os critérios utilizados para a interpretação aeromagnética, foram os seguintes:

- Definição dos eixos de máximos e mínimos relativos das anomalias aeromagnéticas;

- Análises de freqüência espacial e de amplitudes das anomalias aeromagnéticas; 
- Definição dos gradientes (estruturas magnéticas);

- Definição de anomalias isoladas (dipolos).

Os domínios magnéticos caracterizados, apresentados na Figura 3.8, são os seguintes:

\section{Domínio A}

Este domínio está associado às altas freqüências e altas amplitudes, possui relevo magnético elevado e as amplitudes variam de 29.1568 até 29.3508 gama. Dentro deste domínio ocorrem segmentos com freqüências intermediárias. Os parâmetros geomagnéticos observados expressam as características de rochas granitóides reconhecidas no campo, como sendo "tonalitos" (granitóides tipo I a magnetita). A variabilidade de valores de freqüência e de amplitude podem representar mudanças faciológicas dentro do domínio, ou alçamento e afundamento de blocos. É possível verificar dentro do domínio $\mathrm{A}$, padrões aeromagnéticos bidimensionais (pares alto/baixo) que permitem descriminar diques básicos.

\section{Domínio B}

Este domínio está associado a freqüências intermediárias e amplitudes média a média/alta, variando de 29.120 a 29.1568 gama. Dentro do mesmo foram individualizados os subdomínios $\mathrm{B} 1$, com freqüências mais elevadas em relação à média e B2, caracterizado por amplitudes entre 29.120 e 29.1288 gama. Com os dados geológicos disponíveis na porção NE do mapa (Figura 9), foram observados biotita monzogranitos e rochas metavulcânicas não diferenciadas. No subdomínio B1 as características dos parâmetros aeromagnéticos são compatíveis com rochas metavulcânicas (provavelmente anfibolitos). No subdomínio B2 podem predominar rochas granítico-gnaissicas (Alvo Cachoeira). Neste, foi possível identificar, também, corpos bipolares tridimensionais representados por possíveis corpos básicos.

\section{Domínio C}

Este domínio é caracterizado pela frequiência baixa (relevo magnético suave) e amplitudes média a média/baixa, variando de 29.090 a 29.120 gama. Corresponde, principalmente, a zonas para as quais não exitem levantamentos geológicos de reconhecimento. 


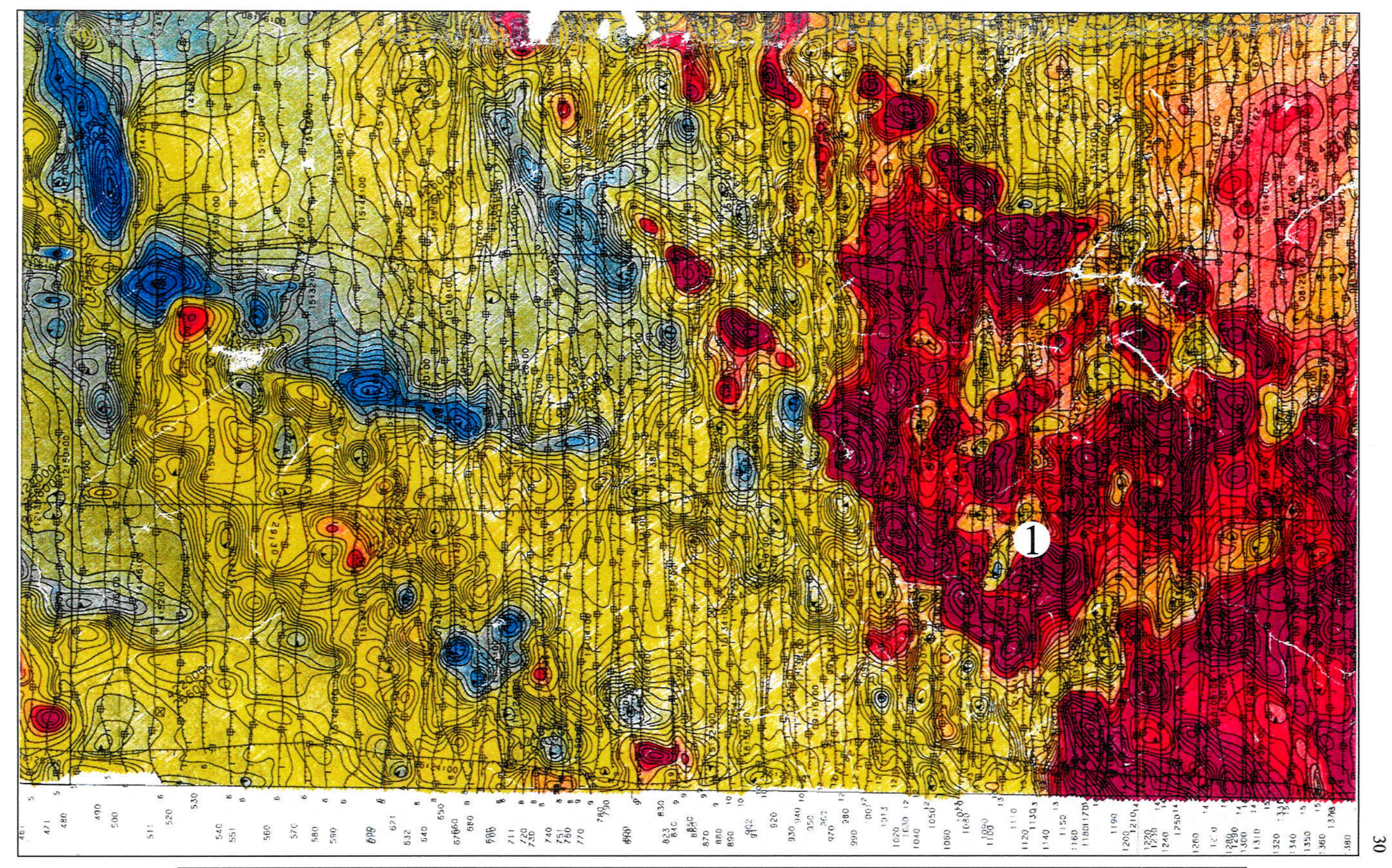

Figura 3.6 - Mapa de contorno de campo magnético. Região de Lourenço, Área II, Amapá. 1. Depósito de Salamangone. 


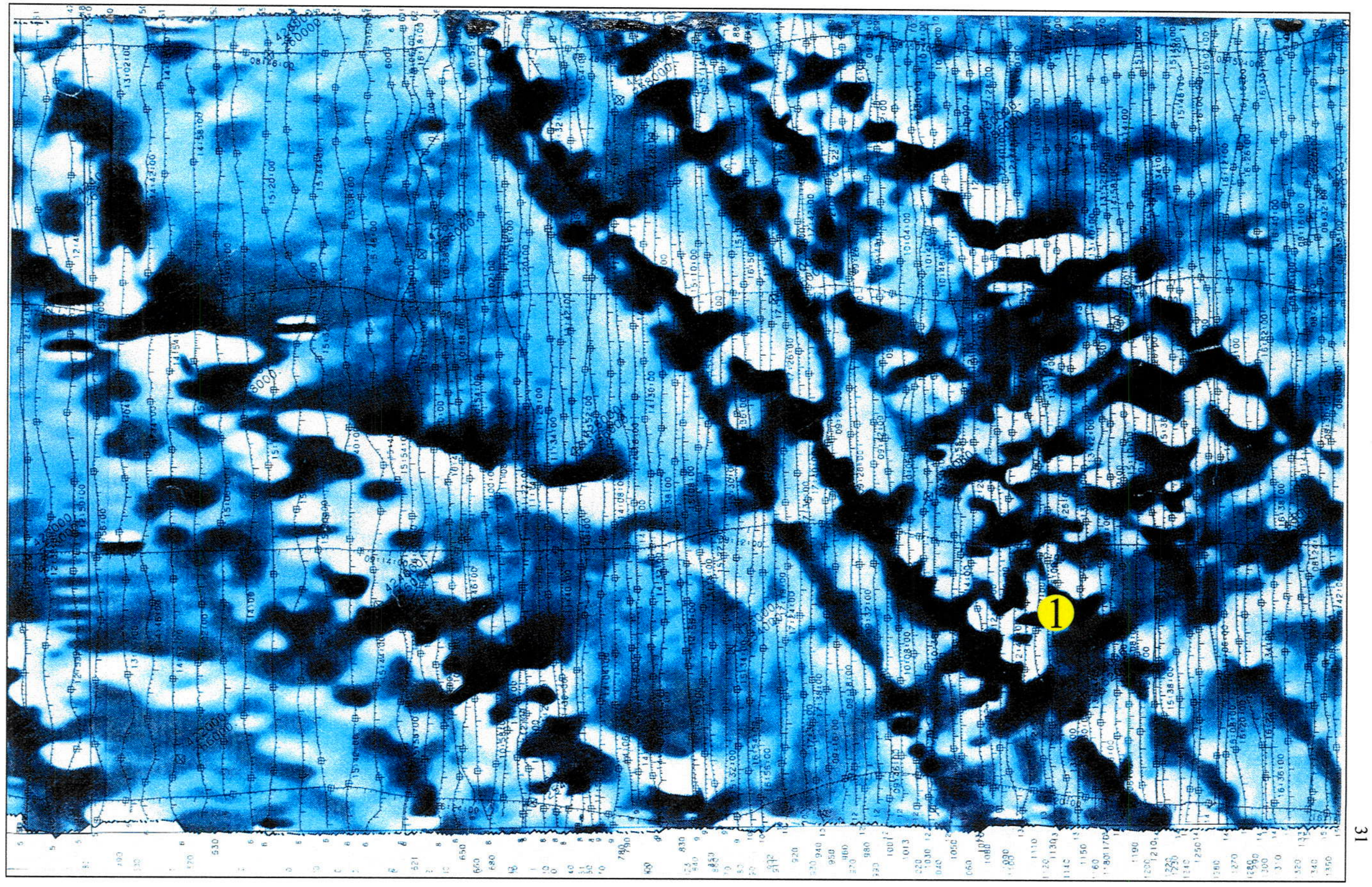

Figura 3.7 - Mapa de sombras. Região do Lourenço, Área II, Amapá. 1. Depósito de Salamangone. 


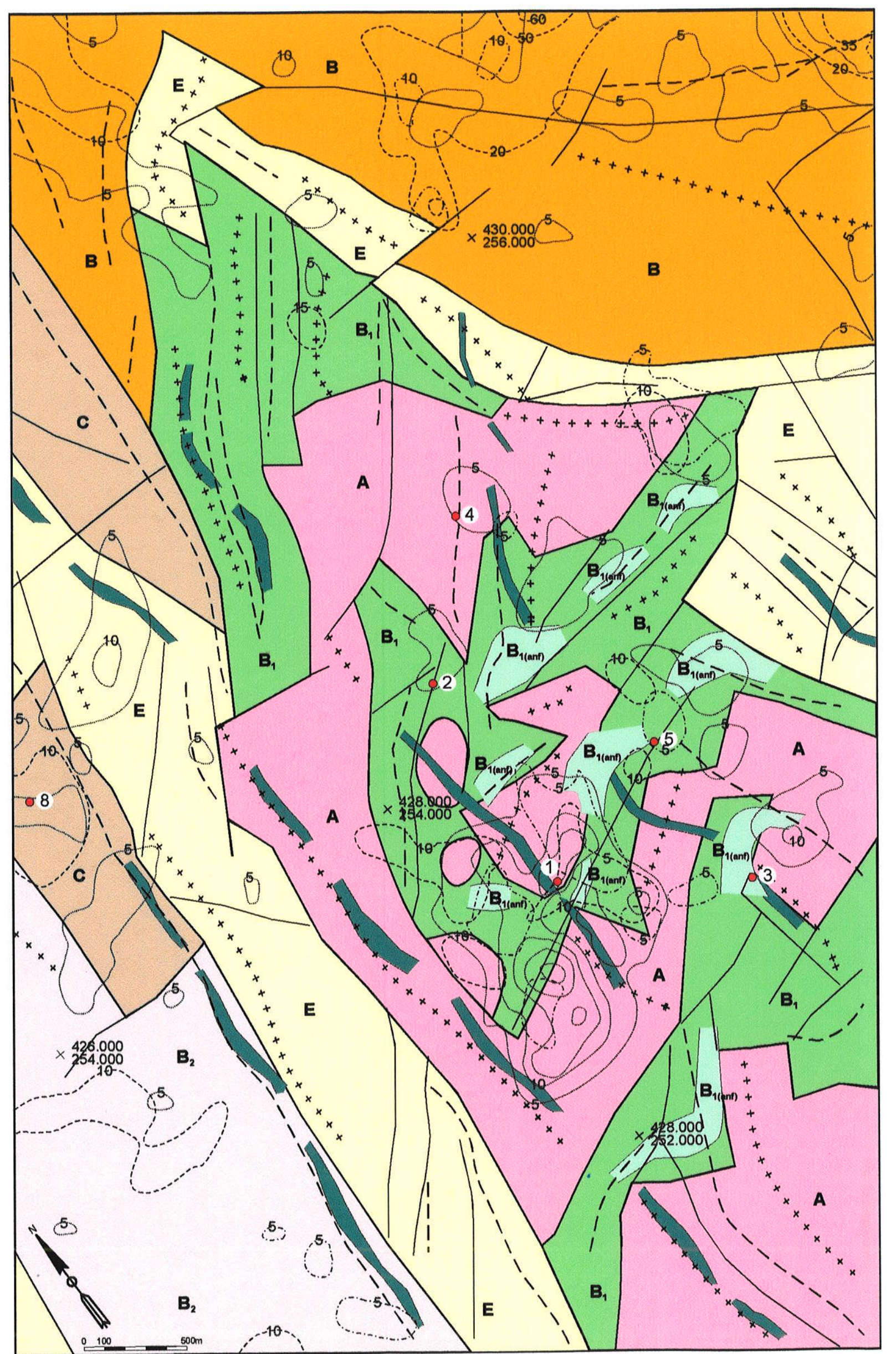

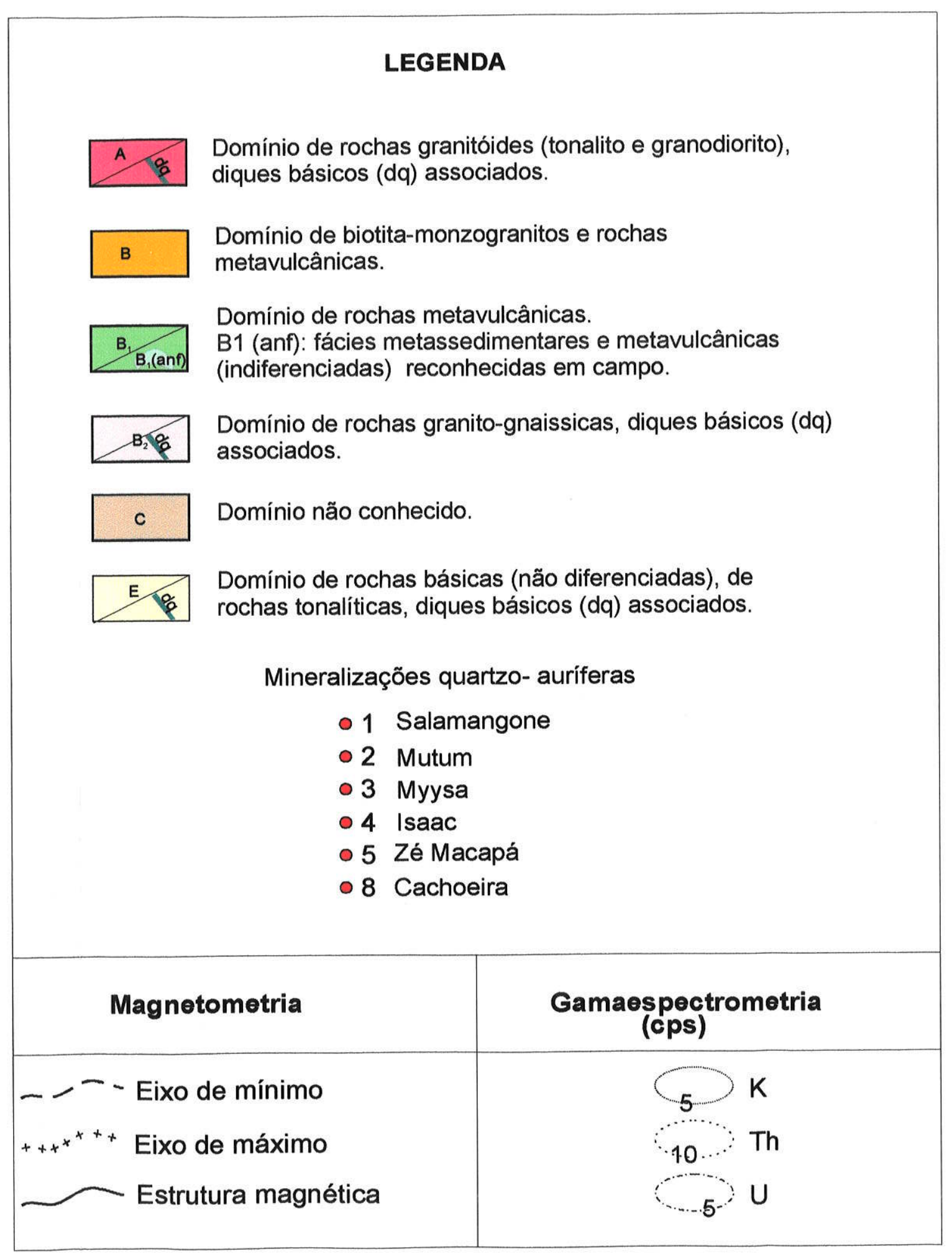

Figura 3.8 - Mapa de interpretação de dados de levantamentos magnetométricos e gamaespectrométricos (Modificado de Bettencourt \& Ferreira 1993) 


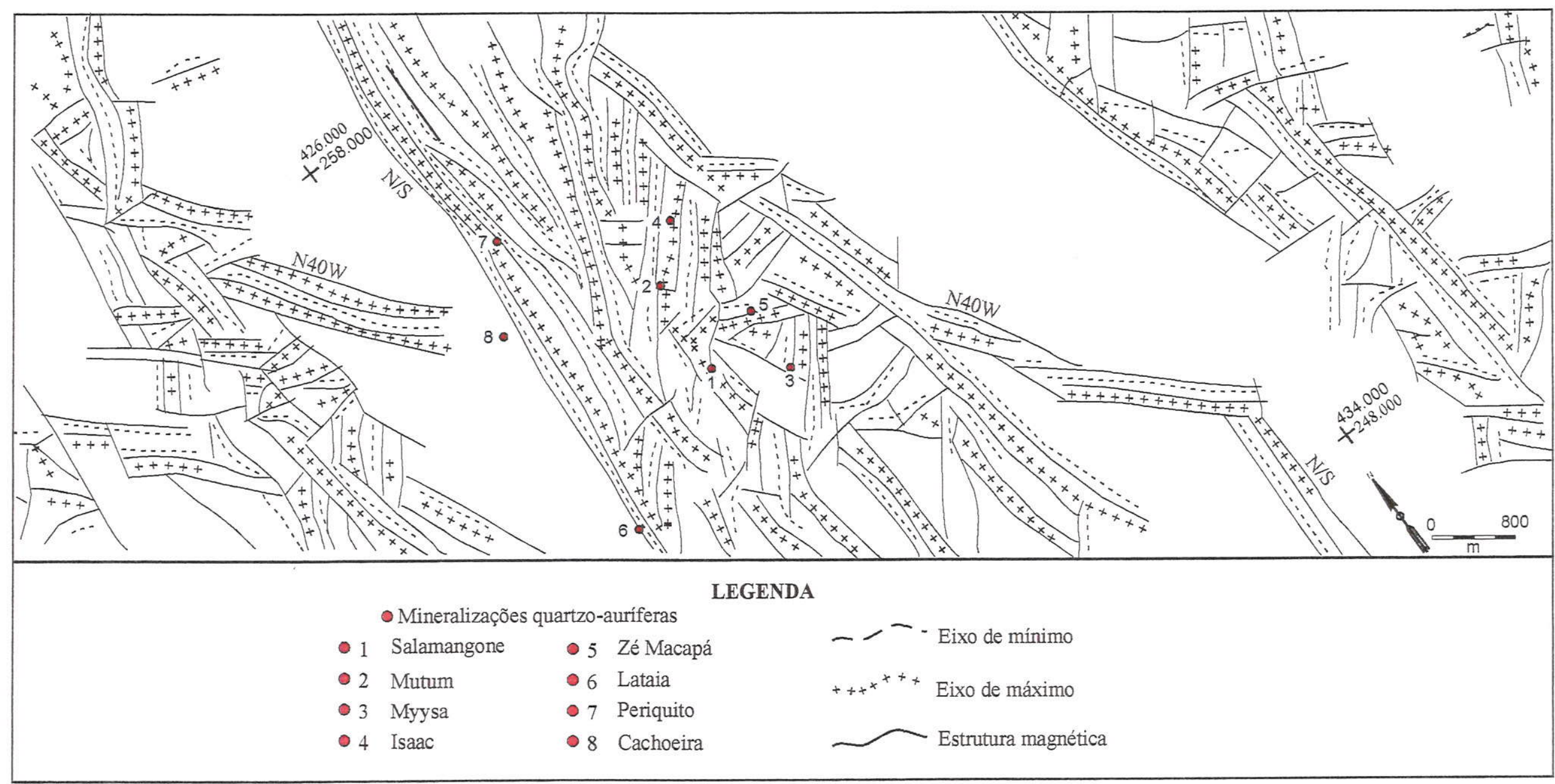

Figura 3.9 - Mapa de interpretação de dados de levantamentos aeromagnéticos, exibindo os padrões de lineamentos que ocorrem no Distrito Aurífero de Lourenço (Modificado de Bettencourt \& Ferreira 1993). 


\section{Domínio E}

É caracterizado pelo alinhamento de anomalias de alta freqüência com amplitudes extremamente variáveis. Relevo magnético bastante movimentado e padrões aeromagnéticos comumente bidimensionais. As amplitudes variáveis podem sugerir tipos distintos de rochas básicas. As características dos padrões bidimensionais aliadas à freqüência alta e controle estrutural N/S foram critérios usados para a identificação deste domínio, porém algumas anomalias de direção NW, que não revelam bipolaridade (apenas anomalias positivas) poderiam ser interpretados como sendo corpos básicos ou tonalíticos.

\subsubsection{Análise de anomalias gamaespectrométricas}

O método permitiu identificar zonas com concentrações anômalas de $\mathrm{K}$, Th e $\mathrm{U}$, e configuração de anomalias relacionadas às assinaturas desses elementos em rocha ou produtos de alteração hidrotermal. O s critérios usados para separação das anomalias individuais de $\mathrm{K}$, The $U$, levaram em conta a:

- identificação empírica e realce das anomalias em função do background e limiar de cada uma. $\mathrm{O}$ uso do termo anomalia, neste resumo, não corresponde à definição estatística.

- análise gráfica das amplitudes e frequiências de perfis pré-selecionados.

A correlação das anomalias de $\mathrm{K}, \mathrm{U}$ e Th nos domínios magnéticos, mostradas na Figura 3.8, foi a seguinte:

\section{Domínio A}

Altos valores de $\mathrm{K} \mathrm{e} \mathrm{U}$, associados a rochas tonalíticas e restritos a halos de alteração contendo mineralização aurifera, em zonas de cisalhamento. Não há anomalias de $T h$, expressivas, associadas ao domínio A.

\section{Domínio B}

Nas seqüências metavulcânicas as anomalias de $\mathrm{K}$ são raras ou inexistentes. Os valores de Th crescem ao se passar dos tonalitos às rochas metavulcânicas. Nas rochas graníticas ocorrem superpostas, altas amplitudes de anomalias de $\mathrm{K}, \mathrm{U}$ e Th. As rochas graníticas podem, provavelmente, serem referidas aos alcali-biotita granitos da Suíte Mapuera. No subdomínio B1 inexistem anomalias de $\mathrm{K}$ e a presença de anomalias de $\mathrm{K}$ em zonas internas aos corpos de tonalito, pode ser devida ao enriquecimento de $\mathrm{K}_{2} \mathrm{O}$ em zonas cisalhadas, sujeitas a alto fluxo fluidal. Anomalias conjugadas de Th e U, também, podem 
ocorrer. A coexistência das três anomalias relativas a $\mathrm{K}, \mathrm{U}$ e Th em rochas metavulcânicas é devida à ocorrência de mineralização aurífera. No subdomínio B2 há ocorrências esparsas de anomalias de U e K. Em toda a área observam-se anomalias significantes de Th.

\section{Domínio C}

Na porção norte da Folha 2, Figuras 3.5 e 3.6, há anomalias superpostas de K, U e Th sendo que os teores de $U$ são menos expressivos. Estas anomalias abrangem aproximadamente 3 vs. $0,7 \mathrm{~km}$. Na porção sul, da mesma folha, ocorrem anomalias expressivas de $\mathrm{K}$ e Th conjugadas a anomalias de $\mathrm{U}$, talvez as mais altas de toda a região em estudo. Este enriquecimento em $\mathrm{K}$ e Th deve refletir, provavelmente, feldspatização e sericitização, associadas à alteração hidrotermal em rochas granitóides, atravessadas por zonas de cisalhamento.

\section{Domínio E}

Ausência de anomalias K, U e Th.

\subsubsection{Análise das zonas de cisalhamento}

Os mapas de derivadas horizontais, verticais e fase de sinal analítico, foram extensivamente usados por Bettencourt e Ferreira (1993), para caracterizar o padrão estrutural do distrito, apesar das dificuldades relativas à elaboração d qualquer mapageolóico do distrito em estudo. Os sistemas de cisalhamento paleoproterozóicos, deduzidos dos mapas aeromagnéticos (Figuras 3.7 e 3.9), parecem ser, em princípio, as estruturas que controlam a mineralização aurífera, e são os seguintes:

\section{Sistema E-W}

Lineamentos cerrados $\mathrm{E}-\mathrm{W}$ que cortam estruturas mais antigas. O espectro aeromagnético não é contínuo, pois é um reflexo da relação sinal/ruído.

\section{Sistema N-S}

Lineamentos regionais orientados segundo a direção N-S ocupados ou não por diques básicos Permo-Triássicos. Possuem espectro aeromagnético contínuo. Os sistemas E-W e N-S deslocam e compartimentam todas as unidade do substrato rochoso mais antigo. Os rejeitos são significativos e podem ser constatados nos mapas aeromagnéticos. Nas zonas onde 
ocorrem tonalito e rochas granitóides ígneas, o padrão de cisalhamento é distinto e reflete as características rígidas dos maciços.

\section{Sistema de lineamentos regionais conjugados $\mathrm{N}_{60}^{\circ} \mathrm{W}$ e $\mathrm{N} 60^{\circ} \mathrm{E}$}

Estes sistemas correspondem a zonas de cisalhamento dúctil a dúctil-rúptil paleoproterozóicas, possivelmente, reativadas não só no Mesoproterozóico e Noproterozóico, como também no Mesozóico ou, mesmo, no Terciário. As estruturas NE não são tão expressivas nos mapas aeromagnéticos devido, provavelmente, à baixa inclinação do vetor campo magnético indutor.

\section{Sistemas lineares $\mathrm{N}_{40}^{\circ}-45^{\circ} \mathrm{W}, \mathrm{N} 10^{\circ}-30^{\circ} \mathrm{W}, \mathrm{N}^{\circ} 0^{\circ}-30^{\circ} \mathrm{E}$ e $\mathrm{N70}-75^{\circ} \mathrm{W}$}

Como hipótese de trabalho, estas estruturas foram admitidas como sendo do tipo Riedel, a saber:

$\mathrm{N} 40^{\circ}-45^{\circ} \mathrm{W}$ - falhas do tipo $\mathrm{R}$

$\mathrm{N} 10^{\circ}-30^{\circ} \mathrm{W}$ - fraturas de partição

$\mathrm{N} 10^{\circ}-30^{\circ} \mathrm{E}$ - falhas $\mathrm{R}^{\prime}$ conjugadas

$\mathrm{N} 70^{\circ}-75^{\circ} \mathrm{W}$ - falhas do tipo $\mathrm{P}$

Estas inferências basearam-se nos dados e padrões estruturais observados na Mina do Salamangone. $\mathrm{O}$ binário externo de cisalhamento nos planos de falhas principais $\mathrm{N} 57^{\circ}-60^{\circ} \mathrm{W}$ indica movimento dextral, o que autoriza a admitir que as estruturas em discussão possam ser enquadradas no modelo Riedel teórico.

As mineralizações auríferas conhecidas, contidas em corpos granitóides, estão associadas às direções de cisalhamento $\mathrm{N} 50^{\circ}-60^{\circ} \mathrm{W}$ (Mina de Salamagone), $\mathrm{N} 40^{\circ}-45^{\circ} \mathrm{W}$ (Mina de Mutum e área de garimpo Periquito) e $\mathrm{N} 20^{\circ}-30^{\circ} \mathrm{W}$ (áreas de garimpo Cachoeira e Isaac). Algumas ocorrências de mineralizações identificadas em rochas metavulcânicas estão associadas principalmente, às direções $\mathrm{N} 10^{\circ}-20^{\circ} \mathrm{W}$. 


\section{CAPÍTULO 4}

\section{Geologia da Área da Mina de Salamangone}

\subsection{CONSIDERAÇÕES GERAIS}

O depósito de Salamangone hospeda-se em um maciço granitóide de forma dômica, com uma composição, nitidamente tonalítica, que, no âmbito da mina, é cortado por diques de rochas básicas (já metamorfisadas), concordantes com as estruturas de cisalhamento (em particular aos corpos filonianos), e seccionado, ainda, por diques mais tardios de rochas granodiorítica, pegmatítica e diabásica. A Figura 4.1, representa a geologia simplificada da galeria de desenvolvimento da mina, no nível $345 \mathrm{~m}$, onde se observam as relações acima citadas, as quais estão caracterizadas com maior detalhe nas Figuras 4.2 e 4.3. Todas as associações litológicas descritas são intrusivas em uma seqüência vulcano-sedimentar metamorfisada, provavelmente relacionada ao Grupo Vila Nova. Restos ainda preservados dessa seqüência, foram identificados em toda a área circundante à mina de Salamangone, configurando grandes enclaves, conforme já mostrado na Figura 3.8.

$\mathrm{O}$ granodiorito apresenta-se na forma de diques, que exibem direção N-S e mergulhos sub-verticais. As suas espessuras variam desde poucos centímetros até cerca de 1 metro, (Figura 4.2). Os corpos são cortados pelas demais rochas presentes na área da mina, e o contato entre eles é feito de forma abrupta, mostrado na Figura 4.4e.

Os corpos pegmatíticos constituem, pelo menos, duas gerações. Os pegmatitos de uma geração mais antiga, apresentam-se como diques de pequena espessura (centimétricos), aparentemente controlados por estruturas que exibem altos ângulos de mergulho, geralmente associados aos veios de quartzo e à rocha tonalítica cataclasada e milonitizada, dentro da zona de cisalhamento. Uma segunda geração de pegmatitos, ocorre como corpos tabulares que podem atingir dezenas de metros de extensão e largura de quase 1 metro, exibindo, em sua maioria, atitudes subhorizontal e seccionando todo o sistema filoniano do depósito de Salamangone e suas rochas encaixantes (Figuras 4.1, 4.2, 4.3 e $4.4 \mathrm{a}$ e b), originando alterações termais e hidrotermais. Apresentam, variações a termos aplíticos, e o contato com as demais litologias é abrupto, Figura $4.4 \mathrm{c}$. 


$$
\stackrel{100}{ \pm}
$$




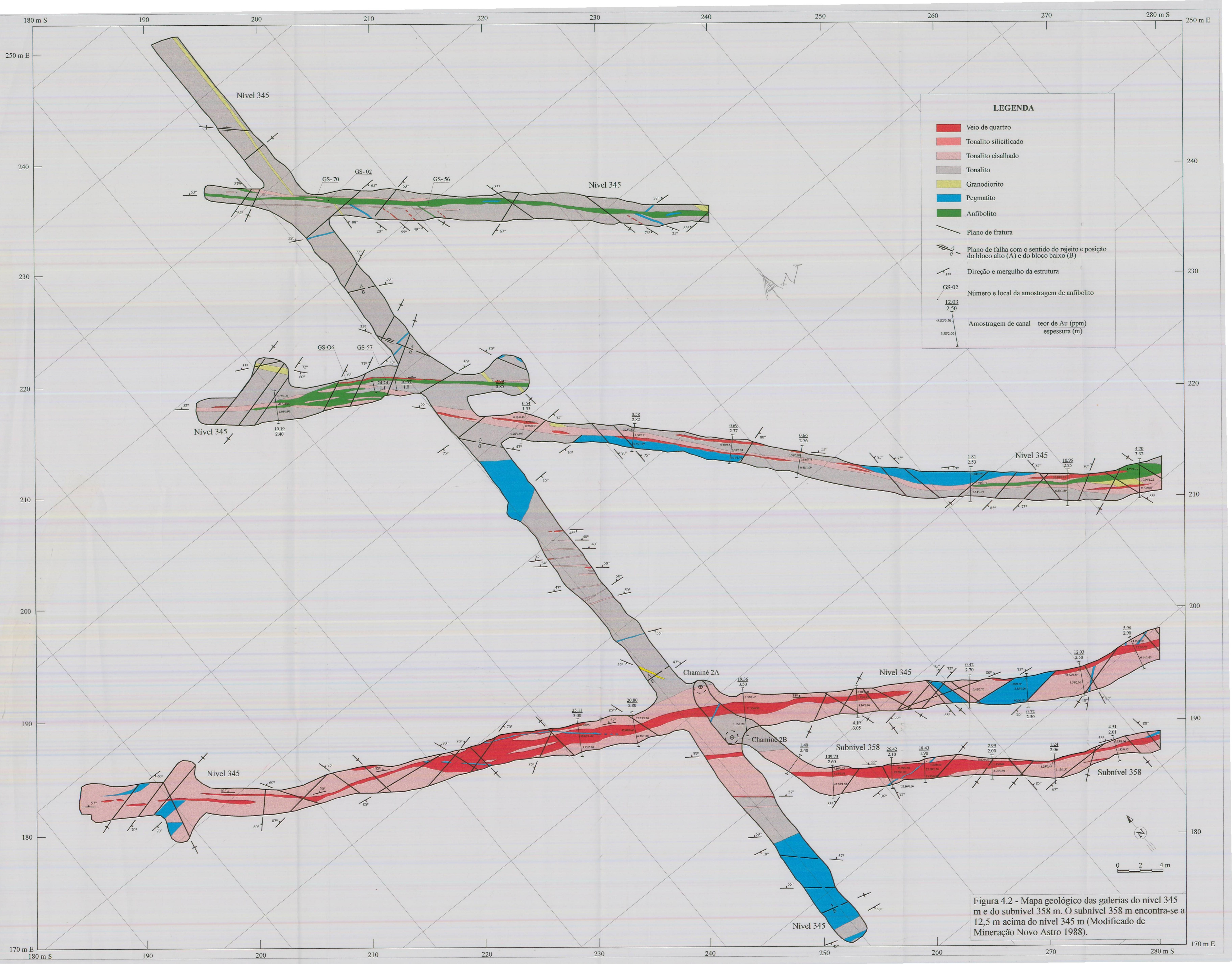




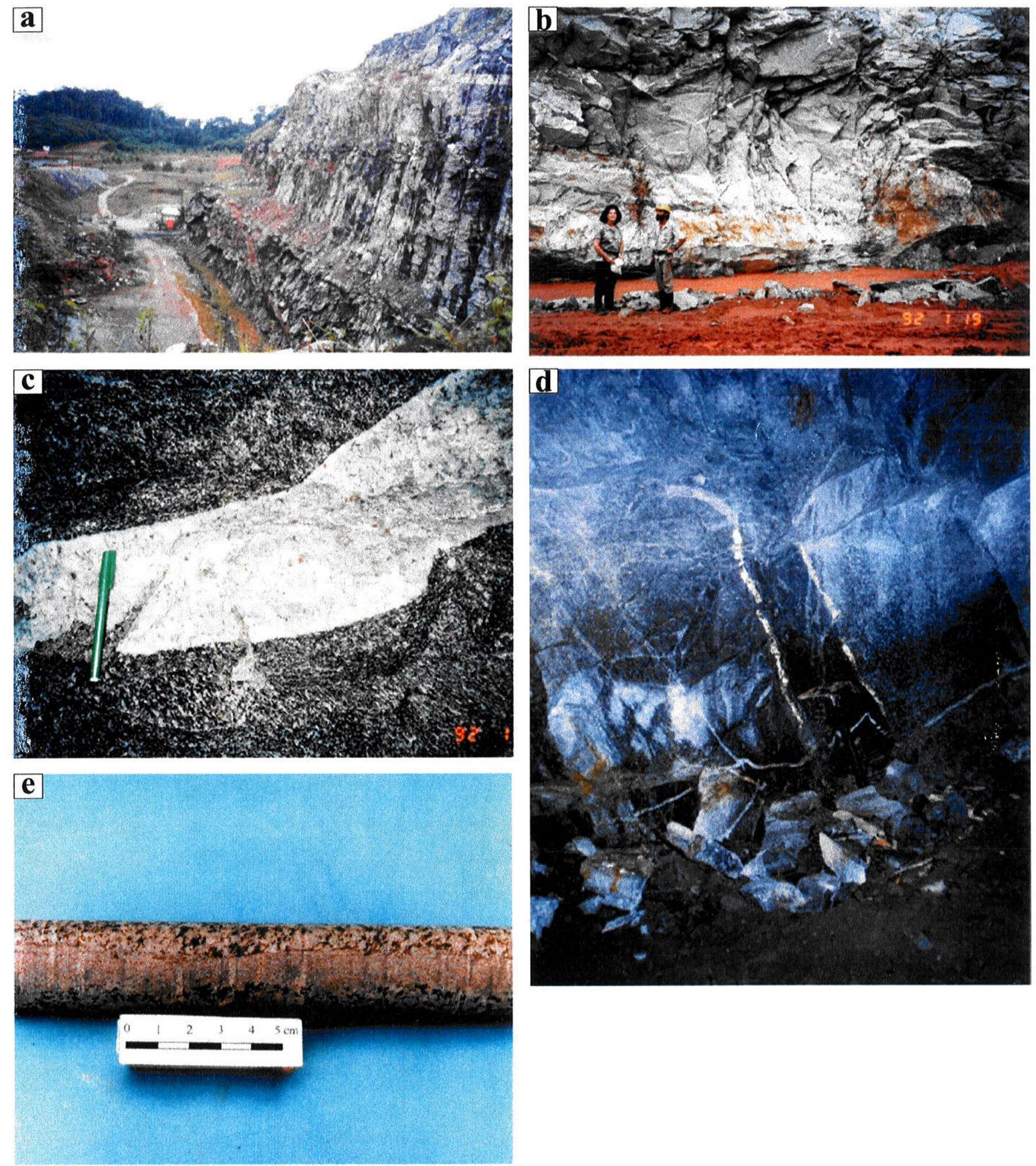

Figura 4.4 - Relações de contato entre as rochas encaixantes da mineralização quartzo-aurífera: a) Vista geral dos corpos pegmatíticos que seccionam a tonalito e o granodiorito, com atitudes em baixo ângulo, b e c) Detalhes do contato brusco entre o pegmatito-aplito e o tonalito, na área da antiga cava a céu aberto e na galeria do nível $290 \mathrm{~m}$ da mina subterrânea, respectivamente, d) Dique de anfibolito em contato com a rocha tonalítica, na travessa de acesso ao nível $229 \mathrm{~m}$ da mina (as bordas do dique estão realçadas com tinta branca), e) Detalhe do contato brusco entre dique granodiorítico e o tonalito (Furo de sondagem interna FI-104, nível $41 \mathrm{~m}$ da mina). 
Os diques de metabasitos (anfibolito) paralelos aos veios de quartzo auríferos, cortam as rochas tonalíticas, granodioríticas e pegmatíticas de primeira geração (Figuras 4.14 .2 e 4.3 e 4.4d). Geralmente mostram-se como rochas deformadas, com orientação mineral evidente, embora tipos levemente anisótropos também sejam encontrados, e apresentam, comumente, evidências de alteração hidrotermal.

Os diques de diabásio mesozóicos são expressivos, cortam todas as litologias descritas, orientam-se segundo direção norte-sul, são subverticais e podem atingir comprimentos de até $17 \mathrm{~km}$ e espessuras máximas de $250 \mathrm{~m}$ (no Distrito), conforme ilustrado nas Figuras 3.4 e 3.8. Na área da Mina de Salamangone, um dique de diabásio secciona o sistema filoniano, não se verificando a continuidade física da mineralização além deste dique, no sentido SW (Figuras 2.1 e 6.4).

\subsection{AS ROCHAS ENCAIXANTES DA MINERALIZAÇÃO}

Os estudos foram realizados para caracterizar, em especial, a rocha tonalítica, hospedeira principal da mineralização.

\subsubsection{A associação tonalítica-granodiorítica}

A associação tonalito-granodiorito constitui a encaixante principal da mineralização quartzo-aurífera, com nítida predominância da facies tonalítica. Sua amostragem foi viabilizada pelos trabalhos de lavra da mina e furos de sondagem, que permitiram a seleção de amostras menos afetadas, ou com poucas evidências da ação dos fluidos hidrotermais mineralizantes e, portanto, mais adequadas à caracterização petrográfica e geoquímica. A localização dos furos de sondagem e afloramentos está indicada na Figura 2.1.

\subsubsection{Caracterização petrográfica}

As composições modais de amostras granitóides representativas das rochas encaixantes pouco afetadas pela mineralização, são apresentadas nas Tabelas $4.1 \mathrm{a}$ e b. A Figura 4.5 apresenta os diagramas modais QAP: a) campos como em Streckesein (1976), onde essas amostras dispõem-se, preferencialmente, segundo agrupamentos pouco dispersos, nos campos do tonalito e granodiorito, com uma amostra incidindo no campo do quartzodiorito e b) campos de acordo com Lameyre \& Bowden (1982), onde os granitóides alinham- 
se segundo o trend cálcio-alcalino, evoluindo de baixo para médio K. A amostra C-01, que incide no campo quartzo-diorítico, seguindo a linha cálcio-alcalina de baixo K, representa um termo com composição similar a trondhjemítico.

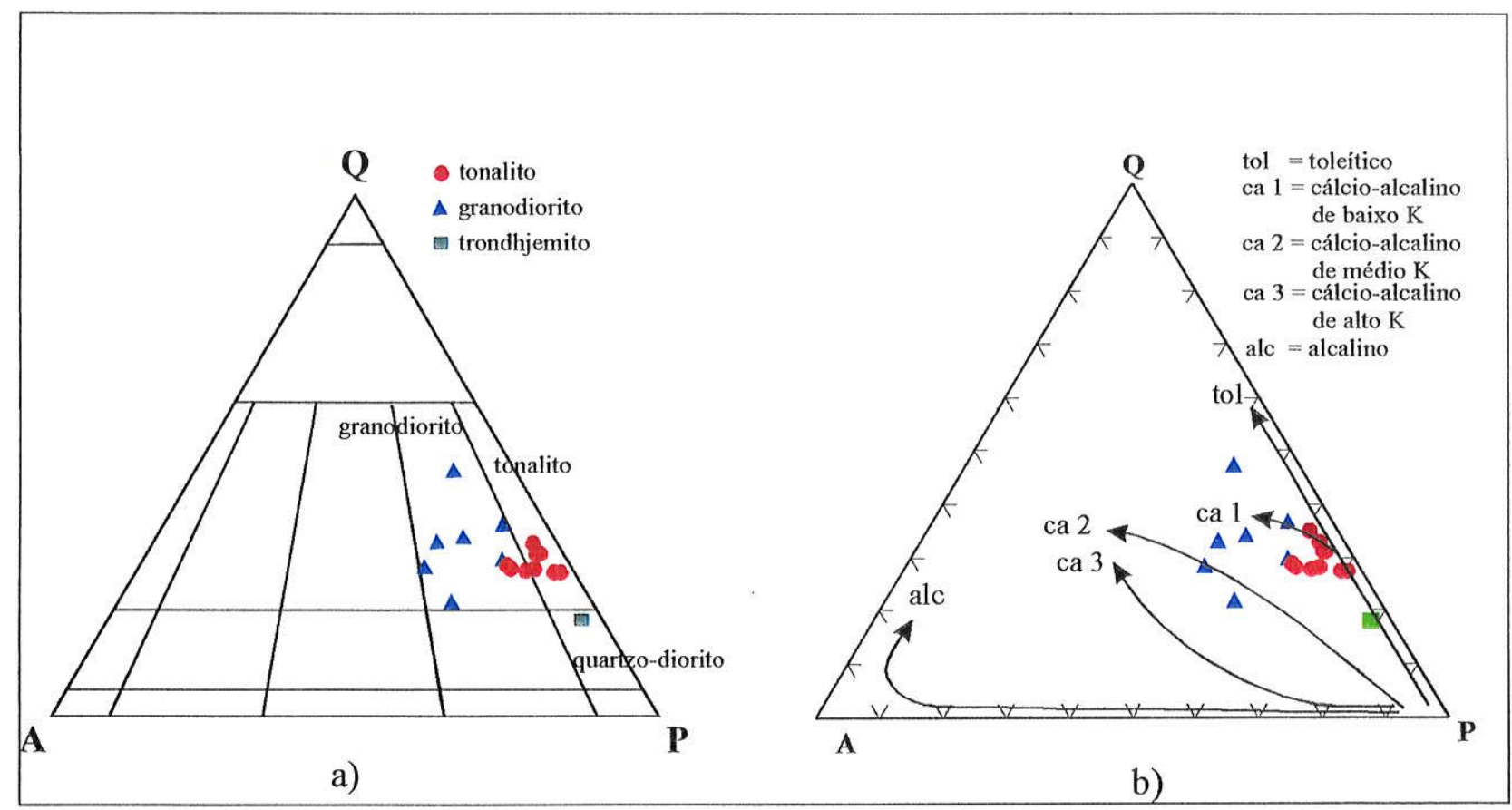

Figura 4.5 - Diagramas modais QAP: a) campos segundo Streckeisen (1976) e b) campos como em Lameyre \& Bowden (1982).

\section{a) Tonalito}

O tonalito é uma rocha de coloração cinza, equigranular, com granulação média, mostrando algumas feições com granulação média a fina e porfirítica, Figura 4.6. Nas proximidades da zona de cisalhamento apresenta foliação, caracterizada pela orientação dos minerais ferromagnesianos. Ao microscópio mostra-se com textura equigranular, granulação média (1 a 3 mm, segundo Williams et al. 1970), e predominância de cristais tabulares de plagioclásio, notando-se que algumas amostras exibem porfirítica caracterizada, por fenocristais de plagioclásio (tamanho médio em torno de $4 \mathrm{~mm}$ ), dispersos em uma matriz de granulação média. 


\begin{tabular}{|c|c|c|c|c|c|c|c|c|c|c|}
\hline Litologia & \multicolumn{10}{|c|}{ Tonalito } \\
\hline $\begin{array}{l}\text { amostra } \\
\text { mineral }\end{array}$ & $\begin{array}{l}\text { SH-113 } \\
\text { SHN-08 } \\
\end{array}$ & $\begin{array}{c}\mathrm{SH}-118 \\
\text { SL-62 } \\
\end{array}$ & $\begin{array}{c}\text { FI-104/G-41 } \\
\text { IH-26 } \\
\end{array}$ & $\begin{array}{l}\text { SH-67 } \\
\text { SL-28 } \\
\end{array}$ & $\begin{array}{l}\text { SH-67 } \\
\text { SL-31 } \\
\end{array}$ & $\begin{array}{l}\text { G-290 } \\
\text { SL-22 } \\
\end{array}$ & $\begin{array}{l}\text { G-264 } \\
\text { SL-01 } \\
\end{array}$ & $\begin{array}{l}\mathrm{T}-54 \\
\mathrm{R}-01 \\
\end{array}$ & $\begin{array}{l}\mathrm{T}-54 \\
\mathrm{R}-07 \\
\end{array}$ & $\begin{array}{c}\mathrm{T}-229 \\
\mathrm{~S}-21 \\
\end{array}$ \\
\hline quartzo & 22,4 & 23,6 & 20,6 & 21,1 & 18,8 & 22,6 & 24,3 & 23,9 & 23,6 & 21,7 \\
\hline plagioclásio & 46,8 & 54,8 & 52,4 & 44,5 & 47,6 & 53,1 & 46,9 & 50,0 & 38,4 & 48,0 \\
\hline feldspato alcalino & 2,8 & 5,4 & 1,8 & 7,6 & 2,2 & 6,3 & 2,9 & 3,2 & 2,5 & 7,8 \\
\hline hornblenda & 9,6 & 2,8 & 9,4 & 1,6 & 12,4 & 6,0 & 7,9 & 17,5 & 15,9 & 9,3 \\
\hline biotita & 16,0 & 10,8 & 13,6 & 21,3 & 17,0 & 10,4 & 17,0 & 12,8 & 11,6 & 11,5 \\
\hline clinopiroxênio & 0,4 & - & - & - & - & - & - & - & - & 0,1 \\
\hline titanita & 0,6 & 0,4 & 0,4 & 1,0 & 1,2 & 0,8 & 0,1 & 1,2 & 1,1 & 0,6 \\
\hline allanita & - & - & - & 0,2 & - & - & - & - & - & - \\
\hline apatita & $\operatorname{Tr}$ & 0,1 & 0,2 & 0,4 & 0,2 & 0,2 & 0,5 & 0,3 & 0,3 & 0,1 \\
\hline zircão & $\operatorname{Tr}$ & - & 0,2 & - & - & - & $\operatorname{Tr}$ & - & - & - \\
\hline opacos & $\operatorname{Tr}$ & - & $\operatorname{Tr}$ & 0,1 & - & 0,5 & $\operatorname{Tr}$ & $\operatorname{Tr}$ & - & - \\
\hline epidoto & 0,4 & 1,3 & 0,6 & 1,7 & 0,4 & - & 0,4 & 0,8 & 0,7 & 0,6 \\
\hline clorita & - & 0,3 & - & 0,3 & - & - & * & - & - & - \\
\hline sericita & - & - & - & - & - & 0,1 & $\mathrm{Tr}$ & $\mathrm{Tr}$ & - & - \\
\hline carbonato & 1,0 & 0,5 & - & 0,2 & 0,2 & - & - & - & 0,3 & 0,3 \\
\hline Índice cor (IC) & 28,0 & 16,2 & 24,4 & 26,8 & 31,6 & 18,0 & 25,9 & 32,6 & 29,9 & 22,5 \\
\hline $\mathrm{n}^{0}$ pontos & 1000 & 1000 & 500 & 1000 & 1000 & 1000 & 1000 & 1000 & 1000 & 1000 \\
\hline
\end{tabular}

Tabela 4.1a - Análise modal de amostras de tonalito, da Mina de Salamangone. $\mathrm{Tr}=$ Traços; $\mathrm{SH}=$ furo de sonda na superfície, $\mathrm{SI}=$ furo de sonda subterrâneo; $\mathrm{G}=$ galeria, $\mathrm{T}=$ travessa de acesso à galeria. 


\begin{tabular}{|c|c|c|c|c|c|c|c|c|}
\hline Litologia & \multicolumn{8}{|c|}{ Granodiorito } \\
\hline $\begin{array}{ll} & \text { amostra } \\
\text { mineral }\end{array}$ & $\begin{array}{l}\text { SH-67 } \\
\text { SL-30 } \\
\end{array}$ & $\begin{array}{l}\text { SH-81 } \\
\text { SL-37 } \\
\end{array}$ & $\begin{array}{l}\text { SH-81 } \\
\text { SL-38 } \\
\end{array}$ & $\begin{array}{c}\text { SH-115 } \\
\text { SL-64 }\end{array}$ & $\begin{array}{c}\text { SH-144 } \\
\text { SHNG-02 }\end{array}$ & $\begin{array}{l}\text { SH-144 } \\
\text { SHN-04 }\end{array}$ & $\mathrm{C}-03$ & C-01 \\
\hline quartzo & 32,6 & 31,4 & 43,4 & 31,6 & 27,2 & 24,4 & 19,7 & 17,0 \\
\hline plagioclásio & 50,0 & 44,8 & 39,1 & 46,8 & 44,8 & 48,7 & 49,3 & 75,0 \\
\hline feldspato alcalino & 6,2 & 18,8 & 9,6 & 13,6 & 23,0 & 8,7 & 20,3 & 3,3 \\
\hline biotita & 10,6 & 4,0 & 4,8 & 7,0 & 3,6 & 16,0 & 9,8 & 3,1 \\
\hline titanita & 0,2 & $\operatorname{Tr}$ & - & 0,2 & $\operatorname{Tr}$ & 0,9 & - & 0,1 \\
\hline apatita & $\operatorname{Tr}$ & $\operatorname{Tr}$ & 0,3 & - & - & 0,3 & 0,8 & - \\
\hline zircão & $\operatorname{Tr}$ & $\operatorname{Tr}$ & - & $\operatorname{Tr}$ & - & * & - & - \\
\hline opacos & $\operatorname{Tr}$ & 0,6 & 1,3 & $\operatorname{Tr}$ & $\operatorname{Tr}$ & - & 0,1 & 0,1 \\
\hline epidoto & 0,4 & - & - & 0,2 & 1,4 & 0,5 & - & 0,3 \\
\hline clorita & - & - & 0,1 & 0,2 & - & 0,1 & - & 0,1 \\
\hline sericita & - & 0,4 & 1,2 & 0,2 & $\operatorname{Tr}$ & - & - & 0,7 \\
\hline carbonato & - & - & 0,2 & - & - & 0,4 & - & 0,3 \\
\hline índice cor (IC) & 11,2 & 5,0 & 7,9 & 7,8 & 5,0 & 18,2 & 10,7 & 4,9 \\
\hline$n^{0}$ pontos & 500 & 500 & 1000 & 500 & 500 & 1000 & 1000 & 1000 \\
\hline
\end{tabular}

Tabela 4.1b - Análise modal de amostras de granodiorito da Mina de Salamangone. $\mathrm{Tr}=$ Traços; $\mathrm{SH}=$ furo de sonda na superficie; $\mathrm{C}=$ amostra na cava da mina. 

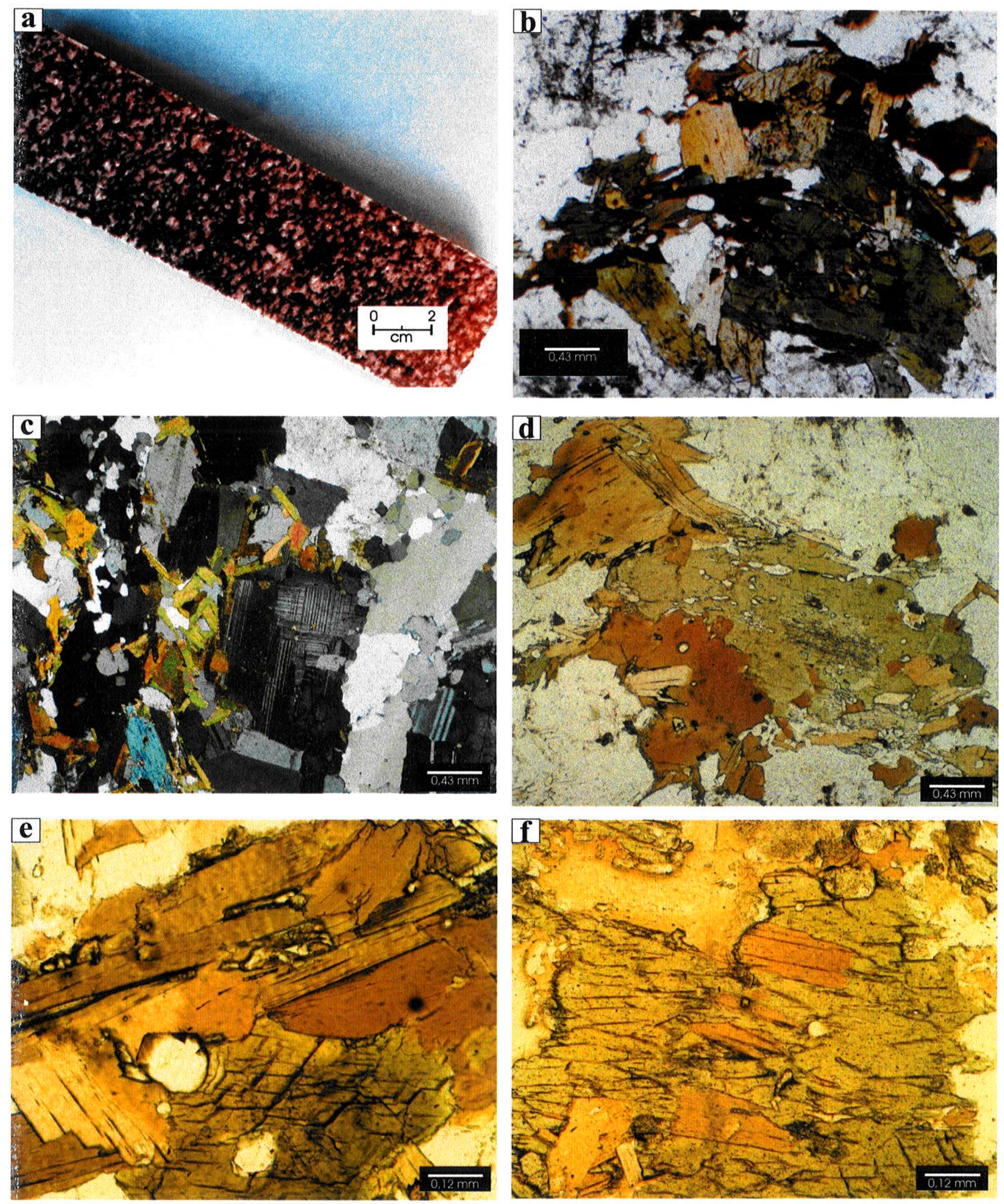

Figura 4.6 - Aspectos petrográficos do tonalito: a) Tonalito de granulação média, hospedeiro da mineralização, b) Aglomerado máfico constituído de hornblenda e biotita (N//), c) Cristal de plagioclásio exibindo geminação albita + periclina (Nx), d) Cristais de hornblenda poiquilítica e biotita associados (N//), e) Biotita e titanita secundária ao lado de hornblenda com inclusão de apatita $(\mathrm{N} / /)$, f) Cristal de hornblenda sendo substituído por biotita (N//). 
Sua constituição essencial é representada por plagioclásio, quartzo, biotita, hornblenda e microclina, ocorrendo como fases menores, acessórias: titanita, apatita, zircão, allanita e raros opacos. As fases minerais secundárias são representadas por: sericita, epídoto e carbonato (produtos da alteração de plagioclásio), clorita (produto de alteração da biotita) e actinolita (produto de alteração da hornblenda). Aglomerados máficos de biotita, hornblenda e titanita são encontrados na maior parte das lâminas estudadas (Figura 4.6b).

O plagioclásio é o mineral dominante, correspondendo de 40 a $55 \%$ da rocha. Apresenta-se sob a forma de cristais irregulares a tabulares, com dimensões que variam entre 0,2 a 4,5 mm, com alguns grãos zonados. A geminação mais comum é a da lei da albita, mostrando algumas combinações de albita + periclina (Figura 4.6c). Pode encontrar-se envolvido por microclina, apresentando contato de reação entre as duas fases, onde se observam intercrescimentos mirmequíticos de quartzo. Intercrescimentos antipertíticos também são verificados. Suas inclusões mais frequentes são constituídas por apatita, zircão, biotita, hornblenda e feldspato potássico (antipertitas). Os produtos de alteração mais comuns são a sericita, o epídoto e o carbonato (saussuritização). A composição dos cristais oscila entre $\mathrm{An}_{24-38}$, campos do oligoclásio e andesina , Figura 4.7, e sua determinação foi efetuada em plagioclásios sem, ou com pequeno grau de saussuritização. As composições químicas obtidas por microssonda eletrônica, encontram-se na Tabela 4.2 (Anexo 1).

O quartzo forma grãos xenomórficos, com dimensões que variam de 0,05 a $1,7 \mathrm{~mm}$, preenchendo espaços entre as outras fases minerais. Exibe, quase sempre, extinção ondulante e inclusões de apatita, zircão, biotita, hornblenda e minerais opacos e, via de regra, mostram inclusões fluidas alinhadas. Intercrescimento de quartzo e plagioclásio ou microclina é comum, sendo que as mirmequitas aparecem com maior frequência nas bordas dos plagioclásios. Próximo à zona de cisalhamento, apresenta-se na forma de mosaico de grãos menores, com contatos relativamente retos e poligonizados, evidenciando recristalização em torno de núcleos maiores, que exibem forte extinção ondulante e desenvolvimento de subgrãos.

$\mathrm{O}$ feldspato alcalino, microclínio ocorre em pequena quantidade, geralmente xenomórfico, com tamanhos que variam de 0,2 a $0,3 \mathrm{~mm}$, mostrando caráter intersticial bem definido. Apresenta típica geminação em grade, e é comum o desenvolvimento de pertitas finas, na forma de filmes. A sericitização é rara ou muito incipiente. 


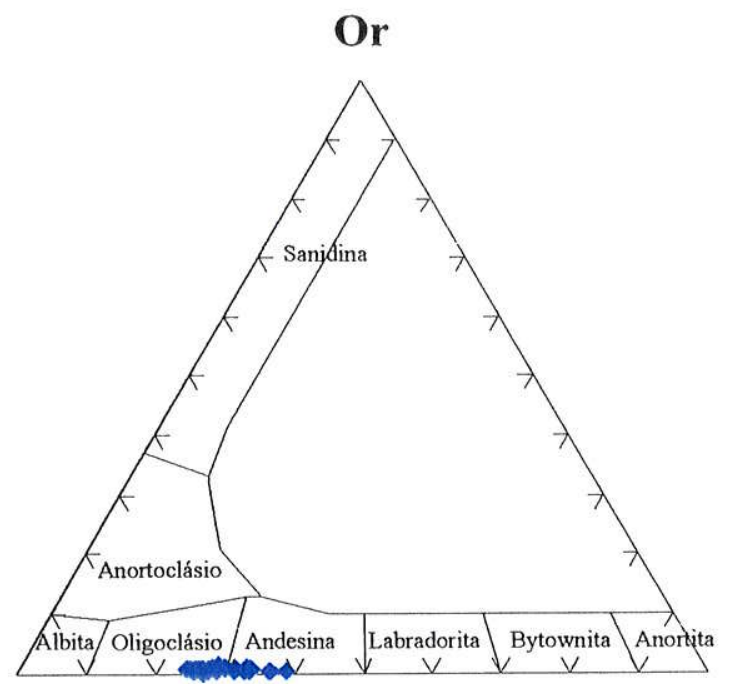

Ab

An

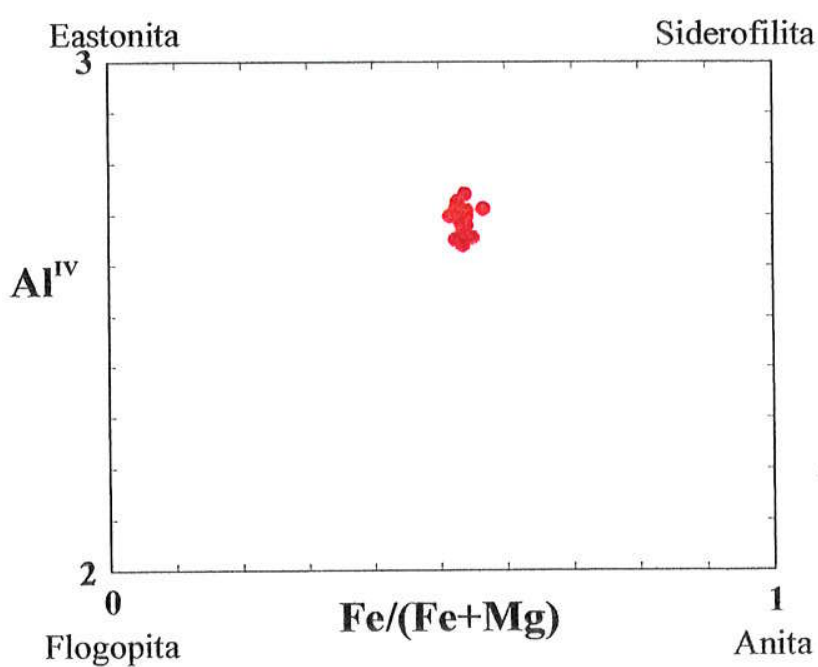

b)

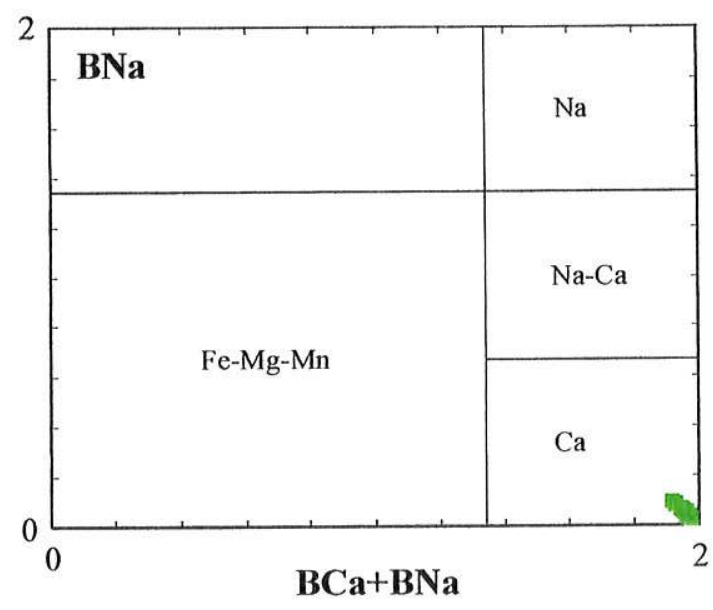

c)

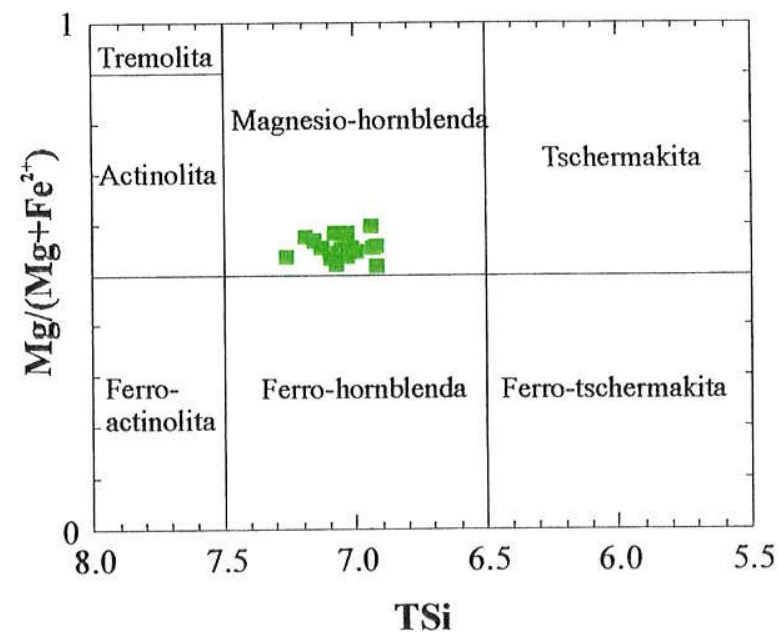

d)

Figura 4.7 - a) Diagrama de classificação de plagioclásios; b) Diagrama de variação catiônica para biotita (Deer et al. 1983); c e d) Diagramas de classificação e composição de anfibólios, respectivamente, segundo Leake et al. (1997), correspondentes ao tonalito da Mina de Salamangone. 
Os minerais máficos mais abundantes são a biotita e a hornblenda. A proporção destes dois minerais é bastante variável, geralmente com a predominância da biotita. Apresentam-se tipicamente na forma de aglomerados de cristais alongados, Figura 4.6d. Os cristais de biotita são de cor castanha, em geral cristais alongados subidiormórficos a irregulares. As dimensões variam entre 0,1 e $3,5 \mathrm{~mm}$ e os contatos são retos ou exibindo borda de reação com a hornblenda e o plagioclásio. Apresenta pleocroísmo forte, entre castanho e castanho escuro e/ou castanho avermelhado escuro. Estão sempre associados à hornblenda e à titanita, substituindo a primeira e apresentando inclusões secundárias da segunda, ao longo dos planos de clivagem, Figuras 4.6e, 4.6f. Diversas inclusões de apatita e zircão (com halos pleocróicos) podem ser observadas. Nas amostras de tonalito localizadas próximas à zona de cisalhamento, as palhetas de biotita exibem evidências de deformação, revelando formas arqueadas do tipo kink band e alteração para clorita, ao longo dos planos de clivagem, ou a partir das suas bordas. As análises químicas pontuais, por microssonda eletrônica, encontram-se compilados na Tabela 4.3, Anexo 1. No diagrama de variações catiônicas (Figura 4.7b), baseado em Deer et al. (1976), verifica-se que as micas estudadas incidem no campo da biotita com uma composição média entre a eastonita e a siderofilita.

A hornblenda é de cor verde, os cristais são idiomórficos a irregulares, as dimensões variam de 0,2 a $4,5 \mathrm{~mm}$, e o pleocroísmo é acentuado, passando de amarelo-esverdeado para verde-escuro, Figuras 4.6e, 4.6f. Apresenta, como a biotita, inclusões de apatita e zircão. Associa-se sempre à biotita, sendo algumas vezes substituída por ela ao longo dos planos de clivagem, e de forma menos frequente é observada junto à titanita. Alguns cristais maiores mostram-se poiquilíticos, com relictos de clinopiroxênio Figuras 4.8a, 4.8b, 4.8c. Nas amostras de tonalito, próximas à zona de cisalhamento, observa-se orientação segundo direção preferencial, com evidências de alteração para actinolita. As análises pontuais com os dados analíticos obtidos por microssonda eletrônica, encontram-se compilados na Tabela 4.4, Anexo1, junto com as respectivas fórmulas estruturais. Para fins de nomenclatura, foi utilizada a nova classificação dos anfibólios proposta pela IMA (International Mineralogical Association). Os valores de $\mathrm{Fe}^{2+} \mathrm{e} \mathrm{Fe}^{3+}$ foram obtidos segundo o método de Schumaker (cf. Leake et al. 1997). Tomando-se por base as condições $(\mathrm{Ca}+\mathrm{Na}) \mathrm{B}$ e $\mathrm{NaB}$, recomendadas por Leake (1978) e Leake et al. (1997), obteve-se $(\mathrm{Ca}+\mathrm{Na}) \mathrm{B}>1,00$ e $\mathrm{NaB}<0,50$, com $\mathrm{CaB}>0,50$. Em relação aos quatro grupos principais de anfibólios, os valores obtidos permitem enquadrar as amostras analisadas no campo dos anfibólios cálcicos, conforme ilustrado pela Figura 4.7c. Utilizando-se o diagrama $\mathrm{Mg} /\left(\mathrm{Mg}+\mathrm{Fe}^{2+}\right)$ vs. $\mathrm{TSi}$, dos mesmos autores, as amostras se situam no campo composicional da hornblenda magnesiana, Figura $4.7 \mathrm{~d}$. 
A titanita é o acessório principal que exibe, dimensões variando de 0,2 a $0,3 \mathrm{~mm}$, cor marrom eformas idiomórficas a irregulares. Apresenta-se, via de regra, associada à biotita $\mathrm{e}$ com menor frequência à hornblenda, ao longo dos planos de clivagem, Figura $4.8 \mathrm{~d}$. Os demais acessórios, excetuando-se a allanita, aparecem na forma de pequenas inclusões nas fases minerais principais. A apatita é idiomórfica a subidiomórfica, geralmente com forma acicular dentro dos plagioclásios, e subarredondada nos minerais máficos, principalmente na hornblenda. $\mathrm{O}$ zircão é idiomórfico, com halos pleocróicos bem desenvolvidos. A allanita é subidiomórfica a irregular, e por vezes, apresenta-se segundo núcleos circundados de epídoto, Figuras $4.8 \mathrm{e}, 4.8 \mathrm{f}$.

A rocha tonalítica acha-se afetada por reações minerais pré-cisalhamento, presentes em graus variados nas amostras estudadas. Esses efeitos incluem: a formação de mirmequitas entre quartzo e plagioclásio, os intercrescimentos pertíticos e antipertíticos, e a geração de titanita ao longo dos planos de clivagem e bordas da biotita, Figura 4.9. As relações de fábrica sugerem que as reações ocorreram em condições de metamorfismo equivalente à facies anfibolito.

A rocha tonalítica nas proximidades dos corpos de minério, exibe algumas feições de alteração, provavelmente, decorrentes da interação rocha-fluido hidrotermal e caracterizadas, principalmente, pela presença de actinolita e clorita, como produtos da instabilização de hornblenda e biotita, pela saussuritazação dos plagioclásios, (Figuras 4.10a, 4.10b, 4.10c); pela deposição de sulfetos junto aos minerais ferro-magnesianos e pela silicificação do tonalito, muitas vezes originando segregações, na forma de vênulas de quartzo. $O$ tonalito, nas proximidades da zona de cisalhamento, apresenta algumas feições de deformação, evidenciadas pelo desenvolvimento de kink-bands nos planos de clivagem dos cristais de biotita (Figura 4.10d), pela orientação dos minerais ferro-magnesianos e, pela extinção ondulante e recristalização dos cristais de quartzo.

\section{b) Granodiorito}

O estudo petrográfico da rocha granodiorítica foi realizado com um caráter preliminar. Dentre as amostras coletadas no depósito de Salamagone, com base no índice de coloração (IC), (Tabela 4.1b), pode ser caracterizado dois tipos distintos: um com IC $<5 \%$ e outro com IC $>8 \%$. No diagrama QAP modal, campos segundo Lameyre \& Bowden (1982), Figura 4.5, as amostras apresentam uma leve evolução do campo de baixo para médio K. Alguns aspectos petrográficos são mostrados na Figura 4.11. 

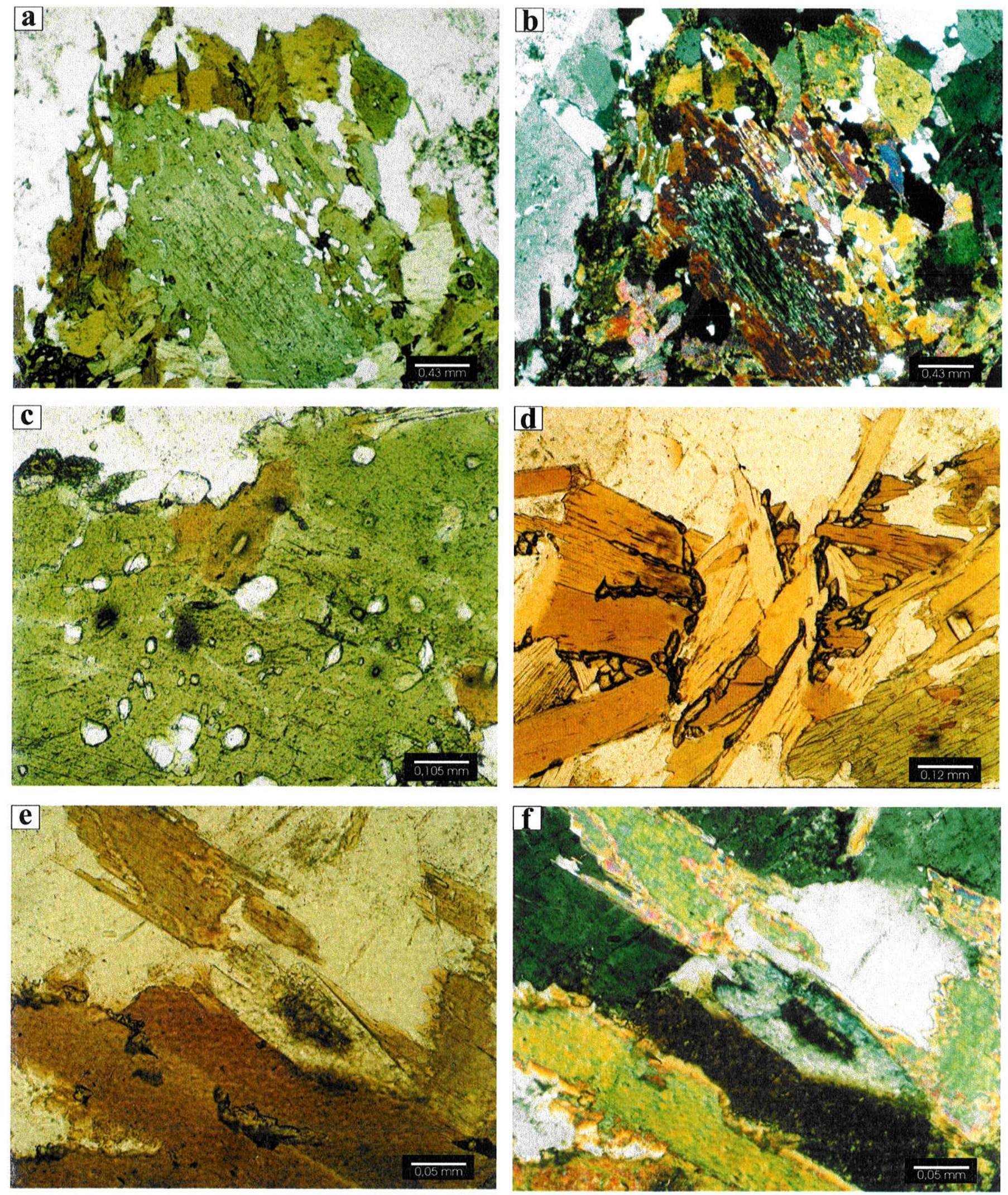

Figura 4.8 - Reações minerais no tonalito: a e b) Cristal de hornblenda com núcleo constituído por clinopiroxênio (N// e NX), c) Textura poiquilitíca (gotas de quartzo) e zircão metamítico na hornblenda (N//), d) Cristais secundários de titanita ao longo das bordas e planos de clivagem da biotita (N//), e e f) Allanita circundada por epidoto, ao lado de biotita, hornblenda e plagioclásio $(\mathrm{N} / / \mathrm{e} \mathrm{NX})$. 

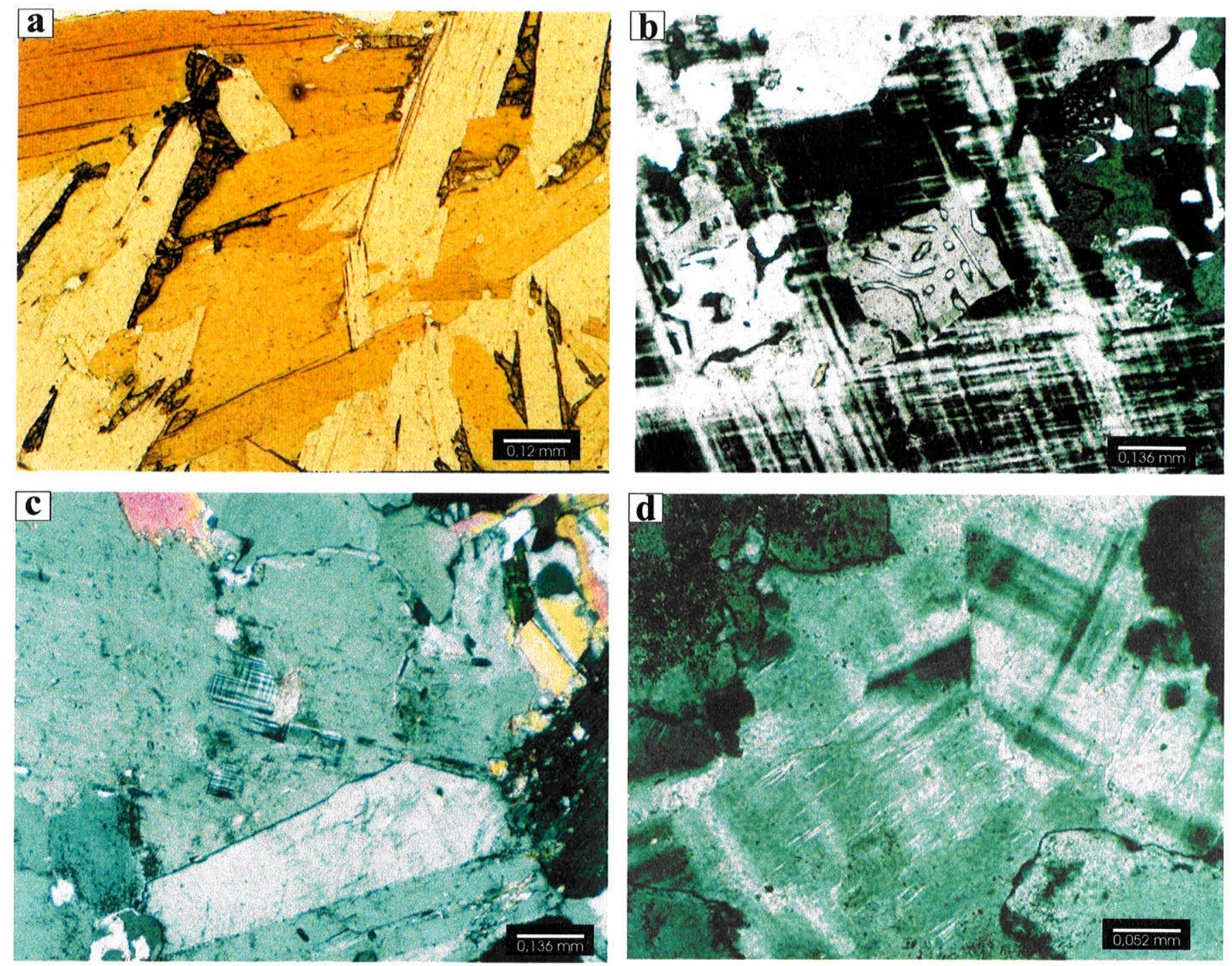

Figura 4.9 - Reações minerais no tonalito: a) Titanita secundária associada com cristais de biotita (N//), b) Mirmequita entre quartzo e plagioclásio (NX), c e d) Intercrescimentos anti-pertítico e pertítico, respectivamente (NX). 

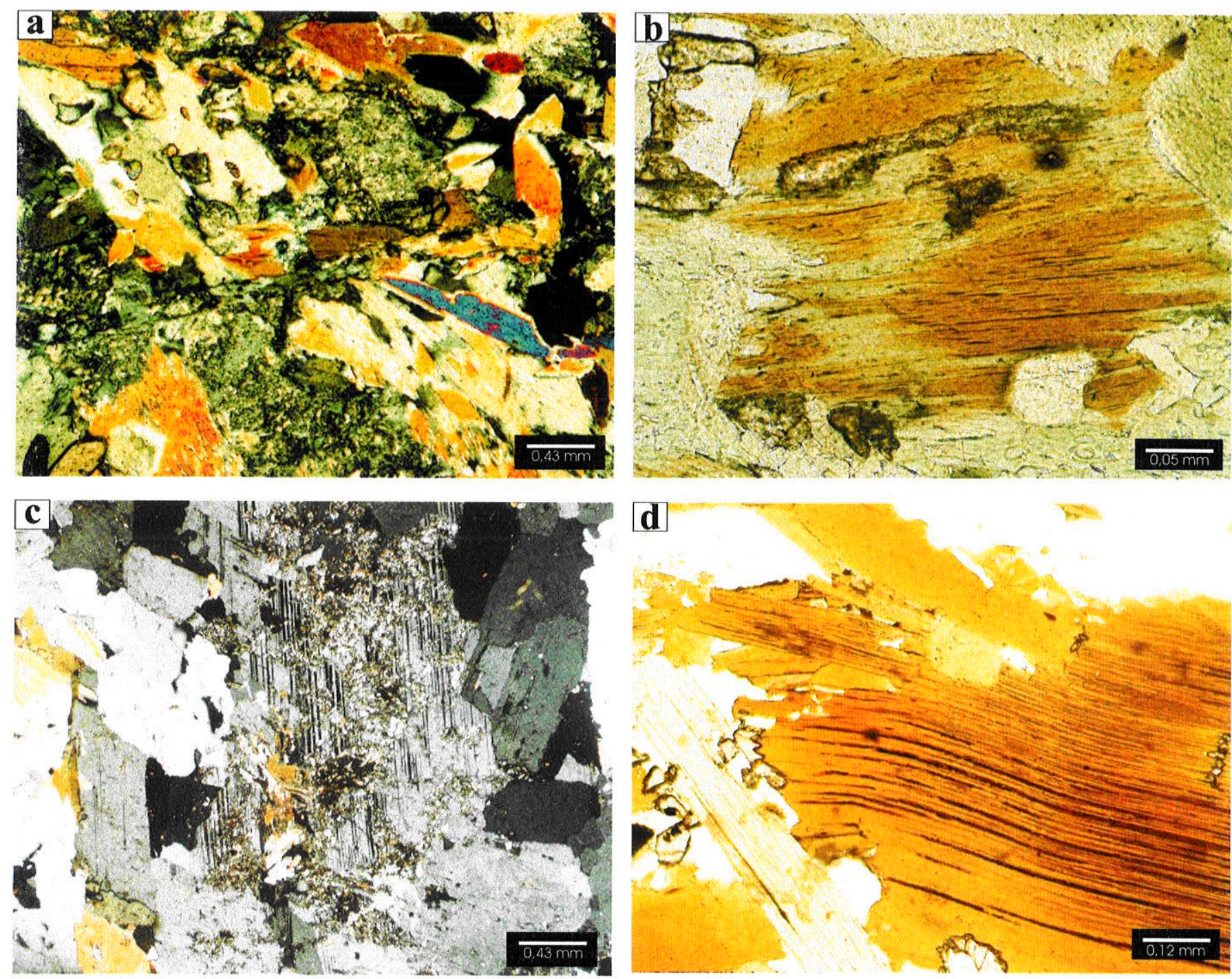

Figura 4.10 - a) Rocha tonalítica alterada pela ação dos fluidos mineralizantes, formando clorita e actinolita a partir de biotita e hornblenda, respectivamente. Os plágioclásios estão saussuritizados (NX), b) Cloritização de cristal de biotita, acompanhando os planos de clivagem (N//), c) Saussuritização do plagioclásio, formando carbonato, epidoto e sericita (NX), d) Desenvolvimento de kink bands nos planos de clivagem da biotita (N//). 

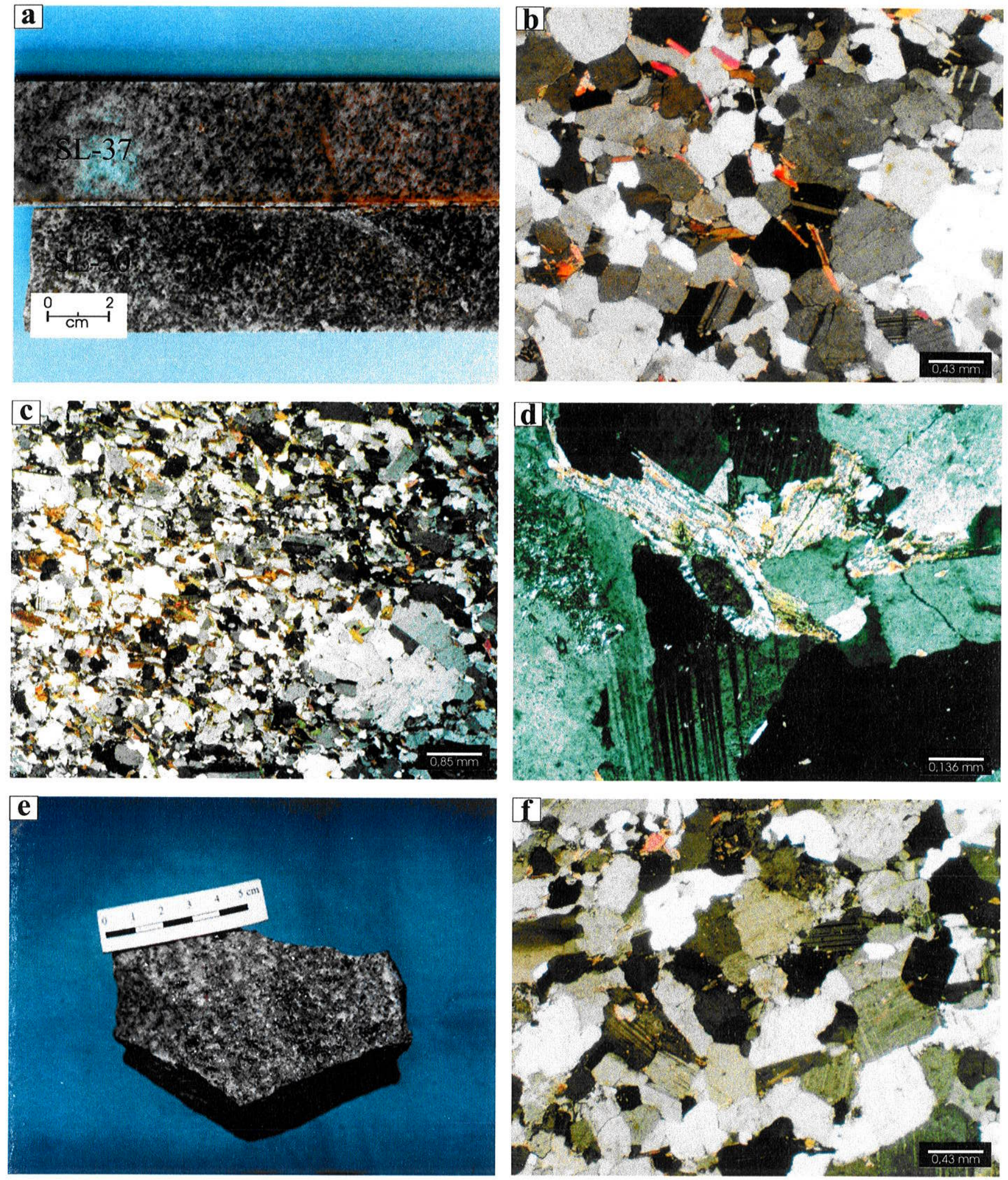

Figura 4.11 - Aspectos petrográficos do granodiorito: a) Granodioritos de granulação média, com índices de coloração IC $\leq 5 \%$ ( amostra SL-37, Furo SH-81) e $>8 \%$ (amostra SL-30, Furo SH-67), b) Textura equigranular em granodiorito com IC $\leq 5 \%$ (NX), c) Textura equigranular em granodiorito com IC $>8 \%$, observando-se uma leve foliação decorrente da orientação dos cristais de biotita (NX), d) Epidoto com núcleo de allanita ao lado de plagioclásio e biotita (NX), e e f) Granodiorito de granulação média e IC $\leq 5 \%$ (amostra C-01), com textura equigranular, e composição química similar a um trondhjemito (NX). 
Essas rochas granodioríticas exibem, de modo geral, uma coloração variando de cinzaclaro a cinza-escuro, uma granulação média a fina e, normalmente, são equigranulares. Os principais minerais constituintes são: plagioclásio, quartzo, feldspato potássico e biotita, ocorrendo como fases menores acessórias, titanita, apatita, allanita, zircão e raros opacos. As fases minerais secundárias estão representadas por epidoto, sericita, carbonato (produtos de alteração dos plagioclásios) e clorita (produto de alteração da biotita).

Uma caracterização petrográfica mais detalhada dessas rochas, faz parte da previsão de estudos futuros, embora, deva enfrentar dificuldades, pela impossibilidade da realização de uma nova amostragem sistemática, mais adequada aos objetivos pretendidos.

\subsubsection{Geotermobarometria da horblenda -plagioclásio}

Os estudos de geotermobarometria foram realizadas apenas no tonalito, para o qual foram efetuadas análises químicas de suas fases minerais, em amostras com pouca ou sem evidência de alteração, relacionada à ação de fluidos hidrotermais.

Para a estimativa dos parâmetros intensivos $\mathrm{T}$ e $\mathrm{P}$ foram combinadas as seguintes expressões de calibração, baseadas na química mineral:

- geotermômetro edenita-tremolita de Blundy \& Holland (1994), baseado no conteúdo de $\mathrm{Al}$ em hornblenda coexistente com plagioclásios, para rochas saturadas ou não em sílica. Para a utilização deste geotermômetro as taxas do anfibólio foram recalculadas segundo o método de Schumaker (cf. Leake et al. 1997), que tem como base o cálculo de fatores de correção que resultam de estimativas de valores mínimos e máximos de $\mathrm{Fe}^{3+}$, muito parecido com o método empregado pelos autores Blundy \& Holland (1994). O erro estimado deste geotermômetro é da ordem de $\pm 40^{\circ} \mathrm{C}$.

$$
T A=\frac{\left[76,95+0,79 P+Y_{a b}+39,4 X_{N a}^{A}+2,4 X_{K}^{A}+(41,5-2,89 P) \cdot X_{A l}^{M 2}\right]}{-0,00650-R \cdot \ln \left[\frac{27 \cdot X^{A} \cdot X_{S i}^{T 1} \cdot X_{a b}^{p l a g}}{256 \cdot X_{N a}^{A} \cdot X_{A l}^{T 1}}\right]}
$$

onde $\mathrm{Y}_{\mathrm{ab}}$ é dado por $\mathrm{X}_{\mathrm{ab}}>0,5 \rightarrow \mathrm{Y}_{\mathrm{ab}}=0$

$$
X_{a b}<0,5 \rightarrow Y_{a b}+12,0\left(1-X_{a b}\right)^{2}-3,0 \mathrm{Kj}
$$

sendo T dada em Kelvin e P em Kbar. 
- expressão derivada por Anderson \& Smith (1995), para o barômetro de Al em hornblenda que incorpora a influência da temperatura. Os autores recomendam restringir o seu uso para hornblenda com \#Fe $<0,65$. A incerteza estimada para a calibração é de $\pm 0,6 \mathrm{kbar}$.

$\mathrm{P}( \pm 0,6 \mathrm{Kbar})=4,76 \mathrm{Al}-3,01\left[\left(\mathrm{~T}\left({ }^{\circ} \mathrm{C}\right)-675 / 85\right] \times\left[0,530 \mathrm{Al}=0,005294\left(\mathrm{~T}^{\circ} \mathrm{c}\right)-675\right)\right]$

onde $\mathrm{Al}=\mathrm{Al}^{\mathrm{IV}}+\mathrm{Al} \mathrm{VI}$

As análises químicas de tonalito, utilizadas para o cálculo de $\mathrm{P}$ e T foram obtidas do furo de sondagem (Furo SH-113) localizado, mais distante da mineralização (Figura 2.1). P e $\mathrm{T}$ calculadas em amostra de rocha tonalítica, situada em travessa do acesso ao Nível $54 \mathrm{~m}$ da mina, portanto mais próxima da zona mineralizada, são apresentadas para mostrar sua influência nos resultados, os dados obtidos constam da Tabela 4.5, Anexo1.

A utilizaçao do geotermômetro para a hornblenda e plagioclásio - $\mathrm{T}(\mathrm{Hbl}-\mathrm{Pl})$, nas amostras pouco afetadas pela mineralização (Furo SH-113), indica temperaturas variáveis entre 645 e $694^{\circ} \mathrm{C}$ e as pressões obtidas situaram-se entre 2,7 e 3,4 Kbar. Os valores da amostra R-07, com maior influência da mineralização, apresentaram valores de T(Hbl-Pl) variando entre 584 e $688^{\circ} \mathrm{C}$ e pressões entre 2,4 e $2,9 \mathrm{Kbar}$, que são relativamente mais baixas que aquelas encontradas nas amostras pouco alteradas. Esta situação, provavelmente, indique que os minerais não estejam em equilíbrio para representar um par primitivo, e as temperaturas reflitam, em parte, as condições de desenvolvimento do processo hidrotermal superimposto, nas rochas encaixantes.

\subsubsection{Geoquímica}

A caracterização geoquímica dos granitóides encaixantes da mineralização filonar quartzo-aurífera no Morro de Salamangone, envolveu a realização de 18 análises químicas em rocha total, representativas dos termos petrográficos identificados, em especial do tonalito, principal hospedeiro. Acham-se apresentadas nas Tabelas 4.6a, b, c e d, Anexo 3. 


\section{Afinidades geoquímicas}

As normas CIPW das rochas granitóides da Mina de Salamangone são mostradas na Tabela 4.7, Anexo 3. No diagrama normativo An-Ab-Or (O'Connor 1965, modificado por Baker 1979), Figura 4.12, as amostras se distribuem principalmente nos campos do tonalito e granodiorito. Apresentam uma tendência modal característica no diagrama QAP modal de Streckeisen (1976), relacionada à série cálcio-alcalina de baixo a médio K, de Lameyre \& Bowden (1982), Figura 4.5. Essa característica é reconhecida, também, no diagrama normativo Q-Ab-Or Figura 4.13a e no diagrama K-Na-Ca Figura 4.13b, ambos de Barker \& Harth (1976), onde as amostras acompanham o trend cálcio-alcalino, mostrando certa afinidade trondhjemítica.

Nos diagramas $(\mathrm{La} / \mathrm{Yb})_{\mathrm{N}}$ vs. $\mathrm{Yb}_{\mathrm{N}}$, de Martin (1986 e 1993), (normalização pelo condrito de Boynton 1984), e Sr/Y vs. Y de Drummond \& Defant (1990) Figuras 4.14a e $4.14 \mathrm{~b}$, podem ser distinguidos dois grupos entre os granitóides de Salamangone. As análises de tonalito apresentando valores relativamente altos de $\mathrm{Yb}\left(5<\mathrm{Yb}_{\mathrm{N}}<10\right)$ e de $\mathrm{Y}(15<\mathrm{Y}<20)$, e um menor fracionamento de $\operatorname{REE}\left((\mathrm{La} / \mathrm{Yb})_{\mathrm{N}}<20\right)$ e de $\mathrm{Sr} / \mathrm{Y}<20$, incidem no campos dos granitóides pós-arqueanos cálcio-alcalinos. As amostras de granodiorioto e trondhjemito (?) com baixo conteúdo de $\mathrm{Yb}$ e de $\mathrm{Y}\left(\mathrm{Yb}_{\mathrm{N}}<5\right.$ e $\left.\mathrm{Y}<7\right)$, e um fracionamento mais alto de REE $\left(16<(\mathrm{La} / \mathrm{Yb})_{\mathrm{N}}<52\right)$ e de maior $\mathrm{Sr} / \mathrm{Y}(39<\mathrm{Sr} / \mathrm{Y}<400)$, incidem, nitidamente, no campo dos granitóides tipo TTG do arqueano.

$\mathrm{O}$ diagrama $\mathrm{A} / \mathrm{NK}$ vs. $\mathrm{A} / \mathrm{CNK}$, da Figura 4.14c, baseado nos índices de Shand (In: Maniar \& Piccoli 1989), evidencia o caráter metaluminoso do tonalito, enquanto que o granodiorito mostra-se levemente peraluminoso.

\section{Comportamento dos elementos maiores e traços}

Os diagramas de variação de $\mathrm{SiO}_{2}$ vs. elementos maiores, (Figura 4.15) e os diagramas nos quais se observa o comportamento geoquímico de alguns elementos traços, (Figura 4.16), evidenciam, claramente, a existência de dois conjuntos de rochas granitóides na Mina de Salamangone. Um conjunto representado por rochas de composição tonalítica com pouca variação interna e um outro conjunto de rochas, com composição granodiorítica, no qual se verifica diferenciação entre os termos amostrados, já destacada nas modas dessas rochas, pela variação em seus índices de coloração. 


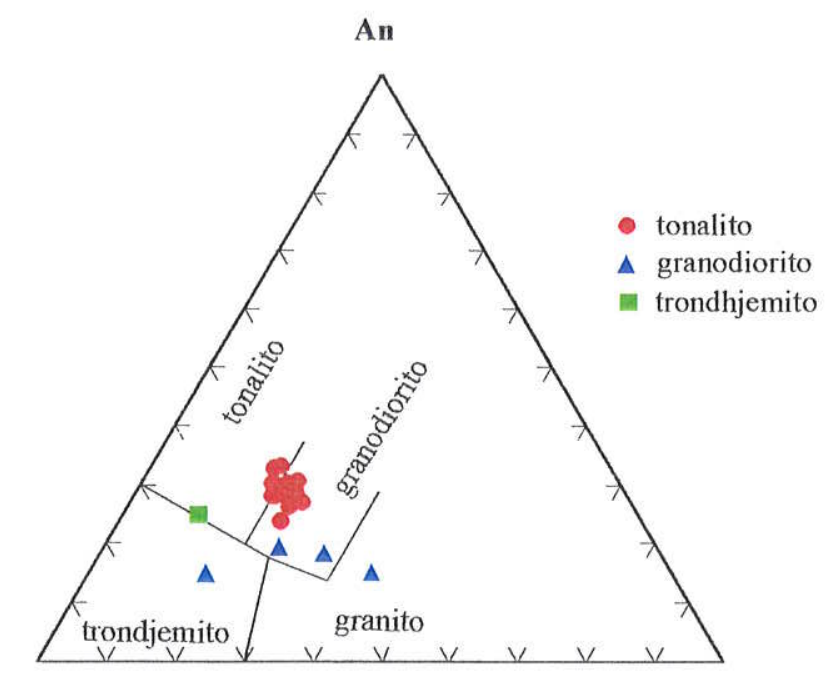

Ab

Or

Figura 4.12 - Diagrama de classificação An-Ab-Or (O'Connor 1965, Baker 1979)

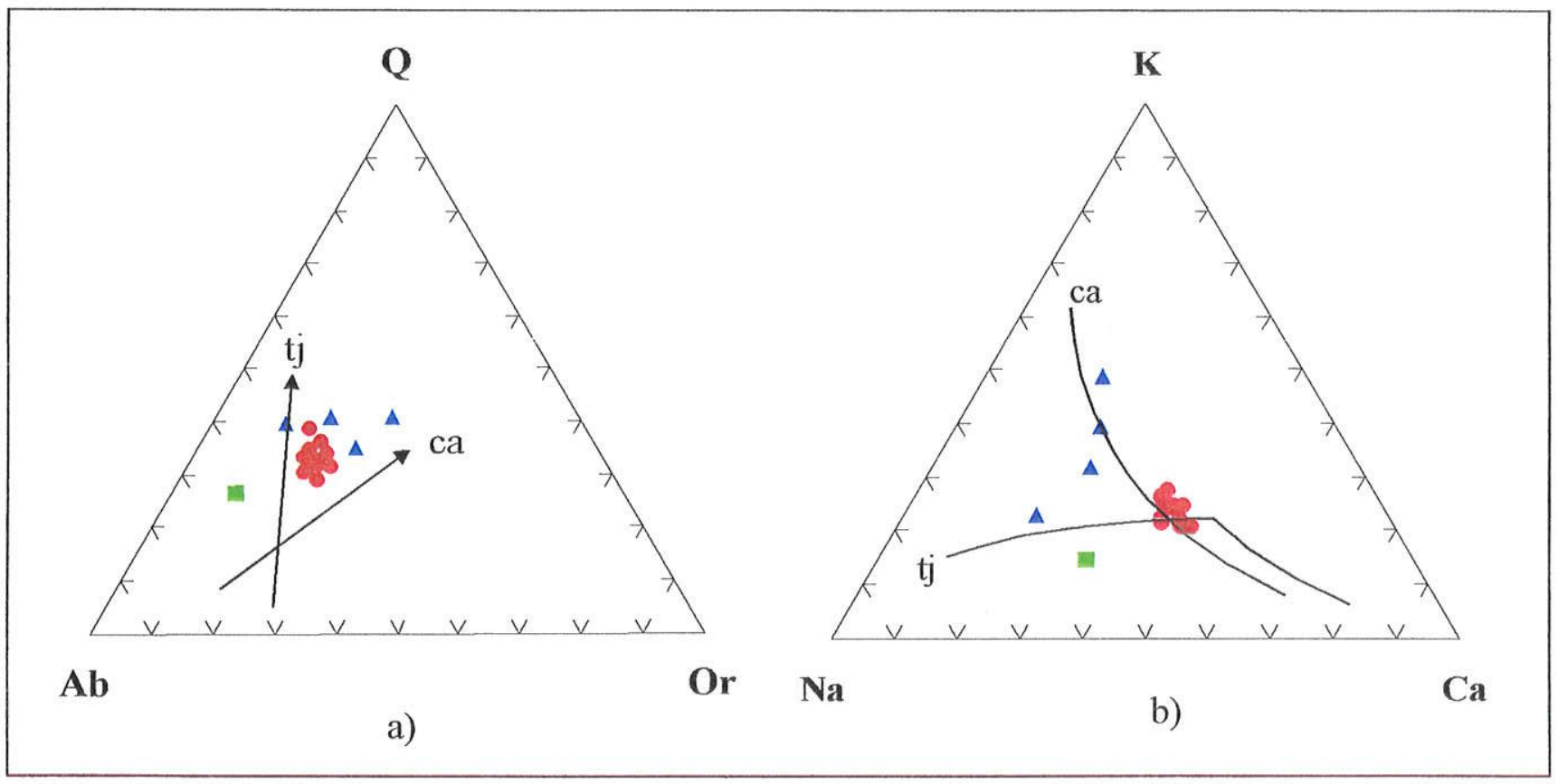

Figuras 4.13a e b ) - Diagramas normativos Q-Ab-Or e K-Na-Ca, respectivamente, de Baker \& Arth (1976), mostrando a característica cálcio-alcalina dos granitóides do Morro de Salamangone, com alguma influência trondhjemítica. 


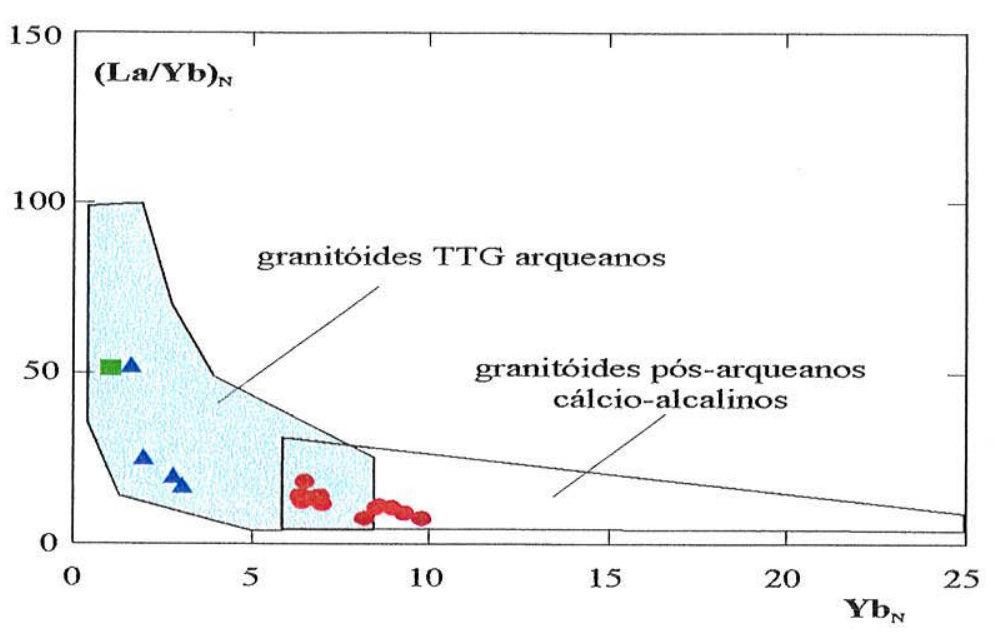

a)

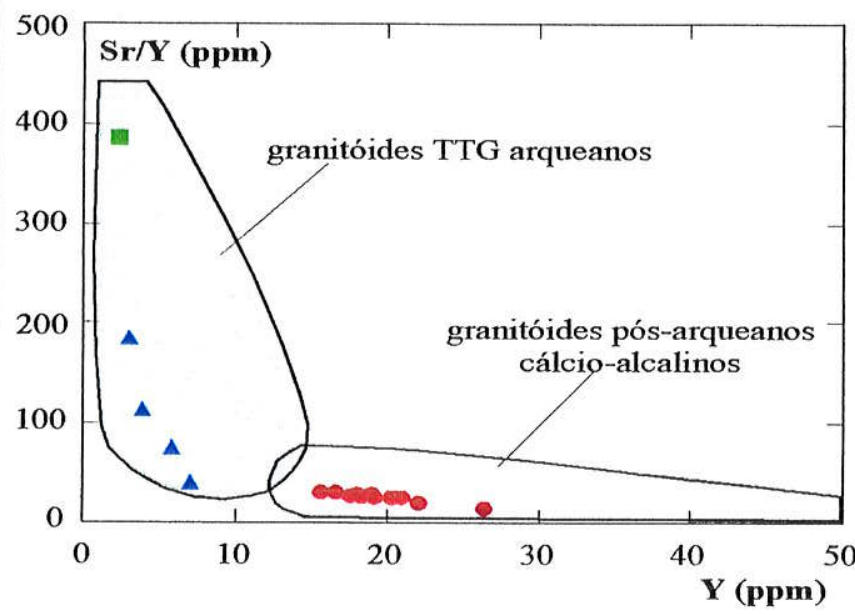

b)

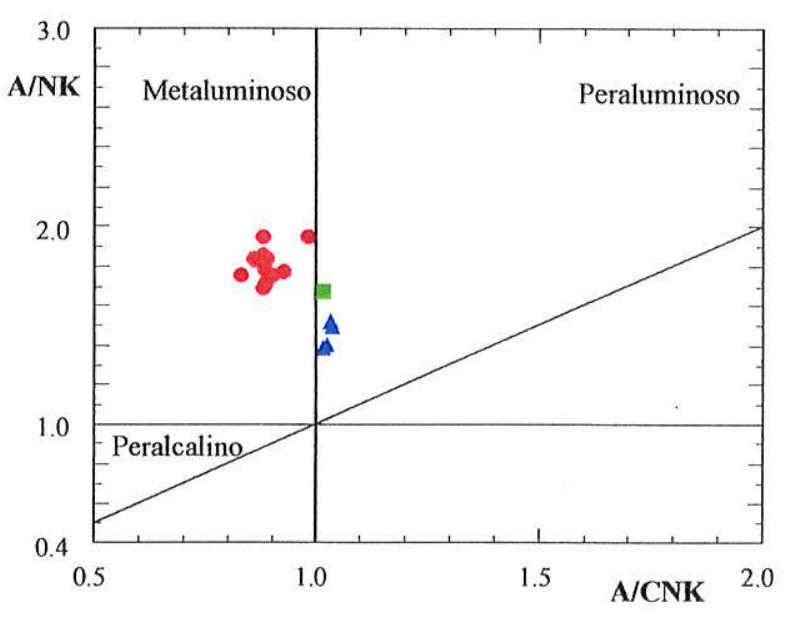

c)

Figura 4.14 - a) Diagrama ( La/Yb $)_{\mathrm{N}}$ vs. $\mathrm{Yb}_{\mathrm{N}}$ segundo Martin (1986 e 1993); b) Diagrama Sr/Y vs. Y de Drummond \& Defant (1990) e c) Diagrama A/NK vs. A/CNK baseado no índice de Shand (In: Maniar \& Piccoli 1989). Simbologia conforme a Figura 12. 

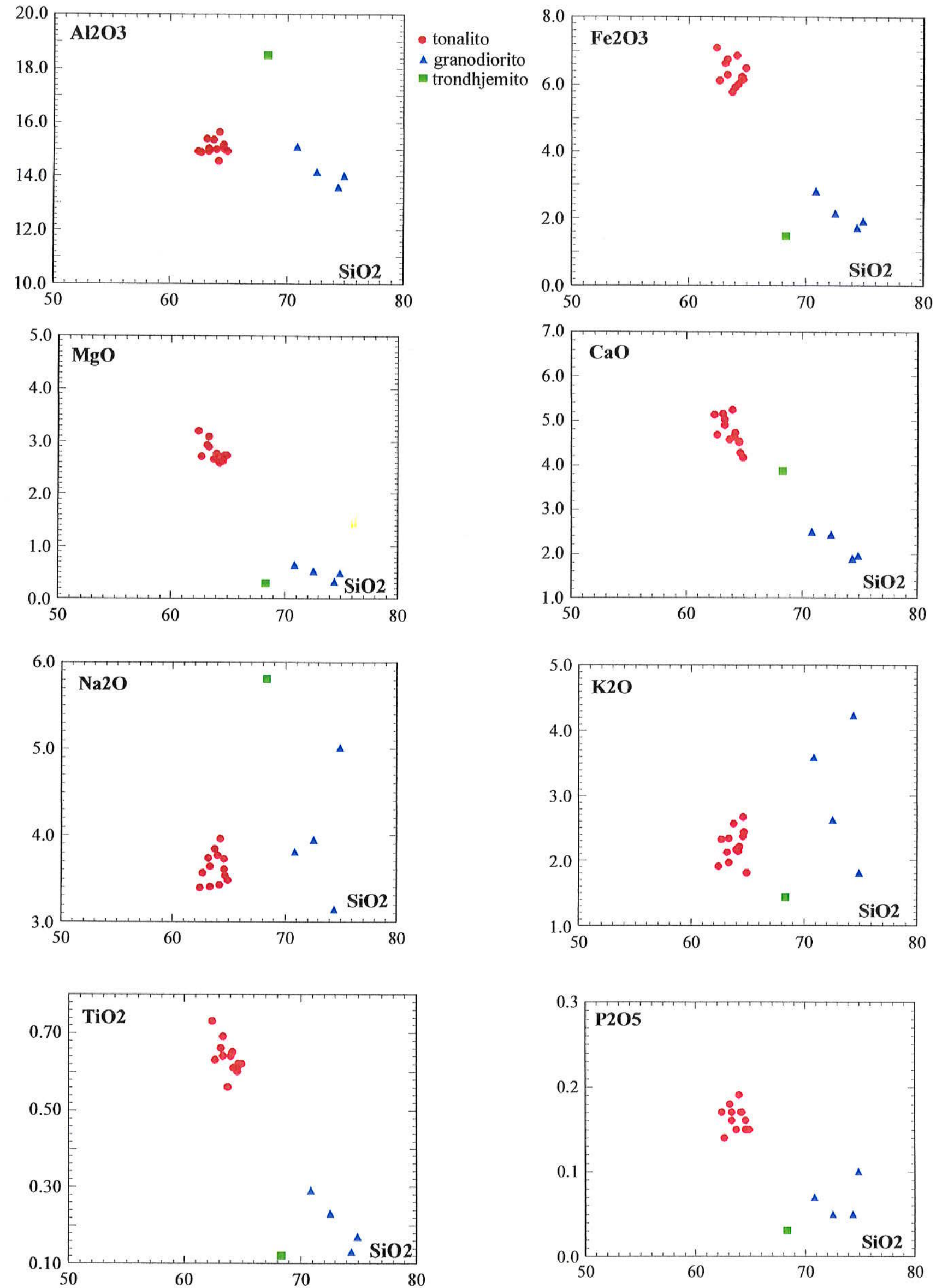

Figura 4.15 - Diagramas de variação de SiO2 para as rochas granitóides da Mina de Salamangone. 


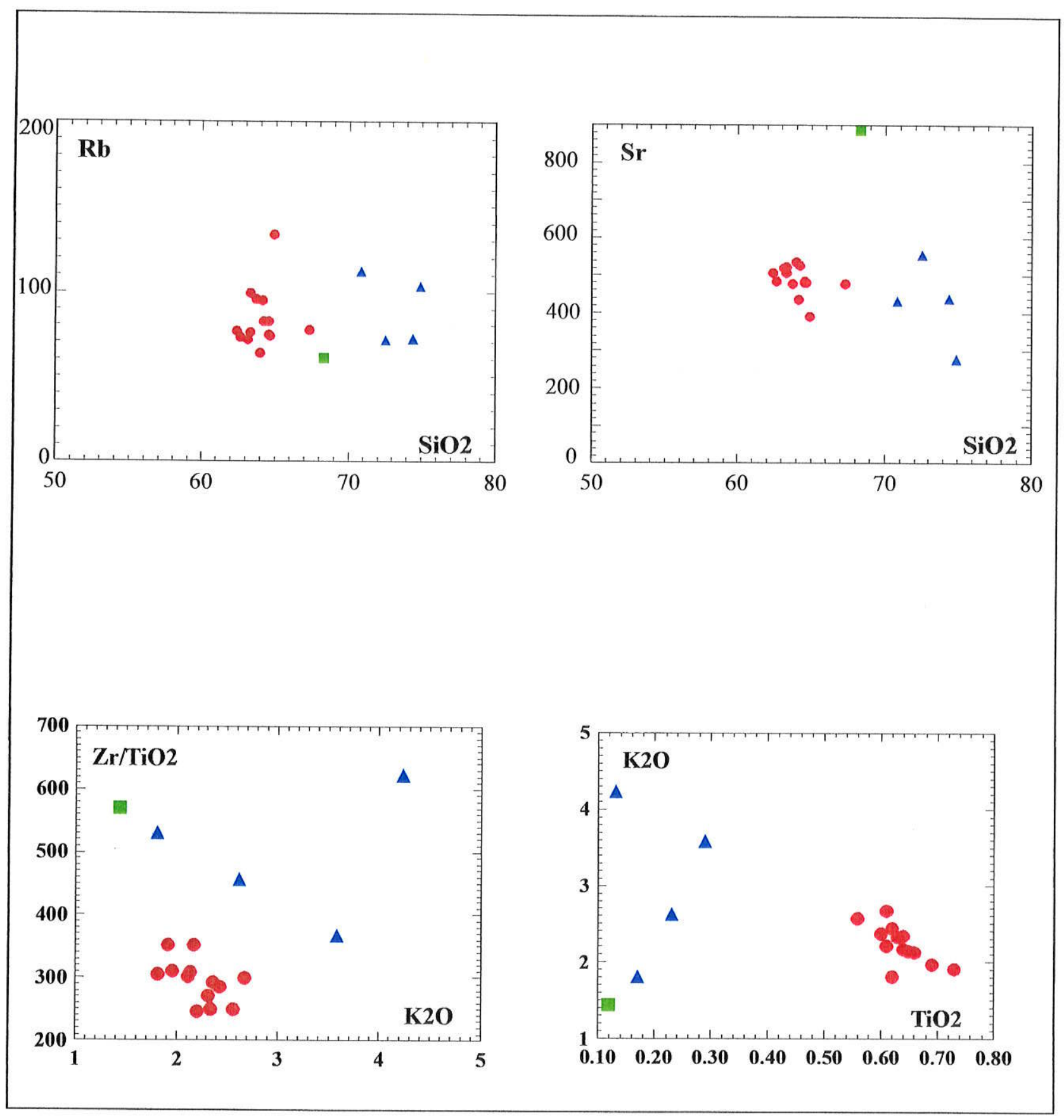

Figura 4.16 - Diagramas de variação entre elementos maiores (\%) e elementos traços (ppm), das rochas granitóides da Mina de Salamangone. Símbologia como na Figura 4.15. 


\section{Elementos Terras Raras e padrão dos elementos expandidos}

Os teores dos elementos terras raras, normalizados pelos valores condríticos de Boynton (1984) mostram, para as rochas granitóides, um padrão de enriquecimento em TRL. $\mathrm{O}$ tonalito apresenta uma leve anomalia negativa ou ausente de Eu e as TRP são pouco variáveis, com padrão sub-horizontal. As rochas granodioríticas apresentam uma leve diferenciação entre os tipos amostrados ( $\mathrm{IC}<5 \%$ e IC $>8 \%$ ), com empobrecimento grande em TRP, o que pode ser devido a um fracionamento magmático e, em algumas amostras observase acentuada anomalia positiva de Eu, Figura 4.17a.

Os padrões expandidos evidenciando o comportamento dos elementos incompatíveis para os granitóides, normalizados por N-MORB (Pearce 1983), são apresentados no diagrama da Figura 4.17b. Mostram um enriquecimento pronunciado em $\mathrm{Cs}, \mathrm{Rb}, \mathrm{Ba}$, Th, U, e K, com anomalias negativas de $\mathrm{Nb}, \mathrm{P}, \mathrm{Ta}$ e Ti.

A caracterização geoquímica desses granitóides definiu um grupo de rochas cálcioalcalina de composições diferenciadas, com concentrações relativamente elevadas de elementos LILE e padrões geralmente fracionados de ETR, com anomalias de $\mathrm{Eu}$ ausente/discreta no tonalito e positiva em alguns termos granodioríticos. Esse comportamento é comparável ao de diversas suítes granitóides de composição cálcio-alcalina, geradas em arcos magmáticos de margem continental ativa.

\section{Ambiente tectônico}

As rochas granitóides mostram afinidade continental, evidenciada pelos teores mais elevados em $\mathrm{K}_{2} \mathrm{O}, \mathrm{Rb}$ e $\mathrm{Sr}$, incidindo no campo dos granófiros continentais no diagrama $\mathrm{K}_{2} \mathrm{O}$ v.s $\mathrm{SiO}_{2}$ de Coleman \& Peterman (1975), Figura 4.18a, e no campo de trondjemitos e quartzodioritos continentais, no diagrama $\mathrm{Rb}$ v.s $\mathrm{Sr}$ de Coleman \& Donato (1979), Figura 4.18b.

$\mathrm{O}$ ambiente tectônico dessas rochas foi caracterizado geoquimicamente pelos diagramas de Pearce et al. (1984), que consideram elementos relativamente imóveis (Ti, $\mathrm{Rb}$, $\mathrm{Sr}, \mathrm{Y}, \mathrm{Sr}, \mathrm{Nb}$ ). No diagrama $\mathrm{Y}$ vs. $\mathrm{Nb}$, Figura $4.18 \mathrm{c}$, as amostras de tonalito e granodiorito incidem no campo dos granitóides de colisão + arcos vulcânicos, enquanto que no diagrama $\mathrm{Rb}$ vs. $\mathrm{Y}+\mathrm{Nb}$, Figura 4.18d, situam-se, nitidamente, no campo de granitóides de arco vulcânico. 


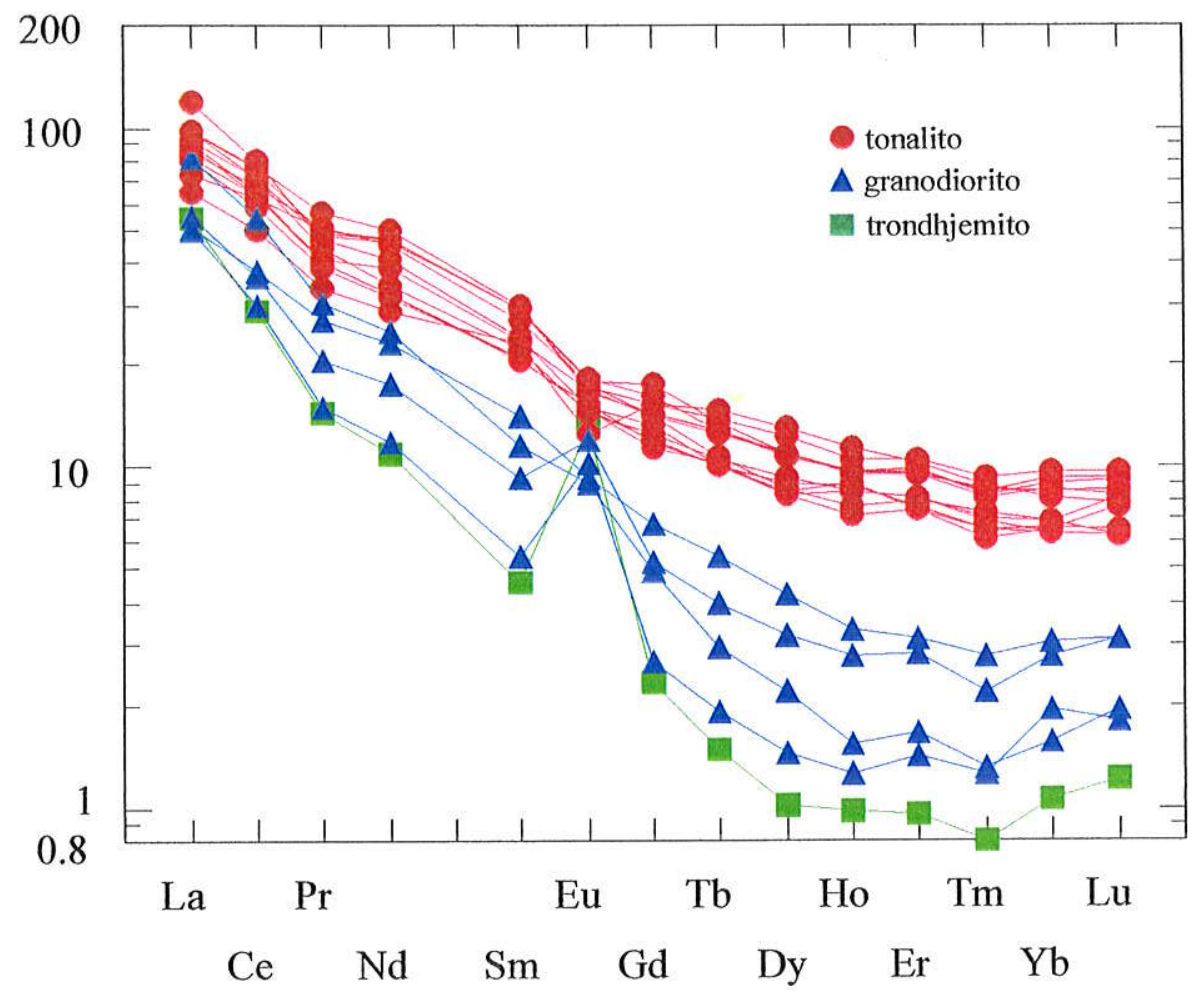

a)

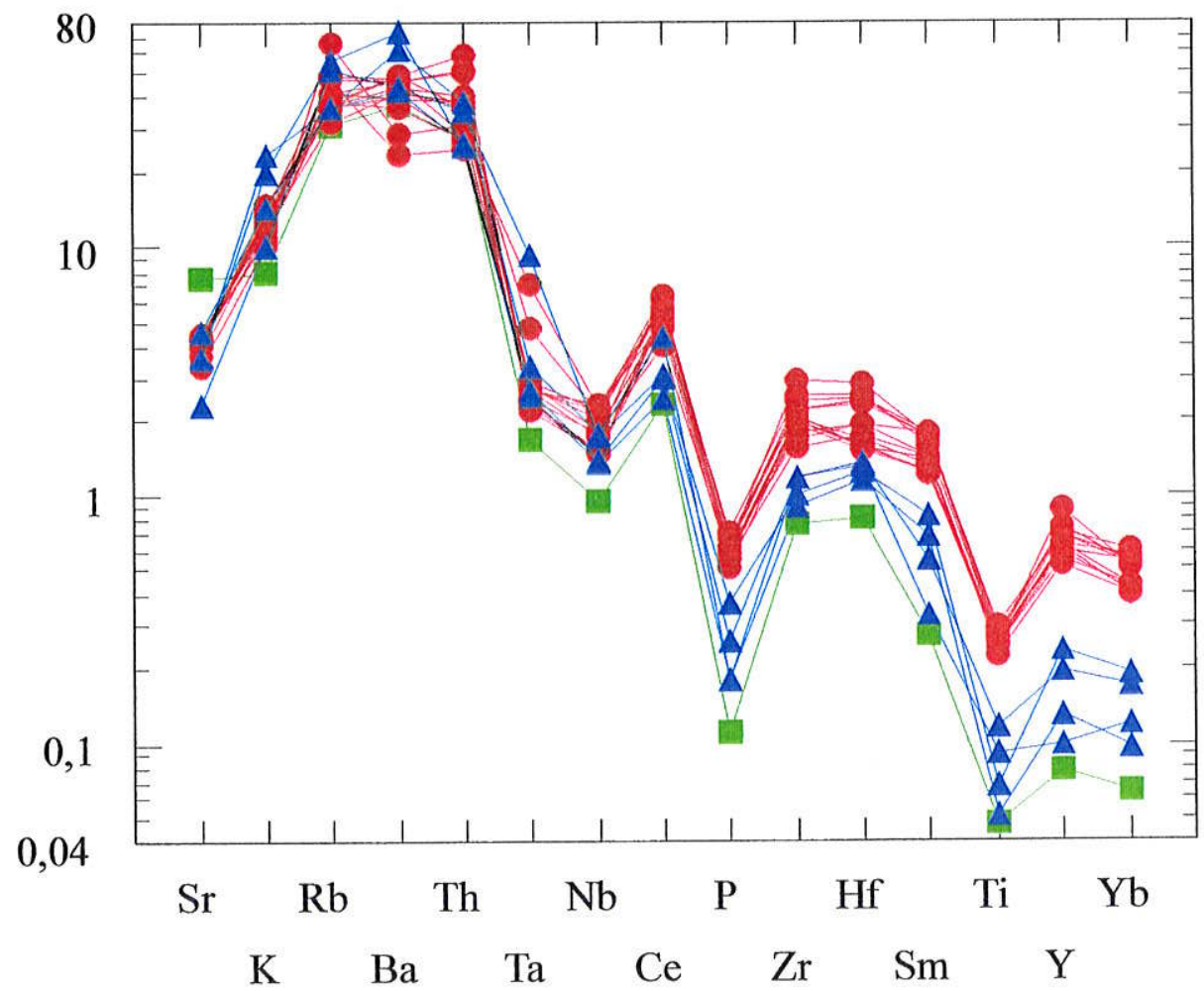

b)

Figura 4.17 - Diagramas a) padrão de distribuição dos ETR, normalizados pelos valores condríticos de Boynton (1984) e b) padrões de elementos expandidos normalizados pelos valores condríticos de Pearce (1983), das rochas granitóides do depósito de Salamangone. 


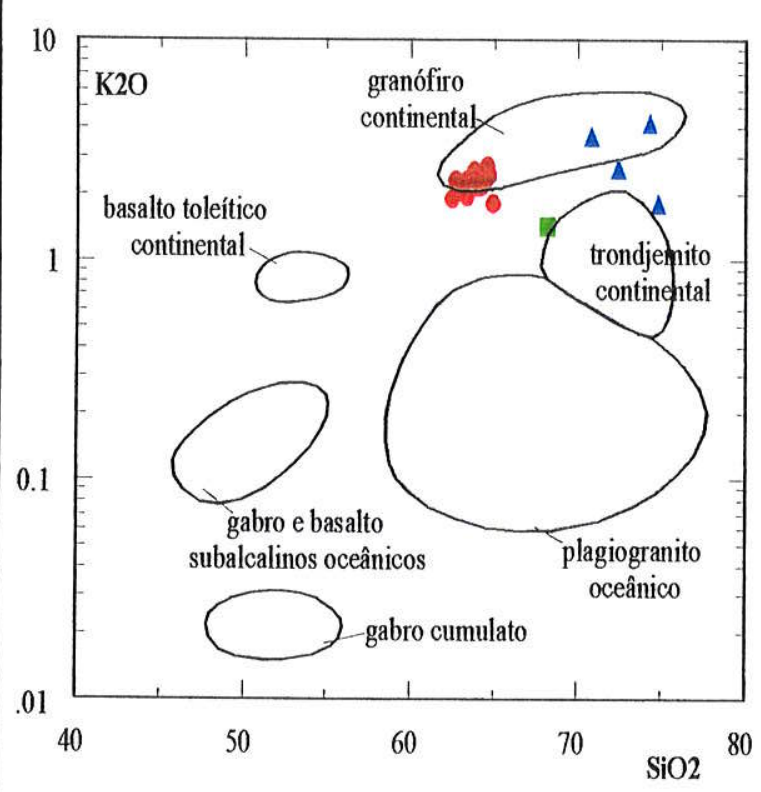

a)

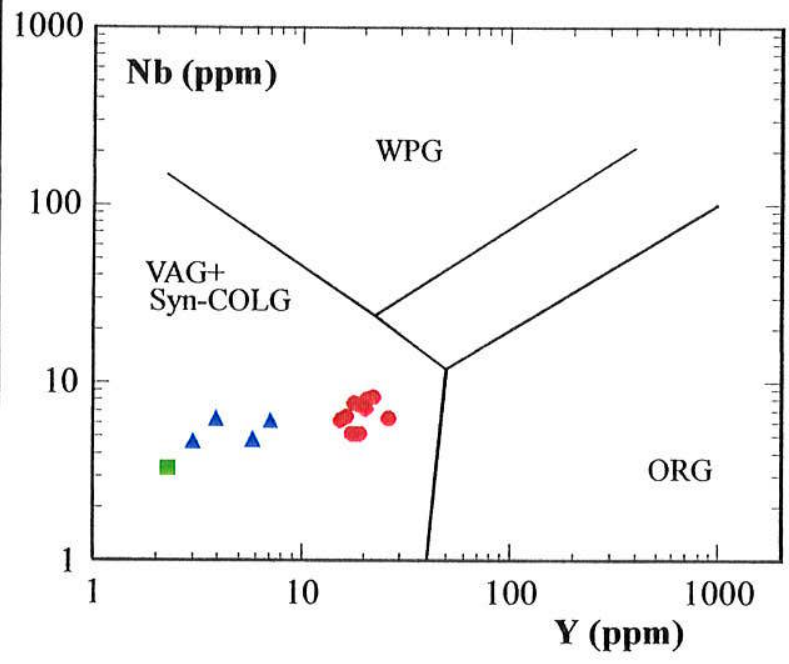

c)

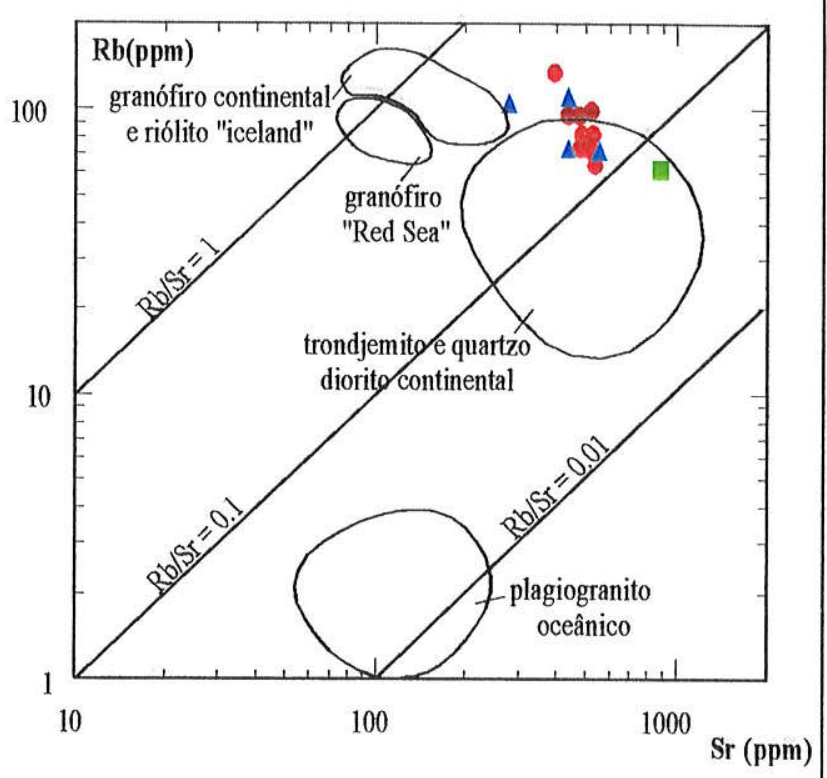

b)

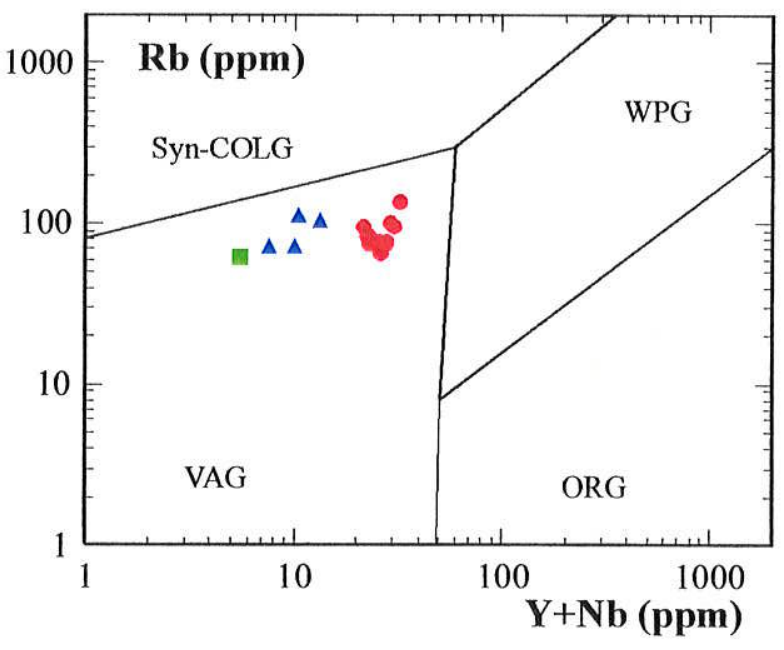

d)

Figura 4.18 - Diagramas de discriminação tectônica: a) $\mathrm{K}_{2} \mathrm{O}$ vs. $\mathrm{SiO}_{2}($ Coleman \& Peterman 1975)e b) Rb vs. Sr (Coleman \& Donato (1979) mostrando a afinidade continental das rochas granitóides da Mina de Salamangone, c) Nb vs. Y e d) Rb vs. Y + Nb, ambos de Pearce et al. (1984), onde essas rochas incidem no campo de granitóides de arco vulcânico. 


\section{Comparação com granitỏides de outras regiões}

Foram selecionadas algumas análises químicas de granitóides da área de CayenneRégina, na Guiana Francesa, Tabela 4.8, Anexo 3, com o objetivo de definir alguns parâmetros comparativos com as rochas encaixantes da Mina de Salamangone. Nesta região ocorrem terrenos do tipo granito-greenstone do Paleoproterozóico, estudados por Vanderhaeghe et al. (1988). Assim como o Distrito Aurífero de Lourenço, a área de CayenneRégina insere-se na Província Geocronológica Maroni-Itacaíunas.

As amostras selecionadas são tonalitos, que junto com dioritos e granitos, representam os componentes principais dos batólitos da área de Cayenne-Régina. No diagrama de classificação normativa de Baker (1979) incidem, principalmente, no campo do tonalito, mostrando caráter metaluminoso, segundo o diagrama $\mathrm{A} / \mathrm{NK}$ vs. $\mathrm{A} / \mathrm{CNK}$. O comportamento geoquímico dos ETR e elementos traços é semelhante ao das rochas tonalíticas da Mina de Salamagone, mostrando, igualmente, um conteúdo mais elevado em TRL, com uma leve anomalia negativa ou ausente de $\mathrm{Eu}$, e um enriquecimento pronunciado em $\mathrm{Cs}, \mathrm{Rb}, \mathrm{Ba}, \mathrm{Th}, \mathrm{U}$, e $\mathrm{K}$, com anomalias negativas de $\mathrm{Nb}, \mathrm{P}$, Ta e Ti. No diagrama ( $\mathrm{La} / \mathrm{Yb})_{\mathrm{N}} v s$. $\mathrm{Yb}_{\mathrm{N}}$ de Martin (1986 e 1993), normalização pelo condrito de Boynton (1984), Figura 4.19, apresentam-se, igualmente, distribuídas no campo dos granitóides cálcio-alcalinos pós-arqueanos e no campo dos granitóides tipo TTG do arqueano. No diagrama Rb vs. Y+Nb, Pearce et al. (1984), situam-se, também, no campo de granitóides de arco vulcânico. De acordo com Vanderhaeghe et al. (1998), esse complexo cálcio-alcalino apresenta uma assinatura geoquímica típica de magmatismo relacionado com arcos vulcanicos, em zonas de subducção. Todos os diagramas citados, acham-se reunidos na Figura 4.19.

\section{Considerações gerais}

A caracterização geoquímica dos granitóides do Morro de Salamangone permitiu ientificar dois conjuntos de rochas granitóides, a saber: tonalito metaluminoso e granodiorito/trondhjemito(?) peraluminoso, com razões relativamente elevadas LILE/HFSE (ressaltadas pelo empobrecimento pronunciado dos conteúdos de $\mathrm{Nb}, \mathrm{Ta}$, $\mathrm{Ti}$ e $\mathrm{Zr}$ ), e padrões geralmente fracionados de elementos terras raras, guardando clara semelhança com o magmatismo granitóide cálcio-alcalino de margens continentais ativas, envolvendo contribuição de fontes vinculadas a zonas de subducção. 


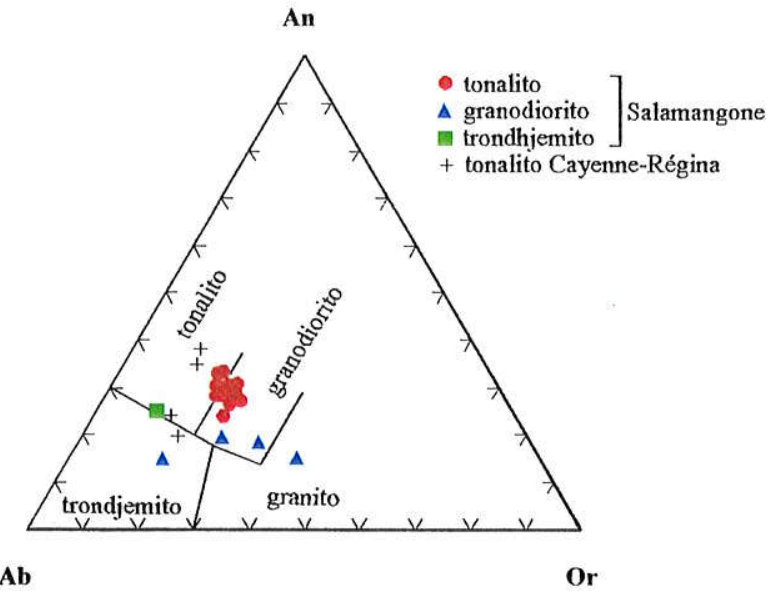

a)

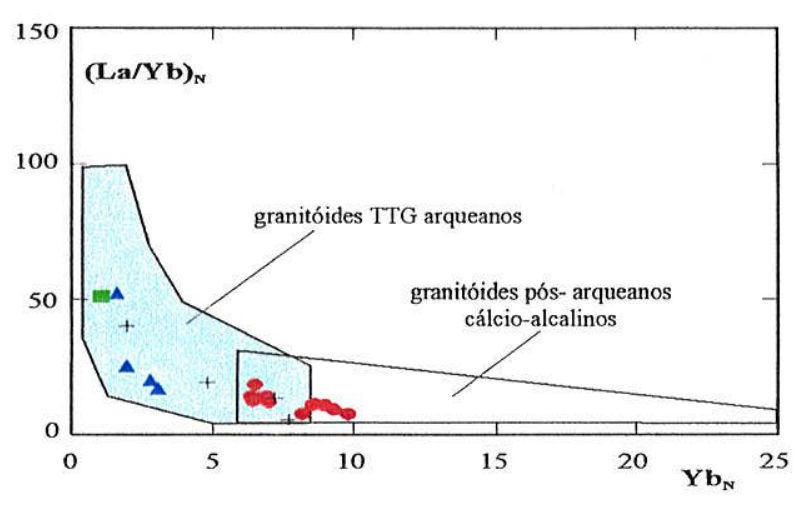

c)

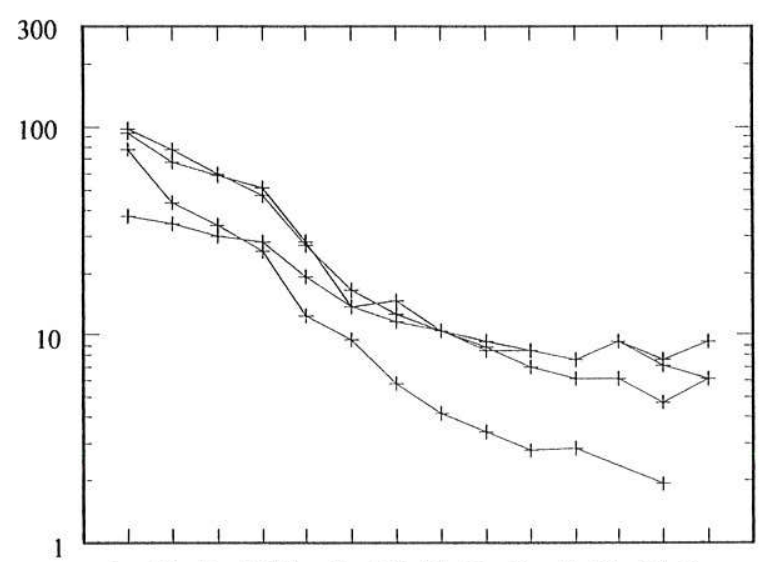

La Ce Pr Nd Sm Eu Gd Tb Dy Ho Er Tm Yb Lu

e)

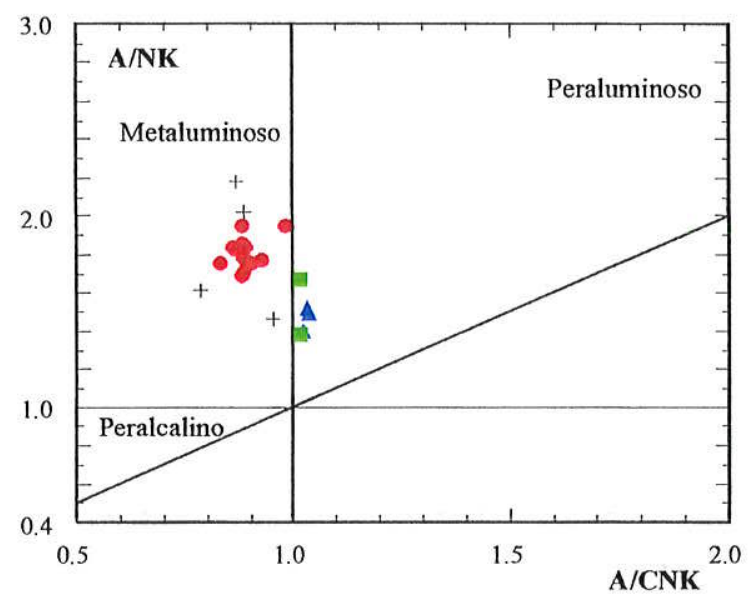

b)

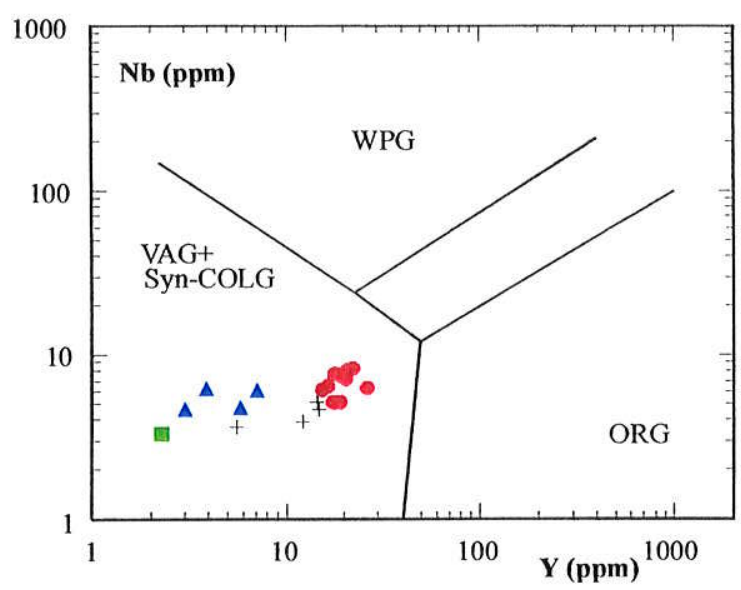

d)

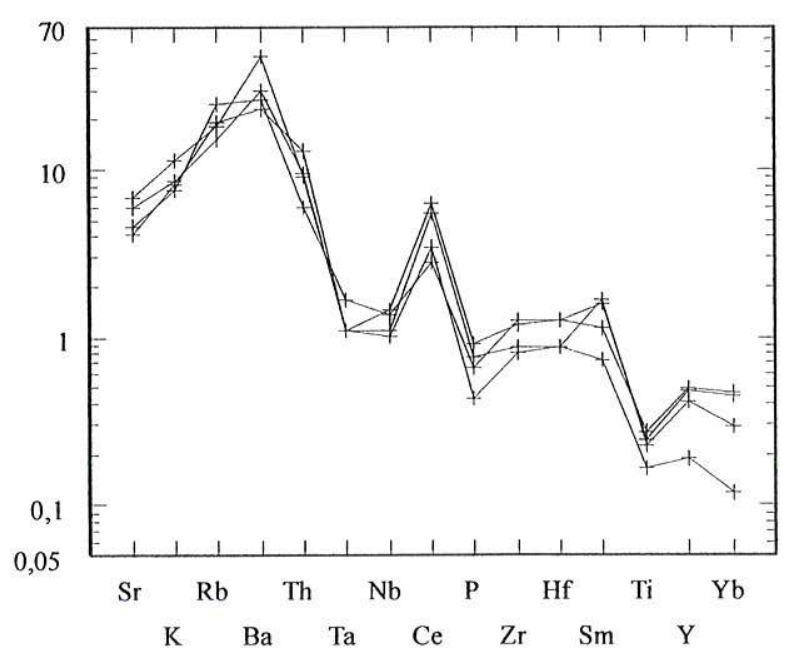

f)

Figura 4.19 - Diagramas de comparação entre os granitóides da Mina de Salamangone e tonalitos da área Cayenne-Régina, na Guiana Francesa.a) diagrama de classificação (O'Connor 1965), b) diagrama A/NK vs.. A/CNK, c) diagrama segundo Martin (1986, 1993), d) diagrama segundo Pearce et al. 1984, e) padrão de distribuição dos ETR (Boyton 1984), f) padrão dos elementos expandidos (Pearce 1983). 
Os fracionamentos mais pronunciados dos ETR, as raõzes $\mathrm{Sr} / \mathrm{Y}$, os baixos conteúdos de $\mathrm{Yb}$ e de Y, (Figura 4.14a e b), e a acentuada anomalia positiva de Eu, (Figura 4.17a), das amostras com composição granodiorítica em relação às amostras de tonalito, conduz à discussão da possibilidade de existência de duas linhagens de rochas granitóides, sugerindo uma fonte mais profunda, com composição de eclogito para a primeira e anfibolítica, com granada e anfibólio residuais para a segunda, de acordo Martin (1993).

\subsubsection{Anfibolitos}

O estudo das rochas anfibolíticas que ocorrem na mina de Salamangone representa uma avaliação preliminar sobre alguns aspectos petrográficos e geoquímicos destas rochas. Tal procedimento se deve ao enfoque dado às rochas tonalíticas e granodioríticas, encaixantes principais da mineralização aurífera. Além disso, por fatores técnicos e econômicos, não foi possível proceder a uma amostragem sistemática destes corpos, bem como realizar um número de análises químicas (em rocha e mineral), necessárias para uma caracterização mais adequada.

\subsubsection{Caracterização petrográfica}

Essas rochas constituem diques e concordantes em relação à zona de cisalhamento e aos veios veios de quartzo mineralizados. Suas espessuras são centimétricas, podendo alcançar, longitudinalmente, algumas dezenas de metros, Figura 4.2.

Macroscopicamente são rochas de coloração cinza-escuro ou negro, granulometria fina, apresentando estrutura maçica a orientada Figura 4.20a. São compostas, essencialmente por hornblenda e/ou actinolita, plagioclásio e biotita, por vezes com pequena quantidade de diopsídio, Figura 4.20b. Titanita, epidoto, apatita, quartzo, opacos, feldspato potássico, clorita e allanita ocorrem como fase minerais acessórias, ou como traços. A textura granoblástica, nos termos isótropos, e granonematoblástica a nematoblástica, nas variedade foliadas, Figuras 4.20 c e $4.20 \mathrm{~d}$. Na amostra S-04 observa-se a presença de faixas ricas em clinopiroxênio, intercalando-se com faixas nematoblásticas com predominância de hornblenda. Não foram verificadas, nas amostras estudadas, arranjo entre cristais de anfibólio e plagioclásio peculiares à textura ofítica, ou presença de cristais de plagiocásio tabulares ripiformes. 
$\mathrm{Na}$ Tabela 4.9, são apresentadas as análises modais representativas dos anfibolitos estudados. Os anfibólios possuem coloração variando de verde a verde-pálido, com pleocroísmo moderado a fraco, passando de verde para amarelo-esverdeado, algumas vezes muito fraco, sugerindo uma composição entre a hornblenda e a actinolita. Os cristais são idiomórficos a irregulares, predominantemente prismáticos, com dimensões variando entre $0,3 \mathrm{~mm}$ e 1,2mm, apresentando, em algumas situações, hábito fibroso, Figura 4.21a.

A substituição parcial ou total de clinopiroxênio, pelo anfibólio, é um processo observado com certa freqüência, encontrando-se muitas vezes preservado como restos no seu núcleo. Mesmo quando o clinopiroxênico se encontra ausente, existem evidências deste processo de substituição, devido à presença de pequenas inclusões de quartzo, em forma de gotas e/ou vermiformes, que se originam do excesso de sílica não incorporada na estrutura do anfibólio, caracterizando uma feição poiquiloblástica Figuras 4.21 b, 4.21c e 4.21d.

Associa-se geralmente a cristais de biotita, chegando a formar agregados, e os produtos de alteração mais comuns, no caso da hornblenda, são actinolita e biotita.

\begin{tabular}{|c|c|c|c|c|c|c|c|}
\hline $\begin{array}{l}\text { AMOSTRAS } \\
\text { MINERAIS }\end{array}$ & $\begin{array}{c}\text { TR. N-54 } \\
\text { R-02 }\end{array}$ & $\begin{array}{c}\text { TR. N-54 } \\
\text { R-03 }\end{array}$ & $\begin{array}{c}\text { TR. N-54 } \\
\text { R-10 }\end{array}$ & $\begin{array}{c}\text { TR. N-229 } \\
\text { S-02 }\end{array}$ & $\begin{array}{c}\text { TR. N-229 } \\
\text { S-04 }\end{array}$ & $\begin{array}{l}\text { SH-77 } \\
\text { SL-70 }\end{array}$ & $\begin{array}{r}\text { FI-121 } \\
\text { IH-04 }\end{array}$ \\
\hline Hornblenda & - & - & 33.0 & 34.8 & 48.6 & 47.5 & 31.0 \\
\hline Actinolita & 61.5 & 49.4 & 6.8 & - & 9.8 & - & 6.4 \\
\hline Plagioclásio & 31.6 & 39.4 & 46.6 & 48.6 & 21.4 & 34.0 & 49.4 \\
\hline Biotita & 4.5 & 8.8 & 1.1 & 11.4 & 4.8 & 10.5 & 7.8 \\
\hline Clinopiroxênio & - & - & - & $=$ & 3.2 & - & - \\
\hline Microclínio & - & 1.8 & 6.3 & 2.4 & 3.2 & 2.5 & 0.8 \\
\hline Titanita & 1.0 & 0.4 & 1.7 & 1.4 & 1.0 & 3.0 & 1.6 \\
\hline Apatita & 0.5 & - & - & 0.2 & 0.4 & 0.5 & 0.2 \\
\hline Allanita & 1.0 & 0.2 & $\operatorname{Tr}$ & 0.2 & - & $\mathrm{Tr}$ & . \\
\hline Quartzo & $\mathrm{Tr}$ & - & 0.6 & 0.4 & 0.6 & 0.5 & 0.4 \\
\hline Epidoto & $\operatorname{Tr}$ & - & 1.1 & - & 5.2 & $\mathrm{Tr}$ & 2.4 \\
\hline Clorita & - & $\sim$ & 1.7 & " & - & 0.5 & - \\
\hline Opacos & $\operatorname{Tr}$ & - & 1.1 & 0.6 & 0.8 & $\operatorname{Tr}$ & - \\
\hline $\mathrm{N}^{\circ}$ Pontos & 1000 & 1000 & 1000 & 1000 & 1000 & 1000 & 1000 \\
\hline
\end{tabular}

Tabela 4.9 - Análises modais dos anfibolitos, amostrados nas travessas de acesso aos Níveis 54 e $229 \mathrm{~m}$ da mina e nos furos de sondagem SH-77 e Fl-121. 

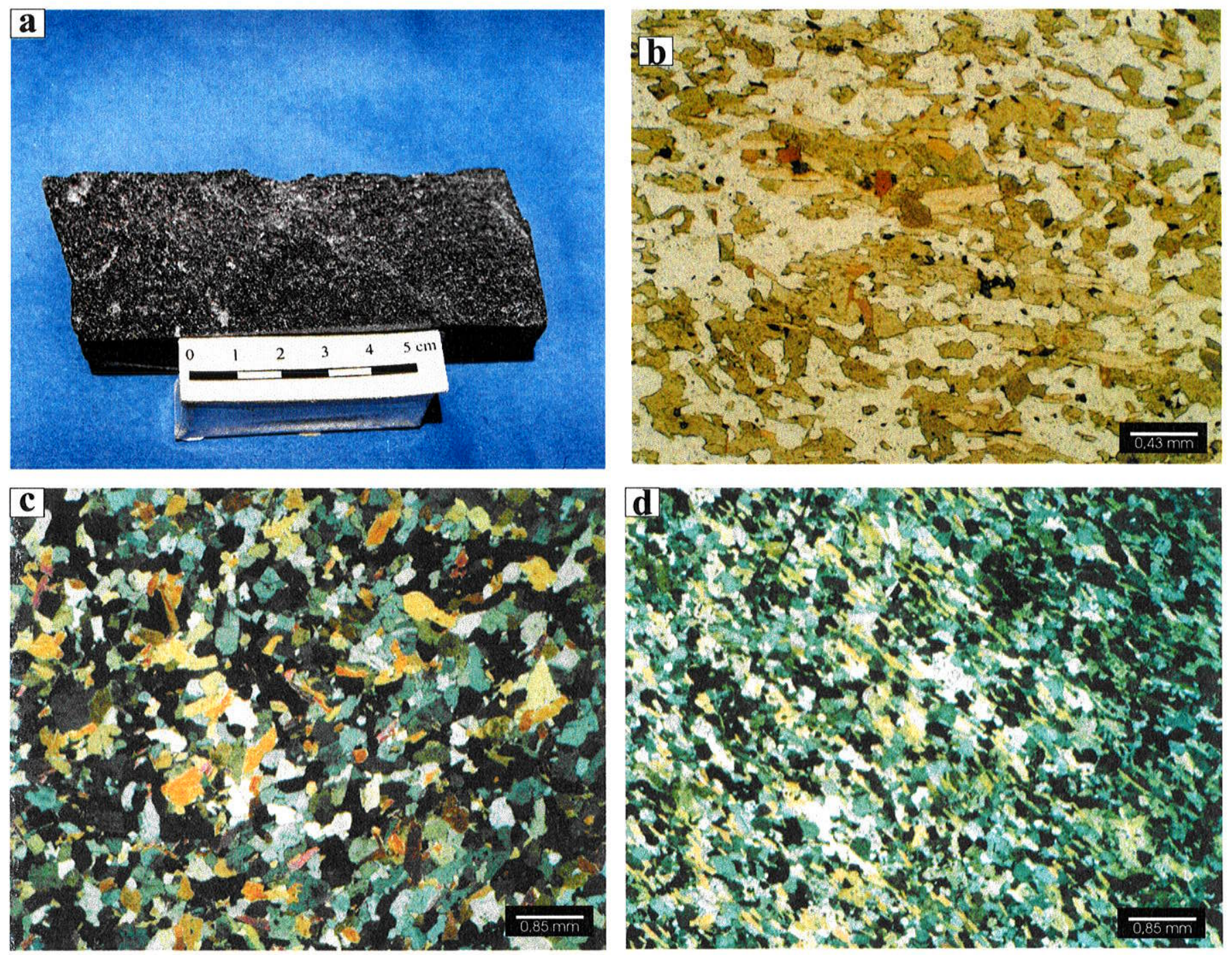

Figura 4.20 - Aspectos petrográficos do anfibolito: a) Anfibolito de coloração cinza-escuro e granulometria fina, b) Aglomerados de cristais de hornblenda e biotita, com titanita associada (N//), c e d) Texturas granonematoblática e nematoblástica, respectivamente, desenvolvidas nos anfibolitos (NX). 

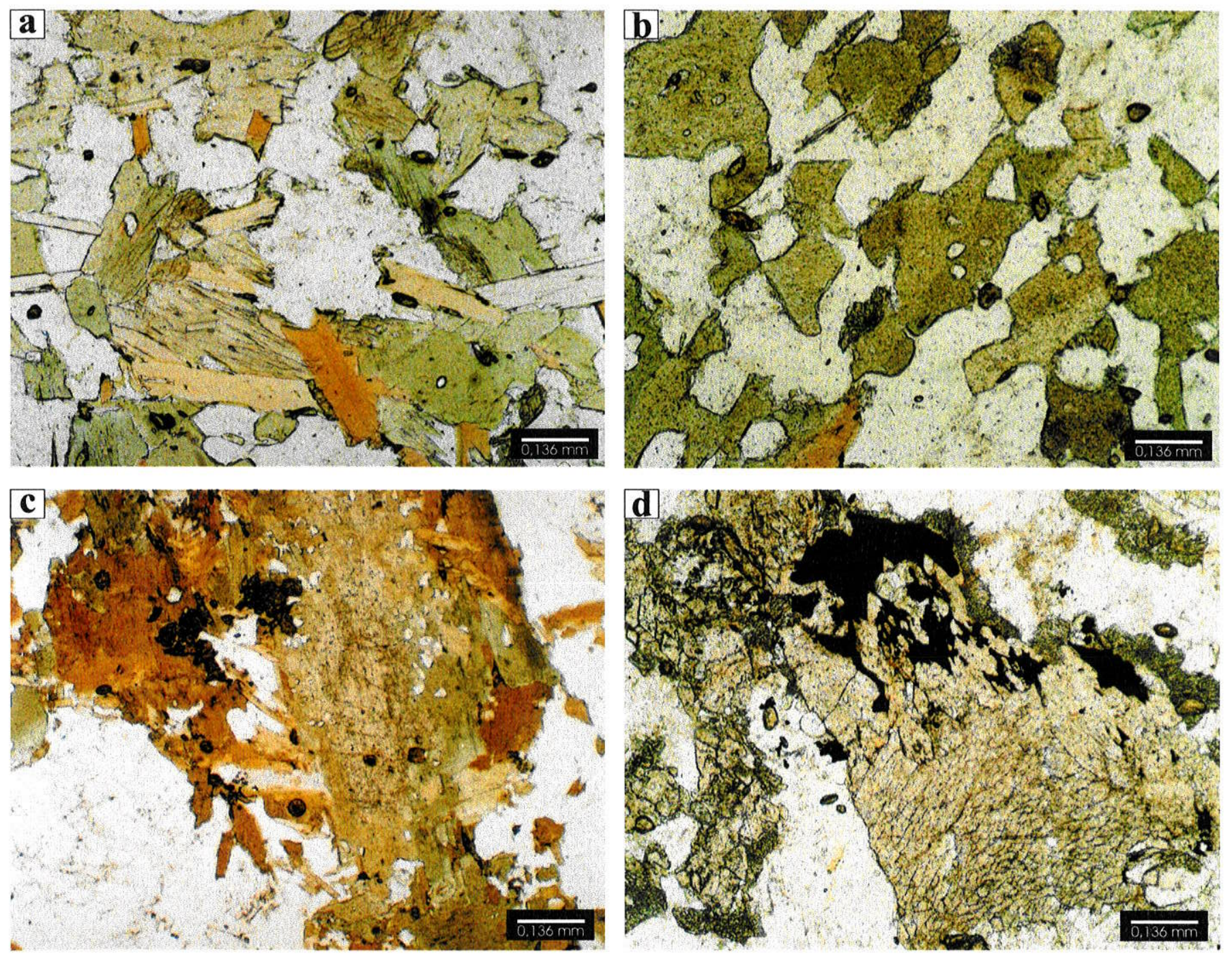

Figura 4.21. - Aspectos petrográficos do anfibolito: a) Cristais de hornblenda associados com biotita e titanita (N//), b) Feição poiquiloblástica na hornblenda, evidenciada pela presença de pequenas gotas de quarzo. Cristais idiomórficos de titanita, com núcleos de opacos $(\mathrm{N} / /)$, c) Relicto de clinopiroxênio preservado no núcleo de hornblenda, a qual apresenta, também, inclusões pequenas de quartzo $(\mathrm{N} / /)$, d) Cristal de clinopiroxênio, incolor, com borda actinolítica e epídoto simpletítico, amostra S-04, nível $229 \mathrm{~m}$ da mina, $(\mathrm{N} / /)$. 
Os dados analíticos por microssonda eletrônica, e as respectivas fórmulas estruturais dos anfibólios encontram-se na Tabela 4.10, Anexo 1. Nos diagramas de classificação e composição, segundo Leake (1978) e Leake et al. (1997), as amostras incidiram no campo dos anfibólios cálcicos, com composição de hornblenda magnesiana e actinolita, Figura $4.22 \mathrm{a}$ e $4.22 \mathrm{~b}$. Os valores de $\mathrm{Fe}^{2+}$ e $\mathrm{Fe}^{3+}$ foram obtidos segundo o método de Schumaker (cf. Leake et al. 1997).

O plagioclásio ocorre como grãos subidiomórficos a irregulares, com tamanhos variando entre 0,3 e $0,8 \mathrm{~mm}$, exibindo comumente geminação polissintética, tipo albita, e mais raramente em grade. Cristais saussuritizados em graus variados são frequentemente encontrados, originando carbonato, sericita e epidoto associados. A saussiritização mostra-se mais acentuada na amostra R-10. As inclusões mais frequentes são de apatita, biotita e anfibólio. Sua composição determinada em cristais sem ou com pouca evidência de alteração, é apresentada na Tabela 4.11, Anexo 1. As amostras incidem no campo do oligoclásio e andesina, Figura 4.22c.

Os cristais de biotita possuem dimensões entre 0,3 e $1,0 \mathrm{~mm}$, apresentando-se tipicamente na forma de cristais alongados, subidiomórficos a irregulares, com coloração marrom acastanhada e pleocroísmo acentuado. Ocorrem sempre associados aos anfibólios e titanita, substituindo, às vezes a primeira e sendo substituida pela segunda, ao longo dos planos de clivagem, Figura 4.21a. Nas amostras mais alteradas, alguns cristais mostram passagem para clorita a partir das bordas, ou acompanhando os planos de clivagem. As análises químicas, apresentadas na Tabela 4.12, Anexo 1. As amostras analisadas, incidem no campo da biotita com uma composição média entre a eastonita e a siderofilita, do diagrama de variações catiônicas baseado em Deer et al. (1983), Figura 4.22d.

O clinopiroxênio ocorre sob duas formas: como cristais concentrados em faixas (amostra S-04), subidiomórficos, incolores, com borda transformada em actinolita e epidoto simplectítico e, como restos de uma mineralogia reliquiar magmática, localizada nos núcleos de anfibólios, Figura 4.21c e 4.21d.

O feldspato alcalino, microlínio em geral, ocorre na forma de cristais irregulares, mostrando caráter intersticial, ocasionalmente com geminação em grade. $O$ quartzo foi encontrado nas amostras estudadas como traços ou em pequena quantidade, formando indivíduos pouco desenvolvidos, geralmente xenomórficos. Ocorrem isolados, na forma intersticial, ou como inclusões gotiformes nos anfibólios. 


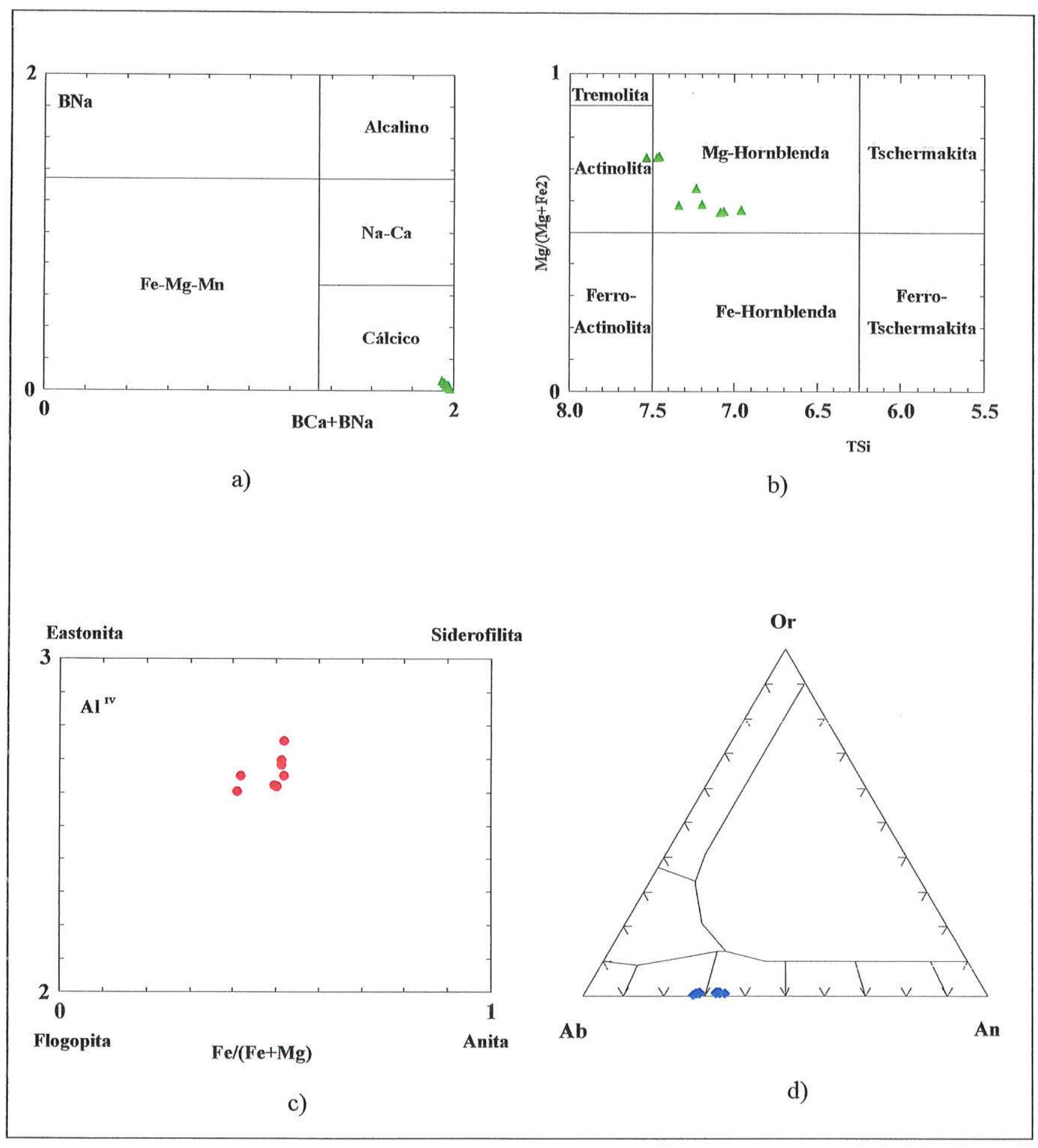

Figura 4.22 - a e b) Diagramas de classificação e composição de anfibólios, respectivamente, segundo Leake et al. 1997; c) Diagrama de variação catiônica para biotita (Deer et al. 1983); d) Diagrama de classificação de plagioclásios, para anfibolitos da Mina de Salamangone. 
A titanita aparece com maior freqüência sob a forma de cristais irregulares de cor marrom, nas bordas e ao longo dos planos de clivagem da biotita, mostrando algumas vezes halos pleocróicos. Ocorre, também, como pequenos cristais idiomórficos, com núcleos de opacos, dispersos na lâmina, Figura 4.21b.

A apatita apresenta-se, geralmente, prismática, inclusa no plagioclásio, e a allanita é observada, quase sempre, como núcleos circundados por epidoto. $\mathrm{O}$ epídoto, a sericita e o carbonato representam produtos de alteração dos plagioclásios, enquanto que a clorita ocorre como alteração, principalmente, da biotita e, às vezes, da hornblenda. $O$ epídoto mostra-se, algumas vezes, em intercrescimentos simplectíticos com o plagioclásio, a partir da substituição de piroxênio. Os minerais opacos apresentam formas irregulares e ocorrem, geralmente, associados aos minerais máficos, nos termos mais alterados.

\section{Considerações gerais}

Os dados petrográficos e as análises químicas das principais fases minerais das rochas anfibolíticas estudadas permitem reuni-las em duas assembléias minerais. Uma constituída por actinolita verde-pálida, às vezes com núcleos de hornblenda verde-clara, oligoclásio e biotita com maior teor de magnésio, mostrando tendência para eastonita. Feições poiquiloblásticas são raras, observando-se acentuada alteração de biotita para titanita ao longo de suas bordas e planos de clivagem e pouca saussuritização dos plagioclásios. Esta assembléia faz parte de uma rocha anfibolítica granoblástica, localmente nematoblástica.

A outra assembléia é constituída de Mg-hornblenda de coloração verde, andesina e biotita com maior conteúdo em ferro, tendendo ligeiramente para siderofilita. Inclui, algumas vezes, faixas com piroxênio, o qual apresenta bordas de actinolita. A hornblenda mostra, freqüentemente, feições poiquiloblásticas, ou núcleos com restos de clinopiroxênio. A titanita aparece associada com biotita e, também, como cristais isolados, bem formados, muitas vezes, com núcleos de opacos. Esta assembléia faz parte de uma rocha anfibolítica que exibe textura, geralmente, nematoblástica.

\subsubsection{Geoquímica}

As amostras R-03 e R-10, coletadas ao longo da travessa de acesso ao Nível 54 da mina, foram analisadas no laboratório ACTLABS. As demais análises apresentadas na Tabela 4.13, Anexo 3, foram coletadas pelo pessoal da mina, na galeria de desenvolvimento do Nível 
345, Figura 4.2, no inicio dos trabalhos de lavra e enviadas para análise nos laboratórios da Geosol. Seu uso foi realizado com cuidado, pois não foi possível ter acesso às amostras e lâminas petrográficas dos corpos amostrados.

Das duas amostras com controle petrográfico, R-03 e R-10, a segunda mostra-se com um padrão mais acentuado de alteração, que se reflete na sua composição química, através da diminuição dos teores de $\mathrm{K}_{2} \mathrm{O}, \mathrm{MgO}$, Cr e ligeiro aumento de $\mathrm{SiO}_{2}$ e $\mathrm{Al}_{2} \mathrm{O}_{3}$.

\section{Natureza ortoderivada}

Vários critérios são utilizados para discriminar anfibolitos orto e paraderivados, baseados principalmente em evidências de campo, petrográficas e químicas. As rochas anfibolíticas estudadas mostram algumas evidências petrográficas sugerindo tratarem-se de feições ígneas, preservadas dos eventos deformacionais e metamórficos a que foram submetidas. Como mineralogia ígnea reliquiar são encontrados clinopiroxênios localizados ou não, em núcleos de hornblenda ou actinolita, com feições poiquiloblásticas.

Com relação aos dados químicos, a natureza ortoderivada das rochas anfibolíticas foi testada utilizando-se o diagrama de Leake (1964), Figura 4.23a, onde são confrontados os parâmetros de Niggli $m g$ e $c$, as amostras aproximam-se da tendência composicional dos doleritos do Karoo. Com base na diferença dos teores de Fe de orto e para-anfibolitos, Gokhale \&Gothe (1978) sugeriram a utilização do diagrama discriminante $\mathrm{SiO}_{2}-\mathrm{FeO}-\mathrm{Fe}_{2} \mathrm{O}_{3}$, Figura $4.23 b$, onde as amostras incidem no campos dos ortoanfibolitos

\section{Nomenclatura e Classificação}

Para uma denominação mais adequada dos anfibolitos, foram utilizados os diagramas $\mathrm{SiO}_{2}$ vs. $\mathrm{Na}_{2} \mathrm{O}+\mathrm{K}_{2} \mathrm{O}$ e de $\mathrm{SiO}_{2}$ vs. $\mathrm{K}_{2} \mathrm{O}$ de Le Maitre (1989) e R1 vs. R2 de De La Roche et al. (1980), Figuras 4.24a, 4.24b e 4.24c ,respectivamente. A nomenclatura proposta nestes diagramas refere-se às rochas ígneas vulcânicas, não implicando necessariamente que os protolitos das rochas anfibolíticas estudadas correspondam a derrames. Sendo assim, esta nomenclatura foi utilizada em seu sentido composicional. Esses diagramas mostram que os anfibolitos correspondem às composições de basalto e andesito basalto, de médio a alto $\mathrm{K}$. As Figuras 4.24a e 4.25b apresentam, respectivamente, os diagramas de Irvine \& Baragar (1971), $\mathrm{SiO}_{2}$ vs. $\mathrm{Na}_{2} \mathrm{O}+\mathrm{K}_{2} \mathrm{O}$ onde a maioria das amostras concentra-se no campo subalcalino 
ou no limite com o campo alcalino, e AFM que destaca a afinidade cálcio-alcalina das rochas anfibolíticas.

\section{Comportamento geoquímico}

As análises realizadas nos anfibolitos são poucas e foram utilizadas com ressalvas, considerando as diferenças de métodos analíticos e, principalmente, por se tratarem de corpos localizados em galeria e travessa de desenvolvimento da mina, concordantes com a zona mineralizada, situados, portanto, dentro da área de influência de seu halo de alteração.

Com relação aos elementos terras raras, analisando-se sua disposição no diagrama ETR normalizado pelo condrito de Boynton (1984), Figura 4.26, observa-se que apresentam um padrão de enriquecimento em ETRL, exibindo características de um leve fracionamento nos corpos amostrados, com empobrecimento relativo dos ETRP, provavelmente muito mais conseqüência do processo de interação rocha-fluido, do que derivação de um material mais diferenciado. As anomalias de Eu são ausentes, ou levemente negativas.

A distribuição dos elementos incompatíveis normalizado por N-MORB, Pearce (1983), Figura 4.27, apresenta forte enriquecimento nos conteúdos de $\mathrm{Sr}, \mathrm{K}, \mathrm{Rb}, \mathrm{Ba}$ e empobrecimento progressivo nos outros elementos, que possuem incompatibilidade decrescente.

\section{Ambientes tectônicos}

Os diagramas discriminantes utilizados, tem seus campos delimitados a partir de confrontos entre elementos considerados imóveis, ou pouco móveis sob condições de metamorfismo até a fácies anfibolito, e também em condições hidrotermais e de alterações de fundo oceânico. No diagrama $\mathrm{TiO}_{2}-\mathrm{K}_{2} \mathrm{O}-\mathrm{P}_{2} \mathrm{O}_{5}$ proposto por Pearce et al. (1975), Figura 4.28, as rochas anfibolíticas distribuem-se no campo dos basaltos continentais, que inclui os basaltos da província de Karoo. Nos diagramas triangulares discriminantes de ambientes geotectônicos, Hf/3-Th-Ta (Wood 1980), Nb*2-Zr/4-Y (Meschede 1976) e Ti/100-Zr-Y*3 (Pearce \& Cann 1973), Figuras 4.29a, 4.29b e 4.29c, respectivamente, as amostras incidem nos campos de basaltos cálcio-alcalinos, relacionados à arcos vulcânicos e margens convergentes. 


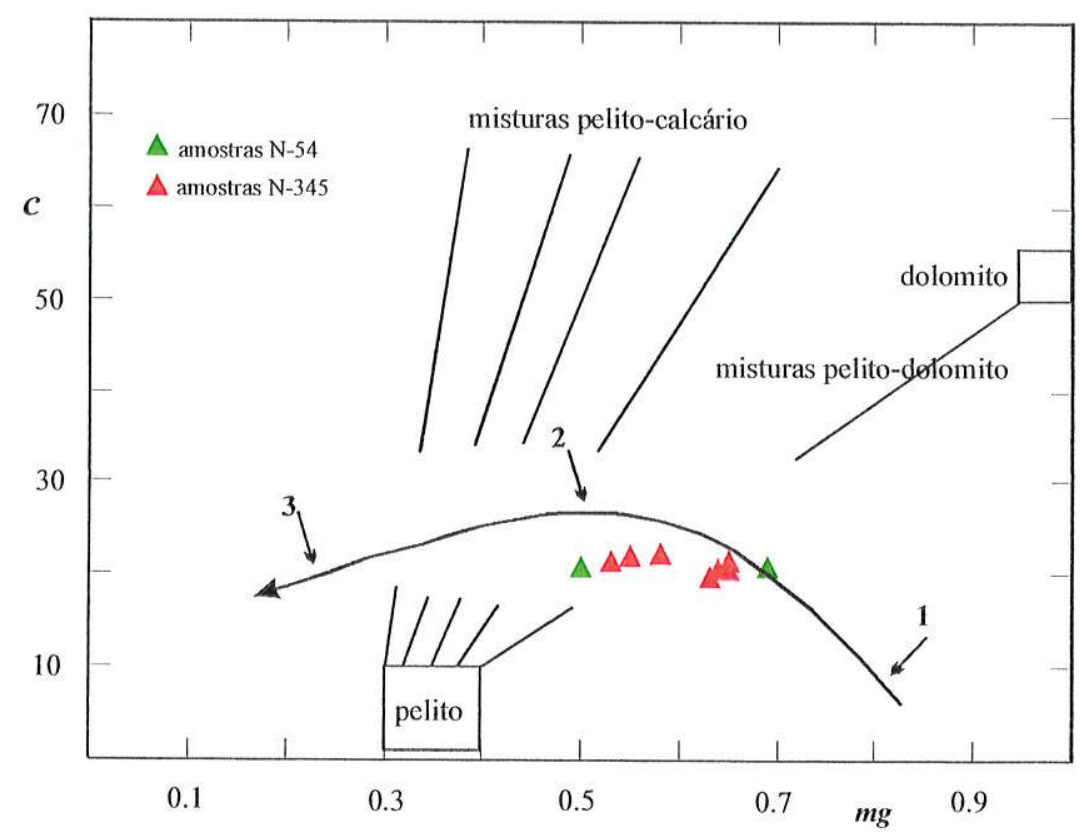

a)

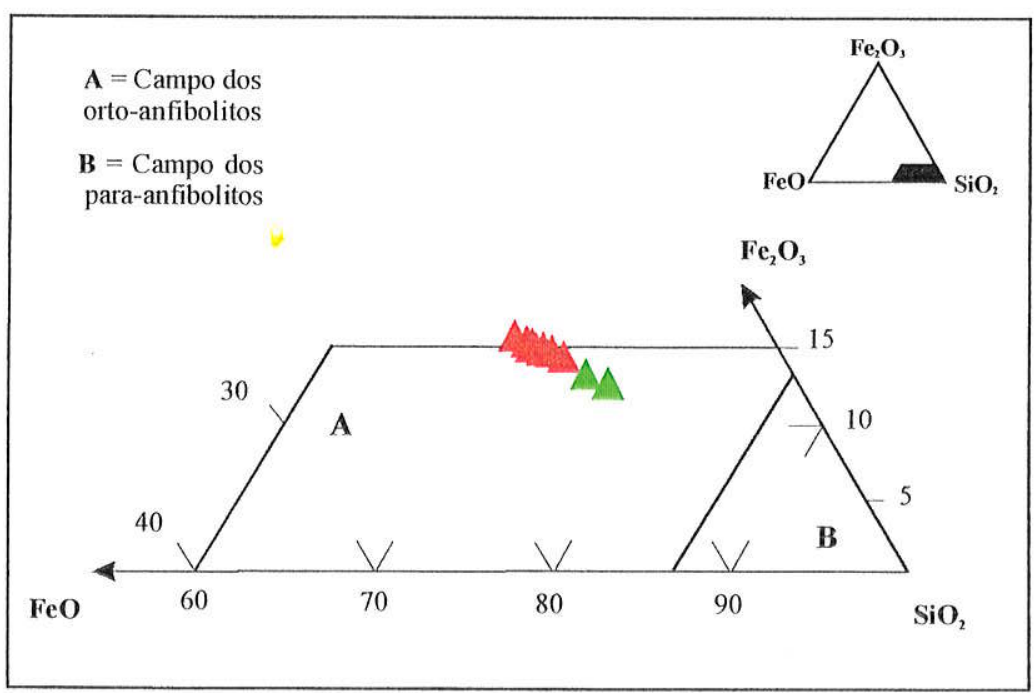

b)

Figura 4.23 - Diagramas para caracterização da origem dos protolitos das rochas anfibolíticas. a) Diagrama de Leake (1964) com a projeção dos valores de $c v s . m g$ de Niggli. 1, 2 e 3 correspondem respectivamente aos estágios de diferenciação iniciais ou cumulatos intermediários e finais dos doleritos do Karoo, b) Diagrama para discriminação entre orto e para-anfibolito de Gokhale \& Gothe (1978). 


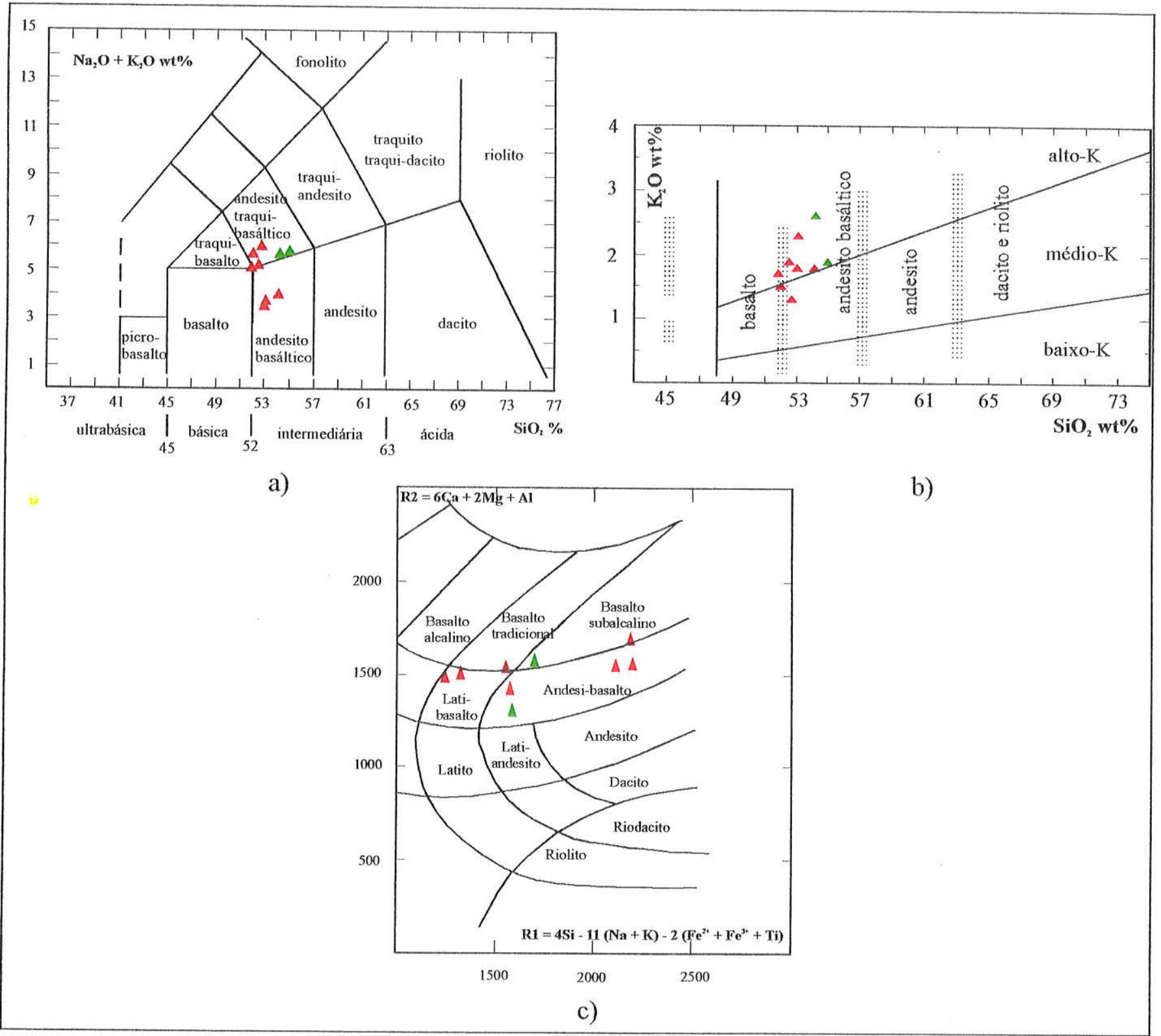

Figura 4.24. Diagramas de classificação química dos anfibolitos: a e b) segundo Le Maitre (1989), e c) segundo De La Roche et al. (1980). Simbologia como a Figura 4.23.

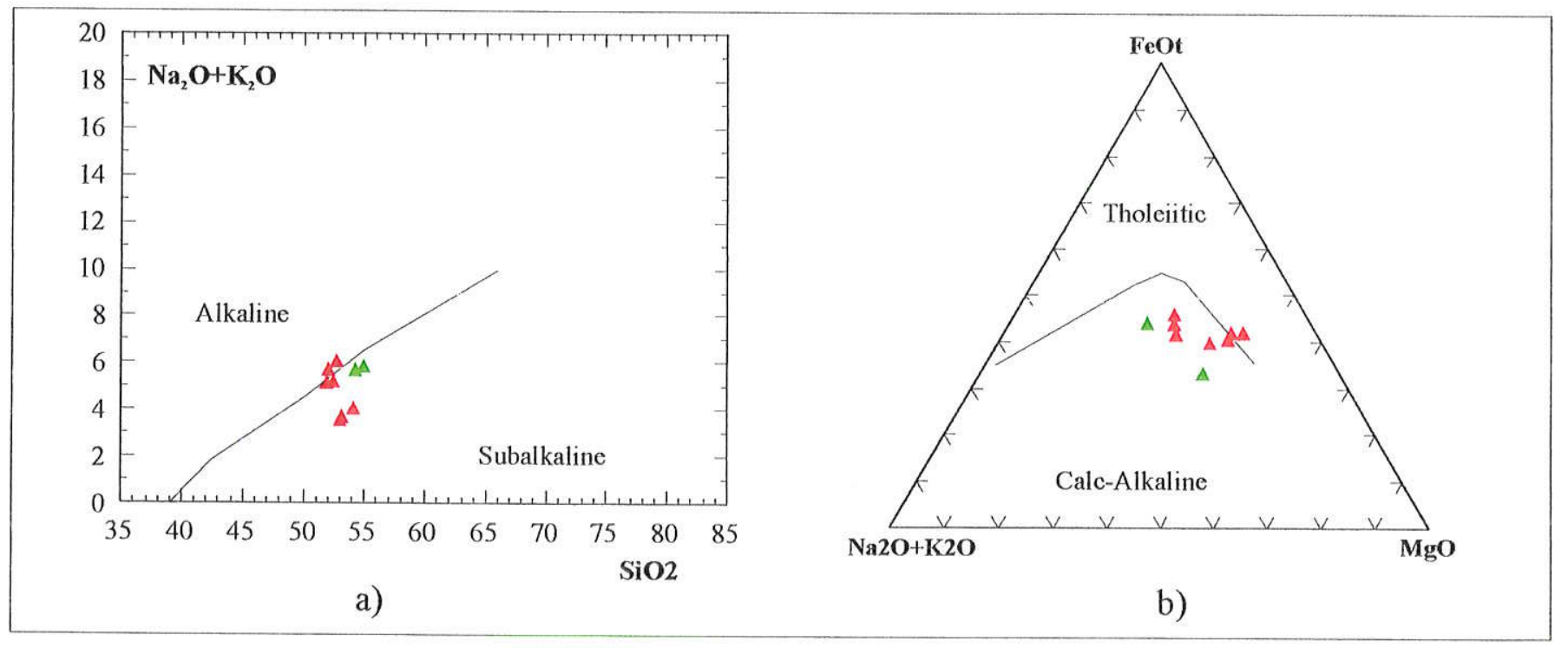

Figura 4.25- Diagramas de: a) sílica vs. álcalis e b) AFM, de Irvine \& Baragar (1971) para as rochas anfibolíticas, mostrando sua tendência cálcio-alcalina. Simbologia como a Figura 4.23. 


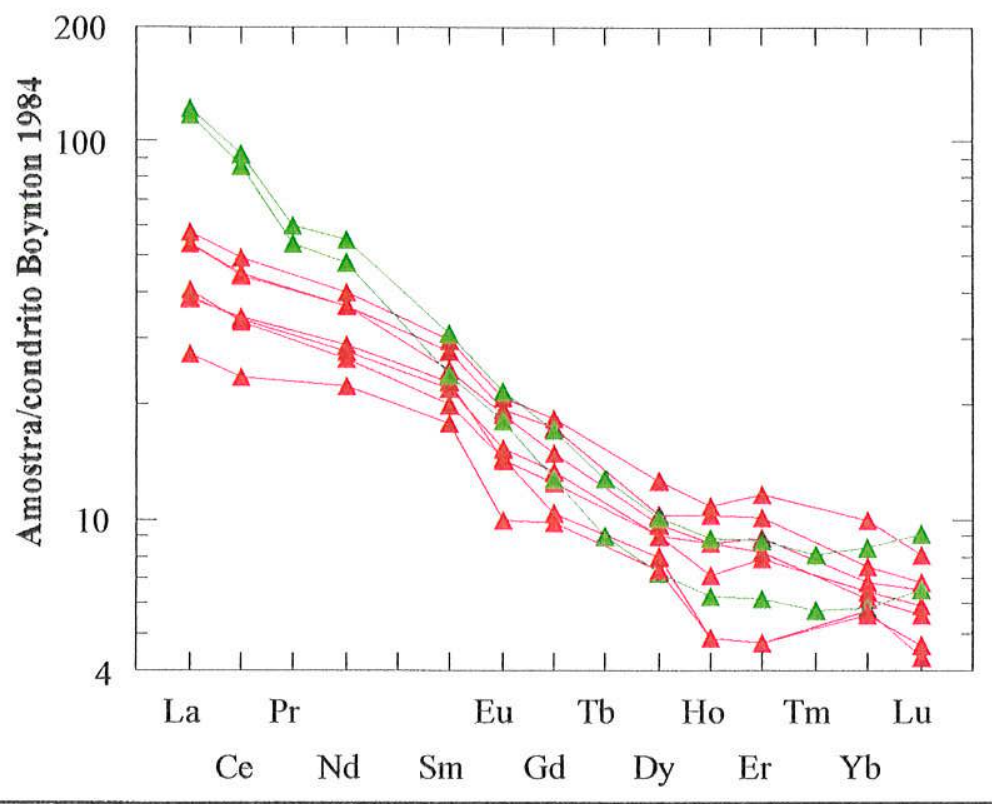

Figura 4.26 - Padrão de distribuição dos ETR normalizados pelo condrito de Boyton (1984), para as rochas anfibolíticas estudadas.

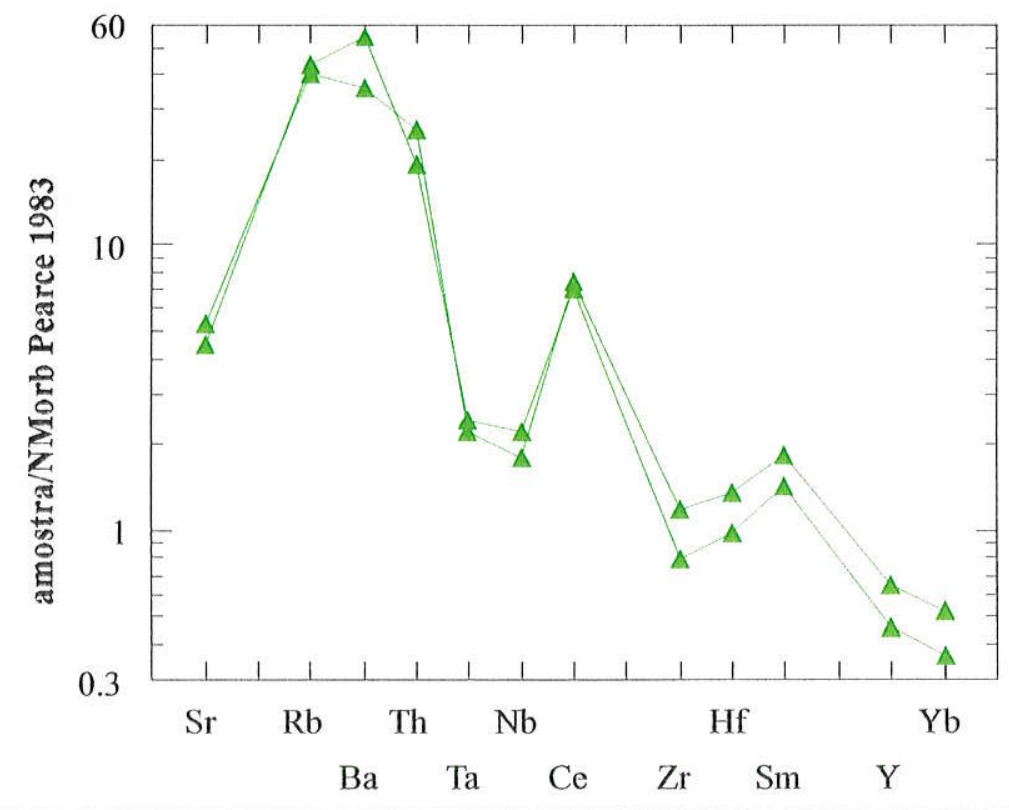

Figura 4.27. Padrão de distribuição dos elementos incompatíveis normalizados por N-MORB Pearce (1984) dos anfibolitos estudados. 


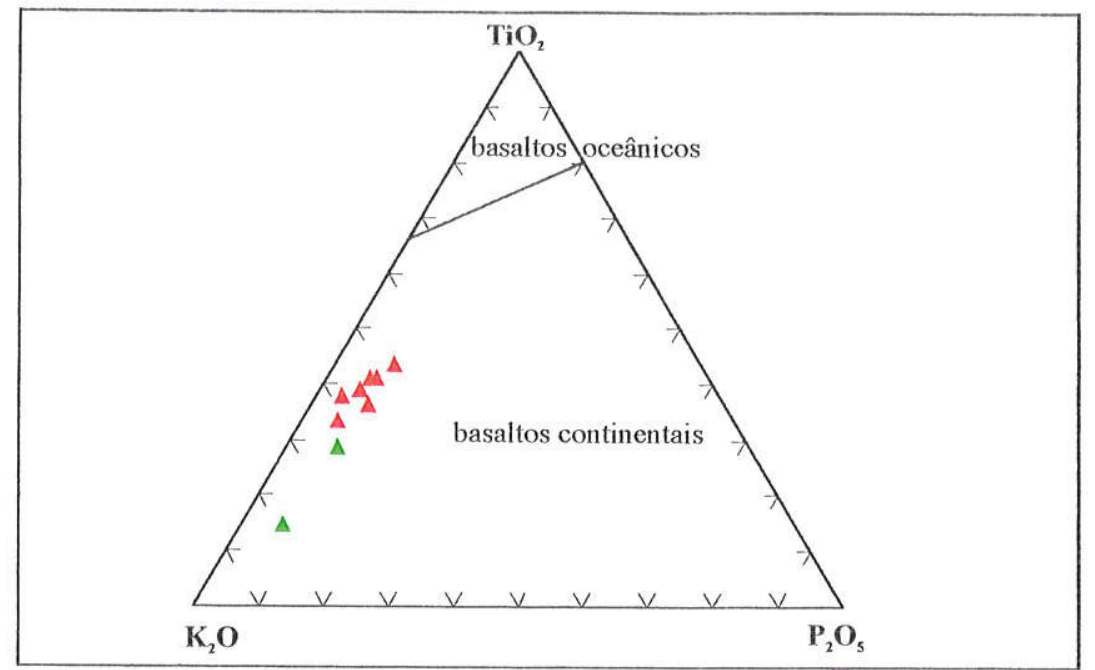

Figura 4.28. Diagrama $\mathrm{K}_{2} \mathrm{O} v s$. $\mathrm{TiO}_{2}$ vs. $\mathrm{P}_{2} \mathrm{O}_{5}$ de Pearce et al. (1975), distinguindo os campos de basaltos oceânicos e continentais, com os teores das rochas anfibolíticas estudadas simbologia como na Figura 4.23.

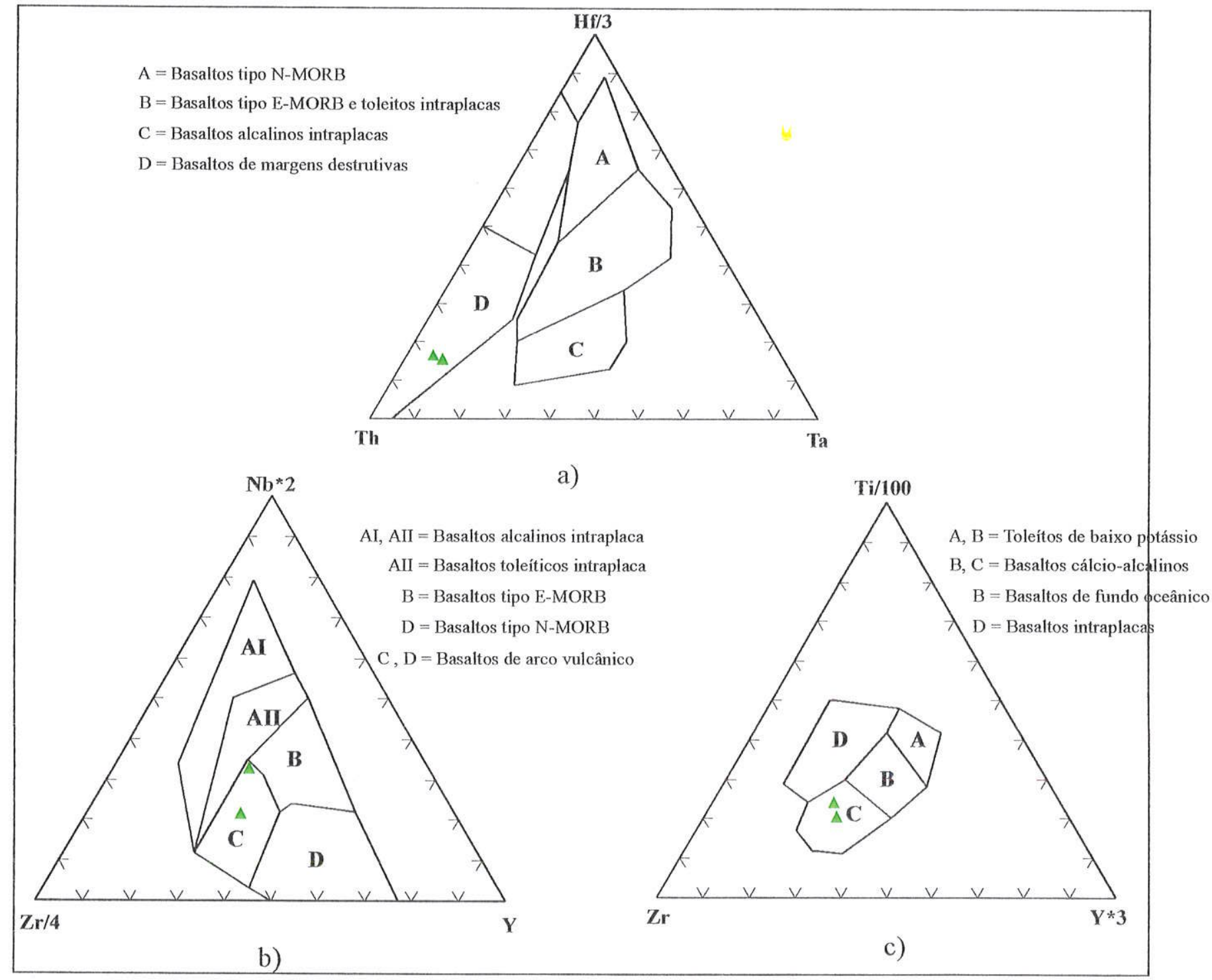

Figura 4.29 - Diagramas triangulares discriminantes de ambientes tectônicos para as rochas anfibolíticas estudadas, segundo: a) Wood (1980), b) Meschede (1976) e c) Pearce \& Cann (1973). Simbologia como na Figura 4.23 . 


\section{Considerações gerais}

As rochas anfibolíticas estudadas são ortoderivadas, possivelmente de caráter intrusivo, com composição de basalto e andesito basalto, cálcio-alcalinos, gerados em arco vulcânico de margens continentais ativas. $O$ padrão geoquímico apresenta enriquecimento em LILE e ETRL, com empobrecimento nos demais elementos incompatíveis. São rochas totalmente anfibolitizadas, apresentando evidências de modificações decorrentes da interação com fluidos hidrotermais mineralizantes, traduzidas, principalmente, pelo teor mais elevado de $\mathrm{SiO}_{2}$, saussuritização acentuada dos plagioclásios, além das transformações de hornblenda em actinolita e da biotita em clorita, nos termos afetados pela mineralização quartzo-aurífera.

\subsubsection{Pegmatitos aplíticos}

$\mathrm{Na}$ área da mina de Salamangone ocorrem veios de composição pegmatítica, com variação a termos aplíticos, que seccionam todo o sistema filoniano. Os estudos de suas características petrográficas e geoquímicas não foram objetivos desta tese. A Figura 4.30 ilustra a relação de contato brusco entre esses corpos e a rocha tonalítica encaixante, mostrando um detalhe de sua composição mineralógica, que é constituída, essencialmente, por plagioclásio, feldspato potássico e quartzo, com participação muito pequena de micas (biotita) e granada. 

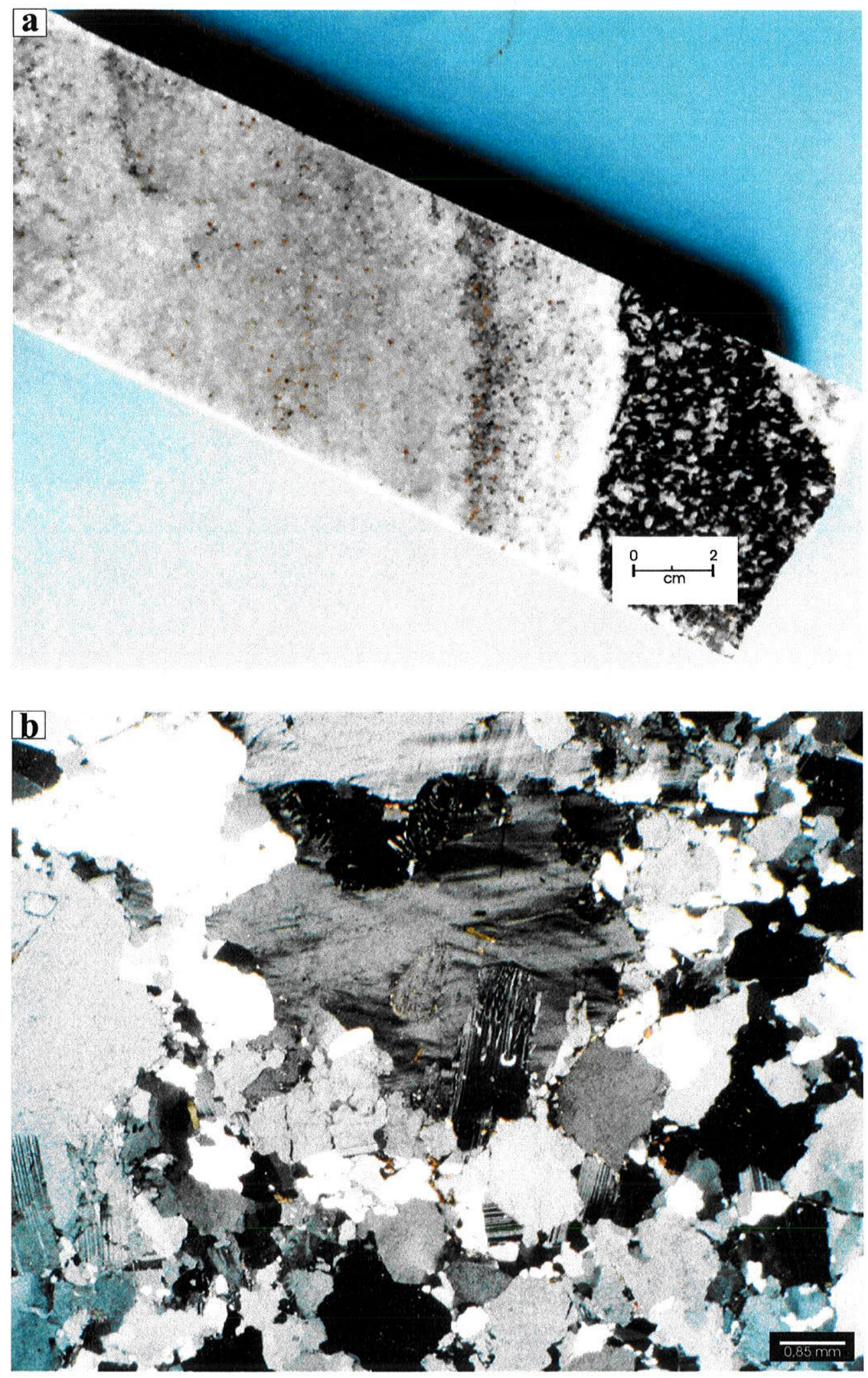

Figura 4.30 - a) Pegmatito aplítico seccionando rocha tonalítica (Furo de sondagem SH-61), b) Plagioclásio, quartzo e feldspato potássico, com mirmequita inclusa, em rocha aplítica $(\mathrm{Nx})$. 


\section{CAPÍTULO 5}

\section{Geocronologia e Geoquímica Isotópica das Rochas Encaixantes da Mineralização}

Os granitóides que constituem o Morro de Salamangone, principalmente o tonalito, foram amostrados e submetidos à análise para determinação de idades radiométricas. Apresenta-se, abaixo, uma contextualização da região do Distrito Aurífero de Lourenço dentro das províncias geocronológicas estabelecidas para o Craton Amazônico, com um resumo sobre as datações existentes no Estado do Amaṕ. Em seguida são mostrados os dados radiométricos obtidos para as rochas granitóides do Morro de Salamangone, sua interpretação, a relação com granitóides de outras regiões do craton e as implicações tectônicas.

\subsection{ASPECTOS GERAIS}

A área estudada insere-se no Domínio Maroni-Itacaiúnas, subdivisão do Craton Amazônico, inicialmente proposto por Cordani et al. (1979), posteriormente modificado por Teixeira et al. (1989) e confirmado em Tassinari (1996), Figura 3.1.

O Domínio Maroni-Itacaiúnas estende-se por uma área muito ampla, que abrange o Suriname, Guiana, Guiana Francesa e partes do Brasil (Pará e Amapá) e da Venezuela, passando por uma evolução metamórfica entre 2.15-1.95Ga. Divide-se, de acordo Tassinari 1996, em terrenos gnáissico-granulíticos com protolitos arqueanos, os quais seriam partes retrabalhadas do Domínio Amazônia Central durante a Orogenia Maroni-Itacaiúnas, e em terrenos granito-greenstone e granulíticos, diferenciados do manto à época da Orogenia Transamazônica.

Sua principal característica é a presença de grande quantidade de sequências metavulcano-sedimentares, metamorfisadas nas fácies xisto-verde e anfibolito, intensamente deformadas, que devido à sua natureza, composição e evolução foram caracterizadas como sequências do tipo greenstone belts, de idade Paleoproterozóica. Estas unidades foram afetadas por vulcanismos ácido, intermediário e básico, aproximadamente contemporâneos à formação de suítes tonalíticas e trondhjemíticas que ocorrem no domínio.

Os trabalhos de caráter geocronológico conduzidos no Estado do Amapá são poucos e foram desenvolvidos principalmente, nas rochas do chamado embasamento, que incluem 
terrenos gnáissicos, migmatíticos e granulíticos, com diversos tipos de granitóides associados e também, nas rochas pertencentes às sequências metavulcano-sedimentares que constituem o Grupo Vila Nova.

De acordo com os dados apresentados, principalmente em Tassinari(1996), temos o seguinte quadro:

a) Montalvão e Tassinari (1984) dataram gnaisses e tonalitos de terrenos granodioríticos e trondhjemítos, das regiões próximas ao rio Cupixi, Ipitinga e Mapari, encontrando uma isócrona $\mathrm{Rb}-\mathrm{Sr}$ em rocha total com idade de $2860 \pm 60 \mathrm{Ma}$ e razão inicial (ri) de $0,7025 \pm 0,0009$. Esta razão inicial baixa indicaria que os granitóides diferenciaram-se do manto superior pouco tempo antes de sua cristalização. Essas rochas caracterizam, segundo os autores, um núcleo Arqueano preservado em meio às rochas do Domínio Maroni-Itacaiúnas. Verificaram a atuação da orogenia Transamazônica nesta região através de idades $\mathrm{K}-\mathrm{Ar}$, em minerais provenientes das rochas dessas áreas, que variaram no intervalo de 2100-1760Ma.

b) Na região leste do rio Falsino onde predominam terrenos granulíticos, Lima et al. (1982) apresentaram uma isócrona $\mathrm{Rb}-\mathrm{Sr}$ em rocha total para os charnoquitos Coatá e os enderbitos Cobra, com idade de $2450 \pm 74 \mathrm{Ma}$ e ri $=0,706 \pm 0,002$, mais elevada que a média da crosta continental inferior.

b) Os metassedimentos do Grupo Vila Nova foram datados, por Hurley et al. (1968), através de isócrona de referência $\mathrm{Rb}-\mathrm{Sr}$ a qual indicou uma idade da ordem de $2100 \mathrm{Ma}$, com razão inicial de 0,706, que corresponderia à idade do metamorfismo que afetou esta seqüência. Algumas poucas idades K-Ar obtidas por Montalvão \& Tassinari (1984) correspondem a valores aparentes entre 2100 e $1970 \mathrm{Ma}$ para anfibólios e 1920 a $1760 \mathrm{Ma}$ para micas, sugerindo períodos de resfriamento concordantes com a interpretação da isócrona $\mathrm{Rb}$-Sr.

d) Montalvão e Tassinari (1984) dataram, também, granitóides ricos em $\mathrm{K}$, intrusivos nos terrenos tonalíticos e trondhjemíticos da região do rio Cupixi, encontrando uma isócrona de referência $\mathrm{Rb}-\mathrm{Sr}$ de $2250 \mathrm{Ma}$, com uma razão inicial muito alta, da ordem de 0,747 . Estes dados, segundo os autores, indicariam a idade da potassificação que afetou os granitóides, tendo em vista que estas rochas são atravessadas por uma zona de cisalhamento. 
e) Atividade tectono-magmática com magmatismo básico associado foi registrada durante o Proterorozóico, caracterizada por intrusões básicas (diabásios e gabros), apresentando idades K-Ar (plagioclásio) em torno de 1760, 780 e 590Ma, segundo Montalvão \& Tassinari (1984).

f) As rochas dos terrenos granodiorítico - trondjhemíticos do núcleo antigo do rio Cupixi de idade próxima a 2,9Ga foram analisadas, também, pelo método $\mathrm{Sm}-\mathrm{Nd}$, por Sato \& Tassinari (1997), indicando idade modelo Sm-Nd manto empobrecido (TDM), em torno de 3,1Ga e valores de $\Sigma \mathrm{Nd}(\mathrm{T})$ em torno de $-0,7$ e $-1,1$, sugerindo que a diferenciação mantélica do protolito ocorreu pouco tempo antes.

Lima. (1974) datou 5 amostras de diabásio associado à manifestação tectonomagmática, denominada de Episódio Cassiporé (Alinhamento Cassiporé, com rumo N0․ $50^{\circ} \mathrm{W}$ ), através do método K-Ar em plagioclásios. As idades obtidas situaram-se entre 250$180 \mathrm{Ma}(207 \pm 18 \mathrm{Ma}, 224 \pm 17 \mathrm{Ma}, 227 \pm 10 \mathrm{Ma}, 254 \pm 27 \mathrm{Ma}$ e $176 \pm 9 \mathrm{Ma})$ e, foram relacionadas ao intenso vulcanismo básico da época da abertura da bacia do Atlântico Norte.

McReath \& Faraco (1997) dataram rochas máficas (anfibolitos e actinolita-xistos) do Grupo Vila Nova na região da Serra do Ipitinga, através do método Sm-Nd, definindo uma isócrona com idade de referência igual a $2264 \pm 34 \mathrm{Ma}$ e ri $=0,5098$, que corresponderia ao manto ligeiramente empobrecido.

\section{2- DADOS GEOCRONOLÓGICOS DA MINA DE SALAMANGONE E SUA INTERPRETAÇÃO}

Não foram encontrados na literatura, até o momento, registro de estudos geocronológicos na região do Distrito Aurífero de Lourenço. O Morro de Salamangone é constituído essencialmente de tonalito e subordinadamente de granodiorito e anfibolito, atravessados por corpos pegmatíticos.

Zircão extraído do tonalito foi analisado pelo método $\mathrm{U}-\mathrm{Pb}$, e os dados analíticos lançados em um diagrama concórdia, definiram uma discórdia, com intercepto superior e inferior de 2,16 $\pm 0,13 \mathrm{Ga}$ e $0,48 \pm 0,13 \mathrm{Ga}$, respectivamente, Figura 5.1a e Tabela 5.1, Anexo 4. A primeira idade foi interpretada como sendo de cristalização dos granitóides, enquanto que a segunda não tem significação geológica devido a intensa perda de $\mathrm{Pb}$ pelos processos contínuos de difusão. 


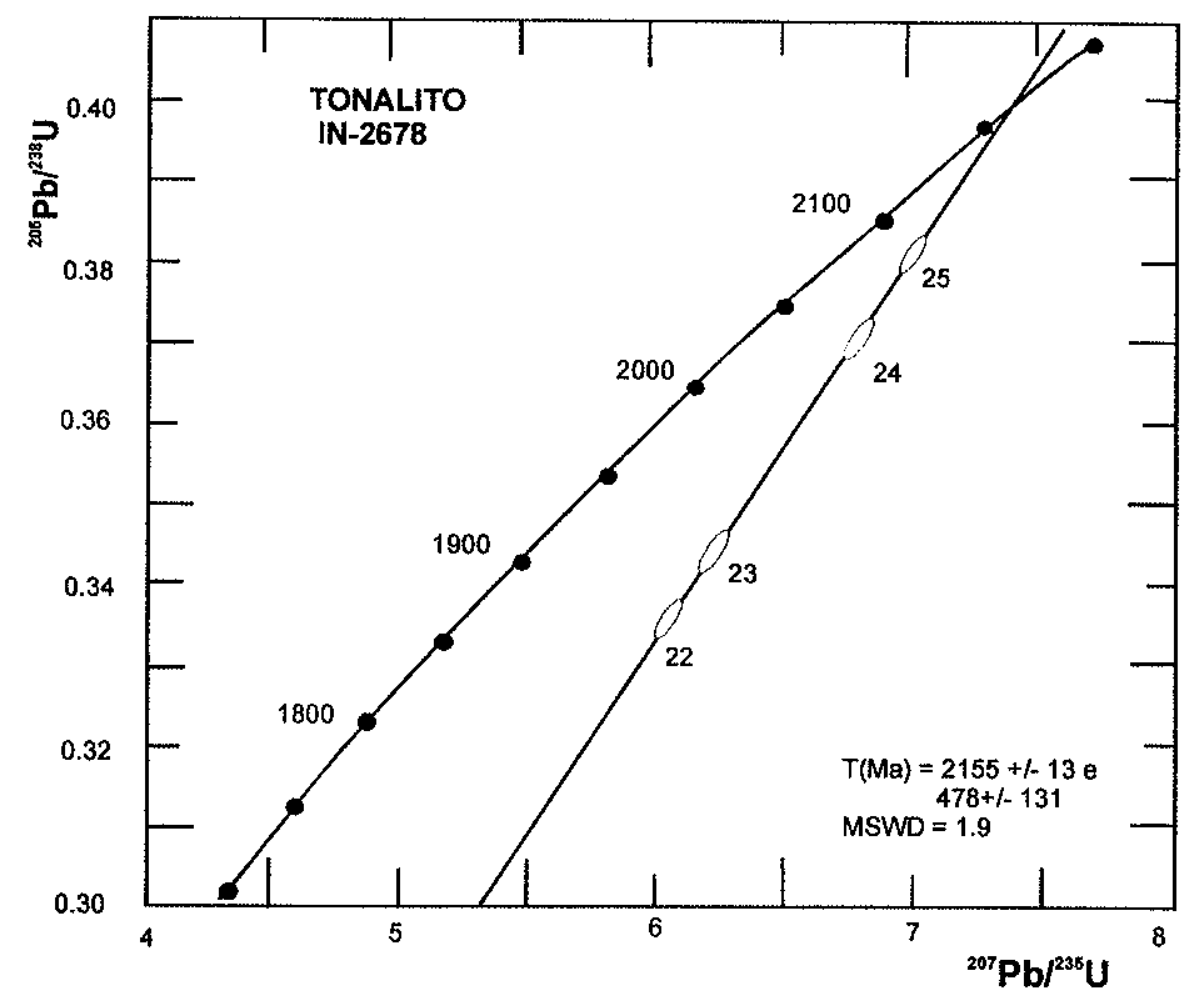

Figura 5.1 - Diagrama isocrônico U/Pb para frações de zircão do tonalito.

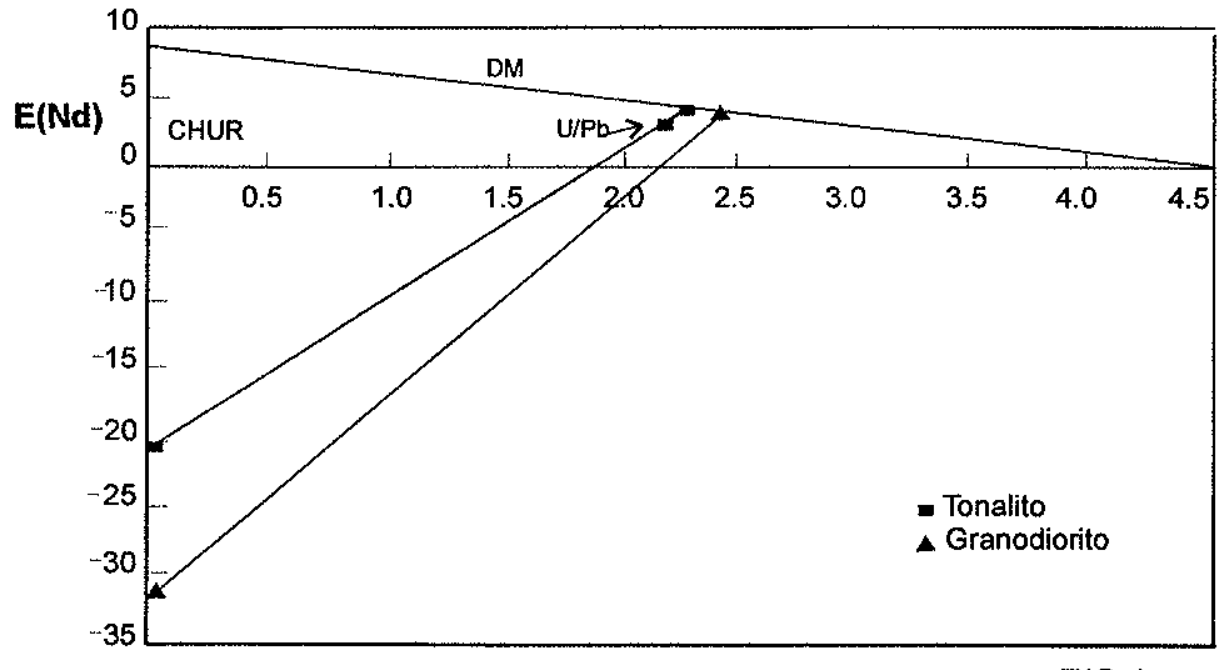

$\mathrm{T}(\mathrm{Ga})$

Figura 5.2 - Diagrama de evolução isotópica (Nd) vs. tempo geológico $\mathrm{T}(\mathrm{Ga})$, mostrando os intervalos de tempo de diferenciação manto-crosta dos protolitos crustais dos granitóides do Morro de Salamangone 
Idades modelos $\left(\mathrm{T}_{\mathrm{DM}}\right) \mathrm{Sm}-\mathrm{Nd}$, calculadas em tonalito e granodiorito forneceram idades de 2,24 e 2,34 Ga, respectivamente, Figura 5.2, Tabela 5.2, anexo 4. Os valores $\varepsilon N d$, calculados para $2.1 \mathrm{Ga}$, variaram de $+2,88$ a $+3,02$, indicando que o episódio de diferenciação manto-crosta, com a extração de magma juvenil, ocorreu a cêrca de 100 a $200 \mathrm{Ma}$, antes do evento de cristalização das rochas granitóides. Também pode ser sugerido que a região de Lourenço representa um grande área de crosta continental juvenil, com pouca ou nenhuma contaminação de crosta Arqueana. Deste modo, os dados isotópicos reforçam a interpretação já existente, que considera a região do Distrito de Lourenço como parte da Província Geocronológica Maroni-Itacaíunas, cuja evolução crustal relaciona-se com o maior evento de acresção do Paleoproterozóico, entre 2.25 e 1.95 Ga.

Os estudos de U-Pb foram complementados com análises $\mathrm{Rb}-\mathrm{Sr}$, Tabela 5.3, Anexo 4. Seis amostras de rocha total de granodiorito forneceram uma idade isocrônica $\mathrm{Rb}-\mathrm{Sr}$ de 2169 $\pm 89 \mathrm{Ma}$, com uma razão inicial $\mathrm{Sr}^{87} / \mathrm{Sr}^{86}$ de $0,7023 \pm 0,0004$ e um valor de $\mathrm{MSWD}=1.3$, Figura 5.3a, enquanto que quatro amostras de rocha total de tonalito, conduziram à idade isocrônica $\mathrm{Rb}-\mathrm{Sr}$ de $2278 \pm 240 \mathrm{Ma}$, com ri $=\mathrm{r}^{87} / \mathrm{Sr}^{86}$ de $0,7019 \pm 0,0012$ e um valor de $\mathrm{MSWD}=0,58$, Figura 5.3b. Os baixos valores da razão inicial $\mathrm{Sr}^{87} / \mathrm{Sr}^{86}$ obtidos para o tonalito e granodiorito, mostram concordância com os dados isotópicos de $\mathrm{Sm}-\mathrm{Nd}$, sugerindo que os magmas parentais possam ter derivados de fontes similares.

Atividades magmáticas mais jovens estão representadas, na região de Lourenço, por pegmatitos- aplitos, que cortam os granitóides de 2,1Ga. Amostras de rocha total de aplito, forneceram uma idade isocrônica $\mathrm{Rb}-\mathrm{Sr}$ de $1976 \pm 200 \mathrm{Ma}$, com uma razão inicial $\mathrm{Sr}^{87} / \mathrm{Sr}^{86}$ de $0,708 \pm 0.021$ e um valor de $\mathrm{MSWD}=0,13$, Figura 5.3c. $\mathrm{O}$ erro elevado para a razão inicial, deve-se à falta de pontos analíticos próximos da origem, responsáveis por uma incerteza alta da idade.

De maneira a auxiliar no estabelecimento de limites para a mineralização aurífera, foram analisadas amostras de rocha total $\left({ }^{87} \mathrm{Sr} /{ }^{86} \mathrm{Sr}\right)$ e de cristais de biotita (K-Ar), do tonalito, com evidências de alteração hidrotermal, Tabela 5.3, anexo 4. Os pontos analíticos, definiram uma idade isocrônica $\mathrm{Rb}-\mathrm{Sr}$ de $1830 \pm 270 \mathrm{Ma}$, com uma razão inicial $\mathrm{Sr}^{87} / \mathrm{Sr}^{86}$ de $0,7045 \pm$ 0,0029 e um valor de $M S W D=5.4$, Figura 5.3d. A dispersão de alguns pontos na isócrona pode ter sido originada pela homogeneização isotópica incompleta do $\mathrm{Sr}$, durante o evento mineralizante, ou pela conseqüente abertura do sistema isotópico, associada com os episódios de cisalhamento e de eventos superpostos de mineralizações. $O$ tonalito alterado exibe uma 
razão inicial mais alta que o tonalito primário, fato este relacionado aos efeitos da interação rocha/fluido e dos processos de fracionamento do $\mathrm{Sr}$.

Determinações de idade K-Ar em cristais de biotita, no tonalito alterado, forneceram valores variando entre 1794 e $1758 \mathrm{Ma}$, Tabela 5.4. É mais provável que essas idades expressem idades de resfriamento regionais, ou idades aparentes que refletem perturbações isotópicas posteriores, durante atividades tectono-metamórficas (remobilizações dentro da zona mineralizada), relacionadas com os corpos ácidos e alcalinos, de 1,76Ga, das suites Falsino e Mapuera (Tassinari et al. 1984), que ocorrem em regiões vizinhas ao Distrito de Lourenço.

\subsection{ANÁLISE COMPARATIVA COM OUTRAS ÁREAS DA PROVÍNCIA MARONI- ITACAÍUNAS}

O conjunto de dados radiométricos obtidos, até o momento, para as rochas granitóides do Morro de Salamangone, no Distrito Aurífero de Lourenço no Amapá, revela que foram formadas durante o Ciclo Orogênico Transamazônico, no Paleoproterozóico (2,3 - 1,9Ga).

Essa região insere-se na Província geocronológica Maroni-Itacaíunas (2,2 - 1,95Ga), definida originalmente em Cordani et al. (1979), a qual se estende pela Guiana Francesa, Suriname e parte da República da Guiana e da Venezuela, Figura 3.1. De modo geral, vem registrando resultados radiométricos semelhantes para rochas granitóides de mesma natureza tonalítica-trondjhemítica.

A Guiana Francesa, que faz limite com o Estado do Amapá, apresenta o maior número de estudos, enfocando, principalmente, a geocronologia e a evolução crustal. Teixeira et al. (1984 e 1985) e Gruau et al. (1985) estudaram o conjunto radiométrico de rochas da associação granito-greenstone, constituído por mais de uma centena de dados obtidos por intermédio de várias metodologias ( $\mathrm{Sm}-\mathrm{Nd}, \mathrm{Pb}-\mathrm{Pb}, \mathrm{Rb}-\mathrm{Sr}$ e $\mathrm{K}-\mathrm{Ar}$ ), disponíveis à época, observando uma sistemática obtenção de idades do Paleoproterozóico, com valores isotópicos iniciais de $\mathrm{Sr}, \mathrm{Pb}$ e $\mathrm{Nd}$ compatíveis com uma derivação mantélica e seguindo um padrão de idades homogêneo e coerente com uma evolução crustal temporalmente ligada ao Ciclo Tansamazônico. 


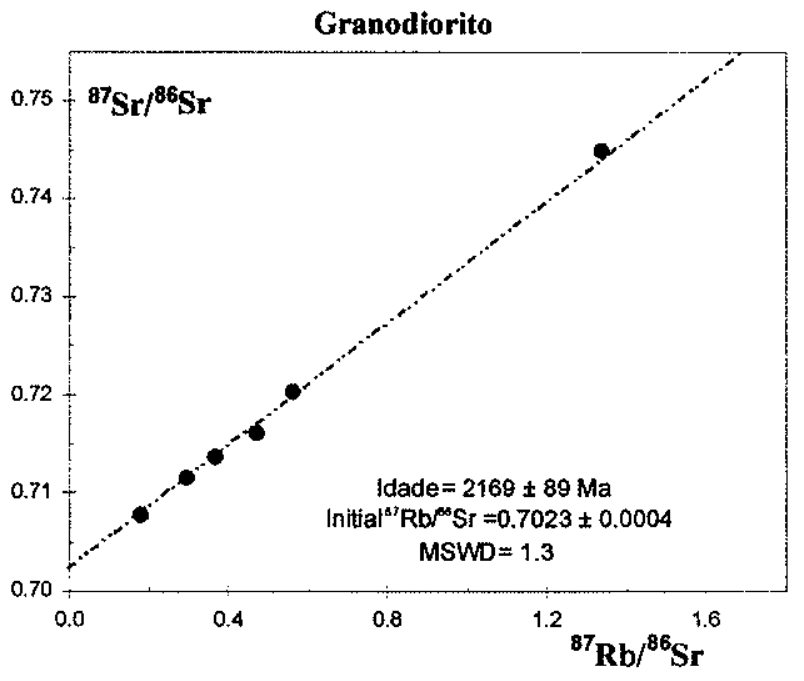

a)

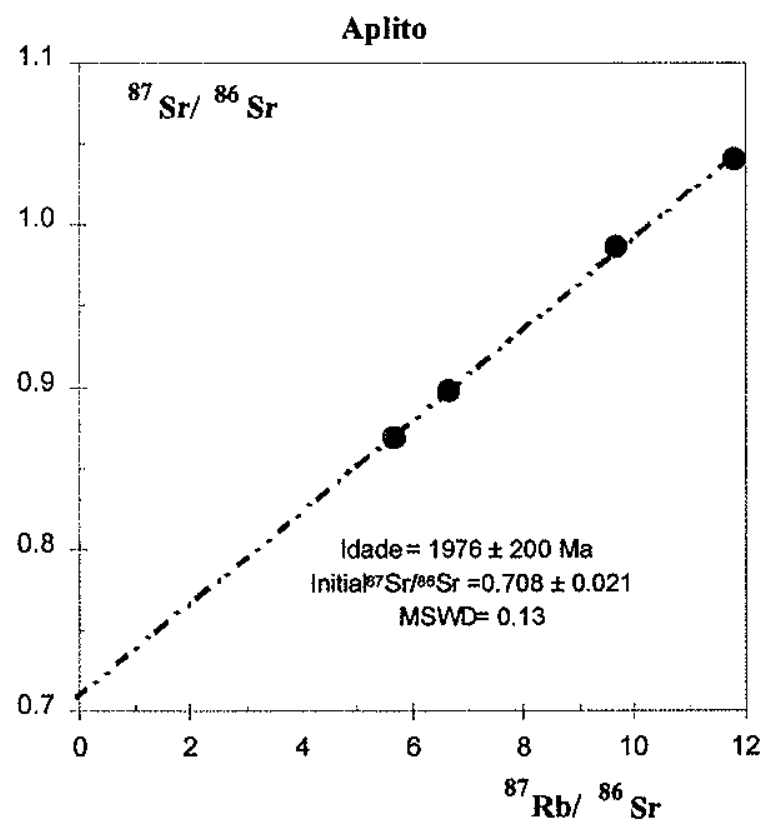

c)

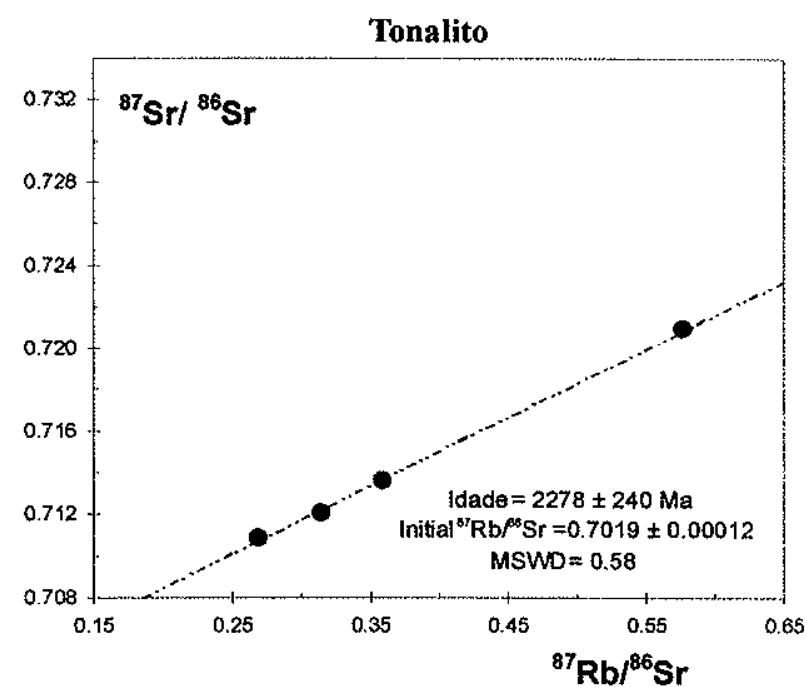

b)

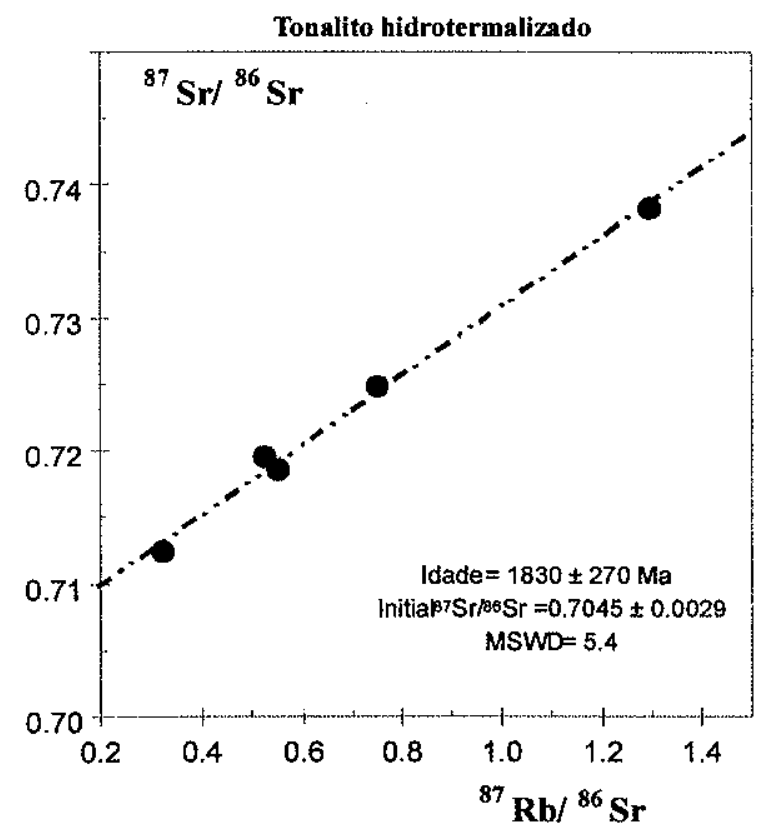

d)

Figura 5.3 - Diagramas isocrônicos $\mathrm{Rb} / \mathrm{Sr}$ para: a) granodiorito; b) tonalito; c) aplito e d) tonalito hidrotermalizado, da Mina de Salamangone. 
Segundo os autores acima citados, os complexos granitóides de composição diorítica, tonalítica e granodiorítica (rochas graníticas do tipo "Guyanais" de Choubert 1974), da região de Cayenne e da fronteira ocidental próximo ao rio Lawa, apresentaram isócronas de referência, $\mathrm{Rb}-\mathrm{Sr}$ com idade de $2030 \pm 65 \mathrm{Ma}$ e razão inicial de 0,7036 e $\mathrm{Pb}-\mathrm{Pb}$ com idade de $2083 \pm 39 \mathrm{Ma}$ e $\mu_{1}=8,095$, além de idade K-Ar em biotita de $2000 \pm 80 \mathrm{Ma}$. A colocação de corpos pegmatíticos, aparentemente acompanha o processo de formação dessas rochas granitóides, mostrando idade isocrônica $\mathrm{Rb}-\mathrm{Sr}$ de 1,96Ma, com razão inicial de 0,7028.

Mais recentemente, Milési et al. (1995), Ledru et al. (1997) e Vanderhaeghe et al. (1998) apresentaram novos dados geocronológicos, estruturais, metamórficos e geoquímicos da Guiana Francesa. As rochas plutônicas cálcio-alcalinas da região de Cayenne - Reginá foram datadas pela técnica de evaporação de $\mathrm{Pb}-\mathrm{Pb}$ em zircão, obtendo-se para um tonalito a idade de cristalização de $2144 \pm 6$ Ma e para um batólito tonalítico-diorítico a idade de $2129 \pm$ 6Ma. Segundo os autores citados, a composição química dessas rochas as situam num campo comparável àquele das atuais zonas de subducção e, os valores positivos de $\varepsilon \mathrm{Nd}$, indicam derivação mantélica, excluindo contaminação crustal significante.

Na região nordeste do Suriname, De Vletter \& Kroonenberg (1987) e De Vletter et al. (1998) estudaram tonalitos e rochas associadas, de filiação cálcio-alcalina, que fazem parte do complexo vulcânico granitóide estabelecido por Bosma et al. (1983) e, que ocorrem intrusivas em rochas metavulcano-sedimentares, da Formação Paramaca de Choubert (1974). Considerando seus dados geoquímicos, verificaram que incidem no campo dos granitos de arco vulcânico (VAG), definido por Pearce et al. (1984).

Priem (1998) reapresenta os dados produzidos anteriormente em Priem et al. (1971), para as rochas dessa região do Suriname, traduzidos numa isócrona $\mathrm{Rb}-\mathrm{Sr}$ de $1874 \pm 40 \mathrm{Ma}$, que reúne dados combinados de diversos tipos de granitóides e, que devem ser considerados como um "reconhecimento geocronológico", indicando apenas uma ordem de grandeza de idade. Afirma, contudo, que todas as rochas investigadas teriam se originado durante o Ciclo Transamazônico e que, sem dúvida, pertenceriam a suítes de diferentes idades. Ressalta a escassez de dados disponíveis e aponta a necessidade de novas datações utilizando-se de outras metodologias

De modo geral, os autores acima citados discutem que os tonalitos e rochas associadas da região nordeste do Suriname seriam mais velhos que $2000 \mathrm{Ma}$, quando teriam sofrido o mesmo tipo de metamorfismo que os cinturões do tipo greenstone, onde são intrusivos. Datações $\mathrm{K} / \mathrm{Ar}$ e $\mathrm{Rb} / \mathrm{Sr}$ indicam uma idade em torno de 2000Ma para o metamorfimo das 
rochas desses cinturões. Acreditam os autores, que os tonalitos seriam corpos intrusivos associados a arcos vulcânicos, desenvolvidos contemporaneamente com o vulcanismo e com a deformação dos cinturões tipo greenstone.

\subsection{DISCUSSÃO}

Os dados obtidos nos granitóides da região de Lourenço são muito semelhantes àqueles já conhecidos em rochas similares de outras áreas da Província Maroni-Itacaiúnas. Na Guiana Francesa, granitóides sintectônicos e terrenos gnaissico-migmatíticos da "Série Ille de Cayenne", apresentam idades de $2,1-1,95 \mathrm{Ga}$, com uma razão inicial $\mathrm{Sr}^{87} / \mathrm{Sr}^{86} \mathrm{em}$ torno de 0,7018-0,7024, valor de $\mu_{1}$ de 8,2 e valores positivos para $\varepsilon_{\mathrm{Nd}}$ (Teixeira et al. 1985 , Milési et al. 1995). O vulcanismo do Grupo Vila Nova no nordeste do Pará e do Grupo Paramaca na Guiana Francesa, ambos relacionados com seqüências de cinturões do tipo greenstone, apresentam idades isocrônica Sm-Nd de 2,26 e 2,1Ga, respectivamente (McReath \& Faraco 1997, Gruau et al. 1985). Da mesma forma, Vanderhaeghe et al. 1998, definiram um episódio de magmatismo trondjhemítico em $2,17 \mathrm{Ga}$, seguido da colocação de intrusões cálcio-alcalinas em 2,14-2,11Ga e de magmatismo potássico tardio, em 2,09-2,08Ga.

Os dados isotópicos do Distrito Aurífero de Lourenço e regiōes vizinhas, no Amapá e Guiana Francesa, sugerem, de forma acentuada, um modelo geodinâmico de evolução crustal, baseado no desenvolvimento de arco magmático cálcio-alcalino, no intervalo de tempo 2,252,0Ga. Tal fato pode ser explicado pela subducção da crosta oceânica, no início da colisão entre massas continentais, constituídas, na época, pelo Bloco Carajás-Iricoumé da Província da Amazônia Central (Tassinari 1996) e o craton do oeste africano (Tassinari \& Macambira 1999). 


\section{capituruor}

\section{O Sistema Filoneano do Depósito de Salamangone}

\subsection{ANÁLISE ESTRUTURAL}

Depósitos filonares auríferos hospedados em rochas granitóides caracterizam-se por uma variedade de estilos estruturais, de tipos granitóides encaixantes e de controles estruturais regionais e locais. De acordo com Cassidy et al. (1998) esses depósitos, tipicamente, constituem corpos tabulares alinhados subparalelamente à direção de falhamentos e/ou zonas de cisalhamentos hospedeiras, podendo ser dominados por um ou vários estilos de mineralização, dependendo do controle estrutural e da progressão temporal do evento mineralizante. A maioria desses depósitos apresenta feições estruturais características de um regime de transição dúctil-rúptil, embora em alguns casos possam predominar estruturas dominantemente dúcteis ou rúpteis.

\subsubsection{Considerações gerais}

Na Mina de Salamangone, as zonas de cisalhamento representam as estruturas de maior importância à mineralização aurífera, com destaque às zonas de cisalhamento dúctil-rúptil que constituem as hospedeiras, por excelência, dos filões auríferos que por sua vez são recortados por falhas e fraturas de natureza rúptil.

Trabalhos de mapeamento geológico-estrutural foram executados, sempre, pela equipe da CMA, em todos os níveis da mina, para subsidiar a lavra dos corpos de minério, embora pouca atenção tenha sido dispensada à hierarquização das zonas de cisalhamento, e à natureza dos regimes de esforços atuantes no Distrito como um todo. Ressalva-se, contudo, que levantamentos sistemáticos, dirigidos ao melhor entendimento da geologia, definição espacial dos corpos de minério, e caracterização geomecânica do maciço com vistas ao dimensionamento de aberturas e estabilidade de realces, foram efetuados por Costa (1991) e Geodinâmica (1991, 1992). Os dados geológicos de superfície e subsuperfície gerados por esses autores foram compilados no presente trabalho e, adicionalmente, complementados com dados de levantamentos por nós executados nos níveis 54, 229, 264, 274 e 290m da mina. 
Inventariou-se cerca de 613 medidas estruturais efetuadas na mina, que foram submetidas a tratamento estatístico, de modo a permitir a análise dinâmica $\mathrm{e}$ caracterização possível das tensões residuais no maciço, bem como os possíveis controles dos corpos de minério.

A compilação e tratamento dos dados foram feitos, individualmente, para as medidas de parâmetros estruturais obtidos à superficie (cava a céu aberto) e nos níveis $262,274,278$ e 290 metros. Todos os valores estruturais disponíveis foram agrupados segundo as categorias seguintes:

a) - Planos de foliação milonítica (X)

b) - Planos de cisalhamento rúptil ou dúctil-rúptil $(\mathrm{Cz})$

c) - Juntas (J)

Os pólos dos elementos planares foram lançados em diagramas de projeção de igual área (Diagrama de Lambert - Rede Schmidt). A avaliação estatística dos dados foi feita pelo programa Stereo (Rockware Scientific Software) e os diagramas de contorno, no hemisfério inferior.

A análise estatística foi elaborada, individualmente, não só para os diferentes tipos de rocha, tonalito, granodiorito e pegmatito, como também para os níveis assinalados. Adicionalmente, procedeu-se à análise global das estruturas em pauta, bem como para os diferentes corpos de minério (Capa, Lapa e Principal).

\subsubsection{Foliação milonítica $(X)$ e cisalhamento dúctil-rúptil ou rúptil $(\mathrm{Cz})$}

As zonas de cisalhamento dúctil caracterizam-se pela forte orientação mineral, possuem grande persistência lateral (centenas de metros) e não representam uma descontinuidade geomecânica. $\mathrm{O}$ cisalhamento dúctil é responsável pela foliação milonítica observada no tonalito, granodiorito e anfibolito e expressa-se segundo faixas miloníticas de até 10 metros de espessura que abrigam, também, os corpos de minério. A foliação é sub-vertical e contem uma lineação expressiva representada por estrias e lineação mineral, Figuras 6.1a, 6.1b e 6.1c.

A foliação milonítica é notória, configurando faixas anastomosadas, bem como lentes e boudins menos deformados, e não pode ser referida como sendo a feição mais antiga, já que as possíveis deformações dúcteis regionais, que afetaram anteriormente as rochas encaixantes da mineralização, não foram estudadas e fogem ao escopo desta tese. 
Os planos de cisalhamento dúctil-rúptil e rúptil dispõem-se segundo padrão anastomosado, sendo sub-paralelas aos planos de foliação milonítica e cortam todas as rochas anteriores, inclusive a própria foliação milonítica. São sub-paralelos, guardando entre si uma relação angular da ordem de $15^{\circ}$.

Essas superficies ocorrem preferencialmente nos contatos dos filões com as rochas encaixantes. $O$ padrão anastomosado configura lentes sigmóides bordejadas por superfícies rúpteis, Figuras $6.2 \mathrm{a}$ e $6.2 \mathrm{~b}$.

Foram elaborados diagramas de contorno da foliação e planos de cisalhamento rúptil a partir de medidas efetuadas em tonalito e granodiorito, relativos aos diferentes níveis, mas em vista da similaridade de padrões obtidos construiu-se, também, um diagrama integrado. Os diagramas obtidos para a cava e diferentes níveis delinearam os conjuntos tanto da foliação quanto do cisalhamento, mais importantes, apresentados na Tabela 6.1, abaixo.

\begin{tabular}{c|c|c} 
Nivel & Foliação $(\mathbf{X})$ & Cisalhamento (Cz) \\
\hline Cava a céu aberto & - & N52W/53NE; N52W/58NE \\
$284 / 290$ & N52W/57NE & N52W/64NE \\
274 & N52W/58NE & N54W/61NE; N45W/65NE \\
264 & N52W/58NE & N52W/59NE; N52W/67NE
\end{tabular}

Tabela 6.1. Resumo das atitudes médias das famílias de descontinuidades das zonas de cisalhamento na cava a céu aberto e níveis inferiores de lavra subterrânea da mina (Fonte: Geodinâmica 1992).

\subsubsection{Juntas e falhas pós intrusão de pegmatitos}

Várias famílias de juntas foram identificadas na mina e correspondem a episódios de deformação rúptil, ainda não datados. Pelo menos $50 \%$ das juntas com mergulhos entre 80 e 86 graus possuem persistência média entre 1 e 3 metros e as restantes têm persistência variável até 10 metros, não havendo juntas maiores do que 10 metros. As juntas sub-horizontais têm comprimentos variáveis, entre 3 e 10 metros. As superfícies são onduladas-rugosas, sem preenchimento e secas. 

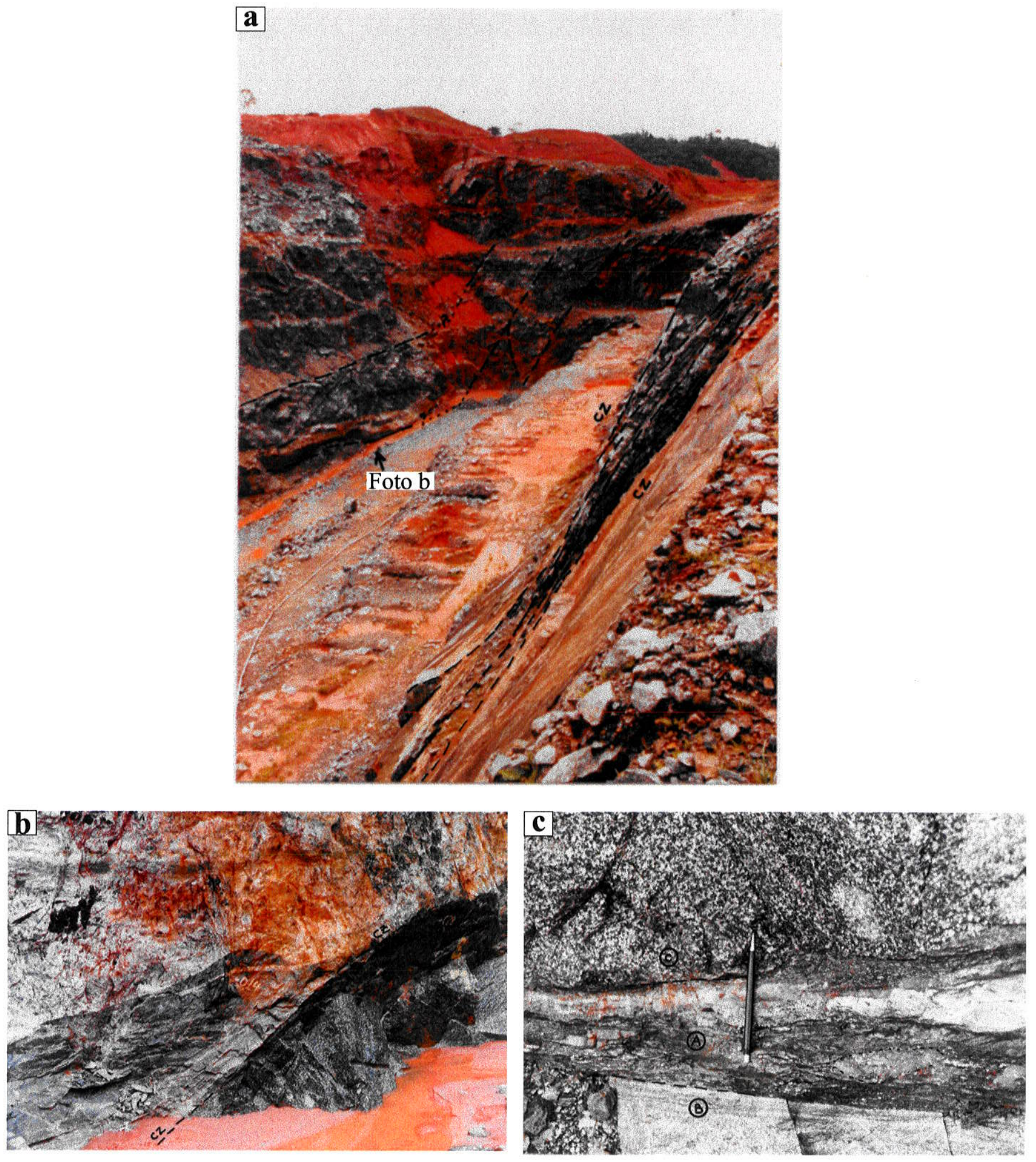

Figura 6.1 - a) Superfícies de cisalhamento rúptil $(\mathrm{Cz})$ indicadas à esquerda e ao centro, na cava a céu aberto. Vista a partir do talude de lapa, b) Destaque da superfície de cisalhamento $(\mathrm{Cz})$, no talude de capa, indicada na fotografia anterior, c) Detalhe da zona de cisalhamento: $\mathrm{A}=$ estiramento mineral, boudin de quartzo e faixas de material milonitizado, $\mathrm{B}=$ desenvolvimento de orientação mineral no tonalito, $\mathrm{C}$ = tonalito maciço, sem deformação vísível. (Fonte das fotografias: Geodinâmica, 1992). 

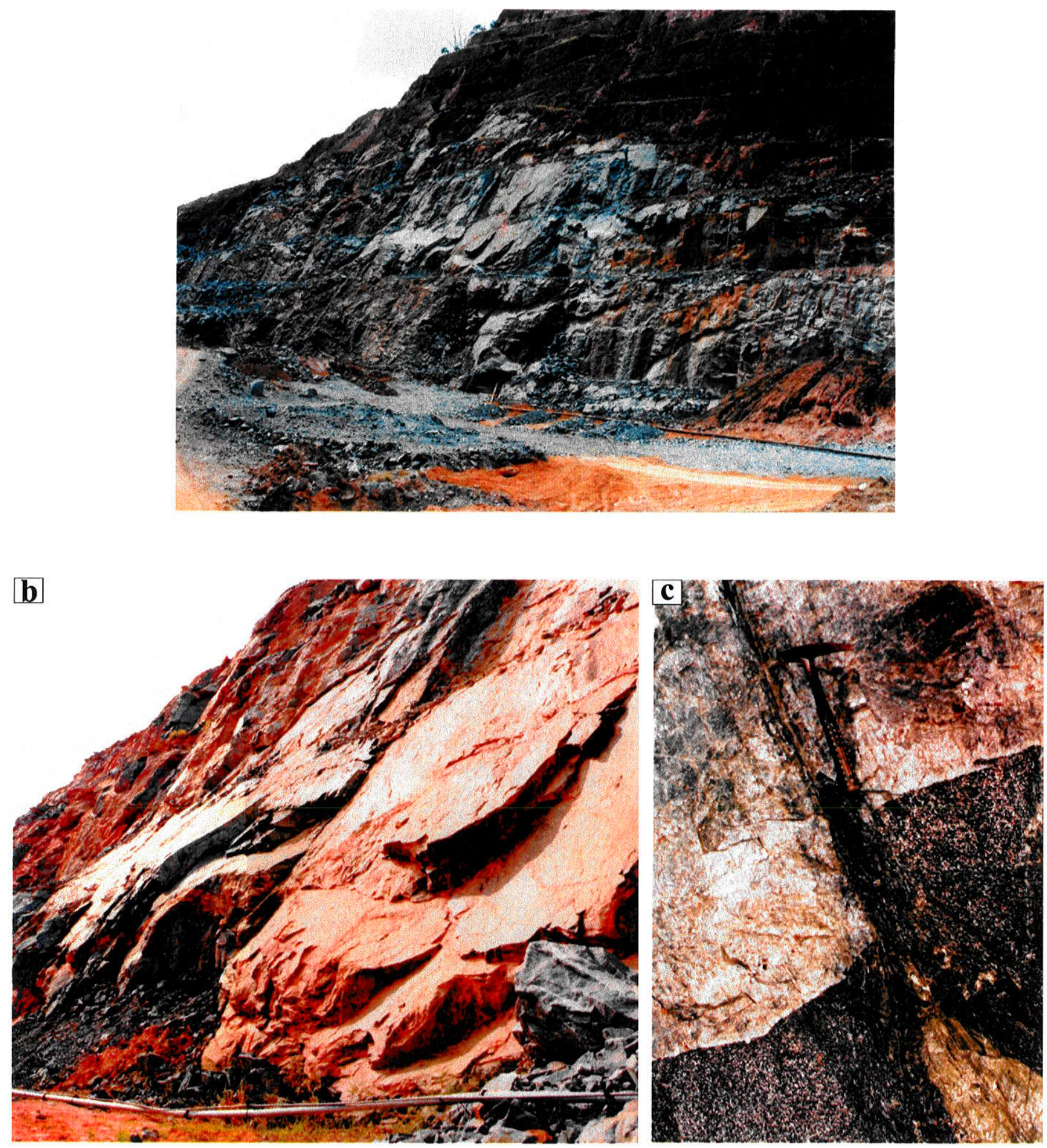

Figura 6.2 - a) Vista do talude da Lapa, entre as seções 220 e 300S (Figura 6.4). Observar a grande ocorrência de superfícies de cisalhamento, b) Detalhe da fotografia anterior, notando-se o padrão anastomosado da zona de cisalhamento, formando estruturas amendoadas, c) Travessa de acesso ao nível $274 \mathrm{~m}$ da mina, aspecto do fraturamento que desloca e fragmenta o pegmatito e o tonalito. (Fonte das fotografias: Geodinâmica, 1991). 
Os estereogramas representativos das famílias de juntas foram elaborados individualmente, para tonalito e pegmatito, Figura 6.3, com o objetivo de esclarecer as relações de idade e regimes de deformação pré e pós-formação dos veios mineralizados.

As famílias de descontinuidades referíveis aos pegmatitos constituem seis conjuntos, a saber: $\mathrm{N} 2^{\circ} \mathrm{E} / 83^{\circ} \mathrm{SE}$ e $\mathrm{N} 14^{\circ} \mathrm{W} / 82^{\circ} \mathrm{NE}$ ocorrem em maior freqüência, seguidas pelo conjunto subhorizontal, $\mathrm{N} 14^{\circ} \mathrm{E} / 4^{\circ} \mathrm{SE}$. As famílias $\mathrm{N} 2^{\circ} \mathrm{E} / 83^{\circ} \mathrm{SE}$ e $\mathrm{N} 79^{\circ} \mathrm{E} / 80^{\circ} \mathrm{SE}$ correspondem, respectivamente, aos lineamentos regionais ocupados por diques de diabásio Permo-Triássicos e aos lineamentos cerrados, E-W, que cortam todas as rochas e estruturas mais antigas da área.

Exceção feita às juntas sub-horizontais que constituem fraturas que podem ser referidas ao resfriamento do stock plutônico tonalítico, ou a componente de cisalhamento oblíqua regional, todas as outras fraturas são pós-intrusão dos pegmatitos sub-horizontais e afetaram, igualmente, as rochas mais antigas, Figura 6.2c. Os sistemas de fraturamentos que cortam os tonalitos, são os mesmos e os comentários são extensivos a eles.

Constata-se, também, a existência de três grupos de falhas que, igualmente, seccionam todas as rochas pegmatíticas, além do tonalito e granodiorito. Trata-se de falhas de alto ângulo com componentes oblíquas, porquanto a sua classificação não tenha sido possível, devido à dificuldade de identificação dos indicadores cinemáticos em paredes das galerias da mina, durante os levantamentos geológicos. $O$ estereograma dos parâmetros estruturais obtidos no Nível 345 metros da mina, Figura 6.3, indica a

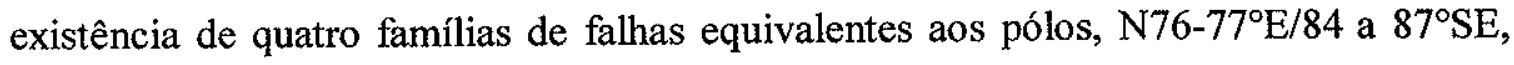
$\mathrm{N} 5^{\circ} \mathrm{W} / 85^{\circ} \mathrm{NE}$ e $\mathrm{N} 17^{\circ} \mathrm{W} / 84^{\circ} \mathrm{NE}$. Isto indica que a maior parte das juntas observadas é paralela às falhas e que porcentagem subsidiária constitue juntas penadas, relativas aos planos principais das falhas.

As direções e atitudes das falhas não coincidem com as direções dos planos de cisalhamento dúctil-rúptil e rúptil $\mathrm{N} 43^{\circ} \mathrm{W} / 60^{\circ} \mathrm{NE}$ e $\mathrm{N} 54^{\circ} \mathrm{W} / 60^{\circ} \mathrm{NE}$ observados e associados à foliação miloníticaN $55^{\circ} \mathrm{W} / 70^{\circ} \mathrm{NE}$. Este fato vem a comprovar a gênese das descontinuidades estruturais relacionada a diferentes regimes de deformação, em tempos também distintos, ressalvando-se, contudo que a mineralização aurífera principal associa-se à deformaçõos pré-intrusão da fase pegmatítica principal. 


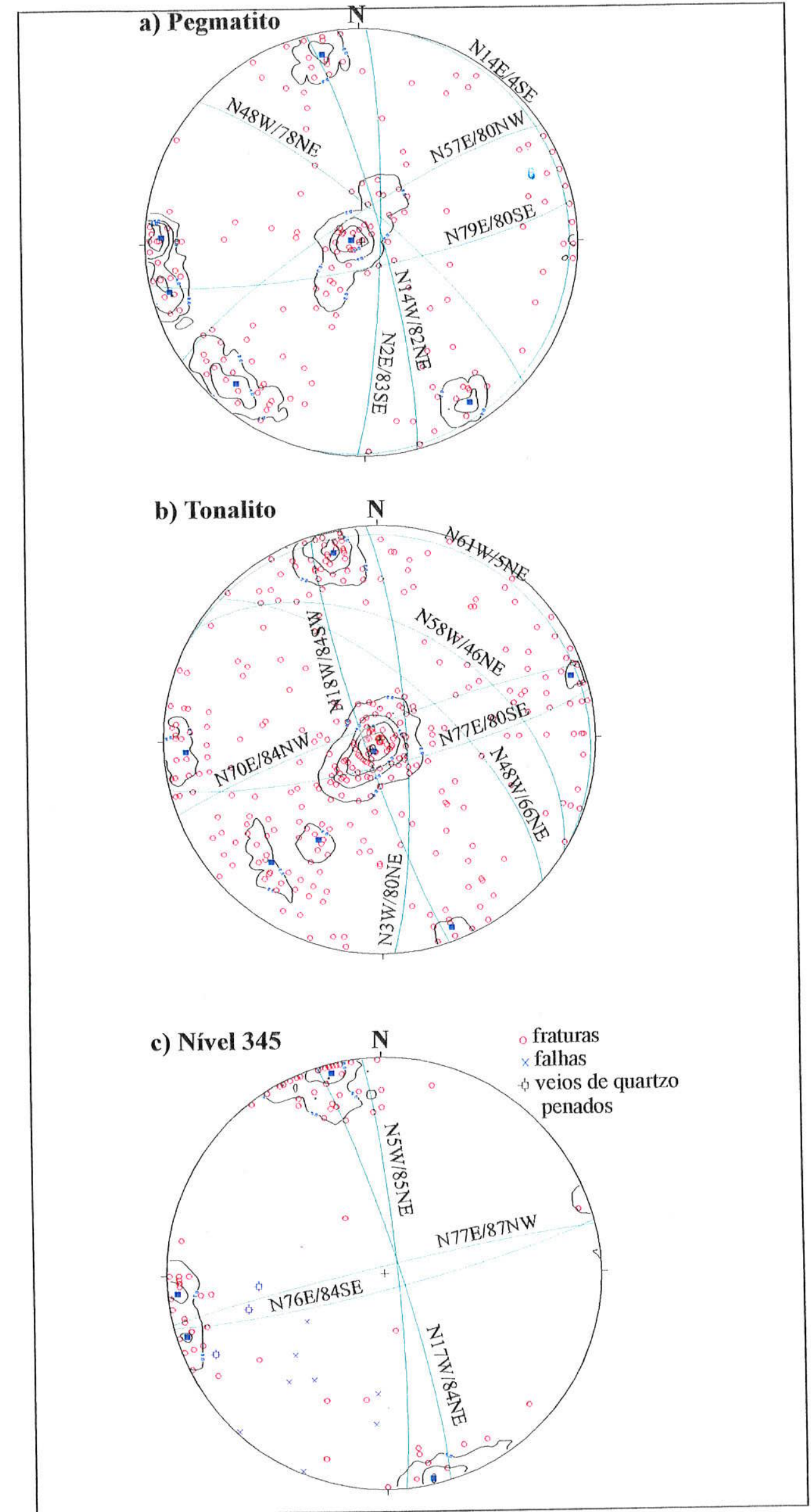

Figura 6.3 - Estereogramas de contornos de polos das normais (obtidas na rede Schmidt-Lambert, hemisfério inferior) a juntas mapeadas: a e b) na rocha pegmatítica e tonalítica, respectivamente, nos níveis 264, 274, 284 e 290m, c) em todas as litologias (tonalito, granodiorito e pegmatito), do nível $345 \mathrm{~m}$, da mina de Salamangone. 


\subsubsection{Indicadores cinemáticos : estrias e lineação mineral}

Trabalhos sistemáticos relativos ao inventário de indicadores cinemáticos em planos, tanto de foliação milonítica quanto de falhas não foram efetuados durante os levantamentos geológico-estruturais. Contudo, Costa (1991) indica que a atitude média de estrias de atrito medidas em planos de foliação milonítica e em planos de cisalhamento de alto ângulo, pré-intrusão dos corpos pegmatíticos que seccionam veios de quartzo, situa-se em $\mathrm{N} 30-40^{\circ} \mathrm{W} / 30^{\circ}$. Infere-se que a movimentação operou-se segundo um binário atuando em plano oblíquo de baixo ângulo, compatível com regime transcorrente. Os elementos estruturais identificados, por nós e por Costa (1991) e equipe de geólogos da mina, sugerem uma componente de cisalhamento direcional destrógira, com esforço principal, aproximadamente N-S, registrando-se, localmente, uma pequena relação angular entre os planos de cisalhamento dúctil e rúptil ou dúctilrúptil, menor do que $15^{\circ}$, Figura 6.4 .

\subsection{FEIÇÕES GEOMÉTRICAS E ESTRUTURAIS DO SISTEMA FILONIANO}

Os sistemas filonianos quartzo-auríferos associados a plutons granitóides tonalíticos a monzoníticos têm sido documentados em terrenos arqueanos do Canadá (Burrows \& Spooner 1989, Callan \& Spooner, 1989 e 1998), no Zimbabwe (Mann 1984) e na Austrália (Cassidy et al. 1998, Cassidy \& Bennett 1993, Wang et al. 1993), assim como em terrenos do Paleoproterozóico da Guiana Francesa (Milési et al. 1995), sudeste da Finlândia (Kontoniemi \& Nurmi 1998) e do oeste africano (Milési et. al. 1992, Oberthür et al. 1998), entre outros. Os veios associam-se, na sua maioria, a sistemas de cisalhamento dúctil-rúptil ou rúptil, que atravessam corpos de natureza intrusiva. Várias tentativas têm sido realizadas para a classificação estrutural dos depósitos auríferos, citando-se como exemplos Hodgson 1989, Hronsky et al. 1990 e Witt and Vanderhor 1998, Sibson 1988 e 1990, que se basearam em propriedades geométricas dos corpos de minério e na importância relativa dos processos de deformação dúctil e rúptil em sua formação.

A zona mineralizada da Mina Salamangone é constituída por veios de quartzo auríferos hospedados em um stock intrusivo de composição predominantemente tonalítica, que pode conter megaxenólitos de seqüências do tipo greenstone belts (Suíte Metamórfica Vila Nova). O sistema filoniano compreende três corpos principais que 
foram designados de Filões Capa, Principal e Lapa, Figuras 6.4, 6.5 e 6.6, sendo considerados como veios de cisalhamento ou veios em falhas, conforme classificação discutida pelo autores acima citados.

A análise estatística global dos parâmetros estruturais inventariados na mina, mais especificamente, planos de foliação milonítica e de cisalhamento, resultantes de mapeamento geológico-estrutural sistemático, tanto na cava quanto nos níveis 290,284 , 274 e 264 metros, foram já objeto de discussão (Tabela 6.1). contudo uma análise estatística mais detalhada desses parâmetro estruturais referíveis aos corpos de minério Principal, Lapa e Capa, especificamente no nível $274 \mathrm{~m}$ permitiu obter os seguintes valores médios, apresentados na Tabela 6.2 e na Figura 6.7.

\begin{tabular}{l|c|c|c}
\multirow{2}{*}{ Nível } & Corpo & Foliação (X) & Cisalhamento (Cz) \\
\cline { 3 - 4 } 274 & Capa & N45W/57NE & N46W/59NE; \\
& Principal & N54W/58NE & N58W/59NE \\
& \multirow{3}{*}{ Lapa } & N54W/58NE & N52W/59NE; \\
& & & N44W/66NE \\
& & N552W/61NE; & N45W/65NE \\
& & (integração global) & (integração global)
\end{tabular}

Tabela 6.2. Resumo dos parâmetros estruturais das zonas de cisalhamento e dos corpos de minério, no nível 274m da Mina Salamangone (Fonte: Geodinâmica 1992).

Todos os elementos estruturais identificados demonstram que os corpos de minério estão contidos em duas zonas de cisalhamento dúctil com direções variáveis $\mathrm{N} 45^{\circ} \mathrm{W}$ e $\mathrm{N} 52^{\circ} \mathrm{W}$, e são controlados pelos planos de foliação milonítica, com as mesmas atitudes. Os planos de cisalhamento dúctil-rúptil (?) ou rúptil são quase paralelos à foliação milonítica ros Níveis 290, 284, 274 e 264m (Tabela 6.1), notandose que o mergulho dos planos de cisalhamento é mais acentuado em relação à foliação. No Corpo Capa, Figura 6.7c, as atitudes tanto da foliação quanto dos planos de cisalhamento são praticamente paralelas, porém, variações de mergulho dos respectivos planos ocorrem, atingindo valores entre $15^{\circ}$ e $20^{\circ}$. 


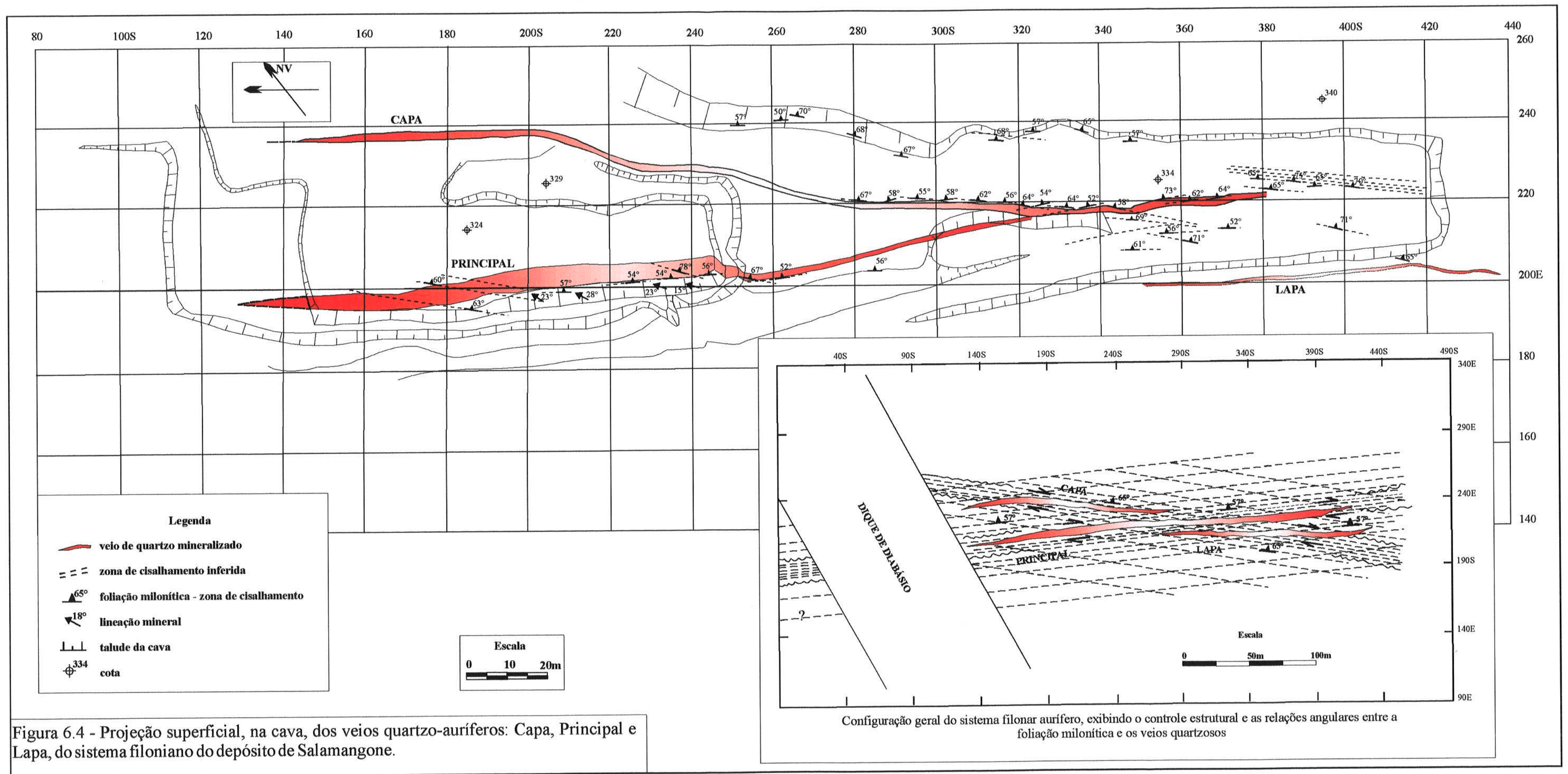




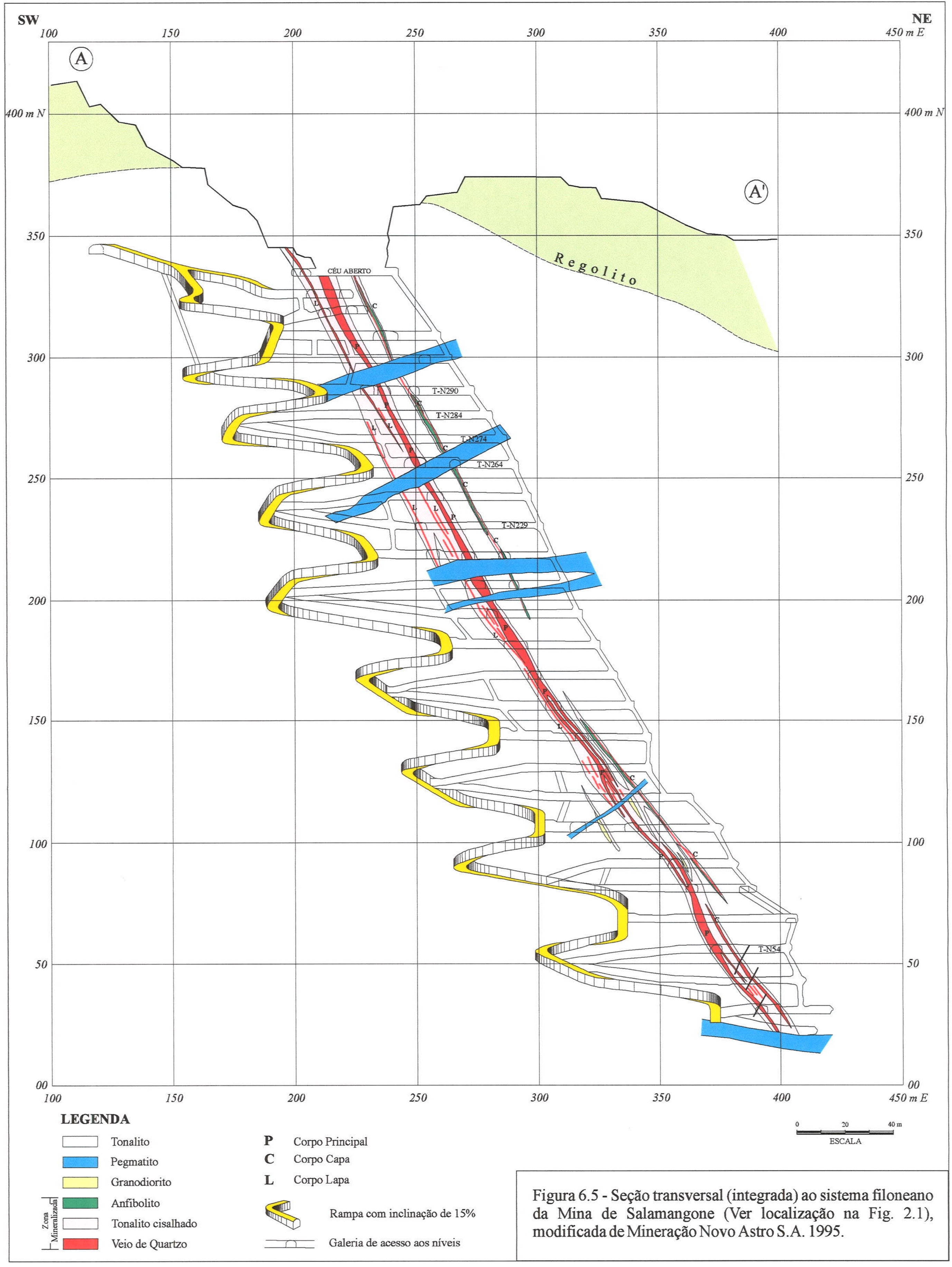




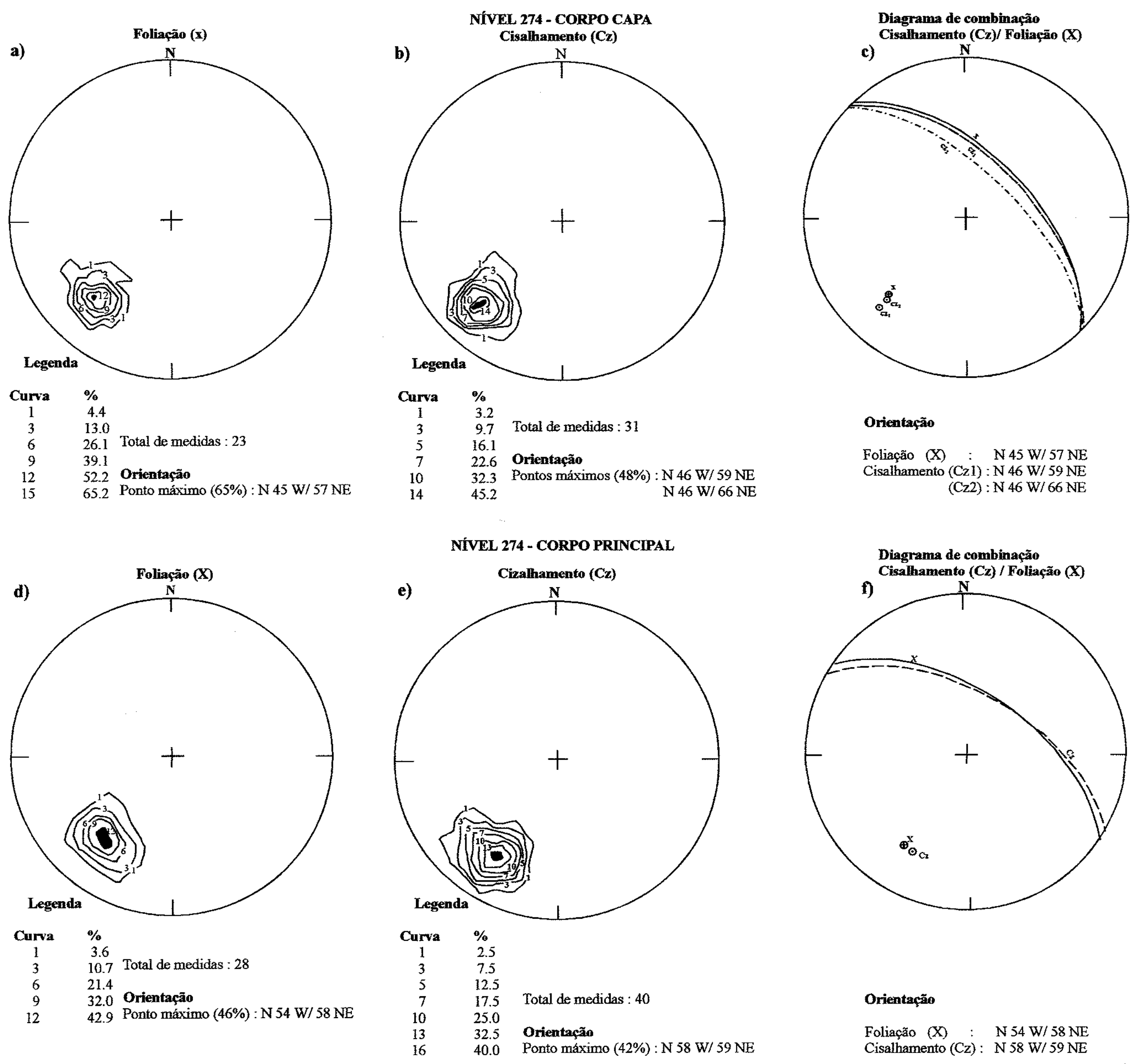

Orientação

Foliação $(\mathrm{X}): \mathrm{N} 45 \mathrm{~W} / 57 \mathrm{NE}$ Cisalhamento (Cz1) : N $46 \mathrm{~W} / 59 \mathrm{NE}$ $(\mathrm{Cz} 2): \mathrm{N} 46 \mathrm{~W} / 66 \mathrm{NE}$
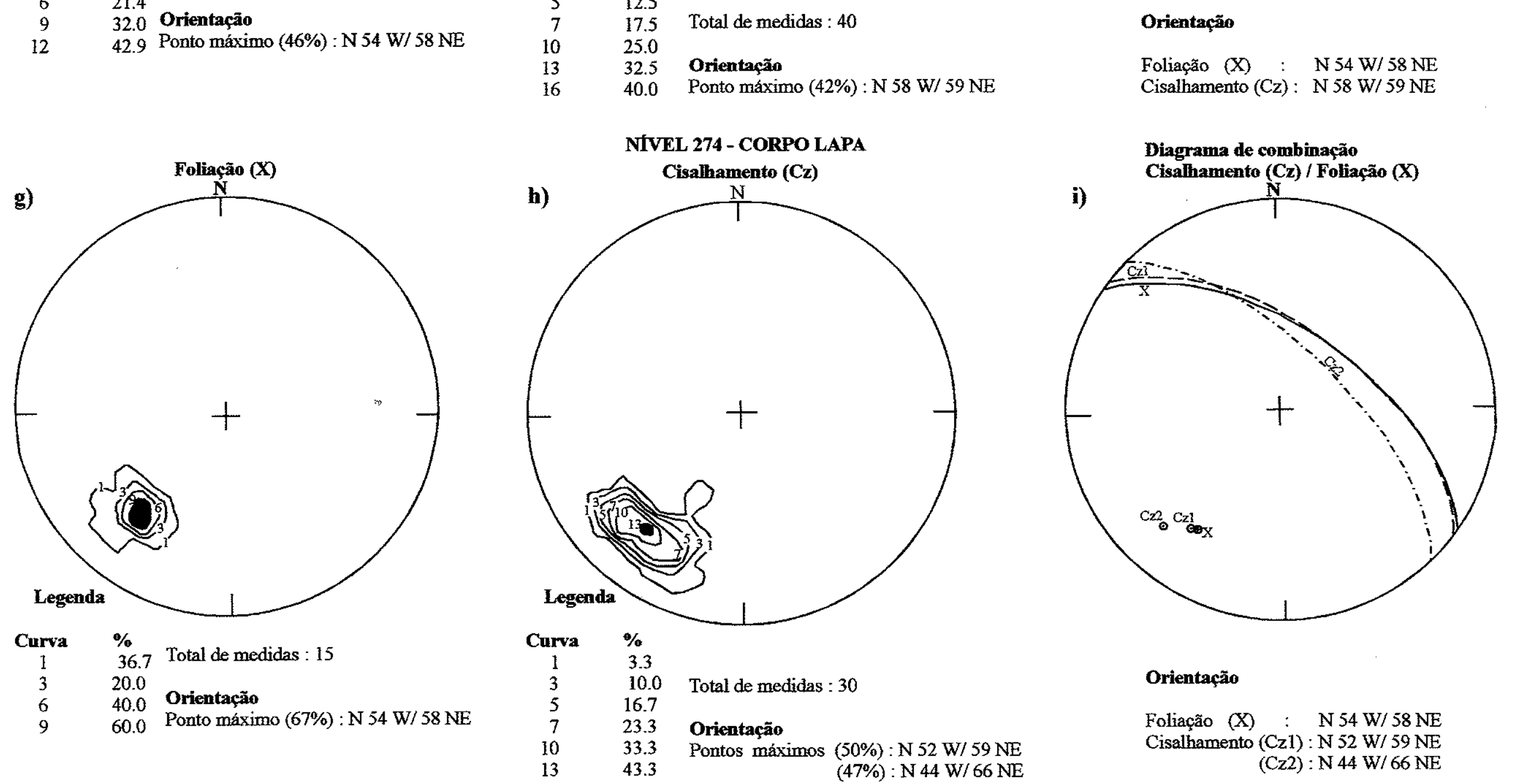

Figura 6.7 Domínios dos corpos de minério Capa, Principal e Lapa. Estereogramas $\mathbf{a}, \mathbf{b}, \mathbf{d}, \mathbf{e}, \mathbf{g}, \mathbf{h}$ : contomo de polos das normais e planos de foliação milonítica e planos de cisalhamento rúptil ou dúctil-rúptil. Estereogramas $\mathbf{c}, \mathbf{f}, \mathbf{i}$ : contorno de polos (valores médios) às normais aos planos médios de foliação e falhas. Os diagramas foram obtidos na rede Schmidt-Lambert, hemisfério inferior. 
Via de regra, os corpos de minério em pauta são acompanhados por veios de extensão oblíquos, controlados por fraturas penadas, em echelon, conjugadas e interligadas aos veios principais, (Figuras 4.2 e 6.6), por vezes exibindo persistência lateral.

Dentro de uma progressão temporal, a fase inicial de cisalhamento dúctil seria responsável pelo desenvolvimento de faixas miloníticas no tonalito encaixante, que serviram de controle à colocação dos veios quartzo-auríferos, estes alinhados subparalelamente à direção dos planos de cisalhamento. Esta fase seria sucedida por outra, de cisalhamento rúptil, caracterizada por superfícies anastomosadas sub-paralelas à direção dos planos de foliação resultantes de cisalhamento dúctil, que seccionam e deslocam as demais unidades litológicas.

A zona mineralizada é cortada por um dique de diabásio de idade PermoTriássica, de direção N-S, (Figura 6.4) e, durante toda a vida da mina, não se constatou a continuidade física da mineralização além deste dique, no sentido $\mathrm{SW}$.

Os veios ostentam dimensões variáveis, exemplificadas nas Figuras 4.2, 4.3, 6.5 e 6.6, e resumidas na Tabela 6.3, abaixo, sendo que a persistência desses corpos foi observada pelo menos até o nível $41 \mathrm{~m}$, Figura 6.5 , o que equivale a 400 metros de comprimento, para o sistema filoneano.

\begin{tabular}{c|c|c} 
Filão & $\begin{array}{c}\text { Comprimento } \\
(\mathbf{m})\end{array}$ & $\begin{array}{c}\text { Espessura } \\
(\mathbf{m})\end{array}$ \\
\hline Capa & \pm 180 & $0,2-1,5$ \\
Principal & \pm 250 & $0,5-6,5$ \\
Lapa & \pm 100 & $0,2-1,5$
\end{tabular}

Tabela 6.3. Dimensões dos corpos de minério Principal, Capa e Lapa, que constituem o sistema filoneano do depósito de Salamangone, a partir do nível $345 \mathrm{~m}$ da mina.

Os corpos de minério formam, via de regra, corpos lenticulares, geralmente paralelos ou sub-paralelos aos limites das zonas de cisalhamento. A aparência bandada dos veios de Salamangone caracteriza uma textura denominada "ribbon" por McKinstry \& Ohle (1949), Dowling \& Morrison (1989) e Vearnacombe (1993). Os veios são característicos e ostentam uma estrutura laminada ou estrutura interna em ribbon, Figuras $6.9,6.10$ e 6.11 , onde se observa a combinação de lentes ou faixas alongadas de quartzo intensamente deformado e recristalizado separadas por bandas milimétricas a 
centimétricas de tonalito milonitizado ou foliado e alterado, que foi incorporado ao veio devido ao crescimento incremental, ou por lâminas de material extremamente triturado ou minerais fibrosos de alteração. Segundo Dowling \& Morrison (1989), esse arranjo interno de veios em "ribbon", indica que os mesmos resultaram de um seqüência complexa de abertura por incrementos sucessivos, reabertura e amalgamação de filetes e vênulas isoladas, que culminam com a incorporação de fragmentos da rocha encaixante, segundo lentes regulares quartzosas.

A intensidade da deformação dentro das zonas de cisalhamento diminui à medida que se afasta do seu centro. A foliação varia desde faixas estreitas centimétricas a milimétricas na sua parte central, constituídas de tonalito alterado e intensamente milonitizado e quartzo deformado, até atingir uma orientação incipiente nos flancos desta zona, definida pelo alinhamento paralelo de biotita e hornblenda da rocha tonalítica pouco alterada (Figuras 6.8, 6.9 e 6.10 ).

De forma semelhante, o sistema de veios quartzo-auriferos hospedados em tonalito/trondhjemito de idade arqueana, em Renabie, Ontário, Canadá, foi caracterizado por Callan \& Spooner (1998) como veios bandados com estrutura tipo ribbon. Os autores sugeriram que este tipo de estrutura seria indicativo de formação de veio por fraturamentos hidráulicos sucessivos, associados com fluidos hidrotermais sob alta pressão, dentro de zonas de cisalhamento dúctil-rúptil. Este processo corresponderia ao mecanismo de formação de veio tipo crack and seal, proposto por Ramsay (1980b).

\subsection{CONTROLES LOCAIS DOS CORPOS DE MINÉRIO}

Em relação aos aspectos práticos tanto à exploração mineral, quanto à lavra, o entendimento da distribuição tridimensional e relações angulares entre os corpos de minério, é de grande importância.

Isto pressupõe a determinação do plunge dos corpos de minério via intersecção das zonas de cisalhamento, conjugados à geometria dos corpos. As estrias e orientação mineral, observadas na mina, configuram uma lineação cuja atitude média é $\mathrm{N} 30^{\circ}$ $40^{\circ} \mathrm{W} / 30^{\circ} \mathrm{W}$ e não controlam a mineralização aurífera. $\mathrm{O}$ cruzamento dos planos das foliações nos Níveis 334 e 224 definem um plunge equivalente a $\mathrm{N} 18^{\circ} \mathrm{W} / 45^{\circ}$, contido no plano $\mathrm{N} 60^{\circ} \mathrm{W} / 57^{\circ} \mathrm{NE}$ correspondente ao corpo de minério Principal, Figura 6.12 , segundo Costa (1991). 
Veio de quartzo deformado, em contato com rocha tonalitica silicificada.

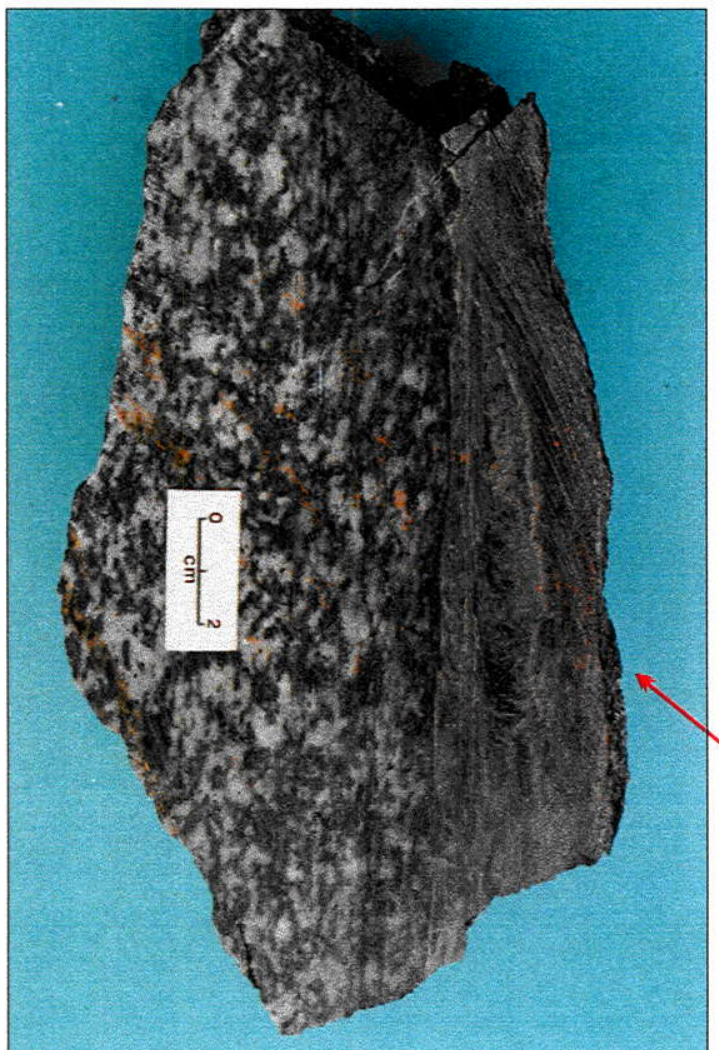

Tonalito da parede do veio, em contato com rocha tonalítica fortemente milonitizada.
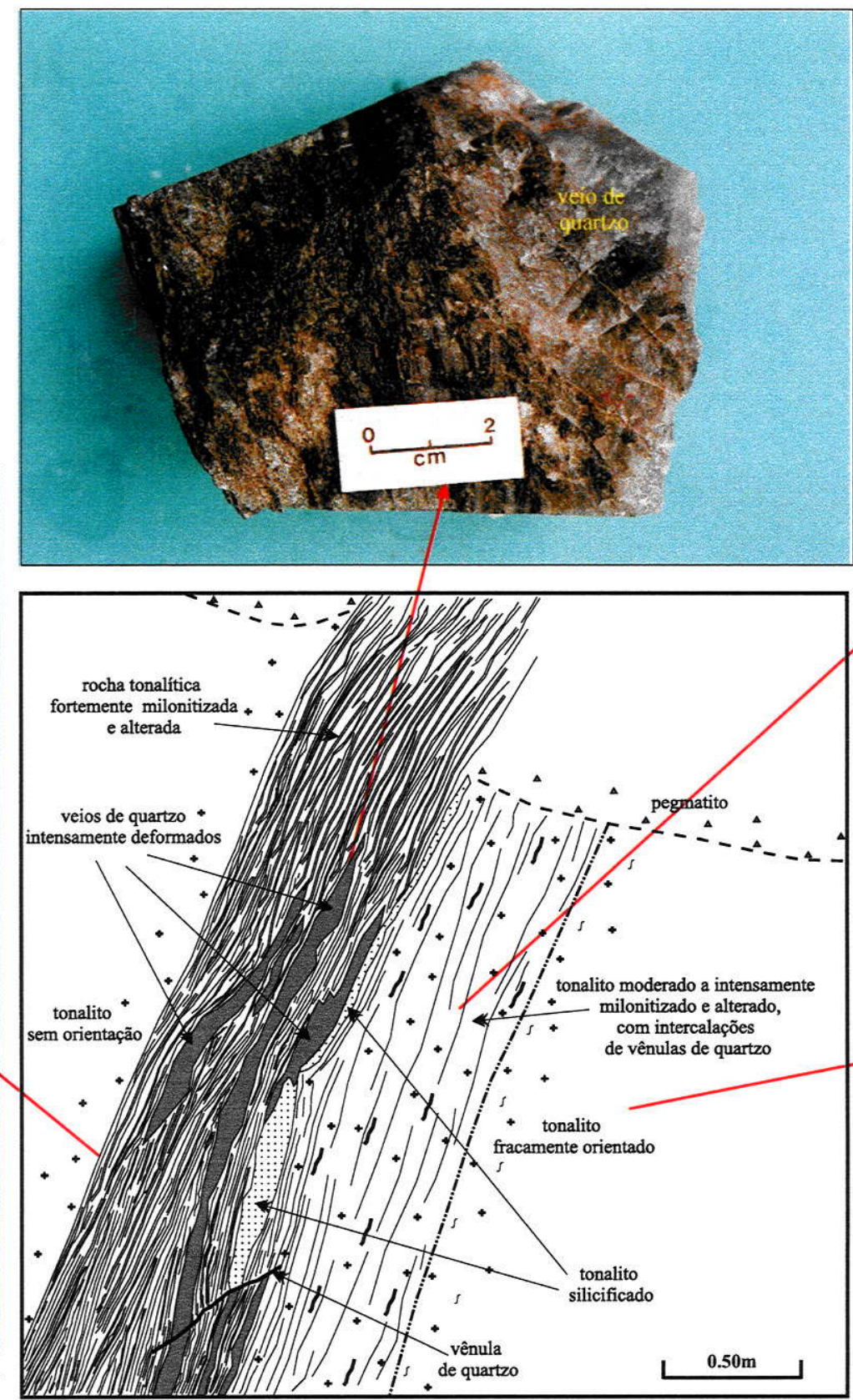

Tonalito milonitizado, com intercalações de vênulas de quartzo.

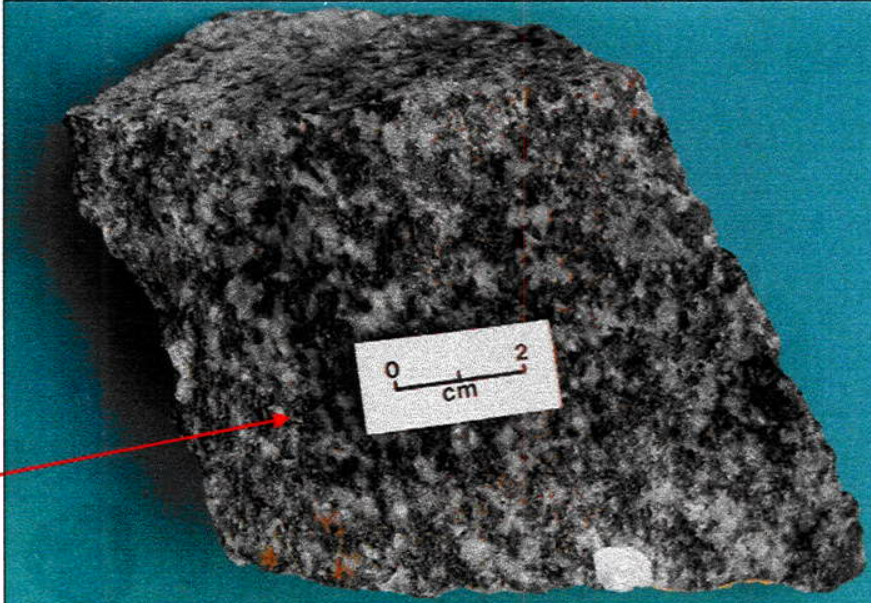

Tonalito encaixante, sem orientação, na parede da galeria.

Figura 6.8 - Desenho esquemático da frente de lavra do Filão Capa, no nível 264m, cabeceira sul, da Mina de Salamangone. 


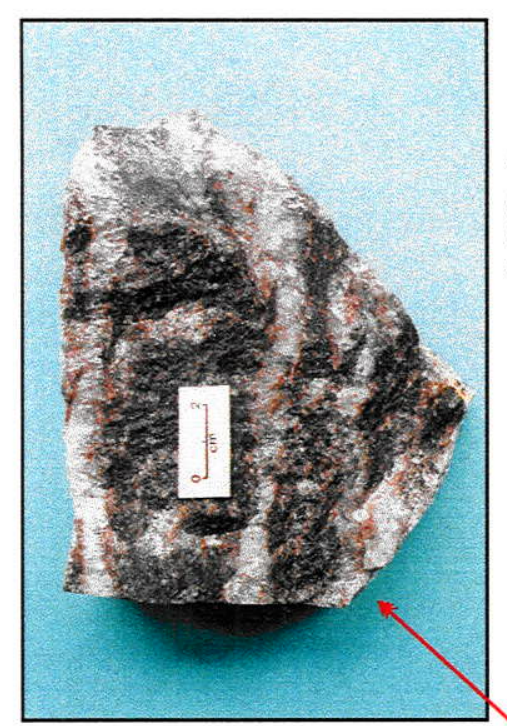

Faixa de rocha tonalítica intensamente milonitizada, com intercalações de vênulas de quartzo.

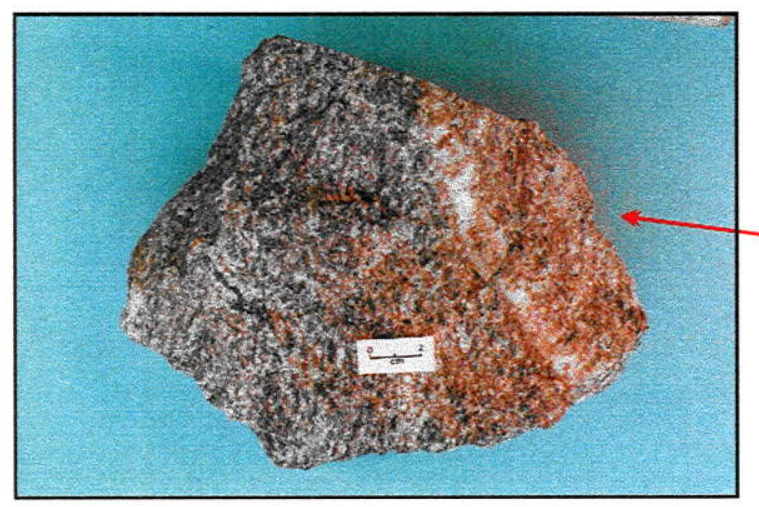

Tonalito encaixante, moderadamente foliado, com intercalações de vênulas de quartzo.

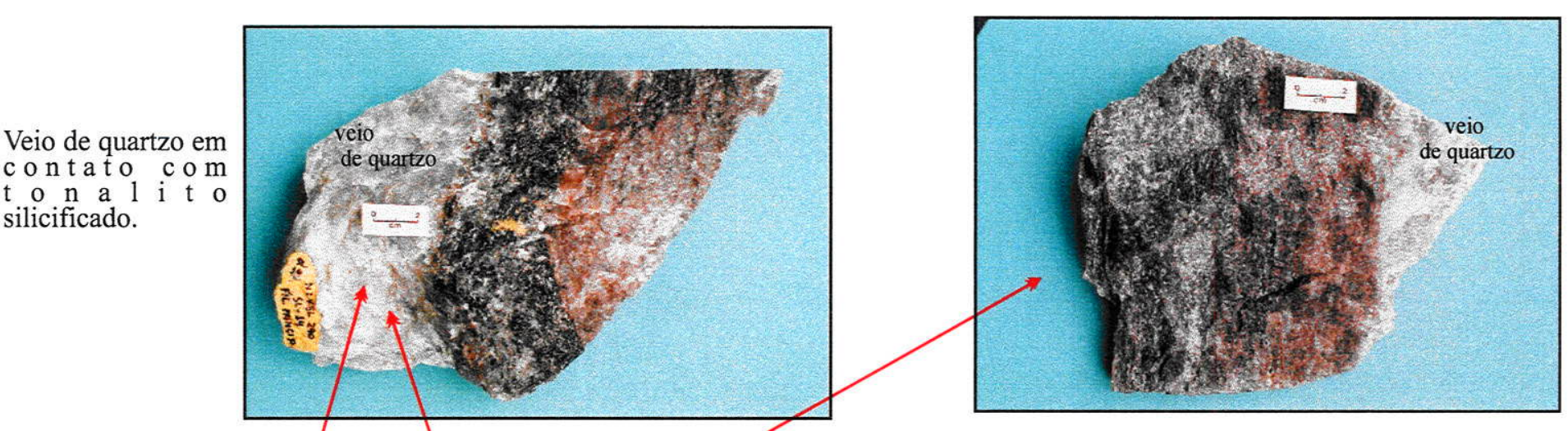

Faixa de rocha tonalítica intensamente milonitizada, passando lateralmente para o veio de quartzo.

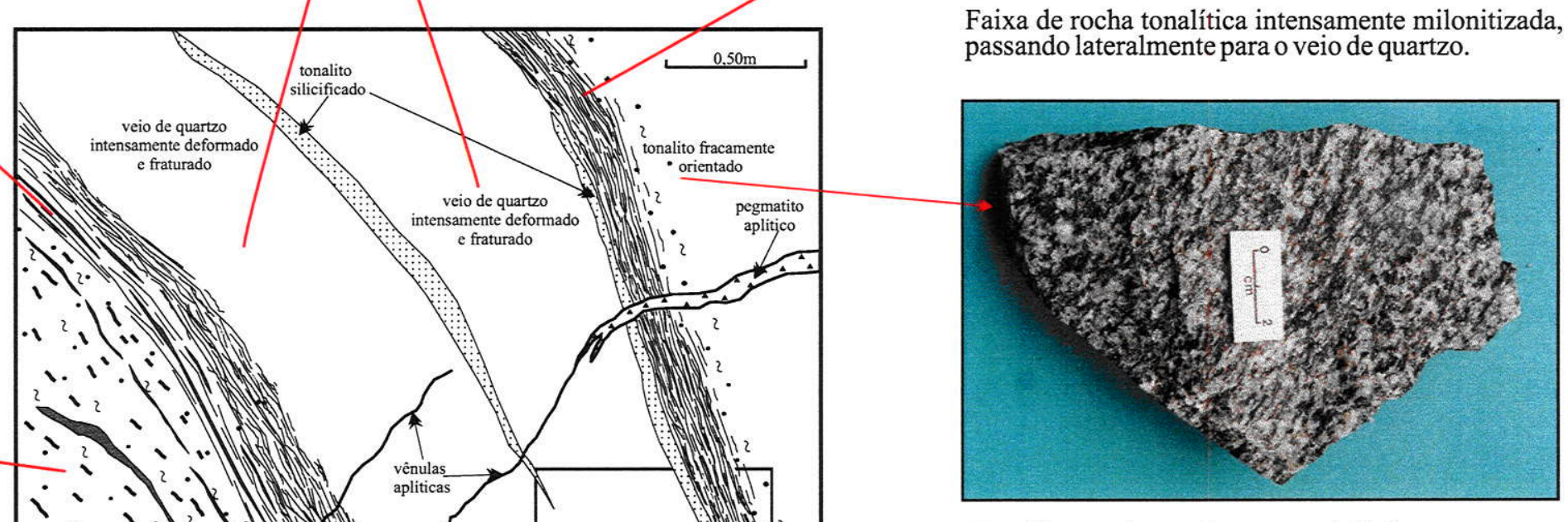

Tonalito encaixante, levemente foliado.

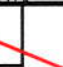

Estrutura do tipo laminada (ribbon), com alternância de bandas de quartzo deformado e alterada.

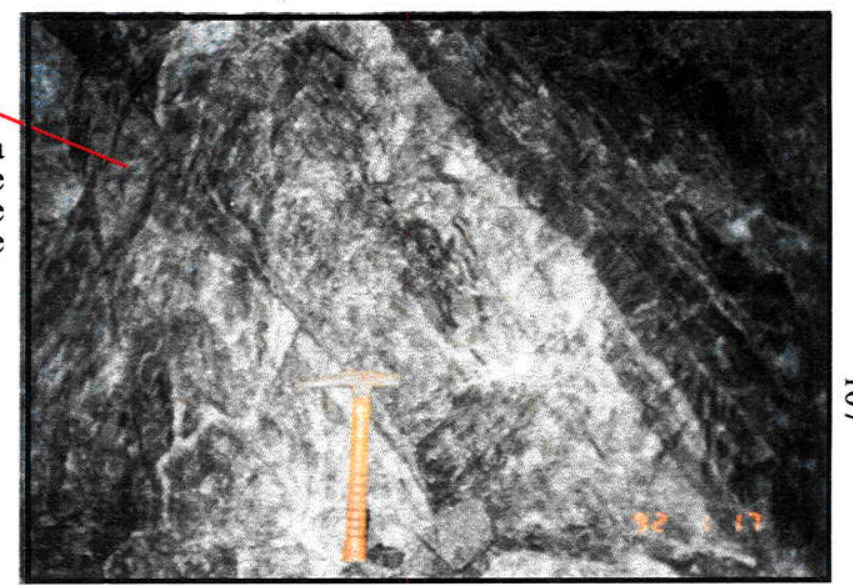




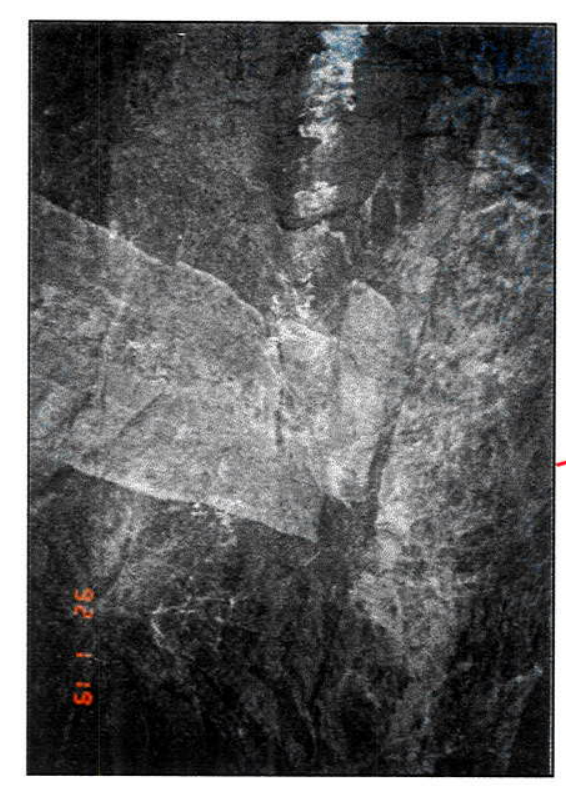

Dique pegmatítico que secciona o sistema filoniano, deslocado por falhamento.

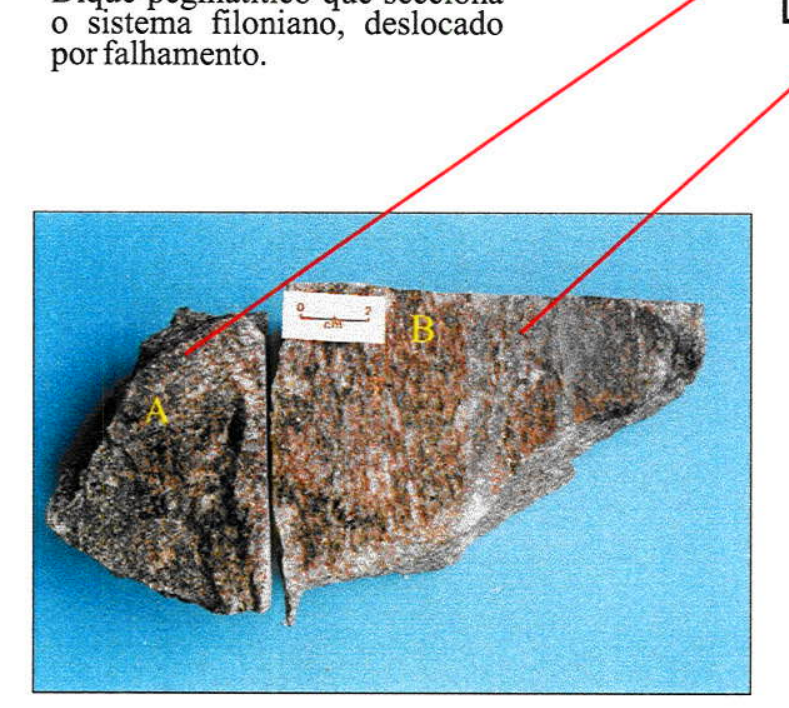

A) Tonalito encaixante, alterado e com pouca orientação, B) Faixa de rocha tonalítica intensamente foliada, com segregaç̃es de quartzo e sulfetos associados aos minerais ferromagnesianos.

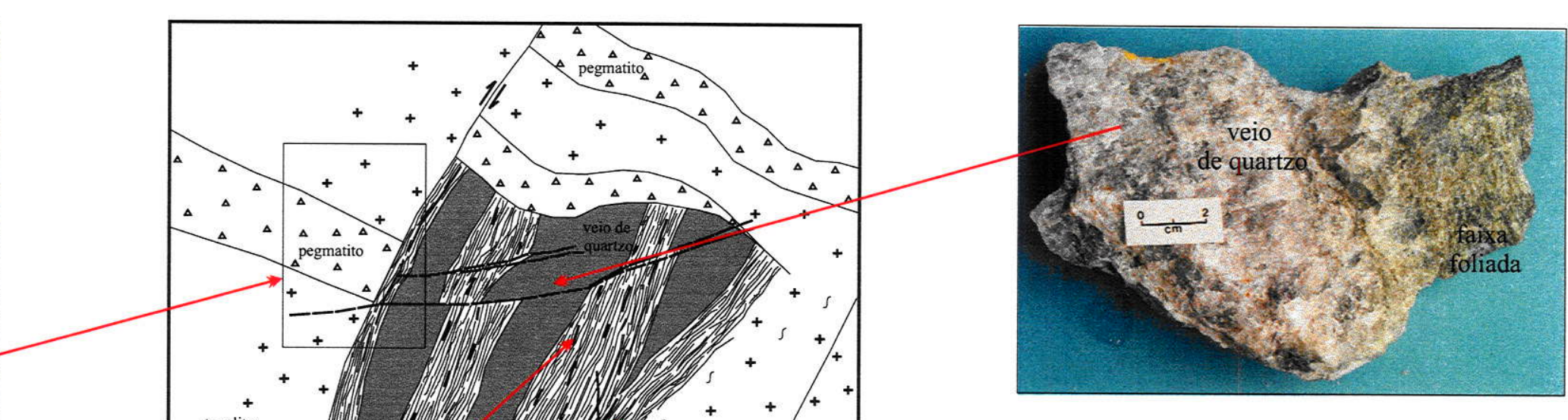

Veio de quartzo deformado, em contato com faixa de tonalito intensamente foliado.

A) Tonalito encaixante, quase sem orientação, B) Rocha tonalítica fortemente milonitizada, em contato com veio de quartzo.

Figura 6.10 - Desenho esquemático da frente de lavra do Filão Lapa, no nível 264, cabeceira sul, da Mina de Salamangone. 

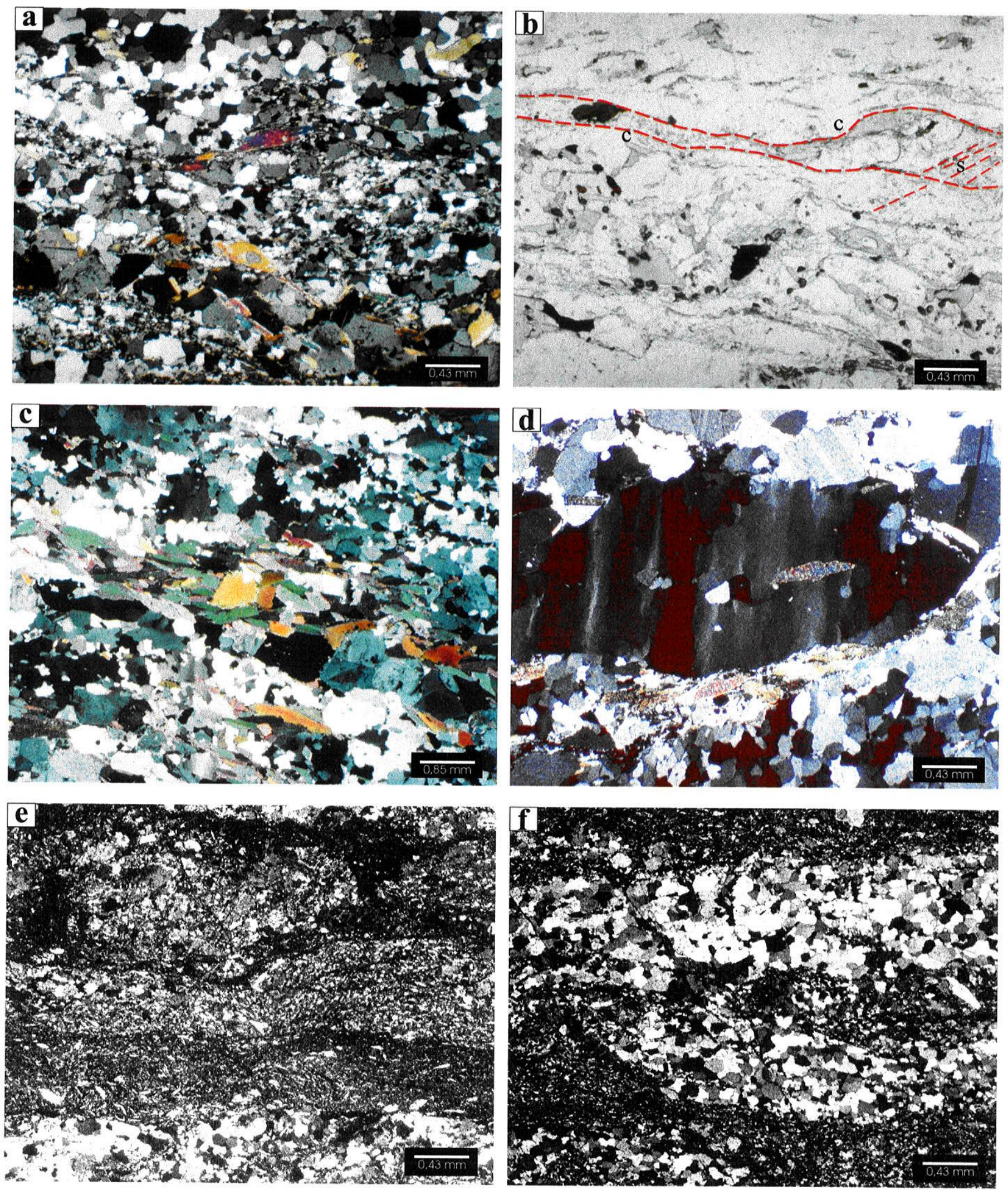

Figura 6.11 - Feições de deformação nos veios de quartzo de Salamangone: a e b) Estrutura S-C em domínio de quartzo recristalizado. Amostra orientada do corpo Principal, nível 54m da mina (Nx e N//), c) Minerais ferro-magnesianos (hornblenda e biotita) incorporados ao domínio de quartzo recristalizado e orientados segundo a direção do cisalhamento (Nx), d) Grão de quartzo deformado e elongado segundo direção de cisalhamento, envolvido por zona quartzosa recristalizada, incorporando minerais ferro-magnesianos ( $\mathrm{Nx}$ ), e e f) Estrutura laminada dentro do corpo Capa, nível 264m da mina, mostrando faixas de quartzo deformado e recristalizado, separadas por bandas de tonalito intensamente milonitizado e alterado (NX). 
As estrias parecem ter o mesmo mergulho das lineações de elongação, vistas nos planos de foliação, o que pode indicar que o movimento ao longo dos veios de cisalhamento, ou das superfícies de deslizamento, foi oblíquo, talvez oblíquo-reverso.

A localização e caimento dos veios individuais são controlados por: variações de mergulhos dos planos de foliação; intersecção das zonas de cisalhamento, determinando o plunge dos corpos de minério; interseç̧ão dos corpos de minério; interseção dos veios principais e intersecção dos veios principais com os veios em echelon oblíquos, etc.

Os veios exibem zonas ricas em $\mathrm{Au}$ com espessuras excepcionais que podem atingir $6,5 \mathrm{~m}$, observáveis ao longo da direção do filão ou no sentido do mergulho, no caso do Filão Principal. Trata-se de corpo de minério com espessura variável até $6,5 \mathrm{~m}$ e persistência até $400 \mathrm{~m}$ de profundidade ao longo do plano do filão e segundo plunge equivalente a $\mathrm{N} 18^{\circ} \mathrm{W} / 45^{\circ}$, contido no plano $\mathrm{N} 60^{\circ} \mathrm{W} / 57^{\circ} \mathrm{NE}$ (Filão Principal), observando-se zonas anômalas (lodes) com teores em Au da ordem de 30 a 40g/t.

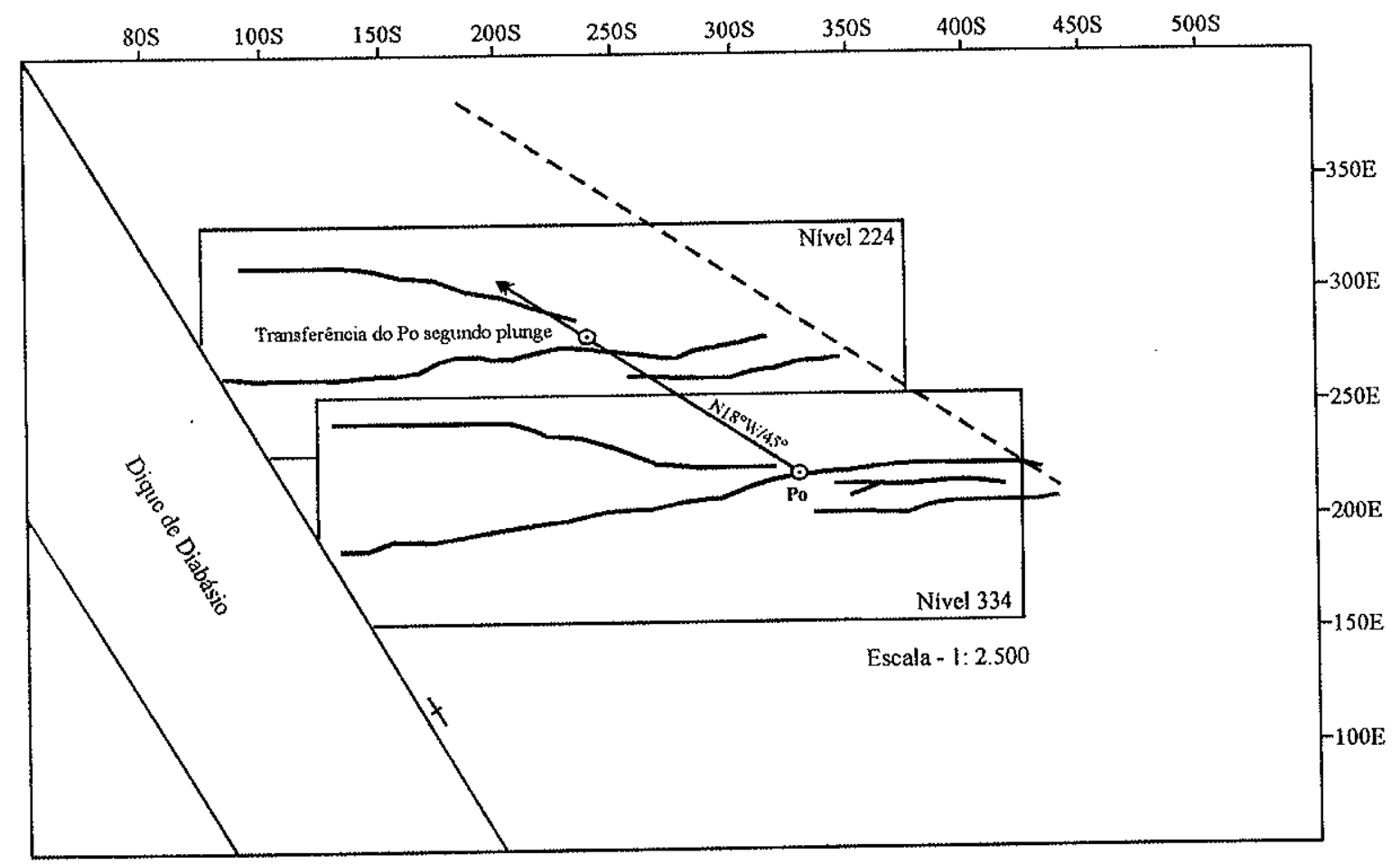

Figura 6.12 - Projeção ortogonal em planta dos corpos mineralizados nos níveis 334 e 224 e sua correspondência com o plunge $\mathrm{N} 18^{\circ} \mathrm{W} / 45^{\circ}$, (Fonte: Costa 1991). 


\subsection{PARAGÊNESE DOS VEIOS QUARTZO-AURÍFEROS}

A paragênese dos veios foi determinada através das relações de intercrescimentos de fases minerais, das texturas de substituição scessiva de minerais precoces por outros mais tardios, observados em amostras de mão e seções delgadas e polidas, dos três corpos de minério: Capa, Principal e Lapa, que compõem o sistema filoniano.

$\mathrm{Na}$ mineralização do depósito de Salamangone o quartzo compreende a maior parte do volume dos veios, enquanto que os sulfetos e outros minerais de ganga não constituem mais do que 3\%. Estes sulfetos ocorrem disseminados e associados com aos minerais ferromagnesianos (hornblenda e biotita), principalmente, nas faixas milonitizadas e alteradas da rocha tonalítica incorporadas aos veios (ribbons), diminuindo seu conteúdo nas faixas silicosas, deformadas e recristalizadas.

A paragênese dos veios de quartzo pode ser dividida em três fases, esquematicamente ilustrada na Figura 6.13. São elas: Fase I - quartzo vítreo de cores cinza-azulada e branca, arsenopirita, pirrotita, lollingita, calcopirita, ouro e biotita; Fase II - quartzo branco, arsenopirita, pirita, galena e ouro e Fase III - quartzo branco, carbonato e clorita.

\begin{tabular}{|c|c|c|c|}
\hline MINERAL & FASE I & FASE II & FASE III \\
\hline Quartzo & & & \\
Biotita & & & \\
Sericita & & & \\
Clorita & & & \\
Carbonato & & & \\
Arsenopirita & & & \\
Pirrotita & & & \\
Lollingita & & & \\
Calcopirita & & & \\
Pirita & & & \\
Galena & & & \\
Ouro Nativo & & & \\
\hline
\end{tabular}

Figura 6.13 - Sequência paragenética esquemática do sistema de veios de quartzo (Capa, Principal e Lapa), do depósito de Salamangone. Minerais presentes como fases frequentes ou pouco frequéentes estão representados por linhas contínua e tracejada respectivamente, e a abundância relativa é proporcional à espessura das barras. 


\section{Fase I}

Na Fase I de mineralização o mineral dominante é o quartzo, que constitui o principal material de preenchimento dos veios, correspondendo a mais de $90 \%$ em volume. É maciço, aocorre segundo grãos vítreos de cor cinza-azulada e granulação média, envolvidos por grãos de quartzo branco translúcidos de granulação mais fina, que se acham firmemente entrelaçados e com grande variação de tamanho e orientação. O conjunto mostra texturas de deformação tais como: extinção ondulante, recuperação, desenvolvimento de subgrãos, além de novos grãos recristalizados que indicam processo de deformação dúctil não homogênea, onde domínios ou faixas de grãos recristalizados acham-se entremeados com domínios de grãos menos deformados, Figura 6.14a.

A estrutura que se desenvolve nos veios de quartzo nesta Fase I, é conhecida como núcleo - borda (core - mantle) segundo terminologia adotada por Passchier \& Trouw (1996), e representa um arranjo típico configurado por um agregado de pequenos grãos de quartzo, dinamicamente recristalizados e poligonizados, em torno de um núcleo reliquiar cristalino de quartzo mais antigo, de mesma composição, Figuras $6.14 \mathrm{~b}$ e $6.14 \mathrm{c}$. As feições observadas de extinção ondulante e subgrãos alongados nos núcleos remanescentes maiores de quartzo (núcleos), que passam lateralmente para faixas/domínios de grãos pequenos recristalizados (bordas), evidenciam que este tipo de estrutura desenvolveu-se por recuperação e recristalização dinâmica do núcleo cristalino ao longo de sua borda, Figuras 6.14e6.14f.

Os cristais de quartzo maiores apresentam abundantes microfraturas cicatrizadas, com inclusões fluidas aprisionadas, indicando episódios de fraturamento rúptil. Essas microfraturas, em sua maioria, atravessam os limites dos grãos e invadem o domínio dos grãos recristalizados, indicando que esse fraturamento aconteceu após os episódios de deformação dúctil, Figura 6.14 (Foto d). Inclusões fluidas com características primárias não foram observadas, tendo sido provavelmente destruídas ou alteradas durante o processos de deformação, Drury \& Urai (1990).

Os sulfetos formados nessa fase incluem, dominantemente, arsenopirita, pirrotita e lollingita, com menor quantidade de calcopirita e encontram-se, geralmente, associados com os minerais ferro-magnesianos (hornblenda e biotita) da rocha tonalítica encaixante, incorporada aos veios, Figuras 6.15a, e 6.15b. 

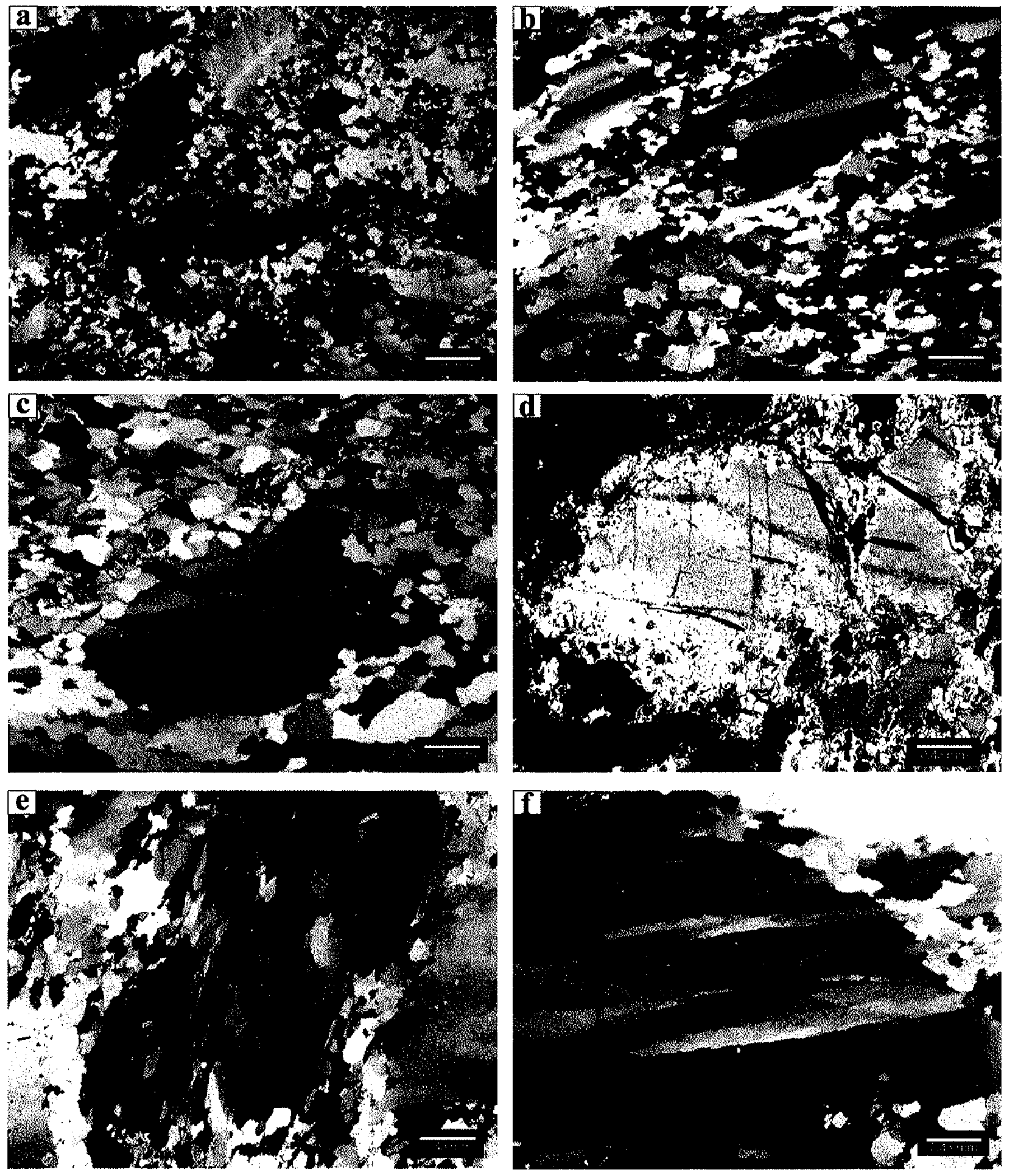

Figura 6.14 - Feições de deformação do quartzo: a) Aspecto geral da estrutura do tipo núcleo borda segundo Passchier \& Trouw(1996), onde relictos de grãos de quartzo maiores passam lateralmente para domínios de grãos menores recristalizados (N//), b e c) Detalhe da estrutura núcleo-manto, observando-se a acentuada extinção ondulante nos cristais maiores de quartzo $(\mathrm{N} / /)$, d) Microfraturas transgranulares, contendo inclusões fluidas, que ultrapassam os limites entre o núcleo e as bordas recristalizadas dos grãos de quartzo (N//), e e f) Detalhe dos processos de recuperação do quartzo, com o desenvolvimento de subgrãos e de acentuada extinção ondulante, respectivamente (N//). 

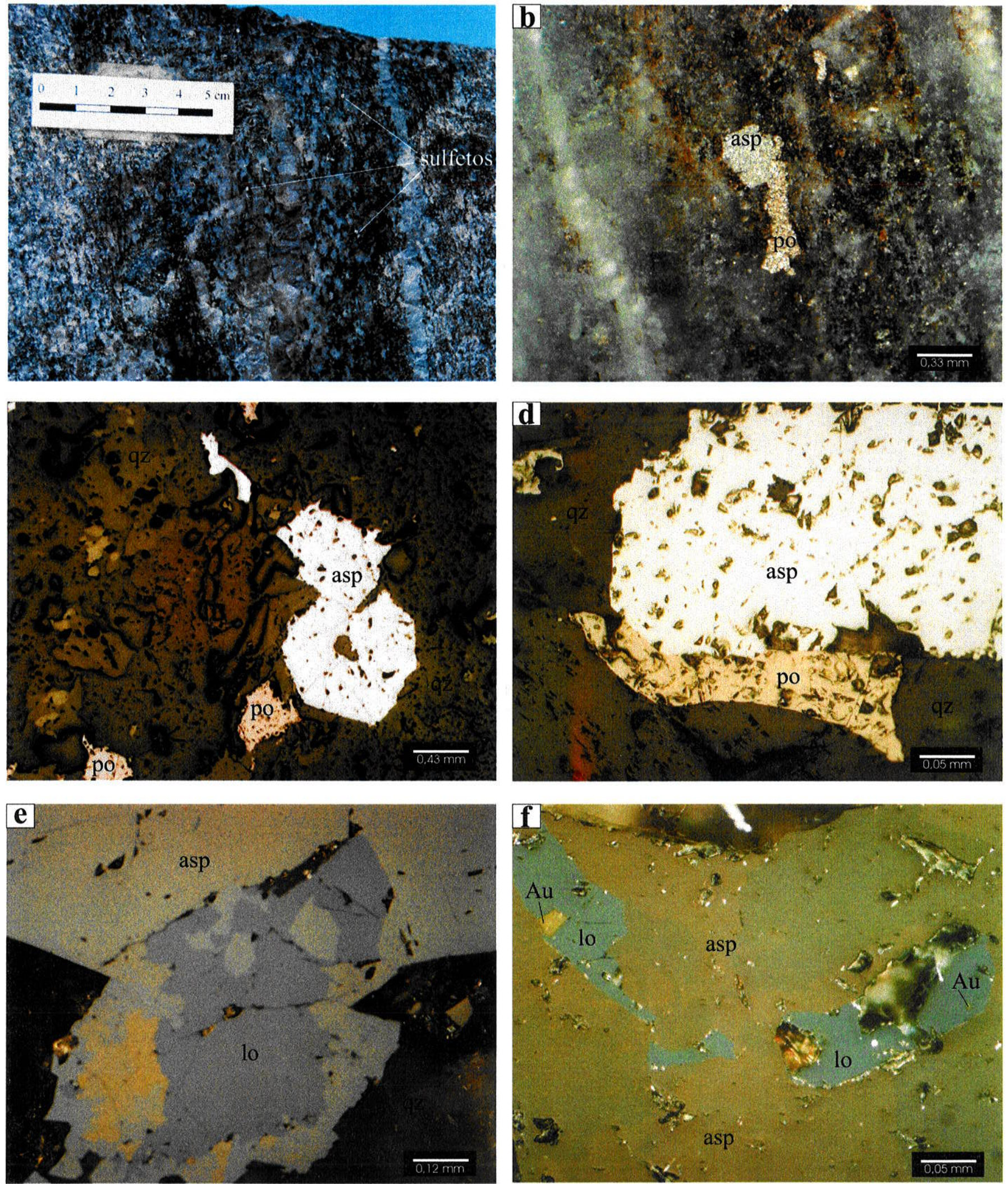

Figura 6.15 - Fase I da mineralização no depósito de Salamangone: a) Tonalito foliado e hidrotermalizado, com silicificação e sulfetação acentuadas, b) Detalhe do tonalito dentro da zona mineralizada, onde cristais de arsenopirita e pirrotita depositam-se, sempre, junto aos minerais ferro-magnesianos (hornblenda e biotita), c e d) Cristais de arsenopirita e pirrotita associados, paragênese comum da Fase I de mineralização (N//), e) Lollingita parcialmente substituída por cristal de arsenopirita (Nx), f) Arsenopirita envolvendo núcleo de lollingita, com ouro nativo localizado no contato das duas fases minerais (Nx). Simbologia: arsenopirita $=\mathrm{asp}$, pirrotita $=\mathrm{po}$, lollingita $=1 \mathrm{o}, \mathrm{ouro}=\mathrm{Au}, \mathrm{quartzo}=\mathrm{qz}$. 
A arsenopirita ocorre finamente disseminada nos grãos de quartzo, forma cristais euedrais a subedrais, com evidências de fraturamento e substituição, os quais estão sempre associados com pirrotita anedral, Figuras $6.15 \mathrm{c}$, e $6.15 \mathrm{~d}$. A presença de fases minrais do sistema Fe-As-S, é verificada pela ocorrência de grãos compostos de arsenopirita-lollingita. Estes grãos são nitidamente zonados, com arsenopirita, geralmente, envolvendo núcleos de lollingita, Figura 6.15 (Fotos e, f), sugerindo uma progressiva substituição da primeira pela segunda, conforme verificado nos depósitos de alta temperatura de Mount York e Griffin's Find, Austrália (Neumayr et al. 1993a e b), de Osikonmäki, Finlândia (Kontoniemi \& Nurmi 1998) e de Challenger, Austrália (Tomkins \& Mavrogenes 2001). Um zoneamento reverso, com arsenopirita envolvida por lollingita, não foi constatado e, os cristais de pirrotita estão sempre separados da lollingita, por uma borda de arsenopirita.

Pirrotita anedral representa, também, um sulfeto dominante nesta Fase I de mineralização. Ocorre isolada, ou envolvendo cristais de arsenopirita e de arsenopiritalollingita. Calcopirita, anedral, aparece sempre em quantidade subordinada, associada à pirrotita, ou isolada na ganga quartzosa.

O ouro microscopicamente vísivel aparece em pequena quantidade e concentra-se na arsenopirita, na forma de pequenas inclusões ou, mais comumente, nos limites dos grãos arsenopirita-lollengita, Figura 6.15f. As relações paragenéticas e texturais entre a associação arsenopirita-lollingita, descritas acima, sugerem que o ouro possa ter sido liberado da estrutura da lollingita e depositado no limite dos grãos entre esses minerais, por ocasião da substituição da uma pela outra, sob cundições de metarmofismo retrógrado, conforme demonstrado por Neumayr et al. (1993a eb) em depósitos de alta temperatura, na Austrália. Segundo os autores, com base em sistemas naturais e experimentais, a formação de ouro nativo resultaria da incapacidade da arsenopirita, de incorporar ouro em sua estrutura, sob condições de alta temperatura.

Os únicos silicatos identificados são a biotita $\mathrm{e}$, mais rararamente, a sericita inclusas dentro dos grãos de quartzo, sob a forma prismática, sendo que a biotita, com forma ovóide e dimensões muito reduzidas $(<30 \mu \mathrm{m})$, é observada, também, sempre junto com sulfeto, (provavelmente arsenopirita, pois não foi possível a sua identificação), de igual dimensões.

\section{Fase II}

A fase Il é, por excelência, o episódio de deposição principal de ouro, acompanhada de quartzo e minerais sulfetados em pequena quantidade, e compreende menos de $5 \%$ do material de preenchimento dos veios. 

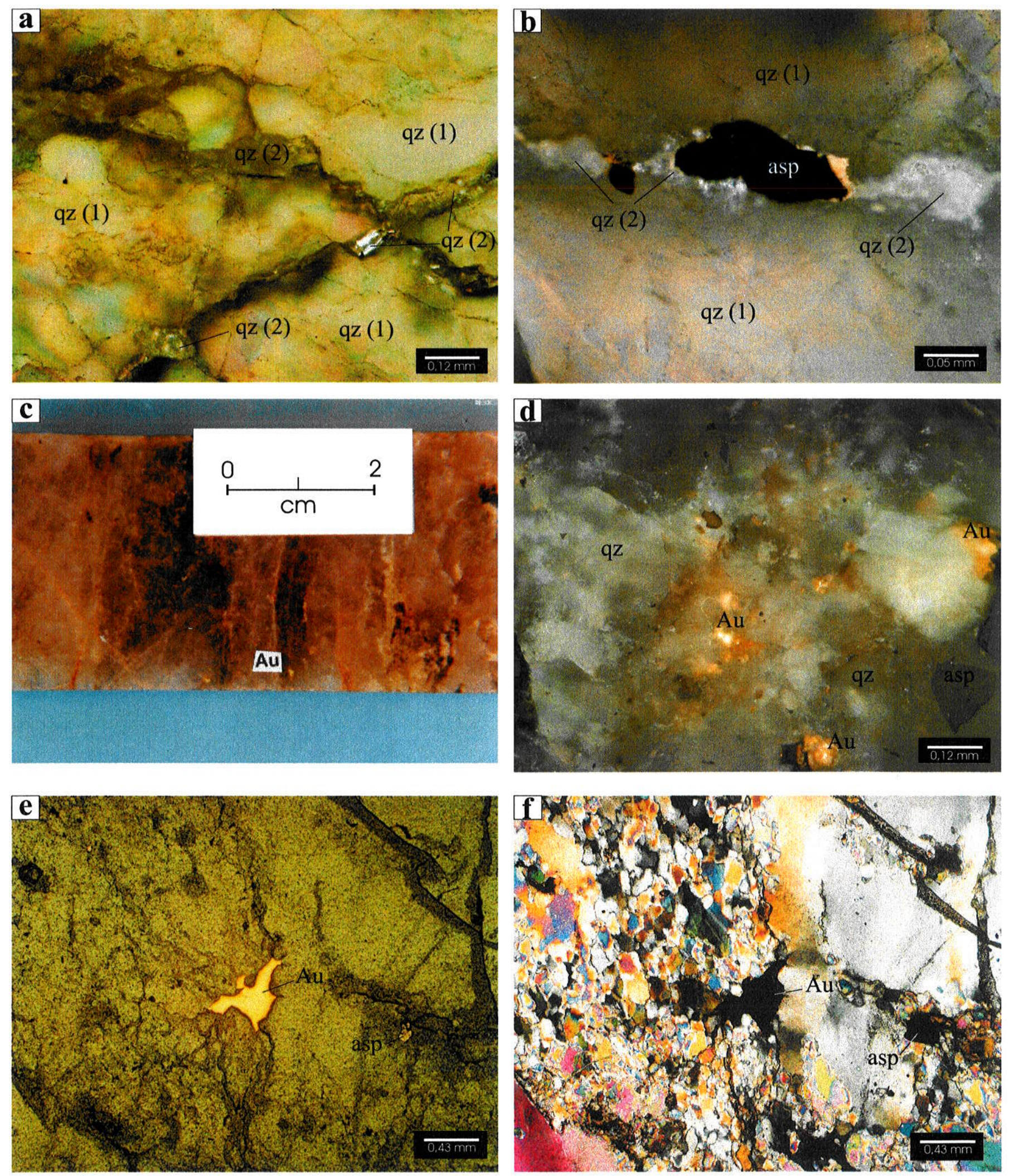

Figura 6.16 - Fase II da mineralização no depósito de Salamangone: a)Domínio de quartzo recristalizado, da Fase I de mineralização, atravessado por fraturas preenchidas com quartzo da Fase II de mineralização (Nx), b) Detalhe de fratura preenchida com quartzo e arsenopirita da Fase II da mineralização (Nx), c) Detalhe de fraturas preenchidas com ouro nativo, d) Zona silicosa fraturada e recristalizada com deposição acentuada de ouro nativo e arsenopirita (Nx), e e f) Ouro nativo depositado em zona fraturada e recristalizada (N// e Nx respectivamente). Simbologia: arsenopirita = asp, ouro = Au, quartzo da Fase I = qz (1), quartzo da Fase II = qz (2). 

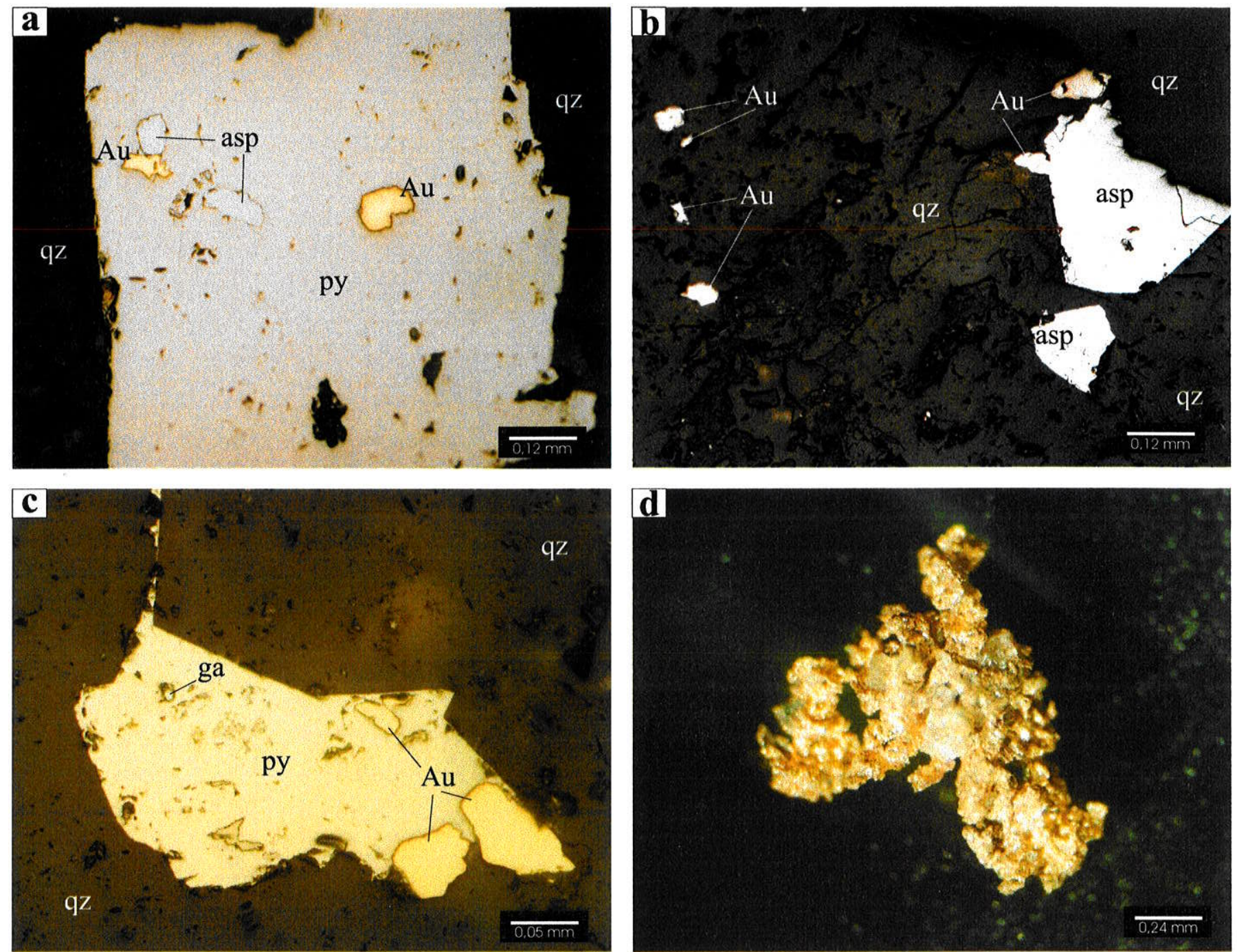

Figura 6.17 - Aspectos da forma de ocorrência do ouro na Fase II de mineralização no depósito de Salamangone: a) Ouro incluso em cristal de pirita, que mostra substituição de arsenopirita (N//), b) Ouro associado a cristais de arsenopirita e livre na ganga quartzosa (N//), c) Ouro associado à cristal de pirita, que apresenta pequena inclusão de galena (N//), d) Grão de ouro com hábito dendrítico. Simbologia: arsenopirita $=\mathrm{asp}$, pirita $=\mathrm{py}$, ouro $=\mathrm{Au}$, galena $=\mathrm{ga}$, quartzo $=\mathrm{qz}$. 
A passagem entre a Fase I e a Fase II de mineralização é marcada por uma deformação rúptil, que originou fraturas no material da Fase I, onde ocorreu a deposição de quartzo incolor sem deformação e inclusões, além de sulfetos e ouro. Estas fraturas geralmente, atravessam o domínio do quartzo recristalizado, Figuras $6.16 \mathrm{a}$ e $6.16 \mathrm{~b}$.

Uma diferença importante entre as duas fases de mineralização é o aparecimento de pirita,e a ausência de pirrotita e calcopirita, da fase I. A arsenopirita continua como sendo o sulfeto principal, na forma de cristais euedrais a subedrais, porém, não se observa mais a associação com lollingita.

O ouro apresenta-se na forma nativa, em grande quantidade, constituindo, geralmente, grãos isolados depositados em fraturas que atravessam domínios de quartzo recristalizado, sempre ao lado de arsenopirita e pirita, Figuras $6.16 \mathrm{c}, 6.16 \mathrm{~d}$, e 6.16f. Aparece, também, associado a esses sulfetos, como inclusões ou em contato com suas bordas, Figuras 6.17a, $6.17 \mathrm{~b}$ e $6.17 \mathrm{c}$. Os grãos de ouro chegam a atingir dimensões de até $2 \mathrm{rmm}$, com hábitos variados, Figura $6.17 \mathrm{~d}$. A ocorrência do ouro, nesta fase de mineralização, sempre na forma nativa e condicionada a fraturas em zonas recristalizadas, com a presença de pirita e arsenopirita, sugere provável remobilização, do ouro depositado nesta fase, sob condições diferentes daquelas que atuaram na primeira fase.

Os cristais de pirita euedrais a subedrais, que são característicos desta fase de mineralização, tem uma abundância relativamente menor com relação aos sulfetos depositados na fase I. Além do ouro, apresentam inclusões de arsenopirita, sugerindo um provável processo de substituição deste sulfeto. Inclusão de galena, de dimensão muito reduzida, foi detectada em análise EDS, utilizando-se o microscópio eletrônico, Figura $6.17 \mathrm{c}$.

\section{Fase III}

A Fase III restringe-se ao desenvolvimento de vênulas de carbonato e quartzo, com clorita subordinada, que atravessam os domínios de quartzo das Fases I e II, e que não foram objeto de estudo detalhado, como as fases anteriores.

\section{Composição química dos sulfetos e geotermometria da arsenopirita}

Análises químicas, por microssonda eletrônica, foram realizadas nos sulfetos e no ouro associados às diferentes fases de mineralização, tendo sido determinado o conteúdo de $\mathrm{Fe}, \mathrm{As}$, $\mathrm{S}, \mathrm{Cu}, \mathrm{Au}$ e A $\mathrm{Ag}$. Os resultados estão apresentados nas Tabelas 6.4 (a, b, c, d, e). 
Diferenças significativas entre as composições de arsenopirita das fases I e Il não foram encontradas, significando, que alguma arsenopirita da segunda fase, possa ter sido herdada da primeira fase. Como o ouro ocorre em maior quantidade, observável ao microscópio, na fase Il da mineralização, apenas uma análise pode ser realizada em grão associado à fase I, mostrando valores muito diferentes nos conteúdos em $\mathrm{Fe}, \mathrm{Au}$ e $\mathrm{Ag}$, quando comparados àqueles determinados na fase II. De modo geral, o conteúdo de $\mathrm{Au}$ e $\mathrm{Ag}$ nos sulfetos é baixo.

As concentrações de As, Fe e $\mathrm{S}$ de sulfetos foram lançadas no diagrama ternário do sistema Fe-As-S ( Clark 1960), Figura 6.18a, que exibem os domínios de ocorrência dos minerais mais conhecidos: arsenopirita, pirita, pirrotita e lollingita, além das fases FeAs e $\mathrm{Fe}_{2}$ As, que não ocorrem na natureza. As composições da arsenopirita I e Il, incidem no mesmo campo formando um conjunto único, sem diferenciação. Essas análises foram representadas num histograma de freqüência da porcentagem atômica do conteúdo em As (\% at. As) na arsenopirita, Figura $6.18 \mathrm{~b}$, com um intervalo de variação entre 32 e 38 (\%at. As), e pico de maior freqüência entre 35 e 36 (\%at As). Observa-se que as análises dos cristais de arsenopirita das fases I e II da mineralização mostram-se, de modo geral, com um comportamento semelhante, coincidindo nos intervalos de maiores freqüências.

A utilizaçã́o de arsenopirita como geotermômetro vem sendo praticada, com algumas ressalvas, obedecendo-se os trabalhos de Kretschmar \& Scott (1985) e Sharp et al. (1985), que apresentam sua viabilidade como termômetro, a partir da excelente correspondência entre a composição de arsenopirita natural e os limites de temperatura determinados em seus experimentos. Segundo os autores, a composição da arsenopirita seria indicativa da sua temperatura inicial de formação. Consideram, também, sua natureza refratária e afirmam, que uma vez depositada, seria pouco provável mudanças em sua composição, em resposta à alteração nas condições de formação do depósito ao qual estão associadas.

No depósito de Salamangone as temperaturas obtidas através do uso das composições atômicas de arsênio (\% at. de As) na arsenopirita, variaram entre aproximadamente $400^{\circ} \mathrm{C}$ e $565^{\circ} \mathrm{C}$ (\% atômica de As entre 33,1 e 36,7), Figura 6.18c e Tabela 6.4, Anexo 2 Levando em consideração que as relações paragenéticas e texturais, já descritas, sugerem a substituição de lollingita por arsenopirita, possivelmente através de reações retrógradas, estas temperaturas representariam as condições mínimas para a deposição dos sulfetos. 

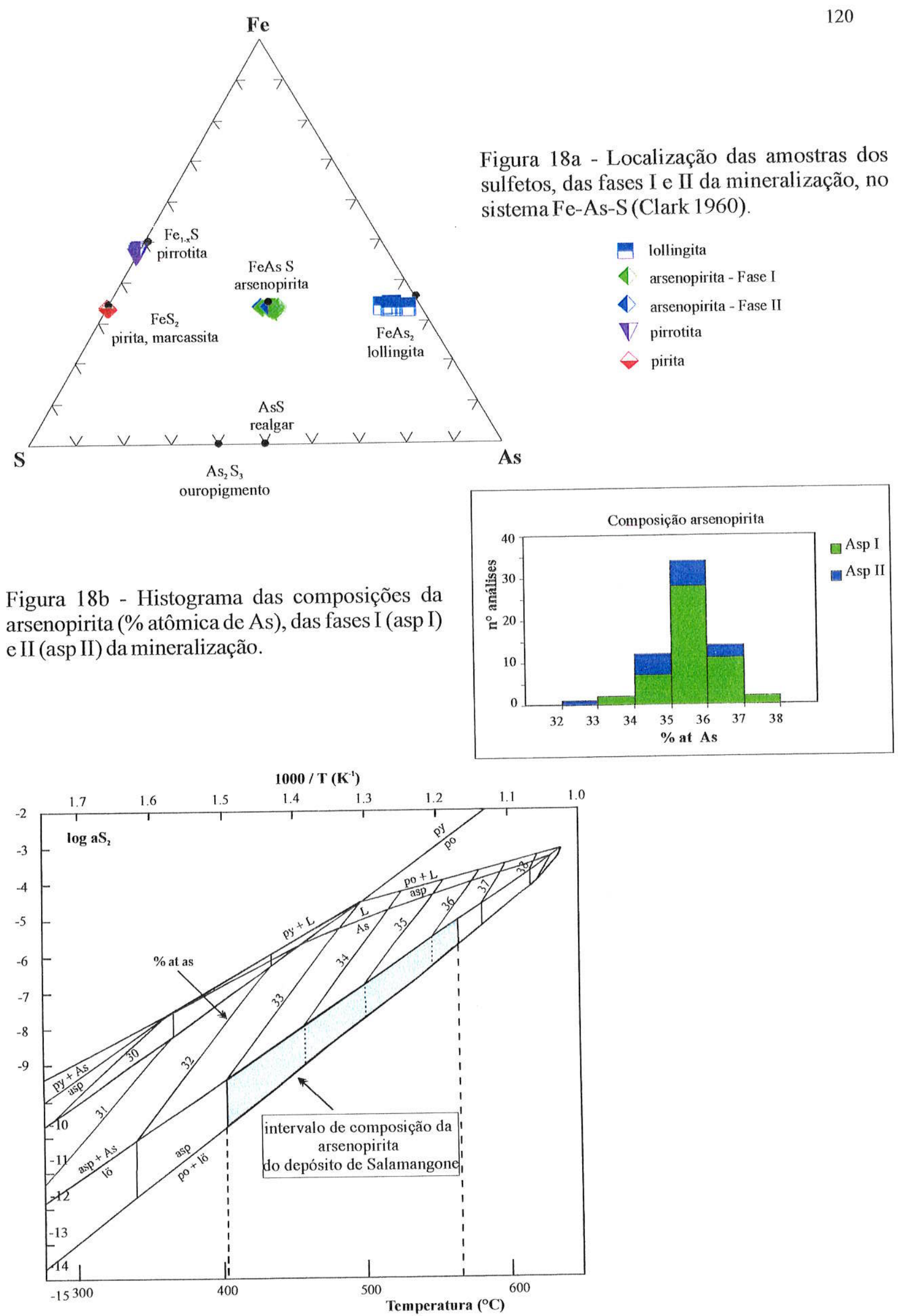

Figura 18c - Campos de estabilidade das fases minerais do sistema Fe-As-S relativos à atividade de $\mathrm{S}_{2}$ e temperatura, limitadas pela concentração de As (\% atomica) na arsenopirita (modificado de Kretschmar \& Scott 1976 - isopleths da \% at. As redesenhadas na vertical nos campos de estabilidade da pirita e lollingita, em Sharp et al. 1985). Simbologia: asp = arsenopirita, py = pirita, po = pirrotita, lö=lollingita, As $=$ arsenio, $L=$ líquido. 


\subsection{ALTERAÇÃO HIDROTERMAL}

Alteração da rocha encaixante associada com depósitos hidrotermais é manifestada por uma mudança na mineralogia, química e/ou textura da rocha hospedeira, em resposta às novas condições físico-químicas, após a ação dos fluidos hidrotermais. Constitui um processo essencialmente metamórfico, raramente isoquímico, onde os fluidos assumem um papel de grande importância (Rose \& Barton 1979).

Metassomatismo ou transferência de componentes químicos para dentro ou fora da rocha encaixante por soluções hidrotermais é uma característica importante e sempre presente, nos depósitos auríferos do Arqueano. Os fatores que controlam o estilo da alteração, a forma e a assembléia mineral resultante, em veios associados a sistemas de fraturas ou zonas de cisalhamentos, segundo Mikucki et al. (1990), envolvem:

a) a composição das litologias ao longo dos canais de acesso dos fluidos hidrotermais e do local de deposição;

b) a composição do fluido hidrotermal;

c) a temperatura e pressão dos fluidos envolvidos;

d) as condições nas quais o equilibrio termodinâmico é atingido.

A assembléia mineral decorrente da alteração hidrotermal associada com depósitos hospedados em rochas granitóides é muito variada e obedece a um zoneamento lateral em relação ao sistema filoniano. Desta forma, no depósito de Salamangone, será denominada, "zona de alteração proximal", aquela localizada imediatamente adjacente aos veios e que reflete com maior intensidade a influência da composição do fluido hidrotermal. À medida que se afasta ortogonalmente da região de fluxo fluidal predominante, atinge-se outra zona, que será chamada de "zona de alteração distal", caracterizada por uma diminuição da interação rocha encaixante-fluido, e por poucas mudanças mineralógicas. Esta zona distal de alteração passa gradualmente para um domínio contíguo constituído por rocha tonalítica menos alterada, cuja assembléia mineral reflete a ação do metamorfismo regional.

No depósito de Salamangone, a rocha tonalítica encaixante menos alterada apresenta os minerais tipomórficos primários, biotita, hornblenda, feldspatos (microlínio, oligoclásio/andesina) e titanita, observando-se a ação de uma alteração deutérica hidrotermal fraca, que resultou na formação de pequenas quantidades de minerais secundários. São observados uma leve saussuritização dos núcleos dos feldspatos cálcicos, pequena formação de epidoto e pouca cloritização da biotita. As texturas ígneas estão típicamente preservadas, 
exceto por feições de deformação de alguns grãos de quartzo, traduzidas por extinção ondulante e recristalização incipiente.

A alteração hidrotermal em torno dos veios quartzo-auríferos não é muito acentuada, podendo ser dividida em duas zonas: proximal e distal, que recobrem a assembléia mineral do tonalito menos alterado. A zona de alteração proximal é estreita, com espessuras inferiores a $1 \mathrm{~m}$ e apresenta um associação mineral diagnóstica típica. A zona de alteração distal pode se estender por algumas dezenas de metros, passando gradualmente para a rocha tonalítica menos alterada.

Uma maior complexidade ocorre, geralmente, na zona proximal devido à sua pequena extensão e à natureza episódica da deformação e aporte de fluidos, que atuam em conjunto durante a formação da mineralização, produzindo uma zona de alteração com uma sequência de relacionamentos interpostas, de difícil estabelecimento (McCuaig \& Kerrich 1998).

A zona de alteração distal se caracteriza por um pequeno aumento na intensidade da saussuritização dos plagioclásios e na cloritização da biotita, enquanto que o quartzo se mostra igualmente deformado, com feições de extinção ondulante e recristalização, mantendo-se preservadas, de modo geral, as feições ígneas primárias, Figura 6.19a. Os minerais sulfetados representam constituintes menores, e a zona foi considerada não econômica, considerando o teor de corte da ordem de 10 ppm, praticado à época da lavra subterrânea.

A zona de alteração proximal localiza-se adjacente ao veio de quartzo através de contato brusco. As fases minerais que definem sua paragênese apresentam ainda, textura ígnea preservada, com a alteração hidrotermal resultando na substituição mais intensa de algumas destas fases.

A alteração se caracteriza por uma saussuritização mais intensa dos plagioclásios, a formação de maior quantidade de clorita às expensas da biotita e, por vezes, na transformação de hornblenda em actinolita, Figura 6.19b. A presença de sulfetos é mais acentuada, com deposição de arsenopirita e pirrotita sempre associadas aos minerais ferro-magnesianos (biotita e hornblenda). A deformação no quartzo também é mais realçada, com feições de extinção ondulante e recristalização mais intensas, presença frequente de "kink bands" em biotita e orientação preferencial dos minerais ferromagnesianos em torno de núcleos de quartzo envolvidos por bordas de cristais recritalizados. O teor de $\mathrm{Au}$ aumenta, ficando acima de $10 \mathrm{ppm}$, chegando a atingir até 1000 vezes o valor do tonalito pouco alterado, mas, no geral, foi considerada subeconômica pelos mesmos motivos expostos e relativos à zona distal. 

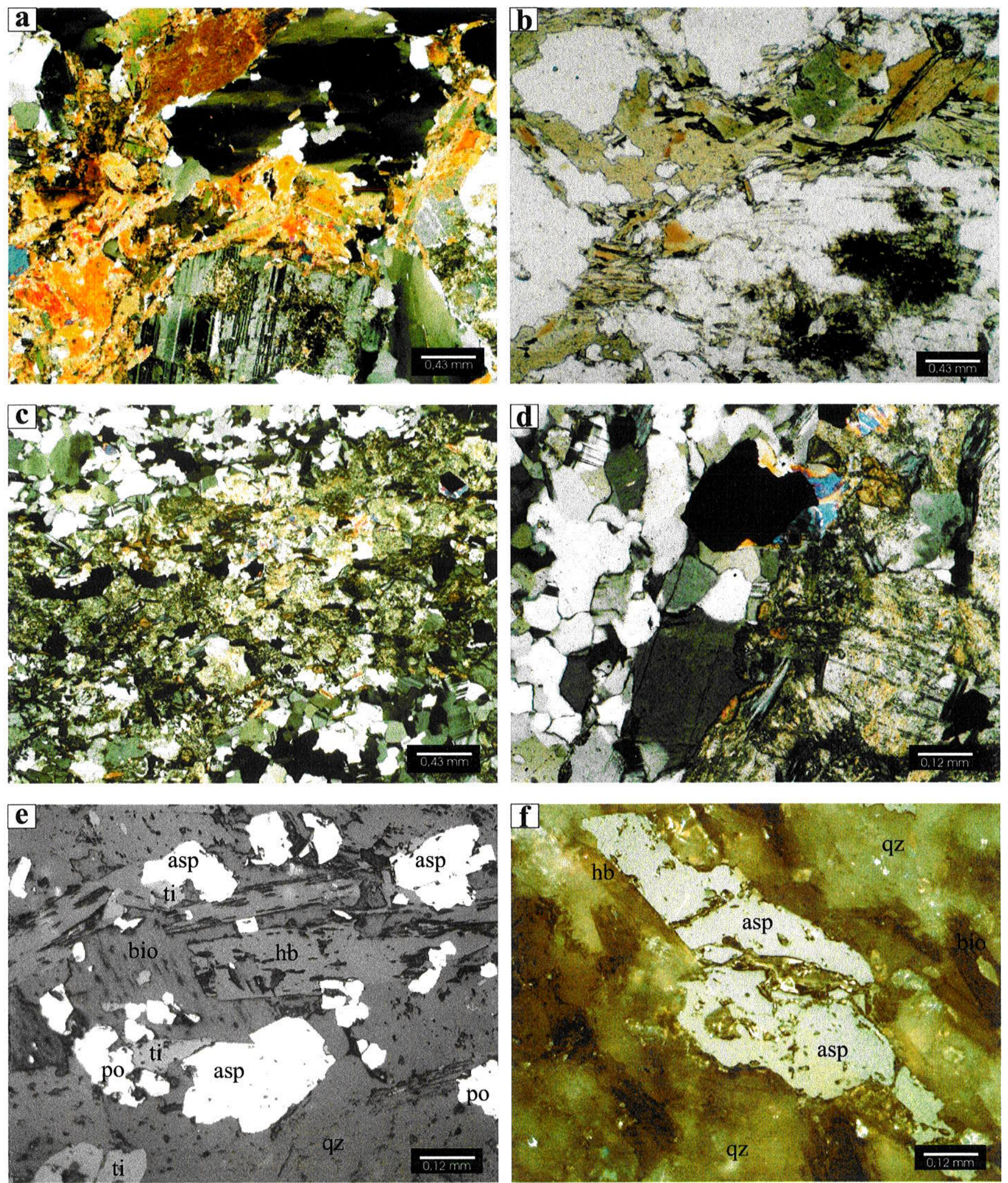

Figura 6.19 Aspectos relativos à alteração hidrotermal do tonalito no depósito de Salamangone; a) Saussuritização pouco acentuada do plagioclásio e deformação do quartzo em tonalito dentro da zona distal de alteração (Nx), b) Reações mais intensas de saussuritização dos plagioclásios, hornblenda passando a actinolita e cloritização acentuada da biotita em tonalito dentro da zona proximal de alteração (N//), c) Faixa de rocha tonalítica (ribbon) intensamente hidrotermalizada dentro do veio de quartzo, com saussuritização e sulfetação acentuadas $(\mathrm{Nx})$, d) Detalhe da fotografia anterior, no contato entre o veio de quartzo e o tonalito $(\mathrm{Nx})$, e e f) Cristais de arsenopirita e pirrotita associados com hornbenda e biotita, dentro de faixas de tonalito, incorporadas ao veio de quartzo (N// e Nx respectivamente). Simbologia: arsenopirita $=$ asp, pirrotita $=$ po, quartzo $=\mathrm{qz}$, bio $=$ biotita, $\mathrm{hb}=$ hornblenda. 
A paragênese sulfetada relativa à zona de alteração proximal é a mesma verificada nas faixas de rocha tonalítica (ribbons) incorporadas dentro dos veios e relacionada à fase I de mineralização. Nestas faixas, no entanto, os processos de hidrotermalização são intensos, transformando, quase que totalmente, os plagioclásios e os minerais ferro-magnesianos, Figuras $6.19 \mathrm{c}$ e6.19d, e a sulfetação ocorre, igualmente, com intensidade muito maior, Figuras $6.19 \%$ e.19f. Um provável zoneamento lateral da alteração hidrotermal, no depósito de Salamangone, é apresentado na Figura 6.20. As zonas proximal e distal de alteração mostram, preliminarmente, uma natureza contemporânea e progressiva, não tendo sido observado o contato direto entre a zona proximal e a rocha menos alterada. As mudanças mineralógicas em ambas as zonas de alteração envolvem, principalmente, hidratação das fases minerais preexistentes, com um metassomatismo potássico e carbonatização muito incipientes.

\begin{tabular}{|c|c|c|c|c|}
\hline Minerais & $\begin{array}{c}\text { Tonalito menos } \\
\text { alterado }\end{array}$ & Zona distal & Zona proximal & $\begin{array}{c}\text { Sistema } \\
\text { filoneano }\end{array}$ \\
\hline Quartzo & & & & \\
\hline Plagioclásio & & & & \\
\hline k-Feldspato & & & & \\
\hline Hornblenda & & & & \\
\hline Biotita & & & & \\
\hline Allanita & & & & \\
\hline Titanita & & & & \\
\hline Apatita & & & & \\
\hline Zircão & & & & \\
\hline Clorita & & & & \\
\hline Actinolita & & & & \\
\hline Sericita & & & & \\
\hline Epidoto & & & & \\
\hline Carbonato & & & & \\
\hline Arsenopirita & & & & \\
\hline Pirrotita & & & & \\
\hline Lollingita & & & & \\
\hline Calcopirita & & & & \\
\hline Ouro & & & & \\
\hline
\end{tabular}

Figura 6.20 - Zoneamento lateral da alteração hidrotermal em torno dos veios de quartzo do depósito de Salamangone. A distância e intensidade do processo, em relação ao centro emanativo fluidal, aumenta no sentido do sistema filoneano. Minerais presentes como fases comuns ou menos frequentes estão representados por linhas contínua e tracejada, respectivamente, e a relativa abundância é proporcional à espessura das barras. 


\subsection{MUDANÇAS QUÚMICAS QUE ACOMPANHAM A ALTERAÇÃo HIDROTERMAL}

Amostras de tonalito representativas das zonas de alteração proximal e distal foram selecionadas para análises químicas, a fim de se avaliar as mudanças químicas que acompanharam a alteração hidrotermal.

A Tabela 6.5a apresenta os dados analíticos de amostras da travessa de acesso à galeria de desenvolvimento de lavra no nível $54 \mathrm{~m}$ da mina, na lapa do corpo de minério, (Figura 6.5). As amostras foram coletadas ao longo de uma extensão de 60 metros, desde a rampa de descida, no tonalito menos alterado (amostra R-1), indo em sentido à galeria de desenvolvimenato, no tonalito hidrotermalizado (amostra R-27) dentro da zona proximal de alteração, ao lado do veio quartzo-aurífero. As análises, na tabela, foram dispostas num arranjo, da esquerda para direita, vindo da zona distal rumo à zona proximal, ao lado do veio.

A Tabela $6.5 b$ reúne os dados analíticos das amostras do Furo de sondagem SH-140, realizado na capa do sistema filoniano, (Figura 2.1). As amostras foram coletadas ao longo de um trecho do furo numa extensão de 80 metros, desde a profundidade de $250 \mathrm{~m}$ no tonalito menos alterado (amostra SHN-11), até 330 metros quando atinge o tonalito hidrotermalizado (amostra SHN-29), na zona proximal de alteração ao lado do veio quartzo-aurífero. As análises também foram apresentadas, obedecendo a mesma disposição da Tabela 6.5a.

A alteração hidrotermal (metassomatismo) em torno de um sistema filoniano reflete uma interação fluido-rocha encaixante percolada, em sistema aberto. As mudanças nas concentraç̃̃es dos elementos pode ser calculada após a identificação dos elementos imóveis, utilizando-se o Método de Gresens (1967).

A base teórica para a realização dos cálculos de balanço de massa, dada por Gresens (1967), apresenta equações para cálculo de ganhos e perdas de componentes a partir de análises químicas e densidades específicas para rochas e minerais inalterados e seus equivalentes alterados. A fórmula básica para esse cálculos é:

$$
\mathbf{X}_{n}=\left[\mathbf{f}_{v}\left(\mathbf{g}^{\mathrm{B}} / \mathrm{g}^{\mathrm{A}}\right) \mathbf{C}^{\mathrm{B}}{ }_{\mathrm{n}}-\mathbf{C}^{\mathrm{A}}{ }_{n}\right] \mathbf{a}, \text { onde: }
$$

$\mathbf{A}=$ amostra original inalterada, $\mathbf{B}=$ amostra final alterada, $\mathbf{n}=$ componente, $\mathbf{g}=$ densidade específica, $v=$ volume da amostra, $\mathbf{f} v=$ fator volumétrico, $\mathbf{a}=$ massa de referência da amostra original, $\mathbf{X}=$ perda ou ganho de massa de um componente em relação à massa de referência, $\mathbf{C}=$ concentração. 
Através desta equação podem ser identificados os elementos relativamente imóveis que interceptarão $\mathbf{X n}=0$, próximo a um mesmo valor de fv (atribuído arbitrariamente e que representará o fator volumétrico da alteração). As mudanças de concentrações de elementos móveis podem, então, serem apresentadas em relação ao fator volumétrico.

O método utilizado neste trabalho, é o método gráfico de Grant (1986), que representa a solução simultânea da equação de Gresens (1967) para todos os componentes, através da relação linear entre a concentração final da amostra alterada e a concentração original da amostra não alterada. Através deste método todos os componentes que não apresentarem perdas ou ganhos de massa definem uma reta, a isocon que une pontos de igual concentração geoquímica antes e após a alteração. A inclinação desta reta define a mudança de massa na alteração e o desvio de um ponto da isocon define a mudança de concentração para o componente correspondente. Assim, a equação da reta isocon é:

$$
C_{i}^{A}=\left(M^{o} / M^{A}\right) C_{i}^{0}, \text { onde: }
$$

$\mathbf{C}_{\mathbf{i}} \mathbf{A}=$ concentração do elemento $\mathbf{i}$ na amostra alterada, $\mathbf{C}_{\mathbf{i}}{ }^{\mathbf{0}}=$ concentração do elemento $\mathrm{i}$ na amostra original, $\mathbf{M}^{\mathbf{0}}=$ massa inicial, $\mathbf{M}^{\mathbf{A}}=$ massa após a alteração.

Este método pode ser utilizado para representar diferentes estágios de alteração simultaneamente em um mesmo gráfico. Neste caso, cada estágio de alteração será representado por uma isocon.

Das amostras de tonalito analisadas ao longo da travessa de acesso à galeria do nível 54 da mina, (Figura 6.5), foram selecionadas as amostras R-1 (tonalito menos alterado, do início da travessa, próxima à rampa de descida), R-11 (tonalito pouco alterado da zona de alteração distal, localizado a uma distância de $40 \mathrm{~m}$ do início da travessa) e R-27 (tonalito alterado dentro da zona de alteração proximal, na parede ao lado do veio quartzo-aurífero).

Para as amostras R-1/R-27 foi possível traçar uma isocon, considerando-se que $\mathrm{TiO}_{2}$, $\mathrm{Fe}_{2} \mathrm{O}_{3}$ e $\mathrm{SiO}_{2}$ apresentam um comportamento relativamente imóvel e definem uma reta $\mathrm{C}^{\mathrm{A}}=$ $0,93 \mathrm{C}^{0}$, que representa um pequeno aumento de massa, de aproximadamente $7 \%$, de acordo com a Figura 6.21. As maiores modificações na amostra alterada relacionam-se às concentrações extremamente altas de As e $\mathrm{Au}$ (80000\% de Au e $36000 \%$ de As), enquanto que $\mathrm{CaO}$ e $\mathrm{MgO}$ apresentam aumentos em torno de $45 \%$, enquanto que $\mathrm{Al}_{2} \mathrm{O}_{3} /$ e $\mathrm{Na}_{2} \mathrm{O}$ mostram perdas de cerca de $30 \%$ e $\mathrm{K}_{2} \mathrm{O}$ ao redor de $50 \%$. Esses valores representam os fatores de concentração relativos à isocon estabelecida. As mudanças no quimismo refletem- 
se em variações mineralógicas, com a formação de minerais magnesianos (clorita, actinolita) e, principalmente, de sulfetos (arsenopirita, pirrotita e lollingita) junto com ouro, que caracterizam a paragênese do tonalito na zona de alteração próxima ao veio e nas faixas de rocha tonalítica englobadas dentro do corpo do minério.

O diagrama isocon de Grant (1986), para as amostras de tonalito R-11 e R-27, Figura 6.22, mostra que a alteração é aproximadamente isovolumétrica, com os componentes maiores (óxidos) e os elementos Au e As, apresentando comportamento relativamente imóvel, principalmente, quando se compara aos seus valores de concentração na zona proximal. Este padrão está de acordo com a alteração hidrotermal na zona distal, que se apresenta pouco acentuada.

Das amostras de tonalito analisadas ao longo do Furo SH-140, foram selecionadas as amostras SHN-11 (tonalito pouco alterado, profundidade de $250 \mathrm{~m}$ ), SHN-17 (tonalito alterado da zona distal de alteração, profundidade de $285 \mathrm{~m}$ ) e SHN-29 (tonalito alterado da zona proximal de alteração, profundidade de 330m). Nos diagramas isocon de Grant (1986), construídos para essas amostras, Figura 6.23 (Amostras SHN-11/SHN-17) e Figura 6.24 (Amostras SHN-11/SHN-29), observa-se que tanto para o tonalito da zona distal como para aquele da zona proximal de alteração, as mudanças químicas ocorrem de maneira isovolumétrica, com os elementos apresentando comportamento relativamente imóvel. As altas concentrações de As e Au, no caso das amostras SHN-11 e SHN-29, com grandes aumentos de cerca de $17580 \%$ de Au e $9080 \%$ de As, refletem a formação de sulfetos (arsenopirita, pirrotita e lollingita) e ouro na zona proximal de alteração, associada com a fase I de mineralização. Esses valores representam os fatores de concentração relativos à isocon estabelecida.

O halo de ocorrência de As e Au, em torno do sistema filoniano, acha-se ilustrado nas Figuras 6.25 e 6.26 , nos furos de sondagem interna realizados no nível $345 \mathrm{~m}$ da mina (Figura 4.1 , onde se verifica a alta correlação entre estes elementos. Estudos mais detalhados sobre o comportamento destes elementos e sua interação com a rocha encaixante, fazem parte de trabalhos futuros.

As Figuras 6.27a e b exibem perfis da variação da composição dos óxidos, das amostras de tonalito coletadas ao longo da travessa de acesso à galeria do nível $54 \mathrm{~m}$ e do Furo SH-140. 


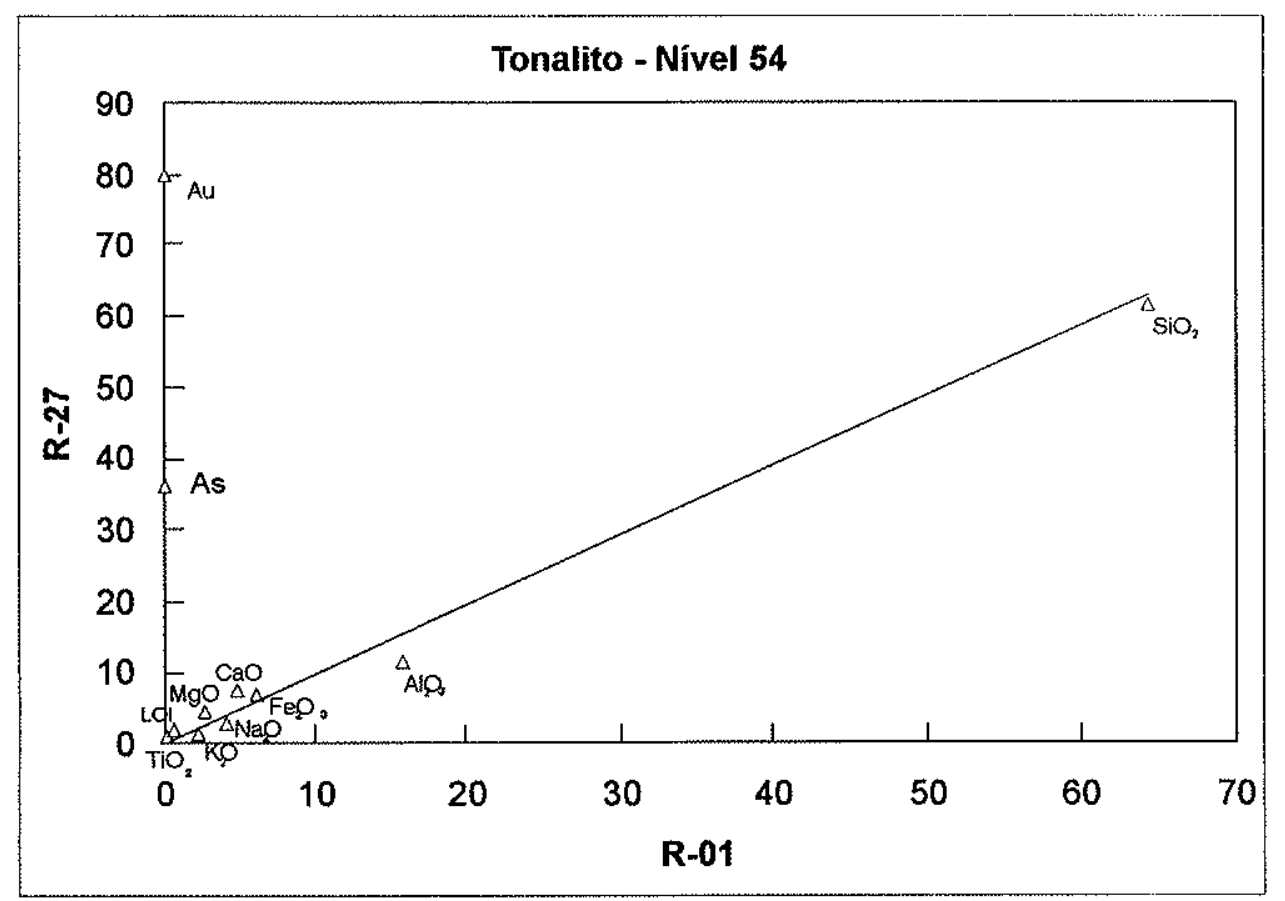

$\mathrm{C}^{\mathrm{A}}=0,93 \mathrm{C}^{\circ}$, portanto $\mathrm{M}^{\mathrm{A}} / \mathrm{M}^{\circ}=1.07$, o que representa um ganho de massa de $7 \%$

Figura 6.21 - Representação gráfica, através do diagrama isocon (Grant 1986), do balanço de massa entre as amostras de tonalito R-01 (amostra pouco alterada) e R-27 (amostra alterada da zona proximal), da travessa de acesso ao nível $54 \mathrm{~m}$ da mina. O melhor alinhamento dos pontos define uma isocon com inclinação 0,93 , representando um aumento de massa de 7\%. Óxidos lançados em porcentagem em peso e elementos traços em $0,01 \mathrm{ppme}$ e $0,01 \mathrm{ppb}$.

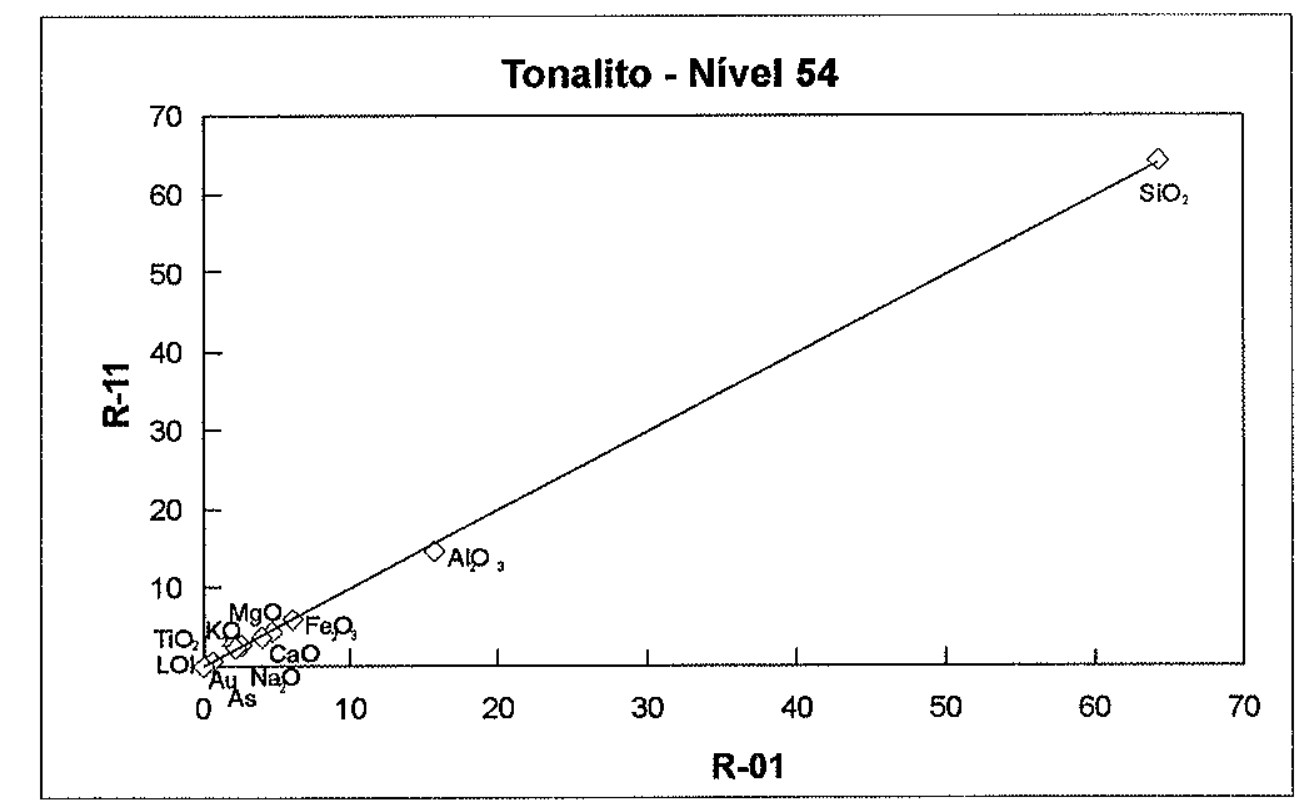

$\mathrm{C}^{\mathrm{A}}=0.99 \mathrm{C}^{\mathrm{o}}$, portanto $\mathrm{M}^{\mathrm{A}} / \mathrm{M}^{\mathrm{O}}=1.01$, o que representa um ganho de massa de $1 \%$.

Figura 6.22 - Representação gráfica, através do diagrama isocon (Grant 1986), do balanço de massa entre as amostras de tonalito R-01 (amostra pouco alterada) e R-11 (amostra levemente alterada da zona distal), da travessa de acesso ao nível $54 \mathrm{~m}$ da mina. O melhor alinhamento dos pontos define uma isocon com inclinação 1.00 , representando um aumento de massa de $1 \%$. Óxidos lançados em porcentagem em peso e elementos traços em $0,01 \mathrm{ppm}$ e $0,01 \mathrm{ppb}$. 


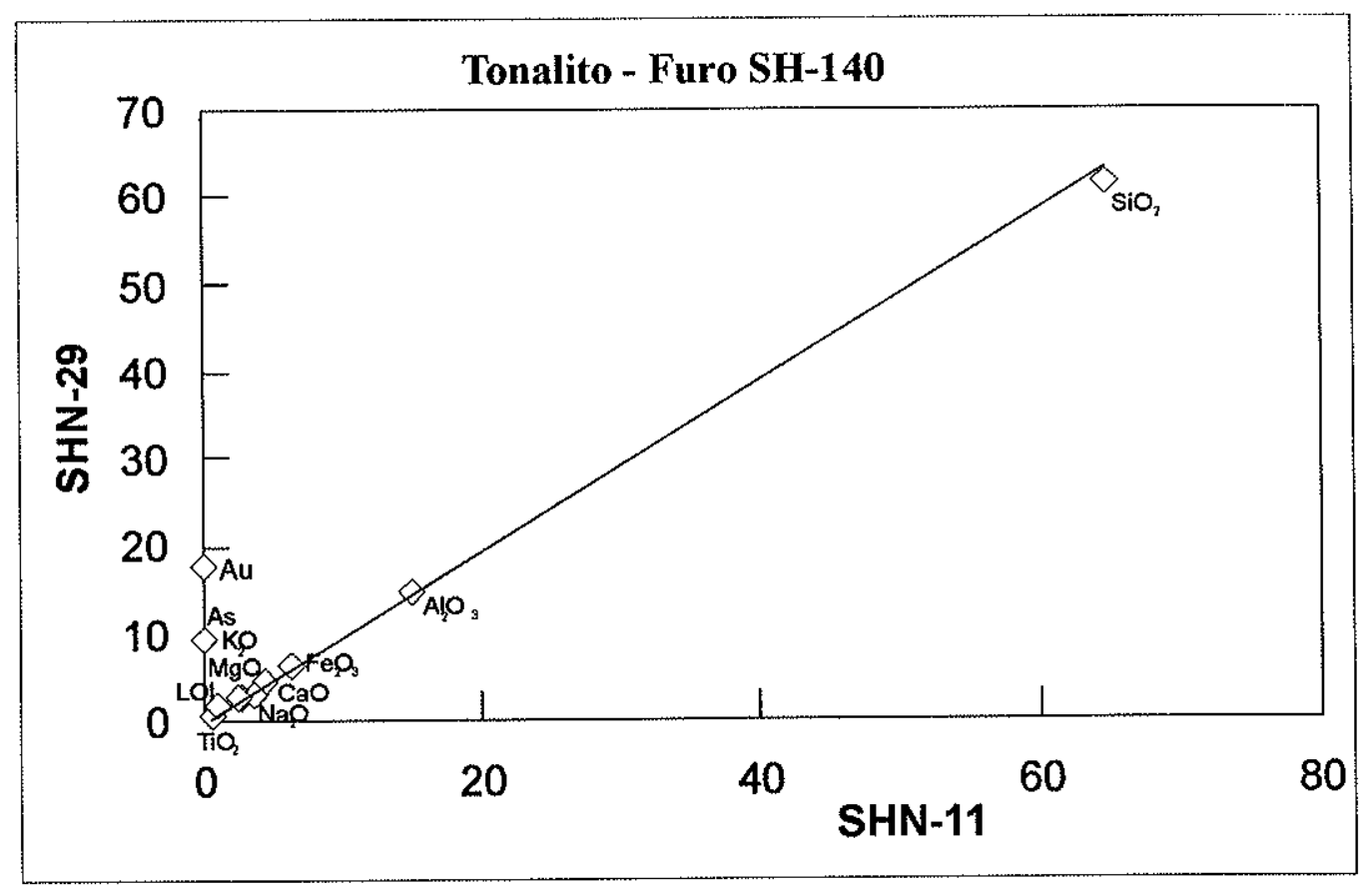

$\mathrm{C}^{\mathrm{A}}=0.99 \mathrm{C}^{\circ}$, portanto $\mathrm{M}^{\mathrm{A}} / \mathrm{M}^{\circ}=1.01$, o que representa um ganho de massa de $1 \%$.

Figura 6.23 - Representação gráfica, através do diagrama isocon (Grant 1986), do balanço de massa entre as amostras de tonalito SHN-11 (amostra pouco alterada) e SHN-29 (amostra alterada da zona proximal), do furo de sondagem SH-140, localizado na capa do corpo de minério. A isocon apresenta uma inclinação de aproximadamente 1.00 , caracterizando uma alteração isovolumétrica. Óxidos lançados em porcentagem em peso e elementos traços em $0,01 \mathrm{ppm}$ e $0,01 \mathrm{ppb}$.

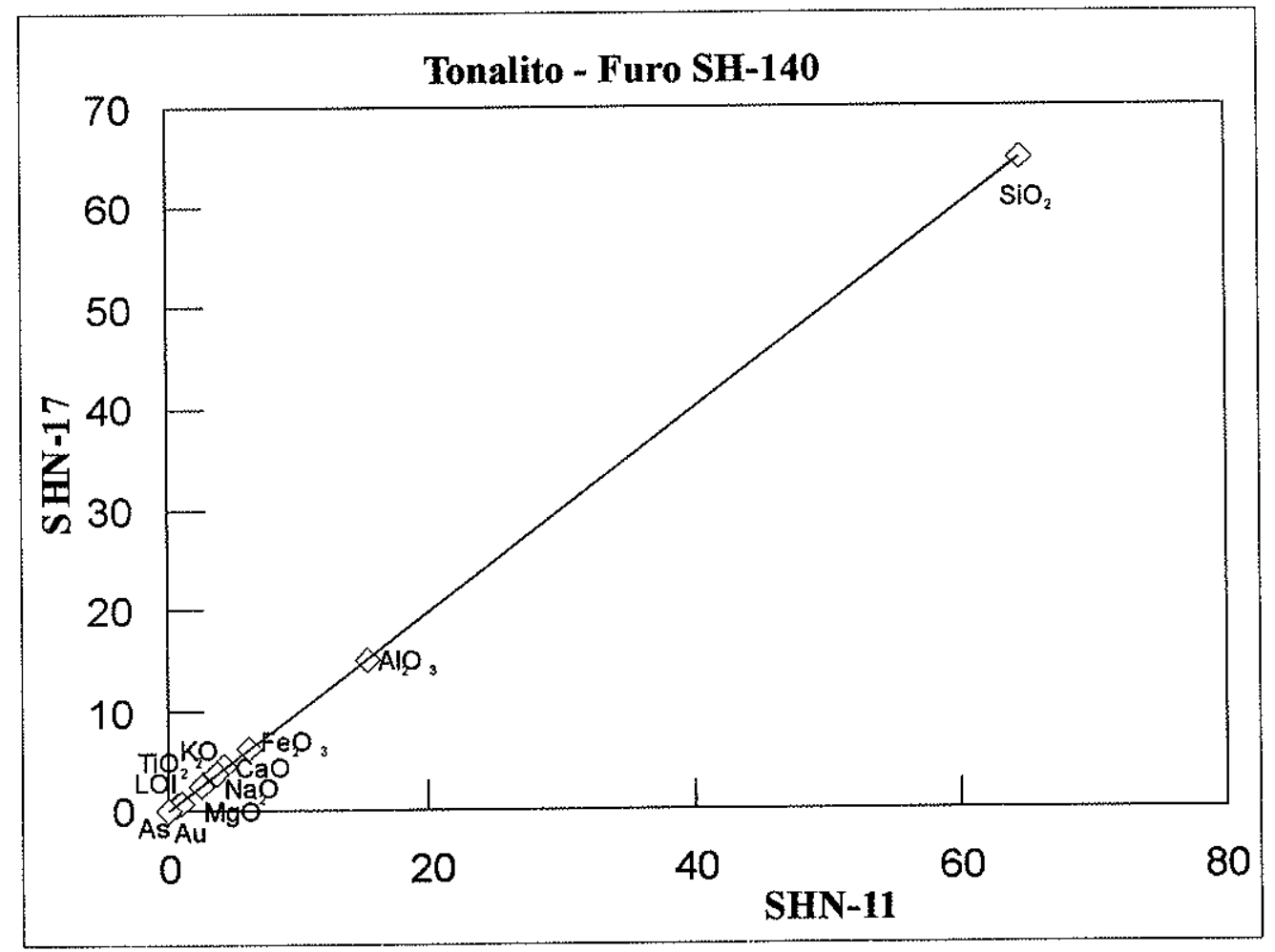

$\mathrm{C}^{\mathrm{A}}=0.99 \mathrm{C}^{\circ}$, portanto $\mathrm{M}^{\mathrm{A}} / \mathrm{M}^{\circ}=1.01$, o que representa um ganho de massa de $1 \%$.

Figura 6.24 - Representação gráfica, através do diagrama isocon (Grant 1986), do balanço de massa entre as amostras de tonalito SHN-11 (amostra pouco alterada) e SHN-17 (amostra levemente alterada da zona distal), do furo de sondagem SH-140, localizado na capa do corpo de minério. A isocon apresenta uma inclinação de aproximadamente 1.00 , caracterizando uma alteração isovolumétrica. Óxidos lançados em porcentagem em peso e elementos traços em $0,01 \mathrm{ppm} \mathrm{e} 0,01 \mathrm{ppb}$. 


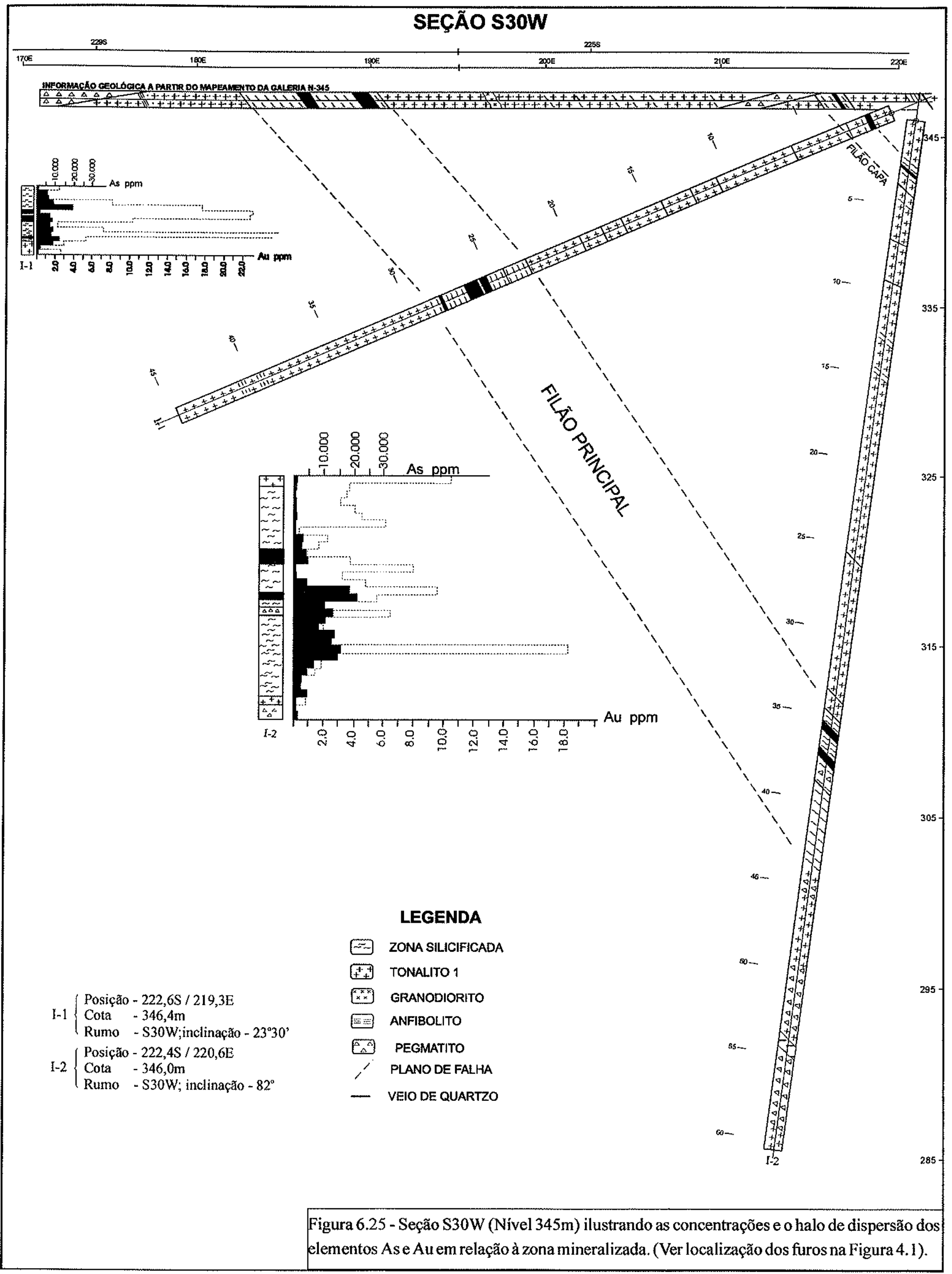




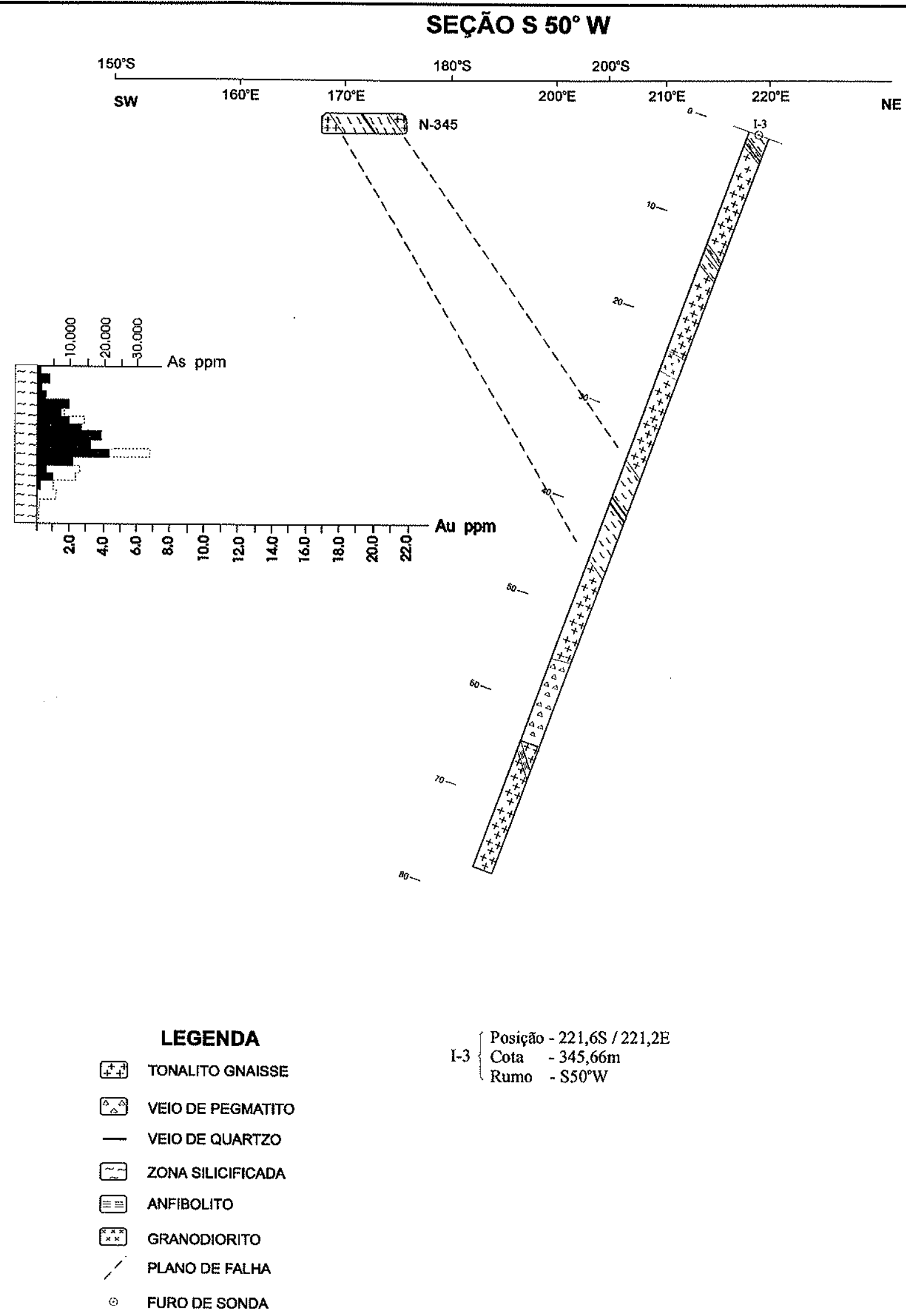

Figura 6.26 - Seção S30W (Nivel 345m) ilustrando as concentrações e o halo de dispersão dos elementos As e Au em relação à zona mineralizada. (Ver localização do furo na Figura4.1). 


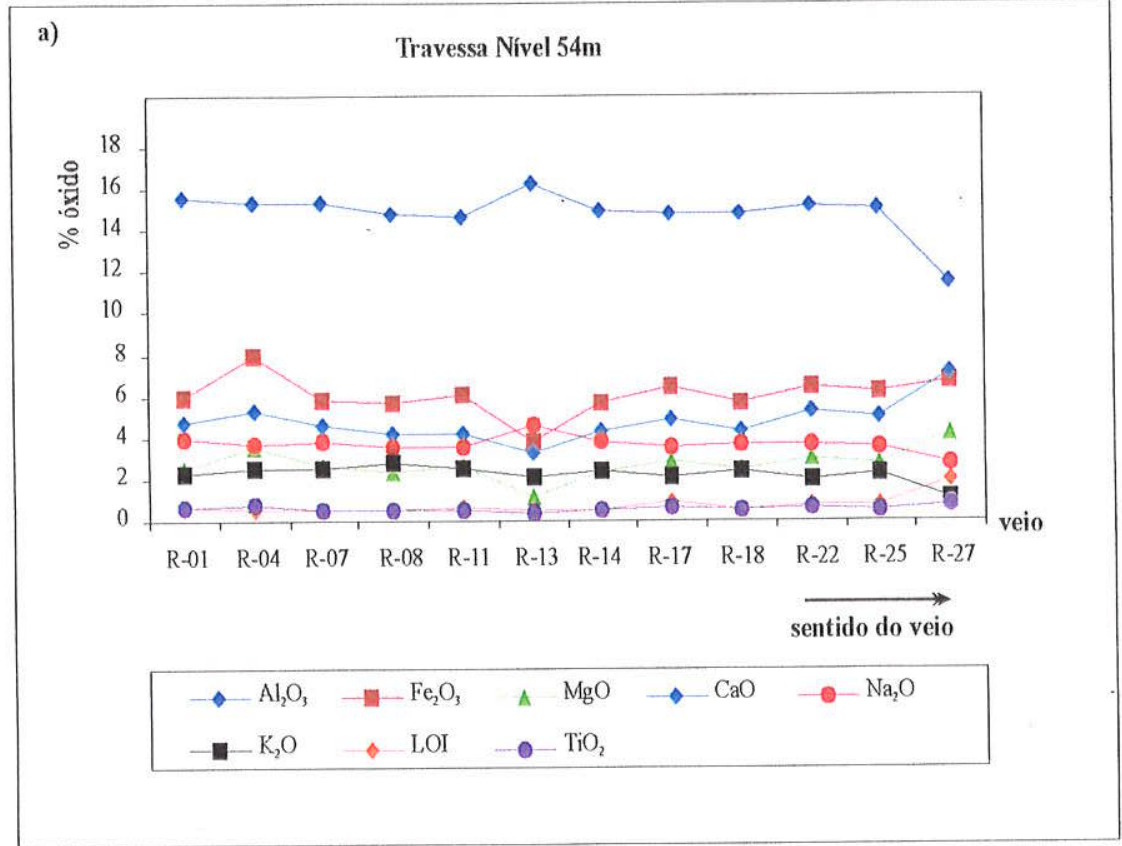

b)

Furo SH-140

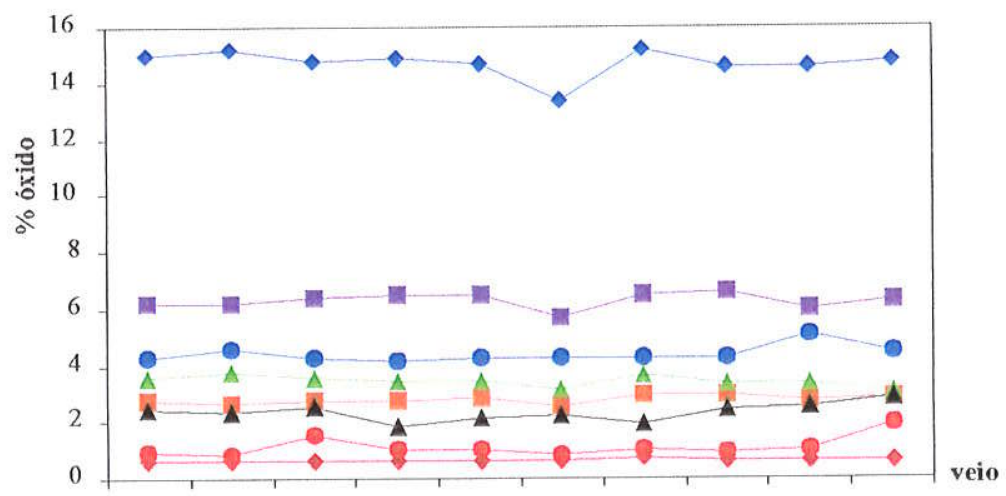

shn-11 shn-17 shn-18 shn-20 shn-23 shn-24 shn-25 shn-27 shn-28 shn-29

sentido do veio

\begin{tabular}{|c|c|c|c|}
\hline $\begin{array}{ll}\Rightarrow & \mathrm{Al}_{2} \mathrm{O}_{3} \\
& \mathrm{Na}_{2} \mathrm{O}\end{array}$ & $\begin{array}{l}-\mathrm{Fe}_{2} \mathrm{O}_{3} \\
-\mathrm{K}_{2} \mathrm{O}\end{array}$ & $\begin{array}{ll} & \mathrm{MgO} \\
& \mathrm{TiO}_{2}\end{array}$ & $\begin{array}{l}-\mathrm{CaO} \\
-\mathrm{LOI}\end{array}$ \\
\hline
\end{tabular}

Figura 6.27 - Perfis mostrando a variação da composição dos óxidos das amostras de tonalito coletadas ao longo: a) da travessa de acesso ao nível $54 \mathrm{~m}$ da mina de Salamangone, na lapa do corpo de minério e b) do furo de sondagem SH-140, executado na capa do corpo de minério. 
O comportamento observado, nestes perfis, confirma as análises de ganhos e perdas, segundo Gresens (1967), de uma alteração isovolumétrica, sob condições de volume de rocha constante, principalmente na zona distal de alteração, ocorrendo pequenos ganhos de $\mathrm{MgO}$, $\mathrm{CaO}$, LOI e perdas de $\mathrm{Al}_{2} \mathrm{O}_{3}, \mathrm{~K}_{2} \mathrm{O}$ e $\mathrm{Na}_{2} \mathrm{O}$ relacionados à alteração dos minerais ferromagnesianos e à formação de clorita e actinolita, na zona proximal. Esta interpretação é apoiada pelos estudos petrográficos das amostras alteradas, que mostram que os minerais primários acham-se bem preservados, com indícios pequenos de alteração, mesmo na zona mais próxima à mineralização. As manifestações mais acentuadas da alteração acham-se expressas pelos altos conteúdos de $\mathrm{As}$ e $\mathrm{Au}$, que guardam uma relação direta com o aumento de sulfetos, na zona proximal e e na fase I da mineralização. Contudo, deve ser lembrado que a presente paragênese de alteração representa o resultado de vários episódios superpostos, o que dificulta bastante sua caracterização. 


\section{CAPÍTULO 7}

\section{Inclusões Fluidas}

A caracterização de sistemas fluidais por meio do estudo de inclusões fluidas, aprisionadas em minerais de minério ou de ganga, representa elemento importante na determinação das propriedades PVTX (pressão, volume/densidade, temperatura e composição) dos fluidos mineralizantes, assim como à compreensão dos processos responsáveis pela deposição do minério.

O trabalho de Roedder (1984) apresenta, ainda, o melhor sumário sobre os registros de inclusões fluidas em depósitos de ouro, embora os estudos venham se ampliando rapidamente nos últimos anos. Cristais de quartzo, de filões quartzosos auríferos, revelam um número muito grande de inclusões primárias que, via de regra, estão relacionadas com os fluidos responsáveis pela mineralização. No entanto, em muitos depósitos, esta correlação é complexa, pois esses fluidos se introduziram em fases posteriores à cristalização inicial do quartzo, deixando registro em algumas gerações de inclusões secundárias, correspondentes a vários estádios de recristalização associados a períodos de deformação e metamorfismo.

\subsection{OCORRÊNCIA E NATUREZA DAS INCLUSÕES FLUIDAS}

O sistema filonar do depósito de Salamangone apresenta feições de desenvolvimento dinâmico, impressas no quartzo na forma de deformações do tipo recristalização e fraturamentos, mostrando estruturas do tipo núcleo e borda (core and mantle, recristalizadas). Essa deformação implicou na dificuldade de preservação das inclusões primárias e até mesmo, das pseudosecundárias. As inclusões passíveis de serem estudadas restringiram-se aos cristais de quartzo menos afetados pela deformação dos veios, encontrando-se localizadas, invariavelmente, em microfraturas cicatrizadas (planos de inclusões fluidas), mostrando orientações diversas, Figura 7.1a.

As microfraturas, normalmente cruzam os limites dos grãos (intergranulares), Figuras $7.1 \mathrm{~b}$ e $7.1 \mathrm{c}$, e as inclusões fluidas não mostram modificações próximas à interseç̧ão das bordas. Com base nos critérios de Roedder (1984), essas inclusões são interpretadas como secundárias em relação aos cristais de quartzo hospedeiro. Algumas vezes, essas microfraturas restringem-se a um grão (intragranular). 

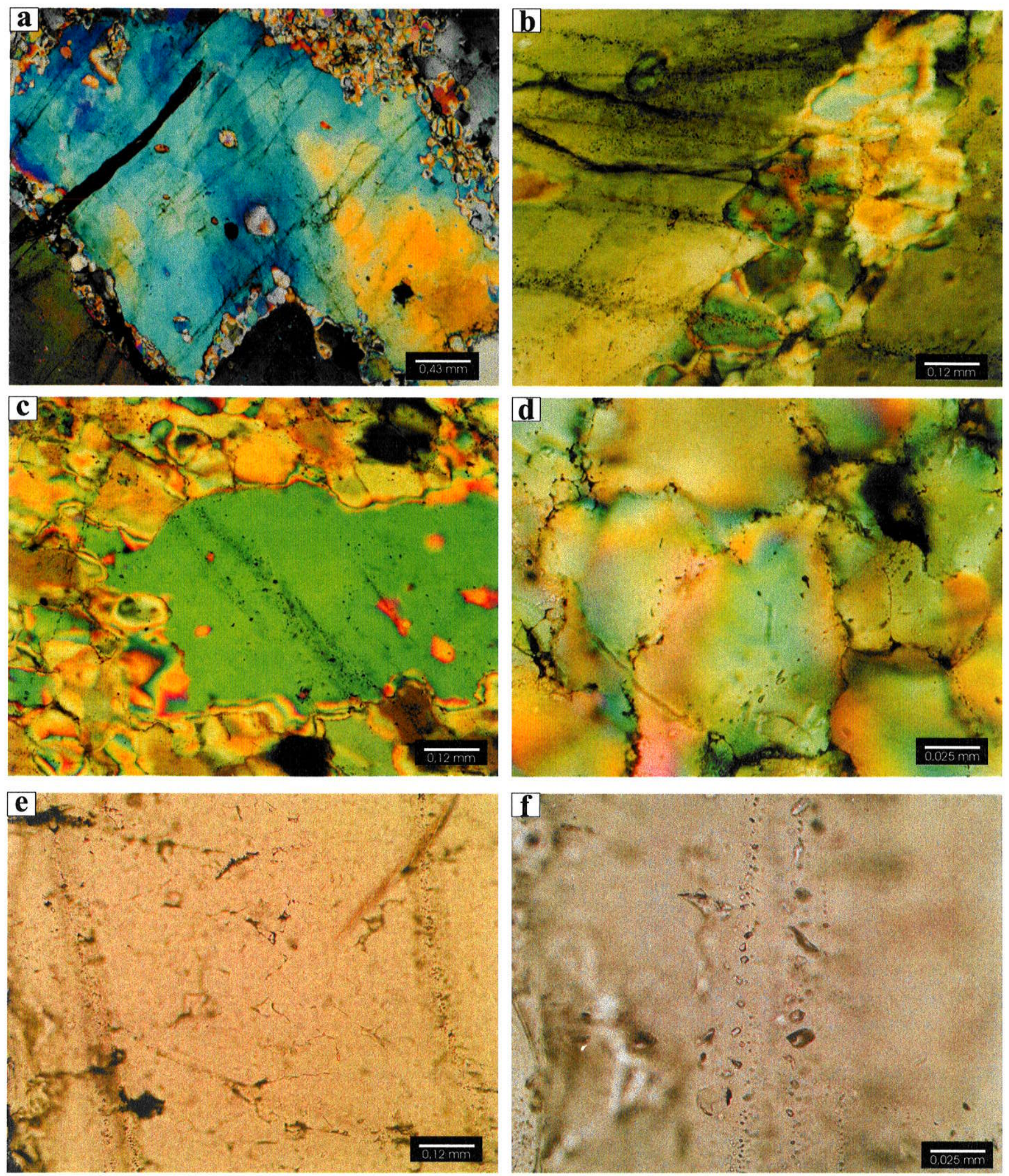

Figura 7.1 - Aspectos da forma de ocorrência das inclusões fluidas em quartzo do depósito de Salamangone: a) Microfraturas cicatrizadas, constituindo planos de inclusões fluidas, que atravessam núcleos e zonas recristalizadas de quartzo (Nx), b e c) Microfraturas transgranulares invadindo relictos maiores de quartzo e bordas recristalizadas (Nx), d) Inclusões fluidas decorando os limites de grãos de quartzo na zona recristalizada $(\mathrm{Nx})$, e) Trilhas de inclusões fluidas aquossalinas do grupo 1, sistema salino complexo $\mathrm{Ca} \pm \mathrm{As}$ (?), em amostra de quartzo não orientada (SL-04, corpo Lapa, nível 274m da mina) (N//), f) Detalhe da trilha da fotografia anterior $(\mathrm{N} / /)$. 
Inclusões fluidas decorando as bordas de grãos recristalizados Figura 7.1d, e, mais raramente, isoladas nos seus interiores, também são observadas, porém com tamanho inadequado para medida. Poderiam representar, segundo Kerrich (1976) e Wilkins \& Barkas (1978), remanescentes de inclusões primárias que escaparam da eliminação durante o processo de recristalização, acompanhando a migração das bordas dos grãos recristalizados e tendo, na maioria das vezes, sofrido modificações. Os trabalhos desses autores e de Hollister (1990) alertam, quanto aos cuidados que, se deve ter na interpretação de dados obtidos em medidas microtermométricas de inclusões fluidas em quartzo de veios que sofreram efeitos de deformação. Os mesmos demonstram, que em inclusões compostas de água e dióxido de carbono, pode ocorrer perda (leakage) do conteúdo das inclusões, com remoção de $\mathrm{H}_{2} \mathrm{O}$ e enriquecimento de $\mathrm{CO}_{2}$ (chegando a produzir inclusões fluidas somente com $\mathrm{CO}_{2}$ ), resultando em temperaturas de homogeneização anomalamente altas. No caso de inclusões aquosas, o escape de $\mathrm{H}_{2} \mathrm{O}$ (líquido) causaria um aumento da fase vapor, refletindo em mudanças nas temperaturas de homogeneização e nas densidades do fluido.

Com relação à composição, todas as inclusões estudadas são do tipo aquossalinas, com dimensões entre 10 e $15 \mu \mathrm{m}$ e formas irregulares, podendo exibir também padrões ovóides, alongados e de cristal negativo. Em temperatura ambiente apresentam-se normalmente bifásicas $\left(\mathrm{H}_{2} \mathrm{O}\right.$ líquida $+\mathrm{H}_{2} \mathrm{O}$ vapor $)$, com a fase vapor representado de 10 a $15 \%$ do volume total da inclusão. Algumas inclusões fluidas exibem feições de estrangulamento, escape de fluidos e crepitação, com formas regulares a irregulares e coloração escura.

\section{2- MICROTERMOMETRIA DAS INCLUSÕES FLUIDAS}

$O$ estudo das inclusões fluidas foi realizado em quartzo de amostras de veios mineralizados e estéreis, e em quartzo de pegmatitos que cortam esses veios, através da análise de seções delgadas, com polimento em ambas as faces. Seu desenvolvimento consistiu de duas etapas: a primeira, de reconhecimento petrográfico, mapeamento e descrição das inclusões fluidas, e a segunda, onde foram efetuadas as medidas microtermométricas das temperaturas do ponto eutético (Te), da fusão do gelo ( $\mathrm{Tfg}$ ) e de homogeneização (Th L-V), visando a caracterização dos parâmetros físico-químicos (densidade, salinidade e composição), e a definição dos tipos de sistemas salinos.

Para uma caracterização inicial das inclusões fluidas foram utilizadas amostras não orientadas, sendo quatro de veios de quartzo mineralizados e uma de veio estéril. Os resultados obtidos fundamentaram uma segunda etapa de trabalho, com seções orientadas, 
visando a definição da direção dos planos de inclusões fluidas, identificação dos sistemas de microfraturamentos e do seu relacionamento com o cisalhamento original.

Nos veios mineralizados, os estudos microtermométricos indicaram a existência de inclusões fluidas aquossalinas que puderam ser agrupadas, em termos composicionais, em três tipos distintos: grupo 1 - temperaturas eutéticas extremamente baixas, atingindo valores de até $-84^{\circ} \mathrm{C}$, e salinidades elevadas ( $>$ equiv. $23 \%$ em peso do $\mathrm{NaCl}$ ); grupo 2 , subgrupo $2 \mathrm{a}$ temperaturas eutéticas mais elevadas (de -54 a $-37,5^{\circ} \mathrm{C}$ ) e salinidades variáveis de valores equivalentes a 4,8 - 13,9\% em peso do $\mathrm{NaCl}$; grupo 2, subgrupo $2 \mathrm{~b}$ - temperaturas eutéticas semelhantes às anteriores e salinidades extremamente baixas (< equiv. a 5\% em peso do $\mathrm{NaCl})$; grupo 3 - temperaturas eutéticas intermediárias $\left(-68\right.$ a $\left.-56^{\circ} \mathrm{C}\right)$ e salinidades variando de valores equivalentes a 16,0 até $20,2 \%$ em peso do $\mathrm{NaCl}$, predominantemente. Essas informações são apresentadas, de forma simplificada, no quadro abaixo:

\begin{tabular}{l|c|c|c} 
& & $\begin{array}{c}\mathrm{T}(\mathrm{eut}) \\
{ }^{\circ} \mathrm{C}\end{array}$ & $\begin{array}{c}\text { Salinidade } \\
\text { Equiv. \% em peso Nacl }\end{array}$ \\
\hline Grupo 1 & & $-84 \mathrm{a}-78,0$ & $>23 \%$ \\
\hline Grupo 2 & Subgrupo 2a & $-54 \mathrm{a}-37,5$ & $4,8-13,9$ \\
\cline { 2 - 4 } & Subgrupo 2b & $-54 \mathrm{a}-37,5$ & $<5 \%$ \\
\hline Grupo 3 & & $-68 \mathrm{a}-56$ & $16-20,2$
\end{tabular}

Nos quartzo dos veios estéreis foram identificadas apenas inclusões de composições semelhantes às dos grupos 2 (subgrupo 2a) e 3 descritos acima.

Realizou-se, ainda, um estudo das inclusões fluidas em quartzo de corpos pegmatíticos, que seccionam o sistema filoneano, visando estabelecer uma provável correlação entre os fluidos presentes nos dois casos. Foram analisadas inclusões secundárias, presentes em trilhas transgranulares e também aquelas distribuídas segundo agrupamentos, sem orientação, com feições sugestivas de serem primárias. Nas trilhas, foram caracterizadas inclusões de composições semelhantes às dos grupos 2 e 3 , enquanto que nos agrupamentos ocorrem, predominantemente, aquelas similares ao grupo 2 .

Deve ser ressaltado o fato de que, como não ocorreu o desaparecimento da fase vapor durante o resfriamento das inclusões estudadas, a pressão interna desenvolvida não interferiu na determinação do ponto eutético. De acordo com Goldstein \& Reynolds (1994), nessa situação, os valores da Te apresentados podem, realmente, refletir as composições dos sistemas salinos identificados.

A Tabela 7.1 reúne os dados microtermométricos obtidos nos estudos dos veios de quartzo mineralizado e estéril e dos pegmatitos. Para os cálculos de salinidade e densidade 
foram utilizados diagramas composicionais de sistemas salinos e o software Flincor, de Brown (1989).

\subsubsection{Estudos em veios mineralizados, auríferos}

As amostras de veio de quartzo auríferos foram selecionadas nas frentes de lavra dos filões Lapa e Principal, nos níveis 264 e 290m de desenvolvimento da mina, respectivamente. A amostra de veio de quartzo estéril foi coletada no Furo de sondagem $\mathrm{SH}-46$.

\subsubsection{Veios mineralizados não orientados}

Os dados microtermométricos em amostras de quartzo, de diferentes veios auríferos, foram tomados em inclusões bifásicas (fase aquosa líquida + fase aquosa vapor) dispostas em trilhas intergranulares, sendo, portanto, secundárias. De acordo com os valores obtidos para a primeira fusão (temperatura do eutético) foram caracterizados, segundo sua composição, três sistemas aquossalinos distintos, a saber:

\section{a) Sistema salino com eutéticos muito baixos}

Grupo 1 - os valores obtidos para a temperatura do ponto eutético (Te), em 66 inclusões investigadas, variaram entre $-81^{\circ} \mathrm{C}$ e $-73^{\circ} \mathrm{C}$, com maior freqüência entre $-80^{\circ} \mathrm{C}$ e $76^{\circ} \mathrm{C}$, Figura 7.2a. Os valores da temperatura de fusão final do gelo (Tfg), de um total de 62 inclusões, variaram entre $-39^{\circ} \mathrm{C} \mathrm{e}-7^{\circ} \mathrm{C}$, caracterizando dois intervalos distintos: (a) entre $-39 \mathrm{e}$ $-29^{\circ} \mathrm{C}$ com maior freqüência de -39 a $-36^{\circ} \mathrm{C}$; (b) entre $-16^{\circ} \mathrm{C}$ e $-7^{\circ} \mathrm{C}$, com maior freqüência de 16 a $-14^{\circ} \mathrm{C}$ Figura $7.2 \mathrm{~b}$. A temperatura de homogeneização para a fase líquida, Th L-V (L), de 46 inclusões estudadas apresentou grande espalhamento, distribuindo-se entre $80^{\circ} \mathrm{C}$ e $190^{\circ} \mathrm{C}$, com maior freqüência entre $110^{\circ} \mathrm{C}$ a $160^{\circ} \mathrm{C}$, Figura $7.2 \mathrm{c}$ e Figuras 7.1e, e 7.1f.

Esse grupo de inclusões apresentou valores de Te fortemente negativos $\left(-81^{\circ} \mathrm{C}\right.$ a $73^{\circ} \mathrm{C}$ ) que, segundo Borisenko (1978), seriam indicativos de sistemas salinos com participação de $\mathrm{Li}$ e outros cátions $(\mathrm{Ca}, \mathrm{K}, \mathrm{Na}, \mathrm{Mg})$, que contribuem para o abaixamento da Te. Alguns autores, como Burrus (1997 e 1998) e Bodnar (1998) explicam os valores muito negativos da Te através de um fenômeno de crescimento de cristais de gelo, a partir do seu pleno estado de congelamento. Representaria assim, um rearranjo dos cristais de gelo em crescimento.

Valores muito baixos de Te também são citados em Davis et al. (1990), Goldstein \& 
Reynolds (1994) e Goldstein (2001), como representantes de sistemas com $\mathrm{MgCl}_{2}$ ou $\mathrm{CaCl}_{2}$. Os autores citam valores de Te de até $-90^{\circ} \mathrm{C}$ no sistema $\mathrm{NaCl}-\mathrm{CaCl}_{2}-\mathrm{H}_{2} \mathrm{O}$ e de até $-80^{\circ} \mathrm{C}$, no sistema $\mathrm{NaCl}-\mathrm{MgCl}_{2}-\mathrm{H}_{2} \mathrm{O}$, decorrentes da formação de hidratos metaestáveis durante $\mathrm{o}$ congelamento.

Por outro lado, Bodnar (1998) levanta a questão de que a quantidade de líquido gerada nas temperaturas do eutético, está diretamente relacionada à salinidade. De forma que, em casos de salinidade muito baixa, a observação da Te seria difícil, pois pouco líquido seria formado no início da fusão, especialmente se as inclusões forem pequenas.

No grupo estudado, embora as inclusões possuam dimensões entre 10 e $15 \mu \mathrm{m}$, a Te foi facilmente obtida, por apresentarem salinidades médias a elevadas. Dessa forma, podem representar sistemas salinos complexos, envolvendo $\mathrm{Ca}$, além de outros cátions, que teriam sido liberados da rocha tonalítica encaixante (hornblenda, biotita e feldspatos) quando da percolação dos fluidos hidrotermais. Merece ainda ser levada em consideração, a alta concentração de As, na zona proximal de alteração e nos ribbons, relacionada com o processo de sulfetação da encaixante, na fase 1 de mineralização. A adição desse cátion à fase fluida, também, poderia ter sido responsável pelo rebaixamento das temperaturas eutéticas, segundo discussões de Yardley (1997).

As inclusões desse grupo apresentam as maiores salinidades, em relação a todas as outras obtidas nas seções não orientadas, com valores equivalentes a 10,5 - 19,4\% em peso do $\mathrm{NaCl}$ e valores maiores que os equivalentes a $23 \%$ em peso do $\mathrm{NaCl}$, dependendo da amostra considerada, Tabela 7.1.

\section{b)-Sistema salino com eutéticos entre $-53^{\circ} \mathrm{C}$ e $-41^{\circ} \mathrm{C}$}

Grupo 2 - constitui a grande maioria das inclusões fluidas estudadas nas amostras não orientadas de veios de quartzo. Os valores de Te, medidos em 102 inclusões, variaram entre $53^{\circ} \mathrm{C}$ e $-41^{\circ} \mathrm{C}$, com intervalos de maior freqüência entre $-46^{\circ} \mathrm{C}$ e $-42^{\circ} \mathrm{C}$, Figura $7.3 \mathrm{a}$. A temperatura de fusão final do gelo ( $\mathrm{Tfg}$ ), em 91 inclusões, variou entre $-9^{\circ} \mathrm{C}$ e $-1^{\circ} \mathrm{C}$, com intervalo de maior concentração entre $-5^{\circ} \mathrm{C}$ e $-3^{\circ} \mathrm{C}$, predominando o subgrupo $2 \mathrm{a}$, Figura $7.3 \mathrm{~b}$. A temperatura de homogeneização para a fase líquida - Th $\mathrm{L}-\mathrm{V}$ (L) - de 100 inclusões, distribuiu-se entre $120^{\circ} \mathrm{C}$ e $230^{\circ} \mathrm{C}$, com intervalo de maior freqüência entre $140^{\circ} \mathrm{C} \mathrm{e} 160^{\circ} \mathrm{C}$, Figura $7.3 \mathrm{c}$ e Figuras $7.4 \mathrm{a}$ e $7.4 \mathrm{~b}$.

Foram observadas, com menor freqüência, inclusões com Te situado entre $-62^{\circ} \mathrm{C}$ e $58^{\circ} \mathrm{C}$, assemelhando-se, nestas temperaturas, ao grupo 3, porém com Tfg bem mais elevadas, variando entre $-3^{\circ} \mathrm{C}$ e $-2^{\circ} \mathrm{C}$, não tendo sido obtidas medidas as $\mathrm{Th}(\mathrm{L}-\mathrm{V})$. 


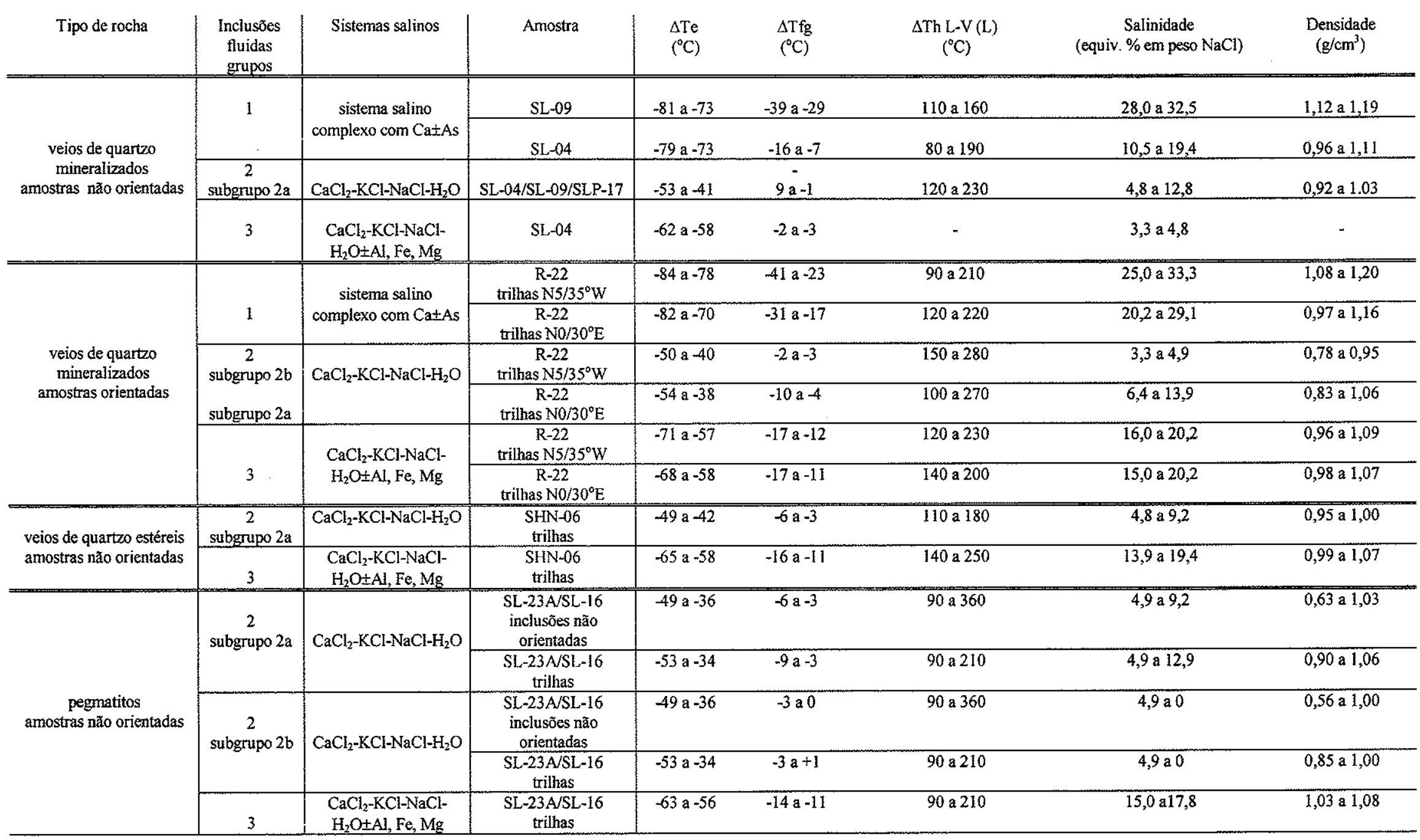

Tabela 7.1 - Sumário dos dados microtermométricos e características das inclusões fluidas aquossalinas presentes em veios de quartzo mineralizados e estéreis e em pegmatitos associados, do depósito de Salamangone. $\Delta \mathrm{Te}\left({ }^{\circ} \mathrm{C}\right)=$ variação das temperaturas eutéticas das soluções; $\Delta \mathrm{Tfg}\left({ }^{\circ} \mathrm{C}\right)=$ variação das temperaturas de fusão do gelo; $\Delta \mathrm{Th} \mathrm{L}-\mathrm{V}(\mathrm{L})\left({ }^{\circ} \mathrm{C}\right)=$ variação das temperaturas de homogeneização das inclusões (homogeneização para o líquido). 


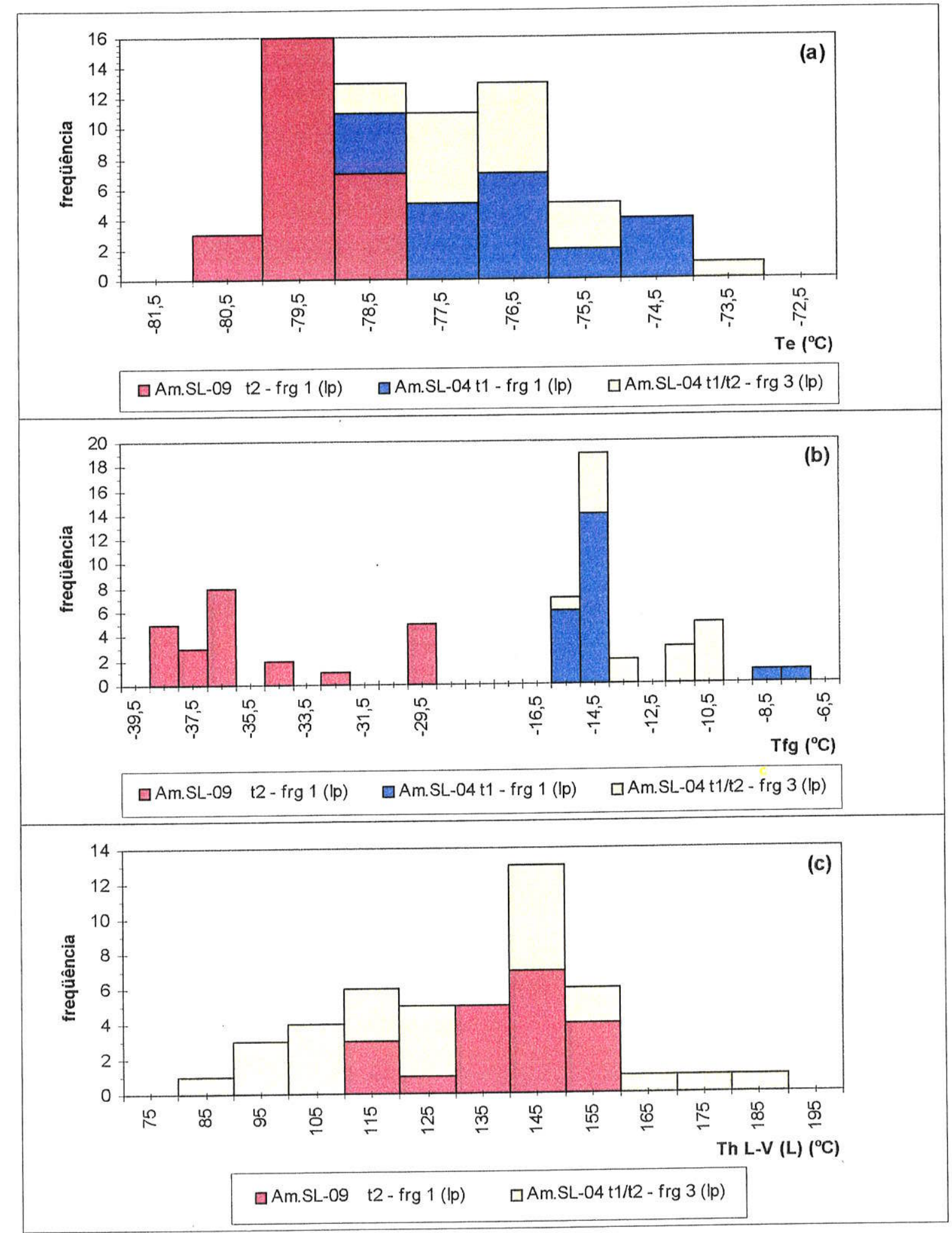

Fig. 7.2 - Histogramas de freqüência das temperaturas de mudança de fase das inclusões, em quartzo, dispostas em trilhas de amostras mineralizadas, não orientadas, compostas por sistemas salinos complexos: (a) Temperaturas do eutético - Te; (b) Temperaturas de fusão do gelo - Tfg; (c) Temperaturas de homogeneização - ThL-V (L).

$(A m=$ amostra $; t=$ trilha frg $=$ fragmento da amostra l $p=$ corpo lapa $)$. 


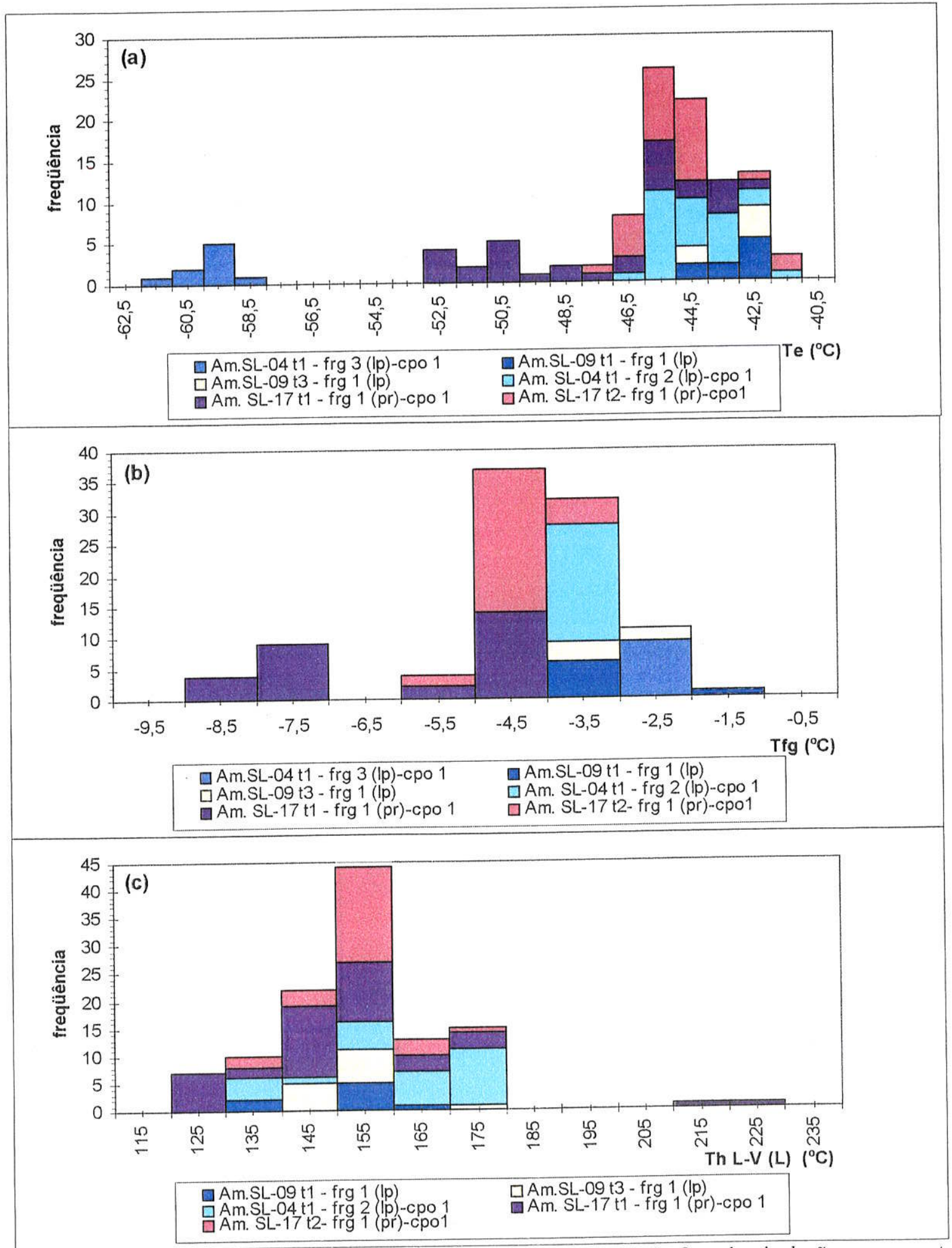

Fig. 7.3- Histogramas de freqüência das temperaturas de mudança de fase das inclusões, em quartzo, dispostas em trilhas de amostras mineralizadas, não orientadas: (a) Temperaturas do eutético - Te; (b) Temperaturas de fusão do gelo - Tfg - para as inclusões de Te mais elevados (sistema $\mathrm{H}_{2} \mathrm{O}-\mathrm{NaCl}-\mathrm{CaCl}{ }_{2}$ ) e intermediários; (c) Temperaturas de homogeneização - Th L-V (L) - para as inclusões do sistema $\mathrm{H}_{2} \mathrm{O}$ $\mathrm{NaCl}-\mathrm{CaCl}_{2}$. $(\mathrm{Am}=$ amostra; $\mathrm{t}=$ trilha; $\mathrm{frg}=$ fragmento da amostra; $\mathrm{cpo}=$ campo estudado; $\mathrm{l} \mathrm{p}=$ corpo lapa; $\mathrm{pr}=$ corpo principal). 

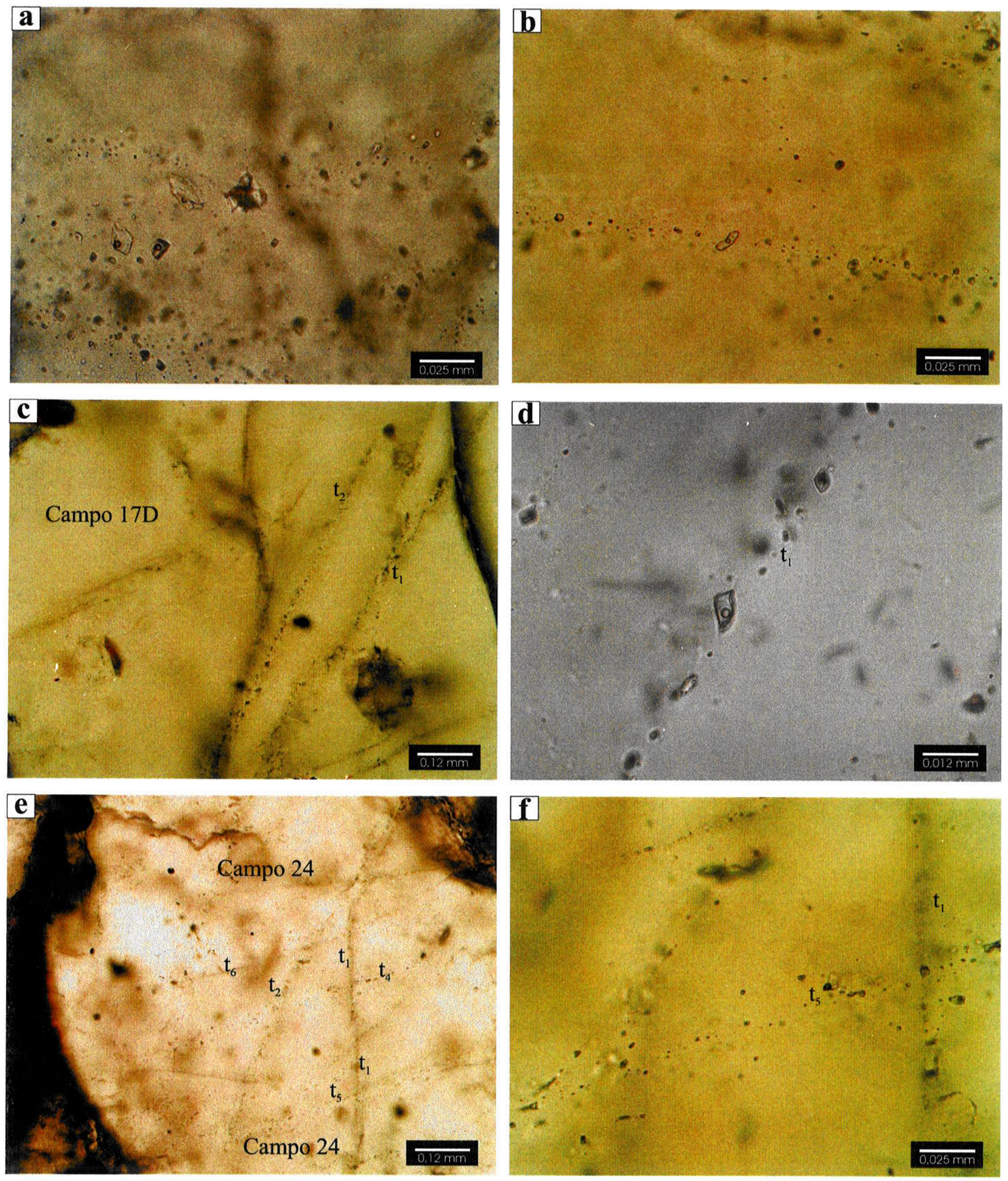

Figura 7.4 - Inclusões fluidas em quartzo de veios mineralizados: a e b) Trilhas de inclusões fluidas aquossalinas do grupo 2a, sistema salino $\mathrm{CaCl}_{2}-\mathrm{KCl}-\mathrm{NaCl}-\mathrm{H}_{2} \mathrm{O}$, em amostras de quartzo não orientadas (SLP-17, corpo Principal, nível 290m da mina e SL03, corpo Lapa, nível $274 \mathrm{~m}$ da mina, respectivamente). As inclusões são sempre bifásicas e, geralmente, apresentam formas irregulares (N//), c) Trilhas de inclusões fluidas t1 e t2 do Campo 17D da amostra de quartzo orientada R-22 (corpo Principal, nível $54 \mathrm{~m}$ da mina), com direções entre $\mathrm{N} 20-25^{\circ} \mathrm{W}$, do grupo 1, sistema salino complexo $\mathrm{Ca} \pm \mathrm{As}($ ?) $(\mathrm{N} / /)$, d) Detalhe das inclusões fluidas da trilha t1, da foto anterior (N//), e) Trilhas de inclusões do campo 24 da amostra orientada R-22 (N//), f) Detalhe da trilha t5 do campo 24 , orientada segundo direção $\mathrm{N} 10^{\circ} \mathrm{E}$, com inclusões fluidas do grupo $2 \mathrm{a}(\mathrm{N} / /)$. 
Os resultados das Te obtidos, por analogia com dados experimentais, indicam, na grande maioria dos casos, uma mistura dos sistemas salinos $\mathrm{CaCl}_{2}-\mathrm{H}_{2} \mathrm{O}$ ( $\mathrm{Te}=-49,8^{\circ} \mathrm{C}$ de Borisenko 1978 e Crawford 1981), $\mathrm{CaCl}_{2}-\mathrm{KCl}-\mathrm{H}_{2} \mathrm{O}\left(\mathrm{Te}=-50,5{ }^{\circ} \mathrm{C}\right.$ de Borisenko 1978) e $\mathrm{CaCl}_{2}-\mathrm{NaCl}-\mathrm{H}_{2} \mathrm{O}\left(\mathrm{Te}=-52,0^{\circ} \mathrm{C}\right.$ de Crawford 1981). Deve ser observado que Goldstein \& Reynolds (1994), mencionam eutéticos mais elevados para sistemas compostos por NaCl$\mathrm{CaCl}_{2}-\mathrm{H}_{2} \mathrm{O}$ puros. Davis et al. (1990) mostram que eutéticos abaixo de $-40^{\circ} \mathrm{C}$ são consistentes com a presença de cátions divalentes $\left(\mathrm{Ca}^{2+} \mathrm{e} / \mathrm{ou} \mathrm{Mg}^{2+}\right)$. Os dados de Yanatieva (1946) e Borisenko (1978) permitem sugerir que as Te observadas para o sistema $\mathrm{CaCl}_{2}-\mathrm{NaCl}-\mathrm{H}_{2} \mathrm{O}$ podem variar de -46 a $-55^{\circ} \mathrm{C}$. $\mathrm{O}$ pequeno grupo de inclusões com $\mathrm{Te}$ de $-62^{\circ} \mathrm{C}$ e $-58^{\circ} \mathrm{C}$ poderia indicar a presença do $\mathrm{CaCl}_{2} \mathrm{e}$, possivelmente, $\mathrm{AlCl}_{3}$ e outros cloretos complexos de ferro e/ou magnésio (Roedder 1984; Linke 1958, in Roedder 1984, Borisenko 1978, Luzhnaya \& Vereshtchetina 1946).

De maneira geral, esse grupo de inclusões apresenta salinidades baixas (equivalentes a 3,3 - 12,8\% em peso do $\mathrm{NaCl}$ ) quando são considerados todos os valores de eutéticos mencionados (Tabela 7.1).

\subsubsection{Veios de quartzo mineralizados orientados}

Foram coletadas várias amostras no Filão Principal da galeria do nível $54 \mathrm{~m}$, orientadas segundo a direção local do veio $\left(\mathrm{N} 40^{\circ} \mathrm{W}\right)$, que condiciona a mineralização, das quais foi selecionada apenas uma (R-22), para os estudos microtermométricos, em função da quantidade e dimensões das inclusões. Inicialmente, foi realizado um estudo petrográfico detalhado, com definição dos planos portadores das inclusões fluidas e de suas orientações em relação à direção e mergulho do filão, o que permitiu a seleção dos campos mais adequados para efetuar as medidas microtermométricas, os quais podem ser observados na Figura 7.5.

As trilhas de inclusões alinham-se segundo dois trends principais de fraturas que exibem direções variando de $\mathrm{N}^{\circ}$ a $35^{\circ} \mathrm{W}$ e de $\mathrm{N}$ a $\mathrm{N} 30^{\circ} \mathrm{E}$, Figuras 7.6 e 7.7, predominando no primeiro, inclusões contendo sistemas salinos complexos do grupo $1 \mathrm{e}$, no segundo, aqueles do grupo 2. 


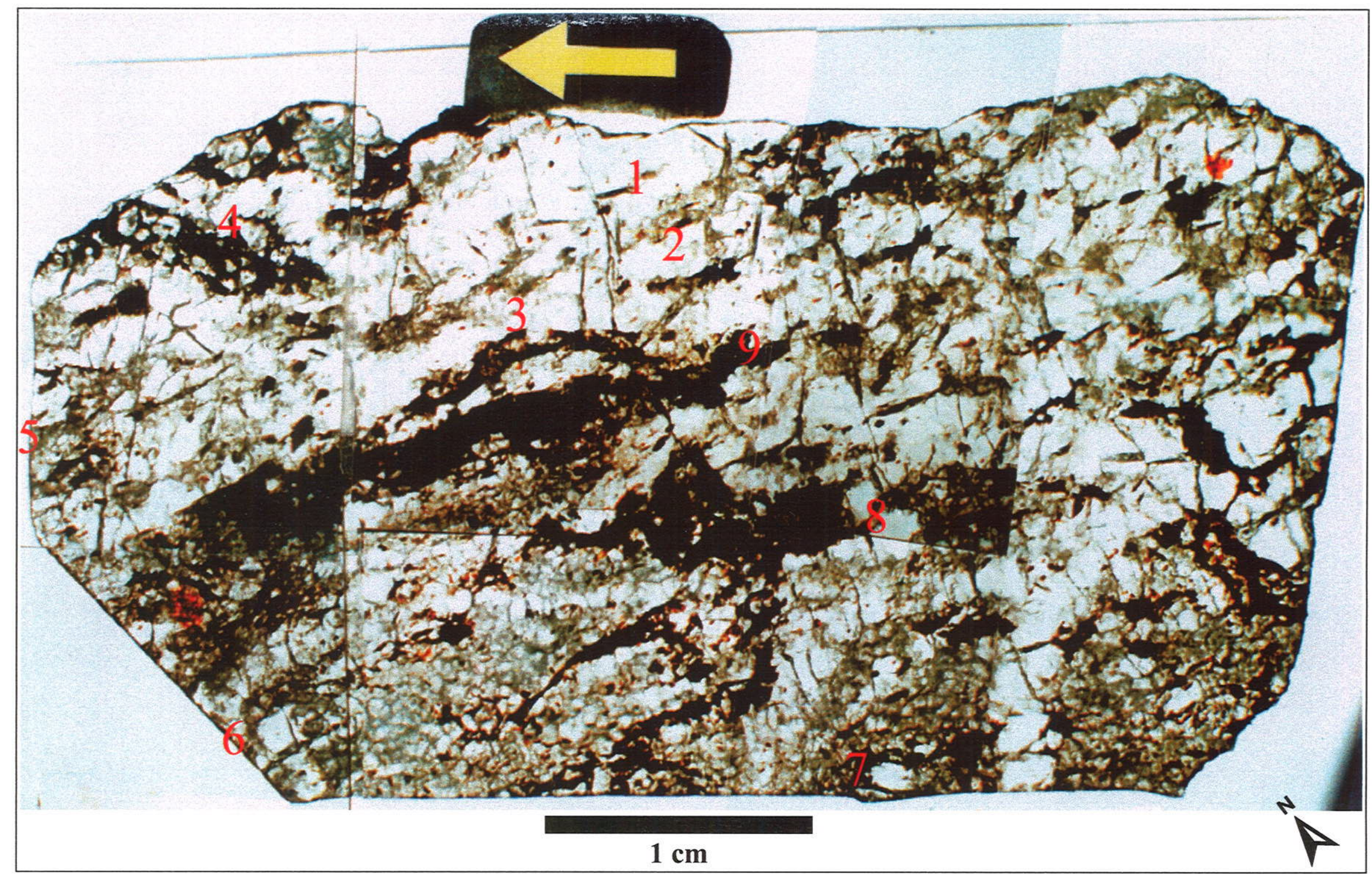

Figura 7.5 - Amostra R-22, orientada segundo a direção N40W do veio de quartzo Principal, no nível 54m da Mina de Salamangone. Os números correspondem às regiões da lâmina onde foram efetuadas medidas microtermométricas, em inclusões fluidas dispostas em trilhas. 1. Campo 17C/D, 2. Campo 30A, 3. Campo 36A/B/C, 4. Campo 24, 5. Campo 44, 6. Campo 55, 7. Campo 15, 8. Campo 71A e 9. Campo 69. 


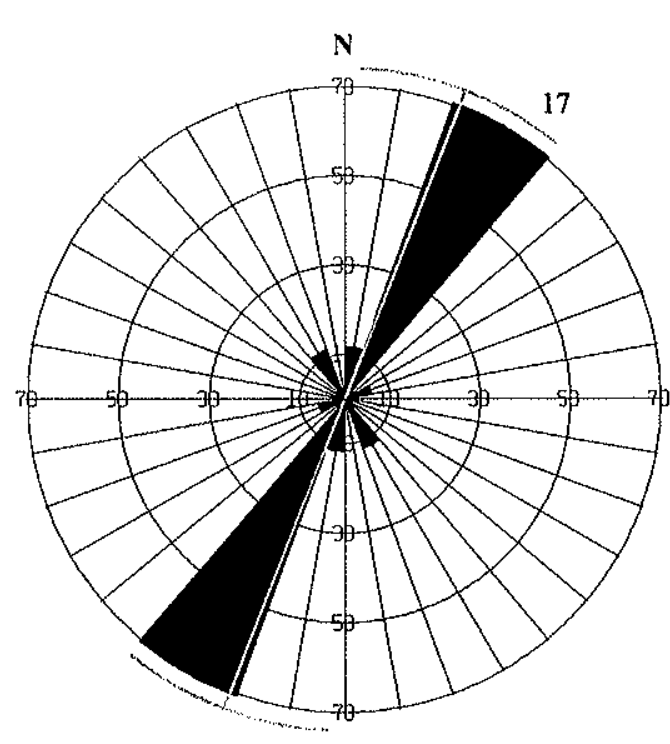

7.6)

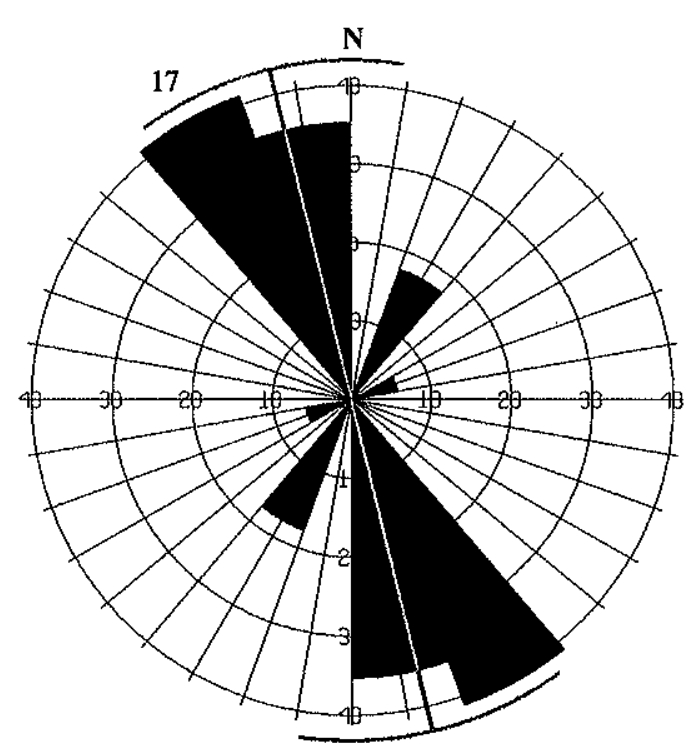

7.7)

Figuras 7.6 e 7.7 - Rosáceas representando a orientação dos principais planos de fraturas portadoras de inclusões fluidas que atravessam domínios de quartzo deformado e recristalizado do Filão Principal do depósito de Salamanone. 7.6) Trilhas orientadas, entre $\mathrm{Ne} \mathrm{N} 30^{\circ} \mathrm{E}$, predominando inclusões fluidas do sistema salino $\mathrm{CaCl} 2-\mathrm{KCl}-\mathrm{NaCl}-\mathrm{H} 2 \mathrm{O}$ e 7.7) Trilhas orientadas segundo $\mathrm{N}^{\circ}-35^{\circ} \mathrm{W}$ predominando inclusões fluidas do sistema salino complexo com $\mathrm{Ca}$ As. $\mathrm{O}$ número de trilhas medidas está indicado ao lado da rosácea.

\section{a) Trilhas segundo a direção $\mathrm{N5}^{\circ} / 35^{\circ} \mathrm{W}$}

Nessas trilhas verifica-se um nítido predomínio das inclusões fluidas do grupo 1, embora ocorram, em pequenas quantidades; aquelas dos grupos $2 \mathrm{~b}$ e 3 . As Te, medidas em 209 inclusões, variaram principalmente de $-84^{\circ} \mathrm{C}$ a $-78^{\circ} \mathrm{C}$, ocorrendo com menor freqüência inclusões de Te intermediárias $\left(-71^{\circ} \mathrm{C}\right.$ a $\left.-57^{\circ} \mathrm{C}\right)$ e mais elevadas, variando entre $-50^{\circ} \mathrm{C}$ e $-40^{\circ} \mathrm{C}$, Figura 7.8a. As Tfg, em 210 inclusões, situaram-se, principalmente, entre $-41^{\circ} \mathrm{C}$ e $-23^{\circ} \mathrm{C}$ (equiv. a 33,3 - $25 \%$ em peso do $\mathrm{NaCl}$ ), naquelas de eutético muito baixos, de, aproximadamente, $-17^{\circ} \mathrm{C}$ a $-12^{\circ} \mathrm{C}$ (equiv. a $20,2-16,0 \%$ em peso do $\mathrm{NaCl}$ ), nas de $\mathrm{Te}$ intermediárias, e de $-3^{\circ} \mathrm{C}$ a $-2^{\circ} \mathrm{C}$ (equiv. a 4,9 a $3,3 \%$ em peso do $\mathrm{NaCl}$ ), nas de $\mathrm{Te}$ mais elevadas, Figura 7.8b. As Th L-V (L), em 126 inclusões, distribuiram-se, principalmente, entre $90^{\circ} \mathrm{C}$ e $210^{\circ} \mathrm{C}$, naquelas de valores de Te muito baixos, entre $120^{\circ} \mathrm{C}$ e $230^{\circ} \mathrm{C}$, nas de eutéticos intermediários, e entre $150^{\circ} \mathrm{C} \mathrm{e} 280^{\circ} \mathrm{C}$, nas de Te mais elevadas, Figuras $7.8 \mathrm{c} 1,7.8 \mathrm{c} 2$ e $7.8 \mathrm{c} 3$ e Figuras $7.4 \mathrm{c}$ e $7.4 \mathrm{~d}$. 

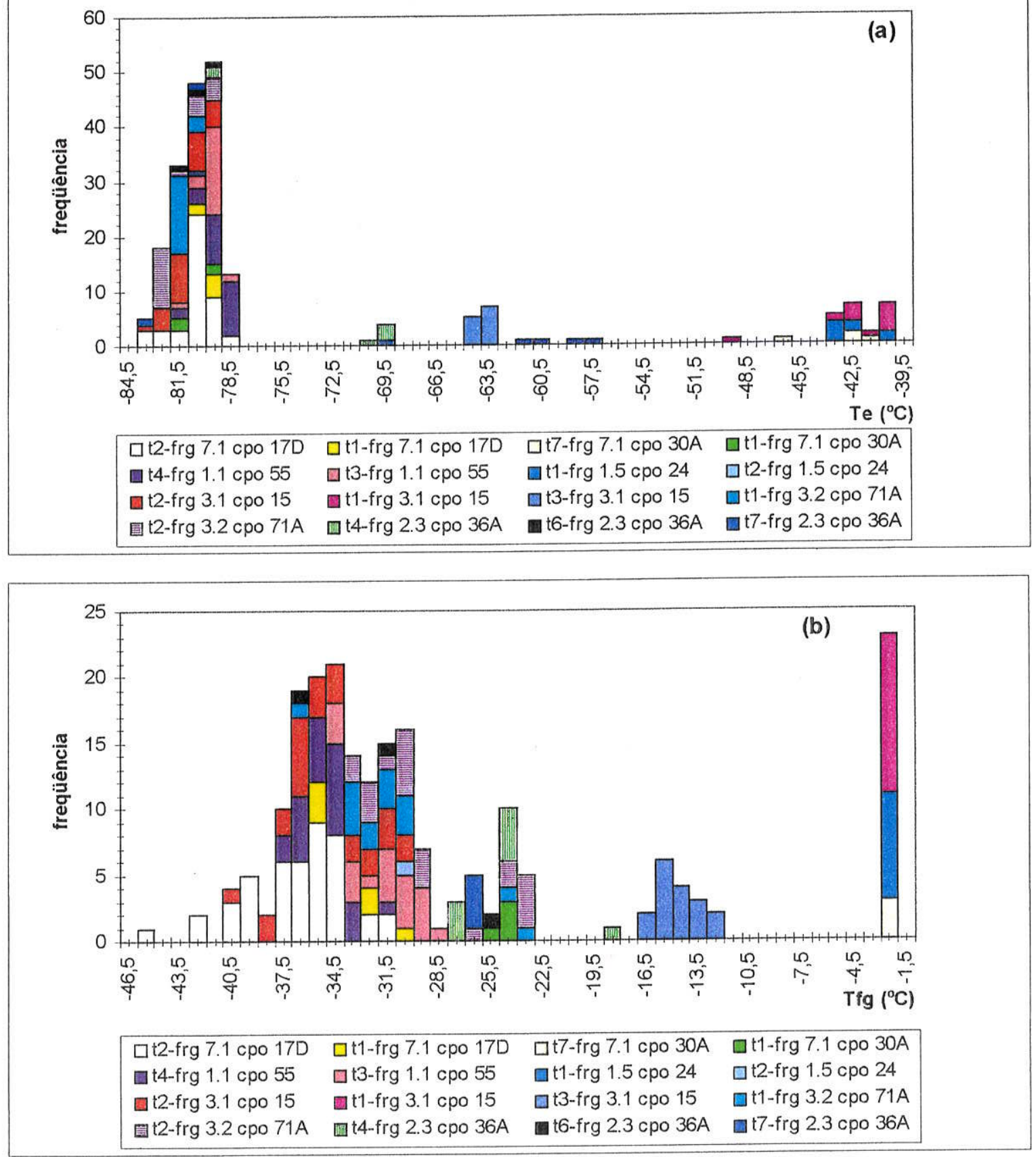

Fig.7.8- Histogramas de freqüência das temperaturas de mudança de fase das inclusões, em quartzo, dispostas em trilhas N05/35 $\mathrm{W}$ da amostra de quartzo orientada R-22 (Filão Principal): (a) Temperaturas do eutético (Te); (b) Temperaturas de fusão do gelo $(T$ fg) $)(t=$ trilha; frg = fragmento da amostra; $\mathrm{cpo}=$ campo estudado). 


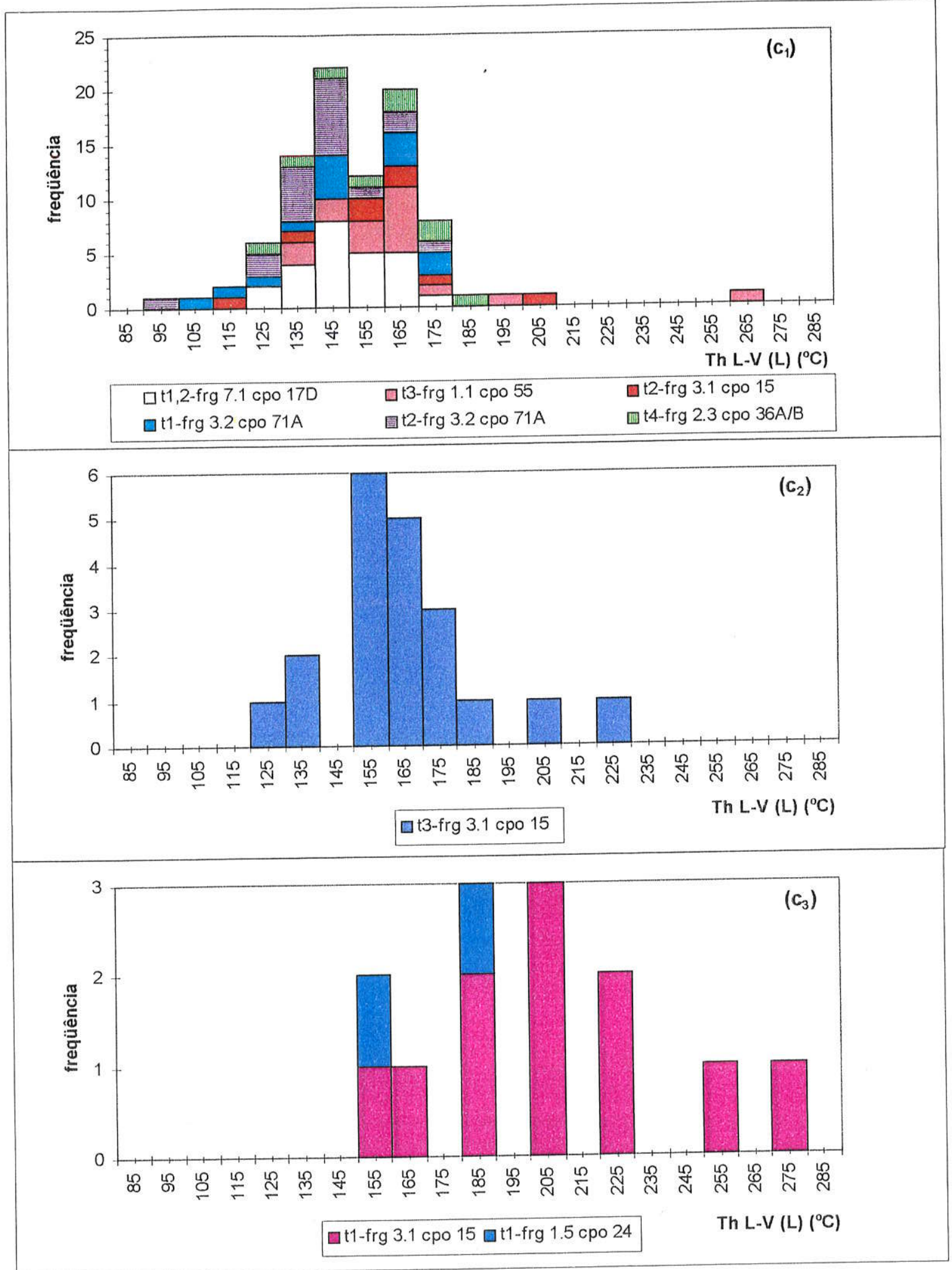

Fig.7.8- Histogramas de freqüência das temperaturas de homogeneização - Th L-V (L) - das inclusões, em quartzo, dispostas em trilhas $\mathrm{N} 05 / 35^{\circ} \mathrm{W}$ da amostra de quartzo orientada R-22 (Filão Principal). ( $\mathrm{c}_{1}$ ) Inclusões de baixos Te; $\left(c_{2}\right)$ Inclusões de Te intermediários; $\left(c_{3}\right)$ Inclusões de Te mais elevados. $(t=$ trilha; frg. fragmento da amostra; cpo = campo estudado). 


\section{b) Trilhas segundo a direção $\mathrm{N}^{\circ} / 30^{\circ} \mathrm{E}$}

Nestas trilhas predominam inclusões fluidas do grupo 2 (subgrupo 2a), embora ocorram em menores quantidades aquelas dos grupos 1 e 3 . As Te situaram-se, principalmente, entre $-54^{\circ} \mathrm{C}$ e $-38^{\circ} \mathrm{C}$, ocorrendo, com menor freqüência inclusões com $\mathrm{Te}$ intermediárias $\left(-68^{\circ} \mathrm{C}\right.$ a $\left.-58^{\circ} \mathrm{C}\right)$ e muito baixas, variando entre $-82^{\circ} \mathrm{C}$ e $-70^{\circ} \mathrm{C}$ Figura $7.9 \mathrm{a}$, num total de 224 medidas. As Tfg, em 116 inclusões, variaram de $-10^{\circ} \mathrm{C}$ a $-4^{\circ} \mathrm{C}$ (equiv. a 13,9 $6,4 \%$ em peso do $\mathrm{NaCl}$ ), naquelas de eutético mais elevados, de $-17^{\circ} \mathrm{C}$ a $-11^{\circ} \mathrm{C}$ (equiv. 20,2 $15,0 \%$ em peso do $\mathrm{NaCl}$ ), nas de Te intermediárias, e de $-31^{\circ} \mathrm{C}$ a $-17^{\circ} \mathrm{C}$ (equiv. a 29,1 a $20,2 \%$ em peso do $\mathrm{NaCl}$ ), nas de Te mais baixas Figura 7.9b. As Th L-V (L), distribuíram-se, essencialmente, entre $100^{\circ} \mathrm{C}$ e $270^{\circ} \mathrm{C}$, nas inclusões de eutéticos mais elevados, entre $140^{\circ} \mathrm{C}$ e $200^{\circ} \mathrm{C}$, nas de Te intermediários, e entre $120^{\circ} \mathrm{C}$ e $220^{\circ} \mathrm{C}$, nas de Te mais baixas, num total de 195 medidas, Figuras 7.9c1 e 7.9c2. e Figuras 7.4e, e 7.4f.

Os resultados de Te revelam que nas trilhas de direções $N 5^{\circ} / 35^{\circ} \mathrm{W}$ predomina o sistema salino complexo com $\mathrm{Ca} \pm$ As? (grupo 1), já verificado nas amostras de quartzo não orientadas. Ocorrem ainda, de maneira menos expressiva, os sistemas compostos por $\mathrm{CaCl}_{2}$ $\mathrm{KCl}-\mathrm{NaCl}-\mathrm{H}_{2} \mathrm{O}$ (grupo 2, subgrupo 2b) e $\mathrm{CaCl}_{2}-\mathrm{KCl}-\mathrm{NaCl}-\mathrm{H}_{2} \mathrm{O} \pm \mathrm{Al}$, Fe e/ou $\mathrm{Mg}$ (grupo 3), igualmente detectados, em maior ou menor quantidade, nas amostras não orientadas. Nas trilhas $\mathrm{N} 0^{\circ} / 30^{\circ} \mathrm{E}$ predomina o sistema salino $\mathrm{CaCl}_{2}-\mathrm{KCl}-\mathrm{NaCl}-\mathrm{H}_{2} \mathrm{O}$ (grupo 2, subgrupo 2a), embora também se verifiquem, em menor quantidade, inclusões dos outros sistemas acima citados. Nestas últimas trilhas, observa-se um espalhamento maior das $\mathrm{Te}$ relativas aos sistemas salinos dos grupos $1 \mathrm{e} 3$.

Deve ser observado, que as poucas inclusões do grupo 1 das trilhas NE apresentam menores salinidades em relação àquelas do mesmo grupo pertencentes às trilhas NW. Nas amostras não orientadas o número reduzido de inclusões definidas como grupo 3 apresentam, na realidade, salinidades bem inferiores em relação àquelas que caracterizam esse grupo nas amostras orientadas, podendo representar também um pequeno subgrupo (Tabela 7.1). Essas variações de salinidades poderiam sugerir a ocorrência de misturas de fluidos.

Os valores das temperaturas eutéticas são muito variáveis, sendo, de modo geral, inferiores à $-38^{\circ} \mathrm{C}$, representando os diferentes sistemas discutidos acima. Igualmente, as temperaturas de fusão do gelo variam consideravelmente nos dois conjuntos de trilhas (-46 a $2^{\circ} \mathrm{C}$ ), indicando um amplo intervalo de salinidades. Essas variações são mostradas nos diagramas Te x Tfg, Figuras 7.10 e 7.11, onde foram também representados, em alguns casos, os valores e intervalos de eutéticos relativos a alguns sistemas salinos estudados experimentalmente. Esses diagramas mostram a existência de uma boa correlação entre Te e 
$\mathrm{Tfg}$, indicando que os fluidos pertencentes ao sistema $\mathrm{CaCl}_{2}-\mathrm{KCl}-\mathrm{NaCl}-\mathrm{H}_{2} \mathrm{O}$ possuem salinidades mais baixas enquanto que naqueles compostos por sistemas salinos complexos com $\mathrm{Ca} \pm \mathrm{As}$ ?, as salinidades são extremamente elevadas. De acordo com discussões de Oberthür et al. (2000), trends desse tipo são característicos de processos de misturas de fluidos e/ou de interação rocha-fluido. Esses processos são ainda evidenciados pelas variações de Tfg em inclusões fluidas de mesmas composições (Te), às vezes pertencentes a uma única trilha, conforme também foi verificado nos estudos do depósito de Yirisen em Sierra Leone, realizados por Barrie \& Touret (1999).

Em relação as temperaturas de homogeneização total observa-se que, de modo geral, as inclusões das trilhas $\mathrm{N}^{\circ} / 30^{\circ} \mathrm{E}$ são as que apresentam valores ligeiramente mais elevados. Entre as composições presentes foi constatado que as inclusões do sistema complexo Ca (As?) mostram, em todos os casos, as menores temperaturas de homogeneização total. Nenhuma correlação perfeitamente definida foi observada nos diagramas Th L-V(L) x Tfg , Figuras 7.12 e 7.13, havendo uma grande variação de salinidades para intervalos de temperaturas de homogeneização relativamente estreitos. Novamente essa relação é melhor explicada pelo processo de mistura de fluidos, igualmente discutido por Oberthür et al. (2000), nas mineralizações auríferas da área Mazowe, no Zimbabwe.

Observa-se, ainda, nas regiões de mais baixas $\mathrm{Tfg}$ dos diagramas, a existência de trilhas de inclusões fluidas com ampla variação em Th total, numa estreita faixa de salinidades. Arranjos desses tipo podem ser indicativos de leakeage, neckdown, ou ainda de um simples resfriamento das soluções (Shepherd et al. 1985). Como nas inclusões estudadas não foram observadas feições indicativas daquelas modificações, esses arranjos podem ser atribuídos ao resfriamento dos termos finais da mistura.

\section{c) Trilhas em outras direções}

Foram, ainda, observadas inclusões fluidas em trilhas orientadas segundo as direções $\mathrm{N} 45-65^{\circ} \mathrm{E}$, que ocorrem com menor freqüência como mostrado na Figura 7.6, nas quais puderam ser obtidos poucos dados microtermométricos. Os resultados mostraram que essas inclusões contém fluidos pertencentes a sistemas de composições semelhantes aos anteriores (grupos 1, 2 e 3), Figuras 7.14a, 7.14b.

Também ocorrem inclusões dispostas em trilhas de outras direções, embora com dimensões muito reduzidas para a obtenção de medidas. 

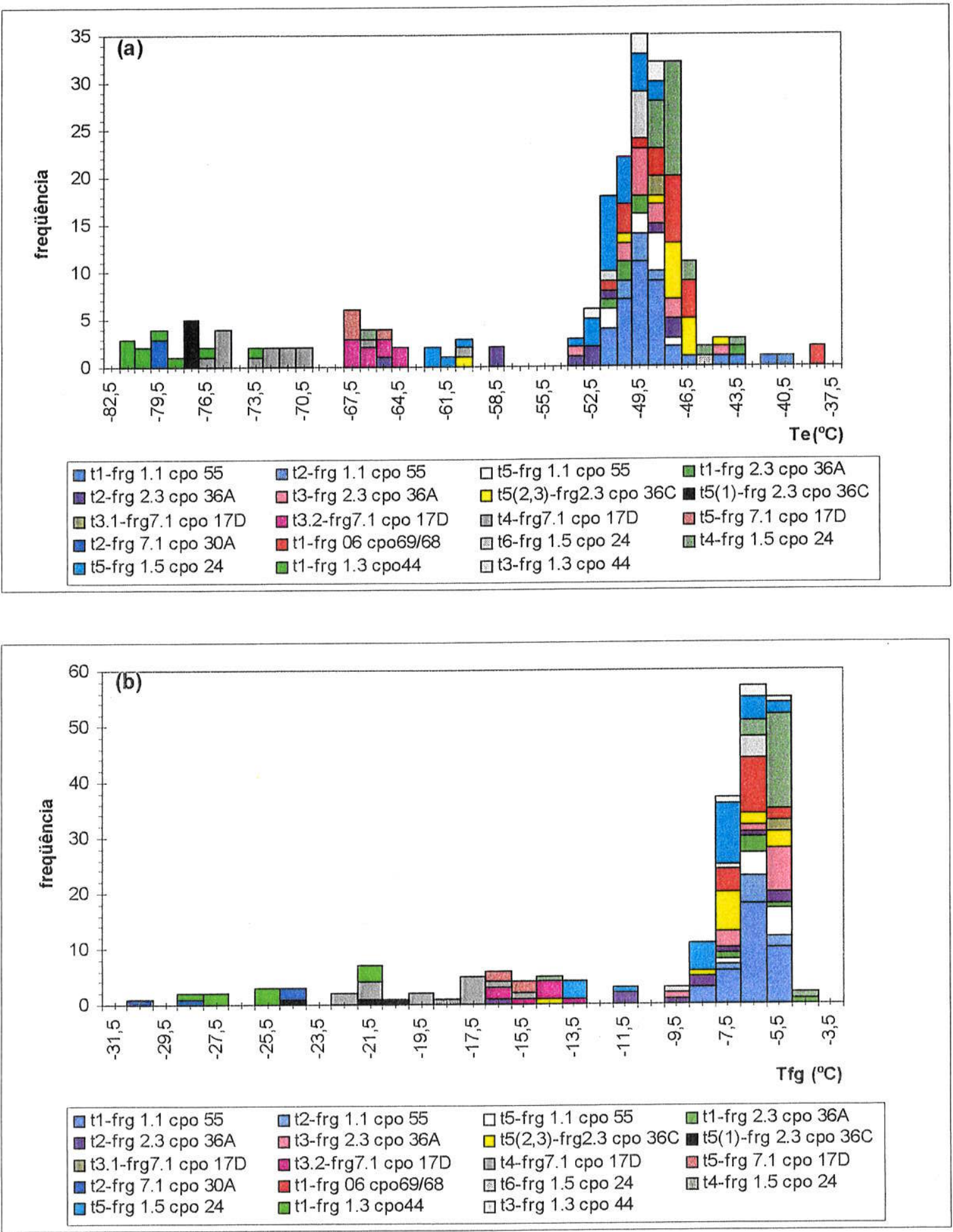

Fig.7.9 - Histogramas de freqüência das temperaturas de mudança de fase das inclusões, em quartzo, dispostas em trilhas N0/30 $\mathrm{E}$ da amostra de quartzo orientada R-22 (Filão Principal): (a) Temperaturas do eutético (Te); (b) Temperaturas de fusão do gelo $(\mathbf{T f g}) .(\mathrm{t}=$ trilha; frg = fragmento da amostra; cpo = campo estudado). 

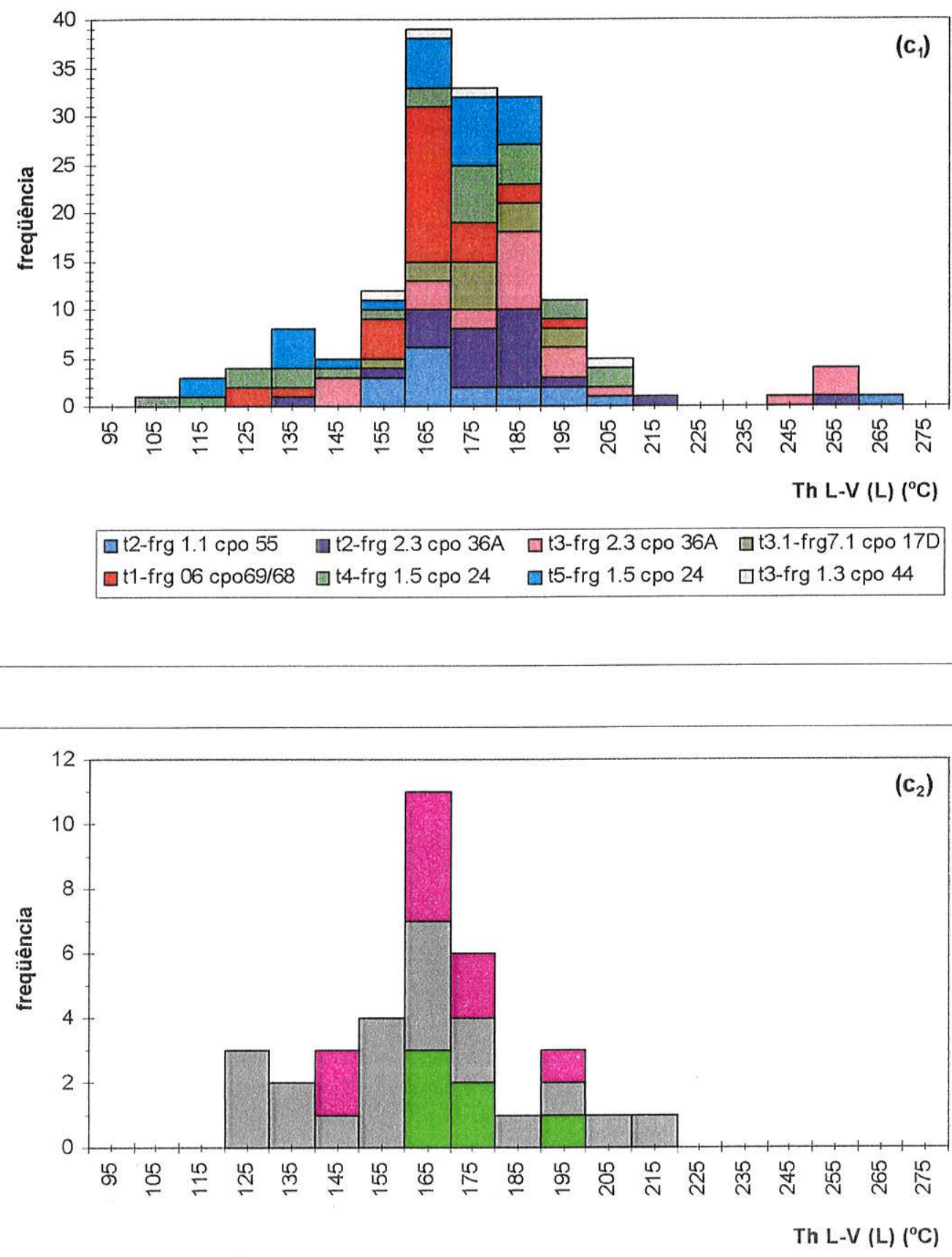

口t1-frg $1.3 \mathrm{cpo} 44$ Te baixos

口t4-frg 7.1 cpo 17D Te baixos a médios

t3.2-frg 7.1 cpo 17D Te médios

Fig. 7.9 - Histogramas de freqüência das temperaturas de homogeneização (para o líquido) - Th L-V (L) das inclusões dispostas em trilhas N0/30 $\mathrm{E}$ da amostra de quartzo orientada R-22 (Filão Principal). ( $\mathrm{c}_{1}$ ) Inclusões de Te mais elevados; $\left(c_{2}\right)$ Inclusões de Te baixos a intermediários. $(t=$ trilha; frg $=$ fragmento da amostra; $\mathrm{cpo}=$ campo estudado). 

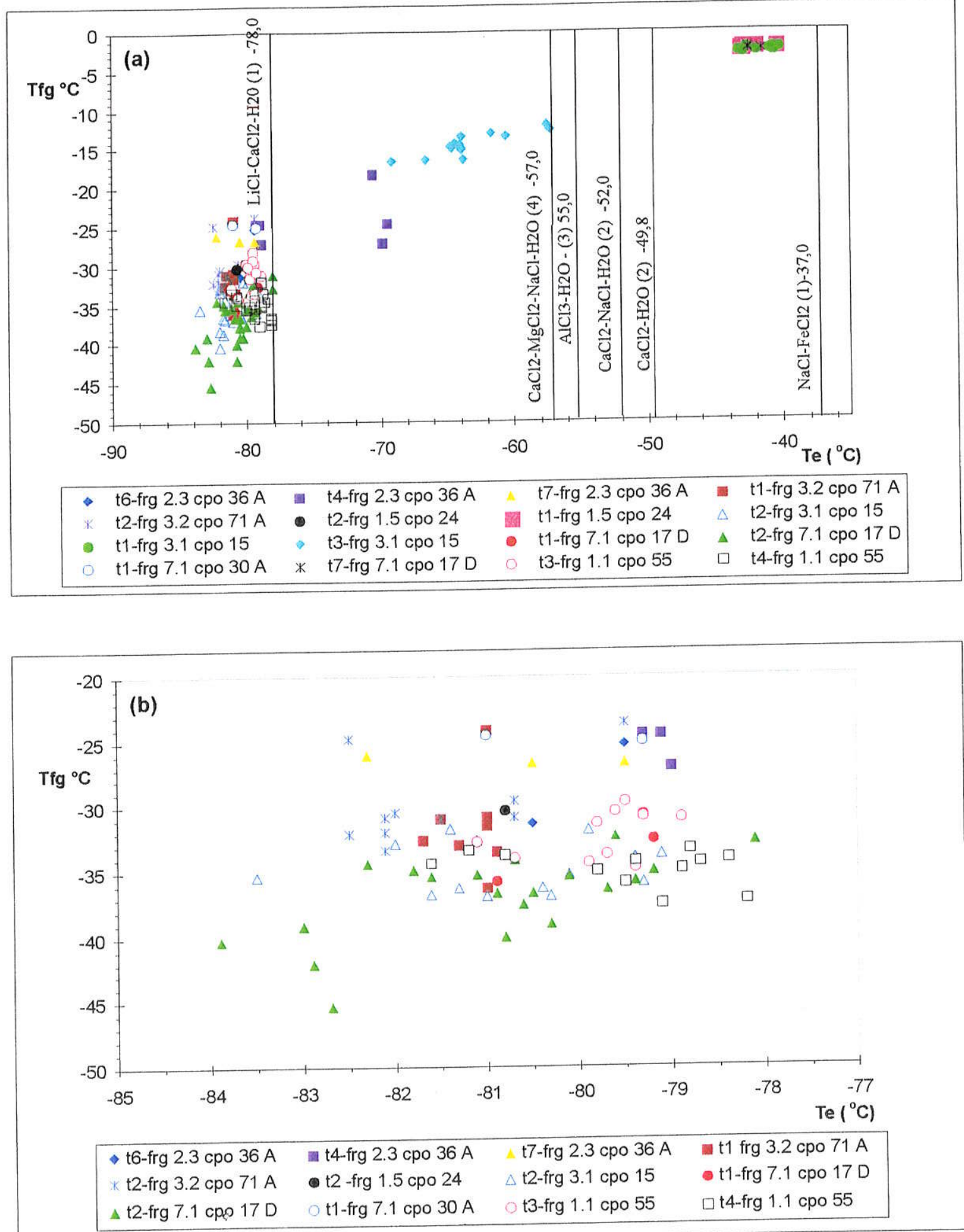

Figura 7.10 - (a) diagrama Tfg x Te para as inclusões dispostas em trilhas N5/35W da amostra de quartzo orientada R-22 (filão Principal); (b) Detalhe de (a) para eutéticos baixos. (1) Borizenko 1978, (2)Crawfor 1981, (3)Linde 1965 in Roedder 1984, (4)Luzhnya \& Vereshtchetina 1946. 

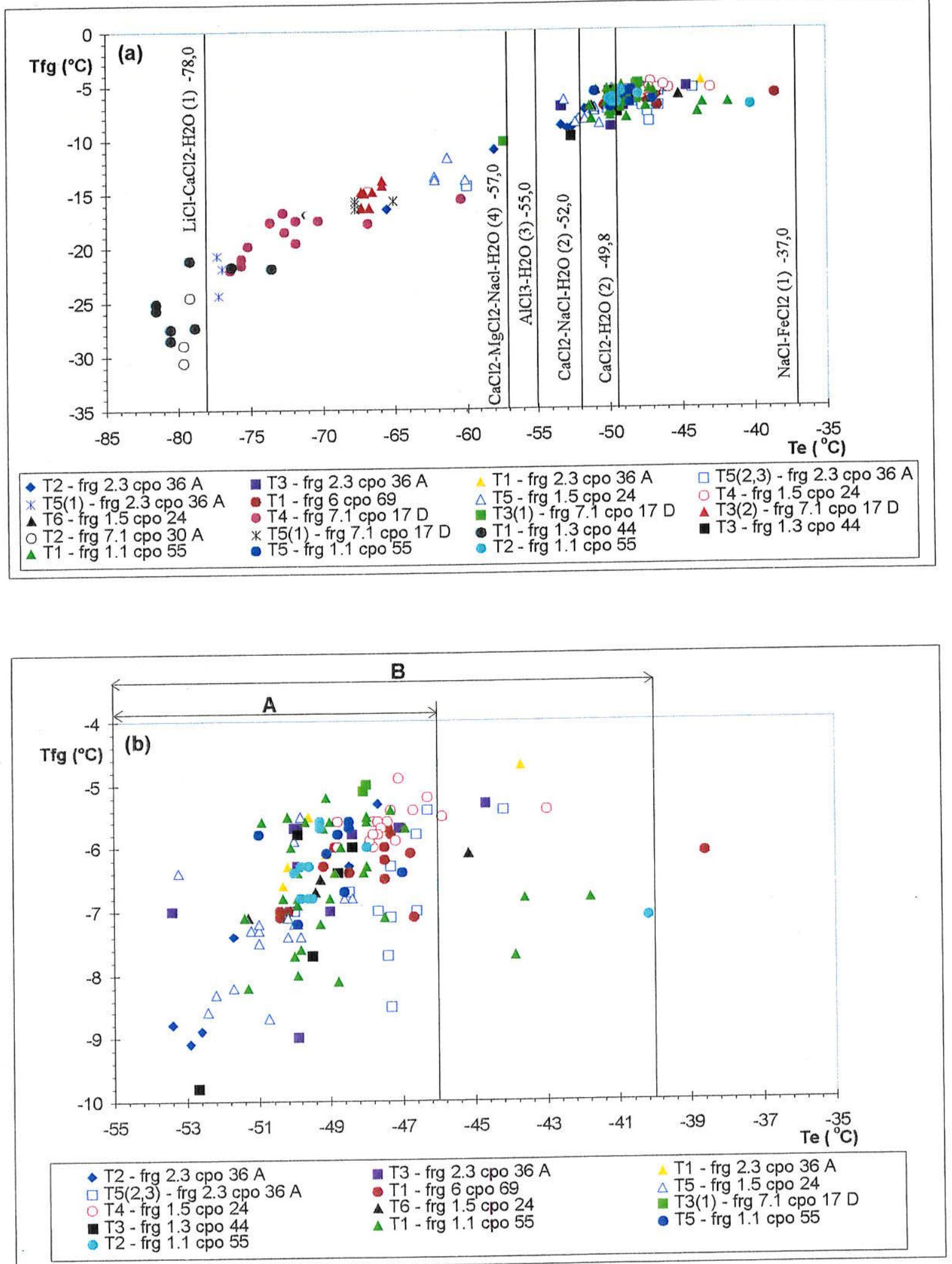

Figura 7.11 - (a) Diagrama Tfg $\times$ Te para as inclusões dispostas em trilhas N/30 $\mathrm{E}$ da amostra de quartzo orientada R22 (Filão Principal), (b) Detalhe de (a) para eutéticos mais elevados. Campo A- Te observadas par o sistema CaCl2-NaCl-H2O (Borisenko 1978 e Yanatieva 1946), Campo B - intervalo de eutéticos indicativos da presença de cations divalentes (Davis et al. 1990). (1) Borisenko 1978, (2) Crawford 1981, (3) Linke 1965 in Roedder 1984, (4) Luzhnaya \& Vereshtchetina, (5) Yanatieva 1946. 


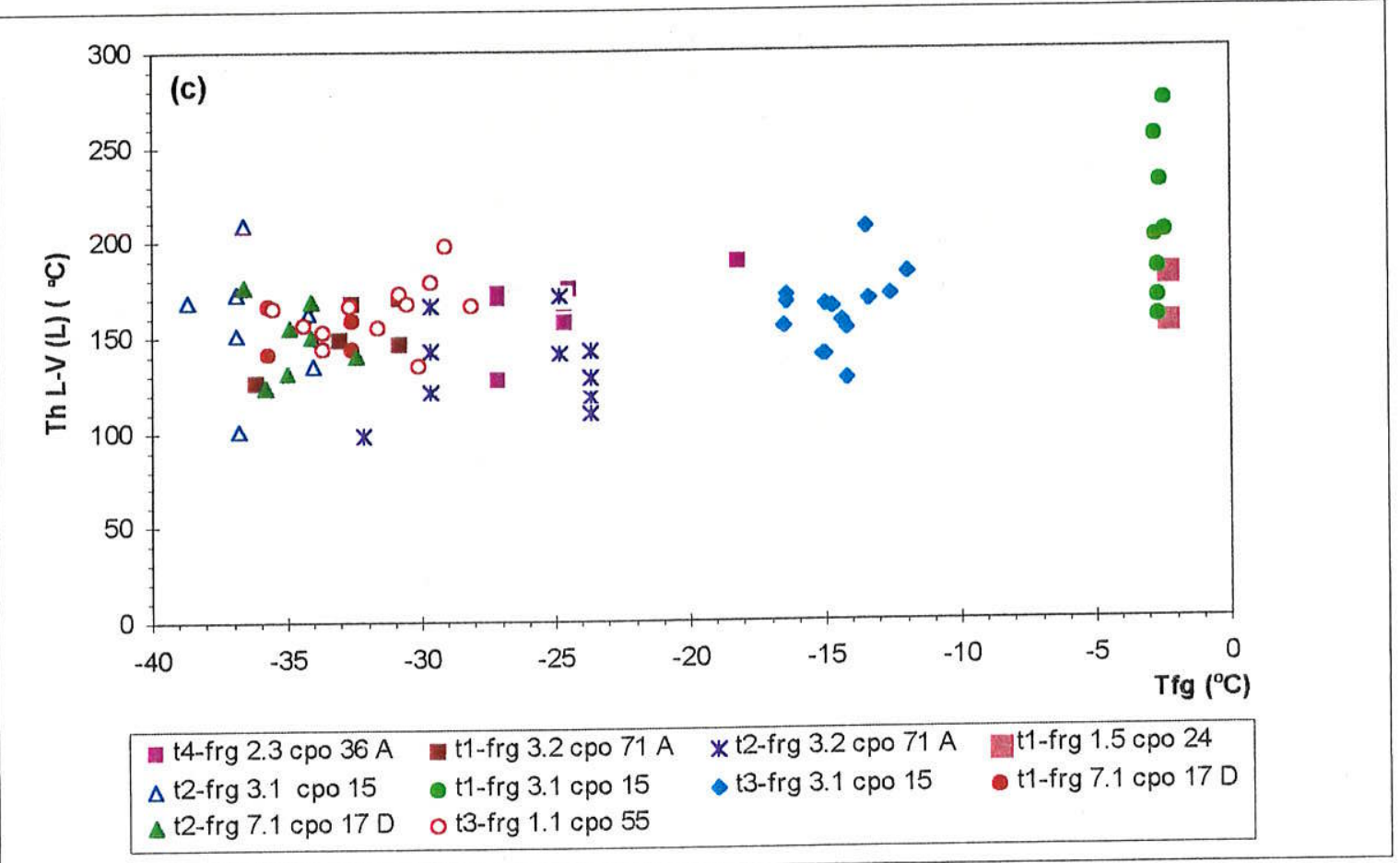

Fig 7.12- Diagrama Th L-V (L) para as inclusões dispostas em trilhas $\mathrm{N} 5 / 35^{\circ} \mathrm{W}$ da amostra de quartzo orientada R-22 (Filão Principal).

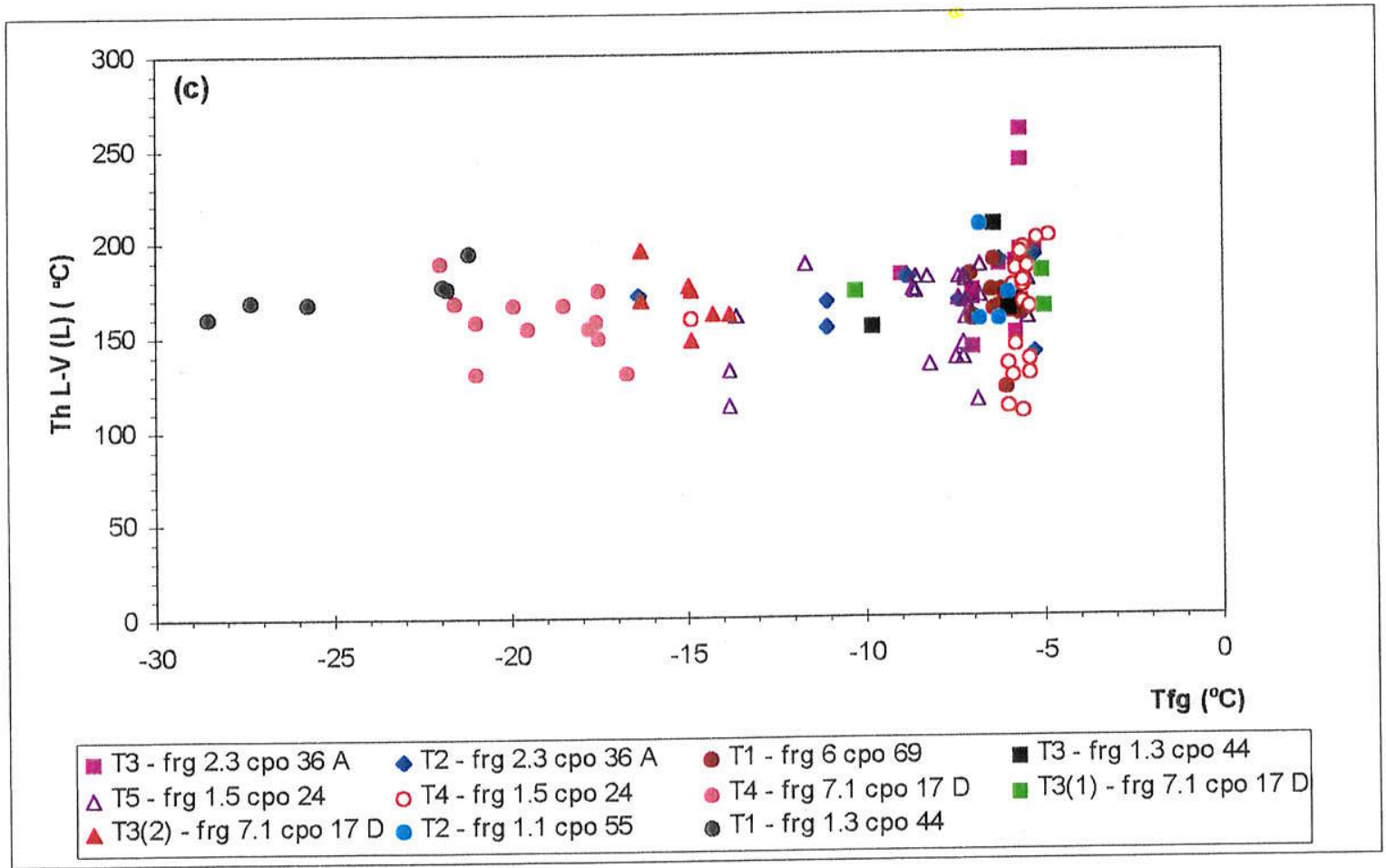

Fig. 7.13 - Diagrama Th L-V (L)X Tfg, para as inclusões dispostas em trilhas N0/30 ${ }^{\circ} \mathrm{E}$ da amostra de quartzo orientada R-22 (Filão Principal). 

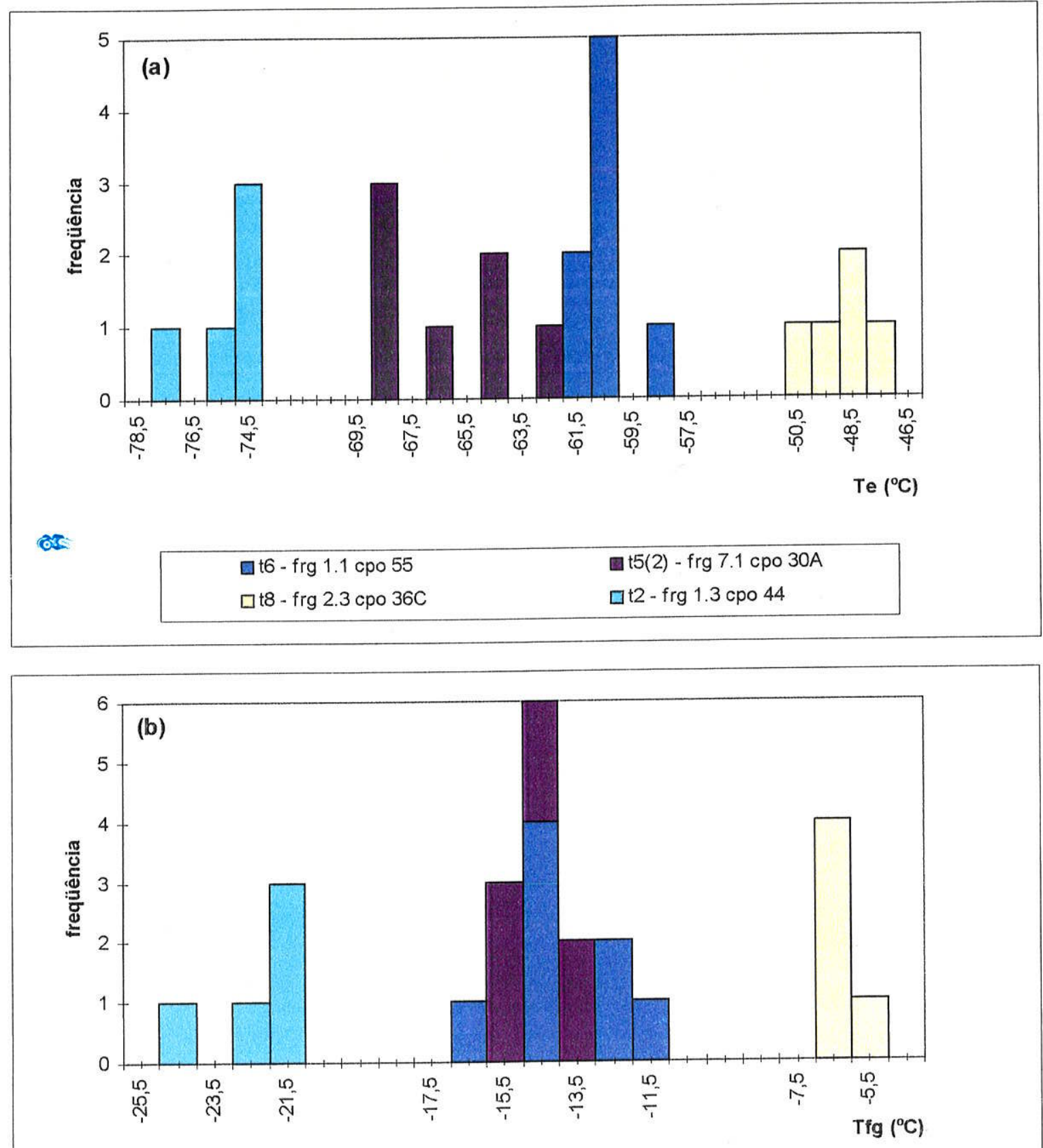
口t6 - frg $1.1 \mathrm{cpo} 55$
t5(2) - frg $7.1 \mathrm{cpo} 30 \mathrm{~A}$
口t8 - frg 2.3 cpo 36C
口t2 - frg 1.3 cро 44

Fig.7.14 - Histogramas de freqüência das temperaturas de mudança de fase das inclusões dispostas em trilhas $\mathrm{N} 45^{\circ} / 60^{\circ} \mathrm{E}$, da amostra orientada R-22: (a) Temperaturas do ponto eutético - Te; (b) Temperaturas de fusão do gelo - Tfg. $(\mathrm{t}=$ trilha; frg $=$ fragmento da amostra; $\mathrm{cpo}=$ campo estudado). 


\subsubsection{Estudo em veios estéreis}

Amostras não orientadas de veios de quartzo estéreis foram também investigadas, com a realização de processos de resfriamento para verificação da presença dos sistemas encontrados nos veios mineralizados. Dentre essas, foi selecionada uma amostra para a obtenção de medidas sistemáticas, por apresentar inclusões de dimensões mais apropriadas para os estudos. Essas análises permitiram, de acordo com a temperatura do eutético, o reconhecimento de dois sistemas de inclusões fluidas, semelhantes aos dos grupos 2 e 3, identificados nas amostras mineralizadas, não tendo sido encontrado aquele de Te muito baixas (grupo 1).

\section{a)-Sistema salino com eutéticos entre $-49^{\circ} \mathrm{Ce}-42^{\circ} \mathrm{C}$}

Os valores de $\mathrm{Te}$, medidos em 16 inclusões, variaram de $-49^{\circ} \mathrm{C}$ a $-42^{\circ} \mathrm{C}$, com intervalo de maior freqüência entre $-47^{\circ} \mathrm{C} \mathrm{e}-45^{\circ} \mathrm{C}$, Figura $7.15 \mathrm{a}$. A temperatura de fusão final do gelo (Tfg), em 15 inclusões, situou-se entre $-6^{\circ} \mathrm{C}$ e $-3^{\circ} \mathrm{C}$ e a temperatura de homogeneização, para a fase líquida - Th $\mathrm{L}-\mathrm{V}(\mathrm{L})$ - de 23 inclusões, ficou entre $110^{\circ} \mathrm{C}$ e $180^{\circ} \mathrm{C}$, com maior freqüência entre $130^{\circ} \mathrm{C}$ e $150^{\circ} \mathrm{C}$, Figuras $7.15 \mathrm{~b}$ e $7.15 \mathrm{c}$ e Figuras $7.16 \mathrm{a}$, e $7.16 \mathrm{~b}$.

Os dados microtermométricos dessas inclusões apresentaram semelhança quanto à composição, com os do grupo 2 a dos veios mineralizados, sendo indicativos do sistema composto por $\mathrm{CaCl}_{2}-\mathrm{KCl}-\mathrm{NaCl}-\mathrm{H}_{2} \mathrm{O}$, embora possuam salinidades ligeiramente mais baixas (equiv. 4,8 a $9,2 \%$ em peso do $\mathrm{NaCl}$ ), Tabela 7.1 .

\section{b)-Sistema salino com eutéticos entre $-65^{\circ} \mathrm{C}$ e $-58^{\circ} \mathrm{C}$}

Os valores de Te, em 30 inclusões, variaram entre $-65^{\circ} \mathrm{C}$ e $-58^{\circ} \mathrm{C}$, com intervalo de maior freqüência entre $-61^{\circ} \mathrm{C}$ e $-69^{\circ} \mathrm{C}$, Figura 7.15a. A temperatura de fusão final do gelo (Tfg), de 28 inclusões, situou-se entre $-16^{\circ} \mathrm{C} \mathrm{e}-11^{\circ} \mathrm{C}$, com pico de maior frequiência entre $13^{\circ} \mathrm{C} \mathrm{e}-12^{\circ} \mathrm{C}$, Figura $7.15 \mathrm{~b}$. A temperatura de homogeneização para a fase líquida - Th $\mathrm{L}-\mathrm{V}$ (L) - de 29 inclusões, ficou entre $140^{\circ} \mathrm{C}$ e $250^{\circ} \mathrm{C}$, com maior freqüência entre $140^{\circ} \mathrm{C}$ e $170^{\circ} \mathrm{C}$, Figura 7.15c.

Essas inclusões são semelhantes àquelas do Grupo 3, dos veios de quartzo mineralizados, sendo constituídas por $\mathrm{CaCl}_{2}-\mathrm{KCL}-\mathrm{NaCl}$, com a provável presença de alumínio, ferro e/ou magnésio, e salinidades com valores equivalentes variando de 13,9 a 19,4\% em peso do $\mathrm{NaCl}$ (Tabela 7.1 ). 


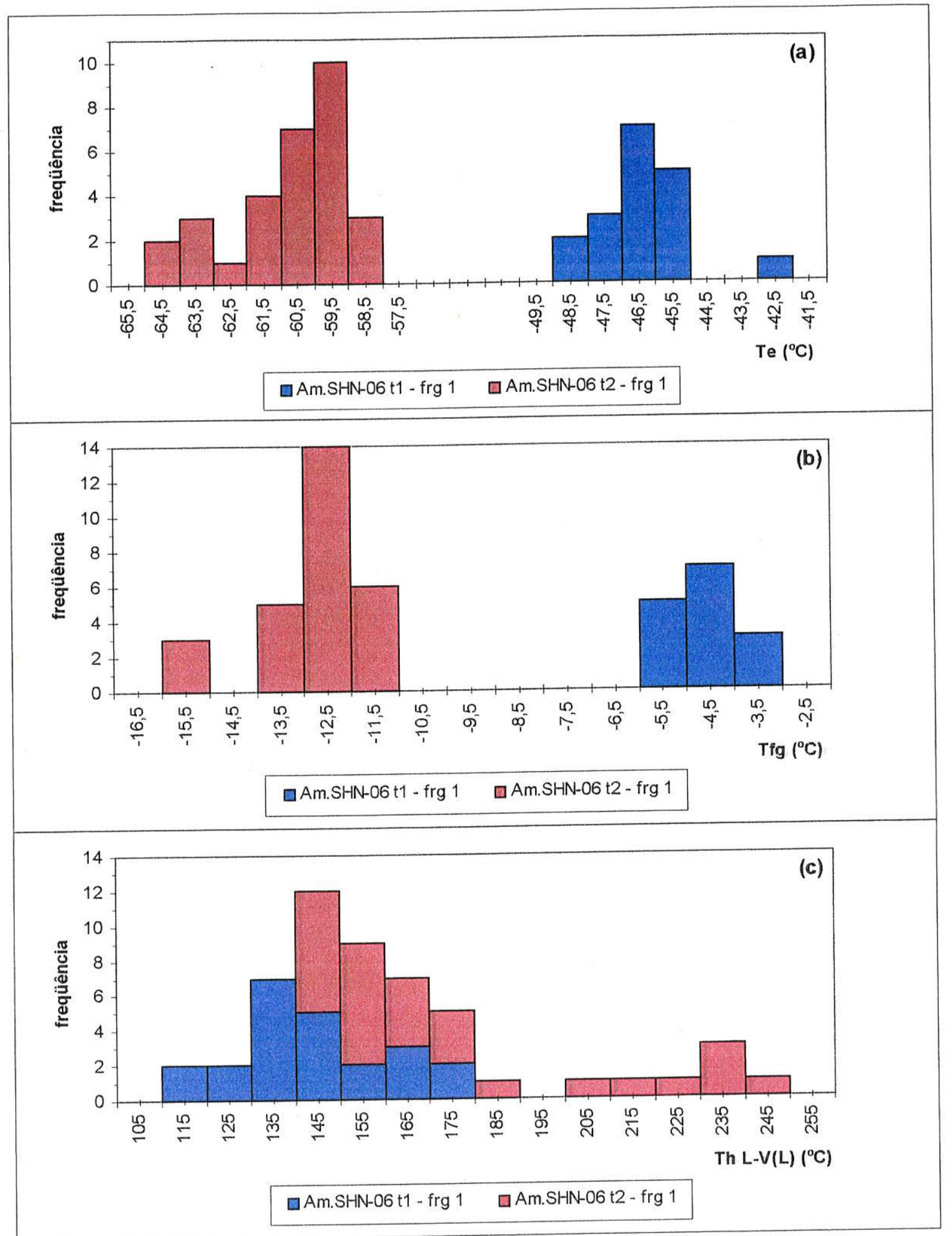

Fig.7.15 - Histogramas de freqüência das temperaturas de mudança de fase das inclusões fluidas dispostas em trilhas presentes em quartzo de amostra não orientada de um veio estéril: (a) Temperaturas do ponto eutético - Te; (b) Temperaturas de fusão do gelo - Tfg; (c) Temperaturas de homogeneização - Th L-V (L). $(A m=$ amostra; $\mathrm{t}=$ trilha; frg $=$ fragmento da amostra. 

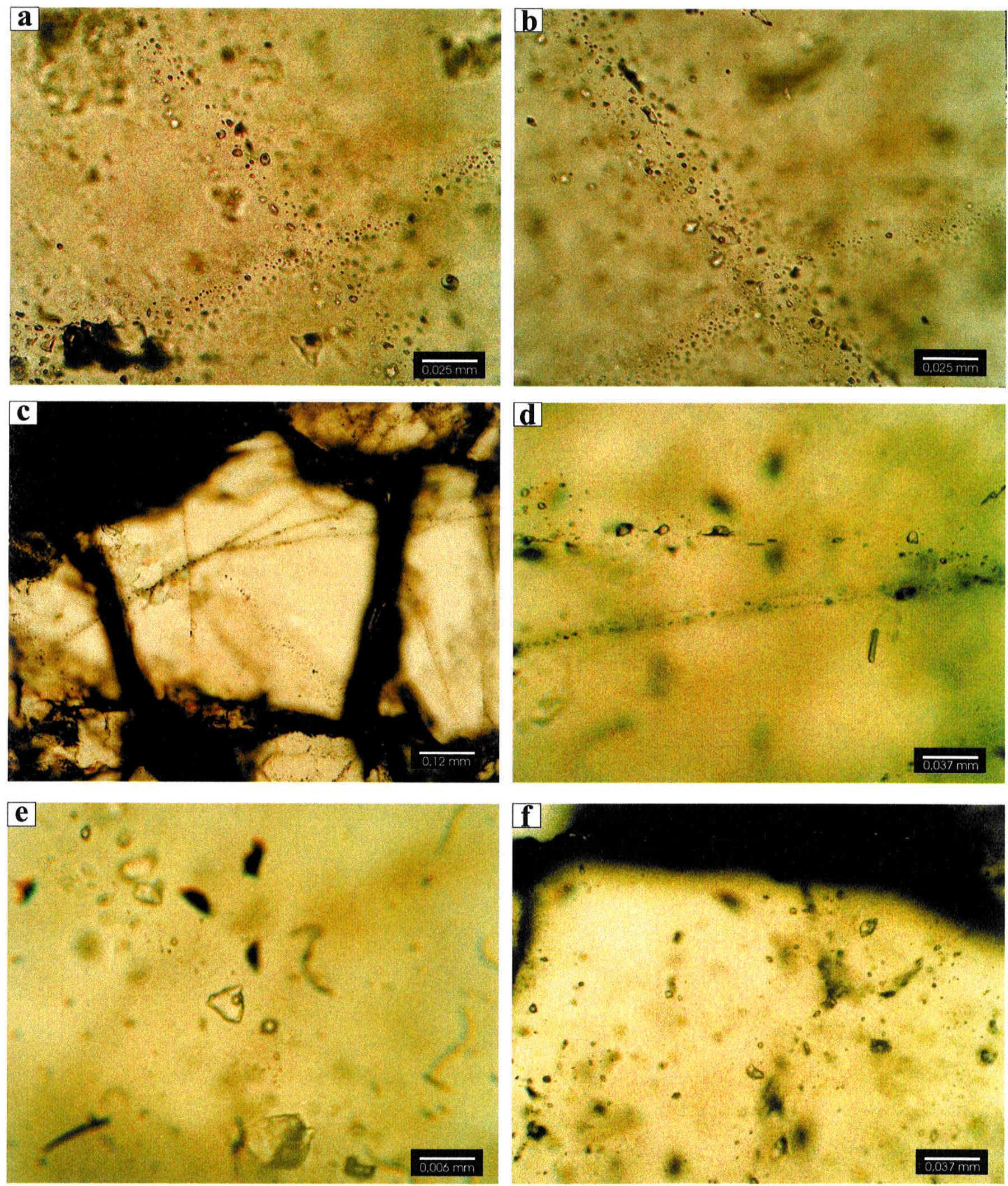

Figura 7.16 - Inclusões fluidas em veio de quartzo estéril e pegmatito: a e b) Trilhas de inclusões fluidas aquossalinas do grupo 2a, sistema salino $\mathrm{CaCl}_{2}-\mathrm{KCl}-\mathrm{NaCl}-\mathrm{H}_{2} \mathrm{O}$ em amostra de quartzo de veio estéril (SHN-06, furo SH-46) (N//), c) Trilhas em quartzo do pegmatito (SL-23A, nível 290m da mina), inclusões fluidas do grupo $2 \mathrm{a}(\mathrm{N} / /)$, d) Detalhe das trilhas da foto anterior (N//), e) Inclusões fluidas do grupo $2 \mathrm{~b}$, sistema salino $\mathrm{CaCl}_{2}-\mathrm{KCl}-\mathrm{NaCl}-\mathrm{H}_{2} \mathrm{O}$, em uma trilha de quartzo do pegmatito, amostra Sl-23A, (N//), f) Inclusões fluidas sem orientação, em amostra de quartzo do pegmatito (SL-16, nível $275 \mathrm{~m}$ da mina), do sistema salino $\mathrm{CaCl}_{2}-$ $\mathrm{KCl}-\mathrm{NaCl}-\mathrm{H}_{2} \mathrm{O}$, grupos $2 \mathrm{a}$ e $2 \mathrm{~b}(\mathrm{~N} / /)$. 


\subsubsection{Pegmatitos}

As seções foram tomadas em 02 amostras não orientadas de pegmatitos que cortam os veios de quartzo Principal e Lapa, nos níveis de desenvolvimento da mina, 290 e $274 \mathrm{~m}$ respectivamente.

\section{a) Inclusões em trilhas}

As inclusões se distribuem em trilhas intergranulares, com caracterïsticas indicativas de origem secundária. Nessas trilhas, em 160 inclusões medidas, predominam aquelas com Te situadas entre $-53^{\circ} \mathrm{C}$ e $-34^{\circ} \mathrm{C}$ (grupo 2), ocorrendo em menor quantidade inclusões com Te mais baixos, entre $-63^{\circ} \mathrm{C}$ e $-56^{\circ} \mathrm{C}$ (grupo 3) Figura 7.17a1. As $\mathrm{Tfg}$, em 148 inclusões, variaram, principalmente, de $-9^{\circ} \mathrm{C}$ a $0^{\circ} \mathrm{C}$, naquelas com eutéticos mais elevados, mostrando similaridades com os grupos $2 \mathrm{a}$ e $2 \mathrm{~b}$, e de $-14^{\circ} \mathrm{C} \mathrm{a}-11^{\circ} \mathrm{C}$ nas de Te mais baixos Figura $7.17 \mathrm{~b} 1$. A temperatura de homogeneização, para a fase líquida, em 170 inclusões, variou de $90^{\circ} \mathrm{C}$ a $210^{\circ} \mathrm{C}$ Figura $7.17 \mathrm{c} 1$ e Figuras $7.16 \mathrm{c}, 7.16 \mathrm{~d}$ e $7.16 \mathrm{e}$.

\section{b) Inclusões não orientadas}

Estudos petrográficos detalhados mostraram que essas inclusões têm características que sugerem uma origem primária, por sua distribuição aleatória, ocorrendo como agrupamentos no interior de cristais de quartzo.

Nestes agrupamentos predominam inclusões (31 medidas) com temperaturas eutéticas variando de $-49^{\circ} \mathrm{C}$ a $-36^{\circ} \mathrm{C}$ (grupo 2), ocorrendo ocasionalmente inclusões com Te mais baixos, Figura 7.17a2. As Tfg, em 29 inclusões, variaram, principalmente, de $-6^{\circ} \mathrm{C}$ a $-1^{\circ} \mathrm{C}$ Figura 7.17b2, apresentando uns poucos valores inferiores, mostrando a existência dos grupos 2a e 2 b. As Th L-V (L), em 59 inclusões, apresentaram grande dispersão, variando entre $90^{\circ} \mathrm{C}$ e $360^{\circ} \mathrm{C}$ Figura $7.17 \mathrm{c} 2$, embora algumas inclusões não tenham sofrido homogeneização até temperaturas superiores a $450^{\circ} \mathrm{C}$, Figura $7.16 \mathrm{f}$.

Os resultados de Te obtidos, revelam que, nas inclusões não orientadas, predomina o sistema $\mathrm{CaCl}_{2}-\mathrm{KCl}-\mathrm{NaCl}-\mathrm{H}_{2} \mathrm{O}$, embora alguns valores de eutéticos mais baixos ou mais elevados, em relação aos representativos deste sistema, sejam indicativos da presença ocasional de outros íons. Nas inclusões dispostas em trilhas os valores da Te também indicam a predominância do sistema $\mathrm{CaCl}_{2}-\mathrm{KCl}-\mathrm{NaCl}-\mathrm{H}_{2} \mathrm{O}$ e, de maneira menos expressiva, daquele representado pelo grupo 3 . 

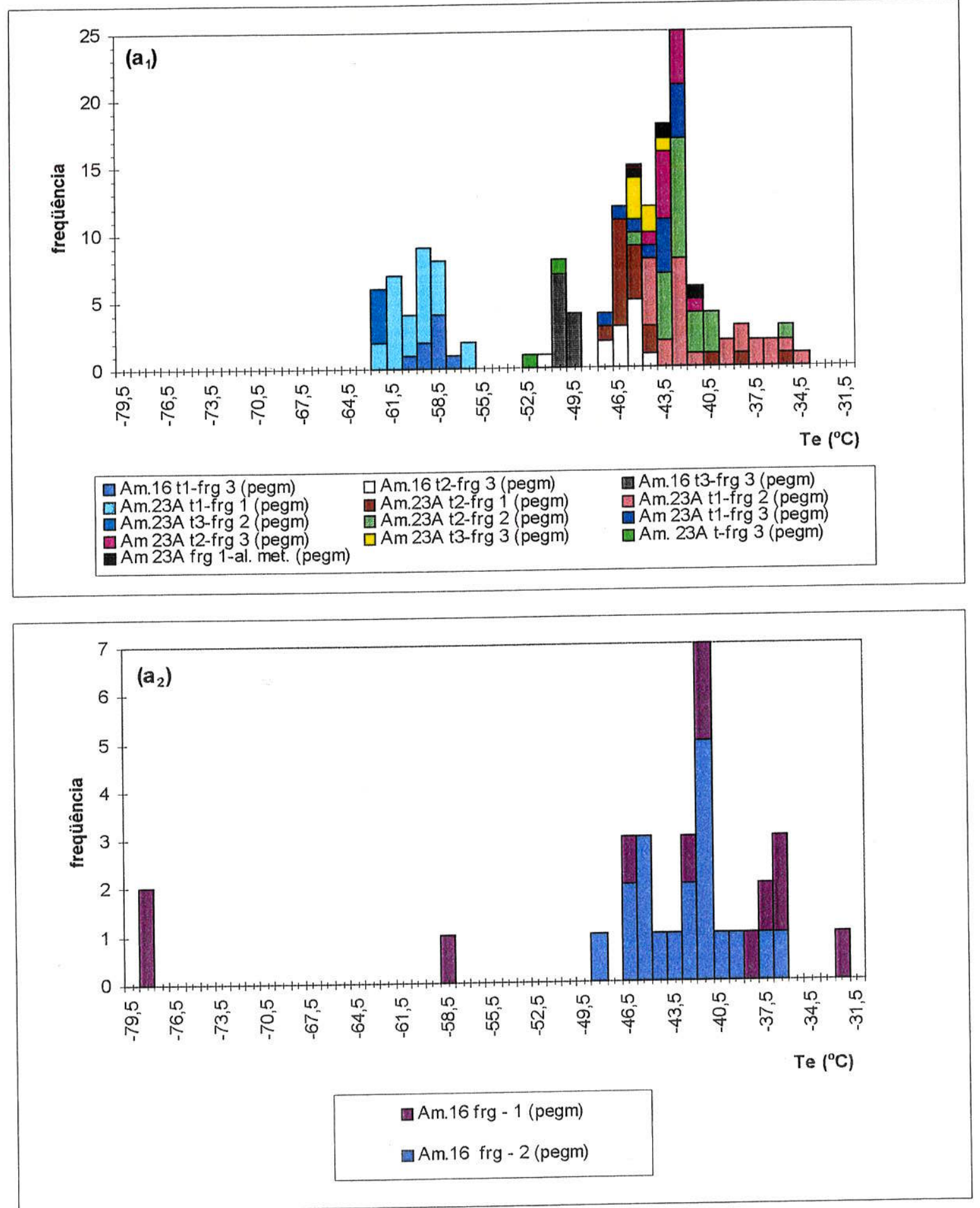

Fig 7.17 - Histogramas de freqüência das temperaturas do eutético (Te) das inclusões presentes em pegmatitos: $\left(a_{1}\right)$ Inclusões dispostas em trilhas; $\left(a_{2}\right)$ inclusões não orientadas. 


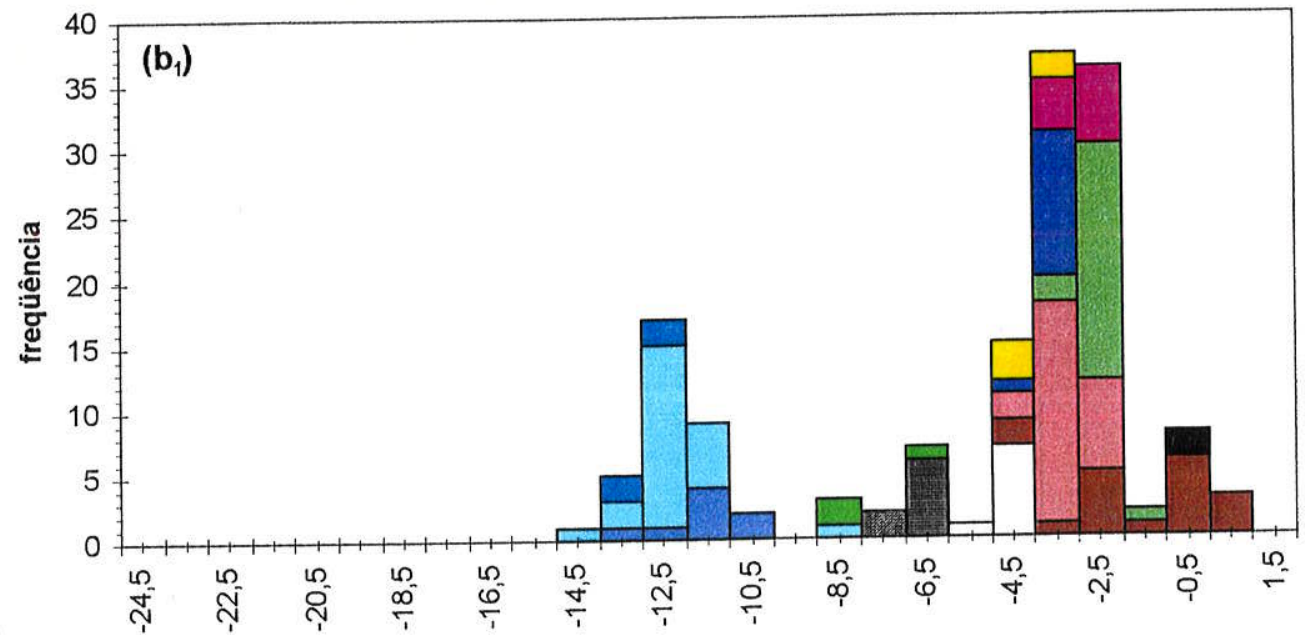

$\operatorname{Tfg}\left({ }^{\circ} \mathrm{C}\right)$

\begin{tabular}{|c|c|c|}
\hline $\begin{array}{l}\text { 口Am.16 t1-frg } 3 \text { (pegm) } \\
\square \text { Am.23A t1-frg } 1 \text { (pegm) } \\
\text { am.23A t3-frg } 2 \text { (pegm) } \\
\text { Am.23A t2-frg } 3 \text { (pegm) } \\
\text { Am.23A frg 1-al. met. (pegm) }\end{array}$ & $\begin{array}{l}\square A m .16 \text { t2-frg } 3 \text { (pegm) } \\
\square A m .23 A \text { t2-frg } 1 \text { (pegm) } \\
\square A m .23 A \text { t2-frg } 2 \text { (pegm) } \\
\square A m .23 A \text { t3-frg } 3 \text { (pegm) }\end{array}$ & $\begin{array}{l}\text { 圆 Am.16 t3-frg } 3 \text { (pegm) } \\
\square \text { Am.23A t1-frg } 2 \text { (pegm) } \\
\text { Am.23A t1-frg } 3 \text { (pegm) } \\
\square \text { Am.23A t-frg } 3 \text { (pegm) }\end{array}$ \\
\hline
\end{tabular}

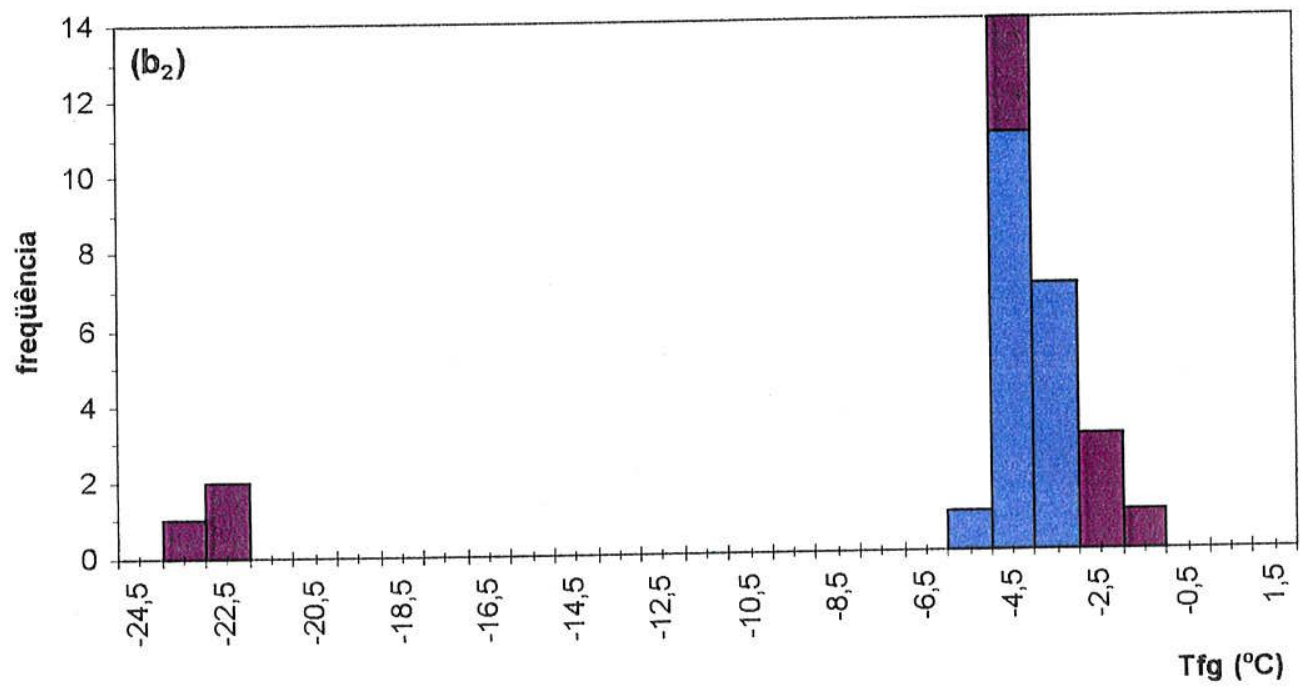

미며․ $16 \mathrm{frg}$ - 1 (pegm)

$\square$ Am. 16 frg - 2 (pegm)

Fig 7.17 - Histogramas de freqüência das temperaturas de fusão do gelo (Tfg) das inclusões presentes em pegmatitos: $\left(b_{1}\right)$ Inclusões dispostas em trilhas; $\left(b_{2}\right)$ inclusões não orientadas. 


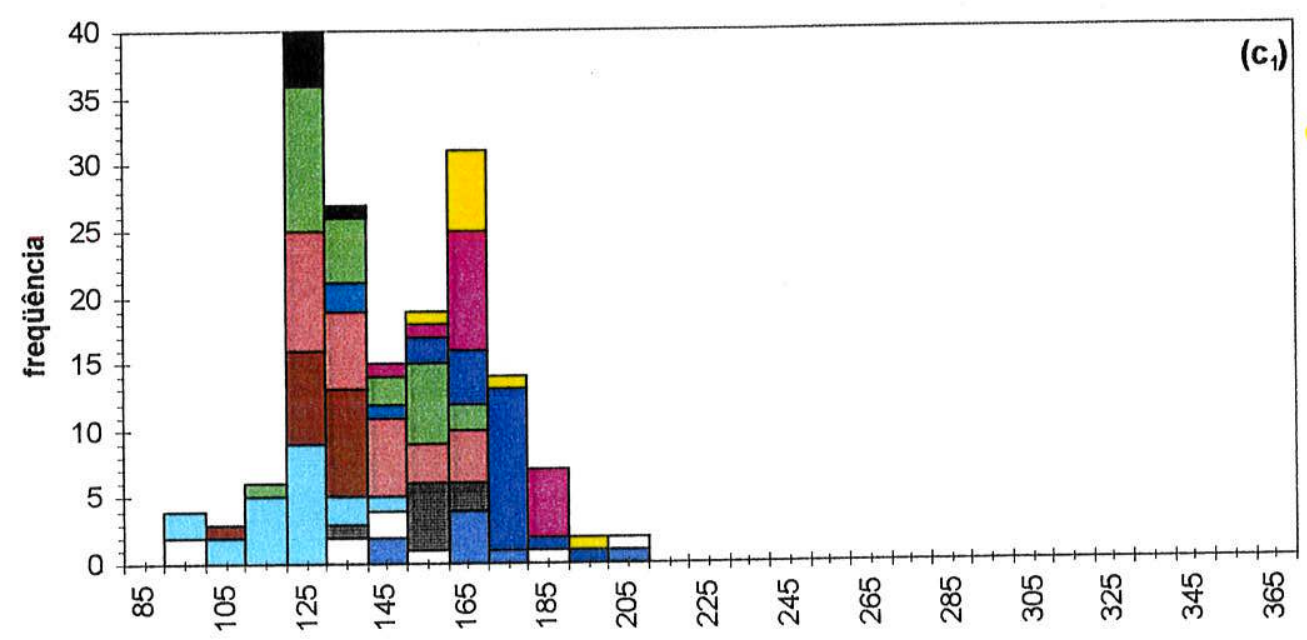

Th L-V (L) $\left({ }^{\circ} \mathrm{C}\right)$

\begin{tabular}{|c|c|c|}
\hline $\begin{array}{l}\text { Am.16 t1-frg } 3 \text { (pegm) } \\
\square \text { Am.23A t1-frg } 1 \text { (pegm) } \\
\text { 口Am.23A t3-frg } 2 \text { (pegm) } \\
\square \text { Am.23A t2-frg } 3 \text { (pegm) }\end{array}$ & $\begin{array}{l}\square A m .16 \text { t2-frg } 3 \text { (pegm) } \\
\square \text { Am.23A t2-frg } 1 \text { (pegm) } \\
\square \text { Am.23A t2-frg } 2 \text { (pegm) } \\
\square A m .23 A \text { t3- frg } 3 \text { (pegm) }\end{array}$ & 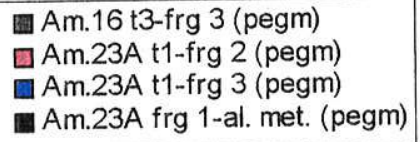 \\
\hline
\end{tabular}

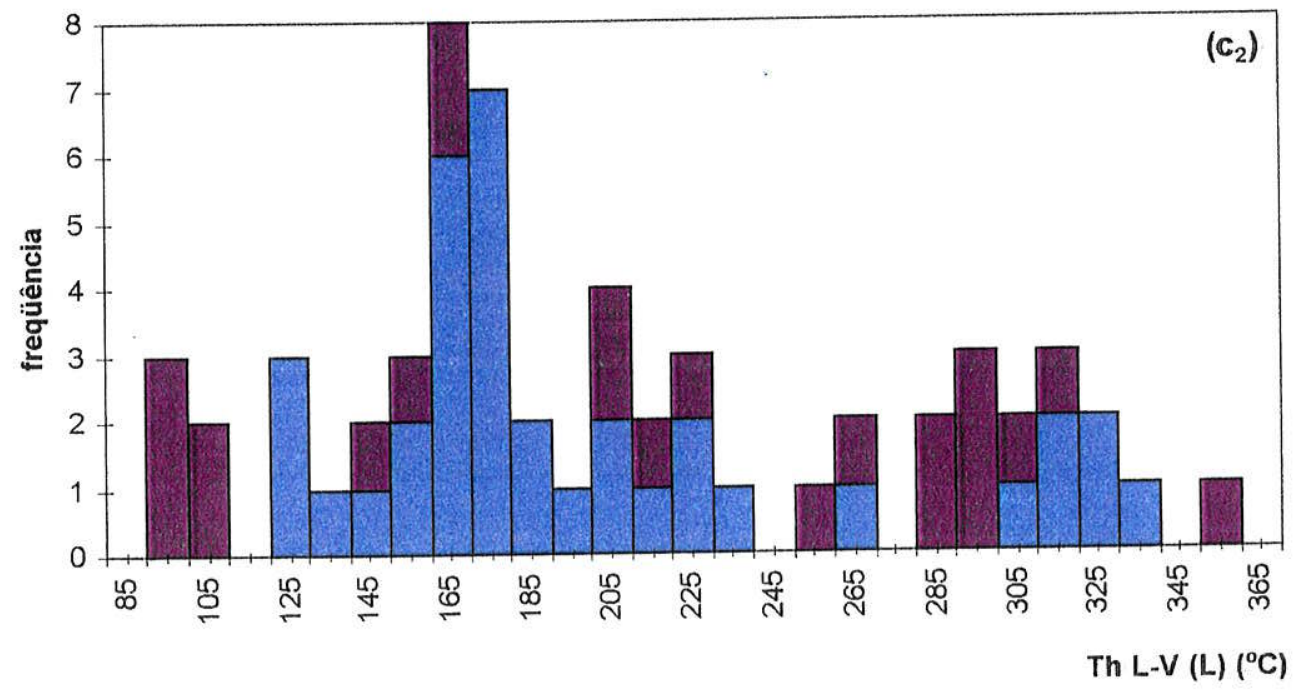

圆Am.16 frg - 1 (pegm)

$\square$ Am.16 frg - 2 (pegm)

Fig 7.17 - Histogramas de freqüência das temperaturas de homogeneização - Th L-V(L) - das inclusões presentes em pegmatitos: $\left(c_{1}\right)$ Inclusões dispostas em trilhas; $\left(c_{2}\right)$ inclusões não orientadas. 
Os valores de $\mathrm{Tfg}$ mostram que as inclusões pertencentes ao sistema salino $\mathrm{CaCl}_{2}$ $\mathrm{KCl}-\mathrm{NaCl}-\mathrm{H}_{2} \mathrm{O}$ possuem baixas salinidades. Nas inclusões dispostas em trilhas as salinidades possuem valores equivalentes variando de 0 a $12,9 \%$ em peso do $\mathrm{NaCl}$, ocorrendo inclusive metaestabilidade representada por $\mathrm{Tfg}$ positivas. Naquelas não orientadas as salinidades apresentam valores equivalentes entre 1,6 e 9,2\% em peso do $\mathrm{NaCl}$. Já as inclusões do grupo 3 , presentes em trilhas, mostram salinidades mais elevadas que as anteriores (equiv a 15,0 a $17,8 \%$ em peso do $\mathrm{NaCl}$ ), Tabela 7.1 .

As temperaturas de homogeneização total das inclusões não orientadas atingem valores mais elevados e apresentam maior dispersão em relação àquelas dispostas em trilhas, provavelmente decorrentes de modificações e reequilíbrios posteriores ao aprisionamento.

Observa-se que, no pegmatito, as inclusões que contém o sistema salino $\mathrm{CaCl}_{2}-\mathrm{KCl}$ $\mathrm{NaCl}-\mathrm{H}_{2} \mathrm{O}$ são muito semelhantes àquelas que foram verificadas apenas nas trilhas $\mathrm{N} 05 / 35^{\circ} \mathrm{W}$ dos veios de quartzo mineralizados, no que se refere à salinidade. Diferem, no entanto, das inclusões pertencentes ao mesmo sistema que ocorrem no veio de quartzo estéril e nas trilhas de direção $\mathrm{N} 0 / 30^{\circ} \mathrm{E}$ dos veios mineralizados. Por outro lado, o sistema salino complexo com $\mathrm{Ca} \pm$ As (?), predominante nos veios mineralizados, não foi detectado nas inclusões dos veios estéreis. No pegmatito esse sistema ocorre, em quantidade irrisória, nas inclusões que constituem agrupamentos não orientados.

\subsection{INTERPRETAÇÃO E DISCUSSÃO}

As inclusões aquosas ao longo de microfraturas que atravessam os limites dos grãos, invadindo núcleo e borda, podem ser interpretadas segundo Johnson \& Hollister (1995), como tendo se formado durante a deformação rúptil que sucede a recristalização dúctil do quartzo. De acordo com os autores citados, as texturas de inclusões aquosas decorando limites de grãos recristalizados e microfraturas seladas indicariam uma complexa história de deformação e aprisionamento de fluidos. Envolveriam a migração dos limites dos grãos num processo contínuo de deformação dúctil, acompanhada por microfraturamento rúptil.

O significado de inclusões fluidas aquosas em depósitos de veios de quartzo-auríferos vem sendo estudada por diversos pesquisadores, entre eles Boullier et al. (1998), que verificaram, em depósitos no Canadá, a existência de dois tipos de fluidos aquosos: (a) fluidos aquosos com alta temperatura de homogeneização (de $212^{\circ} \mathrm{C} \mathrm{a}>450^{\circ} \mathrm{C}$ ) relacionados com os fluidos mineralizantes por guardarem uma associação espacial e textural com inclusões de $\mathrm{CO}_{2}$ e de $\mathrm{H}_{2} \mathrm{O}-\mathrm{CO}_{2}$ dispostas em planos sub-paralelos às paredes dos veios, registrando $\mathrm{o}$ 
crescimento destes; (b) fluidos aquosos, de baixa temperatura de homogeneização (115 a $187^{\circ} \mathrm{C}$ ), temperatura de eutético bastante negativa e salinidade variável. Segundo os autores, os planos aos quais se associam as inclusões portadoras desse segundo tipo de fluido seriam tardios, formando altos ângulos com as paredes dos veios. Portanto, não estariam vinculados com a deposição do ouro, podendo ser correlacionados à mistura derivada da percolação, em profundidade na crosta, de água meteórica e salmouras mais jovens.

Por outro lado, Essaraj et al. (2001) estudando inclusões em amostras orientadas de veios de quartzo auríferos do Maciço Central Francês, associam inclusões aquosas de baixas salinidades e temperaturas de homogeneização entre 140 e $250^{\circ} \mathrm{C}$, com provável temperatura de aprisionamento ao redor de $230^{\circ} \mathrm{C}$, a um segundo estágio de deposição do ouro, que constituiu a principal fase de mineralização. Esses autores, utilizando dados isotópicos, mostraram que esses fluidos aquosos diluídos poderiam ser considerados como águas meteóricas que penetraram profundamente na crosta.

\section{Controle estrutural de trilhas e inclusões fluidas}

Por ordem de freqüência decrescente os planos de inclusões fluidas de fissuras portadoras d inclusões fluidas são representadas pelas seguintes famílias, cujas direções médias são as seguintes:- $\mathrm{N} 5^{\circ} \mathrm{W}$ a $\mathrm{N} 25^{\circ} \mathrm{W}$

$$
\begin{aligned}
& -\mathrm{N} 15^{\circ} \mathrm{E} \text { a N } 25^{\circ} \mathrm{E} \\
& -\mathrm{N} 65^{\circ} \mathrm{E} \text { a N } 50^{\circ} \mathrm{WE} \\
& -\mathrm{N} 35^{\circ} \mathrm{W} \text { a N } 40^{\circ} \mathrm{W} \\
& -\mathrm{N} 85^{\circ} \mathrm{E}
\end{aligned}
$$

Nota-se, conforme Figuras 7.6 e 7.7, que as trilhas de inclusões alinham-se segundo os dois trends principais de fraturas, mais freqüentes, que exibem direções variando de $\mathrm{N} 5^{\circ}$ a $\mathrm{N} 35^{\circ} \mathrm{W}$ e $\mathrm{N}$ a $\mathrm{N} 3^{\circ} \mathrm{E}$. $\mathrm{Na}$ primeira família predomina inclusões contendo sistemas salinos complexos do Grupo 1 e, na segunda, aqueles do grupo2.

Nenhuma das famílias de trilhas de inclusões fluidas estão controladas por planos de cisalhamento dúctil-rúptil ou rúptil (máximos em $\mathrm{N} 55^{\circ} \mathrm{W} / 70^{\circ} \mathrm{NE}, \mathrm{N} 43^{\circ} \mathrm{W} / 60^{\circ} \mathrm{NE}$ e $\mathrm{N} 54^{\circ} \mathrm{W} / 60^{\circ} \mathrm{NE}$ ), pré-intrusão dos grandes corpos de pegmatito-aplito, à exceção do conjunto, pouco freqüente, com atitude $\mathrm{N} 35^{\circ} \mathrm{W}$ e $\mathrm{N} 40^{\circ} \mathrm{W}$, discordante da direção média dos planos de foliação (relação angular variável entre 12 a $17^{\circ}$ ). Esta família poderia eventualmente, corresponder ao pico máximo $\mathrm{N} 43^{\circ} \mathrm{W} / 60^{\circ} \mathrm{NE}$, relacionado a fallhas pós intrusão de pegmatitos. Observa-se, também, que a família $\left(\mathrm{N} 5^{\circ}\right.$ a $\left.N 25^{\circ} \mathrm{W}\right)$ coincide, em parte, com as 2 
famílias de falhas pós-pegmatito equivalente aos polos $\mathrm{N} 5^{\circ} \mathrm{W} / 85^{\circ} \mathrm{NE}$ e $\mathrm{N} 17^{\circ} \mathrm{W} / 84^{\circ} \mathrm{NE}$, (Figura 6.3).

As trilhas mais freqüentes com direções variáveis entre $\mathrm{N} 5^{\circ} \mathrm{W}$ a $\mathrm{N} 25^{\circ} \mathrm{W}$ coincidem com as direções de veios penados, associados aos planos cujas atitudes variam entre $\mathrm{N} 5^{\circ} \mathrm{W} / 49^{\circ} \mathrm{SW}$ a N $25^{\circ} \mathrm{W} / 76^{\circ} \mathrm{SW}$ (Figuras 4.2 e 6.3 ). As trilhas com direções variáveis entre $\mathrm{N} 15^{\circ} \mathrm{E}$ a $\mathrm{N} 25^{\circ} \mathrm{E}$ podem corresponder às direções $\mathrm{N} 10^{\circ}-30^{\circ} \mathrm{E}$ (falhas $\mathrm{R}^{\prime}$ conjugadas), identificadas durante a análise dos dados aeromagnéticos.

\section{Discussão}

No caso dos veios de quartzo do depósito de Salamangone, os resultados microtermométricos revelaram a presença de fluidos de natureza aquossalina, de baixa temperatura de homogeneização, salinidades variáveis e eutéticos indicativos de três sistemas salinos ricos em cálcio, podendo conter outros cátions associados. As inclusões encontram-se sempre condicionadas a microfraturas seladas refletindo os processos de deformação que atuaram nos veios de quartzo, não tendo sido verificadas distribuições que sugiram origens primárias, e nem a presença de fases carbônicas.

Das três composições detectadas pelos eutéticos, o sistema complexo constituído por $\mathrm{Ca}+\mathrm{As}\left(\right.$ ?), grupo 1 , predominante nas trilhas $\mathrm{N} 5 / 35^{\circ} \mathrm{W}$, é o único que se limita aos veios mineralizados, não tendo sido encontrado nem no pegmatito nem nos veios estéreis posteriores. Portanto, parece ser representativo das soluções mais antigas de que se tem registro, podendo estar relacionado, de alguma forma, com a mineralização por ter sido aprisionado em fraturas $\mathrm{N} 5 / 35^{\circ} \mathrm{W}$, de direções equivalentes àquelas de veios penados do sistema filoniano.

O sistema constituído por $\mathrm{CaCl}_{2}-\mathrm{KCl}-\mathrm{NaCl}-\mathrm{H}_{2} \mathrm{O}$, de salinidades mais elevadas, subgrupo $2 \mathrm{a}$, foi observado apenas nas trilhas orientadas segundo a direção $\mathrm{N} 0 / 30^{\circ} \mathrm{E}$ do veio mineralizado. Ocorre ainda nos pegmatitos e nas amostras não orientadas de veios estéreis e mineralizados, dos quais não se conhecem as direções das trilhas. Esse sistema parece ser, portanto, posterior àquele do grupo 1, representando fluidos mais tardios.

$\mathrm{O}$ sistema que constitui o subgrupo $2 \mathrm{~b}$ ocorre de maneira acentuada nas inclusões presentes no pegmatito, mostrando, no entando, diferenças nas temperaturas de homogeneização, condicionadas à forma de ocorrência. Nas inclusões não orientadas as Th $(\mathrm{L}-\mathrm{V})$ atingem valores mais elevados do que os obtidos naquelas dispostas em trilhas, representando, também, as maiores temperaturas de homogeneização, quando consideradas todas as amostras analisadas. Esses valores poderiam, portanto, refletir as condições mais 
próximas de formação do pegmatito, mesmo considerando-se possíveis modificações relacionadas com a evolução e reequilíbrios dos fluidos causados por eventos posteriores. $\mathrm{O}$ subgrupo $2 \mathrm{~b}$ ocorre também, de maneira bastante nítida, nas trilhas $\mathrm{N} 5 / 35^{\circ} \mathrm{W}$ das amostras mineralizadas orientadas, podendo, neste caso, constituir o registro, nos veios auríferos, dos fluidos formadores do pegmatito. Tal sugestão é ainda corroborada pelas maiores temperaturas de homogeneização das inclusões desse subgrupo, em relação a todas as outras presentes no sistema de trilhas NW.

$\mathrm{O}$ sistema representado pelos grupos $3\left(\mathrm{CaCl}_{2}-\mathrm{KCl}-\mathrm{NaCl}-\mathrm{H}_{2} \mathrm{O} \pm \mathrm{Al}\right.$, $\mathrm{Fe}$ e/ou $\left.\mathrm{Mg}\right)$ ocorre tanto nas amostras mineralizadas como nos veios estéreis e no pegmatito.

Merece ser destacado que as inclusões em trilhas dos pegmatitos, cujas composições se assemelham às dos grupos $2 \mathrm{a}, 2 \mathrm{~b}$ e 3 , apresentam os menores valores de temperaturas de homogeneização obtidos em todos os casos analisados. Esse dados, aliados às baixas salinidades e metaestabilidade das inclusões do subgrupo $2 b$, parecem ser indicativos das soluções mais tardias, cujas composições variáveis sugerem a presença de misturas de fluidos.

As discussões apresentadas são indicativas da existência de uma ampla mistura de fluidos inicialmente compostos por um sistema complexo rico em $\mathrm{Ca}$, $\mathrm{As}$ e outros elementos (Fe, Mg), de salinidades elevadas (grupo 1), aprisionado em temperaturas mínimas de 130 a $170^{\circ} \mathrm{C}$, provavelmente relacionado com a mineralização aurífera, conforme discutido anteriormente.

A invasão do sistema filoniano por diques pegmatíticos é responsável pelo aporte de fluidos de composição mais próxima à do sistema aquoso com $\mathrm{Ca}, \mathrm{K}, \mathrm{e} \mathrm{Na}$, de salinidades muito baixas que, também, se encontram registrados nas trilhas $\mathrm{NW}$, como pode ser visto na Figura 7.10. A continuidade do processo de deformação, com o desenvolvimento de fraturas em outras direções, permitiu a entrada de novos fluidos, dando prosseguimento aos processos de mistura já ilustrados nos diagramas das Figuras 7.10 e 7.11. Esses processos seriam responsáveis pelo aparecimento dos fluidos representativos do grupo $3(\mathrm{Ca}, \mathrm{Al}, \mathrm{Fe}, \mathrm{Mg})$ nas trilhas NW e por aqueles dos grupo $3 \mathrm{e}$, predominantemente, $2 \mathrm{a}(\mathrm{Ca}, \mathrm{Na}, \mathrm{K})$ nas trilhas $\mathrm{NE}$, as quais ainda possuem pequenas proporções do fluido mais antigo registrado (grupo 1).

Nos diagramas da Figura 7.11 observa-se uma evolução, por processos de misturas, em direção ao sistema aquoso com $\mathrm{Ca}, \mathrm{Na}, \mathrm{K}$ (eutéticos mais elevados) de mais baixas salinidades, o que é, principalmente, bem caracterizado nas inclusões das trilhas NE.

Finalmente, as inclusões que representam os termos mais evoluídos das misturas, com mais baixas temperaturas de homogeneização e fenômenos de metaestabilidade, são encontradas nas trilhas do pegmatito, das quais não são conhecidas as direções. 


\section{CAPÍTULO 8}

\section{Isótopos Estáveis: Estudos Preliminares}

\subsection{INTRODUÇÃO}

As fontes potenciais para os fluidos hidrotermais e seus componentes nos depósitos filonares auríferos ainda geram muitas controvérsias e estudos isotópicos e geoquímicos, conduzidos em diferentes depósitos da Província Superior do Canadá e do oeste australiano, têm apontado para várias possibilidades entre metamórfica, magmática, mantélica e água meteórica altamente evoluída.

A composição isotópica de oxigênio e hidrogênio de minerais hidrotermais, originados durante o evento mineralizante, pode fornecer informações sobre a temperatura da mineralização e a origem de seus fluidos (Taylor 1997, McCuaig \& Kerrich 1998). Da mesma forma, a composição isotópica de enxofre e carbono trariam informações sobre a fonte destes elementos, e sobre as condições de $\mathrm{f}\left(\mathrm{O}_{2}\right), \mathrm{pH}$ e temperatura durante o processo mineralizador (Ohmoto 1986, Ohmoto \& Goldhaber 1997).

Para auxiliar na caracterização das fontes dos fluidos mineralizantes do depósito de Salamangone, foram selecionadas 08 amostras representativas de veios de quartzo mineralizados e 02 de veios de quartzo estéreis, além de 08 amostras de sulfetos (arsenopirita e pirrotita), de diferentes níveis da mina. Duas amostras do tonalito encaixante da mineralização, também foram selecionadas para análise de grãos de quartzo, biotita e plagioclásio. A separação dos minerais foi realizada com auxílio de uma lupa binocular, a partir de uma fração do material desagregado, com o cuidado de selecionar os grãos sem impurezas visíveis. Para a separação da biotita, foram necessários o uso de processos gravimétricos (via úmida e a seco) e eletromagnético( Frantz).

As dificuldades encontradas durante a etapa de separação das fases minerais, devido as suas características texturais e composicionais, restringiram a obtenção de dados isotópicos mais representativos. Os sulfetos se apresentam em pequena quantidade e no caso da pirrotita, numa granulomentria fina e bastante friável, prejudicando sua 
concentração. A biotita desenvolvida dentro do quartzo dos veios tem dimensões muito reduzidas $(<30 \mu \mathrm{m})$, o que inviabilizou sua separação.

Os dados isotópicos apresentados na Tabela 8.1 representam, tão somente, uma tentativa preliminar de caracterização das condições dos fluidos mineralizantes da fase I da mineralização, exigindo trabalhos complementares futuros.

\subsection{DISCUSSÃO DOS RESULTADOS}

Os valores de $\delta^{18} \mathrm{O}$ dos veios de quartzo mineralizados situam-se entre $+10.8 \mathrm{e}$ $+11.9 \%$, (Tabela 8.1). A pequena variação nos valores de $\delta^{18} \mathrm{O}$ pode refletir que todo o quartzo dos veios foi precipitado a partir de um fluido hidrotermal homogêneo, num regime estável de P e T, durante o processo de mineralização (Golding \& Wilson 1987). A faixa de valores de $\delta^{18} \mathrm{O}$ dos veios quartzo-auríferos de Salamangone é típica dos depósitos filonares mesotermais do arqueano, que estão representados na Figura 8.1. Esses dados são corroborados pela faixa de temperatura mínima, estimada pelo geotermômetro arsenopirita, para a fase I de mineralização, situando-a num ambiente de alta temperatura, condizente com os depósitos auríferos mesotermais, do tipo lode (Groves et. al. 1998).

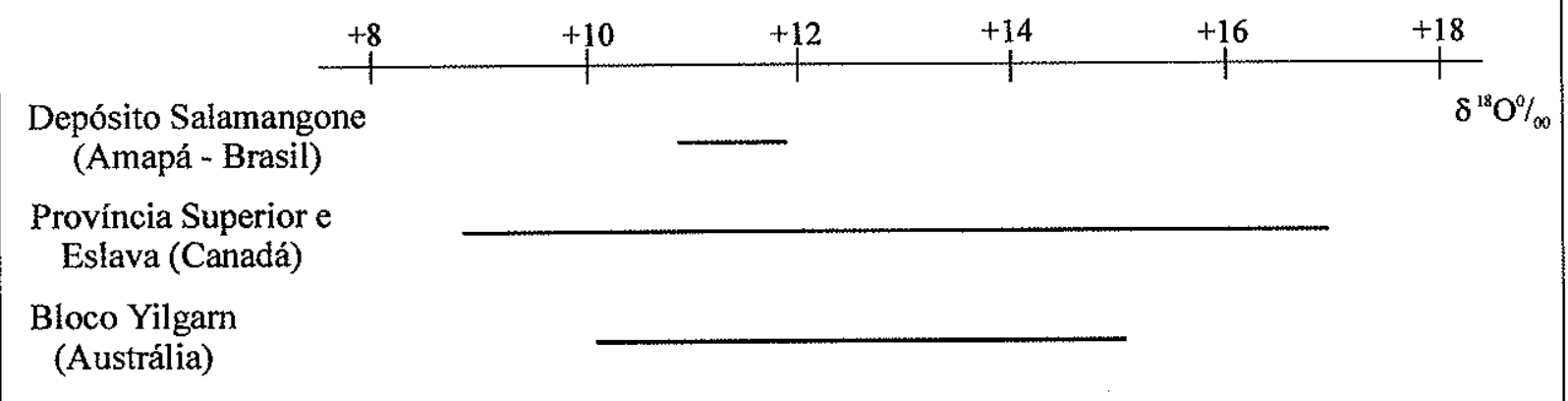

Figura 8.1 - Valores de $\delta^{18} \mathrm{O}$ dos veios de quartzo-auríferos de Salamangone e de depósitos da Austrália (Golding \& Wilson 1987) e do Canadá (McCuaig \& Kerrich 1998). 


\begin{tabular}{|c|c|c|c|c|c|c|}
\hline Amostra & Mineral & $\begin{array}{l}\delta^{18} \mathrm{O}(\%) \\
(\mathrm{SMOW})\end{array}$ & $\begin{array}{l}\delta \mathrm{D}(\%) \\
(\mathrm{SMOW})\end{array}$ & $\begin{array}{c}\delta^{34} \mathrm{~S}(\% \mathrm{o}) \\
(\mathrm{CDT})\end{array}$ & Par & $\mathbf{T}\left({ }^{\circ} \mathrm{C}\right)$ \\
\hline $\begin{array}{l}\text { SL-62/ SH-118 } \\
\text { (tonalito pouco alterado) }\end{array}$ & $\begin{array}{l}\text { Quartzo } \\
\text { Plagioclásio } \\
\text { Biotita }\end{array}$ & $\begin{array}{l}+11.0 \\
+8.5 \\
+3.6\end{array}$ & -78 & & $\mathrm{Qz}-\mathrm{Bt}$ & 407 \\
\hline $\begin{array}{l}\text { SHN-089/ SH-113 } \\
\text { (tonalito pouco alterado) }\end{array}$ & $\begin{array}{l}\text { Quartzo } \\
\text { Plagioclásio } \\
\text { Biotita }\end{array}$ & $\begin{array}{l}+10.8 \\
+8.3 \\
+4.3\end{array}$ & -66 & & $\begin{array}{l}\text { Qz-Plag } \\
\text { Qz-Bt }\end{array}$ & $\begin{array}{l}460 \\
434\end{array}$ \\
\hline $\begin{array}{l}\text { Sl-19B (FP)/ Nível } 290 \mathrm{~m} \\
\text { (ribbons em veio) }\end{array}$ & $\begin{array}{l}\text { Quartzo } \\
\text { Biotita } \\
\text { Arsenopirita }\end{array}$ & $\begin{array}{l}+11.4 \\
+3.8\end{array}$ & -89 & -4.0 & $\mathrm{Qz}-\mathrm{Bt}$ & 399 \\
\hline $\begin{array}{l}\text { L-274 (FL)/ Nível } 274 \mathrm{~m} \\
\text { (ribbons em veio) }\end{array}$ & $\begin{array}{l}\text { Quartzo } \\
\text { Biotita }\end{array}$ & $\begin{array}{l}+11.4 \\
+3.7\end{array}$ & -88 & & $\mathrm{Qz}-\mathrm{Bt}$ & 397 \\
\hline L-2741 (FL)/ Nível 274m & $\begin{array}{l}\text { Quartzo } \\
\text { Arsenopirita }\end{array}$ & +11.0 & & -4.5 & & \\
\hline SL-13B (FP)/ Nível 290m & $\begin{array}{l}\text { Quartzo } \\
\text { Arsenopirita }\end{array}$ & +11.9 & & -3.7 & & \\
\hline R-26 (FP)/ Nivel $54 \mathrm{~m}$ & $\begin{array}{l}\text { Quartzo } \\
\text { Arsenopirita }\end{array}$ & +11.8 & & -3.7 & & \\
\hline $\mathrm{N}-41$ (FP)/ Nível $54 \mathrm{~m}$ & $\begin{array}{l}\text { Quartzo } \\
\text { Arsenopirita }\end{array}$ & +11.6 & & -5.5 & & \\
\hline SL-1510 (FL)/ Nível $264 \mathrm{~m}$ & $\begin{array}{l}\text { Quartzo } \\
\text { Arsenopirita }\end{array}$ & +11.7 & & -4.2 & & \\
\hline $\mathrm{SH}-04 / \mathrm{SH}-46$ (FC) & Quartzo & +10.8 & & & & \\
\hline R-25 (FP)/ Nível $54 \mathrm{~m}$ & Arsenopirita & & & -3.4 & & \\
\hline amostra média composta & Pirrotita & & & -4.1 & & \\
\hline $\begin{array}{l}\text { SHN-01/SHNm144 } \\
\text { veio estéril }\end{array}$ & Quartzo & +11.3 & & & & \\
\hline $\begin{array}{l}\text { SHN-06/SHN-112 } \\
\text { veio estéril }\end{array}$ & Quartzo & +10.4 & & & & \\
\hline
\end{tabular}

Tabela 8.1 - Composição isotópica do conjunto dos minerais amostrados e resultados termométricos. Valores de temperatura aparente de acordo com calibração semi-empírica de Bottinga \& Javoy (1975) e Javoy (1977). Simbologia: $\mathrm{FP}=$ filão principal, $\mathrm{FC}=$ filão capa, $\mathrm{FL}=$ filão lapa. 
A expressão de calibração, semi-empírica de Bottinga \& Javoy (1975) e Javoy (1977) é dada por:

$1000 \ln \alpha(\mathrm{X}, \mathrm{H})=\mathrm{A}_{\mathrm{XH}}+\mathrm{B}_{\mathrm{XH}}\left(10^{6} / \mathrm{T}^{2}\right)$ onde, $\mathrm{X}$ e $\mathrm{H}$ representam os valores de $\delta^{18} \mathrm{O}$ do par de minerais considerado, A e B são constantes e $\mathrm{T}$ é a temperatura em Kelvin.

Por outro lado, os valores de $\delta^{18} \mathrm{O}$ encontrados para o quartzo da rocha tonalítica encaixante, pouco afetada pela mineralização, mostram-se muito semelhantes àqueles encontrados para os veios de quartzo e ribbons de tonalito dentro dos veios, expressando, provavelmente, a abrangência das condições de interação rocha-fluido e o enriquecimento em ${ }^{18} \mathrm{O}$. Deste modo, a tentativa de estimar uma temperatura de cristalização para o tonalito a partir dos pares quartzo-biotita e quartzo-plagioclásio não teve êxito, pois não se encontram em equílibrio isotópico, obtendo-se resultados muito inferiores daqueles calculados pelo geotermômetro Hbl-Pl (Blund \& Holland 1994), que variaram entre $645^{\circ} \mathrm{e}$ $695^{\circ} \mathrm{C}$.

Estudos isotópicos conduzidos na mina de Renco, Zimbabwe (Kolb et al. 2000), revelam que as rochas enderbíticas (denominadas de lithons), incluídas na zona de cisalhamento que controlam a mineralização aurífera, estão enriquecidas em ${ }^{18} \mathrm{O}$ quando comparadas com as rochas encaixantes de mesma composição, não afetadas. A temperatura obtida no par quartzo-biotita é muito inferior, sendo interpretada como resultante da interação com fluidos hidrotermais superficiais.

Com relação à composição isotópica de enxofre, os depósitos minerais hidrotermais apresentam grandes variações nos valores de $\delta{ }^{34} \mathrm{~S}$, onde a maioria deles situa-se entre +50 e $-50 \%$, existindo três grandes reservatórios de enxofre no planeta, de acordo Ohmoto \& Rye (1979), com valores distintos de $\delta{ }^{34} \mathrm{~S}$ : a) enxofre derivado do manto com valores variando entre $-3 \mathrm{a}+3 \%$; b) enxofre da água do mar onde os valores são positivos, variam com o tempo e estão hoje ao redor de $+20 \%$ e c) enxofre sedimentar (reduzido) com valores variáveis e bastante negativos.

Os valores de $\delta^{34} \mathrm{~S}$ obtidos nas amostras de arsenopirita e pirrotita que acompanham a fase I da mineralização, apresentaram pequena variação entre $-5,5$ e $-3,4 \%$, Tabela 8.1 . Os valores negativos e relativamente constantes encontrados, podem ser atribuídos, segundo Lambert et al. (1984), Colvine et al. (1988) e McCuaig \& Kerrich (1998), à 
processos de oxidação dos fluidos mineralizantes. Três mecanismos têm sido propostos para explicar estes processos, segundo McCuaig \& Kerrich (1998): (1) interação acentuada de fluidos hidrotermais com minerais silicatados de $\mathrm{Fe}$ das rochas encaixantes, onde a oxidação dos fluidos é vinculada ao consumo do $S$ na formação de pirita; (2) fluidos magmáticos, intrinsecamente, oxidantes e (3) oxidação dos fluidos, acompanhando separação por imiscibilidade de gases redutores $\mathrm{CH}_{4}, \mathrm{H}_{2} \mathrm{~S}$ e $\mathrm{H}_{2}$. No depósito de Salamangone o processo (1) é o mais provável de ter ocorrido, por meio da interação entre os fluidos hidrotermais e os minerais ferro-magnesianos (biotita e hornblenda) da rocha tonalítica encaixante, que originou arsenopirita, lollingita e pirrotita. 


\section{CAPÍtulo 9}

\section{As condições de formação do depósito de Salamangone: modelo genético preliminar}

\section{a) Controle estrutural}

No depósito de Salamangone as zonas de cisalhamento dúctil-rúptil e rúptil constituem as estruturas hospedeiras, principais, do sistema filoniano aurífero, a exemplo do que se tem documentado em outros depósitos quartzo-auríferos, associados a plutons granitóides. Os corpos de minério são controlados pelos planos de foliação milonítica, constituindo, via de regra, filões paralelos ou sub-paralelos aos limites das zonas de cisalhamento, tipificados por uma textura laminada (ribbon), correspondendo ao mecanismos de formação de veios tipo crack and seal (Ramsay 1980b).

\section{b) A idade da mineralização}

A determinação de um intervalo de tempo para a mineralização é importante para a compreensão de sua gênese e estabelecimento de um modelo deposicional.

No depósito de Salamangone, o sistema filoniano é epigenético com relação à rocha tonalítica encaixante, cuja idade de cristalização, fornecida pela datação $\mathrm{U} / \mathrm{Pb}$ em zircão, apresentou o valor de cerca de $2155 \pm 13 \mathrm{Ma}$. No entanto, é seccionado por corpos pegmatíticos, que apresentam idade isocrônica $\mathrm{Rb}-\mathrm{Sr}$ em torno de $1976 \pm 200 \mathrm{Ma}$.

Pela datação direta de cristais de arsenopirita relacionadas à fase I da mineralização, utilizando-se da sistemática $\mathrm{Pb}-\mathrm{Pb}$ através das técnicas de dissolução total e lixiviação de concentrados, foi obtida uma isócrona de referência que definiu a idade de $2002 \pm 61 \mathrm{Ma}$, para este estágio da mineralização, Figura 9.1a e Tabela 9.1 (Anexo 4). As composições isotópicas de $\mathrm{Pb}$ foram lançadas nos diagramas de plumbotectônicał de Zartman \& Doe (1981), contendo as curvas de evolução do $\mathrm{Pb}$ para a Crosta Superior e Inferior, Manto e ambientes orogênicos, Figuras 9.b e 9.c. Os pontos analíticos correspondentes à arsenopirita da fase I, situados abaixo da curva da Crosta Superior e próximos da curva do ambiente orogênico sugerem um reservatório crustal mais profundo para o $\mathrm{Pb}$. Esses resultados são corroborados por dados preliminares de $\mathrm{Pb}$ (embora não considerados neste estudo), que indicam a possibilidade de reciclagem do $\mathrm{Pb}$ a partir de uma crosta mais antiga. Contudo, duas amostras 
(associadas à ribbons) pressupõem derivação de um reservatório crustal, o que poderia significar a possibilidade de existência de uma segunda geração de arsenopirita. Essa hipótese não foi texturalmente confirmada.

Datações em galena do depósito aurífero de Loulouie na Guiana Francesa, Figura 3.3, forneceram uma idade isocrônica $\mathrm{Pb}-\mathrm{Pb}$ de 2,01 Ga (Voicu et al 1999), da mesma forma que, depósitos quartzo-auríferos do oeste da África, entre eles Ashanti, Banora, Poura, (Milési et al. 1992, Marcoux \& Milési 1993), apresentaram idade isocrônica $\mathrm{Pb}-\mathrm{Pb}$ em galena, de cerca de 2,00 Ga. Esses depósitos, assim como o depósito de Salamangone, possuem muitas feições em comum, constituindo, de modo geral, sistemas filonianos quartzo-auríferos epigenéticos, controlados por zonas de cisalhamento de caráter dúctil-rúptil, desenvolvidas durante eventos orogênicos do Paleoproterozóico.

\section{c) Processos de transporte e deposição do ouro}

Os mecanismos que envolvem a origem do ouro e as condições para seu transporte e deposição em sistemas hidrotermais são muito complexos, sofrendo influência, particularmente, da $\mathrm{T}, \mathrm{fO}_{2}$ e $\mathrm{pH}$ dos fluidos hidrotermais, bem como da quantidade de espécies sulfetadas e/ou clorídicas, neles dissolvidas.

É consenso entre diversos autores, tais como Seward 1984, Benning \& Seward 1996, Mikucki \& Ridley 1993, Ridley et al. 1996, Mikucki 1998, McCuaig \& Kerrich 1998, que o transporte do ouro sob condições hidrotermais é realizado por complexos do tipo $\mathrm{Au}(\mathrm{HS})^{\circ}$, que predomina em temperaturas abaixo de $300^{\circ} \mathrm{C}$, e por $\mathrm{Au}(\mathrm{HS})_{2}{ }^{-}$e $\mathrm{AuCl}_{2}{ }^{-}$, acima deste patamar de temperatura. Para ocorrer a concentração de ouro nos veios a partir de fluidos hidrotermais são necessárias mudanças nas condições químicas dos fluidos, capazes de desestabilizar os complexos auríferos e promover a remoção do ouro da solução. Esta desestabilização relaciona-se com: o estado de redução ou oxidação do fluido, aumento do pH do fluido (especialmente para complexos de $\mathrm{Au}-\mathrm{Cl}$ ), ou diminuição da concentração de $\mathrm{S}$ no fluido (especialmente para complexos de Au-S). De acordo com McCuaig \& Kerrich 1998, vários fatores são responsáveis pelas mudanças, destacando-se: (1) interação rocha-fluido; (2) mistura de fluidos; (3) imiscibilidade e (4) resfriamento.

O fator (1), interação rocha-fluido, pode ter sido fundamental na concentração do ouro verificada na fase I de mineralização no depósito de Salamangone, onde ocorre a sulfetação da rocha tonalítica encaixante, e o ouro encontra-se associado, particularmente, com lollingita e arsenopirita. 
A

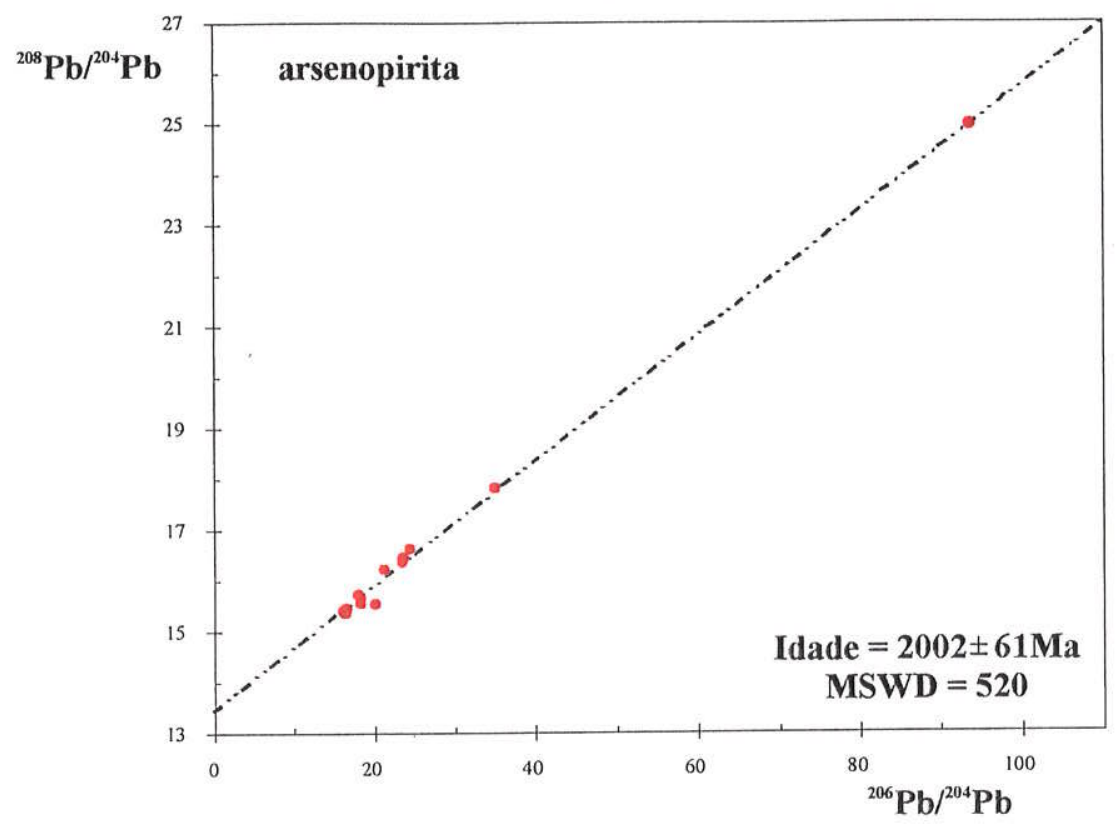

B

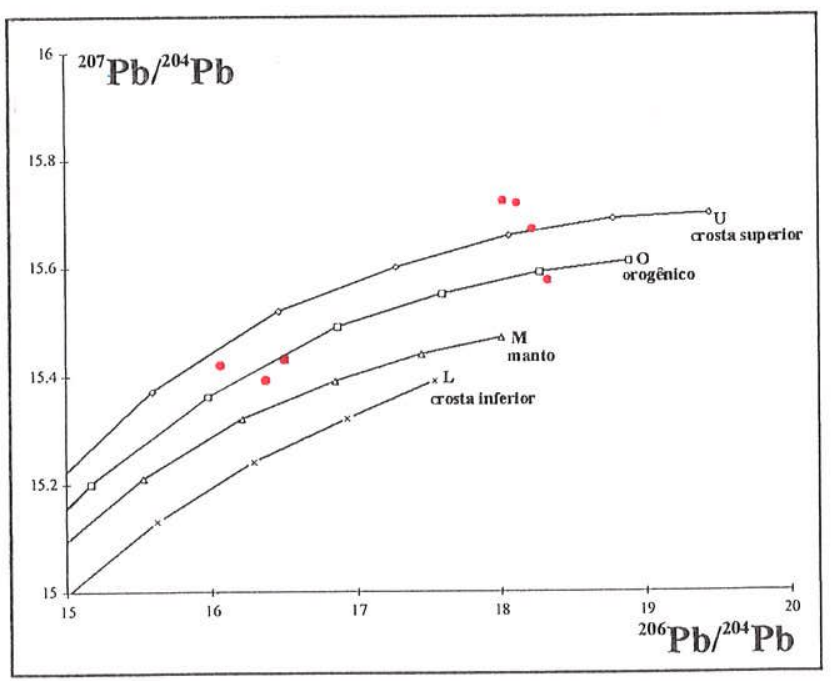

C

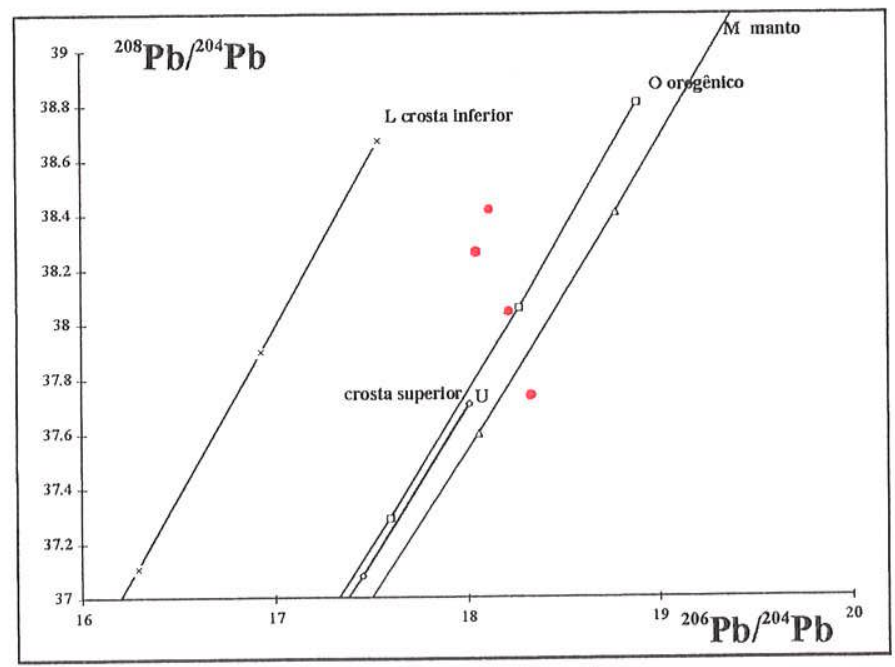

Figura 9.1 - A- Diagrama isocrônico $\mathrm{Pb} / \mathrm{Pb}$ de cristais de arsenopirita, da fase I da mineralização do depósito de Salamangone. B e C - Dados de composição isotópica de Pb de arsenopirita, em curvas de evolução do modelo de plumbotectônica, segundo Zartman \& Doe (1981). 
Neste processo de deposição do ouro, segundo McCuaig \& Kerrich (1998), $\mathrm{H}_{2} \mathrm{~S}$ e S de fluidos mineralizantes enriquecidos em complexos de Au-S-As, são consumidos pela reação com silicatos de ferro ou óxidos de ferro da rochas encaixantes, formando sulfetos. A perda de $\mathrm{S}$, que se traduz por uma diminuição do conteúdo de enxofre $(\Sigma S)$ nos fluidos, desestabiliza os complexos de ouro e arsênio, ocasionando a precipitação do ouro, através de reações envolvendo $\mathrm{Au}(\mathrm{HS})_{2}{ }^{-}+\mathrm{Fe} \mathrm{O}_{\text {(silicato, óxido) }} \rightarrow \mathrm{Au}+\mathrm{FeS}_{2}$ (não balanceada). Uma consequência deste mecanismo, verificada no depósito de Salamangone, é o enriquecimento em magnésio, com a saída de ferro na hornblenda e biotita do tonalito.

Nos depósitos de Mt. York e Griffin's Find, oeste australiano, formados em ambiente de alto grau metamórfico, Neumayr et al. (1993a) demonstraram que o ouro situado nos limites dos grãos da lollingita-arsenopirita, textura também observada em Salamangone, foi precipitado, inicialmente, junto com a lollingita como solução sólida, e depois liberado, localmente, de sua estrutura durante a substituição deste mineral pela arsenopirita, sob condições ligeiramente retrógradas com relação àquelas nas quais se depositaram. Considerando que as temperaturas obtidas através do uso das composições atômicas de arsênio na arsenopirita, como geotermômetro, situaram-se numa faixa entre $400^{\circ} \mathrm{C}$ e $565^{\circ} \mathrm{C}$, estas representariam temperaturas mínimas de formação da paragênese sulfetada no depósito de Salamangone, enquadrando-o no grupo de alta temperatura.

O ouro, na fase II da mineralizaçâo, localiza-se, principalmente, em fraturas na ganga quartzosa, ou acha-se incluso na arsenopirita e pirita, sendo interpretado como decorrente, provavelmente, da remobilização do ouro primário (fase I) por soluções aquoosas de alta salinidade, durante os processos de recristalização e deformação que atuaram no sistema filoniano. Processos desta natureza tem sido documentados em depósitos estudados por Kontoniemi \& Nurmi (1998), Barrie \& Touret (1999), entre outros.

\section{d) A evolução do sistema hidrotermal aurífero}

O depósito de Salamangone, controlado por cisalhamento dúctil-rúptil e rúptil, sofreu modificações após sua formação, registradas nos veios pelas texturas de deformação nos cristais de quartzo, que se apresentam intensamente recristalizados e atravessados por fraturas, a maioria, constituindo planos de inclusões fluidas secundárias. Desta forma, como inclusões fluidas primárias não foram preservadas, a composição e condições de formação dos fluidos na fase I de mineralização não puderam ser determinadas. Sua temperatura foi estimada com base nas fases minerais sulfetadas em equilibrio e nas suas relações texturais. A faixa de 
temperatura entre $400^{\circ}$ e $565^{\circ} \mathrm{C}$, calculada pelo geotermômetro arsenopirita, traduz as condições mínimas para a formação dos sulfetos, provavelmente, precipitados de fluidos, onde o ouro foi transportado como complexos de Au-S-As, sob altas temperaturas.

Os valores de $\delta{ }^{18} \mathrm{O}$ do quartzo dos veios, situados num intervalo de variação pequena, entre $+10,8$ e $+11,9 \%$, indicam um fluido hidrotermal homogêneo, com uma assinatura isotópica típica dos depósitos de ouro mesotermais do Arqueano (Golding \& Wilson 1987). Esses dados são corroborados pelas composições isotópicas de $\mathrm{Pb}$, obtidas nos cristais de arsenopirita da fase I de mineralização, que sugerem origem a partir de um reservatório mais profundo, abaixo da Crosta Superior, compatível com os depósitos orogênicos (também denominados de mesotermais), de alta temperatura, situados entre profundidades de 5 a 10 km, estabelecidos em Groves et al. 1998.

O estudo das inclusões fluidas secundárias no quartzo dos veios, condicionadas sempre a microfraturas, revelaram a presença de fluidos aquosos de sistemas salinos ricos em cálcio, podendo conter outros cátions associados. Estes fluidos, tardios com relação à fase I de mineralização, estiveram ativos dentro da zona de cisalhamento, que controlou a colocação e a deformação dos corpos de minérios no depósito de Salamangone, e podem ter sido responsáveis pela remobilização e deposição do ouro, principalmente, ao longo de fraturas, nas zonas de quartzo recristalizadas, durante a fase II de mineralização.

A definição de duas direções preferenciais dos planos portadores das inclusões fluidas, uma com direções variando de $\mathrm{N} 5^{\circ}$ a $35^{\circ} \mathrm{W}$ e outra de $\mathrm{N}$ a $\mathrm{N} 30^{\circ} \mathrm{E}$ e as características dos fluidos aí existentes, revelaram uma correlação entre um sistema complexo constituído de Ca $+\mathrm{As}($ ?), com salinidades extremamente elevadas (grupo 1), com o primeiro conjunto de trilhas, e um outro sistema, composto por $\mathrm{CaCl}_{2}-\mathrm{KCl}-\mathrm{NaCl}-\mathrm{H}_{2} \mathrm{O}$, exibindo salinidades moderadas a altas (grupo 2a), associadoàs trilhas $\mathrm{N}$ a N30 $0^{\circ}$.

A remobilização de ouro primário por soluções de salinidades elevadas, tem sido verificada por Guha \& Kanwar (1987), Essaraj et al. (2001), Kontoniemi \& Nurmi (1998), Oberthür et al. (2000), entre outros.

No depósito de Salamangone a ocorrência, apenas nos veios de quartzo mineralizados, de um sistema extremamente salino composto por fluidos complexos com $\mathrm{Ca}$ e outros cátions, adquiridos, provavelmente, da interação com a rocha tonalítica encaixante sulfetada na fase I de mineralização, e sua associação a planos de fraturas com orientações mais freqüentes $N 5^{\circ}$ a $25^{\circ} \mathrm{W}$, coincidentes com as direções de veios penados relacionados com fraturas de partição dentro da zona de cisalhamento, sugerem que este sistema de fluidos poderia ter sido responsável pela remobilização e deposição do ouro na fase II da mineralização. 
Por outro lado, o sistema constituído pelo grupo $2 \mathrm{a} \quad\left(\mathrm{CaCl}_{2}-\mathrm{KCl}-\mathrm{NaCl}-\mathrm{H}_{2} \mathrm{O}\right.$, salinidades moderadas a altas), está presente não apenas nos veios de quartzo mineralizados, mas também nos veios de quartzo estéreis e nos diques pegmatíticos, que seccionam o sistema filoninano. Ressalva-se, contudo, com base nos dados disponíveis, que não há condições de caracterizar a participação deste grupo de fluidos a qualquer tipo de mineralização aurífera.

Conforme ressaltado por diversos autores, já citados anteriormente, depósitos auríferos filonares seriam o resultado de sucessivos estágios de circulação de fluidos, decorrentes da evolução das zonas de cisalhamento, às quais, via de regra, se associam. Esta situação, no caso do depósito de Salamangone, é verificada pela existência de uma amplo processo de mistura de fluidos, de salinidades extremamente elevadas, inicialmente compostos por um sistema complexo com $\mathrm{Ca}$, As e outros elementos, evoluindo para a um sistema aquoso com $\mathrm{Ca}, \mathrm{K}$ e $\mathrm{Na}$ de salinidades mais baixas, mostrado, nitidamente, nos diagramas das Figuras 7.10 e 7.11 .

A origem dos fluidos mineralizantes ainda constitui uma questão em aberto. Groves et al. (2000), analisando dados isotópicos $(\mathrm{O}$ e $\mathrm{H})$, disponíveis em depósitos auríferos, do tipo orogênico, de idades desde o Arqueano até o Cenozóico, sugerem um fonte crustal profunda para esses fluidos. Ressaltam, contudo, que a compreensão sobre sua natureza metamórfica, magmática ou mantélica é, ainda, muito pequena, mesmo após mais de uma década de debates e cenários. Cassidy et al. (1998) estudando depósitos auríferos associados a rochas granitóides, descarta uma derivação magmática direta para os fluidos mineralizantes, considerando as relações de espaço e tempo entre a colocação dos corpos granitóides e a mineralização aurífera, sugerindo uma origem profunda (crosta média a inferior).

No depósito de Salamangone a ausência de inclusões fluidas primárias e a conjunção de vários estágios de deformação originando planos de inclusões fluidas secundárias, deixa claro que os fluidos hidrotermais iniciais, relacionados com a fase I de mineralização, não foram preservados. Por outro lado, é flagrante a presença de fluidos essencialmente aquosos, de salinidades variadas, indicando um amplo processo de mistura.

Numa tentativa de se esboçar um quadro evolutivo, simplificado, teríamos que fluidos aquosos complexos, extremamente salinos (grupo 1) seriam responsáveis pela remobilização e deposição do ouro, numa fase imediatamente posterior à fase I de mineralização. A recorrência de episódios de deformação, com aporte e circulação de novos fluidos dentro da zona de cisalhamento, que hospeda o depósito de Salamangone, resultaria numa ampla mistura de fluidos aquosos, com composições cada vez menos salinas (grupos 3 e 2a). Esse processo de mistura aparece de forma contundente, no conjunto de trilhas orientadas segundo 
$\mathrm{N}$ a $\mathrm{N} 30^{\circ} \mathrm{E}$, onde se pode observar, nitidamente, todo o espectro da mistura de fluidos, com as inclusões evoluindo do grupo 1 (altamente salino) para os grupos 3 e $2 \mathrm{a}$, com salinidades decrescentes (Figura 7.11). Por sua vez, é verificado menos acentuadamente, no conjunto de trilhas orientadas segundo $\mathrm{N} 5^{\circ}$ a $35^{\circ} \mathrm{W}$, evidenciado pela presença de inclusões do grupo 3 (Figura 7.10).

Considerando o enquadramento do depósito de Salamangone, hospedado em rochas granitóides, e controlado por zonas de cisalhamento, a origem das soluções hidrotermais, essencialmente aquosas, pode, provavelmente, ser atribuída a uma mistura de salmouras profundas de natureza metamórfica, com fluidos hidatogênicos (águas meteóricas de circulação profunda), sem descartar a presença de fluidos magmáticos relacionados com a presença dos corpos pegmatíticos.

\section{e) Modelo genético preliminar}

A sistematização de informações que descrevem os atributos essenciais do depósito de Salamangone, bem como outros dados geológicos e geocronológicos regionais, são mostradas no Quadro 9.1. A paragênese metálica aliada ao modelo de alteração hidrotermal e às características estruturais e metamórficas regionais indicam que esse depósito, hospedado em rochas granitóides, apresenta muitas feições semelhantes a outros sistemas filonianos quartzoauríferos, igualmente encaixados em rochas de natureza granitóide.

O depósito, do Paleoproterozóico, Osikonmäki, em Rantasalmi, sudeste da Finlândia, estudado por Kontoniemi \& Nurmi (1998), representa o melhor exemplo de similaridades com Salamangone. Hospedado, igualmente, em rocha tonalítica, é epigenético, associando-se a zona de cisalhamento e exibindo forte controle estrutural. A paragênese sulfetada da mineralização é idêntica, constituída de po + asp + lo $+c c p$, apresentando as mesmas relações texturais com o ouro, encontradas em Salamangone. $O$ transporte do ouro foi feito como complexos de S-As, por fluidos hidrotermais primários de origem magmática e/ou metamórfica, sob condições de metamorfismo de facies anfibolito. Assim como em Salamangone, estudos de inclusões fluidas revelam que o principal estágio de mineralização foi seguido por um aporte de fluidos aquosos, de salinidades variáveis, que remobilizou e redistribuiu o ouro, durante episódios mais tardios de deformação da zona de cisalhamento. 


\begin{tabular}{|c|c|}
\hline Parâmetros & Atributos principais \\
\hline Rocha encaixante/idade & tonalito/ U-Pb $2155 \pm 13 \mathrm{Ma}$, granodiorito e anfibolito \\
\hline Intrusões graníticas associadas & pegmatito - aplito \\
\hline Timing da mineralização & pós-pico metamórfico (?), pré-pegmatito - aplito \\
\hline Profundidade na crosta & $5-10 \mathrm{~km}$ \\
\hline Regime estrutural & dúctil-rúptil e rúptil \\
\hline Controle estrutural & \begin{tabular}{|l|ll} 
zonas de cisalhamento com componente destral \\
$\left(\mathrm{N} 45^{\circ} \mathrm{W} / 65 \mathrm{NE}\right.$ e $\mathrm{N} 52^{\circ} \mathrm{W} / 53$ a $\left.67^{\circ} \mathrm{NE}\right)$ \\
\end{tabular} \\
\hline Natureza do sistema filoniano & veios de quartzo laminados (ribbons) \\
\hline Orientação dos veios (Nível $274 \mathrm{~m}$ ) & $\begin{array}{l}\text { Filão Principal N } 52^{\circ} \mathrm{W} / 59^{\circ} \mathrm{NE}, \\
\text { Filão Lapa }-\mathrm{N}^{\circ} 44 \mathrm{~W} / 66^{\circ} \mathrm{NE} \text { Filão Capa } \mathrm{N} 46^{\circ} \mathrm{W} / 59^{\circ} \mathrm{NE}\end{array}$ \\
\hline Mineralogia dos veios & $\begin{array}{l}\text { Silicatos Fase I: } q z+(\text { bio })+(\text { seric }) \\
\text { Fase II: } q z \\
\text { Sulfetos Fase I: asp }+ \text { lo }+ \text { po }+ \text { au }+(\text { ccp }) \\
\text { Fase II: asp }+ \text { py }+ \text { au }+(\text { ga })\end{array}$ \\
\hline Associação metálica & $\mathrm{Au}-\mathrm{Ag}-\mathrm{As}$ \\
\hline Localização do Au & $\begin{array}{l}\text { Fase I: Au em asp + lo } \\
\text { Fase II: Au livre e em asp + py }\end{array}$ \\
\hline Mecanismo de deposição do $\mathrm{Au}$ & $\begin{array}{l}\text { Fase I: sulfetação (interação rocha-fluido) } \\
\text { Fase II: remobilização e sulfetação }\end{array}$ \\
\hline Alteração hidrotermal & Silicificação, sulfetação, saussuritização, cloritização \\
\hline Balanço químico & $\begin{array}{l}\text { Ganhos: } \mathrm{As}, \mathrm{Au}, \mathrm{MgO}, \mathrm{CaO} \\
\text { Perdas: } \mathrm{Al}_{2} \mathrm{O}_{3}, \mathrm{~K}_{2} \mathrm{O}, \mathrm{Na}_{2} \mathrm{O}\end{array}$ \\
\hline Fluidos hidrotermais mineralizantes & $\begin{array}{l}\text { Fase I: sem registro } \\
\text { Fase II: solução aquossalina complexa de } \mathrm{Ca} \pm \mathrm{As}(?)\end{array}$ \\
\hline Temperatura da mineralização (mínimas) & $\begin{array}{l}\text { Fase I: } 400 \text { a } 565^{\circ} \mathrm{C} \text { (geotermômetro arsenopirita) } \\
\text { Fase II: } 130 \text { a } 210^{\circ} \mathrm{C} \text { (Inclusão Fluida) }\end{array}$ \\
\hline Salinidade (IF) & Fase II: 25 a 33 (equiv. $\%$ em peso $\mathrm{NaCl}$ ) \\
\hline$\delta^{18} \mathrm{O}$ silicato (SMOW) & $+10,8 \mathrm{a}+11,0 \%(\mathrm{qz})$ \\
\hline$\delta^{34} \mathrm{~S}$ sulfeto (troilita) & $-5,5 \mathrm{a}-3,4 \%$ (arsenopirita) \\
\hline Idade da mineralização & $\mathrm{Pb} / \mathrm{Pb} \quad 2002 \pm 61 \mathrm{Ma}$ (arsenopirita, fase I) \\
\hline
\end{tabular}

Quadro 9.1 - Sumário dos atributos essenciais do Depósito de Salamangone. 
O depósito de Salamangone consiste num sistema filoniano quartzo-aurífero, epigenético, enriquecido em $\mathrm{Au}$ e $\mathrm{As}$, com baixas concentrações de $\mathrm{Cu}, \mathrm{Pb}$ e $\mathrm{Zn}$ (metais base), controlado estruturalmente por uma zona de cisalhamento de caráter dúctil-rúptil e rúptil, e exibindo uma assembléia mineral de alta temperatura, correspondente à facies anfibolito. Todas estas feições corroboram com a proposta, do modelo de depósito aurífero orogênico mesozonal, conforme estabelecido por Groves et al. (1988), e mostrado na Figura 9.2.

Os dados isotópicos obtidos para a área estudada e regiões vizinhas, na Guiana Francesa e Guiana sugerem um modelo de evolução crustal geodinâmico, baseado no desenvolvimento de um arco magmático cálcio-alcalino, no intervalo de tempo entre 2250 e $2000 \mathrm{Ma}$. Este fato pode ser interpretado considerando a subducção de uma litosfera oceânica, pré-colisão entre massas continentais representadas, à época, por um lado, pela Província Central Amazônica (Bloco Carajás-Iricoumé) e por outro lado pelo Craton do Oeste Africano.

Os períodos mais importantes de formação de depósitos de ouro orogênicos do Paleoproterozóico são correlacionáveis com episódios de acresção da crosta continental juvenil, onde eventos responsáveis pela concentração de ouro se posicionam entre 2,1 e 1,8 $\mathrm{Ga}$, incluindo a formação de importantes depósitos, principalmente, nos cratons do Oeste Africano e Amazônico e no Orógeno Trans-Hudsoniano (Goldfarb et al. 2001). Deste modo, o depósito de Salamangone constituiria um depósito aurífero orogênico mesozonal, originado durante processos de deformações compressional a transpressional, junto à margem convergente Paleoproterozóica. 


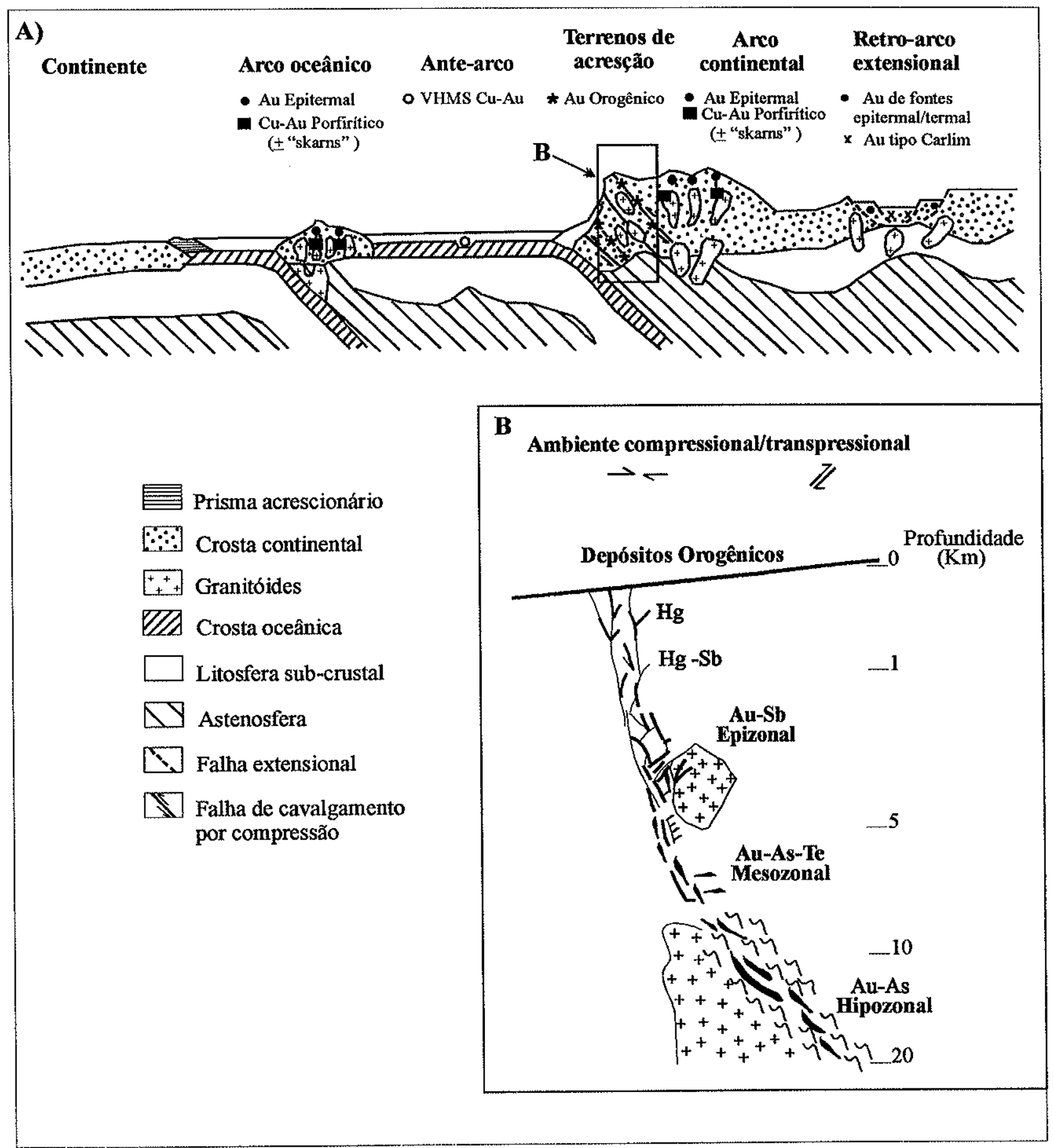

Figura 9.2 - A) Diagrama esquemático dos ambientes tectônicos de depósitos minerais epigenéticos, enriquecidos em ouro. Veios epitermais e depósitos dos tipos skarn e porfíriticos, enriquecidos em ouro, formam-se em profundidades rasas $(<5 \mathrm{~km})$, de arcos oceânicos e continentais, em regimes compressionais a extensionais. Os veios epitermais e os depósitos do tipo Carlin, hospedados em rochas sedimentares, estão localizados em regiões rasas, de retro-arco extensionais. Em contraste, depósitos orogênicos de ouro (também conhecidos como mesotermais), formam-se durante regimes compressionais a transpressionais, dentro da crosta superior, em zonas de acresção adjacentes a arcos magmáticos continentais. B) Perfil em profundidade dos depósitos filonianos auríferos orogênicos. (Groves et al. 1998). 


\section{Considerações Finais}

O depósito de Salamangone, situado no Distrito Aurífero de Lourenço, hospedado em rocha granitóide, faz parte de um pequeno grupo de depósitos filonares auríferos formado sob condições de altas temperaturas, em grandes profundidades na crosta, denominados de orogênicos mesotermais e representando as seções mais inferiores na proposta de modelo para os depósito de ouro tipo lode, envolvendo um crustal continuum, de Groves et al. 1998. As principais considerações e conclusões obtidas neste estudo foram:

a) os granitóides, da região do Distrito Aurífero de Lourenço no Amapá, hospedeiros da mineralização aurífera, encontram-se alojados na Suíte Metamórfica Lourenço (Lima et al. 1991), que junto com o Grupo Vila Nova definido por Lima et al. (1974), que ocorre mais ao sul do Estado do Amapá e o Grupo Paramacá (Série Paramacá de Choubert 1974), na região limítrofe entre o Amapá e Guiana Francesa, representam seqüências supracrustais do Paleoproterozóico;

b) esses granitóides apresentam composição tonalítica a granodiorítica, são metaluminosos a levemente peraluminosos, de caráter cálcio-alcalino, exibindo concentrações relativamente mais elevadas de LILE e TR leves, com empobrecimento pronunciado dos conteúdos de $\mathrm{Nb}$, Ta, Ti e Zr. Guardam semelhança com magmatismo granitóide cálcio-alcalino de margens continentais ativas, com contribuição de fontes enriquecidas vinculadas a zonas de subducção;

c) o comportamento geoquímico desses granitóides em função dos elementos relativamente imóveis (Ti, Rb, Sr, Y, Nb) indica, de acordo com Pearce et al. (1984), que teriam sido gerados em ambientes de arcos vulcânicos;

d) os fracionamentos mais pronunciados dos ETR, as razões $\mathrm{Sr} / \mathrm{Y}$, os baixos conteúdos de $\mathrm{Yb}$ e $\mathrm{Y}$ e a acentuada anomalia positiva de $\mathrm{Eu}$, observados no granodiorito, permitem supor a existência de duas linhagens de rochas granitóides;

e) o padrão geoquímico das rochas metabásicas (anfibolitos) refletindo enriquecimento em LILE e TR leves, e empobrecimento em HFSE, as vinculam a um magmatismo basáltico a andesito-basáltico, também com afinidade cálcio-alcalina, gerado em ambiente de arco vulcânico, junto a margens continentais ativas; 
f) dados isotópicos de $\mathrm{Sr}$ forneceram uma razão inicial para o tonalito de 0,7019 $\pm 0,0012 \mathrm{e}$ para o granodiorito de $0,7023 \pm 0,0004$, apontando uma fonte mantélica (juvenil), para o magma gerador dessas rochas, corroborando os dados de geoquímica obtidos para esses granitóides. Valores semelhantes foram obtidos em rochas tonalíticas a dioríticas intrusivas na Formação Paramacá, na região de Cayenne-Reginá na Guiana Francesa, segundo dados apresentados por Vanderhaeghe et al. (1998);

g) Análises U/Pb (zircão) em tonalito forneceu a idade de cristalização de 2,16Ga, enquanto dados de $\mathrm{Sm} / \mathrm{Nd}$ forneceram idades modelo ( $\mathrm{T}_{\mathrm{DM}}$ ) da ordem de 2,34 Ga(granodiorito) e $2,24 \mathrm{Ga}$ (tonalito), valores positivos de $\varepsilon_{\mathrm{Nd}}\left(\mathrm{T}_{\mathrm{DM}}\right),+2,88$ (granodiorito) $\mathrm{e}+3,02$ (tonalito), com $\mathrm{fSm} / \mathrm{Nd}$ de $-0,59$ (granodiorito) e $-0,42$ (tonalito). Os valores obtidos permitem interpretar que os protólitos dos granitóides estudados foram diferenciados diretamente do manto com pequena residência crustal, e estão relacionados a arco juvenil paleoproterozóico;

h) dados isotópicos de $\mathrm{Rb} / \mathrm{Sr}$ em rocha total e $\mathrm{K} / \mathrm{Ar}$ em biotita de tonalito afetado pela mineralização forneceram, respectivamente, uma isócrona de referência de $1830 \pm 270 \mathrm{Ma}$ com razão inicial de $0,7045 \pm 0,0029$ e idades aparentes entre 1794 e $1758 \mathrm{Ma}$. Esses valores refletem perturbações isotópicas posteriores, relacionadas com os episódios de cisalhamento e eventos superpostos de mineralização, além de resfriamentos regionais. As datações auxiliam no estabelecimento de limites para a mineralização, permitindo posicionar a geração dos granitóides cálcio-alcalinos e o evento mineralizador no Paleoproterozóico, dentro da Província Geocronológica Maroni-Itacaíunas;

i) a exemplo de outros depósitos hospedados em rochas granitóides (Cassidy et al. 1998), o depósito de Salamangone é do tipo epigenético, controlado por uma zona de cisalhamento dúctil-rúptil e rúptil, exibindo uma associação metálica enriquecida em $\mathrm{Au}$ e $\mathrm{As}$, com baixa concentração de $\mathrm{Ag}, \mathrm{Pb}, \mathrm{Cu}$ e $\mathrm{Bi}$. Os elementos estruturais identificados definiram duas direções principais de cisalhamento, $\mathrm{N} 45^{\circ} \mathrm{W}$ e $\mathrm{N} 52^{\circ} \mathrm{W}$, com uma componente direcional destrógira;

j) o sistema filoniano compreende três corpos principais, designados: Capa, Principal e Lapa, considerados como sendo veios de cisalhamento ou veios em falhas, tipificados por uma estrutura laminada ou em ribbon (Dowling et al. 1989 e Vearnacombe 1989), a indicar episódios repetidos de fraturamentos e deposição mineral;

k) a paragênese dos veios comporta 2 fases principais de mineralização a saber: A Fase I, de maior deposição de quartzo, está associada a processos de interação rocha-fluido, que provocou a sulfetação intensa na rocha tonalítica encaixante, incorporada como ribbons 
dentro dos veios, originando asp $+\mathrm{lo}+$ po $+\mathrm{au}+(\mathrm{ccp})$, onde o ouro ocorre, principalmente, nos limites da arsenopirita e lollingita, num intervalo de temperatura (mínima) entre $400^{\circ} \mathrm{e}$ $565^{\circ} \mathrm{C}$ (geotermômetro arsenopirita). A Fase II de mineralização, constitui o episódio principal de deposição do ouro, via processos de remobilização a partir de soluções aquosas de alta salinidade, ao longo de fraturas, sob a forma livre e associado com asp + py + (ga);

1) datação direta de cristais de arsenopirita da Fase I da mineralização forneceram uma isócrona $\mathrm{Pb}-\mathrm{Pb}$ de referência de $2002 \pm 61 \mathrm{Ma}$ e a composição isotópica $\mathrm{Pb}-\mathrm{Pb}$ nos diagramas de plumbotectônica de Zartman \& Doe (1981), sugerem um reservatório crustal mais profundo para o $\mathrm{Pb}$;

m) os processos de alteração hidrotermal envolveram, principalmente, silicificação, sulfetação, saussuritização e cloritização da rocha tonalítica encaixante, desenvolvendo uma zona distal com pouca influência da mineralização, e uma zona proximal onde o balanço químico indica ganhos acentuados em $\mathrm{As}$ e $\mathrm{Au}$, com pequena participação de $\mathrm{MgO}$ e $\mathrm{CaO}$, e perdas de $\mathrm{Al}_{2} \mathrm{O}_{3}, \mathrm{~K}_{2} \mathrm{O}$ e $\mathrm{Na}_{2} \mathrm{O}$;

n) a ausência de inclusões fluidas primárias e a conjunção de vários estágios de deformação originando planos de inclusões fluidas secundárias, deixa claro que os fluidos hidrotermais iniciais, responsáveis pela Fase I de mineralização, não foram preservados;

o) uma solução aquosa complexa, contendo $\mathrm{Ca} \pm \mathrm{As}(?)$, extremamente salina, aprisionada em inclusões fluidas, contidas em um conjunto de trilhas com direção entre $\mathrm{N} 5^{\circ}-35^{\circ} \mathrm{W}$, pode ter sido responsável pela remobilização e precipitação do ouro primário, durante a Fase II de mineralização;

p) a recorrência de episódios de deformação com aporte e circulação de novos fluidos dentro da zona de cisalhamento, que hospeda o depósito de Salamangone, é demonstrada pela presença flagrante de soluções essencialmente aquosas, de salinidades variadas, que indica um amplo processo de mistura, partindo de um fluido extremamente salino e evoluindo para composições com salinidades cada vez mais baixas;

q) considerando a associação do depósito de Salamangone com zonas de cisalhamento, a origem das soluções hidrotermais essencialmente aquosas, pode, provavelmente, ser atribuída a uma mistura de salmouras profundas de natureza metamórfica, com fluidos hidatogênicos (águas meteóricas de circulação profunda), sem descartar a presença de participação de fluidos magmáticos, relacionados com a intrusão de corpos pegmatíticos;

r) estudos preliminares de isotópos estáveis, principalmente em quartzo e sulfetos da mineralização, revelam a pequena variação dos valores de $\delta^{18} \mathrm{O}$ no quartzo dos veios e 
ribbons da rocha tonalitica, os quais situam-se entre $+10,8 \%$ e $+11,9 \%$, podendo refletir que todo o quartzo tenha se originado de um fluido hidrotermal homogêneo, enquanto que os valores negativos de $\delta^{34} \mathrm{~S}(-5,5 \%$ a $-3,4 \%$, em sulfetos da Fase I de mineralização, sugerem oxidação dos fluidos mineralizantes, quando da sua interação com minerais silicatados ferro-magnesianos do tonalito encaixante;

s) o depósito de Salamangone, pode ser incluído em um pequeno grupo de depósitos filonares auríferos formado sob condições de altas temperaturas, a grandes profundidades da crosta, e classificado como depósitos auríferos orogênicos mesotermais. Em relação ao modelo de depósito de ouro do tipo lode, já proposto por Groves et al. 1998, e que pressupõe um continuum crustal, essa tipologia se posiciona na porção inferior do sistema;

t) o Distrito Aurffero de Lourenço no Amapá pode ser relacionado às províncias metalogenéticas ricas em depósitos auríferos, que vêm sendo estudadas em diversas regiões do mundo desde o Arqueano, dentro de domínios associados a cinturões orogênicos. Essas mineralizações ocupam uma posição temporal e espacial marcante, tendo se formado durante os processos de deformação de margens convergentes, em terrenos de acreş̧̃o adjacentes a arcos magmáticos continentais (Groves et al. 1998, MacCuaig \& Kerrich 1998, Goldfarb et al. 2001);

u) os dados isotópicos para a área de Lourenço, no Amapá e regiões vizinhas, na Guiana Francesa e Guiana sugerem um modelo de evolução crustal geodinâmico, baseado no desenvolvimento de um arco magmático cálcio-alcalino, entre 2250 e $2000 \mathrm{Ma}$, durante um dos principais eventos de orogenia do Paleoproterozóico, onde Salamangone constituiria um depósito aurífero orogênico mesozonal (Groves et al. 1998), originado durante processos de deformações compressional a transpressional, em orógenos de acresção, associados à margem convergente Paleoproterozóica;

v) O modelo conceitual do depósito de Salamangone, incluindo o timing da mineralização, correspondem ao modelo de depósito orogenético, proposto por Groves et al 1998. Reforçase, ainda, que a idade da mineralização vinculada ao episódio final da evolução de arco magmático e a própria geometria do depósito e seu controle estrutural, constituem elementos decisivos para a elaboração de modelos exploratórios correlatos, de uso corrente, à escala global à procura e descoberta de depósitos de ouro, conforme noticiado em Groves et al 2000. 


\section{REFERÊNCIAS BIBLIOGRÁFICAS}

ALMEIDA, F.F.M. 1978. A evolução dos cratons Amazonico e de São Francisco comparada com a de seus homólogos do Hemisfério Norte. In Cong. Bras. Geol., 30, Recife. Anais... Recife. SBG, v.6, p. 2393-2407.

ANDERSON, J.L. \& SMITH D.R. 1995. The effect of temperature and oxygen fugacity on Al-inhornblende barometry. Amer. Mineral., 80: 549-559.

BAKER, F. \& ARTH, J.G. 1976. Generation of trondhjemitic-tonalitic liquids and Archaean bimodal trondhjemite-basalt suites. Geology, 4: 596-600.

BAKER, F. 1979. Trondhjemites: definition, environment and hypotheses of origin. In: F. Baker (ed.), Trondhjemites, dacites and related rocks. Elsevier, Amsterdam, pp. 1-12.

BARLEY, M.E. \& GROVES, D.I. 1992. Supercontinent cycles and the distribution of metal deposits through time. Geology, 20: 291-294.

BARLEY, M.E.; BURKHARD, N.E.; GROVES, D.I.; PERRING, C.S. VEARNCOMBE, J.R. 1989. Late archaean convergent margin tectonics and gold mineralization: a new look at the Norseman-Wiluna Belt, Western Australia. Geology, 17: 826-829.

BARRIE, I.J. \& TOURET, J.L.R. 1999. Fluid inclusion studies of gold-bearing quartz veins from the Yirisen deposit, Sula Mountains greenstone belt, Masumbiri, Sierra Leone. Ore Geol. Rev., 14: 203-225.

BENNING, L.G. \& SEWARD, T.M. 1996. Hydrosulphide complexing of gold (I) in hydrothermal solutions from 150 to $500^{\circ} \mathrm{C}$ and 500 to 1500 bars. Geochim. Cosmoch. Acta, 60: 1849-1871.

BETTENCOURT, J.S. \& FERREIRA F.J.F. 1993. Relatório técnico de reavaliação dos dados do levantamento aerogamaespectrométrico do Distrito Aurífero de Lourenço (Inédito).

BETTENCOURT, J.S. 1987, 1988, 1989 e 1990. Relatórios técnicos sobre a geologia e a mineralização quartzo-aurífera do Depósito de Salamangone (Inéditos).

BLUNDY, J. D. \& HOLLAND, T.J.B. 1990. Calcic amphibole equilibria and a new amphiboleplagioclase geothermometer. Contrib. Mineral. Petrol., 104: 208-224.

BODNAR, R. (1998) Additional discussion of apparent low temperature observations that was held in February 1998. http://www.geology. wisc.edu/pbrown/loweutec2.html.

BORISENKO, A.S. 1978. Study of the salt composition of solutions of gas-liquid inclusions in minerals by the cryometric method. Sov. Geol. Geophys., 18: 11-19.

BOSMA, W.; KROONENBERG, S.B.; MAAS, K.; DE ROEVER, E.W.F. 1983. Igneous and metamorphic complexes of the Guiana Shield in Suriname. Geol. Mijnbouw, 62: 241-254.

BOTELHO, N.F. \& MOURA, M.A. 1998. Granite-ore deposit relationship in central Brazil. J. South Am. Earth Sci., 11: 427-438. 
BOTTINGA, Y. \& JAVOY, M. 1975. Oxygen isotope partitioning among the minerals in igneous and metamorphic rocks. Geophys. Space Phys., 13: 401-418.

BOULLIER A.M.; FIRDAOUS, K.; ROBERT, F. 1998. On the significance of aqueous fluid inclusions in gold-bearing quartz veins deposits from the southeastern Abitibi subprovince (Quebec, Canada). Econ. Geol., 93: 216-223.

BOYLE, R.W. 1979. The geochemistry of gold and its deposits. Geol. Surv. Canadá Bull., 280, 580p.

BOYNTON, W.V. 1984. Cosmochemistry of the rare-earth elements: meteorite studies. In: P. Handerson (Ed.): Rare earth elements geochemistry. Elsevier, Amsterdam. p. .63-114.

BROWN, P.E.-1989- FLINCOR. A fluid inclusion data reduction and exploration program (abstr.). In: Second Biennial Pan-American conference on research on fluid inclusions. Program with Abstracts, 1989. 14.

BURROWS, D. R. \& SPOONER, E.T.C. 1989. Relationships between archean gold quartz-vein shear zone mineralization and igneous intrusions in the Val d'Or and Timmins areas Abitibi Subprovince, Canada. Econ. Geol. Monogr., 6: 424-444.

BURROWS, D.R.; WOOD, P.,C.; SPOONER, E.T.C. 1986. Carbon isotope evidence for a magmatic origin for Archaean gold-quartz vein ore deposits. Nature 321: 851-854.

BURRUSS, R. (1997) Short discussion of apparent low eutetic temperature observations that was held during June 1997. http://www.geology.wisc.edu/ pbrown/loweutec.html

BURRUSS, R. (1998) Additional discussion of apparent low temperature observations that was held in February 1998. http:// www.geology.wisc.edu/ pbrown/loweutec2.html

CALLAN, N.J. \& SPOONER, E.T.C. 1989. Archean Au quartz vein mineralization hosted in a tonalite-trondhjemite terrane, Renabie mine area, Wawa, North Ontario, Canada. Econ. Geol. Monograph, 6: 9-18.

CALLAN, N.J., SPOONER, E.T.C. 1998. Repetitive hydraulic fracturing and shear zone inflation in na Archean granitoid-hosted, ribbon banded, Au-quartz vein system, Renabie area, Ontario, Canada. Ore Geol. Rev., 12: 237-266.

CASSIDY, K.F. \& BENETT, J.M. 1993. Gold mineralisation at the Lady Bountiful Mine, western Australia: na example of a granitoid-hosted Archaean lode gold deposit. Mineral. Deposita, 28: $388-408$.

CASSIDY, K.F.; GROVES, D.I.; MCNAUGHATON, N.J. 1998. Late archean granitoid-hosted lodegold deposits, Yilgarn craton, western Australia: Deposits characteristics, crustal architecture and implication for ore genesis. Ore Geol. Reviews, 13: 65-102.

CHOUBERT, B. 1974. Le precambrian de guyenes, Memoire du BRGM. Paris, II, 81-211.

CLARK, L.A. 1960. The Fe-As-S system: phase relations and applications. Part I. Econ. Geol., 55(7): 1345-1381.

COLEMAN, R.G. \& DONATO, M.M. 1979. Oceanic plagiogranite revisited. In: BARKER, F. ed. Trondhjemites, dacites and related rocks (Developments in Petrology, 6: 149-168. 
COLEMAN, R.G. \& PETERMAN, Z. E. 1975. Oceanic plagiogranite. J. Geophys. Res., 80 (8): 10991108 .

COLVINE, A.C. 1989. An empirical model for the formation of Archean gold deposits: Products of final cratonization of the Superior Province, Canada. Econ. Geol. Monograph, 6: 37-53.

COLVINE, A.C; ANDREWS, A.J.; CHERRY, M.E.; FYON, A.J.; LAVIGNE, M.J.; MACDONALD, A.J.; MARMONT, S.; POULSEN, K.H.; SPRINGER, J.S.; TROOP, D.G. 1984. An integrated model for the origin of archean lode deposits, Ontario Geol. Survey. Open File Report 5524, 98 pag.

COLVINE, A.C.; FYON, J.A.; HEATHER, K.B.; MARMONT S.; SMITH, P.M.; TROOP.D.G. 1988. Archean lode gold deposits in Ontario. Ontario Geol. Survey. Miscellaneous Paper 139, 136p.

CORDANI, U.G.; TASSINARI, C.C.G.; TEIXEIRA, W.; BASEI, M.A.S.; KAWASHITA, K. 1979. Evolução tectônica da Amazonia com base nos dados geocronológicos. Actas do 2 Cong. Geol. Chileno, Araica, Chile, 4, 137-148.

COSTA, P.R. 1991. Relatório técnico sobre o mapeamento estrutural da Mina de Salamangone (Inédito).

COUTINHO, M.G.N.; LIVERTON, T.; SOUZA, E.C. 1997. Granitic magmatism and related gold mineralization in Tapajós Mineral Province, Amazonian area, Brazil. In: II Int. Symp. Granites asoc. Mineralization, II ISGAM, Ext. Abstr, 46-47.

CRAWFORD, M.L. 1981. Phase equilibria in aqueous inclusions. Mineral. Assoc. Canada Short Course Handbook. 6: 75-100.

DALL'AGNOL, R.; BETTENCOURT, J.S.; JORGE JOÃO, X.S.; MEDEIROS, H.; COSTI, H.T.; MACAMBIRA, M.J.B. 1987. Granitogenesis in the northern brazilian region: a review. Rev. Bras. Geoc., 17(4): 382-403.

DAVIS, D.W.; LOWENSTEIN, T.K.; SPENCER, R.J. 1990. Melting behavior of fluid inclusions in laboratory-grown halites crystal in the systems $\mathrm{NaCl}-\mathrm{H}_{2} \mathrm{O}, \mathrm{NaCl}-\mathrm{KCl}-\mathrm{H}_{2} \mathrm{O}, \mathrm{NaCl}-\mathrm{MgCl}_{2}-\mathrm{H}_{2} \mathrm{O}$ and $\mathrm{NaCl}, \mathrm{CaCl}_{2}-\mathrm{H}_{2} \mathrm{O}$ Geochim. Acta, 54: 591-601.

DE LA ROCHE, H.; LETERRIER, J.; GRANDE CLAUDE, P.; MARCHAL, M. 1980. A classification of volcanic and plutonic rocks using R1-R2 diagram and major element analyses. Its relationships with current nomenclature. Chem. Geol., 29: 183-210.

DE PAOLO. 1988. Neodymium isotope geochemistry: na introduction. Spring-Verlag, Heidlberg, $187 \mathrm{p}$.

DE VLETTER, D.R. \& KROONENBERG, S.B. 1987. The granitoid-volcanic complex of Suriname. Projeto 204 IUGS-UNESCO. Final meeting of the working group. Ext. Abst. Carajás, Pará, Brazil. p. 9-14.

DE VLETTER, D.R.; ALEVA, G.J.J.; KROONENBERG, S.B. 1998. Research into the Precambriam of Suriname. In: The history of earth sciences in Suriname (Wong, T.E. et al. Eds), 15-64. 
DEER, W.A.; HOWIE, R.A.; ZUSSMAN, M.A. 1983 (1976). Minerais constituintes das rochas. Uma introdução. Lisboa. Fund. Calouste Gulbenkian.

DNPM. 1974. Projeto RADAM - Folhas NA/NB-22 Macapá. Rio de Janeiro. Levantamento de Recursos Naturais, 6, p. 1-120.

DNPM. 1988. Mapa Geológico do Território Federal do Amapá. Escala 1:1.000.000.

DNPM-CPRM. 1979a. Projeto Falsino. Relatório Final. Belém.

DNPM-CPRM. 1979b. Projeto Sudoeste do Amapá. Relatório Final. Brasilia.

DNPM-CPRM. 1985a. Projeto mapas metalogenéticos e de previsão de recursos minerais na Folha NA-22-V-D Lourenço. Escala 1:250.000. CPRM, Belém.

DNPM-CPRM. 1985b. Projeto mapas metalogenéticos e de previsão de recursos minerais na Folha NA-22-Y-D Macapá. Escala 1:250.000. CPRM, Belém.

DNPM-CPRM. 1985c. Projeto mapas metalogenéticos e de previsão de recursos minerais na Folha NA-22-Y-B Rio Araguari. Escala 1:250.000. CPRM, Belém.

DOWLING, K. \& MORRISON, G. 1989. Application of quartz textures to the classification of gold deposits using North Quensland examples. Econ. Geol. Monograph, 6: 342-355.

DRUMMOND, M.S. \& DEFANT, M.J. 1990. A model for trondhjemite-tonalite-dacite genesis and crustal growth via slab melting: Archaean to modern comparisons. J. Geophys. Res., 95: 2150321521.

DRURY, M. \& URAI, J.L. 1990. Deformation-related recrystallization processes. Tectonophysics, 172: $235-253$.

ESSARRAJ, S.; BOIRON, M.C.; CATHELINEAU, M.; FOURCADE, S. 2001. Multistage deformation of Au-quartz veins (Laurieras, French Massif Central): evidence for late gold introduction from microstructural, isotopic and fluid inclusion studies. Tectonophysics, 336: 79 99.

FARACO, M.T.L. \& CARVALHO, J.M.A. 1994. A metalogenia preliminar dos Estados do Pará e Amapá. In: Simp. Geol. Amaz., 4, Belém. Anais...Belém. SBG, p.83-87.

FERRAN, A. 1988. Depósito de ouro de Salamangone e Mutum, Calçoene, Amapá. In: Principais depósitos minerais do Brasil. DNPM. v.3, p. 581-588.

FOSTER, R.P \& PIPER, D.P. 1993. Archaean lode gold deposits in Africa: crustal setting, metallogenesis and cratonization. Econ. Geol., $8(3,4): 301-348$.

FOSTER, R.P. 1984. Proceedings of Gold'82: The geochemistry and genesis of gold deposits. Geol. Soc. Zimbabwe, Spec. Publ. 1, 753p.

FOSTER, R.P. 1989 Archean gold mineralization in Zimbabwe: implications for metallogenesis and exploration. Econ Geol. Monograph, 6: 54-70.

FYFE, W.S. \& HENLEY, R.W. 1973. Some thoughts on chemical transport processes with particular reference to gold. Min. Sci. Eng., 5: 295-303.

FYFE, W.S. \& KERRICH, R. 1985. Fluids and thrusting. Chem. Geol., 49: 353-362. 
FYON, J.A.; TROOP, D.G.; MARMONT, S.; MACDONALD, A.J. 1989. Introduction of gold into Archean crust, Superior Province Ontario - coupling between mantle - initiated magmatism and lower crustal thermal maturation. Econ. Geol. Monograph, 6: 479-490.

GEBRE-MARIAM, M.; HAGEMANN, S.G.; GROVES, D.I. 1995. A classification scheme for epigenetic Archaean lode-gold deposits. Min. Deposita, 30: 408-410.

GEODINAMICA - Projetos e Consultoria S.C. Ltda. 1991. Mina de Salamangone. Relatório Técnico (Inédito).

GEODINAMICA - Projetos e Consultoria S.C. Ltda. 1992. Análise estrutural da Mina de Salamangone, com enfase no nível 274. Relatório Técnico (Inédito).

GIBBS, A.K \& BARRON, C.N. 1993. The geology of the Guiana Shield. Oxford Monographs on Geology and Geophysics number 22, 246p.

GIBBS, A.K. \& BARRON, C.N. 1983. The Guiana Shield reviewed. Episodes, 19 (2): 7-14.

GOKHALE, N.W. \& GOTHE, N.N. 1978. Chemical distinction of amphibolites. J. Geol. Soc., India, 19: 376-379.

GOLDFARB, R..J.; GROVES, D.I.; GARDOLL, S. 2001. Orogenic gold and geologic time: a global synthesis. Ore Geol. Rev., 18: 1-75.

GOLDING, S.D. \& WILSON, A.F. 1987. Oxigen and hydrogen isotope relationships in archaen gold deposits of the eastern goldfields province, western Australia: constraints on the source of archaen gold-bearing fluids. In: Recent advances in understanding Precambriam gold deposits. Geol. Dep. Univ. Ext., Univ. West. Australia. Publ. 11, 203-213.

GOLDSTEIN, R.H. 2001. Fluid inclusions in sedimentary anddiageneic systems. Lithos, 55 (14):159193.

GOODE, A.D. T. AND BOSMA, L.I. 1988. Proceedings of Bicennteniall Gold'88. Geol. Soc. Australia, Melbourne, 1988. Abstracts series, number 22 and 23.

GRANT, J.A. 1986. The isocon diagram. A simple solution to Gresens' Equation for metasomatic alteration. Econ. Geol., 81: 1976-1982.

GRESENS, R.L. 1967. Composition-volume relationships of metasomatism. Chem.Geol., 2: 47-55.

GROVES, D.I. \& PHILLPS, G.N. 1987. The genesis and tectonic controls of Archaean gold deposits of the Western Australia Shield: a metamorphic-replacement model. Ore Geol.Rev., 2: 287* 322.

GROVES, D.I. 1993a. An integrated model for genesis of archaean gold mineralisation within the Yilgarn Block, Western Australia. In: Intern. Conf. on crustal evolution, metallogeny, and exploration of the Eastern Goldfields. Extended Abstracts, p. 115-121.

GROVES, D.I. 1993b. The crustal continuum model for late archaean lode gold deposits of the Yilgarn Block, Western Australia. Mineral. Deposita, 28: 366-374.

GROVES, D.I.; BARLEY, M.E.; CASSIDY, K.C.; HAGEMANN, S.G.; HO, S.E.; HRONSKY, J.M.A.; MIKUCKI, E.J.; MUELLER, A.G.; MCNAUGHTON, N.J.; PERRING, C.S.; 
RIDLEY, J.R. 1991. Archaean lode-gold deposits: the products of crustal-scale hydrothermal system. In: Brazil Gold'91. Extended Abstracts, E.A. Ladeira (ed.), p. 299-304.

GROVES, D.I.; BARLEY, M.E.; HO, S.E. 1989. Nature, genesis and tectonic setting of mesothermal gold mineralization in the Yilgarn Block, Western Australia. Econ. Geol. Monograph, 6: 7185.

GROVES, D.I.; GOLDFARB, R.J.; GEBRE-MARIAM, M.; HAGEMANN, S.G.; ROBERT, F. 1998. Orogenic gold deposits: A proposed classification in the context of their crustal distribution and relationship to other gold deposit types. Ore Geol. Rev., 13: 7-27.

GROVES, D.I.; GOLDFARB, R.J.; KNOX-ROBINSON, C.M.; OJALA, J.; GARDOLL, S.; YUN, G.Y.; HOLYLAND, P. 2000. Late-kinematic timing of orogenic gold deposits and significance for computer-based exploration techniques with emphasis on the Yilgarn Block, Western Australia. Ore Geol. Rev., 17: 1-38.

GROVES, D.I.; PHILLIPS, G.N; HO, S.E.; HENDERSON, C.A.; CLARK, M.E.; WOOD, G.M. 1984. Controls on distribuition of Archaean hydrothemal gold deposits in Western Australia. In:Proceedings of Gold'82: The Geology, Geochemistry and Genesis of Gold Deposits, 689712.

GRUAU, G.; MARTIN, H.; LEVEQUE, B.; CAPDEVILLA, R. 1985. Rb/sr and Sm/Nd geochronology of Lower Proterozoic granite-greenstone terrains in French Guiana, South America. Prec. Res., 30: 63-80.

GUHA, J. \& KANWAR, R. 1987. Vug brines - fluid inclusions: a key to understanding of secondary gold enrichment processes and the evolution of deep brines in the Canadian Shield. In: Fritz, P., Frape, S.K. (Eds.) Saline water and gases in the crystalline rocks. Geol. Assoc. Can. Spec. Pap., 33: 95-101.

HATTORI, K. 1987. Magnetic felsic intrusion associated with Canadian Archean gold deposits. Geology, 15: 1107-1111.

HO, S.E.; GROVES, D.I.; BENNETT, J.M. 1990a. Gold deposits of the Archaean Yilgarn Block, Western Australia: nature, genesis and exploration guides. Geol. Dep. (Key Centre) \& Univ. Extension. The University of Western Australia. Publication 20, $407 \mathrm{p}$.

HO, S.E.; ROBERT, F.; GROVES, D.I. 1990b. Gold and base-metal mineralization in the Abitibi Subprovince, Canada, with enphasis on the Quebec Segment. Geol. Dep. (Key Centre) \& Univ. Extension. The University of Western Australia. Publication 24,

HODGSON, C.J.1989. The structure of shear-related, vein type gold deposits: a review. Ore Geol. Rev., 4(3): 231-273.

HODGSON,C.J. \& HAMILTON, J.V. 1989. Gold mineralization in the Abitibi greenstone belt. End stage result of archaean collisional tectonics? Econ. Geol. Monograph, 6: 86-100.

HOLLAND, T. \& BLUNDY, J. 1994. Non-ideal interactions in calcic amphiboles and their bearing on amphibole-plagioclase thermometry. Contr. Min. Petrol., 116: 433-447. 
HOLLISTER, L.S. 1990. Enrichment of $\mathrm{CO}_{2}$ in fluid inclusions in quartz by removal of $\mathrm{H}_{2} \mathrm{O}$ during crystal-plastic deformation. J. Struct. Geol., 12(7) : 895-901.

HRONSKY, J.M.A; CASSIDY, K.F.; GRIGSON, M.W.; GROVES, D.I.; HAGEMAM, S.G.; MUELLER, AG.; RIDLEY, J.R.; SKWARNEKI, M.S.; VEARNCOMBE, J.R. 1990. Deposit and mine scale structure. In: Ho, S.E., Groves, D.I., Bennett, J.M. (Eds). Gold Deposits of the Yilgarn Block, Western Australia: Nature, Genesis and Exploration Guides. Geol. Depart. (Key Centre) and Univers. Ext., Univ. West. Aust., Publ. 20, 38-54.

HUHN, S.R.B. 1996. São os depósitos cupríferos de Carajás do tipo Cu-Au-U-(ETR). V Simp. Geol. Amazônia. Bol. Res. Exp., SBG, Belém, 140-143.

HURLEY, P.M.; MELCHER, G.C.; PINSON, W.H.; FAIRBAIRN, H.W. 1968. Some orogenic episodes in South America by $\mathrm{K} / \mathrm{Ar}$ and wole rock $\mathrm{Rb} / \mathrm{Sr}$ dating. Can. Journ. Eart. Sci., 5, 633638.

IRVINE, T. N. \& BARAGAR, W.R.A. 1971. A guide to the chemical classification of the commun volcanic rocks. Canadian J. Earth Sci., 8: 523-548.

ISSLER, R.S. \& LIMA, M.I.C. 1987. Amazonic Craton (Brazil) granitogenesis and its relation to geotectonics units. Rev. Bras. Geoc., 17(4): 426-441.

ISSLER, R.S. 1974. Geologia da Folha SA-22 Belém. In: Brasil, DNPM, Projeto RADAM. Rio de Janeiro (Levantamento de Recursos Naturais, 5).

JAVOY, M. 1977. Stable isotopes and geothermometry. J. Geol. Soc. London, 133: 609-636.

JOHNSON, E.L. \& HOLLISTER, L.S. 1995. Syndeformational fluid trapping in quartz: determining from fluid inclusions and the formation of pure $\mathrm{Co} 2$ fluid inclusions during grain-boundary migration. J. Metamorph. Geol., 13: 239-249.

JORGE JOÃO, X.S. \& MARINHO, P.A.C. 1982a. Catametamorfitos arqueanos da região centro leste do Território Federal do Amapá. In: Simp. Geol. Amaz., 1, Belém. Anais...Belém. SBG. v.2, p. $207-228$.

JORGE JOÃO, X.S. \& MARINHO, P.A.C. 1982b. Granitóides sódicos da região centro leste do Território Federal do Amapá. In: Simp. Geol. Amaz., 1, Belém. Anais...Belém. SBG, v.2, p. 229-252.

KEAYS, R. \& SKINNER, J. 1989. The Geology of Gold Deposits: The Perspective in 1988. Econ. Geol. Monograph, 6: 1-8.

KERRICH, R. \& CASSID,Y K.F. 1994. Temporal relationships of lode gold mineralization to accretion, magmatism, metamorphism and deformation - Archean to present: a review. Ore Geol. Rev., 9: 263-310.

KERRICH, R. \& WYMAN, D. 1990. Geodynamic setting of mesothermal gold deposits: an association with accretionary tectonic regimes. Geology, 18: 882-885.

KERRICH, R. 1976 Some effects of tectonic recrystallisation on fluid inclusions in vein quartz. Contrib. Mineral. Petrol., 59: 195-202. 
KERRICH, R. 1993. Perspectives on genetic models for lode gold deposits. Mineral. Dep., 28: 362365.

KISHIDA, A.; SENA, F.O.; DA SILVA, F.C.A. 1991. Rio Itapicuru greenstone belt: geology and gold mineralization. In: Proceedings of Symposium Brazil Gold'91: The economics, geology, geochemistry and genesis of gold deposits, 49-60.

KOLB, J.; KISTERS, A.F.M.; HOERNES, S.; MEYER, F.M. 2000. The origin of fluids and nature of fluid-rock interaction in mid-crustal auriferous mylonites of the Renco mine, southern Zimbabwe. Min. Deposita, 35: 109-125.

KONTONIEMI, O. \& NURMI, P. 1998. Geological setting and characteristics of the tonalite-hosted Paleoproterozoic gold deposit at Osikonmäki, Rantasalmi, southeastern Finland. Geol. Survey of Finland, Special Paper 25, 99 p.

KRETSCHMAR, U. \& SCOTT, S.D. 1976. Phase relations involving arsenopyrite in the system FeAs-S na their apllication. Can. Mineral., 14: 364-386.

KROGH, T.E. 1973. A low-contamination method for hydrothermal decomposition of zircon and extraction of $U$ and $\mathrm{Pb}$ for isotopic age determination. Geochim Cosmoch. Acta, 37: 485-494.

KROGH, T.E. 1982. Improved accuracy of U-Pb zircon by the creation of more concordant systems using an air abrasion technique. Geochim. Cosmoch. Acta, 46: 637-649.

LACERDA, H. 1991. Gold in central Brazil: Types of deposits, their economic significance and regional distribution. In: Proceedings of Symposium Brazil Gold'91: The economics, geology, geochemistry and genesis of gold deposits, 195-202.

LADEIRA, E. A. 1991a. Proceedings of the Symposium Brazil Gold'91: The economics, geology, geochemistry and genesis of gold deposits, $823 p$.

LADEIRA, E.A. 1991b. Genesis of gold in Quadrilátero Ferrífero: a remarkable case of permanency, recycling and inheritance - A tribute to Djalma Guimarães, Pierre Routhier and Hans Ramberg. In: Proceedings of Symposium Brazil Gold'91: The economics, geology, geochemistry and genesis of gold deposits, 11-30.

LAFRANCE J.; BARDOUX, M.; VOICU, G.; STEVENSON, R.; MACHADO, N. 1999. Geological and metallogenic environments of gold deposits of the Guiana Shield: a comparative study between St-Élie (French Guiana) and Omai (Guyana). Explor. Mining Geol., 8(1 - 2): 117135.

LAMBERT, I.B.; PHILLIPS, G.N.; GROVES, D.I. 1984. Sulphur isotope compositions and genesis of Archean gold mineralization, Australia and Zimbabwe. In: Foster, R.P. (Ed), Gold'82. Geol. Soc. Zimbabwe, Spec. Publ. No 1 .

LAMEYRE, J.; BOWDEN, P. 1982. Plutonic rock types series and related rocks. Journ. Volcan. Geothermal. Res., 14: 169-186.

LE MAITRE, R. W. 1989. A classification of igneous rocks and glossary of terms. Blackwell Scientific Publication, Oxford. 193p. 
LEAKE, B.E. 1964. The chemical distiction of between ortho and para-amphibolites. J. Petrol., 5: 238-254.

LEAKE, B.E. 1978. Nomenclature of amphiboles. Can. Mineral., 16: 501-520.

LEAKE, B.E.; WOOLLEY, A.R.; ARPS, C.E.S.; BIRCH, W.D.; GILBERT, M.C.; GRICE, J.D.; HAWTHORNE, F.C.; KATO, A; KISCH, H.J.; DRIVOVICHEV, V.G.; LINTHOUT, K; LAIRD, J.; MANDARINO, J.A.; MARESCH, W.V.; NICKEL, E.H.; ROCK, N.M.S.; SCHUMACHER, J.C.; SMITH, D.C.; STEPHENSON, N.C.N.; UNGARETTI, L.; WHITTAKER, E.J.W.; YOUZHI, G. 1997. Nomenclatures of amphiboles: report of the subcommittee on amphiboles of the international mineralogical association, commission on new minerasl and mineral names. Can. Mineral., 35: 219-246.

LEDRU, P.; VANDERHAEGHE, O.; MILÉSI, J.P.; COCHERIE, A.; EGAL, E.; THIÉBLEMONT, D. 1997. The crustal growth of the Guiana Province: Geochemical and geochronological data from French Guiana. South-American Symp. Isotope Geology. Brazil. 163-166.

LEONARDO, O. H.; JOST, H.; OLIVEIRA, C.G. 1991. Gold deposits and shear zone relationships in the Precambrian of Brazil.In: Proceedings of the Symposium Brazil Gold'91: The economics, geology, geochemistry and genesis of gold deposits, 167-170.

LESTRA, A.D. \& STOLL NARDI, J.I. 1984. O ouro na Amazônia Oriental, o mito e a realidade. Grafisa Belém.

LIMA, M.I.C. 1974. Geologia da Folha SA-22 Belém. In: Brasil, DNPM, Projeto RADAM. Rio de Janeiro (Levantamento de Recursos Naturais, 5).

LIMA, M.I.C.; BEZERRA, P.E.L.; ARAỨJO, H.J.T. 1991. Sistematização da geologia do Amapá. In: Simp. Geol. Amaz., 3, Belém, 1991. Anais... Belém, p. 322-335.

LUDWIG, K.R. 1999. Isoplot/Ex, vs 2.10. A Geochronological Toolkit for Microsoft Excel. Berkeley Geoch. Center. Spec. Publ. No. 1a. 49p.

LUZHNAYA, N.P. \& VERSHTCHETINA, I.P. 1946. Sodium, calcium, magnesium chlorides in aqueous solutions at $-57^{\circ}$ to $+25^{\circ} \mathrm{C}$ (polythermic solubility). Zh. Prikl. Khim. (Moscow), 19: $723-733$.

MACAMBIRA, M.J.B.; LAFON, J.M.; DALL'AGNOL, R.; COSTI, H.; JORGE JOÃO, X.S. 1990. Geocronologia da granitogênese da província da Amazonia Central Brasileira: uma revisão. Rev. Bras. Geoc., 20 (1-4): 258-26

MACDONALD, A.J. 1986. Gold's 86: An International Symposium on the Geology of Gold, Konsult Intern. Inc., Toronto, $517 \mathrm{p}$.

MACREATH, I. \& FARACO, M.T.L. 1997. Sm/Nd and Rb/Sr systems in parts of the Vila Nova metamorphic suite, northern Brazil. In: South- American Symposium on Isotope Geology, Brazil, 194-196.

MANIAR, P.A. \& PICCOLI, P.M. 1989. Tectonic discrimination of granitoids. Geol. Soc. Am. Bull., 101: 636-643. 
MANN, A G. 1984 Gold mines in granitic rocks in Zimbabwe. In: Foster, R.P. (Ed.), Gold'82: The Geology, Geochemistry and Genesis of Gold Deposits. Geol. Soc. Zimbabwe, Spec. Publ. 1, A Balkema Publ., Rotterdam, pp. 553-568.

MARCOUX, E. \& MILÉSI, J.P. 1993. Lead isotope signature of Early Proterozoic ore deposits in Western Africa: comparison with gold deposits in French Guiana. Econ. Geol., 88: 1862-1879.

MARTIN, H. 1986. Effect of steeper Archaean geothermal gradient on geochemistry of subductionzone magmas. Geol. 14: 753-756.

MARTIN, H. 1993. The mecanisms of petrogenesis of the Archaean continental crust - comparison with modern processes. Lithos, 30: 373-388.

MCCUAIG,T.C \& KERRICH, R. 1998. P-T-t deformation fluid characteristics of lode-gold deposits: evidence from alteration. Ore Geol Rev., 12: 381-453.

MCKINSTRY, H.E.\& OHLE, E.L. 1949. Ribbon structure in gold quartz veins. Econ. Geol., 44: 87109.

MESCHED, M. 1986. A method of discriminating between different types of mid-ocean ridge basalts and continental tholeiites with a $\mathrm{Nb}-\mathrm{Zr}-\mathrm{Y}$ diagram. Chem. Geol., 56:207-218.

MIKUCKI, E.J. \& RIDLEY, J.R. 1993. The hydrothermal fluid of Archaean lode-gold deposits at different metamorphic grades: compositional constraints from ore and wallrock assemblages. Miner. Deposita, 28: 469-481.

MIKUCKI, E.J. 1998. Hydrotermal transport and depositional processes in Archean lode-gold systems: a review. Ore Geol. Rev., 13: 307-321.

MIKUCKI, E.J.; GROVE, D.I.; CASSIDY, K.F. 1990. Walrock alteration in sub-amphibolite facies gold deposits. In: Ho, S.E., Groves, D.I., Bennett, J.M. (Eds). Gold Deposits of the Yilgarn Block, Western Australia: Nature, Genesis and Exploration Guides. Geol. Depart. (Key Centre) and Univers. Ext., Univ. West. Aust., Publ. 20, 60-78.

MILÉSI, J.P.; EGEL, E.; LEDRU, P.; VERHET, Y.; THIÉBLEMONT, D.; COCHERIE, A.; TEGYEY, M.; MARTEL-JANTIN, B; LAGNY, P. 1995. Les minéralisations du Nord de la Guyane Française dans leur cadre géologique. Chron.Rech.Min., 518: 5-58.

MILÉSI, J.P.; LEDRU, P.; FRYBESSE, J.P.; DOMMANGET, A.; MARCOUX, E. 1992. Early Proterozoic ore deposits and tectonic of the Birimian Orogenic Belt, West Africa. Prec. Res., 58: 305-344.

MONTALVÃO, R.M.G. \& TASSINARI, C.C.G. 1984. Geocronologia precambriana do Território Federal do Amapá (Brasil). In: Symp. Amaz., 2, Manaus, 1984. Anais... Manaus, DNPM, p. $53-57$.

NESBITT, B.E. \& MUEHLENBACHS, K. 1989. Geology, geochemistry and genesis of mesothermal lode gold deposits of the Canadian Cordillera: evidence for ore formation from evolved meteoric water. Econ. Geol. Monograph, 6: 553-563. 
NESBITT, B.E. 1988. Gold deposit continuum: a genetic model for lode Au mineralization in the continental crust. Geology, 16: 1044-1048.

NEUMAYR, P.; CABRI, L.J.; GROVES, D.I.; MIKUCKI, E.J.; JACKMAN, J.A. 1993a. The mineralogical distribution of gold and relative timing of gold mineralization in two archean settings of high metamorphic grade. Australia. Canad. Mineral., 31: 711-725.

NEUMAYR, P; GROVES, D.I.; RIDLEY, J.R.; KONING, C.D. 1993b. Syn-amphibolite facies Archaean lode gold mineralisation in the Mt. York District, Pilbara Block, Western Australia. Mineral. Deposita, 28: 457-468.

O'CONNOR, J.T. 1965. A classification for quartz-rich igneous rocks based on feldspar ratios. U.S. Geol. Surv. Prof. Pap., 525-B: 79-84.

OBERTHÜR, T.; BLENKINSOP, U.F.; HEIN, U.F.; HÖPPENER, M.; HÖHNDORF, A.; WEISER, T.W. 2000. Gold mineralization in the Mazowe area, Harare-Bindura-Shamva greenstone belt, Zimbabwe: II. Genetic relationships deduced from mineralogical, fluid inclusion and stable isotope studies, and the Sm-Nd isotopic composition of scheelites. Min. Deposita, 35: 138156.

OBERTHÜR, T.; VETTER, U.; DAVIS, D.W.; AMANOR, J.A.1998. Age constraints on gold mineralization and Paleoproterozoic crustal evolution in the Ashanti belt of southern Ghana. Prec. Res., 89: 129-143.

OHMOTO, H. \& GOLDHABER, M.B. 1997. Isotopes of sulphur and carbon. . In: Barnes, H.L. (Ed), Geochemistry of hydrothermal ore deposists, Wiley, New York, p. 435-486.

OHMOTO, H. \& RYE, R.O. 1979. Isotopes of sulphur and carbon. In: Barnes, H.L. (Ed.), Geochemistry of hydrothermal ore deposits. Wiley, New York, pp. 509-567.

OHMOTO, H. 1986. Stable isotope geochemistry of ore deposits. In: Valley, J.W., Taylor Jr, H.P., O'Neil, J.R. (Eds.) Stable isotopes in high temperature geological processes. Min. Soc. Amer., Rev. Mineral., 16: 491-560.

PASSCHIER, C.W. \& TROUW, R.A.J. 1996. Microtectonics. Springer-Verlag, Berlin, Heidelberg, New York. $289 \mathrm{p}$.

PEARCE, J. A.; HARRIS, N. B. W; TINDLE, A. C. 1984. Trace Elements discrimination diagrams for the tectonic interpretation of granitic rocks. J. Petrol., 25: 956-983.

PEARCE, J.A. \& CANN, J.R. 1973. Tectonic setting of basic volcanic rocks determined using trace elements analysis. Earth Planet. Sci. Lett., 19:290 300.

PEARCE, J.A. 1975. Basalt geochemistry used to investigate past tectonic environments on Cyprus. Tectonoph., 25: 41-67.

PEARCE, J.A. 1983. Role of the sub-continental lithosfere in magma genesis at active continental margins. In: C.J. Hawkesworth and M.J. Norry (eds.): Continental basalts and mantle xenoliths. Shiva, Natwich, p.230-249. 
PERRING, C.S.; GROVES, D.I.; HO, S.E. 1987. Constraints on the source of auriferous fluids for archean gold deposits. In: Recent advances in understanding Precambrian gold deposits. Geology Department \& University Extension. Univ. Wester Australia, Public. ${ }^{\circ} 11,287-306$. PHILLIPS, G.N. \& POWELL, R. 1993. Link between gold provinces. Econ. Geol., 88: 1084-1098.

POULSEN, K.H.; ROBERT, F. DUBÉ, B. 2000. Geological classification of canadian gold deposits. Geol Surv. Canada. Bull., 90p.

PRIEM, H.N.A. 1998. Isotope geochronological research in Suriname. In: The history of earth sciences in Suriname (Wong, T.E. et al. Eds), 65-72.

PRIEM, H.N.A.; BOELRIJK, N.A.I.M.; HEBEDA, E.H.; VERDURMEN, E.A.T.H.; VERSCHURE, R.H. 1971. Isotopic ages of the Trans- Amazonian acidic magmatism and the Nickerie metamorphic episode in the Precambrian basement of Suriname, S. America. Geol. Soc. Amer. Bull., 82: 1667-1680.

RAMSAY, J.G. 1980b. Shear zone geometry: a review. J. Struct. Geol., 2: 83-99.

RICHARD, L.R. 1995. MINPET (vs.2.02) Petrological and mineralogical data processing system. Logiciel Géologique Minpet. Québec. Canadá.

RIDLEY, J.; MIKUCKI, E.J.; GROVES, D.I. 1996. Archean lode-gold deposits: fluid flow and chemical evolution in vertically extensive hydrothermal systems. Ore Geol Rev., 1:279-293.

ROBERT, F. \& POULSEN, K.H. 1997. World-class Archaean gold deposits in canada: na overview. Australian J. Earth Sci., 44: 329-351.

ROCK, N.M.S.; GROVES, D.I.; PERRING, C.S. 1988. Gold lamprophyres and porphyries: a new genetic model. In: Bicentennial God'88, Extended Abstracts., Oral Programme. Geol. Soc. Australia, 22: 307-312.

ROEDDER, E. 1984. Fluid Inclusions. Reviews in Mineralogy 12. Mineralogical Society of America, $646 \mathrm{p}$.

ROSE, A.W. \& BURTON, D.M. 1979. Hydrothermal alteration. In: Barnes H.L. (ed) Geochemistry of Hydrothermal Ore Deposits. Wiley-Interscience, New York, pp.173-235.

SANTOS, D.B.; LEAL, J.W.L.; MATOS, S.H.S. 1984. Potencialidade Mineral do Território Federal do Amapá. In: Cong. Bras. Geol., 33, Rio de Janeiro, 1984. Anais... Rio de Janeiro. SBG, v. 8, p. 3537-3549.

SANTOS, M.D. \& LEONARDOS, O.H. 1995. Sistema de fluidos e modelo genético do depósito aurífero do Cumru, SE do Estado do Pará. Bol. Museu Par. Emilio Goeldi. Ser. Ciências da Terra, 7: 237-262.

SATO, K. \& TASSINARI, C.C.G. 1997. Principais eventos de acreção continental no craton amazônico baseados em idade modelo $\mathrm{Sm} / \mathrm{Nd}$, calculada em evoluções de estágio único e estágio duplo. In: Contribuições à Geologia da Amazônia (Lima da Costa, M. e Angélica, R.S. Coordenadores). Belém, FINEP/SBG. 91-142. 
SATO, K.; TASSINARI, C.C.G.; KAWASHISTA, K.; PETRONILLO, L. 1995. O método geocronológico Sm-Nd no IG-USP e suas aplicações. An. Acad. Bras. Ciências, 67(3): 313336.

SCARPELLI, W. 1966. Aspctos genéticos e metamórficos das rochas do distrito da Serra do Navio; Território Federal do Amapá. Avulso Dep. Nac. Prod. Min. Rio de Janeiro, 41: 37-56.

SCHOBBENHAUS, C.E. 1984- Geologia do Brasil. DNPM/MME. $501 \mathrm{p}$.

SEWARD, T.M. 1984. The transport and deposition of gold in hydrothermal systems. In: Foster, R.P. (Ed.). Gold'82: The geology, geochemistry and genesis of gold deposits. Rotterdam: A.A. Balkema. Geol. Soc. Zimbabwe, Special Public., n.1, p. 165-182.

SHARP, Z.D.; ESSENE, E.J.; KELLY, W. 1985. A re-examination of the arsenopyrite geothermometer: pressure considerations and applications to natural assemblages. Can. Mineral., 23: 517-534.

SHEPHERD, T.J.; RANKIN, A.H.; ALDERTON, D.H.M. 1985. A pratical guide to fluid inclusion studies. Blackie, London, 239p.

SIBSON, R.H.; ROBERT, F.; POULSEN, K.H. 1988. High-angle reverse faults, fuid-pressure cycling, and mesothermal gold-quartz deposits. Geology, 16: 551-555.

SIBSON, R.H. 1990. Faulting and fluid flow. In: Nesbitt, B.E. (Ed.), Fluids in Tectonically Active Regimes of the Continental Crust. Mineral. Assoc. Can. Short Course 18 pp. 93-132.

SILVA, A.R.B. 1984. Províncias auríferas do Estado do Pará e Território Federal do Amapá. In: Cong. Bras. Geol., 33, Rio de Janeiro, 1984. Anais... Rio de Janeiro. SBG, v.8, p. 3945-3958.

SKINNER, B.S. 1979. The many origins of hydrothermal mineral deposits. In: Barnes, H.L. (Ed), Geochemistry of hydrothermal ore deposits. New York: Jonh Wiley \& Sons, p. 1-21.

SOLOMON, M. \& GROVES, D.I. 1994. The geology and origin of Australia's Mineral Deposits. Oxford Monographs on geology and geophysics, number 24.

SOUZA JÚNIOR, J.J.; ARAUJO, J.J.; OLIVEIRA, A.B.; DAMBRÓS, L.A.; MAMEDE, L.; GEMAQUE, A.S.; ALMEIDA, D.C.; SILVA, R.T.L. 1988. A geologia, a fisiografia e o meio ambiente do Território Federal do Amapá. In: Cong. Bras. Geol., 35, Belém. Anais... Belém. SBG, v.5, p. 2048-2063.

SPOONER, E.T.C. 1991. The magmatic model for the origin of Archean Au-quartz vein ore systems: an assessment of the evidence. In: Proceedings of Symposium of Brazil Gold'91: The economics, geology, geochemistry and genesis of gold deposits, 313-318.

STEIGER, R.H. \& JAEGER, E. 1977. Subcommission on Geochronology: convention of the use of decay constants in geo and cosmochronology. A.A.P.G, Studies in Geology, pp. 67-71.

STRECKEISEN, A. 1976. To each rock its proper name. Earth Sci. Rev., 12: 1-33.

TASSINARI, C.C.G.; TEIXEIRA, W.; SIGA JR., O. 1984. Épocas metalogenéticas relacionadas a granitogênese do Craton Amazonico. In: SBG, congr. Bras. Eol., 33, Rio de Janeiro, Anais... 6: 2963-2977. 
TASSINARI, C.C.G. \& MACAMBIRA, M.J.B. 1999. Geochronological Provinces of the Amazonian Craton. Episodes, 22(3): 174-182.

TASSINARI, C.C.G. 1996. O mapa geocronológico do Cráton Amazônico no Brasil: Revisão dos dados isotópicos. Inst. de Geociências, Universidade de São Paulo, Tese de Livre Docência, 139p.

TAYLOR, H.P. 1997. Oxigen and hydrogen isotope relationships in hydrothermal mineral deposits. In: Barnes, H.L. (Ed), Geochemistry of hydrothermal ore deposists, Wiley, New York, pp. 229-303.

TEIXEIRA, W.; KAWASHITA, K.; TAYLOR, P.N.; OIMA, S.K.; VIEIRA, A.G. 1985. Reconhecimento geocronológico da Guiana Francesa: novos dados, integração e implicações tectônicas. Anais do II Simpósio de Geologia da Amazônia, Belém, 1985. 194-207.

TEIXEIRA, W.; OJMA, S.K.; KAWASHITA, K: 1984. A evolução geocronológica de rochas metamórficas e ígneas da faixa móvel Maroni-Itacaiúnas, na Guiana Francesa. In: Symp. Amaz., 2, Manaus, 1984. Anais... Manaus, p. 75-85.

TEIXEIRA, W.; TASSINARI, C. C. G.; CORDANI, U. G.; KAWASHITA, K. 1989. A review of the geochronology of the Amazonian Craton: tectonic implication. Prec. Res., 42: 213-227.

TERRACONSULT, A. G. 1986. Mineração Novo Astro S.A. Amapá Exploration Project. Final Report.

TOMKINS, A.G. \& MAVROGENES, J.A. 2001. Redistribution of gold within arsenopyrite and löllingite during pro- and retrograde metamorphism: application to timing of mineralization. Econ. Geol., 96: 525-534.

VANDERHAEGHE, O.; LEDRU, P.; THIÉBLEMONT, D.; EGAL, E.; COCHERIE, A.; TEGYEY, M.; MILÉSI, J.P. 1998. Constrasting mechanism of crustal growth. Geodynamic evolution of the Paleoproterozoic granite-greenstone belts of French Guiana. Prec. Res., 92: 165-193.

VEARNCOMBE, J.R. 1993. Quartz vein morphology and implications for formation depth and classification of Archaean gold-vein deposits. Ore Geol. Rev., 8: 407-424.

VEIGA, T.C.V.; BRAIT FILHO, L.; OLIVEIRA, C.A.C. 1985. Geologia da província aurífera do Cassiporé, Amapá. In: Simp. Geol. Amaz., 2, Belém, 1985. Anais... Belém. SBG, v.3, p. 135146.

VOICU, G.; BARDOUX, M.; STEVENSON, R. 2001. Lithostratigraphy, geochronology and gold metallogeny in the northern Guiana Shield, South America: a review. Ore Geol. Rev., 18: 211 236.

VOICU, G.; BARDOUX, M; JÉBRAK, M.; CRÉPEAU, R. 1999. Structural, mineralogical, and geochemical studies of the Paleoproterozoic Omai Gold Deposit, Guyana. Econ. Geol, 94: 1277-1304.

WANG, L.G.; MCNAUGTON, N.J.; GROVES, D.I. 1993. An overview of the relationship between granitoid intrusions and gold mineralisation in the Archaean Murchison Province, Western Australia. Min. Deposita, 28: 482-494. 
WILKINS, R.W.T. \& BARKAS, J.P. 1978. Fluid inclusions, deformation and recrystallization in granite tectonites. Contrib. Mineral. Petrol., 65: 293-299.

WILLIAMS, H.; TURNER, F.J.; GILBERT, C.M. 1970. Petrografia. Uma introdução ao estudo das rochas em seções delgadas. Ed. Un. São Paulo. 445p.

WITT, W.K. \& VANDERHOR, F. 1998. Diversity within a unified model for Archaen gold mineralization in the Yilgarn Craton of Western Australia: An overview of the late-orogenic, structurally-controlled gold deposits. Ore. Geol. Rev., 13: 29-64.

WOOD, D.A. 1980. The application of a Th-Hf-Ta diagram to problems of tectonomagmatic classification and to establishing the nature of crustal contamination of basalt lavas of the British Tertiary Volcanic Province. Earth Planet. Sci. Lett., 50: 11-30.

WYMAN, D. \& KERRICH, R. 1988. Alkaline magmatism, major structures, and gold deposits: implications for greenstone belt gold metallogeny. Econ. Geol., 83: 451-458.

YANATIEVA, O.K. 1946. Solubility polytherms in the systems $\mathrm{CaCl}_{2}-\mathrm{MgCl}_{2}-\mathrm{H}_{2} \mathrm{O}$. Zh Prikl Khim, 19: 709-722.

YARDLEY, B. (1997) Short discussion of apparent low eutectic temperature observations that was held during June 1997. http:// www.geology.wisc.edu/ pbrown/loweutec.html

ZARTMAN, R.E. \& DOE, B.R. 1981. Plumbotectonic - the model. Tectonophysics, 75(12): 135-162. 
12. ANEXOS 
Anexo 1

Análises Químicas em Fases Minerais Silicatadas 


\begin{tabular}{|c|c|c|c|c|c|c|c|c|c|c|c|c|c|c|c|c|c|c|c|c|c|}
\hline Amostra & TR01 & & & & & & & & & TR07 & & & & & & & TS14 & & & & \\
\hline Análise & $1 \mathrm{c} 2$ & $2 \mathrm{c} 2$ & $3 \mathrm{cl}$ & $4 \mathrm{cl}$ & $5 \mathrm{cl}$ & $6 \mathrm{c} 4$ & $8 \mathrm{cH}$ & $10 \mathrm{c5}$ & $11 \mathrm{c5}$ & $1 \mathrm{cl}$ & $5 \mathrm{cl}$ & $6 \mathrm{cl}$ & $8 \mathrm{c3}$ & $11 \mathrm{c3}$ & 1304 & $15 c 4$ & $\mathrm{Icl}$ & $2 \mathrm{cl}$ & $3 \mathrm{cl}$ & $4 c 3$ & $8 c 3$ \\
\hline SiO2 & 61.71 & 61.58 & 62.02 & 58.2 & 62.05 & 61.28 & 61.42 & 60.21 & 61.11 & 61.58 & 61.93 & 61.65 & 60.86 & 61.68 & 60.06 & 61.09 & 60.88 & 61.15 & 60.27 & 62.06 & 62.3 \\
\hline TiO2 & 0 & 0.02 & 0 & 0.05 & 0 & 0 & 0.01 & 0.01 & 0 & 10 & 0 & 0 & 0 & 0.03 & 0.07 & 0 & 0.02 & 0 & 0 & 0.02 & 0 \\
\hline $\mathrm{Al203}$ & 24.83 & 24.64 & 23.44 & 24.76 & 23.99 & 24.03 & 24.45 & 25.47 & 23.67 & 24.39 & 24.23 & 24.41 & 24.59 & 24.35 & 24.98 & 24.22 & 24.87 & 24.75 & 24.82 & 24.11 & 24.59 \\
\hline $\mathrm{Fe} 203$ & 0 & 0 & 0 & 0 & 0 & 0 & 0 & 0 & 0 & 0 & 0 & 0 & 0 & 0 & 0 & 0 & 0 & 0 & 0 & 0 & 0 \\
\hline $\mathrm{FeO}$ & 0.01 & 0.02 & 0 & 0.15 & 0.02 & 0.09 & 0.03 & 0 & 0.06 & 0.01 & 0.03 & 0.04 & 0.02 & 0.02 & 0.04 & 0.02 & 0.07 & 0 & 0.06 & 0.04 & 0.03 \\
\hline MnO & 0.01 & 0 & 0.01 & 0 & 0 & 0.03 & 0 & 0 & 0 & 0 & 0 & 0 & 0.02 & 0.01 & 0 & 0.02 & 0 & 0 & 0 & 0 & 0.02 \\
\hline MgO & 0.01 & 0 & 0.01 & 0 & 0 & 0 & 0 & 0 & 0.02 & 10 & 0 & 0 & 0 & 0 & 0.01 & 0.01 & 0 & 0 & 0 & 0 & 0 \\
\hline $\mathrm{BaO}$ & 0 & 0 & 0 & 0 & 0 & 0 & 0 & 0 & 0 & 10 & 0 & 0 & 0 & 0 & 0 & 0 & 0 & 0 & 0 & 0 & 0 \\
\hline $\mathrm{CaO}$ & 5.76 & 5.11 & 5.16 & 5.43 & 5.37 & 5.2 & 5.62 & 6.38 & 5.59 & 6.02 & 5.84 & 5.97 & 6.22 & 6.03 & 7.05 & 5.99 & 6.03 & 5.81 & 5.46 & 5.21 & 5.1 \\
\hline $\mathrm{Na2O}$ & 8.34 & 8.81 & 8.29 & 8.55 & 8.34 & 8.57 & 8.09 & 7.77 & 8.13 & 8.24 & 8.32 & 8.27 & 8.04 & 8.3 & 8 & 8.17 & 7.78 & 8.39 & 8.73 & 8.36 & 8.63 \\
\hline K2O & 0.09 & 0.11 & 0.07 & 0.09 & 0.1 & 0.11 & 0.09 & 0.06 & 0.09 & 0.11 & 0.16 & 0.12 & 0.13 & 0.08 & 0.07 & 0.23 & 0.16 & 0.09 & 0.15 & 0.09 & 0.1 \\
\hline Total & 100.76 & 100.29 & 99 & 97.23 & 99.87 & 99.31 & 99.71 & 99.9 & 98.67 & 100.35 & 100.51 & 100.46 & 99.88 & 100.5 & 100.28 & 99.75 & 99.81 & 100.19 & 99.49 & 99.89 & 100.77 \\
\hline$\overline{\mathbf{S i}}$ & 10.87 & 10,895 & 11.08 & 10.67 & 11,004 & 10,949 & 10,917 & $10, \overline{711}$ & 10,981 & 10,899 & 10.94 & 10.9 & 10,833 & 10,902 & 10,689 & 10,888 & 10,827 & 10,842 & 10,781 & 10,999 & 10,953 \\
\hline Al & 5,151 & 5,134 & 4,932 & 5,346 & 5.01 & 5,056 & 5,118 & 5,336 & 5,009 & 5,084 & 5.04 & 5,083 & 5,155 & 5,069 & 5,236 & 5,084 & 5,209 & 5,168 & 5,229 & 5,032 & 5,091 \\
\hline $\mathrm{Fe} 3+$ & 0 & 0 & 0 & 0 & 0 & 0 & 0 & 0 & 0 & 0 & 0 & 0 & 0 & 0 & 0 & 0 & 0 & 0 & 0 & 0 & 0 \\
\hline $\mathbf{T i}$ & 0 & 0.003 & 0 & 0.007 & 0 & 0 & 0.001 & 0.001 & 0 & 0 & 0 & 0 & 0 & 0.004 & 0.009 & 0 & 0.003 & 0 & 0 & 0.003 & 0 \\
\hline $\mathrm{Fe} 2+$ & 0.001 & 0.003 & 0 & 0.023 & 0.003 & 0.013 & 0.004 & 0 & 0.009 & 0.001 & 0.004 & 0.006 & 0.003 & 0.003 & 0.006 & 0.003 & 0.01 & 0 & 0.009 & 0.006 & 0.004 \\
\hline $\mathbf{M n}$ & 0.001 & 0 & 0.002 & 0 & 0 & 0.005 & 0 & 0 & 0 & 0 & 0 & 0 & 0.003 & 0.001 & 0 & 0.003 & 0 & 0 & 0 & 0 & 0.003 \\
\hline Mg & 0.003 & 0 & 0.003 & 0 & 0 & 0 & 0 & 0 & 0.005 & 0 & 0 & 0 & 0 & 0 & 0.003 & 0.003 & 0 & 0 & 0 & 0 & 0 \\
\hline $\mathbf{B a}$ & 0 & 0 & 0 & 0 & 0 & 0 & 0 & 0 & 0 & 0 & 0 & 0 & 0 & 0 & 0 & 0 & 0 & 0 & 0 & 0 & 0 \\
\hline $\mathrm{Ca}$ & 1,087 & 0.969 & 0.988 & 1,067 & 1.02 & 0.995 & 1.07 & 1,216 & 1,076 & 1,142 & 1,105 & 1,131 & 1,186 & 1,142 & 1,344 & 1,144 & 1,149 & 1,104 & 1,046 & 0.989 & 0.961 \\
\hline $\mathrm{Na}$ & 2,848 & 3,022 & 2,872 & 3,039 & 2,868 & 2,969 & 2,788 & 2.68 & 2,833 & 2,828 & 2.85 & 2,835 & 2,775 & 2,845 & 2,761 & 2,824 & 2,683 & 2,884 & 3,028 & 2,873 & 2,942 \\
\hline $\mathbf{K}$ & 0.02 & 0.025 & 0.016 & 0.021 & 0.023 & 0.025 & 0.02 & 0.014 & 0.021 & 0.025 & 0.036 & 0.027 & 0.03 & 0.018 & 0.016 & 0.052 & 0.036 & 0.02 & 0.034 & 0.02 & 0.022 \\
\hline Cations & 19,981 & 20,051 & 19,893 & 20,173 & 19,928 & 20,012 & 19,918 & 19,958 & 19,934 & 19,979 & 19,975 & 19,982 & 19,985 & 19,984 & 20,064 & 20,001 & 19,917 & 20,018 & 20,127 & 19,922 & 19,976 \\
\hline $\mathbf{x}$ & 16,021 & 16,032 & 16,012 & 16,023 & 16,014 & 16,005 & 16,036 & 16,048 & 15.99 & 15,983 & 15.98 & 15,983 & 15,988 & 15,975 & 15,934 & 15,972 & 16,039 & 16.01 & 16.01 & 16,034 & 16,044 \\
\hline $\mathbf{z}$ & 3.96 & 4,019 & 3,881 & 4.15 & 3,914 & 4,007 & 3,882 & 3.91 & 3,944 & 3,996 & 3,995 & 3,999 & 3,997 & 4,009 & 4.13 & 4,029 & 3,878 & 4,008 & 4,117 & 3,888 & 3,932 \\
\hline $\mathbf{A b}$ & 72 & 75.2 & 74.1 & 73.6 & 73.3 & 74.4 & 71.9 & 68.5 & 72.1 & 70.8 & 71.4 & 71 & 69.5 & 71 & 67 & 70.2 & 69.4 & 72 & 73.7 & 74 & 75 \\
\hline An & 27.5 & 24.1 & 25.5 & 25.9 & 26.1 & 24.9 & 27.6 & 31.1 & 27.4 & 28.6 & 27.7 & 28.3 & 29.7 & 28.5 & 32.6 & 28.5 & 29.7 & 27.5 & 25.5 & 25.5 & 24.5 \\
\hline Or & 0.5 & 0.6 & 0.4 & 0.5 & 0.6 & 0.6 & 0.5 & 0.4 & 0.5 & 0.6 & 0.9 & 0.7 & 0.8 & 0.4 & 0.4 & 1.3 & 0.9 & 0.5 & 0.8 & 0.5 & 0.6 \\
\hline
\end{tabular}

Tabela 4.2a - Composições químicas e proporções catiônicas $(\mathrm{O}=32)$ para plagioclásios, de rocha tonalítica pouco afetados pela mineralização, e representativas da Mina de Salamangone. 


\begin{tabular}{|c|c|c|c|c|c|c|c|c|c|c|c|c|c|c|c|c|c|c|c|}
\hline \multirow{2}{*}{$\begin{array}{l}\text { Amostra } \\
\text { Análise }\end{array}$} & \multicolumn{8}{|l|}{ TS21 } & \multicolumn{6}{|c|}{ SHN7/F113 } & \multicolumn{5}{|c|}{ SHN8/F113 } \\
\hline & $1 \mathrm{c} 2$ & $2 \mathrm{c} 2$ & $3 \mathrm{c} 2$ & $4 c 2$ & $5 \mathrm{c} 2$ & $7 \mathrm{c} 3$ & $8 \mathrm{c} 3$ & 1004 & $1 \mathrm{cl}$ & $2 \mathrm{cl}$ & $3 \mathrm{cl}$ & $5 \mathrm{c} 2$ & $6 c 2$ & $8 \mathrm{c3}$ & $2 \mathrm{cl}$ & $4 \mathrm{cl}$ & $5 \mathrm{cl}$ & $7 \mathrm{c3}$ & $9 \mathrm{c3}$ \\
\hline SiO2 & 60.58 & 61.98 & 57.54 & 60.6 & 60.21 & 62.95 & 61.71 & 60.3 & 61.05 & 62.08 & 60.91 & 61.24 & 61.43 & 57.81 & 59.1 & 60.09 & 60.59 & 59.56 & 60.71 \\
\hline TiO2 & 0 & 0.06 & 0.01 & 0.07 & 0.07 & 0 & 0 & 0.04 & 0 & 0.02 & 0 & 0 & 0 & 0.02 & 0 & 0 & 0.03 & 0.05 & 0.04 \\
\hline Al203 & 25.41 & 23.92 & 27.77 & 24.75 & 25.78 & 24.21 & 24.5 & 24.34 & 24.7 & 23.86 & 24.34 & 24.65 & 24.62 & 26.7 & 26.27 & 25.37 & 25.14 & 25.81 & 25.11 \\
\hline $\mathrm{Fe} 2 \mathrm{O3}$ & 0 & 0 & 0 & 0 & 0 & 0 & 0 & 0 & 0 & 0 & 0 & 0 & 0 & 0 & 0 & 0 & 0 & 0 & 0 \\
\hline $\mathrm{FeO}$ & 0.03 & 0.01 & 0.01 & 0.02 & 0.05 & 0.01 & 0.02 & 0 & 0.03 & 0 & 0.03 & 0.02 & 0.01 & 0.05 & 0.05 & 0.02 & 0.06 & 0 & 0.01 \\
\hline MnO & 0.03 & 0 & 0 & 0.02 & 0 & 0 & 0 & 0 & 0 & 0.01 & 0 & 0.01 & 0 & 0 & 0 & 0.03 & 0 & 0 & 0 \\
\hline MgO & 0 & 0.01 & 0 & 0.02 & 0.01 & 0 & 0 & 0 & 10 & 0 & 0.01 & 0 & 0 & 0 & 0.01 & 0.01 & 0 & 0 & 0 \\
\hline $\mathrm{BaO}$ & 0 & 0 & 0 & 0 & 0 & 0 & 0 & 0 & 0 & 0 & 0 & 0 & 0 & 0 & 0 & 0 & 0 & 0 & 0 \\
\hline $\mathrm{CaO}$ & 5.68 & 5.04 & 8.5 & 5.97 & 6.8 & 5.11 & 4.97 & 4.99 & 5.57 & 5.21 & 5.46 & 5.53 & 5.12 & 7.47 & 8.1 & 7.04 & 6.9 & 7.63 & 6.65 \\
\hline $\mathrm{Na2O}$ & 8.27 & 8.52 & 6.33 & 8.02 & 7.41 & 8.8 & 8.73 & 8.84 & 8.35 & 8.47 & 8.25 & 8.43 & 8.59 & 7.24 & 7.08 & 7.69 & 7.68 & 7.28 & 7.99 \\
\hline $\mathbf{K} 20$ & 0.05 & 0.12 & 0.09 & 0.08 & 0.11 & 0.13 & 0.11 & 0.13 & 0.07 & 0.07 & 0.09 & 0.11 & 0.14 & 0.06 & 0.07 & 0.08 & 0.19 & 0.06 & 0.11 \\
\hline Total & 100.05 & 99.66 & 100.25 & 99.55 & 100.44 & 101.21 & 100.04 & 98.64 & 99.77 & 99.72 & 99.09 & 99.99 & 99.91 & 99.35 & 100.68 & 100.33 & 100.59 & 100.39 & 100.62 \\
\hline$\overline{\mathrm{Si}}$ & 10,753 & 11,012 & 10,257 & 10,812 & 10,662 & 11,019 & 10,933 & 10,859 & 10,859 & 11,022 & 10,901 & 10,871 & 10,902 & 10,395 & 10,489 & 10,674 & 10.73 & 10,582 & 10,743 \\
\hline Al & 5,312 & 5,005 & 5.83 & 5.2 & 5,376 & 4,991 & 5,112 & 5,162 & 5,174 & 4,989 & 5.13 & 5,153 & 5,146 & 5,654 & 5,491 & 5,307 & 5,243 & 5.4 & 5,233 \\
\hline $\mathrm{Fe} 3+$ & 0 & 0 & 0 & 0 & 0 & 0 & 0 & 0 & 0 & 0 & 0 & 0 & 0 & 0 & 10 & 0 & 0 & 0 & 0 \\
\hline $\mathbf{T i}$ & 0 & 0.008 & 0.001 & 0.009 & 0.009 & 0 & 0 & 0.005 & 0 & 0.003 & 0 & 0 & 0 & 0.003 & 0 & 0 & 0.004 & 0.007 & 0.005 \\
\hline $\mathrm{Fe} 2+$ & 0.004 & 0.001 & 0.001 & 0.003 & 0.007 & 0.001 & 0.003 & 0 & 0.004 & 0 & 0.004 & 0.003 & 0.001 & 0.008 & 0.007 & 0.003 & 0.009 & 0 & 0.001 \\
\hline $\mathbf{M n}$ & 0.005 & 0 & 0 & 0.003 & 0 & 0 & 0 & 0 & 0 & 0.002 & 0 & 0.002 & 0 & 0 & 0 & 0.005 & 0 & 0 & 0 \\
\hline Mg & 0 & 0.003 & 0 & 0.005 & 0.003 & 0 & 0 & 0 & 0 & 0 & 0.003 & 0 & 0 & 0 & 0.003 & 0.003 & 0 & 0 & 0 \\
\hline $\mathbf{B a}$ & 0 & 0 & 0 & 0 & 0 & 0 & 0 & 0 & 0 & 0 & 0 & 0 & 0 & 0 & 0 & 0 & 0 & 0 & 0 \\
\hline $\mathrm{Ca}$ & 1.08 & 0.959 & 1,623 & 1,141 & 1.29 & 0.958 & 0.943 & 0.963 & 1,061 & 0.991 & 1,047 & 1,052 & 0.974 & 1,439 & 1.54 & 1.34 & 1,309 & 1,452 & 1,261 \\
\hline $\mathrm{Na}$ & 2,846 & 2,935 & 2,188 & 2,775 & 2,544 & 2,987 & 2,999 & 3,087 & 2.88 & 2,916 & 2,863 & 2,902 & 2,956 & 2,524 & 2,437 & 2,649 & 2,637 & 2,508 & 2,742 \\
\hline $\mathbf{K}$ & 0.011 & 0.027 & 0.02 & 0.018 & 0.025 & 0.029 & 0.025 & 0.03 & 0.016 & 0.016 & 0.021 & 0.025 & 0.032 & 0.014 & 0.016 & 0.018 & 0.043 & 0.014 & 0.025 \\
\hline Cations & 20,011 & 19.95 & 19.92 & 19,966 & 19.916 & 19,985 & 20,015 & 20,106 & 19,994 & 19,939 & 19,969 & 20,008 & 20,011 & 20,037 & 19,983 & 19,999 & 19,975 & 19,963 & 20.01 \\
\hline $\mathbf{x}$ & 16,065 & 16,025 & 16,088 & 16,021 & 16,047 & 16.01 & 16,045 & 16,026 & 16,033 & 16,014 & 16,031 & 16,024 & 16,048 & 16,052 & 15.98 & 15,981 & 15,977 & 15,989 & 15,981 \\
\hline $\mathbf{z}$ & 3,946 & 3,925 & 3,832 & 3,945 & 3,869 & 3,975 & 3.97 & 4.08 & 3,961 & 3,925 & 3,938 & 3,984 & 3,963 & 3,985 & 4,003 & 4,018 & 3,998 & 3,974 & 4,029 \\
\hline $\mathbf{A b}$ & 72.3 & 74.9 & 57.1 & 70.5 & 65.9 & 75.2 & 75.6 & 75.7 & 72.8 & 74.3 & 72.8 & 72.9 & 74.6 & 63.5 & 61 & 66.1 & 66.1 & 63.1 & 68.1 \\
\hline An & 27.4 & 24.5 & 42.4 & 29 & 33.4 & 24.1 & 23.8 & 23.6 & 26.8 & 25.3 & 26.6 & 26.4 & 24.6 & 36.2 & 38.6 & 33.4 & 32.8 & 36.5 & 31.3 \\
\hline Or & 0.3 & 0.7 & 0.5 & 0.5 & 0.6 & 0.7 & 0.6 & 0.7 & 0.4 & 0.4 & 0.5 & 0.6 & 0.8 & 0.4 & 0.4 & 0.4 & 1.1 & 0.4 & 0.6 \\
\hline
\end{tabular}

Tabela 4.2a - (continuação) Composições químicas e proporções catiônicas $(O=32)$ para plagioclásios, de rocha tonalítica pouco afetados pela mineralização, e representativas da Mina de Salamangone. 


\begin{tabular}{|c|c|c|c|c|c|c|c|c|c|c|c|c|c|c|c|c|}
\hline Amostra & R01/N54 & & & & & & SH113/07 & & SH113/08 & & & SH118/62 & & & SH140/ & \\
\hline Local & 104 & 10c5borda & c5centro & 404 & $5 \mathrm{c} 4$ & $6 \mathrm{c5}$ & $4 \mathrm{c} 2$ & $6 \mathrm{c3}$ & $32 \mathrm{c} 2$ & $33 \mathrm{c} 2$ & $35 \mathrm{c} 3$ & $25 \mathrm{cl}$ & $27 \mathrm{c} 2$ & $29 \mathrm{c3}$ & $28 \mathrm{c3}$ & $29 \mathrm{c3}$ \\
\hline$\overline{\mathrm{SiO} 2}$ & 35.62 & 36.31 & 36.74 & 36.96 & 36.96 & 36.96 & 35.73 & 36.27 & 36.85 & 35.68 & 36.48 & 36.72 & 36.45 & 36.57 & 35.96 & 35.9 \\
\hline TiO2 & 1.37 & 1.71 & 2.04 & 1.69 & 1.49 & 1.43 & 1.11 & 1.36 & 1.77 & 1.5 & 1.66 & 1.59 & 1.72 & 1.05 & 1.34 & 1.54 \\
\hline $\mathrm{Al}_{203}$ & 16.46 & 16.4 & 16.34 & 16.79 & 16.89 & 16.68 & 16.78 & 16.91 & 16.38 & 16.32 & 16.42 & 16.5 & 16.3 & 16.93 & 16.47 & 16.65 \\
\hline $\mathrm{Cr} 203$ & 0.02 & 0.03 & 0.03 & 0.04 & 0.04 & 0.03 & 0.06 & 0.08 & 0.07 & 0.14 & 0.09 & 0 & 0.05 & 0.07 & 0.06 & 0.04 \\
\hline $\mathrm{FeO}$ & 20.73 & 21.43 & 21.04 & 21.01 & 21.32 & 20.78 & 20.37 & 19.95 & 20.71 & 22.06 & 21.49 & 20.7 & 21.15 & 21.29 & 21.37 & 21.41 \\
\hline $\mathrm{Fe} 203$ & 0 & 0 & 0 & 0 & 0 & 0 & 0 & 0 & 0 & 0 & 0 & 0 & 0 & 0 & 0 & 0 \\
\hline MnO & 0.26 & 0.31 & 0.28 & 0.31 & 0.3 & 0.27 & 0.28 & 0.26 & 0.28 & 0.33 & 0.32 & 0.32 & 0.34 & 0.34 & 0.36 & 0.3 \\
\hline MgO & 10.41 & 10.18 & 10.04 & 10.15 & 10.43 & 10.5 & 10.37 & 10.44 & 10.47 & 9.46 & 10.52 & 10.07 & 9.7 & 10.11 & 10.19 & 10.25 \\
\hline $\mathrm{BaO}$ & 0.11 & 0 & 0.06 & 0.04 & 0.08 & 0.03 & 0.12 & 0.15 & 0.1 & 0.19 & 0 & 0.08 & 0.08 & 0.14 & 0.19 & 0.16 \\
\hline $\mathrm{CaO}$ & 0 & 0.04 & 0 & 0 & 0 & 0 & 0.02 & 0 & 10 & 0.06 & 0 & 0 & 0 & 0 & 0.01 & 0 \\
\hline $\mathrm{Na2O}$ & 0.08 & 0.05 & 0.07 & 0.07 & 0.09 & 0.08 & 0.1 & 0.08 & 0 & 0.01 & 0.07 & 0.12 & 0.06 & 0.08 & 0.06 & 0.1 \\
\hline $\mathbf{K 2 O}$ & 9.62 & 9.48 & 9.55 & 9.73 & 9.61 & 9.58 & 9.56 & 9.99 & 9.43 & 9.41 & 9.36 & 9.49 & 9.74 & 9.74 & 9.45 & 9.57 \\
\hline Total & 94.68 & 95.94 & 96.19 & 96.79 & 97.21 & 96.34 & 94.5 & 95.49 & 96.06 & 95.16 & 96.41 & 95.59 & 95.59 & 96.32 & 95.46 & 95.92 \\
\hline$\overline{\mathrm{Si}}$ & 5.277 & 5.305 & 5.341 & 5.336 & 5.318 & 5.351 & 5.289 & 5.306 & 5.351 & 5.291 & 5.299 & 5.362 & 5.349 & 5.324 & 5.293 & 5.261 \\
\hline AIIV & 2.723 & 2.695 & 2.659 & 2.664 & 2.682 & 2.649 & 2.711 & 2.694 & 2.649 & 2.709 & 2.701 & 2.638 & 2.651 & 2.676 & 2.707 & 2.739 \\
\hline AlVI & 0.148 & 0.127 & 0.138 & 0.191 & 0.18 & 0.195 & 0.214 & 0.219 & 0.152 & 0.141 & 0.108 & 0.2 & 0.166 & 0.227 & 0.148 & 0.134 \\
\hline $\mathbf{T i}$ & 0.153 & 0.188 & 0.223 & 0.184 & 0.161 & 0.156 & 0.124 & 0.15 & 0.193 & 0.167 & 0.181 & 0.175 & 0.19 & 0.115 & 0.148 & 0.17 \\
\hline $\mathrm{Fe} 3+$ & 0 & 0 & 0 & 0 & 0 & 0 & 0 & 0 & 0 & 0 & 0 & 0 & 0 & 0 & 0 & 0 \\
\hline $\mathrm{Fe} 2+$ & 2.568 & 2.619 & 2.558 & 2.537 & 2.565 & 2.516 & 2.522 & 2.441 & 2.515 & 2.736 & 2.611 & 2.528 & 2.596 & 2.592 & 2.631 & 2.624 \\
\hline $\mathrm{Cr}$ & 0.002 & 0.003 & 0.003 & 0.005 & 0.005 & 0.003 & 0.007 & 0.009 & 0.008 & 0.016 & 0.01 & 0 & 0.006 & 0.008 & 0.007 & 0.005 \\
\hline $\mathbf{M n}$ & 0.033 & 0.038 & 0.034 & 0.038 & 0.037 & 0.033 & 0.035 & 0.032 & 0.034 & 0.041 & 0.039 & 0.04 & 0.042 & 0.042 & 0.045 & 0.037 \\
\hline $\mathbf{M g}$ & 2.299 & 2.217 & 2.176 & 2.185 & 2.237 & 2.266 & 2.288 & 2.277 & 2.266 & 2.091 & 2.278 & 2.192 & 2.122 & 2.194 & 2.236 & 2.239 \\
\hline $\mathbf{B a}$ & 0.006 & 0 & 0.003 & 0.002 & 0.005 & 0.002 & 0.007 & 0.009 & 0.006 & 0.011 & 0 & 0.005 & 0.005 & 0.008 & 0.011 & 0.009 \\
\hline $\mathrm{Ca}$ & 0 & 0.006 & 0 & 0 & 0 & 0 & 0.003 & 0 & 0 & 0.01 & 0 & 0 & 0 & 0 & 0.002 & 0 \\
\hline $\mathrm{Na}$ & 0.023 & 0.014 & 0.02 & 0.02 & 0.025 & 0.022 & 0.029 & 0.023 & 0 & 0.003 & 0.02 & 0.034 & 0.017 & 0.023 & 0.017 & 0.028 \\
\hline $\mathbf{K}$ & 1.818 & 1.767 & 1.771 & 1.792 & 1.764 & 1.769 & 1.805 & 1.864 & 1.747 & 1.78 & 1.735 & 1.768 & 1.823 & 1.809 & 1.775 & 1.789 \\
\hline Cations & 15.05 & 14.979 & 14.926 & 14.95 & 14.979 & 14.96 & 15.034 & 15.024 & 14.921 & 14.996 & 14.982 & 14.942 & 14.967 & 15.018 & 15.02 & 15.035 \\
\hline$\overline{0}$ & 22 & 22 & 22 & 22 & 22 & 22 & 22 & 22 & 22 & 22 & 22 & 22 & 22 & 22 & 22 & 22 \\
\hline$\overline{F e}$ _FeMg & 0.53 & 0.54 & 0.54 & 0.54 & 0.53 & 0.53 & 0.52 & 0.52 & 0.53 & 0.57 & 0.53 & 0.54 & 0.55 & 0.54 & 0.54 & 0.54 \\
\hline Mg_FeMg & 0.47 & 0.46 & 0.46 & 0.46 & 0.47 & 0.47 & 0.48 & 0.48 & 0.47 & 0.43 & 0.47 & 0.46 & 0.45 & 0.46 & 0.46 & 0.46 \\
\hline
\end{tabular}

Tabela 4.3 - Composições químicas e proporções catiônicas $(O=22)$ para biotita de amostras de tonalito pouco afetado pela mineralizaçãđু representativas da Mina de Salamangone. 


\begin{tabular}{|c|c|c|c|c|c|c|c|c|c|c|c|c|c|c|c|c|c|}
\hline Amostra & R1/N54 & & & & & & SH113/7 & & & |SH113/8 & & & SH118/62 & & & SH140/1 & \\
\hline Local & $11 \mathrm{c} 2$ & $2 c 4$ & $4 \mathrm{cl}$ & $7 \mathrm{c5}$ & $8 c 5$ bor & $9 \mathrm{c} 5$ cen & $2 \mathrm{cl}$ & $3 \mathrm{c} 2$ & $5 \mathrm{c} 3$ & $30 \mathrm{cl}$ & $31 \mathrm{cl}$ & $\overline{34 c 3}$ & $24 \mathrm{cl}$ & $26 \mathrm{c} 2$ & $28 \mathrm{c} 3$ & $27 \mathrm{c3}$ & $30 \mathrm{c} 3$ \\
\hline $\mathrm{SiO2}$ & 488.72 & 48.84 & 47.99 & 46.52 & 47.55 & 48.16 & 46.84 & 46.44 & 48.96 & 47.17 & 47.42 & 46.34 & 47.34 & 47.22 & 47.73 & 46.69 & 47.74 \\
\hline $\mathrm{TiO} 2$ & 0.63 & 0.76 & 0.86 & 0.85 & 0.68 & 0.51 & 0.8 & 0.87 & 0.7 & 0.73 & 0.74 & 1.01 & 0.28 & 0.74 & 0.84 & 1 & 0.92 \\
\hline $\mathrm{Al} 203$ & 6.39 & 6.35 & 6.85 & 6.99 & 6.8 & 6.56 & 6.9 & 7.42 & 5.73 & 7.03 & 7.52 & 7.85 & 6.78 & 6.76 & 6.62 & 7.57 & 7.06 \\
\hline $\mathrm{FeO}$ & 17.22 & 17.68 & 17.21 & 17.78 & 17.82 & 18.01 & 17.5 & 18.45 & 17.83 & 17,89 & 18.24 & 18.37 & 19.16 & 19.36 & 19.56 & 18.13 & 17,85 \\
\hline $\mathrm{Cr} 2 \mathrm{O3}$ & 0 & 0.03 & 0.09 & 0 & 0.01 & 0.04 & 0.04 & 0.06 & 0.06 & 0.1 & 0.09 & 0 & 0.06 & 0.06 & 0 & 0 & 0 \\
\hline MnO & 0.43 & 0.46 & 0.49 & 0.47 & 0.48 & 0.44 & 0.41 & 0.44 & 0.47 & 0.45 & 0.44 & 0.44 & 0.54 & 0.57 & 0.58 & 0.47 & 0.45 \\
\hline MgO & 10.75 & 11.37 & 10.95 & 11.27 & 11.25 & 11.35 & 10.59 & 10.58 & 11.55 & 10.81 & 10.66 & 10.17 & 10.53 & 10.38 & 10.19 & 10.73 & 10.59 \\
\hline $\mathrm{CaO}$ & 12.02 & 12.1 & 11.78 & 11.96 & 12.16 & 12.33 & 12.02 & 11.75 & 12.1 & 12.24 & 12.13 & 12.09 & 11.55 & 11.39 & 11.59 & 12.27 & 11.9 \\
\hline $\mathrm{Na2O}$ & 0.6 & 0.56 & 0.68 & 0.6 & 0.59 & 0.52 & 0.64 & 0.75 & 0.56 & 0.72 & 0.76 & 0.94 & 0.76 & 0.93 & 0.69 & 0.64 & 0.74 \\
\hline K2O & 0.63 & 0.58 & 0.74 & 0.65 & 0.58 & 0.55 & 0.69 & 0.73 & 0.51 & 0.64 & 0.67 & 0.86 & 0.67 & 0.66 & 0.64 & 0.73 & 0.72 \\
\hline Total & 97.39 & 98.7 & 97.55 & 97.09 & 97.91 & 98.43 & 96.39 & 97.43 & 98.41 & 97.68 & 98.58 & 98.07 & 97.61 & 98.01 & 98.44 & 98.23 & 97.97 \\
\hline TSi & 7,259 & 7,156 & 7,129 & 6,937 & 7.03 & 7,077 & 7,065 & 6,933 & 7,191 & 7,018 & 6,993 & 6,921 & 7,052 & 7,027 & 7,075 & 6,917 & 7,092 \\
\hline TAl & 0.741 & 0.844 & 0.871 & 1,063 & 0.97 & 0.923 & 0.935 & 1,067 & 0.809 & 0.982 & 1,007 & 1,079 & 0.948 & 0.973 & 0.925 & 1,083 & 0.908 \\
\hline TFe3+ & 0 & 0 & 0 & 0 & 0 & 0 & 10 & 0 & 0 & 0 & 0 & 0 & 0 & 0 & 0 & 0 & 0 \\
\hline TTi & 0 & 0 & 0 & 0 & 0 & 0 & 10 & 0 & 0 & 0 & 0 & 0 & 10 & 0 & 0 & 0 & 0 \\
\hline Sum_T & 8 & 8 & 8 & 8 & 8 & 8 & 8 & 8 & 8 & 8 & 8 & 8 & 8 & 8 & 8 & 8 & 8 \\
\hline CAl & 0.38 & 0.252 & 0.327 & 0.164 & 0.214 & 0.212 & 0.29 & 0.238 & 0.183 & 0.249 & 0.299 & 0.302 & 0.241 & 0.212 & 0.231 & 0.238 & 0.327 \\
\hline $\mathrm{CCr}$ & 0 & 0.003 & 0.011 & 0 & 0.001 & 0.005 & 0.005 & 0.007 & 0.007 & 0.012 & 0.01 & 0 & 0.007 & 0.007 & 0 & 0 & 0 \\
\hline CFe3+ & 0.074 & 0.26 & 0.172 & 0.506 & 0.403 & 0.405 & 0.2 & 0.399 & 0.312 & 0.281 & 0.28 & 0.183 & 0.457 & 0.39 & 0.356 & 0.356 & 0.156 \\
\hline CTi & 0.071 & 0.084 & 0.096 & 0.095 & 0.076 & 0.056 & 0.091 & 0.098 & 0.077 & 0.082 & 0.082 & 0.113 & 0.031 & 0.083 & 0.094 & 0.111 & 0.103 \\
\hline $\mathrm{CMg}$ & 2,388 & 2,484 & 2,425 & 2,505 & 2.48 & 2,486 & 2,381 & 2,355 & 2,529 & 2,398 & 2,343 & 2,264 & 2,338 & 2,303 & 2,252 & 2.37 & 2,345 \\
\hline $\mathrm{CFe} 2+$ & 2,061 & 1,888 & 1,939 & 1,699 & 1,796 & 1,808 & 2,007 & 1,876 & 1,863 & 1,945 & 1,958 & 2,109 & 1,891 & 1,969 & 2,031 & 1.89 & 2.04 \\
\hline CMn & 0.027 & 0.028 & 0.031 & 0.03 & 0.03 & 0.027 & 0.026 & 0.028 & 0.029 & 0.034 & 0.027 & 0.028 & 0.034 & 0.036 & 0.036 & 0.035 & 0.028 \\
\hline $\mathrm{CCa}$ & 0 & 0 & 0 & 0 & 0 & 0 & 0 & 0 & 0 & 0 & 0 & 0 & 0 & 0 & 0 & 0 & 0 \\
\hline Sum_C & 5 & 5 & 5 & 5 & 5 & 5 & 5 & 5 & 5 & 5 & 5 & 5 & 5 & 5 & 5 & 5 & 5 \\
\hline$\overline{\mathrm{BMg}}$ & 10 & 0 & 0 & 0 & 0 & 0 & 0 & 0 & 0 & 10 & 0 & 0 & 0 & 0 & 0 & 0 & 0 \\
\hline $\mathrm{BFe} 2+$ & 0.011 & 0.018 & 0.027 & 0.012 & 0.004 & 0 & 0.001 & 0.028 & 0.015 & 10 & 0.011 & 0.002 & 0.039 & 0.05 & 0.038 & 0 & 0.021 \\
\hline BMn & 0.027 & 0.029 & 0.031 & 0.03 & 0.03 & 0.027 & 0.026 & 0.028 & 0.029 & 0.023 & 0.028 & 0.028 & 0.034 & 0.036 & 0.037 & 0.024 & 0.028 \\
\hline $\mathrm{BCa}$ & 1,919 & 1.9 & 1,875 & 1,911 & 1,926 & 1,941 & 1,942 & 1,879 & 1,904 & 1,951 & 1,916 & 1,935 & 1,843 & 1,816 & 1,841 & 1,948 & 1,894 \\
\hline $\mathrm{BNa}$ & 0.043 & 0.054 & 0.067 & 0.048 & 0.039 & 0.031 & 0.031 & 0.064 & 0.051 & 0.026 & 0.045 & 0.035 & 0.083 & 0.098 & 0.085 & 0.028 & 0.057 \\
\hline Sum_B & 2 & 2 & 2 & 2 & 2 & 2 & 2 & 2 & 2 & 2 & 2 & 2 & 2 & 2 & 2 & 2 & 2 \\
\hline$\overline{\mathrm{ACa}}$ & 0 & 0 & 0 & $\overline{0}$ & $\overline{0}$ & 0 & 10 & $\overline{0}$ & 0 & 10 & 0 & 0 & 0 & $\overline{0}$ & 0 & 10 & 0 \\
\hline $\mathbf{A N a}$ & 0.13 & 0.106 & 0.129 & 0.126 & 0.13 & 0.117 & 0.156 & 0.153 & 0.108 & 0.182 & 0.173 & 0.237 & 0.136 & 0.17 & 0.113 & 0.156 & 0.157 \\
\hline AK & 0.12 & 0.108 & 0.14 & 0.124 & 0.109 & 0.103 & 0.133 & 0.139 & 0.096 & 0.121 & 0.126 & 0.164 & 0.127 & 0.125 & 0.121 & 0.138 & 0.136 \\
\hline Sum_A & 0.25 & 0.214 & 0.269 & 0.249 & 0.239 & 0.22 & 0.289 & 0.292 & 0.204 & 0.303 & 0.299 & 0.401 & 0.263 & 0.296 & 0.235 & 0.294 & 0.293 \\
\hline Sum_cat & 15.25 & 15,214 & 15,269 & 15,249 & 15,239 & 15.22 & 15,289 & 15,292 & 15,204 & 15,303 & 15,299 & 15,401 & 15,263 & 15,296 & 15,235 & 15,294 & 15,293 \\
\hline Sum__oxy & 23.03 & 23 & 23,017 & 23 & 23 & 23 & 23 & 23 & 23 & 23 & 23 & 23 & 23 & 23 & 23 & 23 & 23,009 \\
\hline
\end{tabular}

Tabela 4.4 - Composições químicas e proporções catiônicas $(\mathrm{O}=23)$ para anfibólios, de amostras de tonalito pouco afetado pela mineralização, representativas da Mina de Salamangone. Cálculo de $\mathrm{Fe}^{+}$e $\mathrm{Fe}^{+}$segundo método de Schumaker (Leake et al. 1997). 


\begin{tabular}{|c|c|c|c|c|c|c|c|c|c|}
\hline $\begin{array}{l}\text { Amostra } \\
\text { Análise }\end{array}$ & \begin{tabular}{|l|}
$\mathrm{R1}$ \\
$11 \mathrm{c} 2$ \\
\end{tabular} & $\begin{array}{l}R 1 \\
4 \mathrm{cl}\end{array}$ & $\begin{array}{l}R 1 \\
7 c 5\end{array}$ & $\begin{array}{l}\text { R1 } \\
3 \mathbf{c 4}\end{array}$ & $\begin{array}{l}113 / 7 \\
2 \mathrm{c} 1\end{array}$ & $\begin{array}{l}113 / 7 \\
3 \mathrm{c} 2\end{array}$ & $\begin{array}{l}113 / 8 \\
30 \mathrm{c} 1\end{array}$ & $\begin{array}{l}113 / 8 \\
31 \mathrm{c} 1\end{array}$ & $\begin{array}{l}113 / 8 \\
34 \mathrm{c} 3\end{array}$ \\
\hline$\overline{\mathrm{Si}}$ & 7.26 & 7.13 & 6.94 & 7.16 & 7.07 & 6.94 & 7.02 & 7 & 6.92 \\
\hline $\mathrm{Ti}$ & 0.07 & 0.1 & 0.1 & 0.08 & 0.09 & 0.1 & 0.08 & 0.08 & 0.11 \\
\hline Al & 1.12 & 1.2 & 1.23 & 1.1 & 1.23 & 1.31 & 1.23 & 1.31 & 1.38 \\
\hline $\mathrm{Fe} 3+$ & 0.07 & 0.17 & 0.51 & 0.26 & 0.2 & 0.4 & 0.28 & 0.28 & 0.18 \\
\hline $\mathrm{Fe} 2+$ & 2.07 & 1.97 & 1.71 & 1.91 & 2.01 & 1.91 & 1.95 & 1.97 & 2.11 \\
\hline $\mathrm{Mn}$ & 0.05 & 0.06 & 0.06 & 0.06 & 0.05 & 0.06 & 0.06 & 0.06 & 0.06 \\
\hline $\mathrm{Mg}$ & 2.39 & 2.43 & 2.51 & 2.48 & 2.38 & 2.36 & 2.4 & 2.35 & 2.25 \\
\hline $\mathrm{Ca}$ & 1.92 & 1.88 & 1.91 & 1.9 & 1.94 & 1.88 & 1.95 & 1.92 & 1.95 \\
\hline $\mathrm{Na}$ & 0.17 & 0.2 & 0.17 & 0.16 & 0.19 & 0.22 & 0.21 & 0.22 & 0.27 \\
\hline K & 0.12 & 0.14 & 0.12 & 0.11 & 0.13 & 0.14 & 0.12 & 0.13 & 0.16 \\
\hline $\mathrm{F}$ & 0 & 0 & 0 & 0 & 0 & 0 & 0 & 0 & 0 \\
\hline $\mathrm{Cl}$ & 0 & 0 & 0 & 0 & 0 & 0 & 0 & 0 & 0 \\
\hline Cátions & 15.25 & 15.26 & 15.25 & 15.21 & 15.29 & 15.29 & 15.31 & 15.3 & 15.41 \\
\hline mg\# & 0.53 & 0.53 & 0.53 & 0.53 & 0.52 & 0.51 & 0.52 & 0.51 & 0.5 \\
\hline fe\# & 0.47 & 0.47 & 0.47 & 0.47 & 0.48 & 0.49 & 0.48 & 0.49 & 0.5 \\
\hline $\mathrm{Fe} 3+/ \mathrm{Fe} 2+$ & 0.04 & 0.09 & 0.3 & 0.14 & 0.1 & 0.21 & 0.14 & 0.14 & 0.09 \\
\hline X plaglab & 0.75 & 0.74 & 0.72 & 0.74 & 0.72 & 0.73 & 0.61 & 0.66 & 0.63 \\
\hline $\mathrm{X}$ plaglan & 0.24 & 0.25 & 0.27 & 0.25 & 0.26 & 0.26 & 0.39 & 0.33 & 0.37 \\
\hline $\begin{array}{l}\text { TA(-) } \\
\text { PA(-) }\end{array}$ & $\begin{array}{l}584.03 \\
2.45\end{array}$ & $\begin{array}{l}608.72 \\
2.92\end{array}$ & $\begin{array}{l}688.79 \\
2.71\end{array}$ & $\begin{array}{l}622.04 \\
2.4\end{array}$ & 645.27 & $\begin{array}{l}673.24 \\
3.22\end{array}$ & $\begin{array}{l}693.76 \\
2.69\end{array}$ & $\begin{array}{l}668.16 \\
3.26\end{array}$ & $\begin{array}{l}694.01 \\
3.38 \\
\end{array}$ \\
\hline
\end{tabular}

Tabela 4.5 - Temperaturas obtidas do geotermômetro hornblenda-plagioclásio T(HblPl), segundo Blundy \& Holland (1994),em amostras de tonalito pouco afetado pela mineralização. Cálculo de $\mathrm{Fe} 2^{+}$e $\mathrm{Fe}^{+}{ }^{+}$segundo método de Schumaker (cf. Leake et al.1997). 


\begin{tabular}{|c|c|c|c|c|c|c|c|c|c|}
\hline Amostra & R-03 & R-03 & R-03 & R-10 & R-10 & R-10 & S-04 & S-04 & S-04 \\
\hline Localiz. & $15 \mathrm{c} 2$ & $16 \mathrm{c3}$ & $17 \mathrm{c3}$ & $47 \mathrm{c3}$ & $49 \mathrm{c} 2$ & $52 \mathrm{c1}$ & $1 \mathrm{c} 1$ & $3 \mathrm{c2}$ & $5 \mathrm{c} 2$ \\
\hline SiO2 & 52.04 & 51.31 & 51.71 & 49.71 & 49.86 & 49.35 & 46.89 & 47.84 & 47.93 \\
\hline TiO2 & 0.19 & 0.29 & 0.21 & 0.64 & 0.51 & 0.66 & 0.90 & 0.80 & 0.76 \\
\hline $\mathrm{Al} 2 \mathrm{O3}$ & 3.64 & 3.72 & 2.89 & 5.20 & 5.50 & 6.36 & 7.78 & 7.08 & 6.97 \\
\hline $\mathrm{FeO}$ & 12.41 & 11.97 & 12.02 & 16.04 & 16.10 & 16.62 & 16.85 & 16.94 & 16.93 \\
\hline Cr2O3 & 0.00 & 0.05 & 0.25 & 0.06 & 0.02 & 0.09 & 0.15 & 0.03 & 0.05 \\
\hline MnO & 0.30 & 0.29 & 0.26 & 0.43 & 0.33 & 0.40 & 0.28 & 0.36 & 0.31 \\
\hline MgO & 15.87 & 15.60 & 15.82 & 13.08 & 12.09 & 12.01 & 11.17 & 11.36 & 11.33 \\
\hline $\mathrm{CaO}$ & 12.58 & 12.61 & 12.60 & 12.22 & 12.37 & 12.03 & 12.15 & 12.27 & 12.31 \\
\hline $\mathrm{Na2O}$ & 0.55 & 0.41 & 0.39 & 0.58 & 0.43 & 0.68 & 0.71 & 0.77 & 0.65 \\
\hline K2O & 0.29 & 0.26 & 0.33 & 0.48 & 0.48 & 0.60 & 0.73 & 0.68 & 0.71 \\
\hline Total & 97.87 & 96.46 & 96.23 & 98.38 & 97.67 & 98.71 & 97.46 & 98.10 & 97.90 \\
\hline $\mathbf{T S i}$ & 7.47 & 7.47 & 7.54 & 7.23 & 7.34 & 7.20 & 6.96 & 7.07 & 7.09 \\
\hline TAl & 0.53 & 0.54 & 0.47 & 0.77 & 0.66 & 0.81 & 1.04 & 0.94 & 0.91 \\
\hline TFe3+ & 0.00 & 0.00 & 0.00 & 0.00 & 0.00 & 0.00 & 0.00 & 0.00 & 0.00 \\
\hline TTi & 0.00 & 0.00 & 0.00 & 0.00 & 0.00 & 0.00 & 0.00 & 0.00 & 0.00 \\
\hline Sum_T & 8.00 & 8.00 & 8.00 & 8.00 & 8.00 & 8.00 & 8.00 & 8.00 & 8.00 \\
\hline CAI & 0.09 & 0.10 & 0.03 & 0.13 & 0.29 & 0.29 & 0.32 & 0.30 & 0.30 \\
\hline $\mathrm{CCr}$ & 0.00 & 0.01 & 0.03 & 0.01 & 0.00 & 0.01 & 0.02 & 0.00 & 0.01 \\
\hline $\mathrm{CFe3+}$ & 0.26 & 0.24 & 0.22 & 0.34 & 0.10 & 0.19 & 0.24 & 0.17 & 0.17 \\
\hline CTi & 0.02 & 0.03 & 0.02 & 0.07 & 0.06 & 0.07 & 0.10 & 0.09 & 0.09 \\
\hline $\mathrm{CMg}$ & 3.40 & 3.38 & 3.44 & 2.84 & 2.65 & 2.61 & 2.47 & 2.50 & 2.50 \\
\hline $\mathrm{CFe} 2+$ & 1.21 & 1.22 & 1.24 & 1.59 & 1.88 & 1.80 & 1.84 & 1.92 & 1.92 \\
\hline CMn & 0.02 & 0.02 & 0.02 & 0.03 & 0.02 & 0.03 & 0.02 & 0.02 & 0.02 \\
\hline $\mathrm{CCa}$ & 0.00 & 0.00 & 0.00 & 0.00 & 0.00 & 0.00 & 0.00 & 0.00 & 0.00 \\
\hline Sum_C & 5.00 & 5.00 & 5.00 & 5.00 & 5.00 & 5.00 & 5.00 & 5.00 & 5.00 \\
\hline BMg & 0.00 & 0.00 & 0.00 & 0.00 & 0.00 & 0.00 & 0.00 & 0.00 & 0.00 \\
\hline $\mathrm{BFe} 2+$ & 0.01 & 0.00 & 0.00 & 0.02 & 0.00 & 0.03 & 0.01 & 0.01 & 0.00 \\
\hline $\mathbf{B M n}$ & 0.02 & 0.02 & 0.02 & 0.03 & 0.02 & 0.03 & 0.02 & 0.02 & 0.02 \\
\hline $\mathrm{BCa}$ & 1.94 & 1.97 & 1.97 & 1.91 & 1.95 & 1.88 & 1.93 & 1.94 & 1.95 \\
\hline $\mathrm{BNa}$ & 0.04 & 0.02 & 0.02 & 0.05 & 0.03 & 0.06 & 0.04 & 0.03 & 0.03 \\
\hline Sum_B & 2.00 & 2.00 & 2.00 & 2.00 & 2.00 & 2.00 & 2.00 & 2.00 & 2.00 \\
\hline $\mathrm{ACa}$ & 0.00 & 0.00 & 0.00 & 0.00 & 0.00 & 0.00 & 0.00 & 0.00 & 0.00 \\
\hline ANa & 0.12 & 0.10 & 0.09 & 0.11 & 0.10 & 0.13 & 0.17 & 0.19 & 0.16 \\
\hline AK & 0.05 & 0.05 & 0.06 & 0.09 & 0.09 & 0.11 & 0.14 & 0.13 & 0.13 \\
\hline Sum_A & 0.17 & 0.15 & 0.15 & 0.20 & 0.19 & 0.24 & 0.31 & 0.32 & 0.29 \\
\hline Sum_cat & 15.17 & 15.15 & 15.15 & 15.20 & 15.19 & 15.24 & 15.31 & 15.32 & 15.29 \\
\hline
\end{tabular}

Tabela 4.10 - Composições químicas e proporções catiônicas $(O=23)$ para anfibólios de amostras de anfibolito, da Mina de Salamangone. Cálculo de $\mathrm{Fe}^{+}$e $^{+} \mathrm{Fe}^{+}$segundo método de Schumaker (cf. Leake et al. 1997). 


\begin{tabular}{|c|c|c|c|c|c|c|c|c|c|c|c|c|}
\hline \multirow[b]{2}{*}{ Amostra } & \multicolumn{5}{|c|}{ NIVEL 54} & \multicolumn{7}{|c|}{ NÍVEL 229} \\
\hline & R-03 & R-03 & R-03 & R-03 & R-03 & S-04 & S-04 & S-04 & S-04 & S-04 & S-04 & S-04 \\
\hline Localiz. & $1 \mathrm{c3}$ & $2 \mathrm{c3}$ & $\mathbf{3 c 3}$ & $4 \mathrm{c2}$ & $5 \mathrm{c2}$ & 1c1 & $3 \mathrm{c1}$ & $4 \mathrm{c}^{2}$ & $5 c 2$ & $6 \mathrm{c2}$ & $7 \mathrm{c2}$ & $8 \mathrm{c2}$ \\
\hline $\mathrm{SiO2}$ & .20 & 61.80 & 61.39 & 61.50 & 61.01 & 60.39 & 59.93 & 59.92 & 60.26 & 59.54 & 59.60 & 60.18 \\
\hline TiO2 & 04 & 0.00 & 0.01 & 0.00 & 0.00 & 0.00 & 0.01 & 0.02 & 0.00 & 0.00 & 0.00 & 0.02 \\
\hline $\mathrm{Al2O3}$ & 24.07 & 24.26 & 24.00 & 24.49 & 24.21 & 25.22 & 25.39 & 25.49 & 25.37 & 24.75 & 25.37 & 24.94 \\
\hline $\mathrm{Fe} 2 \mathrm{O3}$ & 0.03 & 0.03 & 0.07 & 0.10 & 0.12 & 0.09 & 0.07 & 0.04 & 0.07 & 0.09 & 0.11 & 0.05 \\
\hline MnO & 0.00 & 0.01 & 0.00 & 0.00 & 0.00 & 0.03 & 0.00 & 0.00 & 0.00 & 0.03 & 0.00 & 0.00 \\
\hline MgO & 0.01 & 0.00 & 0.00 & 0.01 & 0.01 & 0.00 & 0.00 & 0.01 & 0.00 & 0.01 & 0.00 & 0.00 \\
\hline $\mathrm{Ca}$ & 5.98 & 5.99 & 5.64 & 5.87 & 5.78 & 6.84 & 7.01 & 7.15 & 6.89 & 7.10 & 7.31 & 6.76 \\
\hline $\mathrm{Na2O}$ & 8.15 & 8.22 & 8.28 & 8.32 & 8.36 & 7.76 & 7.76 & 7.82 & 7.72 & 7.68 & 7.53 & 7.65 \\
\hline K2O & 0.13 & 0.15 & 0.06 & 0.09 & 0.13 & 0.18 & 0.17 & 0.17 & 0.15 & 0.11 & 0.15 & 0.10 \\
\hline Total & 99.61 & 100.47 & 99.44 & 100.38 & 99.63 & 100.50 & 100.34 & 100.60 & 100.45 & 99.32 & 100.07 & 99.69 \\
\hline Si & 0.91 & 10.92 & 10.95 & 10.88 & 10.89 & 10.71 & 10.66 & 10.63 & 10.69 & 10.70 & 10.63 & 10.74 \\
\hline Al & 5.05 & 5.05 & 5.04 & 5.10 & 5.09 & 5.27 & 5.32 & 5.33 & 5.30 & 5.24 & 5.33 & 5.24 \\
\hline $\mathrm{Fe} 3$ & 0.00 & 0.00 & 0.01 & 0.01 & 0.02 & 0.01 & 0.01 & 0.01 & 0.01 & 0.01 & .01 & 0.01 \\
\hline $\mathbf{T i}$ & 0.01 & 0.00 & 0.00 & 0.00 & 0.00 & 0.00 & 0.00 & 0.00 & 0.00 & 0.00 & .00 & 0.00 \\
\hline Mn & 0.00 & 0.00 & 0.00 & 0.00 & 0.00 & 0.01 & 0.00 & 0.00 & 0.00 & 0.00 & .00 & 0.00 \\
\hline $\mathbf{M g}$ & 0.00 & 0.00 & 0.00 & 0.00 & 0.00 & 0.00 & 0.00 & 0.00 & 0.00 & 0.00 & 0.00 & 0.00 \\
\hline $\mathbf{B a}$ & 0.00 & 0.00 & 0.00 & 0.00 & 0.00 & 0.00 & 0.00 & 0.00 & 0.00 & 0.00 & 0.00 & 0.00 \\
\hline Ca & 1.14 & 1.14 & 1.08 & 1.11 & 1.11 & 1.30 & 1.34 & 1.36 & 1.31 & 1.37 & 1.40 & 1.29 \\
\hline $\mathrm{Na}$ & 2.82 & 2.82 & 2.86 & 2.86 & 2.89 & 2.67 & 2.67 & 2.69 & 2.66 & 2.68 & 2.61 & 2.65 \\
\hline $\mathbf{K}$ & 0.03 & 0.03 & 0.01 & 0.02 & 0.03 & 0.04 & 0.04 & 0.04 & 0.03 & 0.03 & 0.03 & 0.02 \\
\hline Cations & 19.97 & 19.97 & 19.95 & 19.99 & 20.02 & 20.00 & 20.03 & 20.06 & 19.99 & 20.02 & 20.01 & 19.96 \\
\hline $\mathbf{X}$ & 15.98 & 15.98 & 16.00 & 16.00 & 15.99 & 15.99 & 15.98 & 15.97 & 16.00 & 15.95 & 15.97 & 16.00 \\
\hline $\mathbf{Z}$ & 3.99 & 3.99 & 3.95 & 3.99 & 4.03 & 4.01 & 4.05 & 4.09 & 4.00 & 4.07 & 4.04 & 3.96 \\
\hline $\mathbf{A b}$ & 70.70 & 70.70 & 72.40 & 71.60 & 71.80 & 66.60 & 66.10 & 65.80 & 66.40 & 65.80 & 64.60 & 66.80 \\
\hline An & 28.60 & 28.50 & 27.20 & 27.90 & 27.40 & 32.40 & 33.00 & 33.30 & 32.70 & 33.60 & 34.60 & 32.60 \\
\hline Or & 0.70 & 0.90 & 0.40 & 0.50 & 0.70 & 1.00 & 0.90 & 0.90 & 0.80 & 0.60 & 0.80 & 0.60 \\
\hline
\end{tabular}

Tabela 4.11 - Composições químicas e proporções catiônica $(\mathrm{O}=32)$, para plagioclásios de amostras de anfibolito, representativas da Mina de Salamangone. 


\begin{tabular}{|c|c|c|c|c|c|c|c|c|c|}
\hline \multirow[b]{2}{*}{ Amostra } & \multicolumn{6}{|c|}{\begin{tabular}{|c|} 
NiVEEL \\
54 \\
\end{tabular}} & \multicolumn{3}{|c|}{ NÍVEL 229} \\
\hline & R-03 & R-03 & R-03 & R-10 & R-10 & R-10 & S-04 & S-04 & S-04 \\
\hline Localiz. & $15 \mathrm{c} 2$ & $16 \mathrm{c} 3$ & $17 \mathrm{c} 3$ & $47 \mathrm{c3}$ & $49 \mathrm{c} 2$ & $52 \mathrm{c1}$ & ic1 & $3 \mathrm{c2}$ & $5 \mathrm{c} 2$ \\
\hline$\overline{\mathrm{SiO2}}$ & 52.04 & 51.31 & 51.71 & 49.71 & 49.86 & 49.35 & 46.89 & 47.84 & 47.93 \\
\hline TiO2 & 0.19 & 0.29 & 0.21 & 0.64 & 0.51 & 0.66 & 0.90 & 0.80 & 0.76 \\
\hline $\mathrm{Al} 2 \mathrm{O3}$ & 3.64 & 3.72 & 2.89 & 5.20 & 5.50 & 6.36 & 7.78 & 7.08 & 6.97 \\
\hline $\mathrm{FeO}$ & 12.41 & 11.97 & 12.02 & 16.04 & 16.10 & 16.62 & 16.85 & 16.94 & 16.93 \\
\hline $\mathrm{Cr} 2 \mathrm{O3}$ & 0.00 & 0.05 & 0.25 & 0.06 & 0.02 & 0.09 & 0.15 & 0.03 & 0.05 \\
\hline Mno & 0.30 & 0.29 & 0.26 & 0.43 & 0.33 & 0.40 & 0.28 & 0.36 & 0.31 \\
\hline MgO & 15.87 & 15.60 & 15.82 & 13.08 & 12.09 & 12.01 & 11.17 & 11.36 & 11.33 \\
\hline $\mathrm{CaO}$ & 12.58 & 12.61 & 12.60 & 12.22 & 12.37 & 12.03 & 12.15 & 12.27 & 12.31 \\
\hline $\mathrm{Na2O}$ & 0.55 & 0.41 & 0.39 & 0.58 & 0.43 & 0.68 & 0.71 & 0.77 & 0.65 \\
\hline K2O & 0.29 & 0.26 & 0.33 & 0.48 & 0.48 & 0.60 & 0.73 & 0.68 & 0.71 \\
\hline Total & 97.87 & 96.46 & 96.23 & 98.38 & 97.67 & 98.71 & 97.46 & 98.10 & 97.90 \\
\hline TSi & 7.47 & 7.47 & 7.54 & 7.23 & 7.34 & 7.20 & 6.96 & 7.07 & 7.09 \\
\hline TAl & 0.53 & 0.54 & 0.47 & 0.77 & 0.66 & 0.81 & 1.04 & 0.94 & 0.91 \\
\hline TFe3+ & 0.00 & 0.00 & 0.00 & 0.00 & 0.00 & 0.00 & 0.00 & 0.00 & 0.00 \\
\hline TTi & 0.00 & 0.00 & 0.00 & 0.00 & 0.00 & 0.00 & 0.00 & 0.00 & 0.00 \\
\hline Sum_T & 8.00 & 8.00 & 8.00 & 8.00 & 8.00 & 8.00 & 8.00 & 8.00 & 8.00 \\
\hline CAl & 0.09 & 0.10 & 0.03 & 0.13 & 0.29 & 0.29 & 0.32 & 0.30 & 0.30 \\
\hline $\mathrm{CCr}$ & 0.00 & 0.01 & 0.03 & 0.01 & 0.00 & 0.01 & 0.02 & 0.00 & 0.01 \\
\hline CFe3+ & 0.26 & 0.24 & 0.22 & 0.34 & 0.10 & 0.19 & 0.24 & 0.17 & 0.17 \\
\hline CTi & 0.02 & 0.03 & 0.02 & 0.07 & 0.06 & 0.07 & 0.10 & 0.09 & 0.09 \\
\hline CMg & 3.40 & 3.38 & 3.44 & 2.84 & 2.65 & 2.61 & 2.47 & 2.50 & 2.50 \\
\hline CFe2+ & 1.21 & 1.22 & 1.24 & 1.59 & 1.88 & 1.80 & 1.84 & 1.92 & 1.92 \\
\hline CMn & 0.02 & 0.02 & 0.02 & 0.03 & 0.02 & 0.03 & 0.02 & 0.02 & 0.02 \\
\hline $\mathrm{CCa}$ & 0.00 & 0.00 & 0.00 & 0.00 & 0.00 & 0.00 & 0.00 & 0.00 & 0.00 \\
\hline Sum_C & 5.00 & 5.00 & 5.00 & 5.00 & 5.00 & 5.00 & 5.00 & 5.00 & 5.00 \\
\hline BMg & 0.00 & 0.00 & 0.00 & 0.00 & 0.00 & 0.00 & 0.00 & 0.00 & 0.00 \\
\hline BFe2+ & 0.01 & 0.00 & 0.00 & 0.02 & 0.00 & 0.03 & 0.01 & 0.01 & 0.00 \\
\hline BMn & 0.02 & 0.02 & 0.02 & 0.03 & 0.02 & 0.03 & 0.02 & 0.02 & 0.02 \\
\hline $\mathbf{B C a}$ & 1.94 & 1.97 & 1.97 & 1.91 & 1.95 & 1.88 & 1.93 & 1.94 & 1.95 \\
\hline $\mathrm{BNa}$ & 0.04 & 0.02 & 0.02 & 0.05 & 0.03 & 0.06 & 0.04 & 0.03 & 0.03 \\
\hline Sum_B & 2.00 & 2.00 & 2.00 & 2.00 & 2.00 & 2.00 & 2.00 & 2.00 & 2.00 \\
\hline ACa & 0.00 & 0.00 & 0.00 & 0.00 & 0.00 & 0.00 & 0.00 & 0.00 & 0.00 \\
\hline ANa & 0.12 & 0.10 & 0.09 & 0.11 & 0.10 & 0.13 & 0.17 & 0.19 & 0.16 \\
\hline $\mathbf{A K}$ & 0.05 & 0.05 & 0.06 & 0.09 & 0.09 & 0.11 & 0.14 & 0.13 & 0.13 \\
\hline Sum_A & 0.17 & 0.15 & 0.15 & 0.20 & 0.19 & 0.24 & 0.31 & 0.32 & 0.29 \\
\hline Sum_cat & 15.17 & 15.15 & 15.15 & 15.20 & 15.19 & 15.24 & 15.31 & 15.32 & 15.29 \\
\hline
\end{tabular}

Tabela 4.12 - Composições químicas e proporções catiônicas $(\mathrm{O}=22)$, para biotita de anfibolitos representativos da Mina de Salamangone. 
Anexo 2

Análises Químicas em Fases Minerais Sulfetadas 
comp. (\% at) $\quad$ comp. (\%wt)

\begin{tabular}{|c|c|c|c|c|c|c|c|c|c|c|}
\hline Amostra & Localização & Paragênese & $\mathrm{Fe}$ & As & $\mathbf{s}$ & Au & Fe & $\mathbf{A S}$ & $\mathbf{s}$ & $\mathbf{A u}$ \\
\hline CSL-06 & pto $16 / c 4$ & po-cep & 33.17 & 36.35 & 30.48 & 0.00 & 33.32 & 48.97 & 17.57 & 0.00 \\
\hline CSL-06 & pto $5 / \mathrm{cl}$ & po-cep & 33.02 & 34.90 & 32.03 & 0.01 & 33.31 & 47.24 & 18.55 & 0.04 \\
\hline CSL-06 & pto $6 / \mathrm{cl}$ & po-ccp & 32.62 & 36.68 & 30.70 & 0.00 & 32.55 & 49.09 & 17.58 & 0.00 \\
\hline CSL-06 & pto $7 / \mathrm{c} 2$ & po-cep & 33.46 & 34.99 & 31.55 & 0.00 & 34.15 & 47.90 & 18.48 & 0.00 \\
\hline CSL-06 & pto 9/c3 & po-ccp & 32.89 & 35.70 & 31.40 & 0.00 & 32.98 & 48.01 & 18.07 & 0.00 \\
\hline LSL 10 & pto $1 / \mathrm{cl}$ & po-au & 33.48 & 35.35 & 31.15 & 0.00 & 34.10 & 48.31 & 18.22 & 0.00 \\
\hline LSL-10 & pto $3 / c 1$ & po-au & 33.48 & 35.12 & 31.39 & 0.01 & 33.85 & 47.64 & 18.22 & 0.00 \\
\hline $\operatorname{LSL}_{-10}$ & pto $4 / \mathrm{cl}$ & po-au & 33.63 & 34.95 & 31.38 & 0.01 & 34.32 & 47.84 & 18.38 & 0.02 \\
\hline LSL-10 & pto $6 / \mathrm{c} 2$ & po-au & 33.65 & 35.13 & 31.23 & 0.00 & 34.24 & 47.95 & 18.24 & 0.05 \\
\hline LSL-10 & pto 8/c3 & po-au & 33.65 & 34.96 & 31.36 & 0.03 & 34.30 & 47.81 & 18.35 & 0.09 \\
\hline LSL-13 & pto $3 / 02$ & po & 33.58 & 33.35 & 33.06 & 0.00 & 34.31 & 45.71 & 19.39 & 0.00 \\
\hline LSL-13 & pto $8 / \mathrm{cl}$ & po & 33.22 & 35.24 & 31.52 & 0.01 & 33.68 & 47.92 & 18.34 & 0.02 \\
\hline LSL-13 & pto $9 / \mathrm{cl}$ & po & 32.78 & 35.51 & 31.69 & 0.00 & 32.68 & 47.49 & 18.14 & 0.00 \\
\hline PSL-19 & pto $10 / \mathrm{c} 2$ & po-lo-ccp-au & 33.72 & 34.43 & 31.84 & 0.00 & 34.13 & 46.74 & 18.50 & 0.00 \\
\hline PSL-19 & pto $13 / \mathrm{c} 4$ & po-lo-ccp-au & 33.76 & 34.72 & 31.49 & 0.00 & 34.27 & 47.30 & 18.36 & 0.00 \\
\hline PSL-19 & pto $15 / \mathrm{c} 5$ & po-lo-cep-au & 33.37 & 34.47 & 32.12 & 0.01 & 34.07 & 47.21 & 18.83 & 0.02 \\
\hline PSL-19 & pto $16 / c 5$ & po-lo-ccp-au & 33.68 & 34.47 & 31.83 & 0.00 & 34.58 & 47.47 & 18.76 & 0.01 \\
\hline PSL-19 & pto $4 / \mathrm{c} 2$ & po-lo-ccp-au & 33.78 & 33.89 & 32.33 & 0.01 & 34.65 & 46.62 & 19.03 & 0.02 \\
\hline PSL-19 & pto $8 / \mathrm{c} 2$ & po-lo-ccp-au & 33.59 & 34.48 & 31.89 & 0.01 & 34.19 & 47.09 & 18.63 & 0.03 \\
\hline R-18 & pto $13 / \mathrm{c} 4$ & po-ccp & 33.65 & 35.81 & 30.51 & 0.00 & 34.18 & 48.80 & 17.79 & 0.00 \\
\hline R-18 & pto $14 / \mathrm{c} 2$ & po-ccp & 33.75 & 34.84 & 31.37 & 0.02 & 34.21 & 47.37 & 18.25 & 0.06 \\
\hline R-25 & pto $13 / \mathrm{c} 4$ & po-lo-cep-au & 33.50 & 34.64 & 31.85 & 0.00 & 33.38 & 46.31 & 18.22 & 0.00 \\
\hline R-25 & pto $15 / \mathrm{c} 4$ & po-lo-ccp-au & 33.58 & 34.35 & 32.03 & 0.00 & 33.77 & 46.35 & 18.49 & 0.00 \\
\hline R-25 & pto $18 / \mathrm{c} 4$ & po-lo-ccp-au & 33.73 & 34,82 & 31.44 & 0.00 & 34.03 & 47.12 & 18.21 & 0.00 \\
\hline R-25 & pto $20 / 04$ & po-lo-ccp-au & 33.95 & 34.11 & 31.93 & 0.01 & 33.92 & 45.73 & 18.32 & 0.04 \\
\hline R-25 & pto $3 / \mathrm{c} 2$ & po-lo-ccp-au & 33.67 & 33.10 & 33.23 & 0.00 & 34.26 & 45.19 & 19.42 & 0.00 \\
\hline R-25 & pto $7 / \mathrm{c} 3$ & po-lo-сcp-au & 33.91 & 35.14 & 30.94 & 0.00 & 34.09 & 47.39 & 17.86 & 0.00 \\
\hline$R-41-1$ & pto $10 / \mathrm{cl}$ & po-1o-au & 33.73 & 35.88 & 30.38 & 0.00 & 34.15 & 48.73 & 17.66 & 0.00 \\
\hline$R-41-1$ & pto $11 / \mathrm{cl}$ & po-1o-au & 33.39 & 36.53 & 30.07 & 0.01 & 33.51 & 49.18 & 17.32 & 0.05 \\
\hline R-41-1 & pto $2 / \mathrm{c} 3$ & po-lo-au & 33.37 & 35.47 & 31.15 & 0.00 & 33.30 & 47.49 & 17.85 & 0.00 \\
\hline R-41-1 & pto $3 / c 4$ & po-lo-au & 33.38 & 35.60 & 30.98 & 0.03 & 33.86 & 48.45 & 18.04 & 0.09 \\
\hline R-41-1 & pto $4 / c 4$ & po-lo-au & 33.58 & 34.89 & 31.51 & 0.00 & 34.25 & 47.74 & 18.45 & 0.00 \\
\hline SHN-30 & pto $10 / \mathrm{cl}$ & po-lo-au & 33.87 & 34.90 & 31.21 & 0.01 & 34.57 & 47.80 & 18.29 & 0.02 \\
\hline SHN-30 & pto $2 / \mathrm{c} 3$ & po-lo-au & 33.75 & 34.90 & 31.35 & 0.00 & 34.37 & 47.66 & 18.32 & 0.00 \\
\hline SHN-30 & pto $6 / \mathrm{cl}$ & po-lo-au & 33.85 & 35.42 & 30.71 & 0.00 & 34.37 & 48.24 & 17.90 & 0.02 \\
\hline SHN-30 & pto $8 / \mathrm{cl}$ & po-lo-au & 34.07 & 34.58 & 31.34 & 0.01 & 34.81 & 47.40 & 18.38 & 0.04 \\
\hline SHN-30 & pto $9 / \mathrm{cl}$ & po-lo-au & 33.72 & 34.87 & 31.42 & 0.00 & 34.47 & 47.81 & 18.44 & 0.00 \\
\hline SL-06 & pto $1 / \mathrm{cl}$ & po & 33.61 & 35.34 & 31.02 & 0.01 & 34.13 & 48.14 & 18.08 & 0.63 \\
\hline SL-06 & pto $10 / c 4$ & po & 33.27 & 35.74 & 30.96 & 0.00 & 33.74 & 48.63 & 18.02 & 0.00 \\
\hline SL-06 & pto $3 / \mathrm{c} 3$ & po & 33.95 & 35.14 & 30.90 & 0.01 & 34.55 & 47.98 & 18.05 & 0.05 \\
\hline SL-06 & pto $4 / \mathrm{c} 2$ & po & 33.72 & 35.07 & 31.19 & 0.00 & 34.10 & 47.59 & 18.11 & 0.00 \\
\hline$S L-06$ & pto 5/c5 & po & 33.92 & 35.16 & 30.90 & 0.00 & 34.51 & 47.98 & 18.04 & 0.01 \\
\hline SL-06 & pto $6 / \mathrm{c} 2$ & po & 33.63 & 35.12 & 31.24 & 0.00 & 34.07 & 47.73 & 18.17 & 0.01 \\
\hline SL,-11 & pto $3 / c 2$ & po & 33.56 & 35.31 & 31.13 & 0.00 & 34.05 & 48.05 & 18.13 & 0.00 \\
\hline SL-11 & pto $6 / \mathrm{c} 2$ & po & 33.64 & 35.27 & 31.06 & 0.01 & 34.25 & 48.17 & 18.15 & 0.03 \\
\hline SL-11 & pto $8 / \mathrm{c} 3$ & po & 33.95 & 36.23 & 29.80 & 0.00 & 34.36 & 49.19 & 17.32 & 0.00 \\
\hline SLin 16 & pto $2 / \mathrm{c} 2$ & po-ccp & 33.77 & 35.55 & 30.69 & 0.00 & 34.21 & 48.31 & 17.85 & 0,00 \\
\hline SL-16 & pto $3 / \mathrm{cl}$ & po-ccp & 33.44 & 35.76 & 30.79 & 0.00 & 34.03 & 48.82 & 17.99 & 0.00 \\
\hline SL-21 & pto 3/cl & po-ccp & 32.97 & 35.89 & 31.15 & 0.00 & 32.71 & 47.77 & 17.74 & 0.00 \\
\hline SL 21 & pto /c29 & po-ccp & 33.42 & 35.13 & 31.43 & 0.00 & 33.63 & 47.42 & 18.16 & 0.00 \\
\hline
\end{tabular}

Tabela 6.4a - Análises químicas de arsenopirita, da fase I da mineralização, dos filões Capa, Lapa e

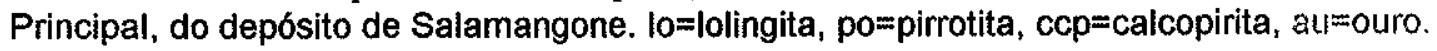


comp. (\%at) $\quad$ comp. (\%wt)

\begin{tabular}{l|l|l|llll|llll}
\hline Amostra & Localizaçāo & Paragênese & Fe & As & S & Au & Fe & AS & S & Au \\
\hline CSL-24 & pto 1/c1 & py-au & 33.82 & 34.17 & 32.00 & 0.00 & 34.50 & 46.77 & 18.74 & 0.00 \\
CSL-24 & pto 2/c1 & py-au & 34.02 & 33.85 & 32.13 & 0.00 & 34.88 & 46.56 & 18.91 & 0.00 \\
CSL-24 & pto 3/c2 & py-au & 33.80 & 35.33 & 30.85 & 0.01 & 34.05 & 47.75 & 17.84 & 0.02 \\
CSL-24 & pto 4/c2 & py-au & 33.52 & 35.35 & 31.10 & 0.02 & 33.72 & 47.71 & 17.96 & 0.06 \\
CSL-24 & pto 5/c3 & py-au & 33.98 & 32.43 & 33.55 & 0.03 & 35.09 & 44.94 & 19.89 & 0.09 \\
CSL-24 & pto 6/c3 & py-au & 33.77 & 34.03 & 32.17 & 0.02 & 34.49 & 46.61 & 18.86 & 0.05 \\
CSL-24 & pto 8/c4 & py-au & 33.58 & 35.18 & 31.19 & 0.00 & 33.93 & 47.68 & 18.09 & 0.00 \\
L-01 & pto 1/c1 & py-au & 33.64 & 35.74 & 30.61 & 0.00 & 33.86 & 48.26 & 17.69 & 0.00 \\
L-01 & pto 2/c1 & py-au & 33.72 & 34.99 & 31.28 & 0.01 & 34.06 & 47.41 & 18.14 & 0.02 \\
L-01 & pto 4/c2 & py-au & 33.70 & 34.12 & 32.16 & 0.02 & 34.37 & 46.68 & 18.83 & 0.03 \\
L-01 & pto 5/c2 & py-au & 33.74 & 35.29 & 30.96 & 0.01 & 33.92 & 47.60 & 17.87 & 0.03 \\
SL-01 & pto 11/c2 & py-au & 33.16 & 35.55 & 31.29 & 0.01 & 33.79 & 48.60 & 18.30 & 0.02 \\
SL-01 & pto 13/c2 & py-au & 33.37 & 35.41 & 31.19 & 0.00 & 33.82 & 48.14 & 18.15 & 0.00 \\
SL-01 & pto 8/c2 & py-au & 33.07 & 36.36 & 30.56 & 0.01 & 33.58 & 49.54 & 17.81 & 0.05 \\
SLP-17 & pto 7/c2 & py-au & 33.80 & 34.18 & 31.99 & 0.01 & 34.62 & 46.96 & 18.81 & 0.03
\end{tabular}

Tabela 6.4b - Análises químicas de arsenopirita, da fase Il da mineralização, dos filões Capa, Capa, Lapa e Principal do depósito de Salamangone. py=pirita, au=ouro. 
compos. (\% at)

\begin{tabular}{|c|c|c|c|c|c|c|c|c|c|c|c|c|}
\hline Amostra & Localização & Mineral & $\mathrm{Fe}$ & As & $\mathbf{s}$ & $\mathrm{Cu}$ & Au & $\mathrm{Fe}$ & $\mathbf{A S}$ & $\mathbf{s}$ & $\mathrm{Cu}$ & $\mathbf{A u}$ \\
\hline CSL-06 & pto $1 \mathrm{cl}$ & po & 46.99 & 0.01 & 53.00 & 0.00 & 0.00 & 59.34 & 0.01 & 38.43 & 0.01 & 0.00 \\
\hline CSL-06 & pto $10 c 3$ & ccp & 25.39 & 0.00 & 49.42 & 25.19 & 0.00 & 30.23 & 0.00 & 33.78 & 34.13 & 0.02 \\
\hline CSL 06 & pto $12 \mathrm{c} 3$ & po & 47.30 & 0.01 & 52.69 & 0.00 & 0.00 & 59.41 & 0.01 & 37.99 & 0.00 & 0.01 \\
\hline CSL-06 & pto $15 \mathrm{c} 4$ & po & 46.90 & 0.00 & 53.08 & 0.00 & 0.02 & 59.33 & 0.00 & 38.55 & 0.00 & 0.07 \\
\hline CSL-06 & pto $2 \mathrm{cl}$ & po & 46.87 & 0.01 & 53.11 & 0.00 & 0.01 & 59.33 & 0.02 & 38.59 & 0.00 & 0.04 \\
\hline CSLm06 & pto 301 & po & 46.51 & 0.00 & 53.46 & 0.00 & 0.01 & 58.85 & 0.01 & 38.83 & 0.00 & 0.04 \\
\hline LSL-10 & pto $2 \mathrm{cl}$ & po & 47.28 & 0.00 & 52.71 & 0.00 & 0.04 & 60.14 & 0.00 & 38.49 & 0.00 & 0.02 \\
\hline LSL-10 & pto $5 \mathrm{cl}$ & po & 47.43 & 0.01 & 52.56 & 0.00 & 0.00 & 60.27 & 0.02 & 38.33 & 0.00 & 0.00 \\
\hline LSL-10 & pto $7 \mathrm{c} 2$ & po & 47.32 & 0.02 & 52.64 & 0.00 & 0.02 & 59.97 & 0.03 & 38.29 & 0.00 & 0.07 \\
\hline LSL-10 & pto $9 \mathrm{c} 3$ & po & 47.77 & 0.02 & 52.21 & 0.00 & 0.00 & 60.55 & 0.03 & 37.99 & 0.00 & 0.00 \\
\hline LSL-13 & pto $1 \mathrm{c} 2$ & po & 47.45 & 0.01 & 52.50 & 0.04 & 0.01 & 60.20 & 0.01 & 38.24 & 0.05 & 0.06 \\
\hline LSL-13 & pto $2 \mathrm{c} 2$ & po & 47.28 & 0.00 & 52.70 & 0.01 & 0.01 & 60.24 & 0.00 & 38.55 & 0.01 & 0.05 \\
\hline LSL-13 & pto $4 c 3$ & po & 47,92 & 0.01 & 52.07 & 0.01 & 0.00 & 60.86 & 0.02 & 37.96 & 0.01 & 0.00 \\
\hline LSL-13 & pto $7 \mathrm{c} 4$ & po & 47.56 & 0.04 & 52.42 & 0.00 & 0.01 & 60.42 & 0.00 & 38.23 & 0.00 & 0.03 \\
\hline PSL-19 & pto $11 \mathrm{c} 3$ & ccp & 25.61 & 0.01 & 48.97 & 25.38 & 0.01 & 30.17 & 0.01 & 33.12 & 34.03 & 0.03 \\
\hline PSL-19 & pto $12 \mathrm{c} 3$ & po & 48.27 & 0.01 & 51.72 & 0.00 & 0.01 & 59.41 & 0.01 & 36.54 & 0.00 & 0.05 \\
\hline PSL-19 & pto $14 \mathrm{c} 4$ & 10 & 33.42 & 60.63 & 5.94 & 0,00 & 0.02 & 28.75 & 69.99 & 2.93 & 0.00 & 0.06 \\
\hline PSL-19 & pto $18 \mathrm{c} 6$ & 10 & 33.64 & 60.53 & 5.83 & 0.00 & 0.00 & 28.70 & 69.29 & 2.86 & 0.00 & 0.00 \\
\hline PSL-19 & pto $2 \mathrm{c} 1$ & lo & 33.51 & 63.39 & 3.10 & 0.00 & 0.00 & 28.04 & 71.15 & 1.49 & 0.00 & 0.00 \\
\hline PSL-19 & pto $20 \mathrm{c} 6$ & to & 34.29 & 59.81 & 5.86 & 0.00 & 0.03 & 28.00 & 65.49 & 2.75 & 0.00 & 0.09 \\
\hline PSL-19 & pto $3 \mathrm{cl}$ & 10 & 33.68 & 60.60 & 5.71 & 0.01 & 0.00 & 28.74 & 69.37 & 2.80 & 0.01 & 0.00 \\
\hline PSL-19 & pto $5 \mathrm{c} 2$ & lo & 33.67 & 62.98 & 3.35 & 0.00 & 0.01 & 28.31 & 71.05 & 1.62 & 0.00 & 0.01 \\
\hline PSL-19 & pto $6 \mathrm{c} 2$ & to & 33.57 & 63.18 & 3.26 & 0.00 & 0.00 & 27.96 & 70.60 & 1.56 & 0.00 & 0.00 \\
\hline PSL-19 & pto $9 \mathrm{c} 2$ & lo & 33.50 & 60.41 & 6.07 & 0.00 & 0.00 & 28.76 & 69.56 & 2.99 & 0.00 & 0.00 \\
\hline R-18 & pto $1 \mathrm{c} 3$ & po & 47.60 & 0.00 & 52.39 & 0.00 & 0.00 & 59.64 & 0.01 & 37.68 & 0.01 & 0.00 \\
\hline$R-18$ & pto $12 \mathrm{c} 4$ & po & 47.78 & 0.00 & 52.20 & 0.01 & 0.00 & 60.61 & 0.00 & 38.01 & 0.02 & 0.00 \\
\hline R-18 & pto $15 \mathrm{c} 2$ & po & 47.67 & 0.01 & 52.30 & 0.00 & 0,02 & 60.34 & 0.02 & 38.00 & 0.00 & 0.07 \\
\hline R-18 & pto $6 \mathrm{c} 3$ & po & 48.07 & 0.01 & 51.91 & 0.01 & 0.01 & 61.33 & 0.02 & 38.02 & 0.01 & 0.03 \\
\hline R-18 & pto $8 \mathrm{c} 3$ & po & 47.70 & 0.00 & 52.26 & 0.02 & 0.00 & 59.81 & 0.00 & 37.62 & 0.03 & 0.00 \\
\hline$R-25$ & pto $1 \mathrm{cl}$ & po & 46.47 & 0.00 & 53.42 & 0.06 & 0.03 & 59.58 & 0.01 & 39.31 & 0.09 & 0.11 \\
\hline R-25 & pto $11 \mathrm{c} 4$ & lo & 33.78 & 58.37 & 7.83 & 0.00 & 0.02 & 28.57 & 66.24 & 3.80 & 0.00 & 0.06 \\
\hline R-25 & pto $19 \mathrm{c} 4$ & po & 47.65 & 0.01 & 52.34 & 0.00 & 0.00 & 59.86 & 0.02 & 37.75 & 0.00 & 0.01 \\
\hline R-25 & pto $2 \mathrm{cl}$ & cop & 25.12 & 0.01 & 50.26 & 24.61 & 0.00 & 30.22 & 0.02 & 34.71 & 33.69 & 0.00 \\
\hline $\mathrm{R}-25$ & pto $5 \mathrm{c} 2$ & po & 47.24 & 0.03 & 52.70 & 0.03 & 0.00 & 60.08 & 0.04 & 38.48 & 0.04 & 0.00 \\
\hline $\mathrm{R}-25$ & pto 602 & $c c p$ & 25.16 & 0.02 & 50.22 & 24.58 & 0.00 & 30.15 & 0.03 & 34.54 & 33.51 & 0.00 \\
\hline R-25 & pto $8 \mathrm{c} 3$ & po & 47.77 & 0.01 & 52.19 & 0.02 & 0.01 & 60.21 & 0.02 & 37.76 & 0.03 & 0.04 \\
\hline R-41-1 & pto $12 \mathrm{cl}$ & po & 47.88 & 0.01 & 52.11 & 0.00 & 0.00 & 60.02 & 0.02 & 37.51 & 0.00 & 0.00 \\
\hline$R-41-1$ & pto $7 \mathrm{c} 4$ & 10 & 33.62 & 59.82 & 6.55 & 0.00 & 0.00 & 28.85 & 68.86 & 3.23 & 0.00 & 0.00 \\
\hline$R-41-1$ & pto $9 \mathrm{c} 4$ & po & 47.85 & 0.01 & $\$ 2.14$ & 0.00 & 0.00 & 60.45 & 0.02 & 37.81 & 0.00 & 0.01 \\
\hline SIIN-30 & pto $4 \mathrm{c} 2$ & to & 33.48 & 60.53 & 5.98 & 0.01 & 0.00 & 28.57 & 69.31 & 2.93 & 0.01 & 0.00 \\
\hline SLL. 06 & pto $12 \mathrm{c} 4$ & po & 48.21 & 0.01 & 51.78 & 0.01 & 0.00 & 60.21 & 0.01 & 37.12 & 0.01 & 0.00 \\
\hline SL -06 & pto $13 \mathrm{c} 4$ & po & 47.53 & 0.01 & 52.44 & 0.00 & 0.00 & 60.34 & 0.02 & 38.22 & 0.00 & 0.00 \\
\hline SL-(-06 & pto $14 \mathrm{cs}$ & po & 48.05 & 0.00 & 51.94 & 0.00 & 0.00 & 60.34 & 0.00 & 37.45 & 0.00 & 0.00 \\
\hline SL-06 & pto $15 \mathrm{cs}$ & po & 47.09 & 0.00 & 52.91 & 0.00 & 0.00 & 60.18 & 0.00 & 38.82 & 0.00 & 0.00 \\
\hline SL_-06 & pto $8 \mathrm{c} 3$ & po & 47.95 & 0.01 & 52.01 & 0.01 & 0.01 & 60.88 & 0.01 & 37.91 & 0.01 & 0.06 \\
\hline SL-11 & pto $1 \mathrm{c} 2$ & po & 47.28 & 0.01 & 52.70 & 0.01 & 0.01 & 60.51 & 0.01 & 38.72 & 0.01 & 0.03 \\
\hline SL-11 & pto $5 \mathrm{c} 2$ & po & 47.01 & 0.00 & 52.99 & 0.00 & 0.00 & 59.57 & 0.01 & 38.55 & 0.00 & 0.00 \\
\hline SL-11 & pto $7 \mathrm{c} 3$ & po & 47.53 & 0.01 & 52.46 & 0.00 & 0.00 & 60.57 & 0.01 & 38.38 & 0.00 & 0.01 \\
\hline SL 16 & pto $1 \mathrm{c} 2$ & po & 47.83 & 0.01 & 52.15 & 0.00 & 0.00 & 60.60 & 0.02 & 37.93 & 0.00 & 0.00 \\
\hline SI-16 & pto $4 \mathrm{cl}$ & ccp & 24.96 & 0.02 & 49.80 & 25.23 & 0.00 & 30.11 & 0.03 & 34.49 & 34.64 & 0.00 \\
\hline SL-16 & pto $5 \mathrm{cl}$ & сро & 47.60 & 0.01 & 52.39 & 0.00 & 0.00 & 60.24 & 0.02 & 38.06 & 0.00 & 0.00 \\
\hline SL-21 & pto $5 \mathrm{cl}$ & po & 47.43 & 0.01 & 52.54 & 0.01 & 0.00 & 59.68 & 0.02 & 37.96 & 0.02 & 0.00 \\
\hline
\end{tabular}

Tabela 6.4c - Análises químicas de pirrotita, lollingita e calcopirita da fase I da mineralização, dos filões Capa, Lapa e Principal do depósito de Salamangone. po=pirrotita, lo=lollingita, $\mathrm{ccp}=$ calcopirita. 
compos. (\% at) compos. (\% wt)

\begin{tabular}{lll|lllll|ll|llll}
\hline Amostra & Localizaça & Mineral & Fe & As & S & Cu & Au & fe & As & S & Cu & Au \\
\hline SLP-17 & pto $5 c 2$ & py & 33.72 & 0.00 & 66.25 & 0.01 & 0.00 & 46.57 & 0.00 & 52.51 & 0.02 & 0.00 \\
SL-01 & pto 1c1 & py & 33.59 & 0.00 & 66.41 & 0.00 & 0.00 & 46.78 & 0.00 & 53.10 & 0.00 & 0.00 \\
SL-01 & pto 2cl & py & 33.66 & 0.46 & 65.88 & 0.00 & 0.00 & 46.79 & 0.85 & 52.57 & 0.00 & 0.00 \\
L-01 & pto 3c1 & py & 33.77 & 0.01 & 66.22 & 0.00 & 0.00 & 46.92 & 0.02 & 52.82 & 0.00 & 0.00
\end{tabular}

Tabela 6.4d - Análises químicas de pirita da fase II da mineralização, dos filões capa, lapa e principal do depósito de Salamangone. py=pirita.

compos. (\% at) $\quad$ compos. (\% wt)

\begin{tabular}{lll|lllllll|llllll}
\hline Amostra & Localizacão & Mineral & Fe & As & S & Cu & Au & Ag & Fe & As & S & Cu & Au & Ag \\
\hline R-25 & pto 10c4 & au/fase I & 0.46 & 0.19 & 0.31 & 0.03 & 53.56 & 45.46 & 0.17 & 0.09 & 0.06 & 0.01 & 67.28 & 31.27 \\
& & & & & & & & & & & & & \\
SLP-17 & pto 1c1 & au/fasell & 0.03 & 0.12 & 0.12 & 0.07 & 81.60 & 18.06 & 0.01 & 0.05 & 0.02 & 0.02 & 87.03 & 10.55 \\
SLP-17 & pto 2cl & au/fasell & 0.02 & 0.14 & 0.11 & 0.07 & 81.73 & 17.93 & 0.01 & 0.06 & 0.02 & 0.03 & 88.59 & 10.64 \\
SLP-17 & pto 3cl & au/faselI & 0.00 & 0.19 & 0.07 & 0.00 & 82.20 & 17.55 & 0.00 & 0.08 & 0.01 & 0.00 & 88.88 & 10.29 \\
SLP-17 & pto 4c3 & au/faselI & 0.00 & 0.11 & 0.25 & 0.07 & 82.00 & 17.57 & 0.00 & 0.05 & 0.04 & 0.02 & 88.71 & 10.41 \\
SLP-17 & pto 6c2 & au/fasell & 0.13 & 0.13 & 0.24 & 0.01 & 81.61 & 17.89 & 0.04 & 0.05 & 0.04 & 0.00 & 89.32 & 10.72 \\
SL-01 & pto 15c2 & au/fasell & 0.02 & 0.14 & 0.19 & 0.00 & 79.42 & 20.23 & 0.01 & 0.06 & 0.03 & 0.00 & 87.72 & 12.24 \\
SL-01 & pto 16c1 & au/fasell & 0.64 & 0.15 & 0.87 & 0.00 & 78.54 & 19.80 & 0.20 & 0.06 & 0.16 & 0.00 & 86.58 & 11.95
\end{tabular}

Tabela 6.4e - Análises químicas de ouro das fases I e II da mineralização, dos filões Capa, Lapa e Principal, do depósito de Salamangone. $a u=$ ouro. 


\section{$\underline{\text { Anexo } 3}$}

Análises Químicas em Rocha 


\begin{tabular}{|c|c|c|c|c|c|c|c|c|c|c|c|c|c|}
\hline \multirow[b]{2}{*}{ Amostra } & \multirow{2}{*}{$\begin{array}{c}\text { SH-144 } \\
\text { SHNT-02 }\end{array}$} & \multirow{2}{*}{$\begin{array}{l}\text { SH-113 } \\
\text { SHN-08 } \\
\end{array}$} & \multirow{2}{*}{$\begin{array}{l}\text { SH-67 } \\
\text { SL-28 } \\
\end{array}$} & \multirow{2}{*}{\begin{tabular}{|l|l|} 
FI-104 \\
IH-26
\end{tabular}} & \multicolumn{2}{|c|}{ T-N 54} & \multicolumn{2}{|c|}{ T- N 229} & \multicolumn{3}{|c|}{ SH-140 } & \multicolumn{2}{|c|}{ SH-100 } \\
\hline & & & & & R-01 & R-07 & S-14 & s-21 & SHN-11 & SHN-17 & SHN-20 & SHN-44 & SHN-52 \\
\hline $\mathrm{SiO2}$ & 62.4 & 63.1 & 64.1 & 63.3 & 64.2 & 63.8 & 62.6 & 64.6 & 64.6 & 64.6 & 64.9 & 64.0 & 63.4 \\
\hline $\mathrm{THO}_{2}$ & 0.7 & 0.7 & 0.7 & 0.6 & 0.6 & 0.6 & 0.6 & 0.6 & 0.6 & 0.6 & 0.6 & 0.6 & 0.7 \\
\hline Al2O3 & 14.9 & 15.4 & 14.6 & 15.0 & 15.6 & 15.3 & 14.9 & 15.1 & 15.0 & 15.2 & 14.9 & 15.0 & 14.9 \\
\hline Fe2O3 & 7.1 & 6.6 & 6.9 & 6.3 & 6.0 & 5.8 & 6.1 & 6.2 & 6.1 & 6.2 & 6.5 & 5.9 & 6.8 \\
\hline MnO & 0.2 & 0.1 & 0.1 & 0.1 & 0.1 & 0.1 & 0.1 & 0.1 & 0.1 & 0.1 & 0.1 & 0.1 & 0.1 \\
\hline MgO & 3.2 & 2.9 & 2.7 & 2.9 & 2.6 & 2.7 & 2.7 & 2.7 & 2.7 & 2.6 & 2.7 & 2.8 & 3.1 \\
\hline $\mathrm{CaO}$ & 5.1 & 5.2 & 4.6 & 4.9 & 4.7 & 4.6 & 4.7 & 4.5 & 4.3 & 4.5 & 4.2 & 5.2 & 5.0 \\
\hline $\mathrm{Na2O}$ & 3.4 & 3.7 & 3.4 & 3.4 & 4.0 & 3.8 & 3.6 & 3.6 & 3.5 & 3.7 & 3.5 & 3.8 & 3.6 \\
\hline $\mathbf{K 2 O}$ & 1.9 & 2,1 & 2.1 & 2.3 & 2.2 & 2.6 & 2.3 & 2.7 & 2.4 & 2.4 & 1.8 & 2.2 & 2.0 \\
\hline P2O5 & 0.2 & 0.2 & 0.2 & 0.2 & 0.2 & 0.2 & 0.1 & 0.2 & 0.2 & 0.2 & 0.2 & 0,2 & 0.2 \\
\hline LOI & 0.9 & 0.7 & 0.7 & 0.5 & 0.6 & 0.6 & 0.6 & 0.7 & 0.9 & 0.8 & 1.0 & 0.8 & 0.7 \\
\hline Total & 100.0 & 100.7 & 100.1 & 99.6 & 100.8 & 99.9 & 98.3 & 100.8 & 100.5 & 100.8 & 100.4 & 100.5 & 100.4 \\
\hline ACNK & 0.9 & 0.9 & 0.9 & 0.9 & 0.9 & 0.9 & 0.9 & 0.9 & 0.9 & 0.9 & 1.0 & 0.8 & 0.9 \\
\hline mg\# & 0.5 & 0.5 & 0.4 & 0.5 & 0.4 & 0.5 & 0.5 & 0.5 & 0.5 & 0.4 & 0.5 & 0.5 & 0.5 \\
\hline $\mathbf{Y}$ & 20.2 & 20.4 & 22.0 & 18.0 & 16.6 & 15.6 & 18.4 & 19.1 & 18.1 & 17.6 & 26.4 & 19.0 & 21.0 \\
\hline $\mathrm{Cr}$ & 29.0 & 19.0 & 11.0 & 68.0 & 0.0 & 11.0 & 0.0 & 0.0 & 0.0 & 0.0 & 13.0 & 63.0 & 70.0 \\
\hline $\mathbf{v}$ & 118.0 & 111.0 & 105.0 & 102.0 & 97.0 & 94.0 & 103.0 & 101.0 & 99.0 & 99.0 & 100.0 & 97.0 & 114.0 \\
\hline Sc & 17.0 & 17.0 & 17.0 & 16.0 & 32.0 & 14.0 & 15.0 & 15.0 & 15.0 & 14.0 & 15.0 & 15.0 & 17.0 \\
\hline $\mathbf{N i}$ & 13.0 & 11.0 & 13.0 & 36.0 & 13.0 & 13.0 & 13.0 & 13.0 & 13.0 & 11.0 & 14.0 & 28.0 & 20.0 \\
\hline Co & 22.9 & 19.1 & 16.3 & 17.0 & 16.7 & 15.9 & 14.6 & 14.1 & 14.1 & 19.4 & 15.0 & 32.0 & 52.0 \\
\hline $\mathrm{Cu}$ & 13.0 & 26.0 & 10.0 & 15.0 & 46.0 & 0.0 & 18.0 & 13.0 & 24.0 & 33.0 & 0.0 & 55.0 & 26.0 \\
\hline $\mathbf{Z n}$ & 82.0 & 84.0 & 88.0 & 75.0 & 67.0 & 74.0 & 60.0 & 58.0 & 54.0 & 48.0 & 50.0 & 73.0 & 76.0 \\
\hline Cs & 3.9 & 3.0 & 5.0 & 4.0 & 5.2 & 5.7 & 4.3 & 3.7 & 3.2 & 6.4 & 7.5 & 3.7 & 5.7 \\
\hline Rb & 76.9 & 71.9 & 94.6 & 76.0 & 82.5 & 95.3 & 73.4 & 74.5 & 73.7 & 82.3 & 133.5 & 64.0 & 99.0 \\
\hline $\mathrm{Tl}$ & 2.5 & 3.2 & 1.2 & 0.6 & 1.0 & 1.0 & 1.5 & 1.4 & 1.2 & 1.8 & 2.2 & 0.5 & 0.7 \\
\hline $\mathbf{B a}$ & 723.1 & 807.3 & 472.9 & 977.0 & 785.1 & 925.9 & 862.7 & 978.1 & 888.7 & 935.7 & 564.1 & 824.0 & 948.0 \\
\hline $\mathbf{P b}$ & 17.0 & 31.0 & 24.0 & 15.0 & 18.0 & 24.0 & 14.0 & 15.0 & 11.0 & 13.0 & 12.0 & 14.0 & 15.0 \\
\hline $\mathbf{S r}$ & 505.3 & 518.1 & 436.5 & 507.0 & 524.4 & 478.8 & 484.4 & 480.8 & 479.6 & 485.2 & 391.5 & 535.0 & 524.0 \\
\hline Th & 5.3 & 5.4 & 4.9 & 7.2 & 7.7 & 10.2 & 7.3 & 11.8 & 8.1 & 10.3 & 6.2 & 7.7 & 5.7 \\
\hline U & 1.8 & 1.4 & $\mid 1.9$ & 2.2 & 3.5 & 3.7 & 2.1 & 3.4 & 2.4 & 3.0 & 4.1 & 2.6 & 2.3 \\
\hline $\mathbf{Z r}$ & 256.6 & 198.6 & 200.0 & 159.0 & 149.9 & 139.5 & 170.7 & 181.9 & 176.9 & 175.0 & 188.6 & 224.0 & 213.0 \\
\hline Hf & 6.8 & 5.7 & 5.6 & 4.6 & 4.6 & 4.1 & 3.6 & 4.0 & 3.7 & 3.8 & 3.7 & 6.1 & 5.9 \\
\hline $\mathbf{N b}$ & 7.8 & 7.1 & 8.2 & 7.6 & 6.4 & 6.1 & 5.1 & 5.2 & 5.2 & 5.2 & 6.2 & 7.4 & 8.0 \\
\hline Sn & 1.7 & 1.6 & 3.0 & 1.9 & 1.3 & 1.5 & 1.2 & 1.2 & 1.3 & 1.7 & 2.0 & 2.1 & 2.9 \\
\hline Mo & 1.1 & \begin{tabular}{l|l} 
&
\end{tabular} & 1.1 & 1.3 & 1.5 & 2.1 & 2.0 & 1.6 & 1.9 & 1.5 & 2.0 & 1.1 & 1.1 \\
\hline W & 0.5 & 0.6 & 0.5 & 0.0 & 0.4 & 0.0 & 0.0 & 0.0 & 0.0 & 0.0 & 0.0 & 155.0 & 318.0 \\
\hline $\mathbf{G a}$ & 21.0 & 22.0 & 21.0 & 21.0 & 21.0 & 20.0 & 16.0 & 16.0 & 16.0 & 16.0 & 16.0 & 21.0 & 22.0 \\
\hline $\mathbf{T a}$ & 0.5 & 0.5 & 0.5 & 0.5 & 0.5 & 0.5 & 0.4 & 0.4 & 0.4 & 0.4 & 0.4 & 0.8 & 1.3 \\
\hline
\end{tabular}

Tabela 4.6a - Análises químicas de elementos maiores (\%) e traços (ppm) em rocha total de tonalito da Mina de salamangone. $\mathrm{Fe}_{2} \mathrm{O}_{3}$ como ferro total. $\mathrm{Mg} \#=\mathrm{MgO} / \mathrm{MgO}+\mathrm{FeO}$ 
219

\begin{tabular}{|c|c|c|c|c|c|c|c|c|c|c|c|c|c|}
\hline \multirow[b]{2}{*}{ Amostra } & \multirow{2}{*}{\begin{tabular}{|l|} 
SH-144 \\
SHNT-02 \\
\end{tabular}} & \multirow{2}{*}{\begin{tabular}{|l|} 
SH-113 \\
SHN-08 \\
\end{tabular}} & \multirow{2}{*}{\begin{tabular}{|l|} 
SH-67 \\
SL-28 \\
\end{tabular}} & \multirow{2}{*}{\begin{tabular}{|l|} 
FI-104 \\
IIH-26 \\
\end{tabular}} & \multicolumn{2}{|c|}{ T- nivel 54} & \multicolumn{2}{|c|}{ T- ável 229} & \multicolumn{3}{|c|}{ SHF-140 } & \multicolumn{2}{|c|}{ SH-100 } \\
\hline & & & & & R-01 & R-07 & S-14 & S-21 & SHN-11 & SHN-17 & SHN-20 & SHN-44 & SHN-52 \\
\hline $\mathbf{L a}$ & 28.7 & 30.2 & 28.7 & 30.3 & 25.5 & 37.2 & 24.9 & 30.4 & 27.7 & 28.0 & 19.9 & 26.6 & 22.4 \\
\hline $\mathrm{Ce}$ & 57.3 & 61.3 & 57.3 & 62.9 & 50.9 & 64.3 & 47.2 & 57.2 & 50.7 & 51.8 & 40.1 & 54.8 & 50.2 \\
\hline $\mathrm{Pr}$ & 5.8 & 6.0 & 5.8 & 6.9 & 5.0 & 5.7 & 4.7 & 5.5 & 4.9 & 4.9 & 4.1 & 6.3 & 6.1 \\
\hline Nd & 27.8 & 28.4 & 27.8 & 29.8 & 23.1 & 24.9 & 19.1 & 20.8 & 19.4 & 19.3 & 17.2 & 27.2 & 28.2 \\
\hline Sm & 5.8 & 5.7 & 5.8 & 5.8 & 4.6 & 4.7 & 4.1 & 4.3 & 4.1 & 4.0 & 4.6 & 5.3 & 5.8 \\
\hline Eu & 1.3 & 1.3 & 1.3 & 1.2 & 1.2 & 1.1 & 1.1 & 1.1 & 1.1 & 1.1 & 0.9 & 1.3 & 1.3 \\
\hline Gd & 4.6 & 4.2 & 4.6 & 3.7 & 3.7 & 3.5 & 3.1 & 3.2 & 3.0 & 3.1 & 3.9 & 3.7 & 4.0 \\
\hline $\mathrm{Tb}$ & 0.6 & 0.6 & 0.6 & 0.6 & 0.5 & 0.5 & 0.5 & 0.5 & 0.5 & 0.5 & 0.7 & 0.6 & 0.7 \\
\hline Dy & 3.5 & 3.4 & 3.5 & 3.5 & 2.8 & 2.6 & 2.9 & 3.0 & 2.7 & 2.7 & 4.2 & 3.5 & 3.9 \\
\hline Ho & 0.7 & 0.7 & 0.7 & 0.7 & 0.6 & 0.5 & 0.6 & 0.6 & 0.6 & 0.6 & 0.8 & 0.7 & 0.8 \\
\hline Er & 2.0 & 2.1 & 2.0 & 2.0 & 1.7 & 1.6 & 1.6 & 1.7 & 1.7 & 1.6 & 2.2 & 2.0 & 2.2 \\
\hline Yb & 1.8 & 1.9 & 1.8 & 1.8 & 1.5 & 1.4 & 1.3 & 1.4 & 1.3 & 1.4 & 1.7 & 1.9 & 2.0 \\
\hline Tm & 0.3 & 0.3 & 0.3 & 0.3 & 0.2 & 0.2 & 0.2 & 0.2 & 0.2 & 0.2 & 0.3 & 0.3 & 0.3 \\
\hline $\mathbf{L u}$ & 0.3 & 0.3 & 0.3 & 0.3 & 0.3 & 0.2 & 0.2 & 0.2 & 0.2 & 0.2 & 0.3 & 0.3 & 0.3 \\
\hline LaYb & 16.1 & 16.3 & 16.1 & 16.9 & 17.5 & 27.4 & 18.6 & 21.1 & 20.8 & 20.2 & 11.7 & 13.7 & 11.0 \\
\hline LaSm & 5.0 & 5.3 & 5.0 & 5.2 & 5.5 & 7.9 & 6.1 & 7.0 & 6.8 & 7.0 & 4.4 & 5.1 & 3.9 \\
\hline LaYbN & 10.9 & 11.0 & 10.9 & 11.4 & 11.8 & 18.4 & 12.5 & 14.2 & 14.1 & 13.6 & 7.9 & 9.2 & 7.4 \\
\hline LaSmN & 3.2 & 3.4 & 3.2 & 3.3 & 3.5 & 5.0 & 3.8 & 4.5 & 4.3 & 4.4 & 2.8 & 3.2 & 2.5 \\
\hline
\end{tabular}

Tabela 4.6b - Análises químicas de elementos terras raras - ETR (ppm), em rocha total de tonalito da mina de Salamangone. Normalização pelo condrito de Boynton (1984). 


\begin{tabular}{|c|c|c|c|c|c|}
\hline & cava & FSH-144 & FSH-67 & FSH-81 & FSH-115 \\
\hline Amostra & C-01 & SHNG-02 & SL-30 & SL-38 & SL-64 \\
\hline $\mathrm{SiO} 2$ & 68.3 & 74.4 & 70.9 & 74.9 & 72.6 \\
\hline TiO2 & 0.1 & 0.1 & 0.3 & 0.2 & 0.2 \\
\hline $\mathrm{Al}_{2} \mathbf{O 3}$ & 18.5 & 13.6 & 15.1 & 14.0 & 14.2 \\
\hline $\mathrm{Fe} 2 \mathrm{O3}$ & 1.5 & 1.7 & 2.8 & 1.9 & 2.2 \\
\hline MnO & 0.0 & 0.1 & 0.1 & 0.0 & 0.1 \\
\hline MgO & 0.3 & 0.3 & 0.7 & 0.5 & 0.5 \\
\hline $\mathrm{CaO}$ & 3.9 & 1.9 & 2.5 & 2.0 & 2.4 \\
\hline $\mathrm{Na2O}$ & 5.8 & 3.1 & 3.8 & 5.0 & 4.0 \\
\hline $\mathrm{K} 2 \mathrm{O}$ & 1.4 & 4.2 & 3.6 & 1.8 & 2.6 \\
\hline P2O5 & 0.0 & 0.1 & 0.1 & 0.1 & 0.1 \\
\hline LOI & 0.3 & 0.3 & 0.4 & 0.5 & 0.4 \\
\hline Total & 100.2 & 99.8 & 100.2 & 100.9 & 99.1 \\
\hline ACNK & 1.0 & 1.0 & 1.0 & 1.0 & 1.0 \\
\hline mg\# & 0.3 & 0.3 & 0.3 & 0.3 & 0.3 \\
\hline $\mathbf{Y}$ & 2.3 & 3.9 & 5.8 & 7.1 & 3.0 \\
\hline $\mathbf{v}$ & 8.0 & 6.0 & 19.0 & 14.0 & 12.0 \\
\hline $\mathbf{S e}$ & 1.0 & 2.0 & 4.0 & 3.0 & 2.0 \\
\hline $\mathbf{N i}$ & 28.0 & 0.0 & 5.0 & 15.0 & 29.0 \\
\hline Co & 3.7 & 21.2 & 61.0 & 56.0 & 10.2 \\
\hline $\mathrm{Cu}$ & 14.0 & 0.0 & 115.0 & 26.0 & 8.0 \\
\hline Zn & 24.0 & 27.0 & 26.0 & 35.0 & 31.0 \\
\hline Cs & 3.0 & 1.6 & 6.2 & 14.0 & 2.6 \\
\hline $\mathbf{R b}$ & 61.0 & 72.8 & 111.7 & 103.0 & 72.0 \\
\hline $\mathrm{Tl}$ & 0.8 & 2.1 & 3.3 & 0.6 & 3.2 \\
\hline $\mathbf{B a}$ & 750.2 & 1233.3 & 1450.9 & 881.0 & 855.2 \\
\hline $\mathbf{P b}$ & 36.0 & 26.0 & 34.0 & 12.0 & 42.0 \\
\hline $\mathbf{S r}$ & 886.6 & 437.9 & 433.7 & 277.0 & 555.9 \\
\hline $\mathbf{T h}$ & 5.4 & 7.6 & 5.1 & 7.1 & 5.2 \\
\hline $\mathbf{U}$ & 2.6 & 3.5 & 2.9 & 4.2 & 3.5 \\
\hline $\mathbf{Z r}$ & 68.4 & 81.0 & 106.3 & 90.0 & 105.2 \\
\hline Hf & 1.9 & 2.8 & 3.2 & 3.0 & 3.2 \\
\hline Nb & 3.3 & 6.1 & 4.8 & 6.1 & 4.7 \\
\hline Sn & 1.7 & 0.0 & 1.2 & 4.4 & 0.0 \\
\hline Mo & 1.4 & 2.2 & 2.6 & 0.8 & 3.1 \\
\hline $\mathbf{w}$ & 0.9 & 1.0 & 0.9 & 457.0 & 0.4 \\
\hline Ga & 21.0 & 19.0 & 20.0 & 20.0 & 18.0 \\
\hline $\mathbf{T a}$ & 0.3 & 0.6 & 0.5 & 1.7 & 0.4 \\
\hline
\end{tabular}

Tabela 4.6c - Análises químicas de elementos maiores (\%) e traços (ppm) em rocha total de granodiorito da Mina de Salamangone. $\mathrm{Fe}_{2} \mathrm{O}_{3}$ como ferro total. $\mathrm{Mg} \#=\mathrm{MgO} / \mathrm{MgO}+\mathrm{feO}$ 


\begin{tabular}{l|lllll} 
& cava & FSH-144 & FSH-67 & FSH-81 & FSH-115 \\
\hline amostra & C-01 & SHNG-02 & SL-30 & SL-38 & SL-64 \\
\hline La & 16.7 & 25.4 & 17.1 & 15.7 & 15.5 \\
Ce & 23.4 & 43.3 & 29.4 & 30.6 & 24.2 \\
Pr & 1.8 & 3.7 & 2.5 & 3.3 & 1.8 \\
Nd & 6.5 & 15.0 & 10.6 & 14.0 & 7.0 \\
Sm & 0.9 & 2.3 & 1.8 & 2.7 & 1.1 \\
Eu & 1.0 & 0.7 & 0.9 & 0.7 & 0.8 \\
Gd & 0.6 & 1.3 & 1.4 & 1.8 & 0.7 \\
Tb & 0.1 & 0.1 & 0.2 & 0.3 & 0.1 \\
Dy & 0.3 & 0.7 & 1.0 & 1.4 & 0.5 \\
Ho & 0.1 & 0.1 & 0.2 & 0.2 & 0.1 \\
Er & 0.2 & 0.4 & 0.6 & 0.7 & 0.3 \\
Yb & 0.2 & 0.3 & 0.6 & 0.6 & 0.4 \\
Tm & 0.0 & 0.0 & 0.1 & 0.1 & 0.0 \\
Lu & 0.0 & 0.1 & 0.1 & 0.1 & 0.1 \\
LaYb & 75.8 & 77.1 & 29.5 & 24.5 & 37.7 \\
LaSm & 18.5 & 11.3 & 9.4 & 5.8 & 14.4 \\
LaYbN & 51.1 & 52.0 & 19.9 & 16.5 & 25.4 \\
LaSmN & 11.7 & 7.1 & 6.0 & 3.6 & 9.1 \\
& & & & &
\end{tabular}

Tabela 4.6d - Análises químicas de elementos terras raras - ETR (ppm) em rocha total, de granodiorito da Mina de Salamangone. Normalização pelo condrito de Boynton (1984). 
a) tonalito

\begin{tabular}{|c|c|c|c|c|c|c|c|c|c|c|c|c|c|}
\hline amostra & |1H26/FI104 & R01/N54 & R07/N54 & S14/N229 & $\mathrm{S} 21 / \mathrm{N} 229$ & SHN8/F113 & SHN11/F140 & SHN17/F140 & SHN20/F140 & SHN44/F100 & SHN52/F100 & SHNT02/F144 & SL.28/F67 \\
\hline $\bar{Q}$ & 21.4 & 20.1 & 19.5 & 20.9 & 21.1 & 19.6 & 22.6 & 21.6 & 25.3 & 20.6 & 21.0 & 21.3 & 23.5 \\
\hline $\mathbf{C}$ & 0.0 & 0.0 & 0.0 & 0.0 & 0.0 & 0.0 & 0.0 & 0.0 & 0.0 & 0.0 & 0.0 & 0.0 & 0.0 \\
\hline Or & 14.0 & 13.1 & 15.3 & 14.1 & 15.8 & 12.5 & 14.4 & 14.0 & 10.8 & 12.9 & 11.6 & 11.4 & 12.7 \\
\hline $\mathbf{A b}$ & 29.0 & 33.4 & 32.7 & 30.8 & 30.4 & 31.5 & 30.0 & 31.4 & 29.6 & 31.9 & 30.9 & 28.9 & 29.1 \\
\hline An & 19.0 & 18.3 & 17.1 & 18.1 & 17.0 & 18.9 & 17.9 & 17.7 & 19.9 & 17.6 & 18.6 & 20.0 & 18.1 \\
\hline Di & 3.6 & 3.2 & 3.7 & 3.7 & 3.6 & 4.4 & 2.0 & 3.0 & 0.0 & 5.7 & 4.3 & 3.7 & 3.1 \\
\hline Hy & 5.6 & 4.9 & 4.9 & 5.2 & 5.0 & 5.3 & 5.9 & 5.2 & 6.8 & 4.3 & 5.8 & 6.4 & 5.4 \\
\hline Mt & 0.4 & 0.3 & 0.3 & 0.3 & 0.3 & 0.4 & 0.3 & 0.4 & 0.4 & 0.3 & 0.4 & 0.5 & 0.4 \\
\hline $\mathrm{Hm}$ & 6.1 & 5.8 & 5.6 & 6.0 & 5.9 & 6.3 & 6.0 & 6.0 & 6.3 & 5.7 & 6.5 & 6.8 & 6.6 \\
\hline Ap & 0.4 & 0.4 & 0.3 & 0.3 & 0.4 & 0.4 & 0.3 & 0.3 & 0.3 & 0.4 & 0.4 & 0.4 & 0.4 \\
\hline
\end{tabular}

\begin{tabular}{|c|c|c|c|c|c|c|c|c|c|c|}
\hline \multirow[b]{2}{*}{ amostra } & \multirow[b]{2}{*}{ C-01/cava } & \multirow[b]{2}{*}{ SL-30/F67 } & \multicolumn{3}{|c|}{ b) granodiorito } & \multirow[b]{2}{*}{ amostra } & \multicolumn{4}{|c|}{ c) área Cayenne-Reginá } \\
\hline & & & SL-38/F81 & SL-64/F115 & SHNG2/F144 & & Cay-12A & Cay-12D & Reg-27A & Reg-27B \\
\hline $\mathbf{Q}$ & 20.5 & 29.0 & 34.1 & 34.2 & 35.7 & $\mathbf{Q}$ & 14.9 & 18.1 & 22.8 & 12.7 \\
\hline C & 0.4 & 0.6 & 0.5 & 0.5 & 0.5 & $\mathbf{C}$ & 0.0 & 0.0 & 0.0 & 0.0 \\
\hline Or & 8.5 & 21.2 & 10.6 & 15.7 & 25.2 & Or & 8.1 & 8.7 & 12.0 & 9.2 \\
\hline $\mathbf{A b}$ & 49.2 & 32.3 & 42.2 & 33.8 & 26.7 & $\mathbf{A b}$ & 33.2 & 33.5 & 43.0 & 40.1 \\
\hline An & 19.1 & 12.0 & 9.1 & 11.9 & 9.1 & An & 25.7 & 22.7 & 13.4 & 15.7 \\
\hline Di & 0.0 & 0.0 & 0.0 & 0.0 & 0.0 & Di & 4.8 & 3.4 & 1.1 & 8.2 \\
\hline Hy & 0.7 & 1.6 & 1.2 & 1.3 & 0.8 & Hy & 5.6 & 6.0 & 3.4 & 6.9 \\
\hline Mt & 0.1 & 0.3 & 0.1 & 0.2 & 0.2 & Mt & 0.3 & 0.3 & 0.2 & 0.4 \\
\hline Hm & 1.4 & 2.7 & 1.8 & 2.1 & 1.6 & $\mathbf{H} \mathbf{m}$ & 6.3 & 6.1 & 3.4 & 5.9 \\
\hline Ap & 0.1 & 0.2 & 0.2 & 0.1 & 0.1 & $\mathbf{A p}$ & 0.4 & 0.6 & 0.3 & 0.5 \\
\hline
\end{tabular}

Tabela 4.7 - Norma CIPW do tonalito (a) e granodiorito (b) da mina de Salamangone e de tonalito da área de Cayenne-Reginá (c), na Guiana Francesa, 


\begin{tabular}{|c|c|c|c|c|}
\hline \multirow[b]{2}{*}{ amostra } & \multicolumn{4}{|c|}{ Cayenne-Reginá } \\
\hline & CAY12A & CAY12D & REG27A & REG27B \\
\hline $\mathrm{SiO2}$ & 59.9 & 62.0 & 68.6 & 61.3 \\
\hline TIO2 & 0.7 & 0.6 & 0.4 & 0.6 \\
\hline $\mathrm{Al2O} 3$ & 17.3 & 16.4 & 15.5 & 15.2 \\
\hline $\mathrm{Fe} 2 \mathrm{O} 3$ & 6.5 & 6.3 & 3.5 & 6.1 \\
\hline Mno & 0.1 & 0.1 & 0.1 & 0.1 \\
\hline $\mathrm{MgO}$ & 3.1 & 3.0 & 1.6 & 4.2 \\
\hline $\mathrm{CaO}$ & 0.6 & 5.7 & 3.1 & 5.5 \\
\hline $\mathrm{Na2O}$ & 3.9 & 4.0 & 5.1 & 4.7 \\
\hline $\mathrm{K} 2 \mathrm{O}$ & 1.4 & 1.5 & 2.0 & 1.5 \\
\hline P2OS & 0.2 & 0.3 & 0.1 & 0.2 \\
\hline LOI & 0.6 & 0.6 & 0.4 & 0.5 \\
\hline Total & 100.3 & 100.4 & 100.4 & 100.0 \\
\hline ACNK & 0.9 & 0.9 & 1.0 & 0.8 \\
\hline mg\# & 0.5 & 0.5 & 0.5 & 0.6 \\
\hline $\mathbf{Y}$ & 14.8 & 14.5 & 5.6 & 12.3 \\
\hline $\mathrm{Cr}$ & 32.0 & 32.0 & 14.0 & 119.0 \\
\hline $\mathbf{v}$ & 556,0 & 496.0 & 806.0 & 706.0 \\
\hline $\mathrm{Ni}$ & 34.0 & 41.0 & 0.0 & 76.0 \\
\hline Co & 19.0 & 20.0 & 8.0 & 18.0 \\
\hline $\mathbf{R b}$ & 49.0 & 38.0 & 36.0 & 30.0 \\
\hline Ba & 517.0 & 460.0 & 940.0 & 596.0 \\
\hline $\mathbf{S r}$ & 556.0 & 496.0 & 806.0 & 706.0 \\
\hline Th & 1.2 & 2.6 & 1.8 & 1.9 \\
\hline U & 1.2 & 0.5 & 0.6 & 0.8 \\
\hline $\mathbf{Z r}$ & 113.0 & 107.0 & 73.0 & 78.0 \\
\hline Hf & 3.0 & 3.0 & 2.1 & 2.1 \\
\hline $\mathrm{Nb}$ & 4.7 & 5.1 & 3.6 & 3.9 \\
\hline $\mathrm{Ta}$ & 0.3 & 0.2 & 0.2 & 0.2 \\
\hline SrY & 37.6 & 34.2 & 143.9 & 57.4 \\
\hline $\mathbf{L a}$ & 11.6 & 30.0 & 24.1 & 29.1 \\
\hline $\mathrm{Ce}$ & 27.8 & 63.3 & 34.9 & 54.7 \\
\hline $\mathbf{P r}$ & 3.6 & 7.3 & 4.1 & 7.2 \\
\hline Nd & 16.7 & 27.8 & 15.1 & 30.1 \\
\hline Sm & 3.7 & 5.2 & 2.4 & 5.5 \\
\hline $\mathbf{E u}$ & 1.0 & 1.2 & 0.7 & 1.0 \\
\hline Gd & 3.0 & 3.3 & 1.5 & 3.8 \\
\hline $\mathbf{T b}$ & 0.5 & 0.5 & 0.2 & 0.5 \\
\hline Dy & 2,7 & 3.0 & 1.1 & 2.8 \\
\hline Ho & 0.6 & 0.6 & 0.2 & 0.5 \\
\hline Er & 1.6 & 1.6 & 0.6 & 1.3 \\
\hline $\mathbf{Y b}$ & 1.6 & 1.5 & 0.4 & 1.0 \\
\hline $\mathrm{Tm}$ & 0.3 & 0.3 & 0.0 & 0.2 \\
\hline $\mathbf{L u}$ & 0.3 & 0.2 & * & 0.2 \\
\hline LaYb & 3.3 & 20.0 & 60.3 & 29.1 \\
\hline LaSm & 3.1 & 5.8 & 10.0 & 5.3 \\
\hline LaYbN & 4.9 & 13.5 & 40.6 & 19.6 \\
\hline $\mathbf{L} \mathbf{a S m N}$ & 2.0 & 3.7 & 6.4 & 3.4 \\
\hline
\end{tabular}

Tabela 4.8 - Ánalises químicas de tonalito da região de Cayenne-Reginá, Guiana Francesa (Fonte: Vanderhaeghe et al. 1998). Elementos maiores (\%), e traços (ppm) $\mathrm{Fe}_{2} \mathrm{O}_{3}$ como ferro total. 
Nível 345

Nível 54

\begin{tabular}{|c|c|c|c|c|c|c|c|c|c|}
\hline Amostra & GS-02 & GS-05 & GS-56 & GS-57 & GS-70 & SL-01 & SLf02 & R-03 & $\mathrm{R}-10$ \\
\hline $\mathrm{SiO2}$ & 52.50 & 54.10 & 52.70 & 51.90 & 52.00 & 53.00 & 53.10 & 54.22 & 55.00 \\
\hline TiO2 & 1.50 & 1.20 & 1.20 & 1.20 & 1.20 & 0.99 & 1.50 & 0.49 & 0.87 \\
\hline A1203 & 13.90 & 10.60 & 11.10 & 11.10 & 13.40 & 8.90 & 11.10 & 13.28 & 15.73 \\
\hline $\mathrm{Fe} 2 \mathrm{O3}$ & 1.70 & 0.83 & 2.60 & 2.90 & 1.60 & 2.10 & 2.00 & 8.17 & 9.32 \\
\hline $\mathrm{FeO}$ & 8.27 & 8.70 & 7.18 & 7.18 & 8.33 & 8.85 & 7.99 & 0.00 & 0.00 \\
\hline FeOT & 9.80 & 9.45 & 9.52 & 9.79 & 9.77 & 10.74 & 9.79 & 7.35 & 8.39 \\
\hline Fe203T & 10.89 & 10.50 & 10.58 & 10.88 & 10.85 & 11.93 & 10.88 & 8.17 & 9.32 \\
\hline $\mathrm{MnO}$ & 0.18 & 0.18 & 0.16 & 0.16 & 0.16 & 0.19 & 0.18 & 0.15 & 0.16 \\
\hline $\mathrm{MgO}$ & 6.40 & 10.00 & 7.40 & 9.70 & 6.90 & 11.50 & 9.90 & 9.18 & 4.88 \\
\hline $\mathrm{CaO}$ & 7.80 & 7.90 & 8.40 & 7.80 & 8.40 & 8.80 & 7.90 & 8.01 & 7.06 \\
\hline $\mathrm{Na2O}$ & 3.30 & 2.20 & 4.70 & 3.40 & 4.20 & 1.70 & 1.40 & 3.07 & 3.90 \\
\hline $\mathrm{K} 20$ & 1.90 & 1.80 & 1.30 & 1.70 & 1.50 & 1.80 & 2.30 & 2.61 & 1.90 \\
\hline P2O5 & 0.25 & 0.29 & 0.25 & 0.19 & 0.23 & 0.16 & 0.16 & 0.21 & 0.23 \\
\hline LOI & $*$ & $*$ & $*$ & $*$ & $*$ & $*$ & $*$ & 0.93 & 0.85 \\
\hline Total & 97.70 & 97.80 & 96.99 & 97.23 & 97.92 & 97.99 & 97.53 & 100.32 & 99.90 \\
\hline $\mathbf{B a}$ & $*$ & $*$ & $*$ & $*$ & * & $*$ & $*$ & 1079.57 & 715.91 \\
\hline $\mathbf{R b}$ & 73.00 & 75.00 & 23.00 & 56.00 & 66.00 & 67.00 & 100.00 & 87.04 & 80.73 \\
\hline $\mathbf{S r}$ & 390.00 & 190.00 & 290.00 & 210.00 & 450.00 & 62.00 & 190.00 & 530.08 & 632.94 \\
\hline $\mathbf{Y}$ & $*$ & $*$ & $*$ & $*$ & $*$ & $*$ & $*$ & 13.60 & 19.12 \\
\hline $\mathbf{Z r}$ & $*$ & $*$ & $*$ & $*$ & $*$ & $*$ & $*$ & 71.79 & 106.52 \\
\hline $\mathbf{N b}$ & $*$ & $*$ & $*$ & $*$ & $*$ & $*$ & $*$ & 7.66 & 6.32 \\
\hline Th & $*$ & $*$ & $*$ & $*$ & $*$ & $*$ & $*$ & 3.87 & 5.08 \\
\hline $\mathbf{P b}$ & 20.00 & 20.00 & 12.00 & 11.00 & 14.00 & 27.00 & 20.00 & 22.00 & 12.00 \\
\hline Ga & * & $*$ & $*$ & $*$ & $*$ & $*$ & $*$ & 16.00 & 21.00 \\
\hline $\mathbf{Z n}$ & 84.00 & 84.00 & 23.00 & 52.00 & 30.00 & 33.00 & 73.00 & 86.00 & 93.00 \\
\hline $\mathrm{Cu}$ & 52.00 & 2.00 & 3.00 & 10.00 & 6.00 & 5.00 & $*$ & 109.00 & 71.00 \\
\hline $\mathrm{Ni}$ & * & $*$ & $*$ & $*$ & $*$ & $*$ & * & 124.00 & 27.00 \\
\hline $\mathbf{V}$ & 250.00 & 172.00 & 170.00 & 140.00 & 160.00 & 250.00 & 250.00 & 166.00 & 177.00 \\
\hline $\mathrm{Cr}$ & 220.00 & 620.00 & 310.00 & 660.00 & 210.00 & 890.00 & 840.00 & 656.00 & 38.00 \\
\hline Hf & $*$ & $*$ & $*$ & $*$ & $*$ & $*$ & $*$ & 2.34 & 3.22 \\
\hline $\mathrm{Cs}$ & * & $*$ & $*$ & $*$ & $*$ & $*$ & $*$ & 4.46 & 4.84 \\
\hline $\mathrm{Sc}$ & * & $*$ & $*$ & $*$ & $*$ & $*$ & $*$ & 32.00 & 25.00 \\
\hline Ta & $*$ & $*$ & $*$ & $*$ & $*$ & $*$ & $*$ & 0.44 & 0.40 \\
\hline Co & * & $*$ & $*$ & $*$ & $*$ & $*$ & $*$ & 34.40 & 27.00 \\
\hline $\mathbf{U}$ & $*$ & $*$ & $*$ & $*$ & $*$ & $*$ & $*$ & 1.40 & 1.87 \\
\hline Sn & $*$ & $*$ & * & $*$ & $*$ & $*$ & $*$ & 2.00 & 1.30 \\
\hline Mo & $*$ & $*$ & $*$ & * & $*$ & $*$ & $*$ & 1.23 & 0.73 \\
\hline La & 17.90 & 11.90 & 16.60 & 12.00 & 16.60 & 8.47 & 12.60 & 36.47 & 37.75 \\
\hline $\mathrm{Ce}$ & 39.90 & 27.50 & 35.90 & 27.20 & 35.80 & 19.10 & 26.90 & 69.75 & 74.57 \\
\hline Pr & $*$ & * & $*$ & $*$ & $*$ & $*$ & $*$ & 6.52 & 7.28 \\
\hline Nd & 24.00 & 17.40 & 22.10 & 16.60 & 22.00 & 13.40 & 16.00 & 28.71 & 33.07 \\
\hline Sm & 5.80 & 4.50 & 5.40 & 4.30 & 4.80 & 3.50 & 3.90 & 4.70 & 6.08 \\
\hline $\mathbf{E u}$ & 1.55 & 1.06 & 1.44 & 1.13 & 1.40 & 0.73 & 1.07 & 1.33 & 1.60 \\
\hline Gd & 4.75 & 3.21 & 4.50 & 3.47 & 3.90 & 2.56 & 2.70 & 3.34 & 4.44 \\
\hline $\mathrm{Tb}$ & $*$ & $*$ & $*$ & $*$ & * & $*$ & * & 0.43 & 0.61 \\
\hline Dy & 4.08 & 2.90 & 3.30 & 2.90 & 3.10 & 2.35 & 2.56 & 2.32 & 3.25 \\
\hline Ho & 0.78 & 0.51 & 0.74 & 0.62 & 0.62 & 0.35 & 0.35 & 0.45 & 0.64 \\
\hline $\mathbf{E r}$ & 2.43 & 1.66 & 2.13 & 1.73 & 1.86 & 1.00 & 1.00 & 1.30 & 1.84 \\
\hline Tm & $*$ & * & * & * & $*$ & $*$ & $*$ & 0.19 & 0.26 \\
\hline $\mathbf{Y b}$ & 2.09 & 1.35 & 1.57 & 1.30 & 1.43 & 1.17 & 1.21 & 1.23 & 1.76 \\
\hline Lu & 0.26 & 0.19 & 0.22 & 0.18 & 0.21 & 0.15 & 0.14 & 0.21 & 0.30 \\
\hline c & 21.51 & 20.67 & 22.47 & 19.87 & 22.21 & 21.55 & 20.68 & 20.93 & 20.86 \\
\hline $\mathbf{m g}$ & 0.53 & 0.65 & 0.58 & 0.63 & 0.55 & 0.65 & 0.64 & 0.69 & 0.50 \\
\hline
\end{tabular}




\begin{tabular}{|c|c|c|c|c|c|c|c|c|c|c|c|c|}
\hline Amostras & R-01 & R-04 & R-07 & R-08 & R-11 & R-13 & R-14 & R-17 & R-18 & R-22 & R-25 & R-27 \\
\hline $\mathrm{SiO} 2$ & 64.22 & 60.22 & 63.77 & 65.15 & 64.18 & 66.86 & 64.32 & 63.60 & 65.27 & 62.75 & 62.77 & 61.42 \\
\hline TiO2 & 0.61 & 0.74 & 0.56 & 0.58 & 0.59 & 0.43 & 0.57 & 0.65 & 0.58 & 0.60 & 0.59 & 0.81 \\
\hline Al203 & 15.63 & 15.35 & 15.34 & 14.80 & 14.71 & 16.24 & 14.90 & 14.76 & 14.82 & 15.16 & 15.06 & 11.46 \\
\hline $\mathrm{Fe} 203$ & 5.99 & 7.92 & 5.77 & 5.63 & 6.04 & 3.89 & 5.71 & 6.45 & 5.67 & 6.43 & 6.28 & 6.70 \\
\hline MnO & 0.10 & 0.14 & 0.09 & 0.09 & 0.10 & 0.05 & 0.12 & 0.14 & 0.09 & 0.11 & 0.10 & 0.21 \\
\hline MgO & 2.58 & 3.57 & 2.65 & 2.43 & 2.63 & 1.15 & 2.44 & 2.85 & 2.49 & 3.01 & 2.84 & 4.17 \\
\hline $\mathrm{CaO}$ & 4.73 & 5.24 & 4.57 & 4.21 & 4.28 & 3.28 & 4.34 & 4.88 & 4.35 & 5.28 & 4.97 & 7.21 \\
\hline $\mathrm{Na} 2 \mathrm{O}$ & 3.96 & 3.64 & 3.84 & 3.54 & 3.53 & 4.60 & 3.78 & 3.58 & 3.71 & 3.77 & 3.63 & 2.82 \\
\hline K2O & 2.21 & 2.52 & 2.56 & 2.73 & 2.49 & 2.14 & 2.40 & 2.09 & 2.43 & 2.04 & 2.30 & 1.09 \\
\hline P2O5 & 0.17 & 0.20 & 0.15 & 0.14 & 0.15 & 0.14 & 0.15 & 0.16 & 0.15 & 0.17 & 0.15 & $\mathrm{Nd}$ \\
\hline LOI & 0.61 & 0.55 & 0.55 & 0.53 & 0.62 & 0.47 & 0.51 & 0.97 & 0.54 & 0.77 & 0.80 & 1.95 \\
\hline Total & 100.80 & 100.52 & 99.86 & 99.82 & 99.32 & 99.24 & 99.24 & 100.13 & 100.10 & 100.08 & 99.49 & 97.84 \\
\hline Cs & 5.24 & 7.33 & 5.74 & 3.93 & 5.58 & 7.16 & 6.07 & 3.11 & 4.99 & 3.11 & 3.63 & 0.73 \\
\hline Ba & $\begin{array}{c}5.44 \\
785.06\end{array}$ & 718.23 & 925.88 & 1061.8 & 817.82 & 617.53 & 685.94 & 739.81 & 733.62 & 731.62 & 799.46 & 469.75 \\
\hline $\mathbf{R b}$ & 82.47 & 99.49 & 95.28 & 89.64 & 110.97 & 95.90 & 106.64 & 84.48 & 75.73 & 58.09 & 76.91 & 57.94 \\
\hline $\mathrm{Sr}$ & 524.38 & 447.59 & 478.77 & 486.68 & 435.73 & 638.00 & 447.03 & 475.42 & 468.95 & 525.43 & 480.89 & 354.79 \\
\hline $\mathbf{Y}$ & 16.6 & 23.7 & 15.6 & 16.6 & 18.3 & 7.9 & 17.1 & 19.6 & 16.5 & 18.6 & 17.0 & 16.8 \\
\hline $\mathrm{Zr}$ & 149.93 & 170.81 & 139.52 & 167.80 & 163.63 & 122.83 & 157.37 & 177.72 & 151.25 & 146.47 & 161.16 & 106.29 \\
\hline $\mathrm{Nb}$ & 6.43 & 8.15 & 6.08 & 6.30 & 7.16 & 7.29 & 6.54 & 7.34 & 4.70 & 4.84 & 6.41 & 11.78 \\
\hline $\mathbf{N i}$ & 13 & 18 & 11 & 11 & 16 & $\mathrm{Nd}$ & 12 & 13 & 12 & 12 & 12 & 49 \\
\hline $\mathrm{Cu}$ & 46 & 14 & $\mathrm{Nd}$ & $\mathrm{Nd}$ & 45 & $\mathrm{Nd}$ & $\mathrm{Nd}$ & $\mathrm{Nd}$ & 7 & 5 & $\mathrm{Nd}$ & 64. \\
\hline $\mathbf{Z n}$ & 67 & 84 & 70 & 70 & 63 & $\mathrm{Nd}$ & 58 & 81 & 52 & 55 & 55 & 84 \\
\hline $\mathbf{P b}$ & 18 & 21 & 24 & 20 & 19 & 25 & 26 & 23 & 14 & 14 & 12 & 26 \\
\hline Th & 7.69 & 3.89 & 10.18 & 6.43 & 10.55 & 8.49 & 12.39 & 8.41 & 11.19 & 6.93 & 7.83 & 4.67 \\
\hline $\mathbf{U}$ & 3.50 & 2.63 & 3.71 & 2.01 & 3.54 & 3.78 & 3.58 & 2.75 & 3.13 & 2.57 & 2.75 & 2.85 \\
\hline As & $\mathrm{Nd}$ & $\mathrm{Nd}$ & $\mathrm{Nd}$ & $\mathrm{Nd}$ & $\mathrm{Nd}$ & $\mathrm{Nd}$ & 7 & 9 & 5 & 9 & 40 & 3615 \\
\hline Sn & 1.30 & 4.4 & 1.5 & 1.3 & 1.9 & 2.0 & 2.6 & 2.0 & 1.1 & 1.7 & 1.7 & 5.5 \\
\hline Sb & 0.17 & 0.07 & 0.12 & 0.07 & 0.06 & 0.10 & 0.18 & 0.13 & $\mathrm{Nd}$ & $\mathrm{Nd}$ & 0.10 & 0.37 \\
\hline $\mathrm{Au}$ & 3 & 45 & 9 & 2 & 3 & 33 & 4 & 20 & 41 & 68 & 329 & 7986 \\
\hline Pt & 1.9 & 1.8 & 1.4 & 1.3 & 1.2 & 0.9 & 1.5 & 0.7 & 0.5 & 0.5 & 0.7 & 3.6 \\
\hline Pd & $\begin{array}{l}1.7 \\
0.4\end{array}$ & $\begin{array}{l}1.0 \\
1.1\end{array}$ & 0.3 & 0.2 & 0.3 & $\mathrm{Nd}$ & 0.6 & 0.6 & 0.3 & 0.3 & 0.3 & 0.1 \\
\hline
\end{tabular}

Tabela 6.5a - Análises químicas de elementos maiores (\%) e traços (ppm), Au, Pt e Pd (ppb), em rocha total de tonalito da travessa de acesso ao nível $54 \mathrm{~m}$ da Mina de Salamangone. $\mathrm{Fe}_{2} \mathrm{O}_{3}$ como ferro total. 


\begin{tabular}{|c|c|c|c|c|c|c|c|c|c|c|}
\hline Amostras & SHN-11 & SHN-17 & SHN-18 & SHN-20 & SHN-23 & SHN-24 & SHN-25 & SHN-27 & SHN-28 & $\begin{array}{l}226 \\
\text { SHN-29 }\end{array}$ \\
\hline SiO2 & 64.64 & 64.60 & 63.69 & 64.90 & 63.33 & 65.45 & 63.11 & 63.48 & 62.65 & 61.65 \\
\hline TiO2 & 0.62 & 0.60 & 0.63 & 0.62 & 0.64 & 0.56 & 0.66 & 0.64 & 0.61 & 0.59 \\
\hline $\mathrm{Al} 2 \mathrm{O3}$ & 14.97 & 15.16 & 14.75 & 14.93 & 14.72 & 13.32 & 15.23 & 14.57 & 14.63 & 14.83 \\
\hline $\mathrm{Fe} 2 \mathrm{O3}$ & 6.14 & 6.22 & 6.36 & 6.49 & 6.50 & 5.71 & 6.53 & 6.61 & 5.94 & 6.26 \\
\hline Mno & 0.09 & 0.11 & 0.12 & 0.12 & 0.10 & 0.10 & 0.13 & 0.11 & 0.10 & 0.10 \\
\hline MgO & 2.73 & 2.62 & 2.71 & 2.72 & 2.79 & 2.53 & 2.89 & 2.92 & 2.76 & 2.80 \\
\hline $\mathrm{CaO}$ & 4.27 & 4.51 & 4.26 & 4.16 & 4.22 & 4.25 & 4.22 & 4.29 & 5.03 & 4.48 \\
\hline $\mathrm{Na2O}$ & 3.53 & 3.72 & 3.59 & 3.48 & 3.48 & 3.11 & 3.65 & 3.33 & 3.38 & 3.02 \\
\hline $\mathrm{K2O}$ & 2.43 & 2.36 & 2.51 & 1.81 & 2.16 & 2.23 & 1.97 & 2.39 & 2.49 & 2.80 \\
\hline P2O5 & 0.15 & 0.15 & 0.14 & 0.15 & 0.16 & 0.15 & 0.17 & 0.16 & 0.13 & 0.16 \\
\hline LOI & 0.94 & 0.77 & 1.48 & 1.04 & 1.03 & 0.77 & 1.01 & 0.94 & 1.03 & 1.89 \\
\hline Total & 100.51 & 100.81 & 100.23 & 100.42 & 99.14 & 98.17 & 99.56 & 99.45 & 98.59 & 98.57 \\
\hline Cs & 3.15 & 6.43 & 0.99 & 7.54 & 3.78 & 6.79 & 7.01 & 3.81 & 1.52 & 3.66 \\
\hline $\mathbf{B a}$ & 888.72 & 935.73 & 801.29 & 564.11 & 753.84 & 942.63 & 375.05 & 851.55 & 917.80 & 995.41 \\
\hline $\mathbf{R b}$ & 73.67 & 82.34 & 113.15 & 133.54 & 77.04 & 76.85 & 106.34 & 73.79 & 70.08 & 84.82 \\
\hline $\mathrm{Sr}$ & 479.57 & 485.20 & 436.97 & 391.52 & 458.41 & 381.77 & 397.14 & 455.50 & 460.03 & 437.90 \\
\hline $\mathbf{Y}$ & 18.1 & 17.6 & 20.1 & 26.4 & 18.9 & 17.1 & 24.0 & 20.3 & 18.7 & 19.1 \\
\hline $\mathbf{Z r}$ & 176.92 & 175.04 & 173.42 & 188.57 & 191.12 & 174.85 & 180.33 & 176.18 & 165.95 & 174.07 \\
\hline Nb & 5.19 & 5.20 & 5.07 & 6.19 & 5.29 & 4.99 & 6.47 & 5.35 & 4.81 & 5.35 \\
\hline $\mathbf{N i}$ & 13 & 11 & 11 & 14 & 18 & 12 & 14 & 19 & 21 & 20 \\
\hline $\mathrm{Cu}$ & 14 & 33 & 24 & Nd & 15 & 17 & 17 & 9 & 60 & 80 \\
\hline $\mathbf{Z n}$ & 54 & 48 & 49 & 50 & 56 & 48 & 62 & 51 & 49 & 51 \\
\hline $\mathbf{P b}$ & 11 & 13 & 11 & 12 & 12 & 11 & 14 & 11 & 11 & 11 \\
\hline Th & 8.07 & 10.34 & 9.31 & 6.19 & 6.67 & 5.13 & 5.26 & 15.82 & 5.99 & 9.69 \\
\hline $\mathbf{U}$ & 2.41 & 2.98 & 2.57 & 4.11 & 3.09 & 1.79 & 3.50 & 2.83 & 2.17 & 3.43 \\
\hline As & $\mathrm{Nd}$ & $\mathrm{Nd}$ & $\mathrm{Nd}$ & 9 & 32 & 16 & 186 & 206 & 1129 & 918 \\
\hline Sn & 1.3 & 1.7 & 2.1 & 2.0 & 1.4 & 2.3 & 2.4 & 1.4 & 1.3 & 1.2 \\
\hline $\mathbf{S b}$ & 0.29 & 0.14 & 0.03 & 0.05 & 0.17 & 0.15 & 0.19 & 0.23 & 0.21 & 0.17 \\
\hline Au & 4 & 6 & 10 & 15 & 12 & 14 & 259 & 194 & 737 & 1768 \\
\hline $\mathbf{P t}$ & 0.5 & 0.4 & 0.5 & 0.5 & 0.4 & 0.4 & 0.2 & 0.5 & 0.2 & $\mathrm{Nd}$ \\
\hline Pd & 0.2 & 0.3 & 0.3 & 0.4 & 0.3 & 0.3 & $\mathrm{Nd}$ & 0.3 & 0.1 & $\mathrm{Nd}$ \\
\hline
\end{tabular}

Tabela 6.5b - Análises químicas de elementos maiores (\%), traços (ppm), Au, Pt e Pd (ppb) em rocha total, de amostras de tonalito do furo de sondagem $\mathrm{SH}-140$, localizado na capa dos corpos de minério, da Mina de Salamangone. $\mathrm{Fe}_{2} \mathrm{O}_{3}$ como ferro total. 


\section{$\underline{\text { Anexo } 4}$}

\section{Análises Isotópicas}




\begin{tabular}{|c|c|c|c|c|c|c|c|c|c|c|c|c|c|}
\hline \multirow[t]{2}{*}{$\mathbf{N}$} & \multirow{2}{*}{ 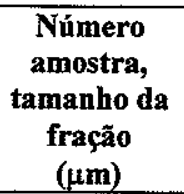 } & \multirow{2}{*}{$\begin{array}{c}\text { Peso da } \\
\text { fração } \\
\text { (mg) }\end{array}$} & \multicolumn{2}{|c|}{$\begin{array}{c}\text { Concentração } \\
(\mathrm{ppm})\end{array}$} & \multirow[b]{2}{*}{${ }^{206} \mathrm{~Pb} /{ }^{204} \mathrm{~Pb}^{\mathrm{a}}$} & \multicolumn{4}{|c|}{ Proporção isotópica corrigida para $\mathbf{P b}^{b}$ comum e branco } & \multirow[b]{2}{*}{$\mathbf{R h o}^{\mathrm{c}}$} & \multicolumn{3}{|c|}{$\begin{array}{l}\text { Idade } \\
\text { (Ma) }\end{array}$} \\
\hline & & & $\mathbf{P b}$ & $\mathbf{U}$ & & ${ }^{207} \mathbf{P b} /{ }^{206} \mathrm{~Pb}$ & ${ }^{208} \mathrm{~Pb} /{ }^{206} \mathrm{~Pb}$ & ${ }^{207} \mathrm{~Pb} /{ }^{235} \mathrm{U}$ & ${ }^{206} \mathrm{~Pb} /{ }^{238} \mathrm{U}$ & & ${ }^{207} \mathrm{~Pb} /{ }^{235} \mathrm{U}$ & ${ }^{206} \mathrm{~Pb} /{ }^{238} \mathrm{U}$ & ${ }^{207} \mathrm{~Pb} /{ }^{206} \mathrm{~Pb}$ \\
\hline 22 & $\begin{array}{c}\text { NN-2678 } \\
<100\end{array}$ & 0.72 & 61.6 & 167.0 & 1736 & $0.1308 \pm 1$ & $0.11581 \pm 1$ & $6.0444 \pm 187$ & $0.3353 \pm 10$ & 0.99 & $1982 \pm 6.1$ & $1864 \pm 5.8$ & $2108 \pm 0.8$ \\
\hline 23 & $\begin{array}{c}\mathrm{IN}-2678, \\
>100\end{array}$ & 0.24 & 60.6 & 160.0 & 2266 & $0.1316 \pm 1$ & $0.13115 \pm 2$ & $6.2513 \pm 200$ & $0.3445 \pm 11$ & 0.98 & $2012 \pm 6.4$ & $1908 \pm 5.9$ & $2120 \pm 1.0$ \\
\hline 24 & $\begin{array}{c}\mathrm{IN}-2678, \\
>100 \\
\mathrm{~A} 70 \%\end{array}$ & 0.19 & 43.7 & 99.8 & 566.9 & $0.1329 \pm 1$ & $0.14863 \pm 1$ & $6.7957 \pm 224$ & $0.3707 \pm 12$ & 0.95 & $2085 \pm 6.9$ & $2033 \pm 6.5$ & $2137 \pm 1.9$ \\
\hline 25 & $\begin{array}{c}\text { IN-2678, } \\
<100 \\
\text { A } 90 \%\end{array}$ & 0.22 & 31.0 & 70.1 & 646.9 & $0.1335 \pm 1$ & $0.13207 \pm 3$ & $7.0171 \pm 253$ & $0.3813 \pm 13$ & 0.96 & $2114 \pm 7.6$ & $2082 \pm 7.3$ & $2144+1.9$ \\
\hline
\end{tabular}

Tabela 5.1 - Composição isotópica U/Pb em zircão de tonalito da Mina de Salamangone. 


\begin{tabular}{|c|c|c|c|c|c|c|c|c|c|c|}
\hline $\begin{array}{l}\text { Número } \\
\text { amostra }\end{array}$ & Rocha & $\begin{array}{c}\text { Sm } \\
(\mathbf{p p m} \\
)\end{array}$ & $\begin{array}{c}\mathrm{Nd} \\
(\mathrm{ppm} \\
\quad) \\
\end{array}$ & ${ }^{147} \mathrm{Sm} /{ }^{144} \mathrm{Nd}$ & Erro & ${ }^{143} \mathrm{Nd} /{ }^{144} \mathrm{Nd}$ & Erro & $\begin{array}{c}\mathbf{T}_{\mathrm{dm}}(\mathbf{G A}) \\
\text { (De Paolo) }\end{array}$ & $\varepsilon_{\mathrm{Nd}}(0)$ & $\varepsilon_{\mathrm{Nd}}(T)$ \\
\hline IH-26 & Tonalito & 4.809 & 25.417 & 0.1144 & 0.0001 & 0.511587 & 0.000044 & $2.242 \pm 0.063$ & -20.50 & +3.02 \\
\hline C-01 & Granodiorito & 0.937 & 6.992 & 0.0810 & 0.0001 & 0.511010 & 0.000036 & $2.344 \pm 0.039$ & -31.76 & +2.84 \\
\hline
\end{tabular}

Tabela 5.2 - Composição isotópica $\mathrm{Sm} / \mathrm{Nd}$ de tonalito e granodiorito da Mina de Salamangone.

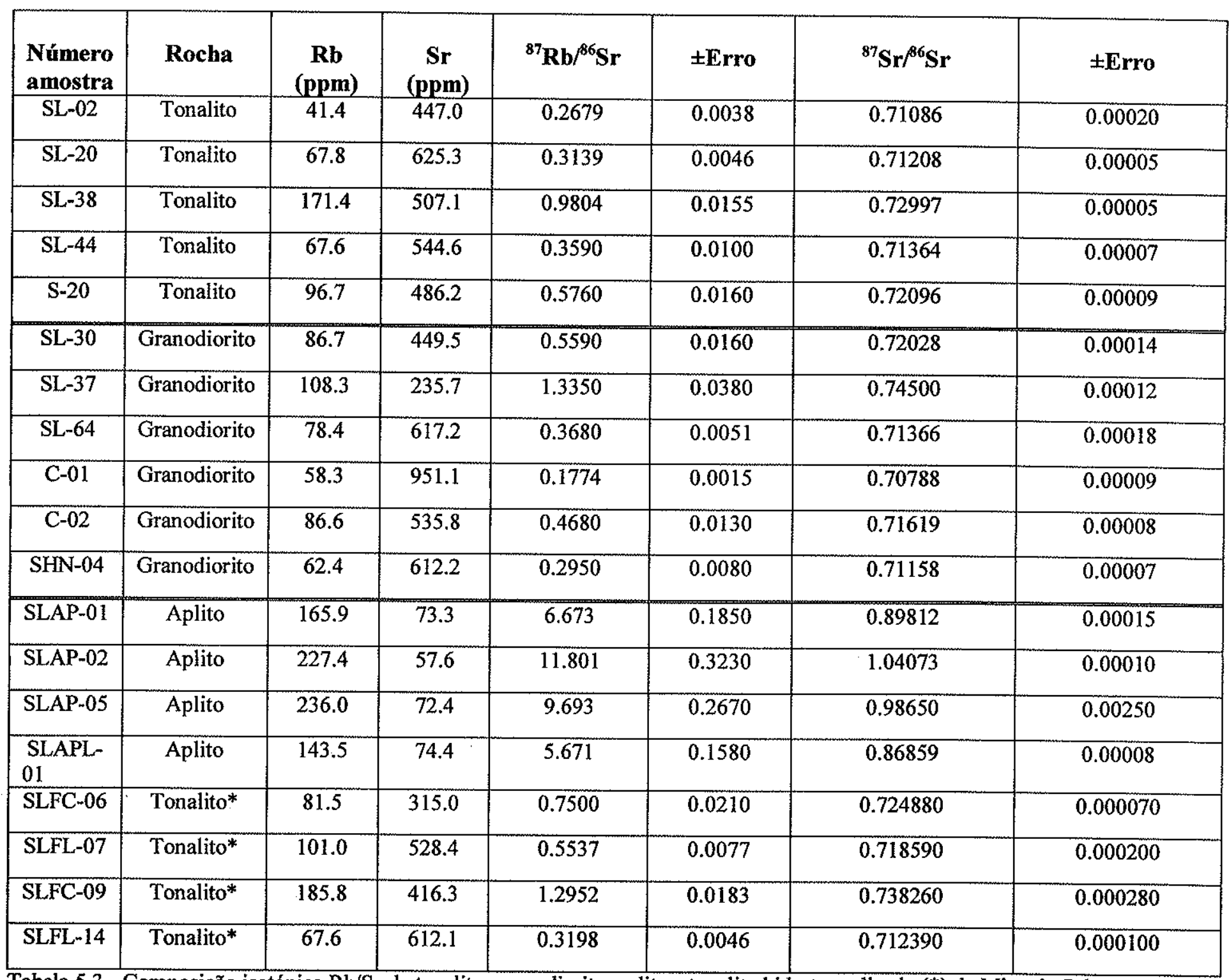

Tabela 5.3 - Composição isotópica $\mathrm{Rb} / \mathrm{Sr}$ do tonalito, granodiorito, aplito e tonalito hidrotermalizado (*) da Mina de Salamangone. 


\begin{tabular}{|c|c|c|c|c|c|c|c|}
\hline $\begin{array}{c}\text { Número } \\
\text { Amostra }\end{array}$ & Rocha & Mineral & $\%$ K & \pm Erro & $\begin{array}{c}\mathbf{A r}^{40} \text { Rad.10 } \\
(\mathbf{c c S T P / g})\end{array}$ & $\begin{array}{c}\text { Ar Atm } \\
(\%)\end{array}$ & $\begin{array}{c}\text { Idade } \\
\text { (Ma) }\end{array}$ \\
\hline SLFL-01 & Tonalito & Biotita & 7.3898 & 0.5482 & 863.73 & 0.53 & 1770.4 \\
\hline SLFP-21 & Tonalito & Biotita & 7.4669 & 0.5000 & 891.25 & 0.38 & 1794.1 \\
\hline SLFP-22 & Tonalito & Biotita & 7.3699 & 0.9054 & 852.39 & 2.09 & 1758.6 \\
\hline
\end{tabular}

Tabela 5.4 - Composição isotópica K-Ar em biotita do tonalito da Mina de Salamangone.

\begin{tabular}{|c|c|c|c|c|c|c|}
\hline Amostra & $206 \mathrm{~Pb} / 204 \mathrm{~Pb}$ & Erro $(1 \sigma)$ & $207 \mathrm{~Pb} / 204 \mathrm{~Pb}$ & Erro $(1 \sigma)$ & $208 \mathrm{~Pb} / 204 \mathrm{~Pb}$ & Erro (1o) \\
\hline $\begin{array}{l}\text { R26T - FP } \\
\text { (nivel } 54 \mathrm{~m} \text { ) }\end{array}$ & 16.521 & 0.12 & 15.434 & 0.12 & 35.859 & 0.12 \\
\hline $\begin{array}{l}\text { R26L1 - FP } \\
\text { (nível 54m) }\end{array}$ & 18.220 & 0.03 & 15.670 & 0.03 & 38.043 & 0.03 \\
\hline $\begin{array}{l}\text { R26L2 - FP } \\
\text { (nível 54m) }\end{array}$ & 18.039 & 0.34 & 15.722 & 0.36 & 38.259 & 0.36 \\
\hline $\begin{array}{l}\text { R26L 3 - FP } \\
\text { (nivel 54m) }\end{array}$ & 18.323 & 0.11 & 15.577 & 0.10 & 37.734 & 0.12 \\
\hline $\begin{array}{l}\text { R26L4 - FP } \\
\text { (nível 54m) }\end{array}$ & 16.374 & 0.27 & 15.389 & 0.23 & 35.144 & 0.21 \\
\hline $\begin{array}{l}\text { N41T - FP } \\
\text { (nível } 41 \mathrm{~m} \text { ) }\end{array}$ & 23.721 & 0.04 & 16.448 & 0.04 & 44.874 & 0.04 \\
\hline $\begin{array}{l}\text { N41L1- FP } \\
\text { (nivel 41m) }\end{array}$ & 24.405 & 0.01 & 16.618 & 0.01 & 44.028 & 0.01 \\
\hline $\begin{array}{l}\text { N41L2 - FP } \\
\text { (nível 41m) }\end{array}$ & 23.469 & 0.04 & 16.362 & 0.04 & 41.237 & $\overline{0.04}$ \\
\hline $\begin{array}{l}\text { N41L3 - FP } \\
\text { (nível 41m) }\end{array}$ & 34.847 & 0.07 & 17.803 & 0.06 & 45.114 & 0.07 \\
\hline $\begin{array}{l}\text { N41LA - FP } \\
\text { (nível 4lm) }\end{array}$ & 93.808 & 0.10 & 24.939 & 0.10 & 54.719 & 0.10 \\
\hline $\begin{array}{l}\text { N41L5 - FP } \\
\text { (nivel } 41 \mathrm{~m} \text { ) }\end{array}$ & 20.088 & 1.29 & 15.541 & 1.33 & 36.477 & 1.32 \\
\hline $\begin{array}{c}\text { SL19T - FP } \\
\text { (nivel 290m) }\end{array}$ & 16.059 & 0.03 & 15.417 & 0.03 & 35.946 & 0.03 \\
\hline $\begin{array}{l}\text { SL1015CT- FL } \\
\text { (nível 264m) }\end{array}$ & 18.111 & 0.03 & 15.721 & 0.02 & 38.426 & 0.02 \\
\hline $\begin{array}{c}\text { L274T-FL } \\
\text { (nível 274m) }\end{array}$ & 21.301 & 0.05 & 16.229 & 0.03 & 41.208 & 0.05 \\
\hline
\end{tabular}

Tabela 9.1 - Dados isotópicos $\mathrm{Pb} / \mathrm{Pb}$ de cristais de arsenopirita da fase I de mineralização. Nota: composições isotópicas corrigidas para fracionamento de massa. $\mathrm{T}=$ dissolução total da amostra, $\mathrm{L} 1 \mathrm{a}$ $\mathrm{L} 5=$ lixiviados. FP = filão Principal, $\mathrm{FL}=$ filão Lapa. 